أفنانستان - طان ان 10

9

سـياستهاى جمانى

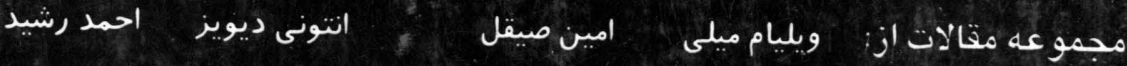

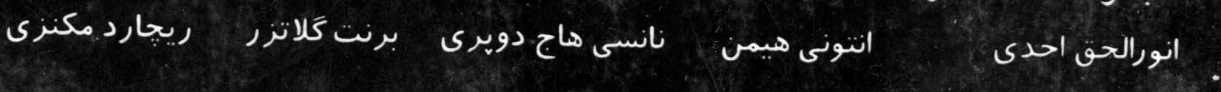
ترجمه: عبدالغفار محقق بل كوشش: ويليام ميلى

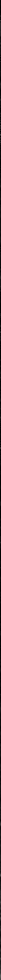




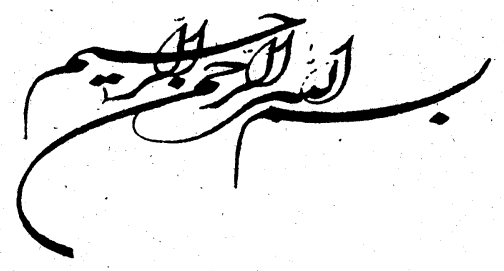

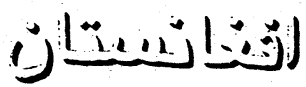

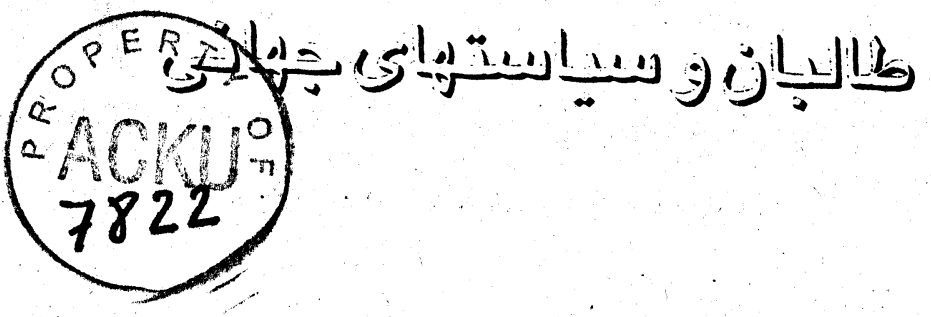

ترد آَورنده: ويليام ميلى

مترجم: عبدالغفَار محقق

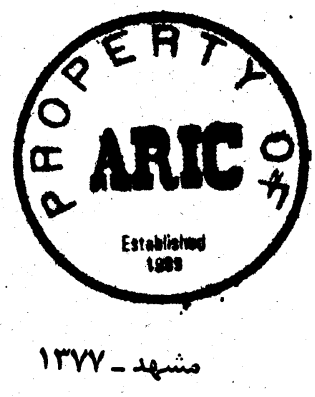




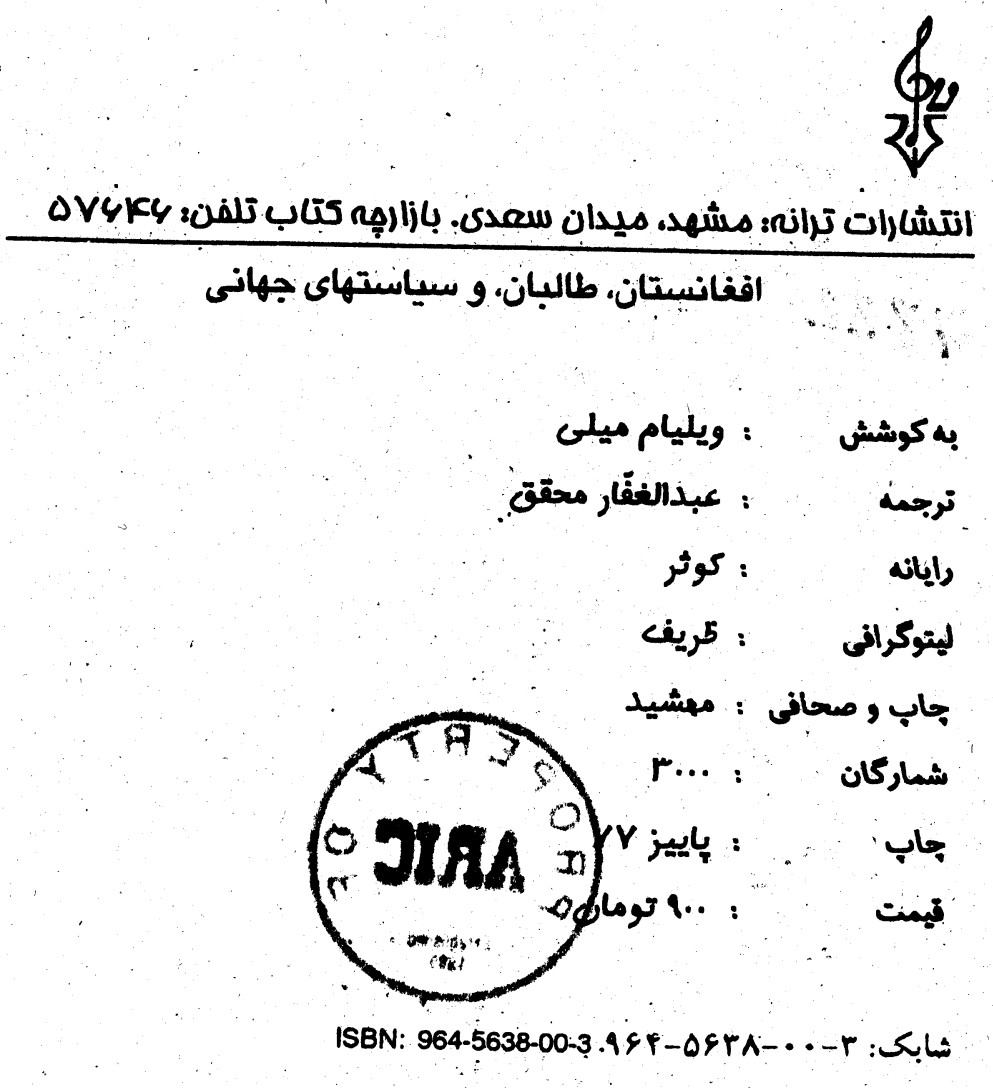




\section{فهر ست}
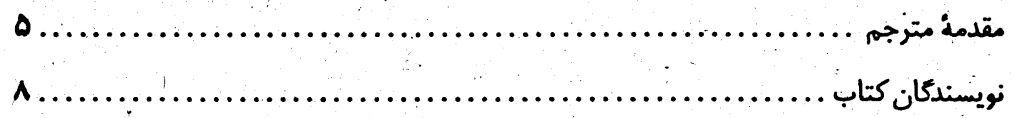

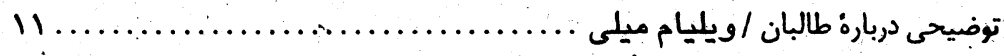
دو

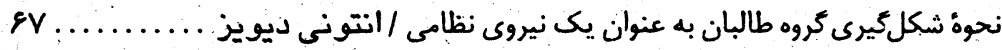

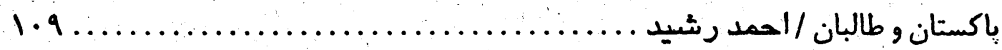
Irv ................................ IOV ................... عربستان سعودى، ايران و جنك در افغانستان / انورالحق احدى

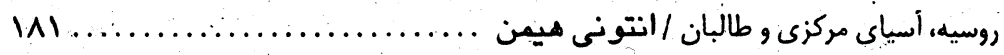

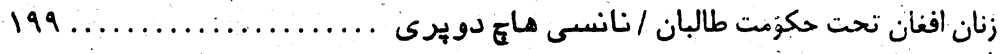

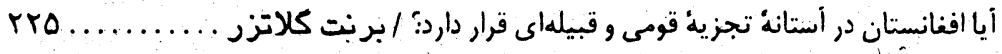




\section{مقدمهُ مترجم}

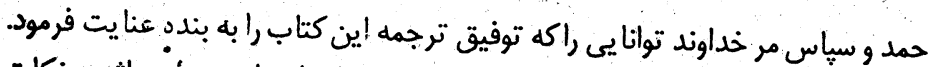

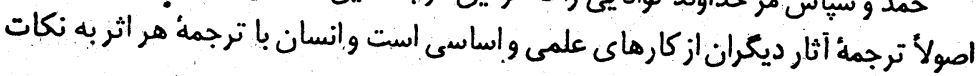
ارززمندئ دست مى يابد.

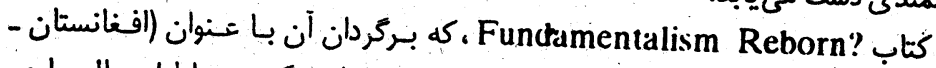

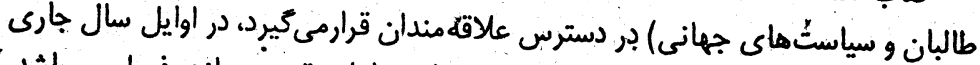

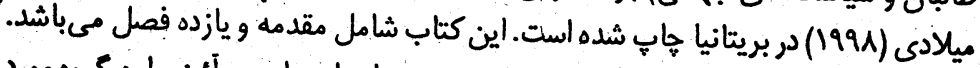

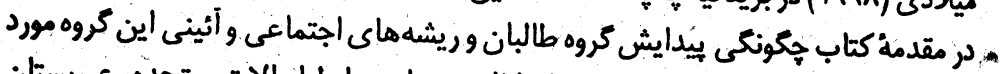

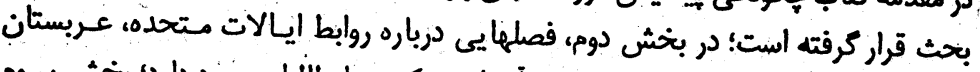

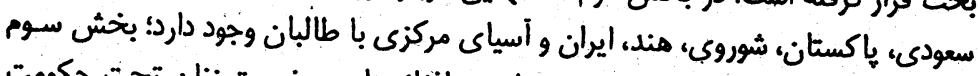

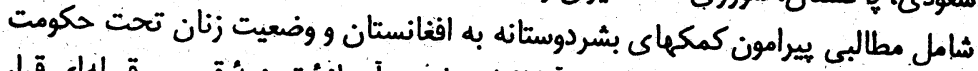

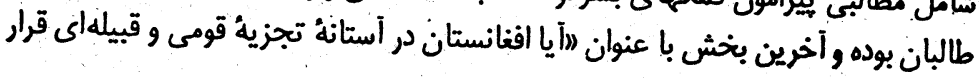
دارد؟ آمده آست.

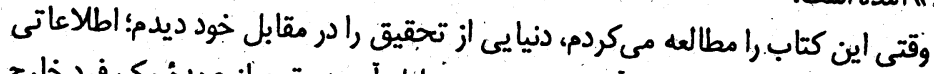

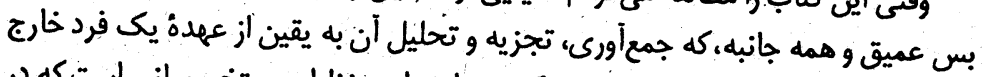

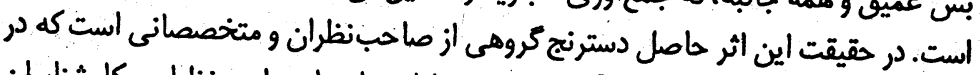

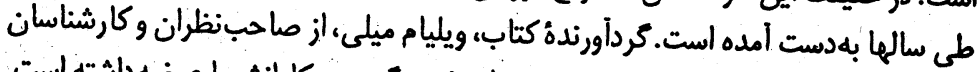

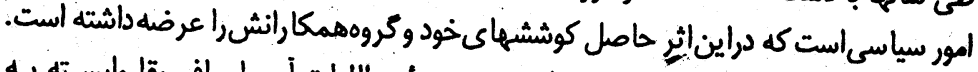

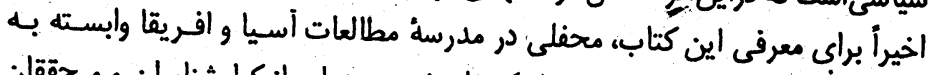

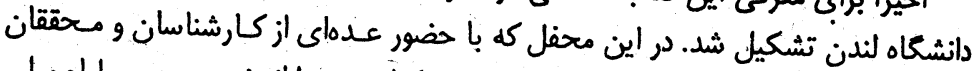

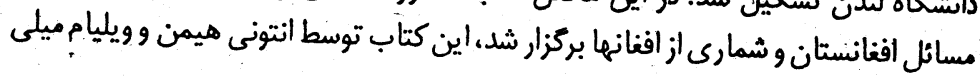

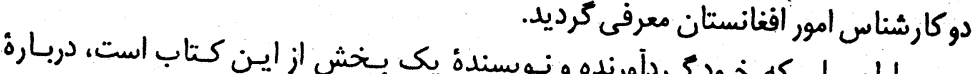




\section{A $: 1 C$}

\section{William Maley editor}

4. 3842

MAL

7822
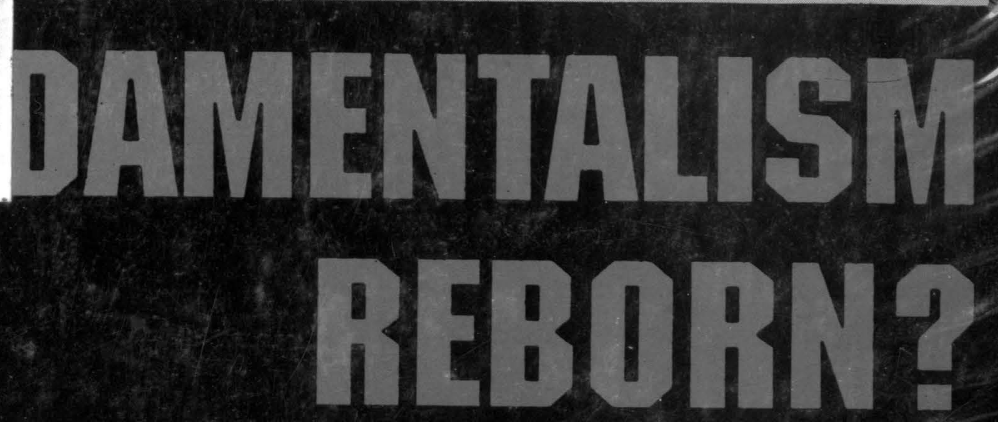

\section{FPIANISTI}
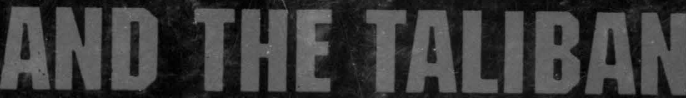

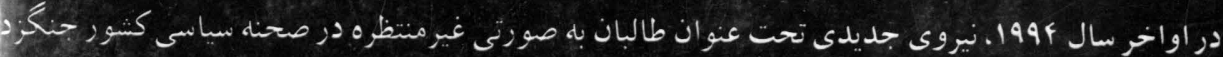
افغانستان ظهور كرد. جنبش طالبان كمكروهكى بود منسجم از طلاب علوم دينى با الهام از تعبر خواب ملا

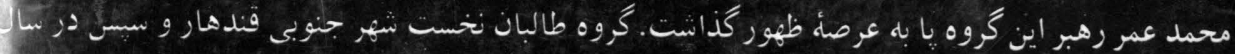

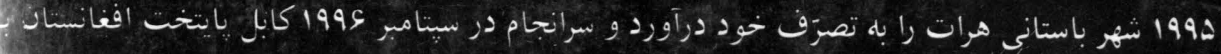
دست اين جنب افناد. ديرى نكذشت كه رفنار غير انسانى اين كروه نسبت به زنان توجه جهانيان را به خو جلب كرو.

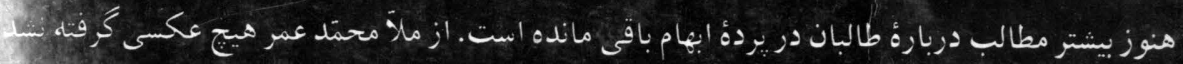

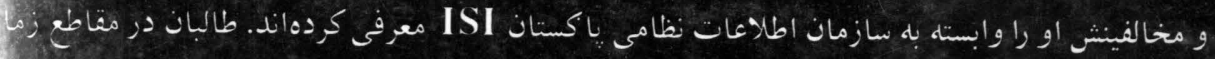

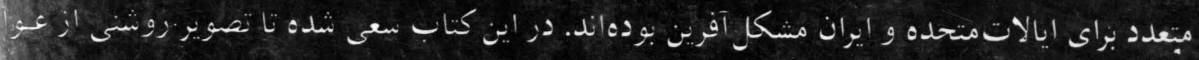

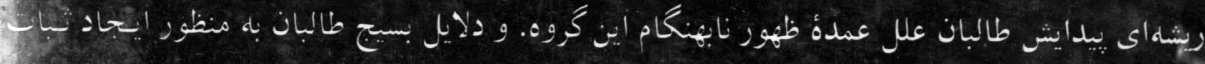

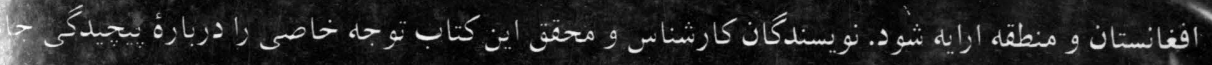

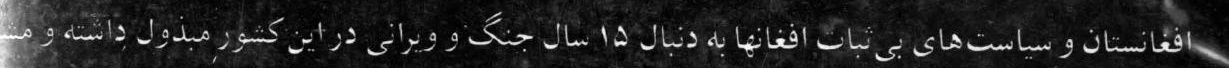

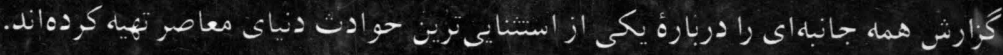

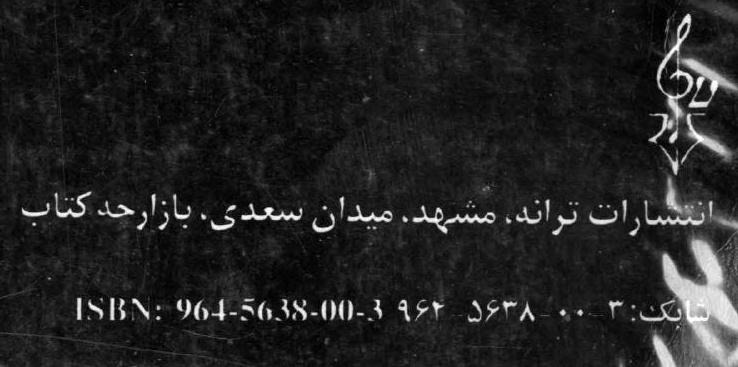




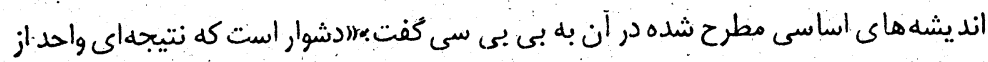

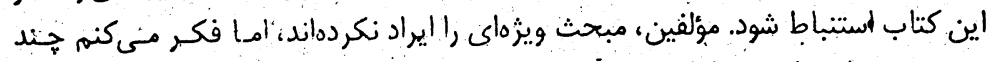

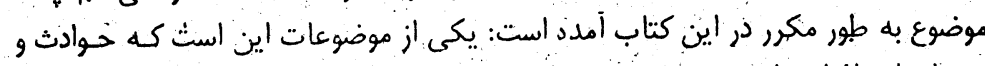

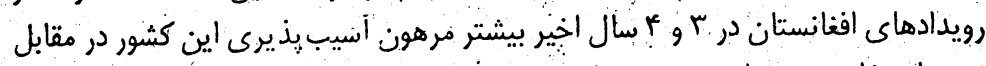

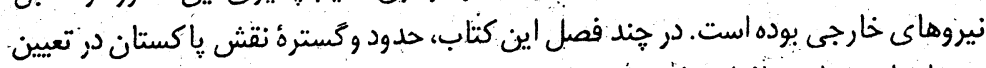

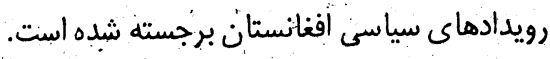

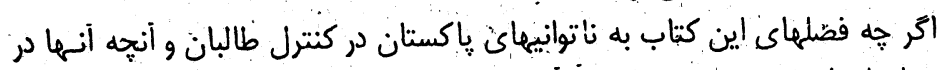

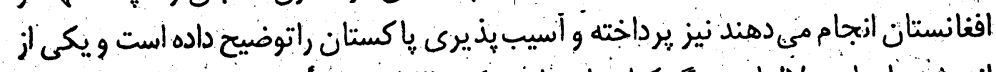

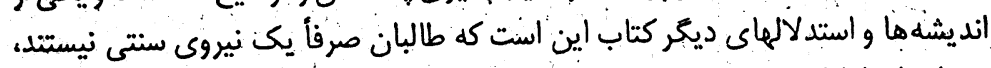

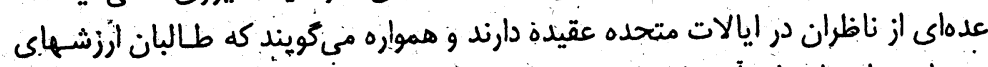

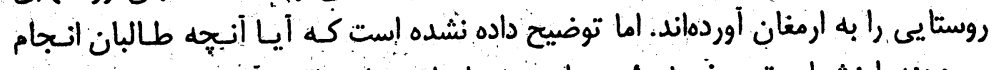

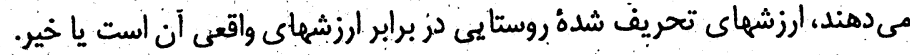

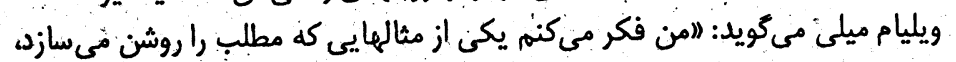

\section{نويسندكان كتاب}

| ـ انورالجق احذىى: او استّاد علوم سياسى در دانشكدة Providence بوده؛

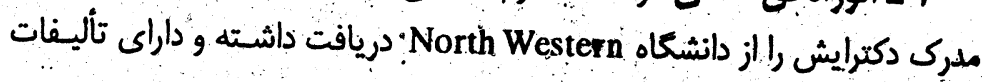
زيادى راجع به خاورميانه و مسايل امنيتى آسياى غربى إبت.

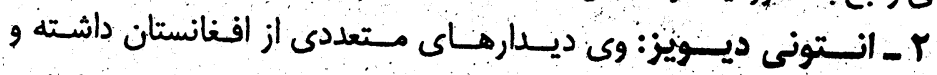

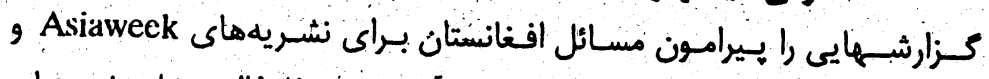
Janes Information Group جينى از دانشكاه ملي استراليا و عضو مؤسسة تحقيقاتي Macarthar نيز مىباشد.

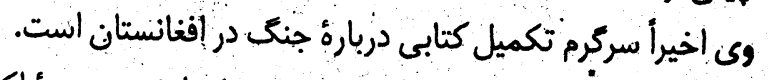

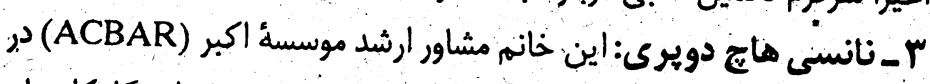

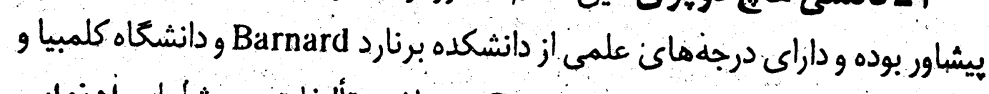

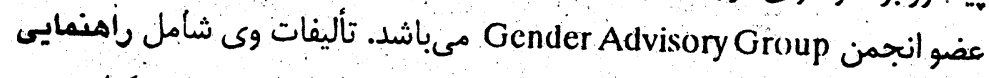

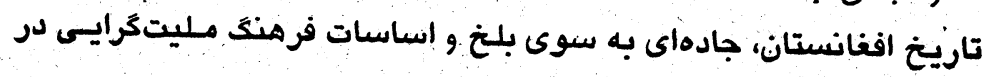
افغانستان است.

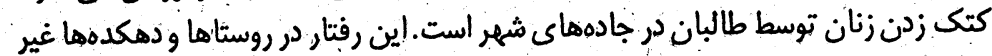

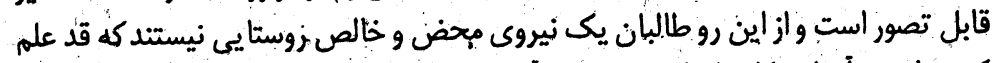

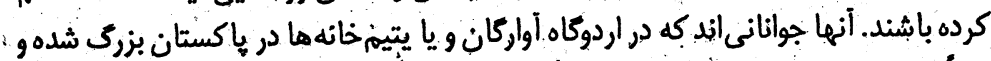

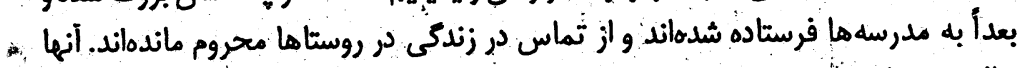

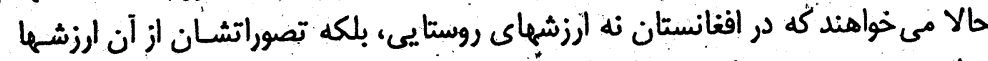

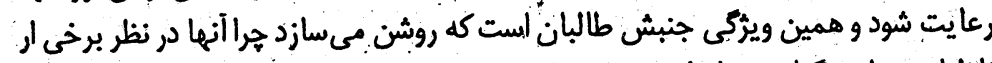

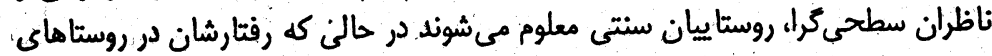

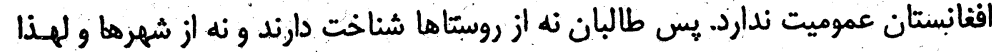

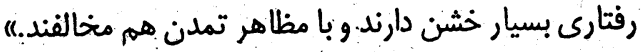

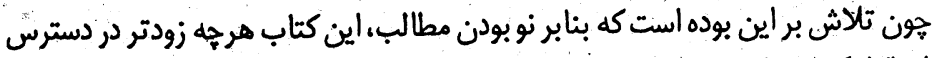

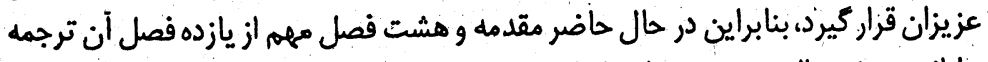

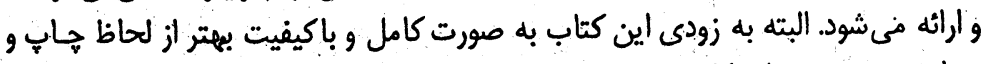

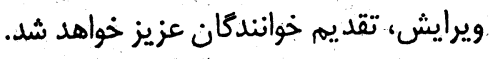

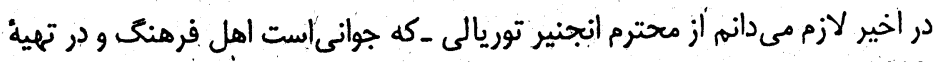

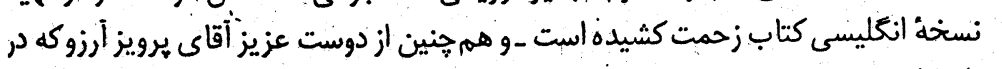
عبدالغفار محقق (سمان

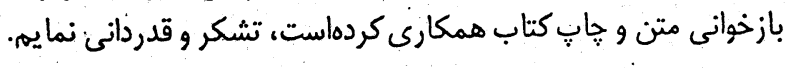
تير (سرطان) ت 
1

كتاب ظهور آسياى مركزى: اسلام يا ناسيو ناليزم؟ هىباشد.

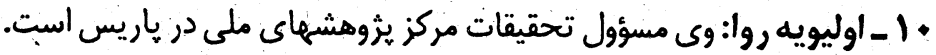

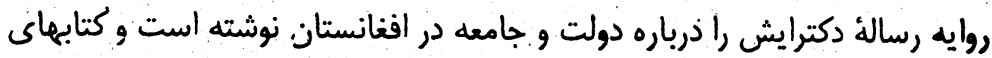

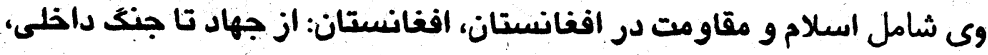

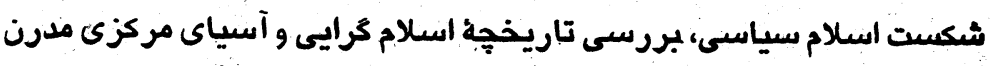
مىباشد.

( 1 ـ امين صيقل: او استاد علوم سياسى و مدير مركز مطالعات خـاورميانه و

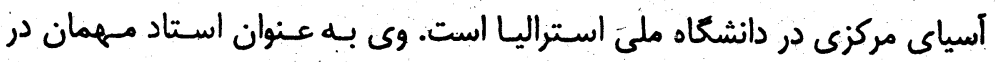
دانشكدة كينك، كمبريج، انستيتوت توسعة مطالعات دانشكاه ولهاه

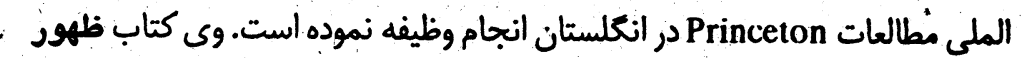
و سقوط شاه را نوشته و داراى مقالات و جزوات ديكرى نيز هست.

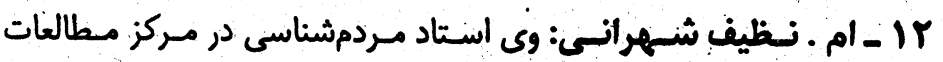
Indiana University

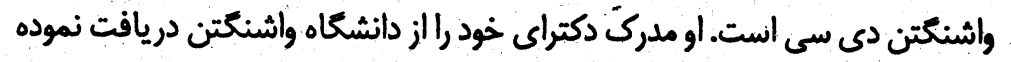

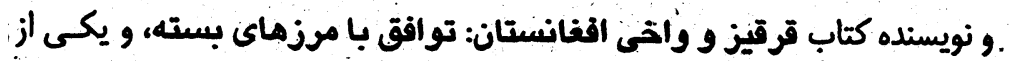

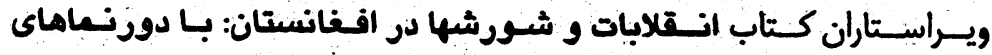
مردمشناختى مىباشد.

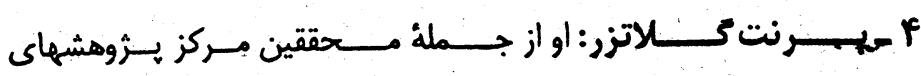
Zentium Moderner Orient

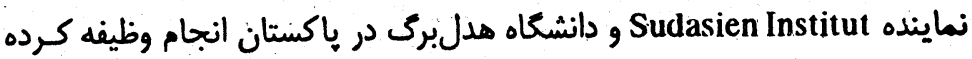

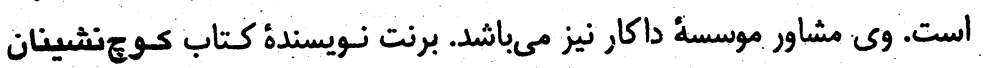

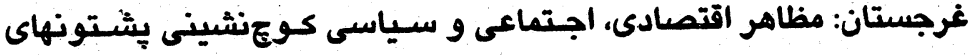
درانى در شمالغربى افغانستان است.

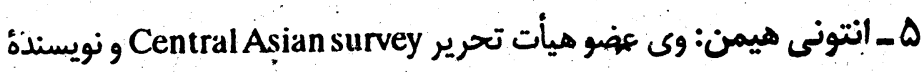

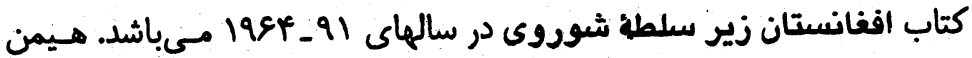

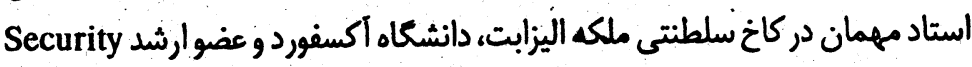
هSRC - Macarthur (New Foundation on York) Peace and صاخب أثار مفصلى دربارة آسياى مركزى يس از فروياشى اتحاد شوروى است.

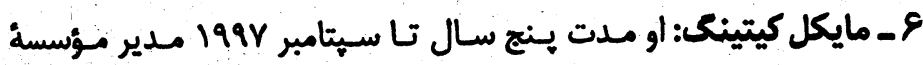
Media Natura

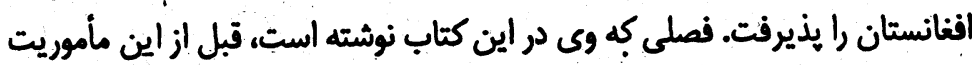
بوده و بعدأ اصلاح كرديده است.

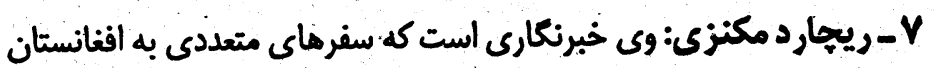

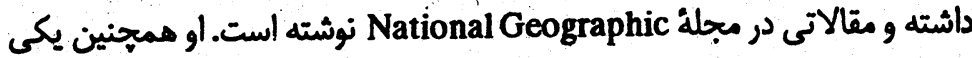
از تهيه كنندكان بـرنامهناى CNN و مـردبير بـخش است.

1 - نniversity College ويليام مـيلى: او اسـاد ارشـد عـلوم سـياسى در و اكادمى نيروهاى دفاعى استراليا بـوده و University of New South Wales. يكى از ويراستاران كتاب عقب نشينى روس از افغانستان ويكى از نويسنده كان كتاب

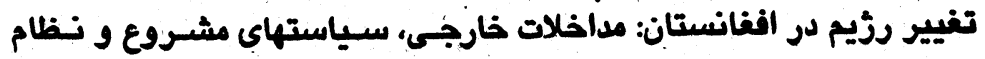
سياسى در افغانستان يس از كمونيست مى باشيد. 9 ـ احمد رشيد: وى فارغالتحصيل دانشكاه كمبريج لندن و خبرنكار نشرية The Far Eastern Economic Review 
توضيحى دربار هُطالبان

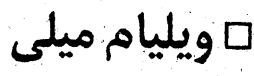

صآنكس كه در جستوجوى رستكاري دوح

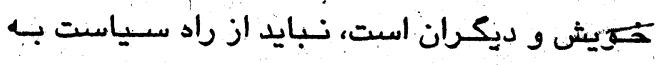

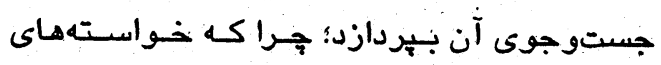

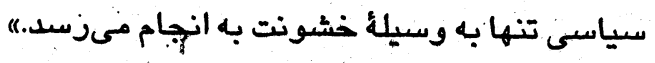

ماكس وبر

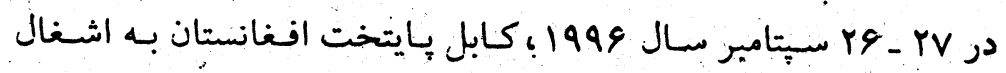

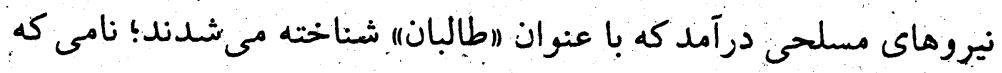

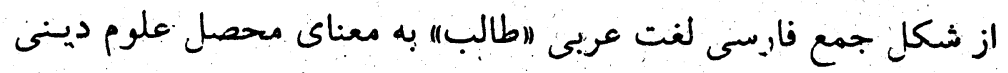

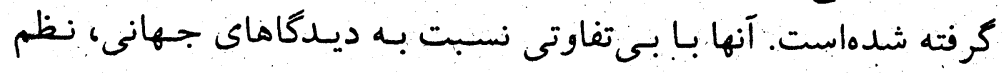

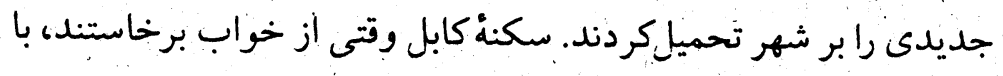

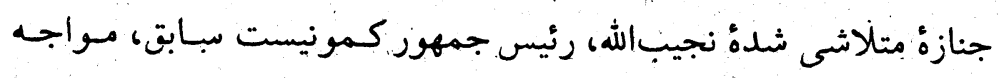

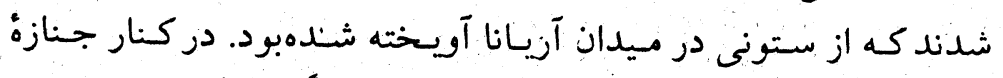

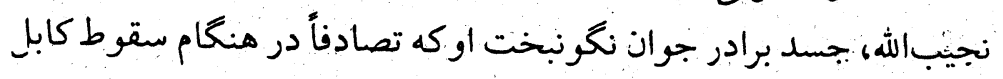

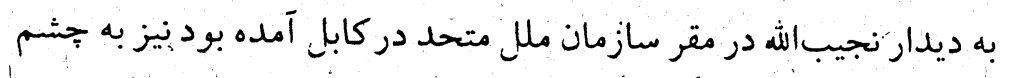

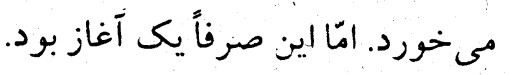
طى حند روز -بر اساس يك سلسله تغييرات بسياركستردهتر -رهبرى
با يوزش از خوأندكان اصلاح فرمايد

درسث

غلל

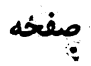

(Parckh)

Parchk

r)

امين صيقز

م امين سيكل

الحمد رشيد

ra-l.q

اوليويه روا

اوليويه روايه

fr.

Special Service Group

$\gamma$

أمجراي

I IV

مصطاخبه

ov

سازمانهائ خير يه غير انتفاعى

NGOS rIO 


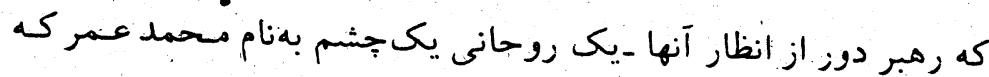

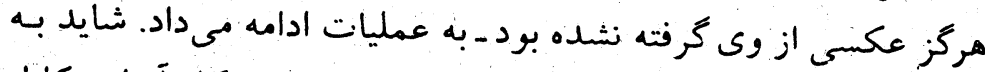
دليل. دور بودن مركز فرماندهى طالبان بود كه اجراى احكام آنها در كابل

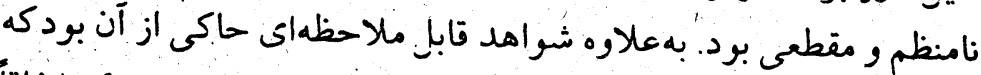
طالبان قوياً مورد حمايت دولت باكستان به رهبرى بـ نظير بوتو، كه اتفاقاً

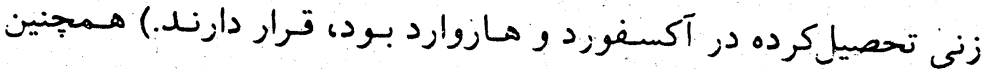

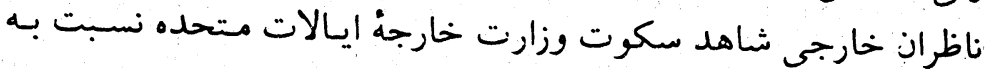

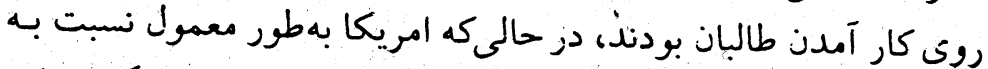

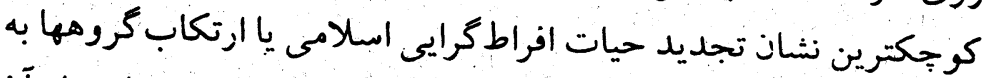
كشت خشخخاش ـكه طالبان در مناطق تحت كنترل خود سود زيادى از آن آن

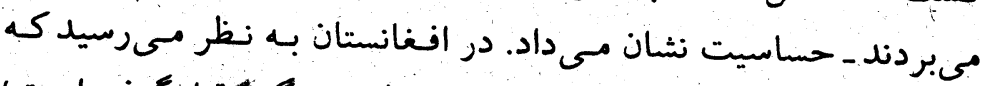

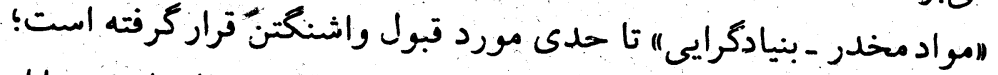

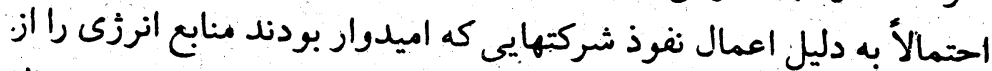

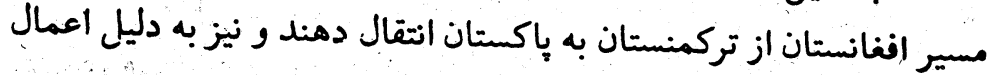
نفوذ مخالفان ايران، كشورى كه هيج علاقهاي به طالبان ندارد.

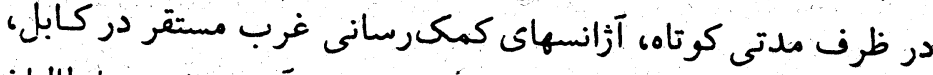
خود را دركير مجادلهاى سخت يافتند، بز سر اينكه آيا بهتر است باس بال طالبان كار كنند تا رماندن كمكهاى مادى به به مردم محلى را تضمين كنيند؛ يا طالبان

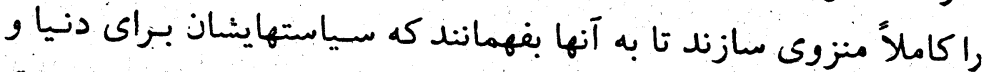

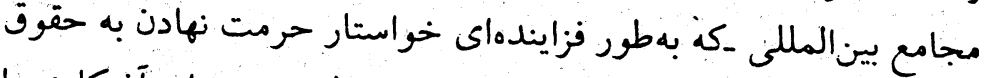

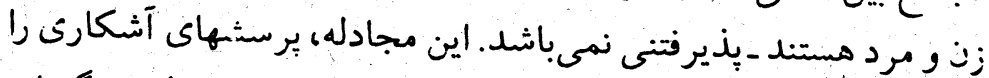

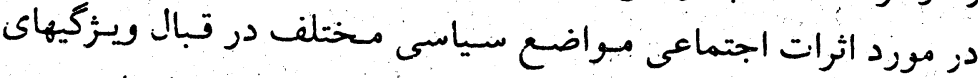

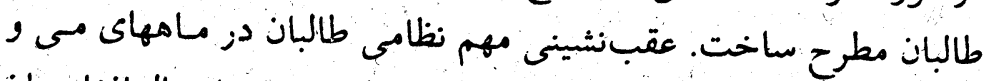

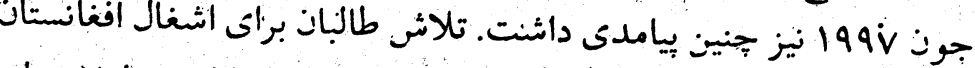

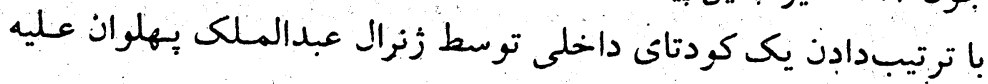

افغانستان، طالبان، و سياستهاى جهانى

جديد، فرمانهايى راجع به يك رشته مسـائلم اجتماعى صادر كرد كـه

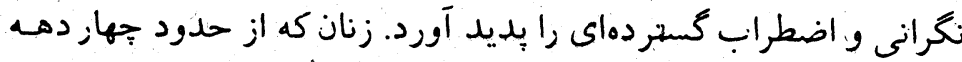

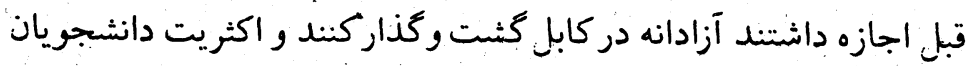
دانشگاه كابل را تشكيل مي دادند، ازَ اين بس فقط در صورتئ مى دوانستيند

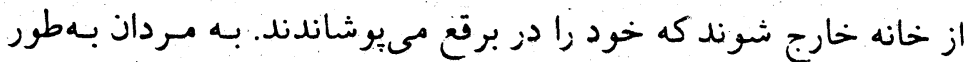

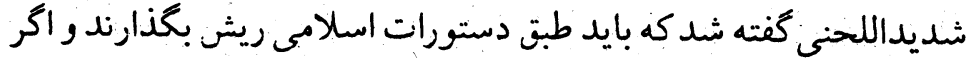

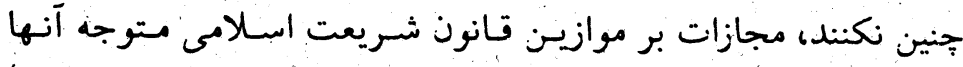
خواهد بود. در روزهاى بعد، روزنامهنغاران خارجى داستانهايى زاجع به موانه

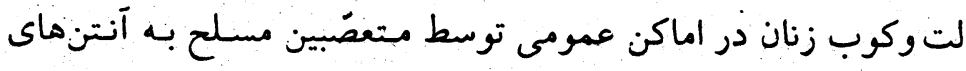

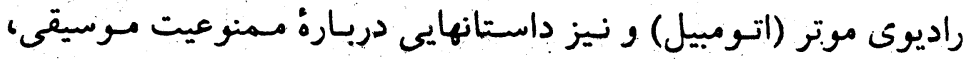

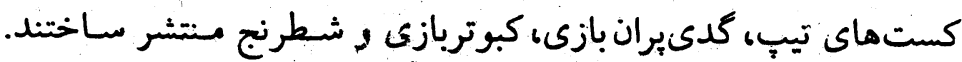

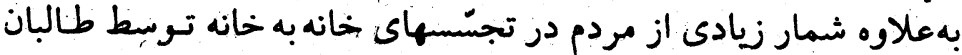

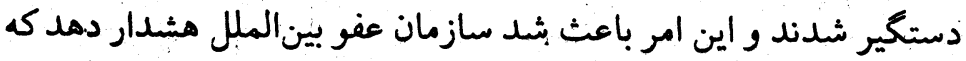

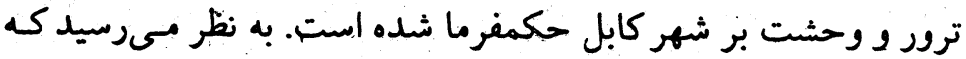
بنيادكرايى مذهبى از نوع بسيار خصومت آميز آن متولد شده است.

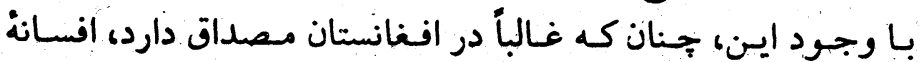

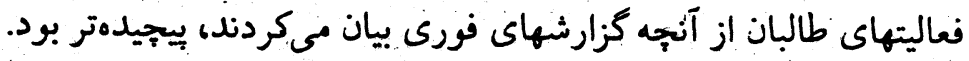

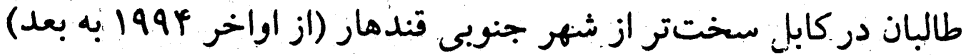
كوشيده بودند و نيز سخت التر از شهر غربي هرات (إز بستامبر 1990 به

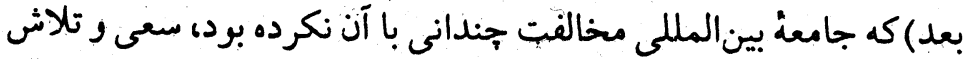

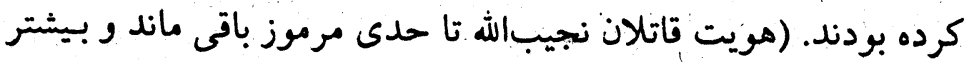

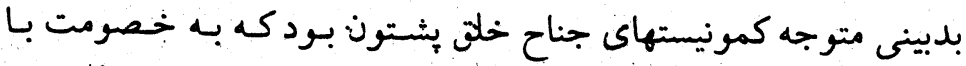

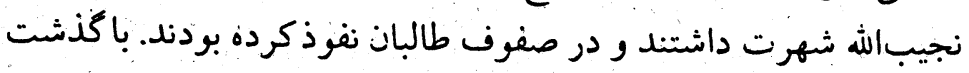

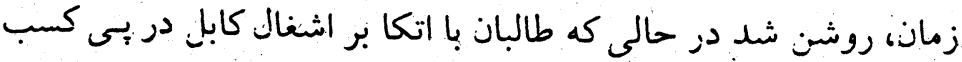

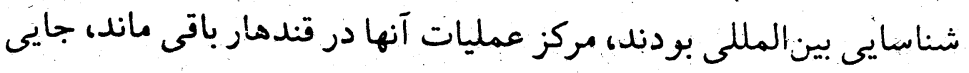




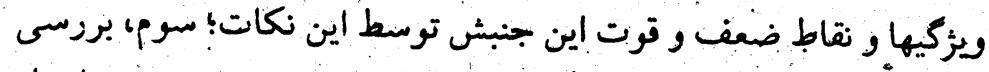

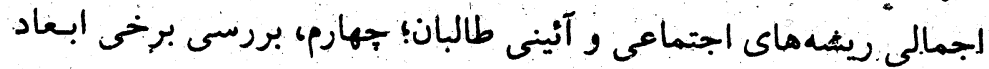

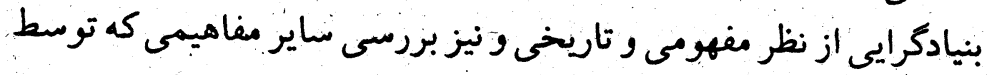

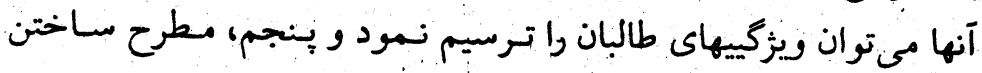
برخجى نتيجه كيرى انهاى نويسندكان اين كتاب.

\section{م. افغانستان به سوى بجران}

افغانستان كشورى است مجصور در خشكي، واقع در آمنياى مركزى كه با

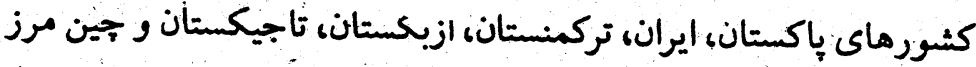

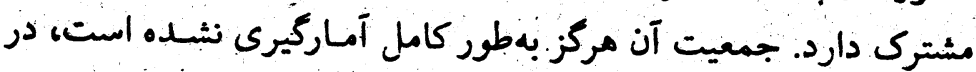

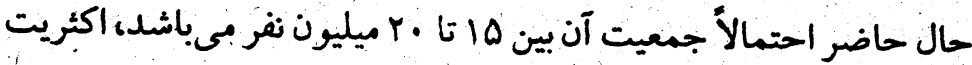

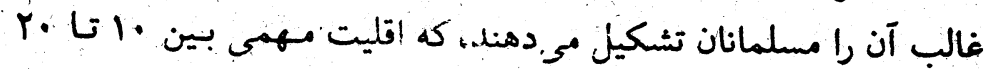
درصد آن ييرو مذهب شيعه هستند.

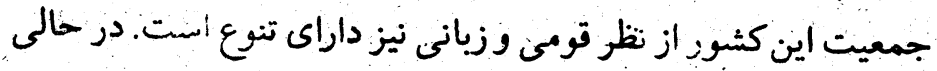

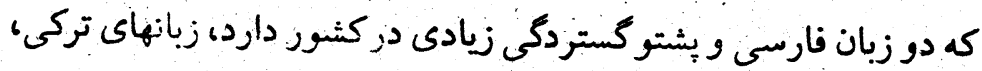

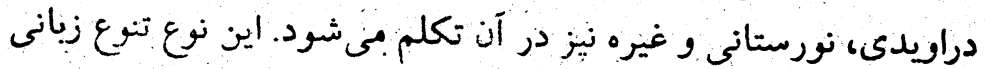

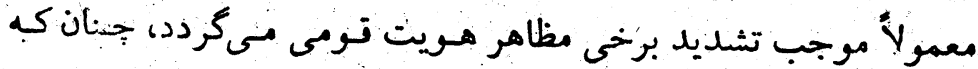

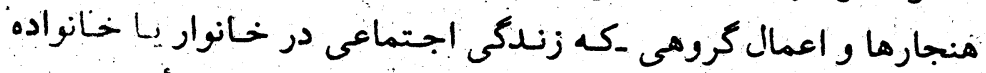

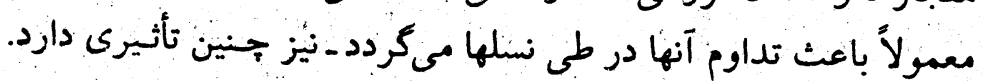

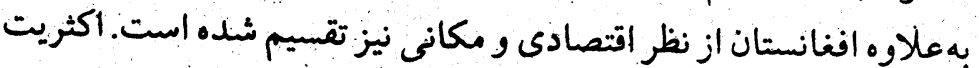

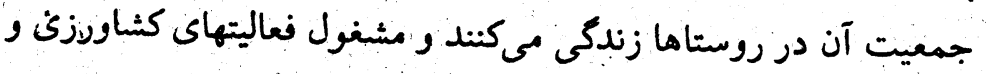

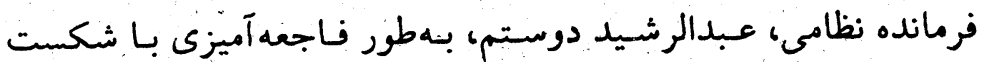

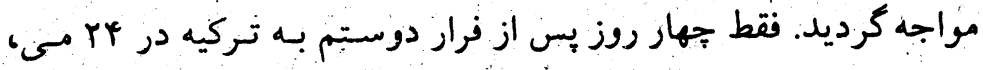

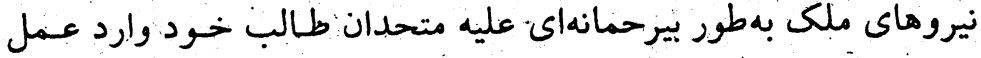

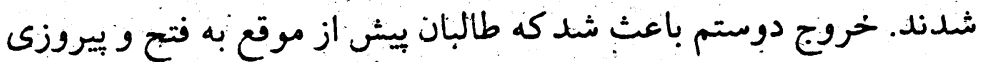

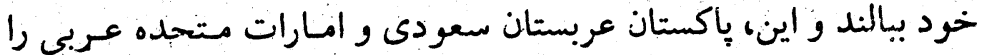

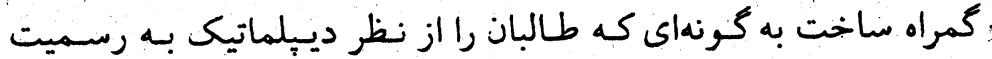

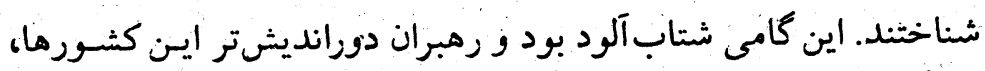

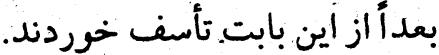

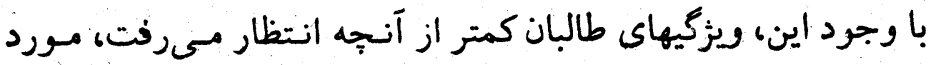

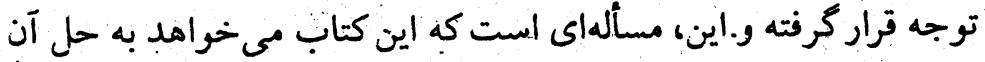

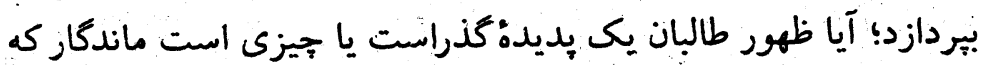

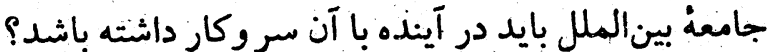

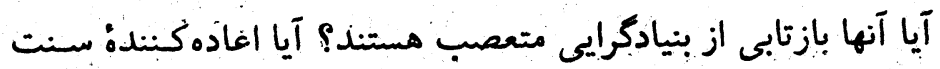

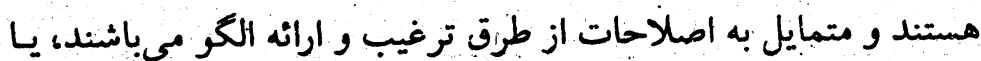

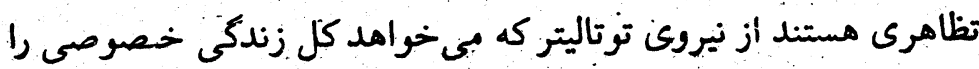

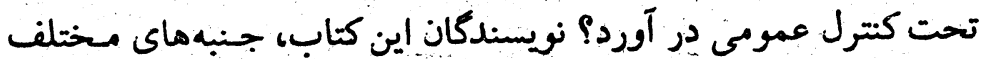

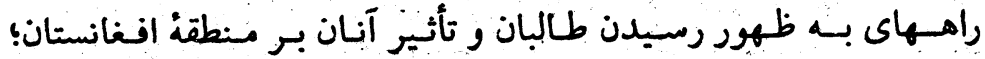

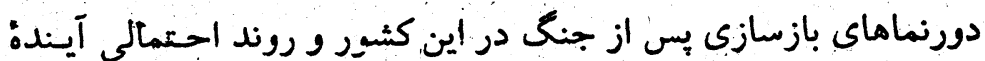

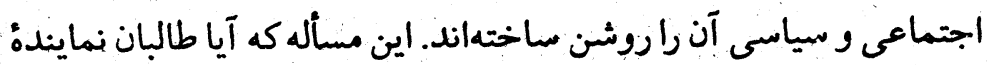

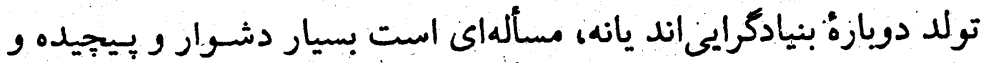

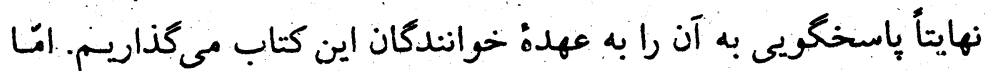

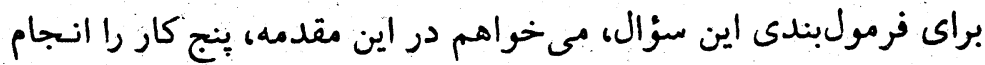

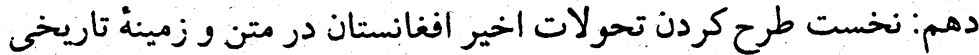

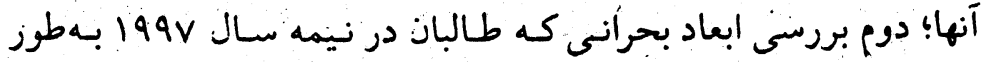

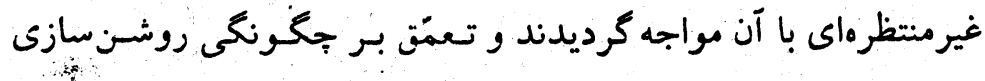




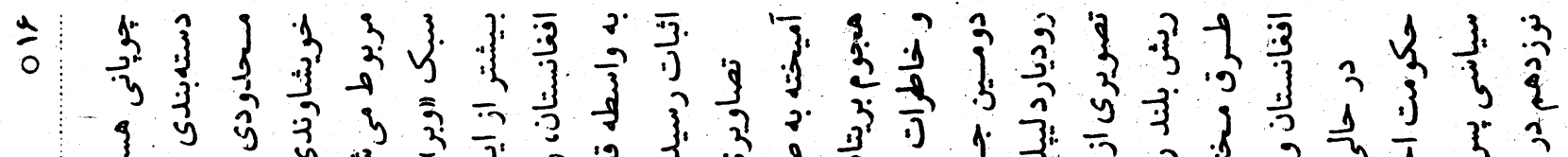

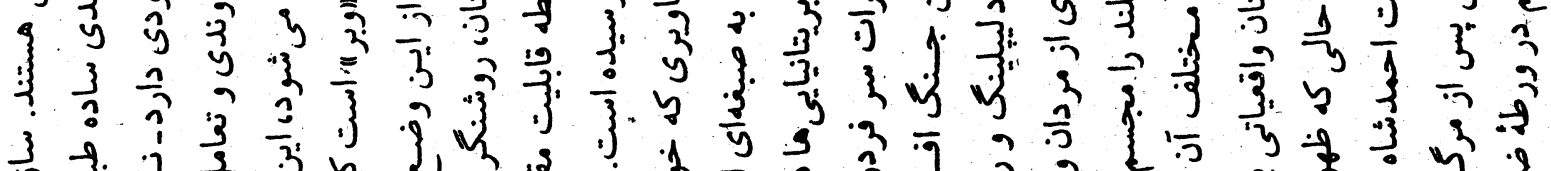

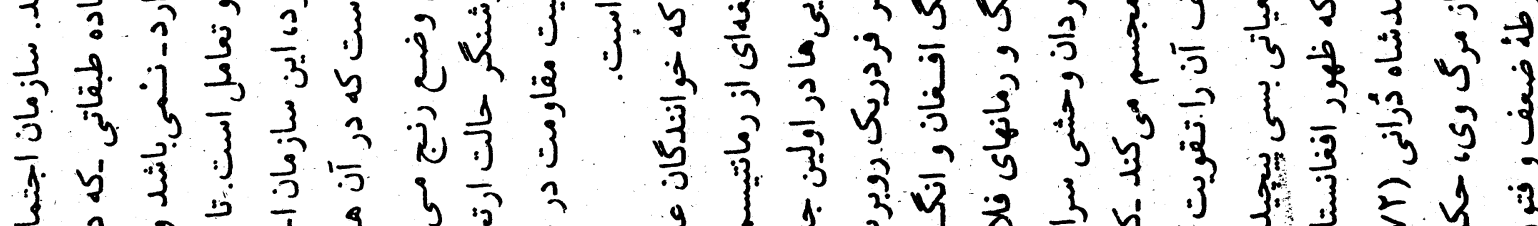

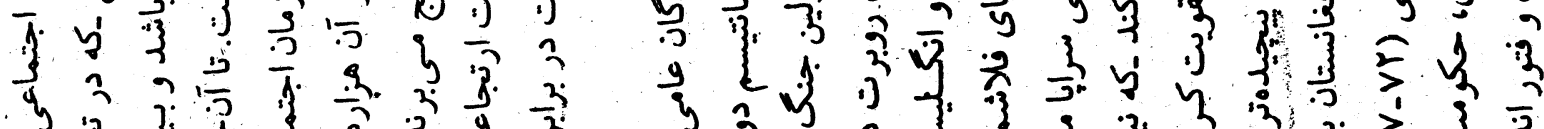

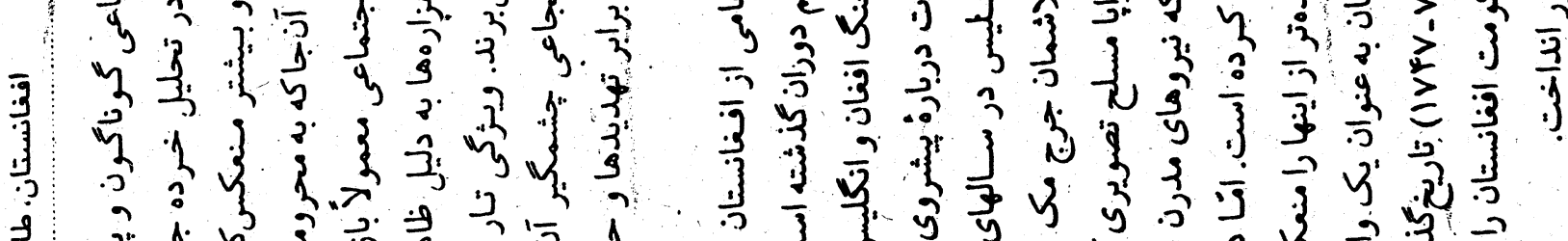

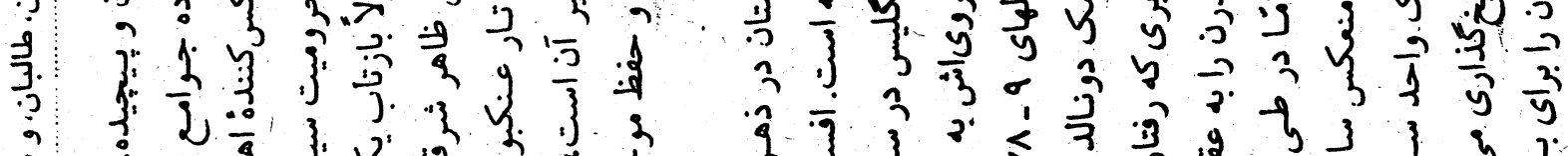

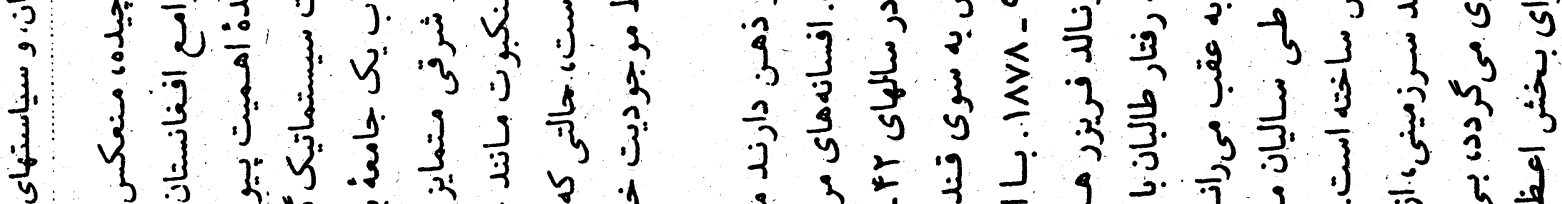

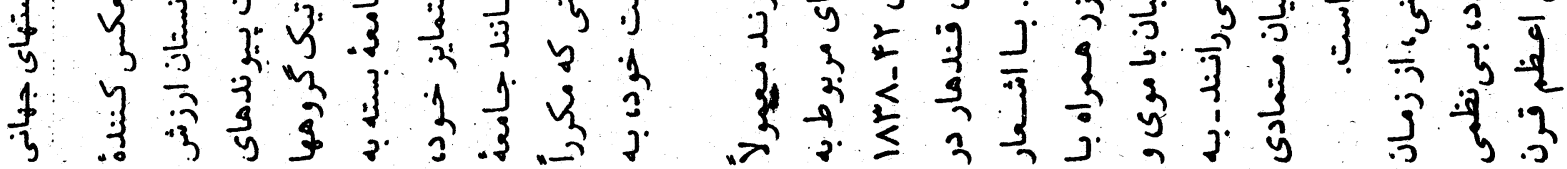

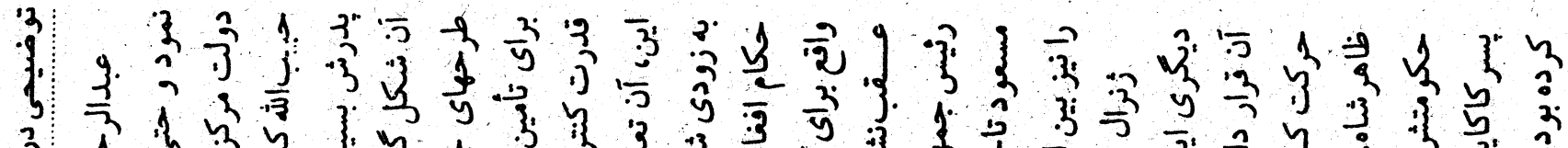

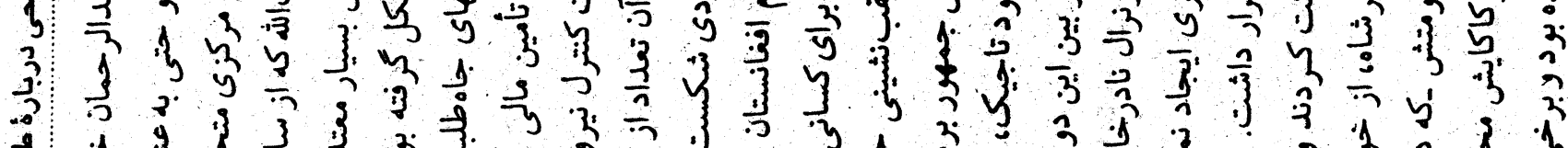

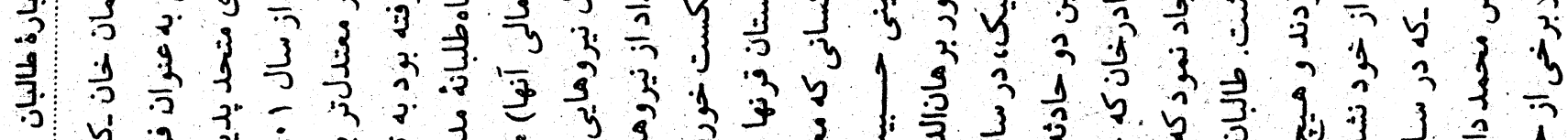

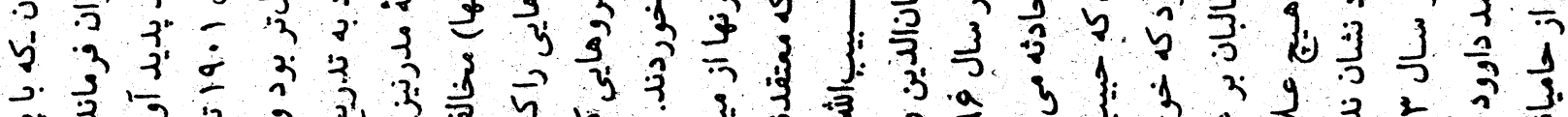

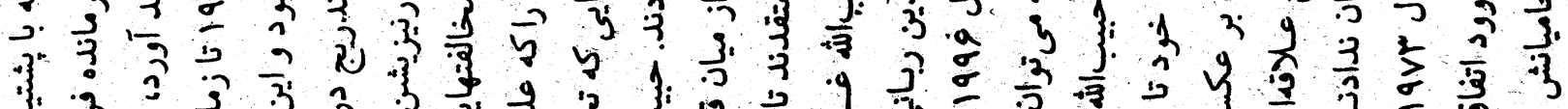

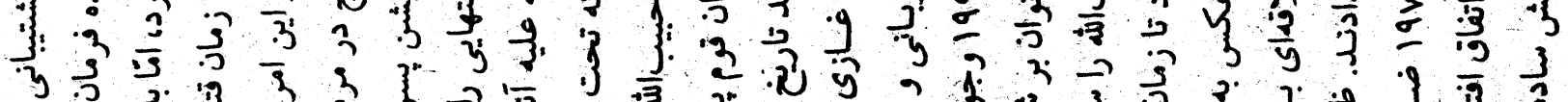

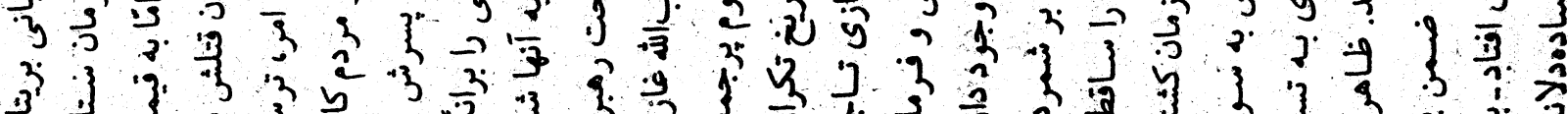

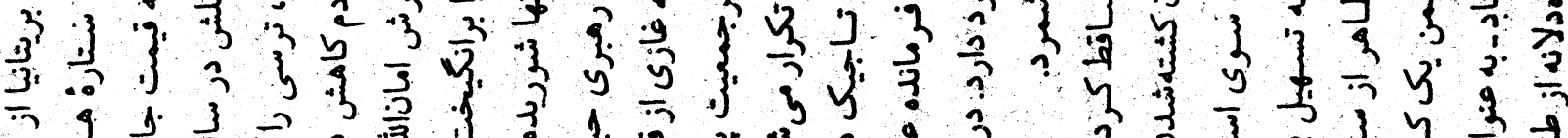

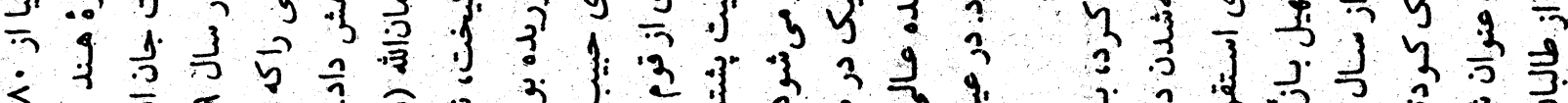

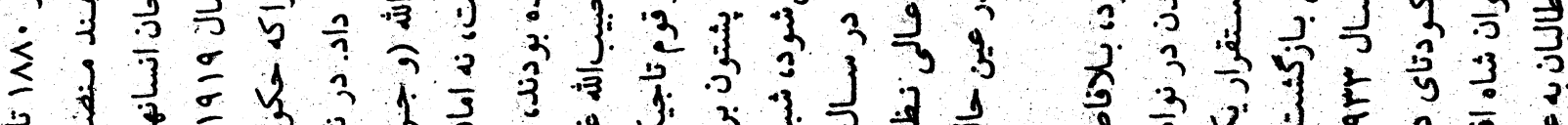

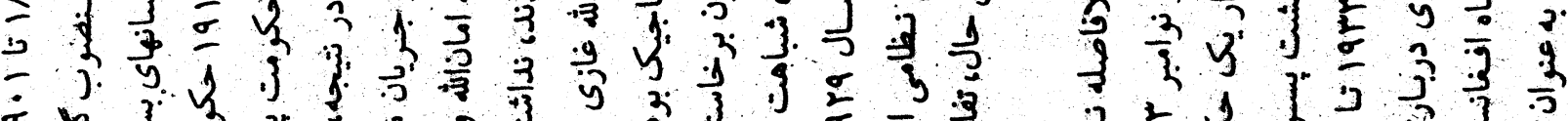

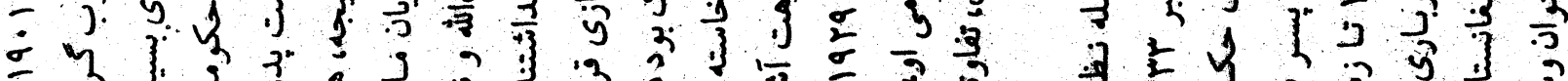

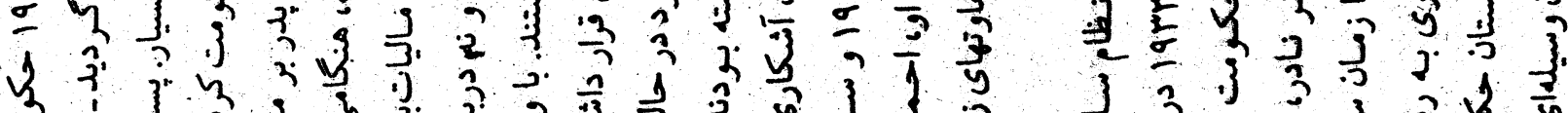

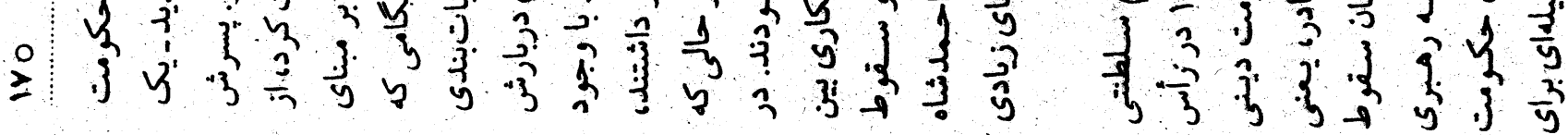


بر اساس دركي عميقاً نادرست از بيجيدگى مكانيسمهاى افغانستنان براى

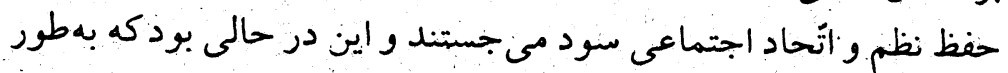

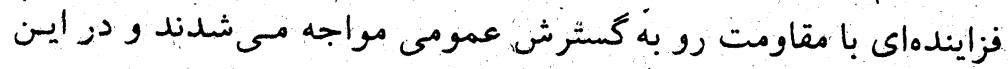

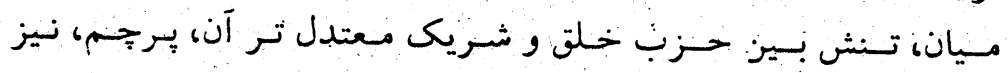

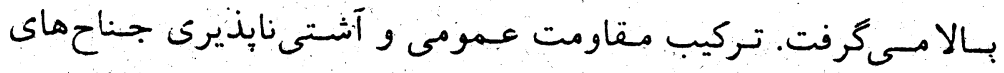

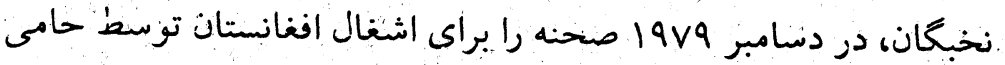

رزيم يعنى اتخاد شوروى آماده ساخت.

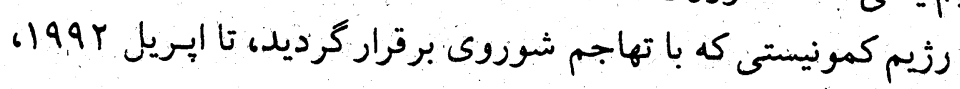

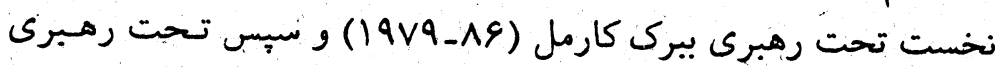

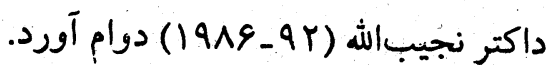

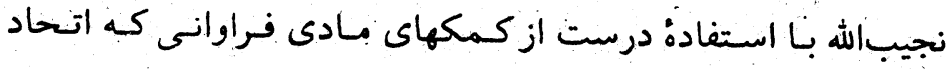

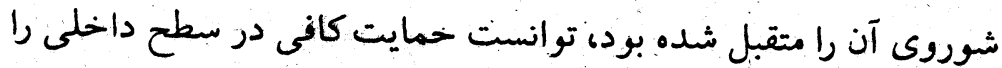

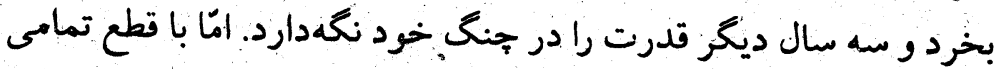

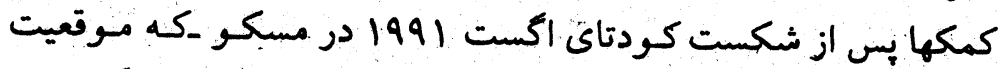

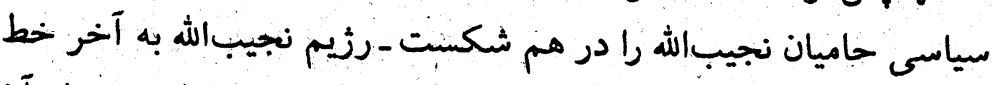

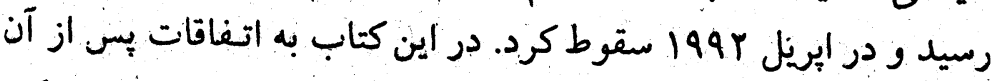

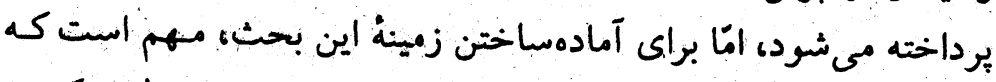

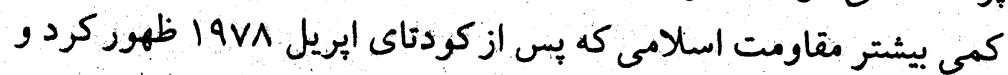

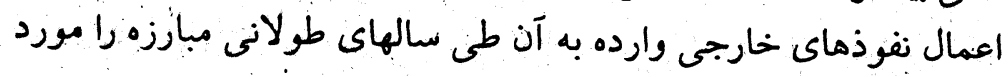

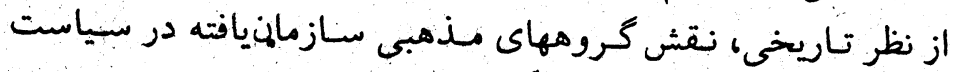

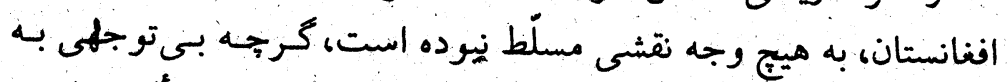

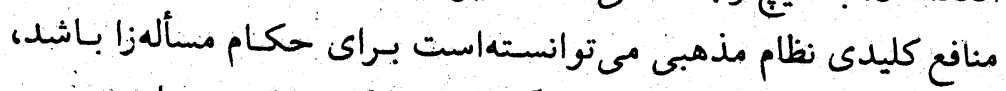

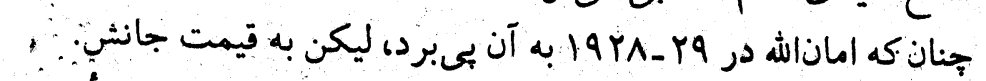

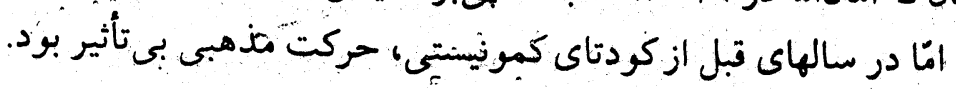

اعادة بقاياى حكومت قديم طرفدارى كردند.

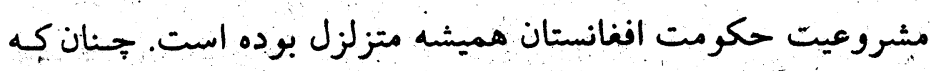

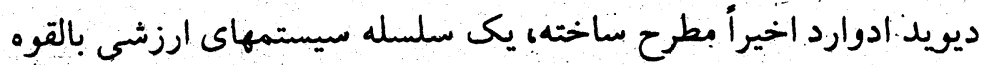

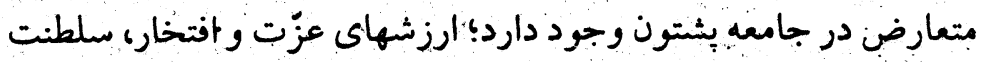

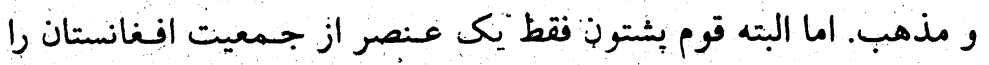

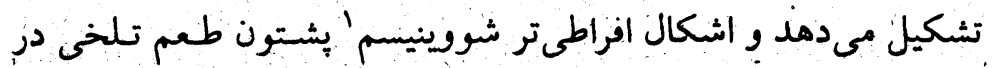

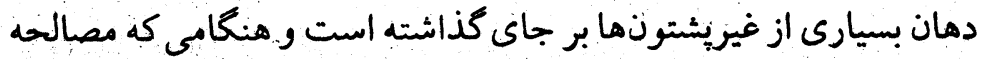

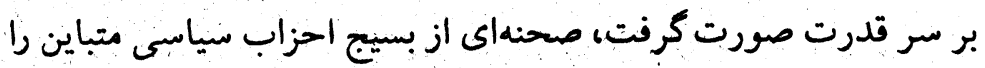

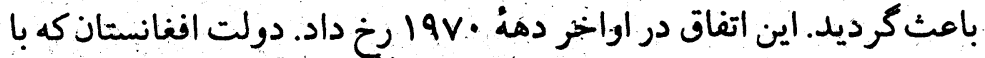

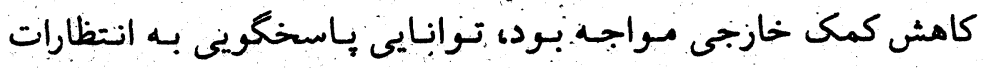

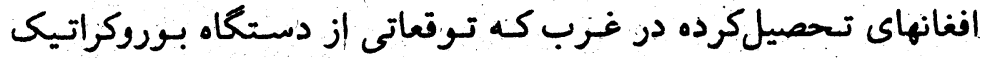

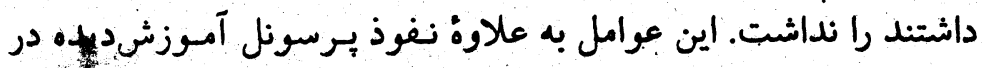

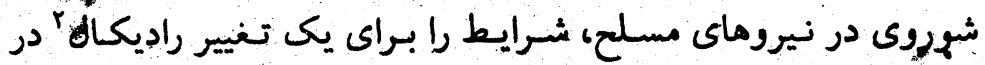

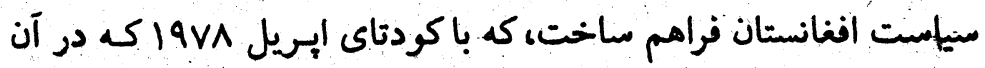

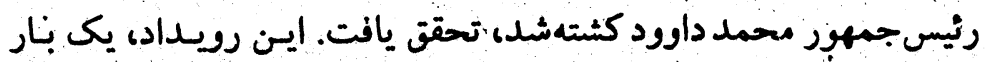

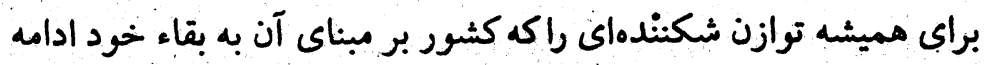

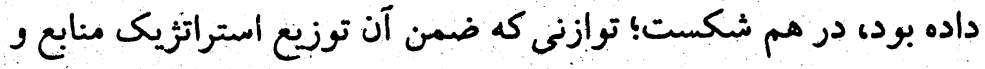

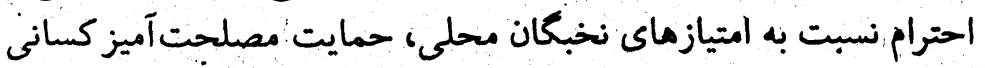

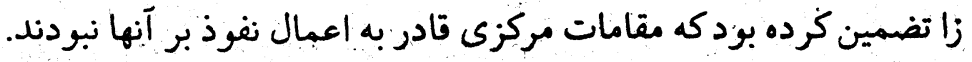

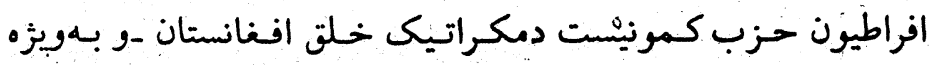

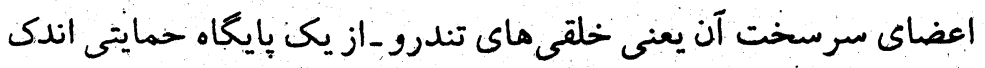

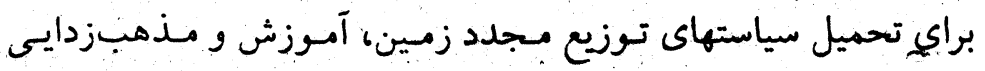

إ. ـ -شبورينيسم (ناسيوناليسم افراطى): سياستى كه هدف أن تحت نفوذ درأوردن و بردهناختن ملتهاى ديكر

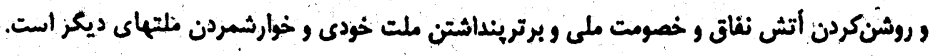

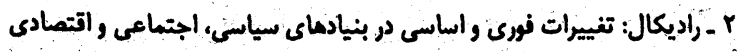




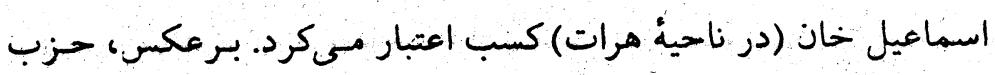

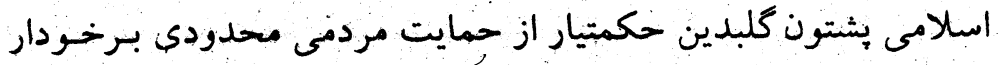

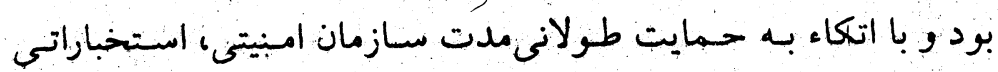

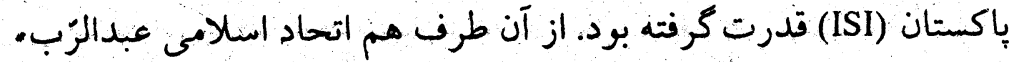

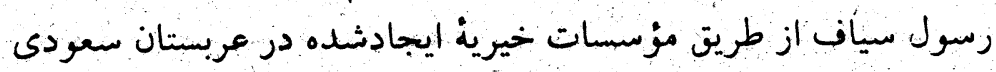

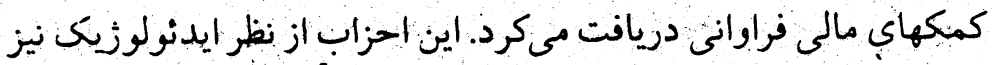

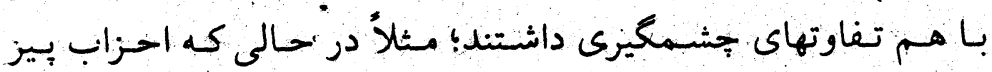

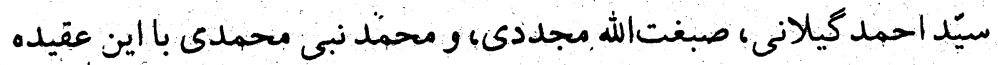

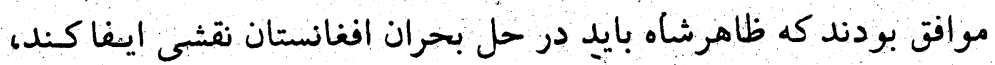

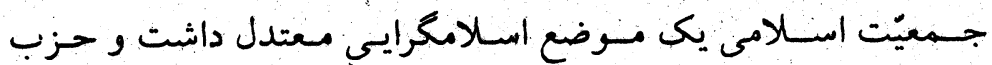

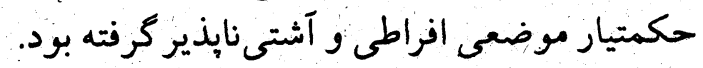

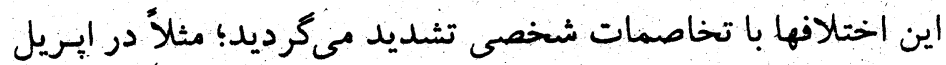

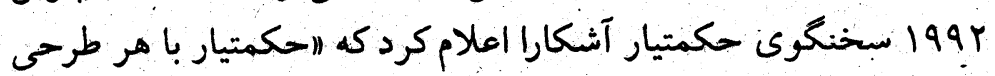

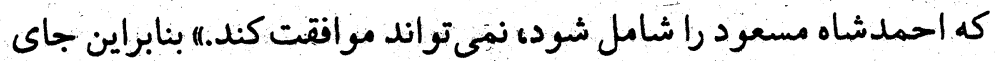

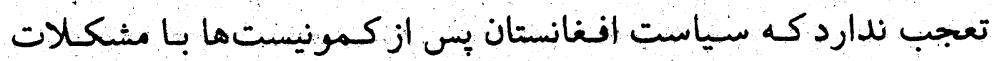
زيادى دست به كريبان كرديد.

\section{• بحران شمال}

وقتى طالبان كابل را تسخير كردند، منخالفين آنها دجبار بـىنظمى قابلز

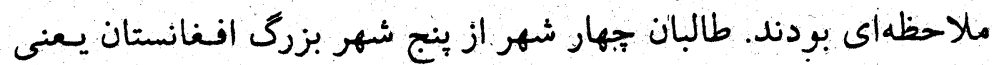

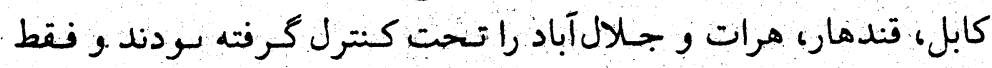

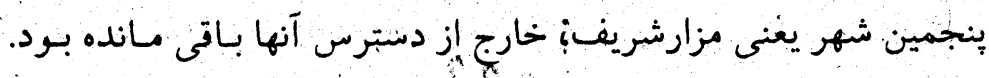

افنانستان، طالبان، و سينياستهاى جهابنى

كسانى كه مى خواستند به مخالفت باكثبف حجاب زنان در مسال 1909

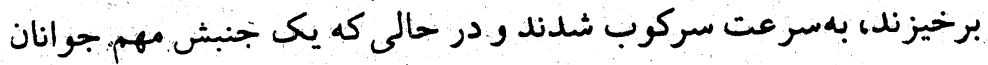

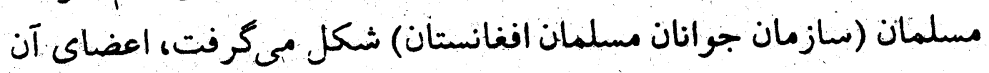

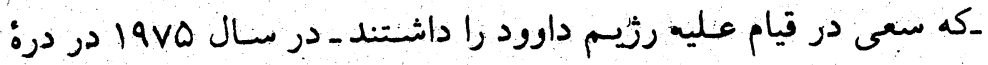

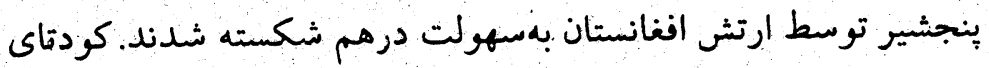

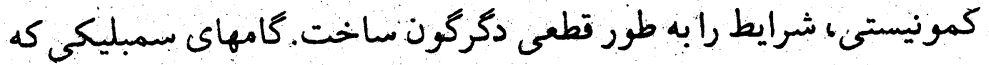

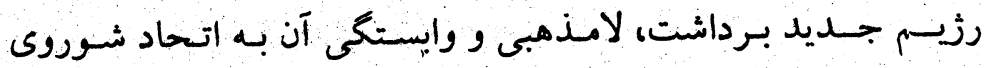

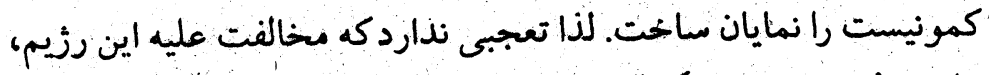

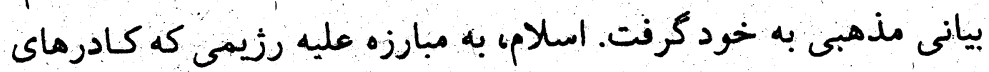

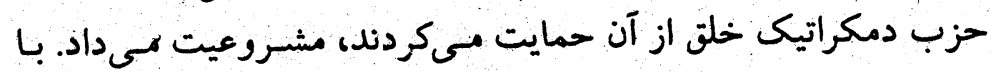

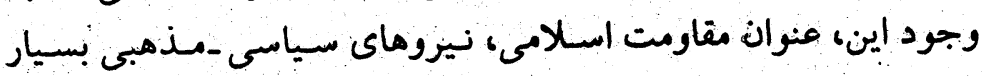

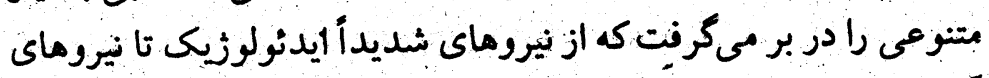

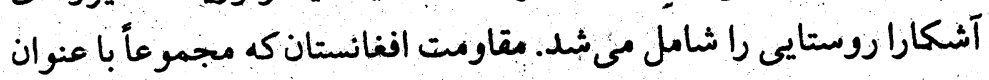

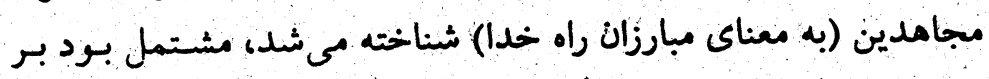

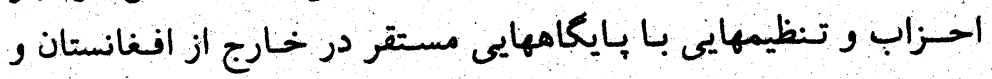

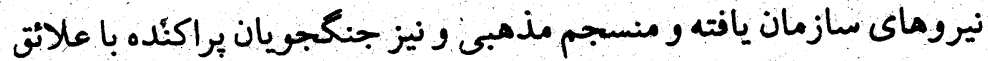

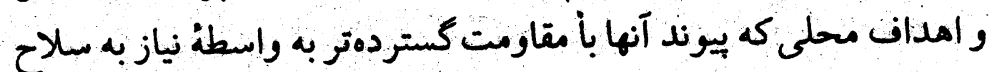

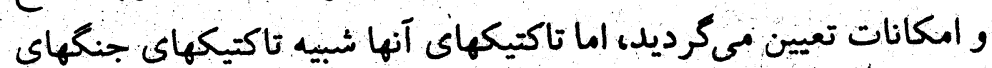

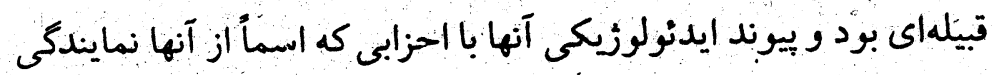

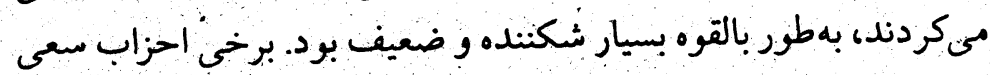

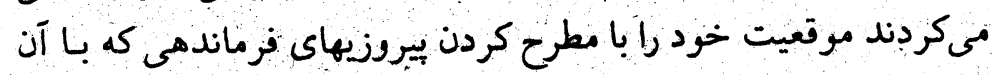

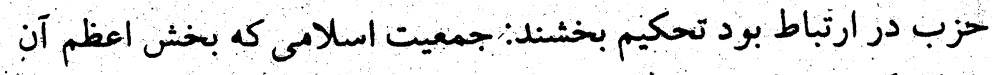

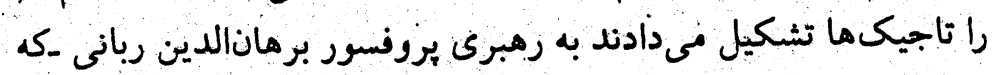

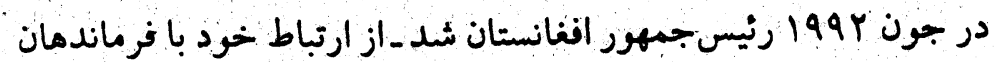

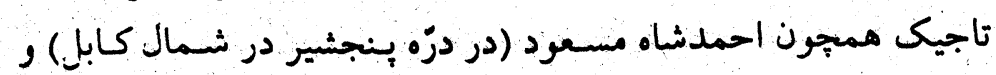




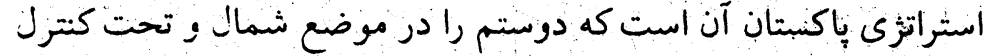

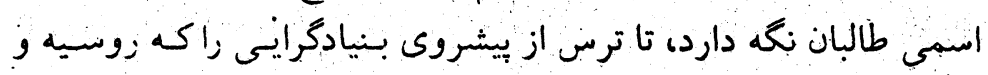

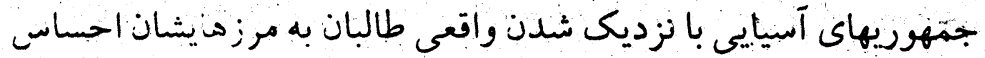

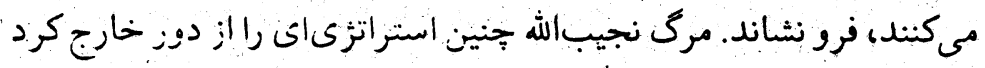

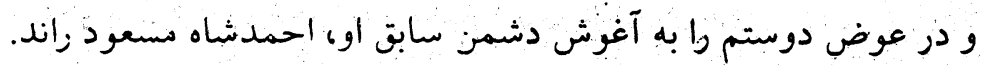

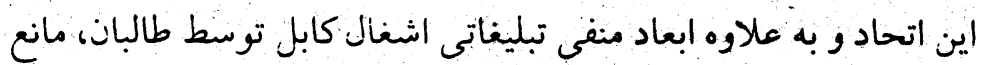

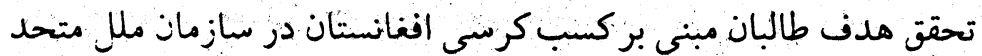

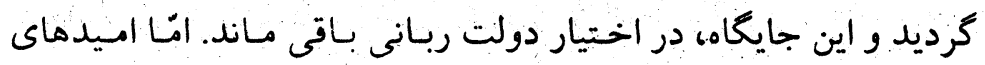

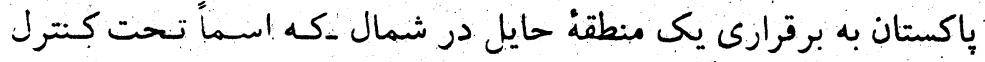

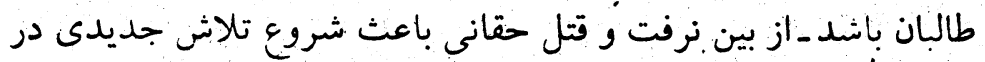
جهت تحقق اين امبر كرديد.

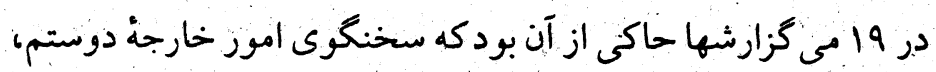

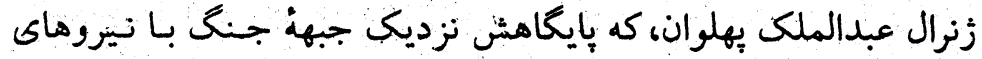

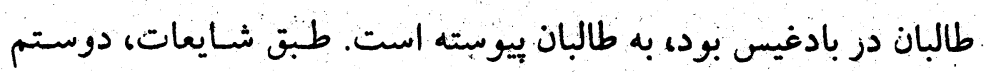

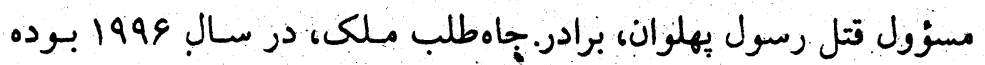

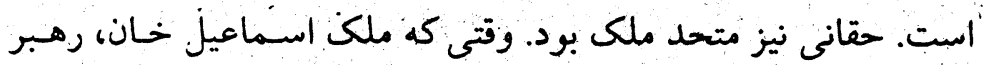

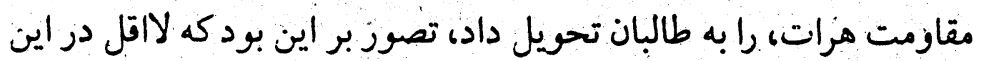

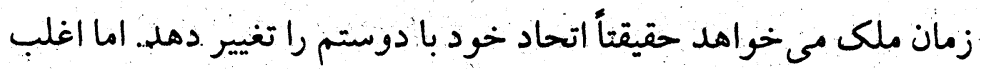

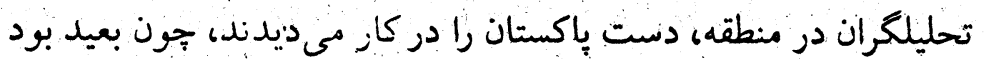

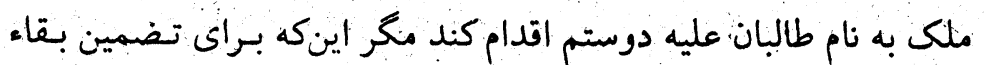

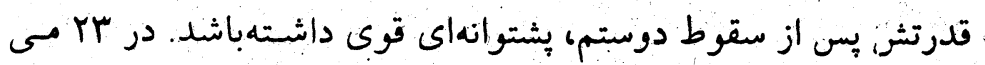

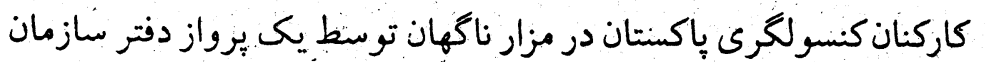

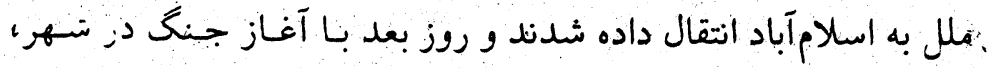

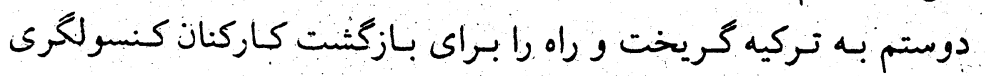
باكستان هموار ساخت.

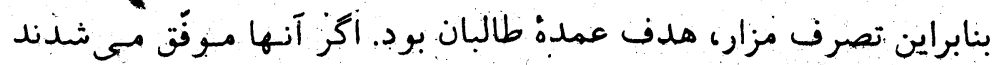

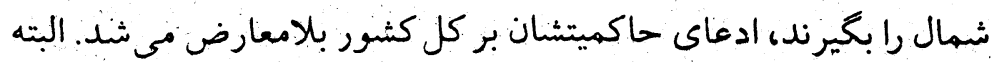

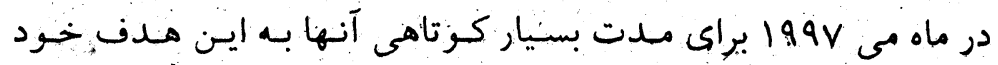

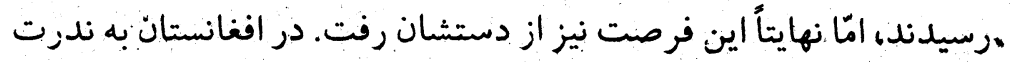

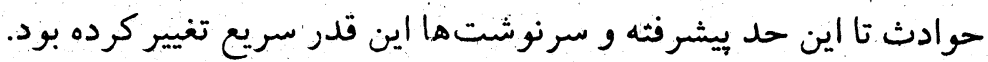

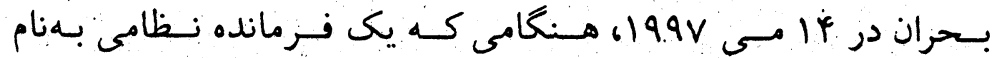

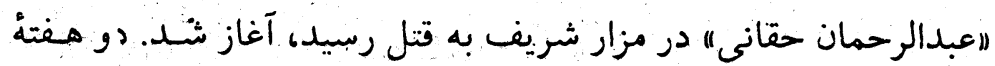

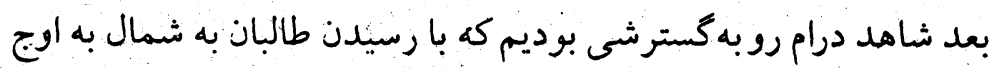

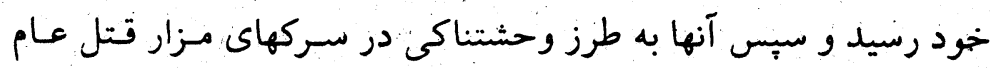

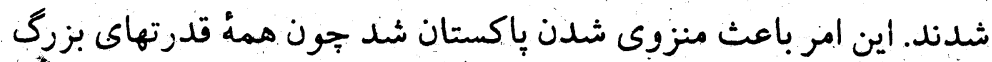

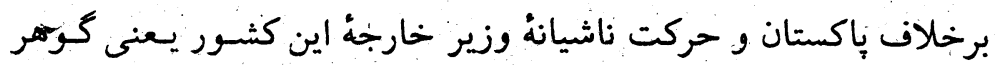

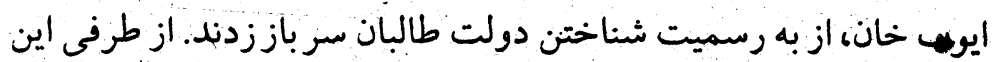

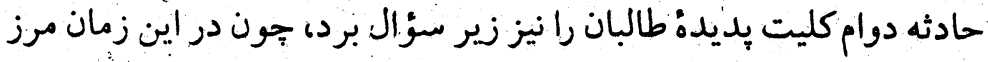
, موفقيت و شكست نيز. درهم ريخته بود.

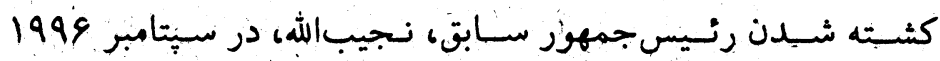

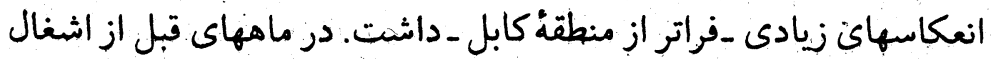

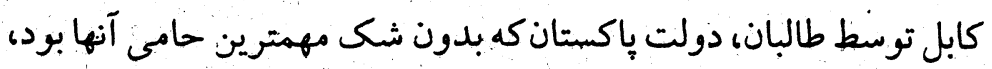

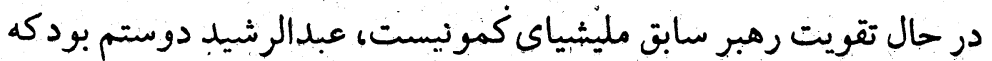
در مزار استقرار داشت. رو آوردن دوستم بـه مسجاهدين در اوائل سـال

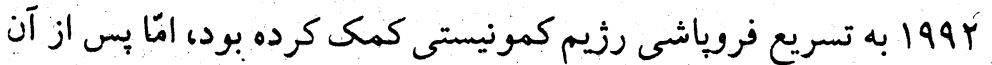

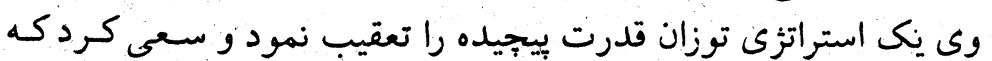

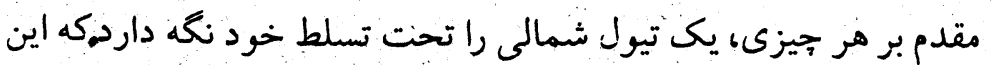

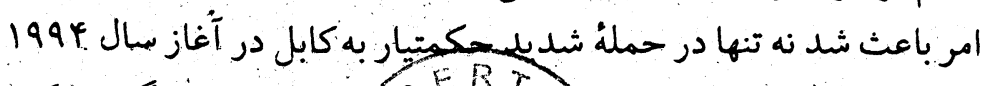

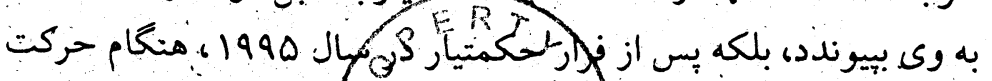

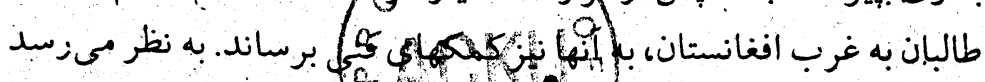
7822 
اضلى طالبان در مزار دستخير شدند و ديخر رهبران آنها در تونل مالنح بـان

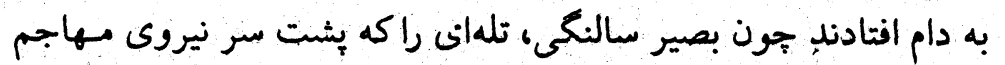

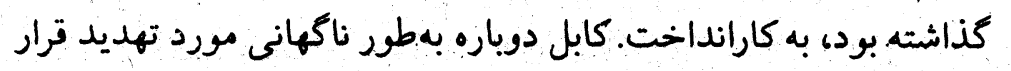

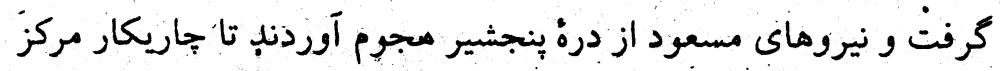

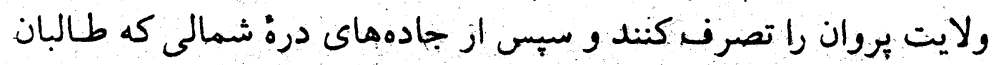

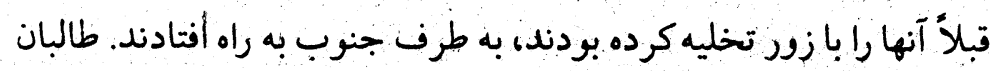

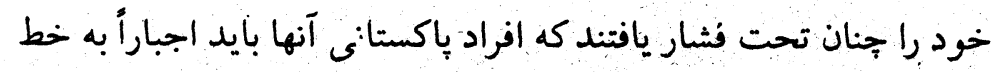

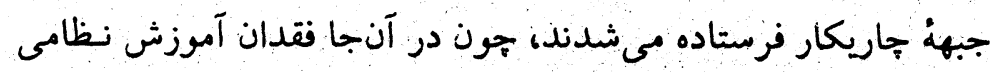

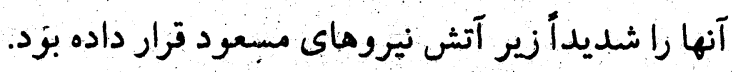

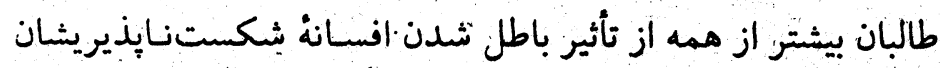

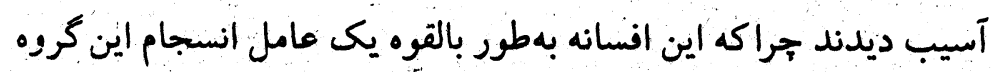

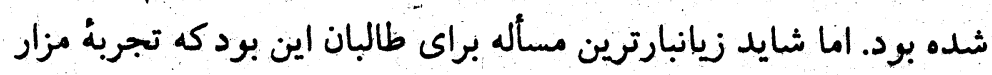

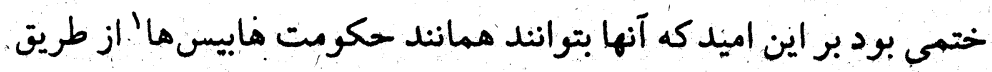

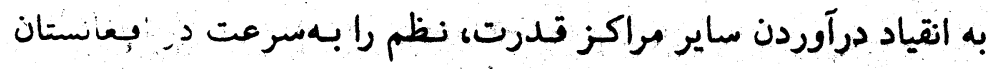

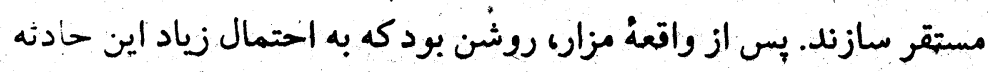

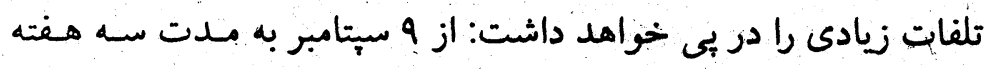

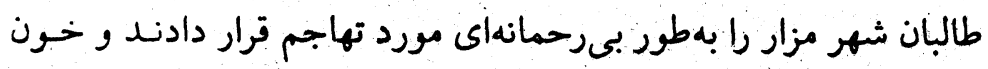

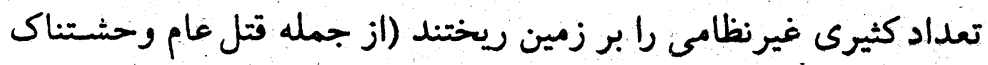

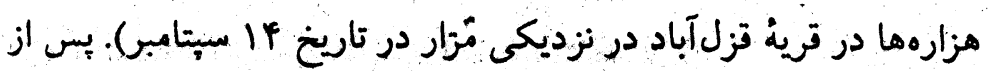

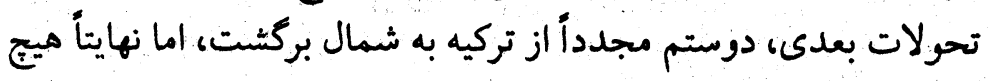

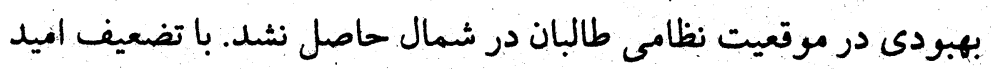

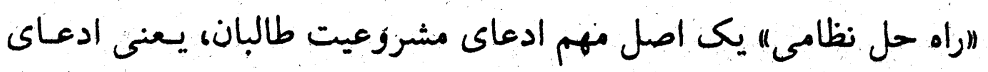

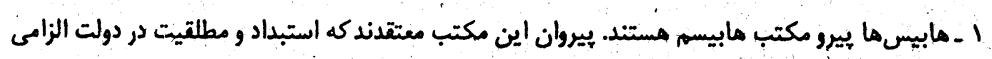

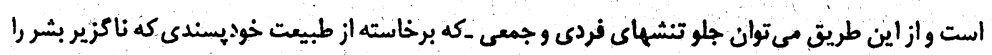

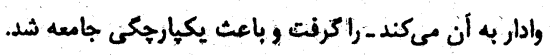

بعدازظهر روز YO مى باكستان ضمن يك كنفرانس مطبو عاتى عجولانه

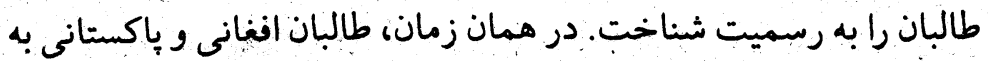

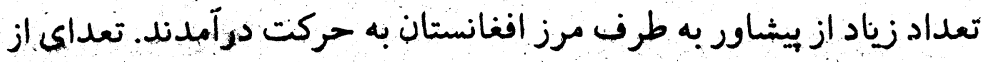

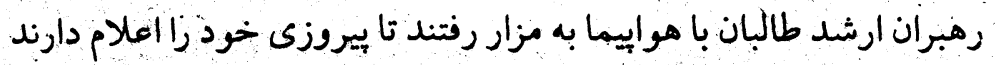

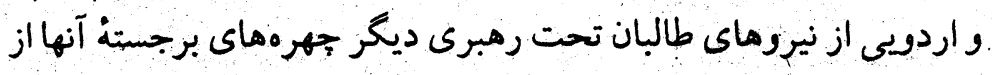

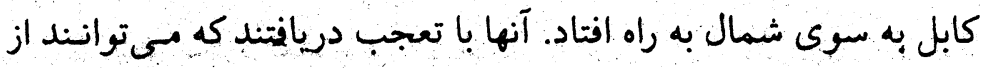
سلسله جبال هندوكث عبور كنند جراكه يكى از فوماندهان ارشد مسعود

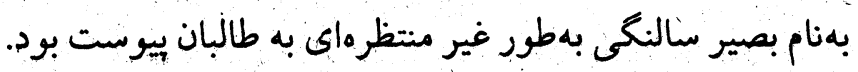

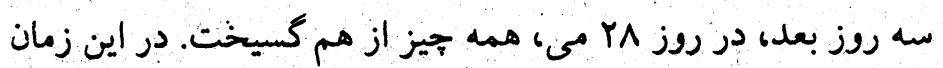

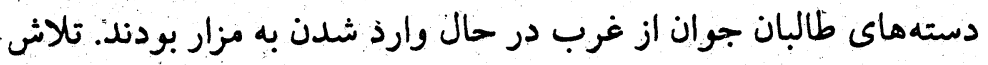
آنها برأى خلع سلاح برخى از نيروهاى ملنى منجر به تبادل آتش بين آنها

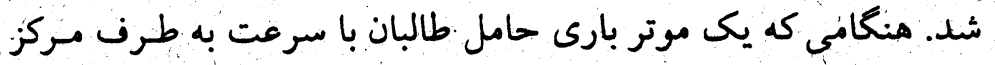

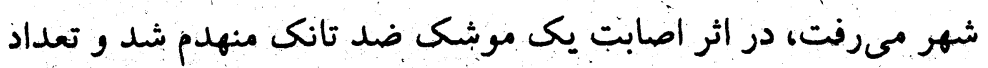

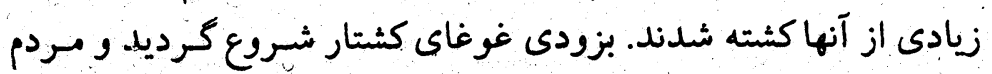

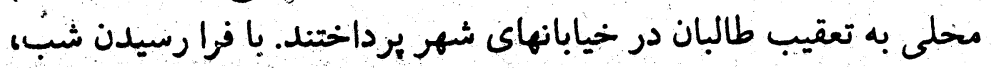

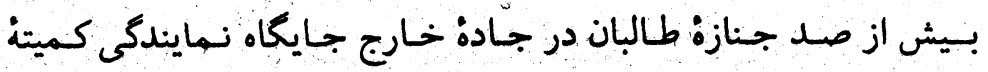
بين المللى صليب سرخ افتاده بود. اتحاد بين ملبل و طالبان به كلى از بين رفت و على رغم تلاثرقتانكيز باكستان در ه جون براى تسجديد ايسن

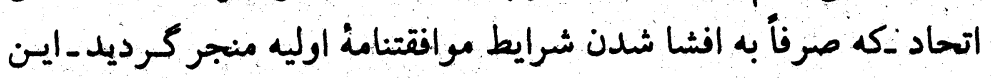

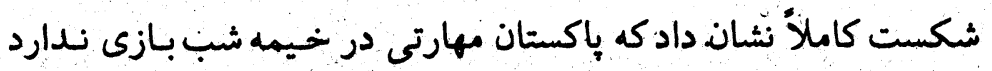

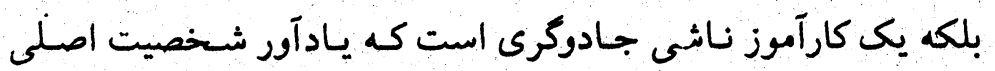

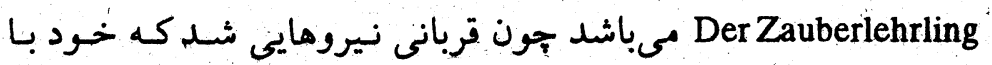

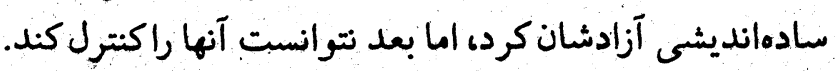

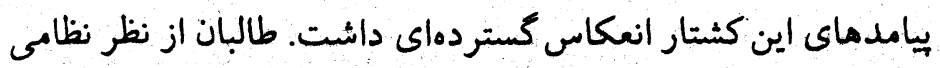

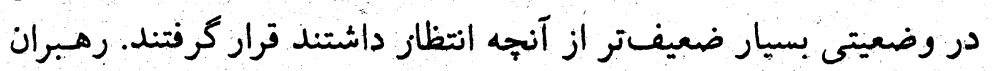


نوشته است. در افغانستان در قرن بيستم مؤسساتى با خرج دولت بـراى

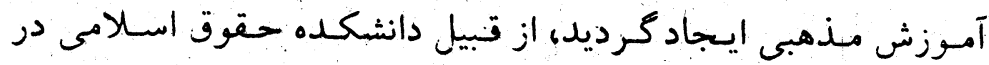

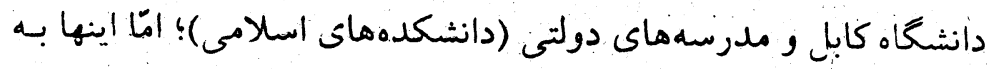

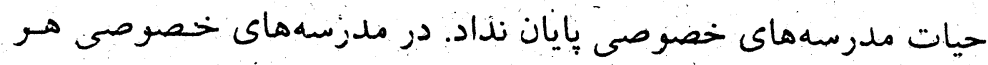
طالب در هر زمان يك موضوع را با سرعت فردى خود مى آموخت. ظهور

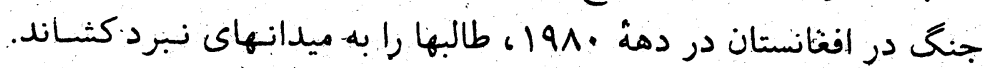

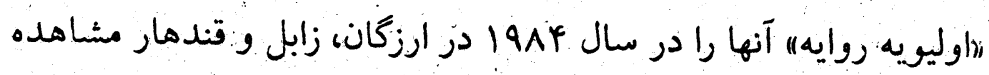

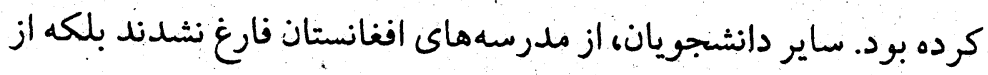

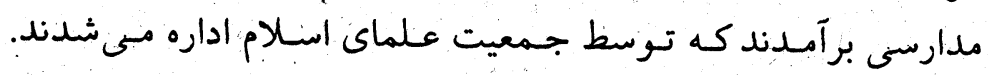

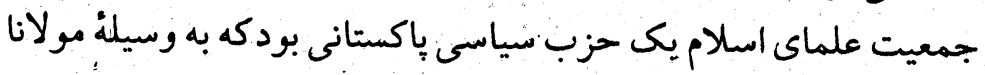

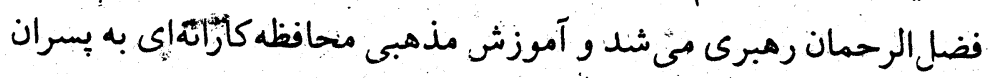

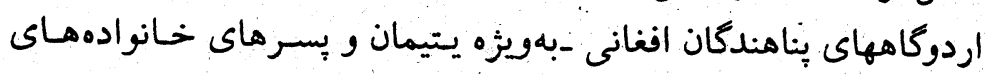

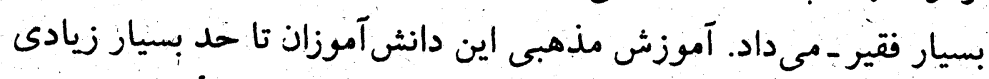

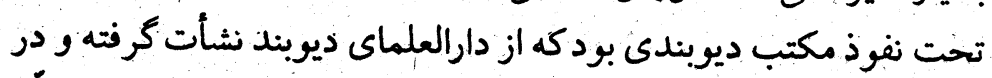

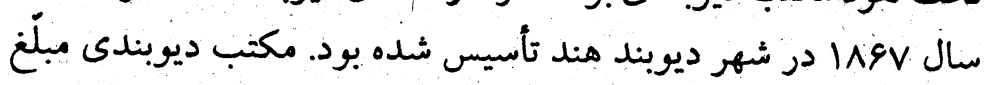

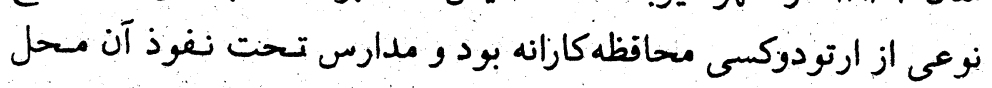

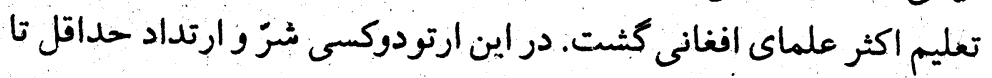

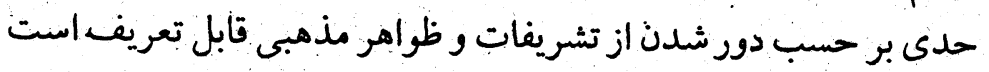

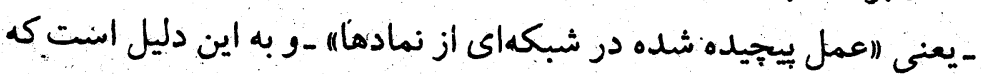

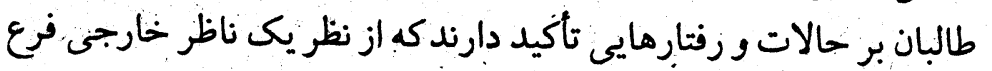

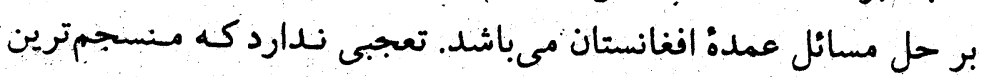

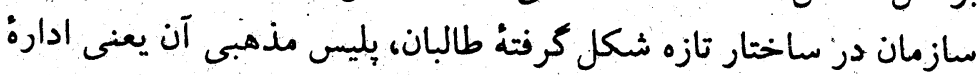

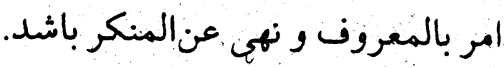

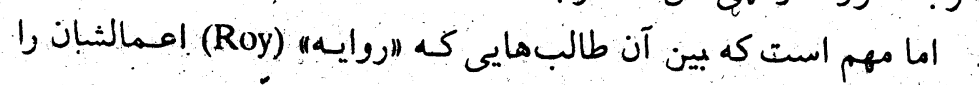

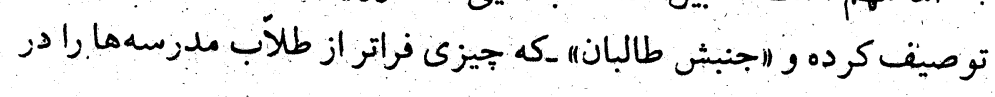

توانيى بر خاتمه دادن به هرج و مرج، رو به ضعف نهاد و اكنون مسبلم

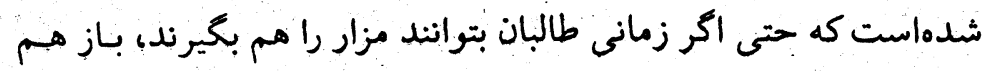

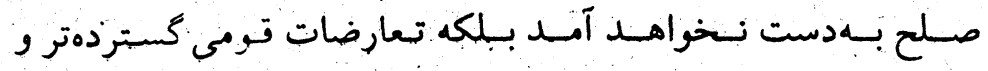

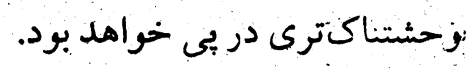

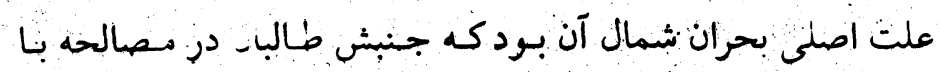

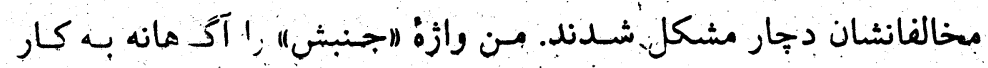

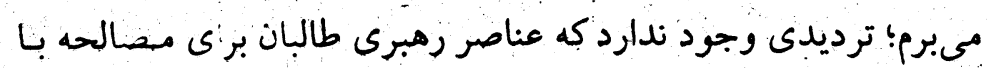

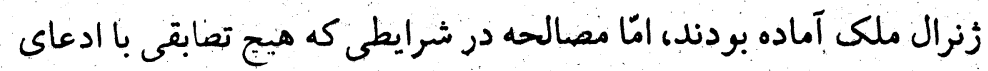
طالبان مبنى بر خلع سلاح نيروهاى فساد نداشت و به خوبى روشن بودئه

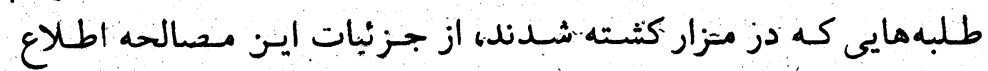

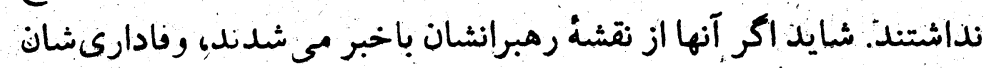

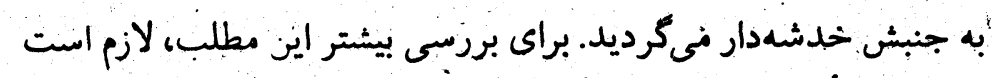

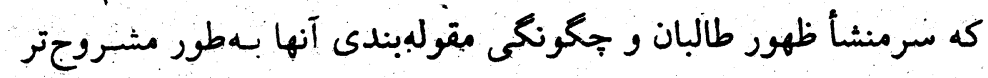

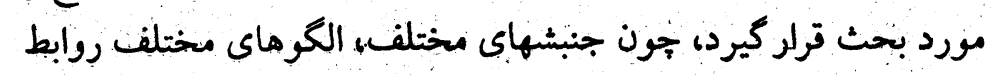

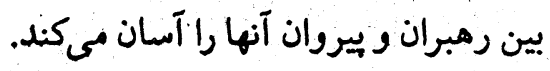

\section{• ريشههاى اجتماعى و آثينى طالبان}

طالبان از ناكجاآباد نيامده بودند، هي جند محيط مشخص رشد آنها مورد

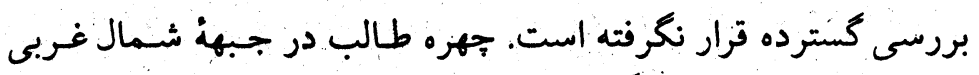

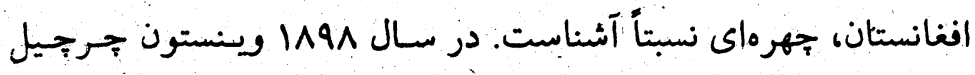

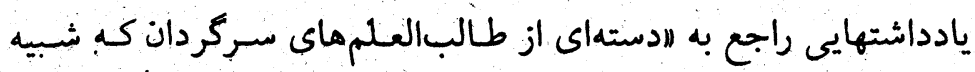

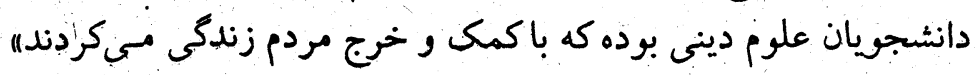


بإكستان و عربستان سعودى بهره مي كيرد كه اين امر آن را از شَسكل يكن

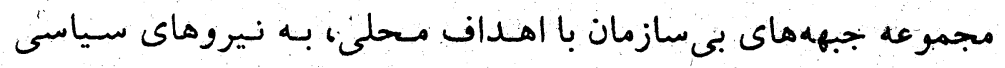

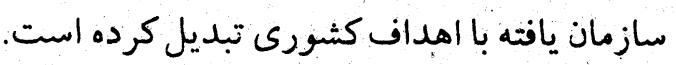

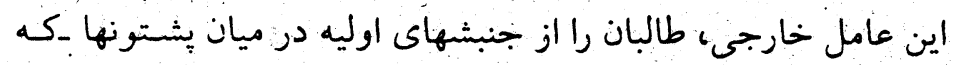

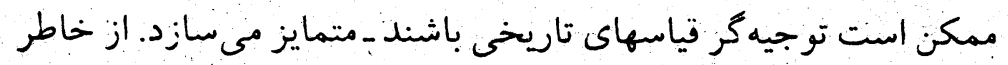

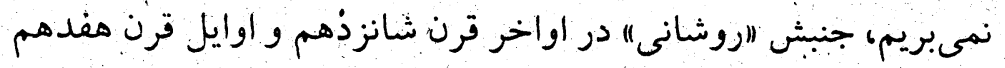

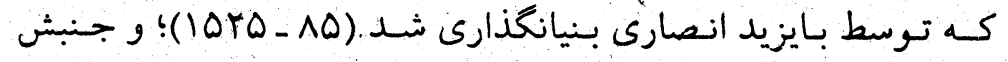
مجاهدين ضد سيك كه به رهبرى سـيد احسمد بـارلوى در اوايلن ترن

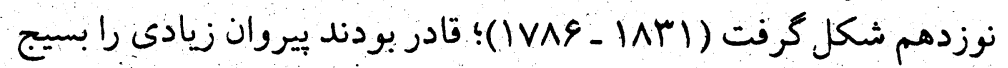
كنند، اما در مقاطع حساس زمانى، از انسنجام سنازماني برخوردار نبودند در حالى كه اين آسيبيذيرى سازمانى را حمايت خارجى مسى توانست

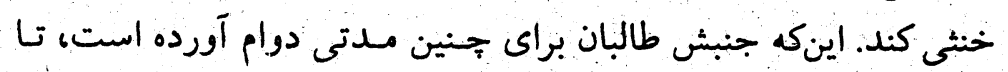

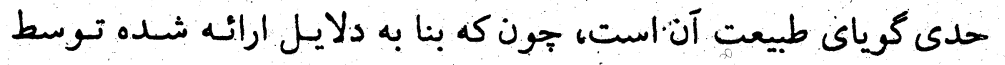

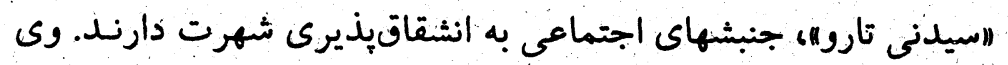

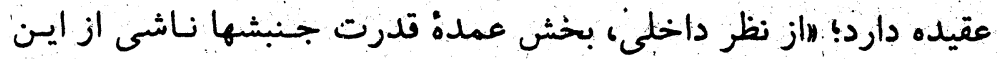

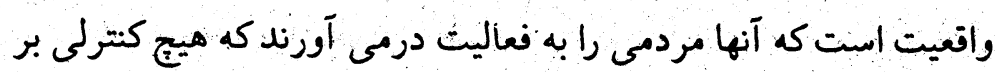

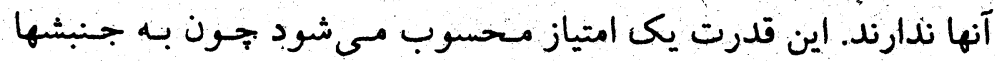

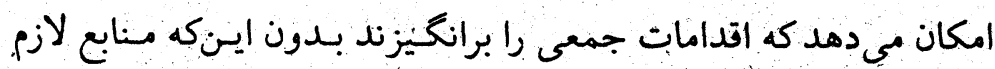

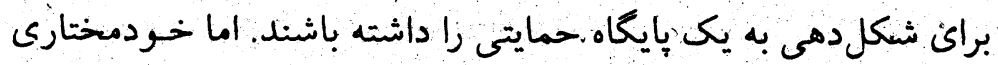

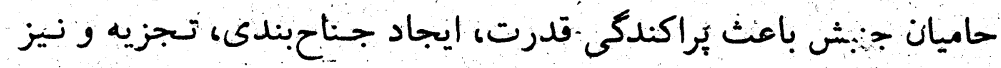

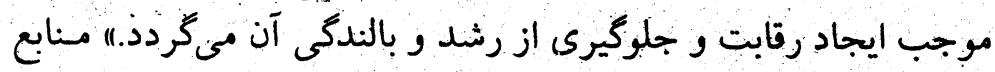

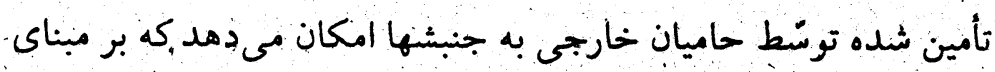

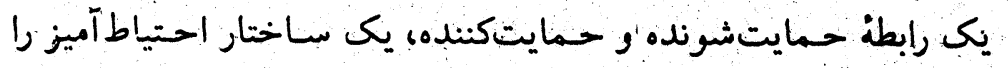

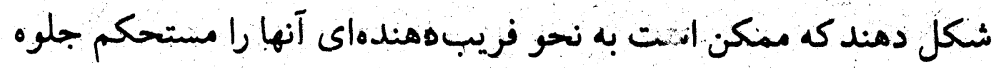

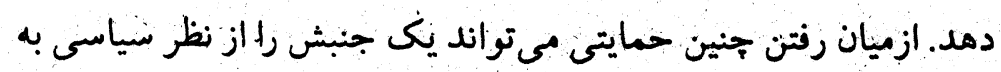

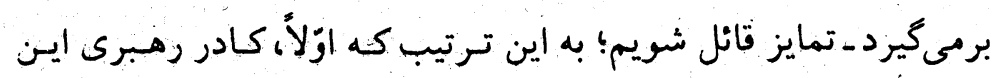

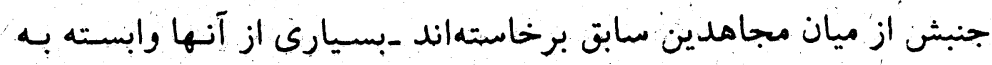

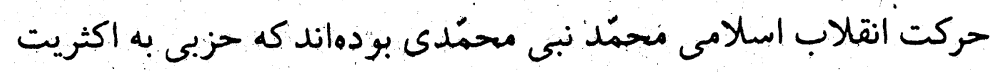

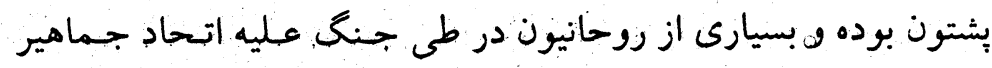

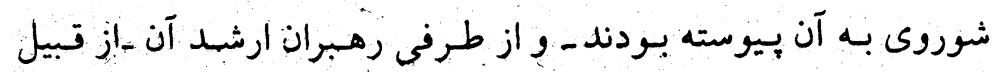

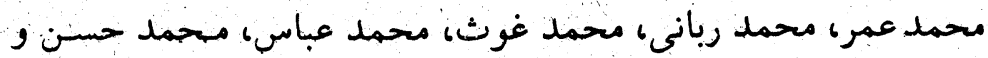

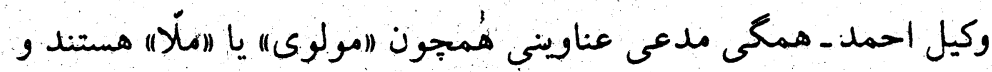

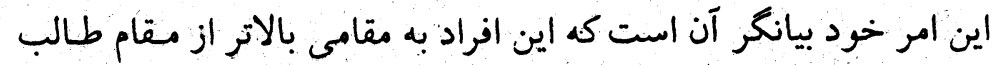

رسيدهاند. ثانياً، جنبش طالبان شامل بشتونهايى با مبابقة آشَكار غيرمذهبى نيز

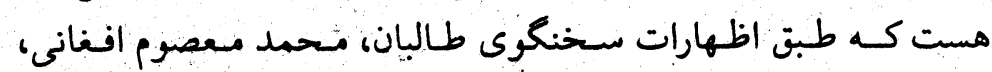

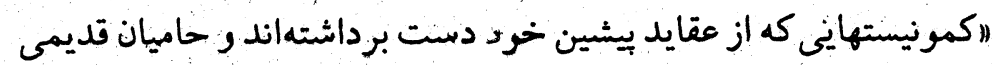

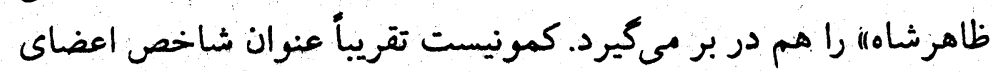

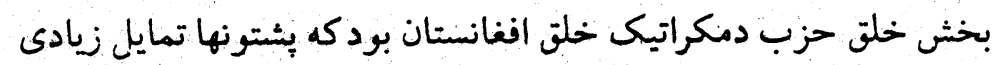
به آن داشتند.

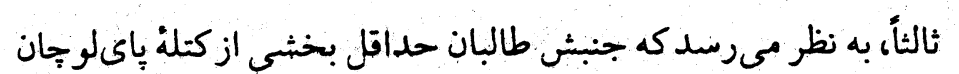

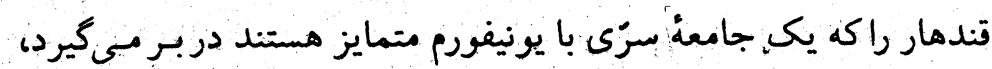

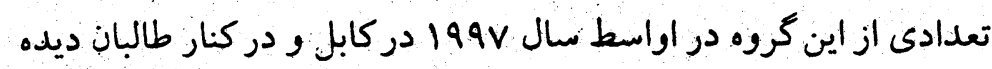

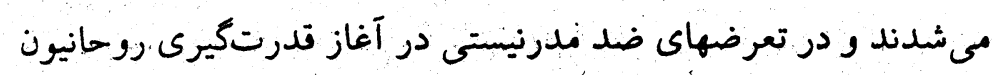

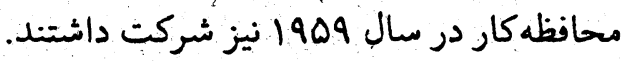

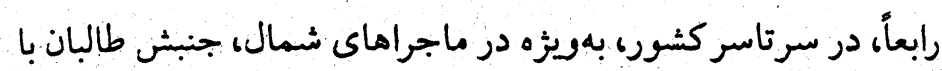

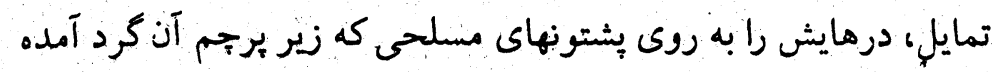

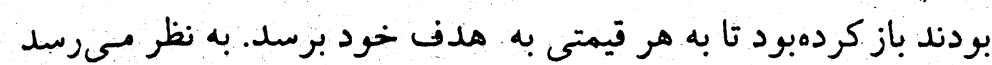

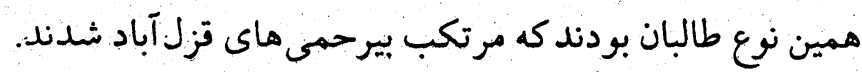

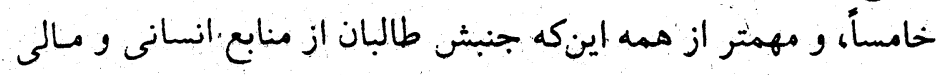


إست. طلق نظر "إِارخ" (Parehk) بنيادگراييى مستلزم جدايى بين مذهب و

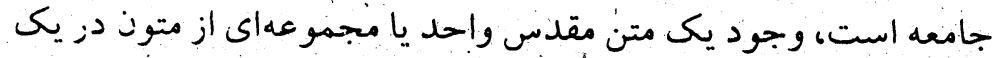
رابطة هرارشيك (سلسله مراتبى) با يكديخر؛ دسترسى مستقيم معتقدان.

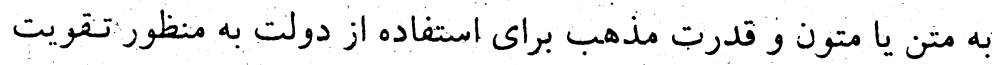

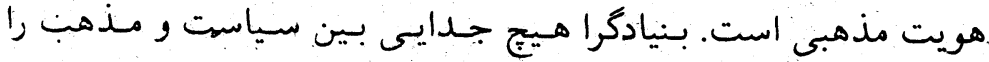
نمى يذيرد؛ هدفش اين است كه دولت را بهدست آورد و از آنا استفاده

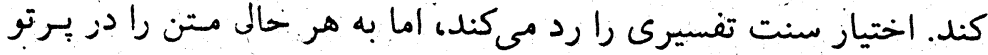

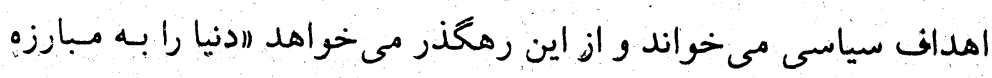

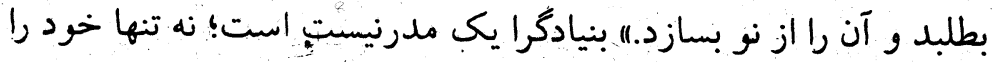

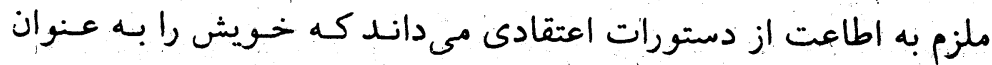

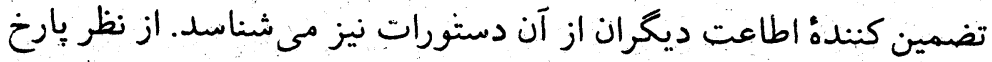

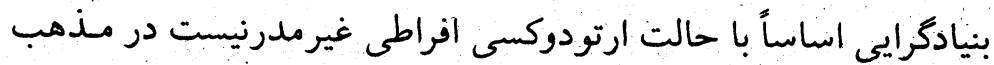

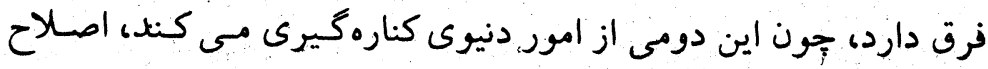

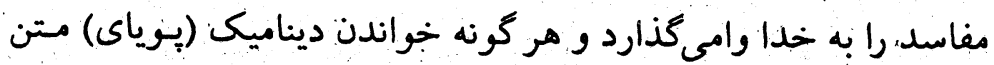

$$
\text { مذهبى را مردود مى شمارد. }
$$

نكته ذيخرى كه غالباً ناديده گرفته مى شود د امًا مهم است، به نقش رهبر در جنبشهاى بنيادگرايانه مربوط مىباشد. از آنجايع كه متنهاى مقدس

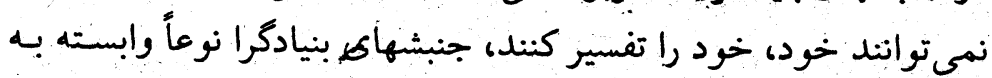

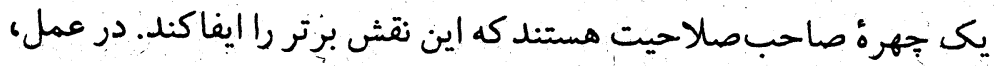
بنيادگرايى بيشتر به يك رهبر خاص متكى است تا به يك دكترين خاض.

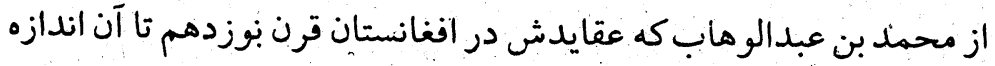

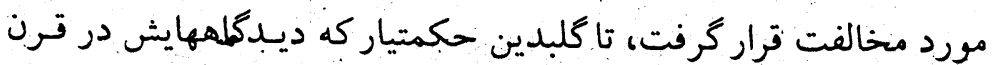

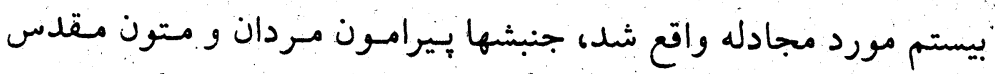

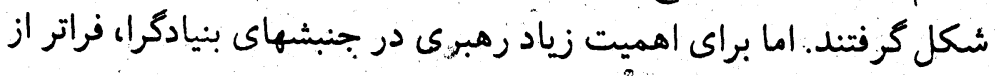

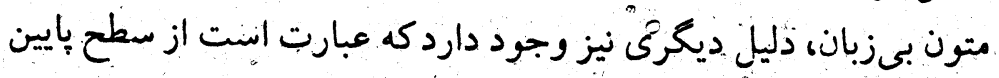

نابو دى بكشباند. لذا، در حالى كه اسلام آباد تأمين نيازهاى طالبان را بهطور

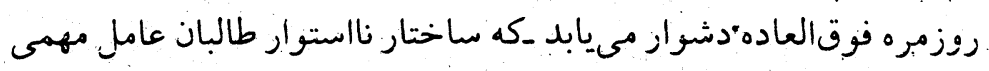

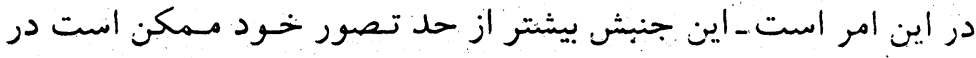

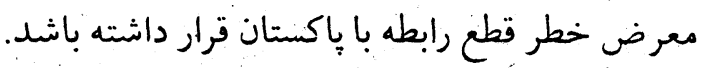

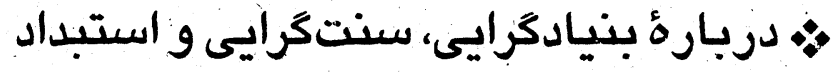

رفتار طالبان ممكن است ديدگاه كبانى راكه طالبان را بنيادخرا توصيف

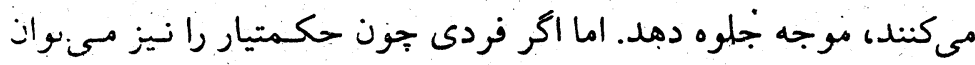

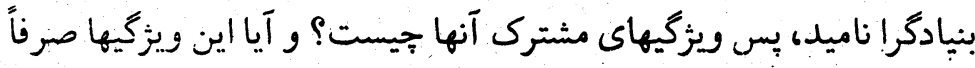

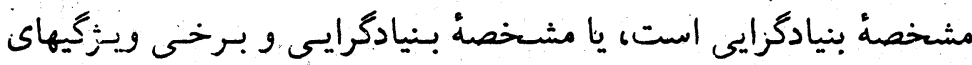

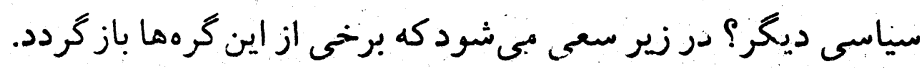

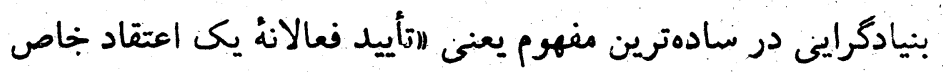

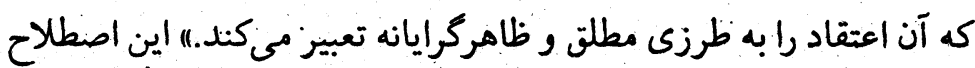

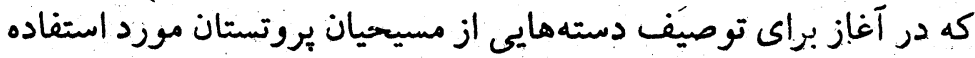

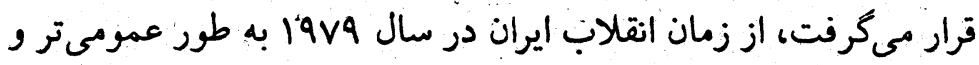

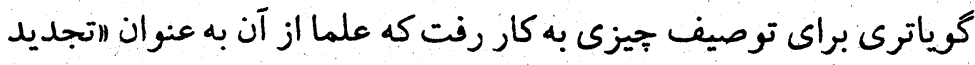

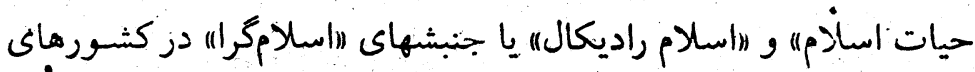

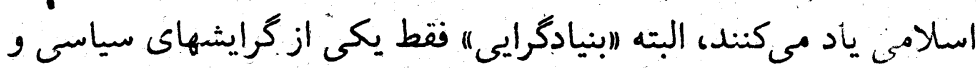

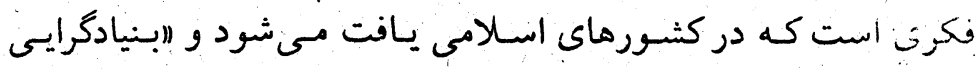

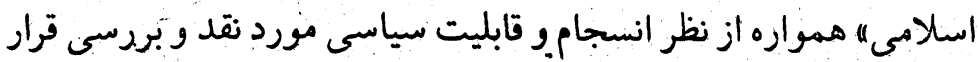

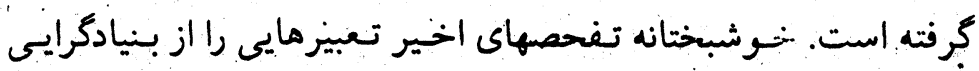

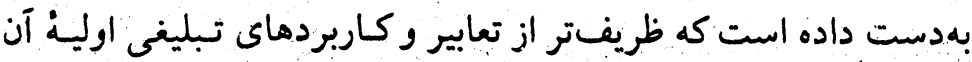




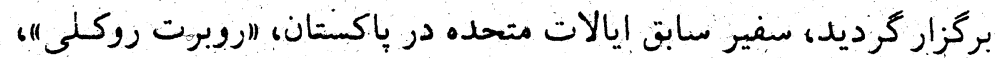

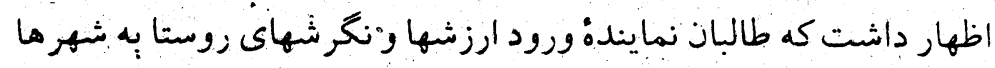

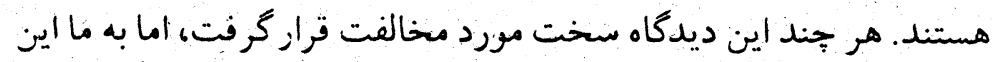

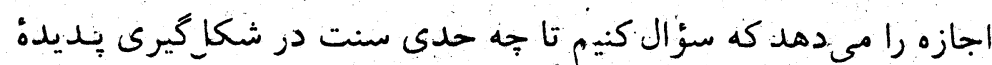

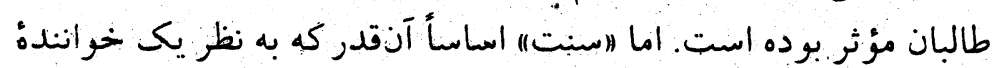
عادى مىرسلد، روشن نيست مؤردان

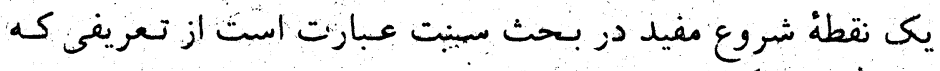

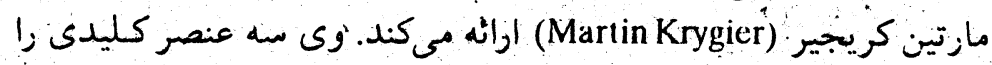

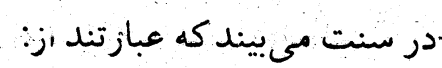

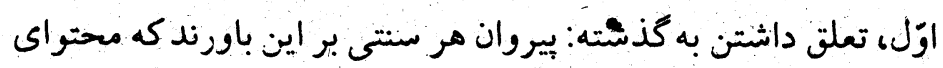

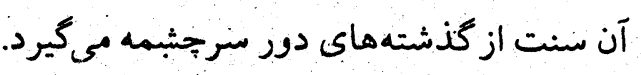

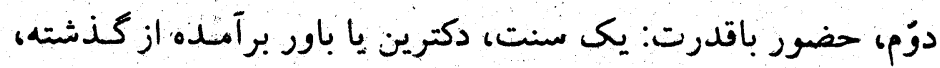

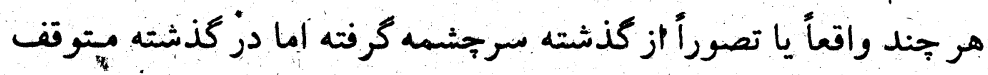

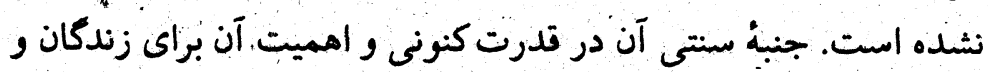
افكار يا نعاليتهاى بيروان آن تهفته است.

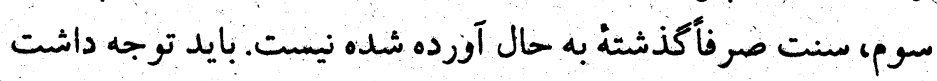
كه سنت طن نسلهاى متوالى به طرق مختلف تداوم يافته؛ نه اينكه بدون

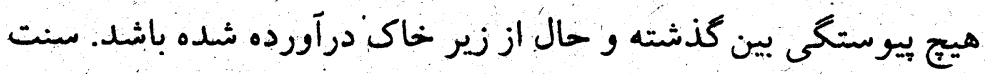

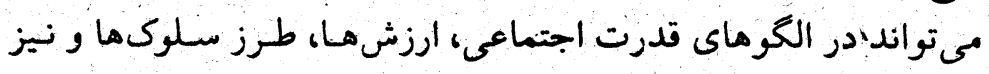
مكاتب تفسيرى دكترين مقدم يا غيرمذهبى تبلور يـابد. در حسالى كه

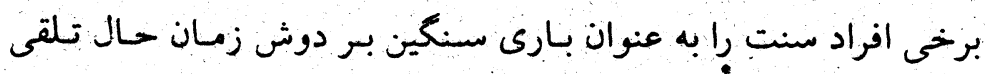

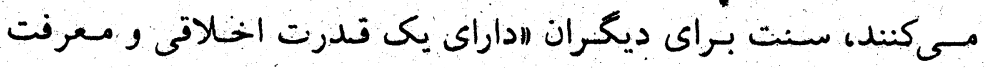
شناختى است كه علت آن نه تنها قدمت سنت بلكه حيات كرفتن آن از از

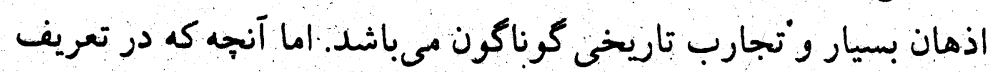
كريجير بهطور ضمنى و در نوشتههاى ديخران بهطور صريح بيان شده، آن
نـهادينكى سـياسى ايسن جسنبشها. در سيستمهاى كمونيستى، لاكيش

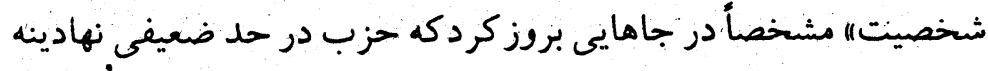

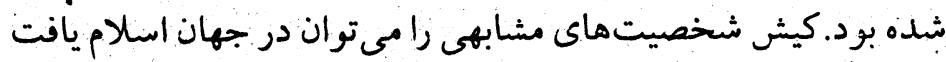

اين كه آيا طالبان از اين نظر بنيادكرا هستند يا خير، مسألهاى است كه.

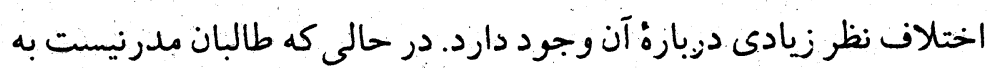

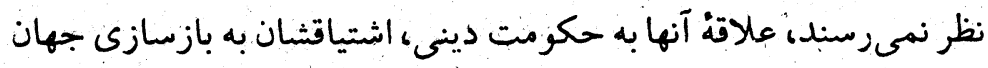

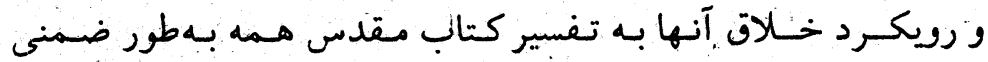

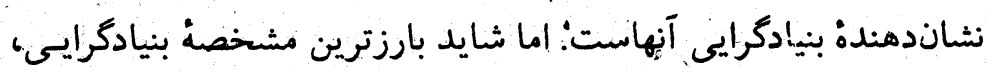

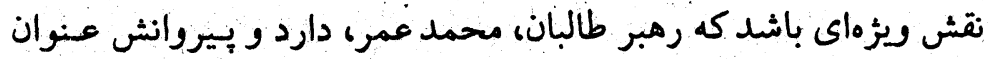

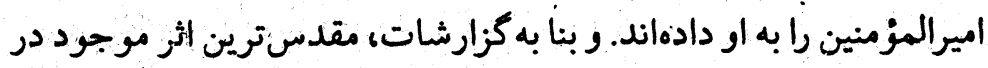

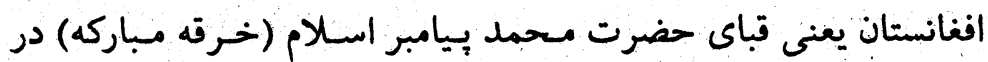
اختيار اين شخص است كه در حقيقت منشاء مشروعيت مسمبليكن قدرث وى مىباشد. طريقه سياسى مورد ادعاى محمد عمر از طريت دعوت به آنه

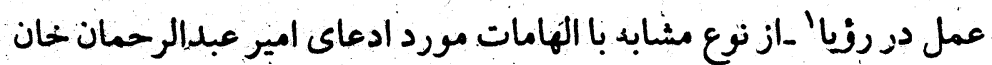

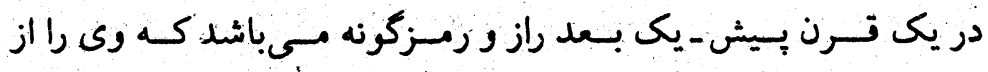

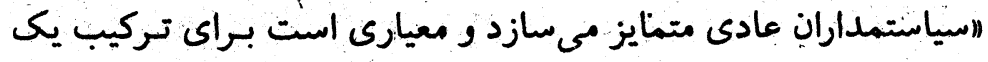

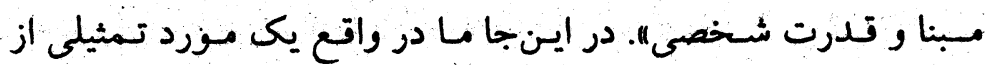
شكلكيرى يك رهبر بنيادكرا را مشاهده مي كنيم.

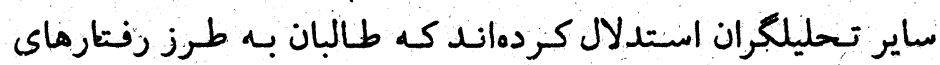

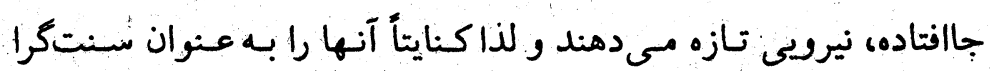

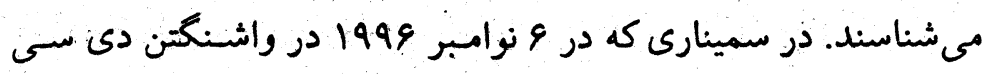

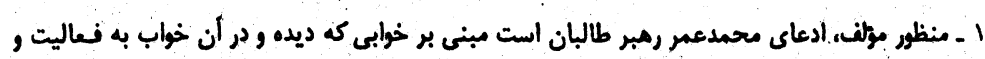

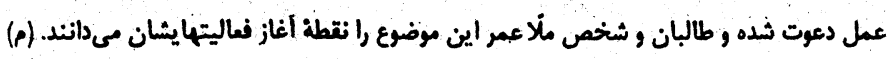




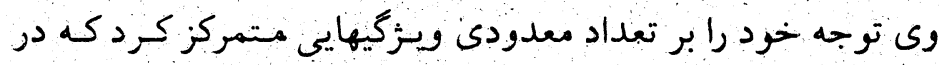

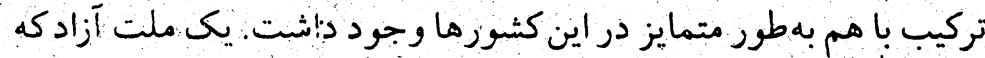

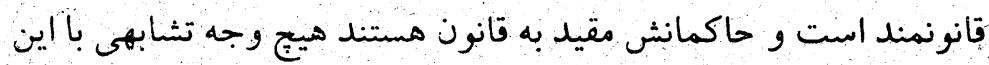

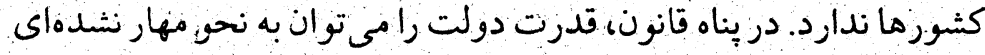

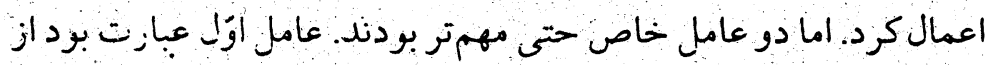

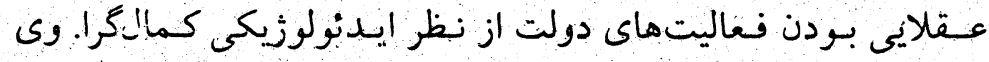

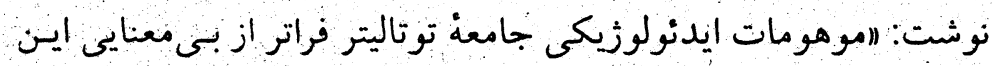

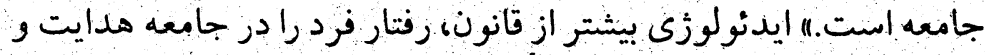

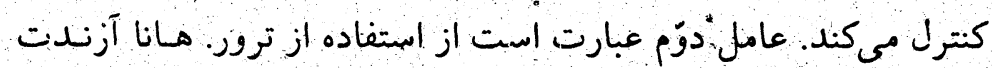

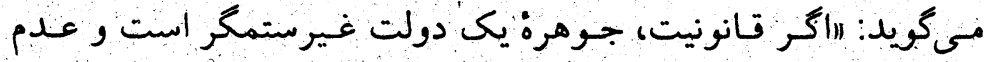

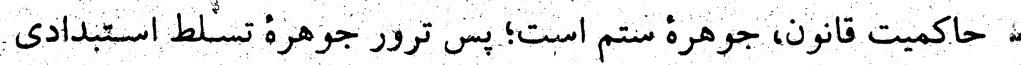

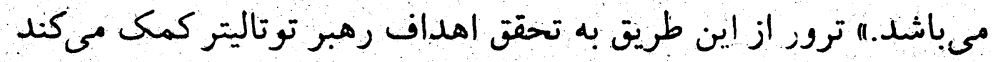

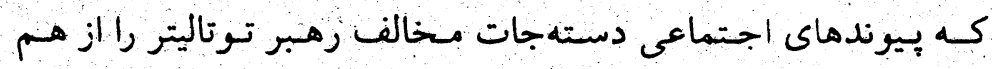

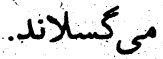
اين مفهوم، تاريخى بر فراز و نشيب دارد و بسيارى از مطالبى كه راجع

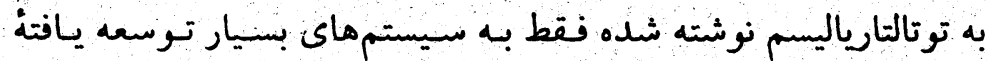

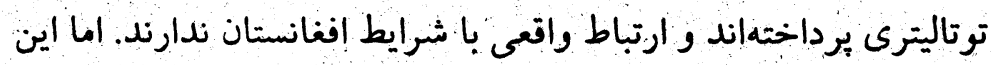

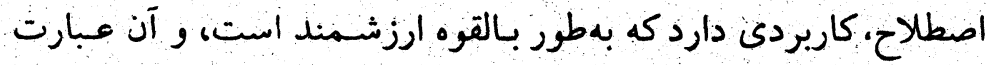

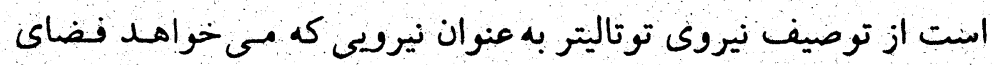
سياسى رابه صورت انحصارى درآورد و تمام حيات إجتماعى رادر در آن آن

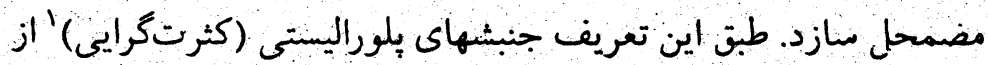

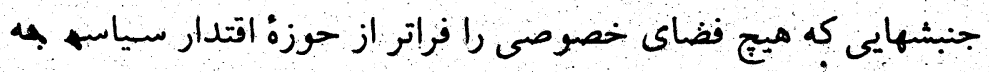

است كه اسنتهاها ثابت نيستند، بلكه در يك وروبه بازسازي مداوم يا حتى اببلاع قرا دارند. طإلبان بيشتر به نوع سنت تصورى خود توجه دارند تا به سنن خالص و

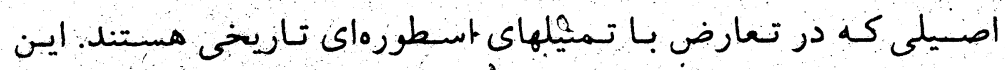
ارزشهاي روستايى نيست كه طالبان مى خو اهند بر مكانهايى هميحون كابل

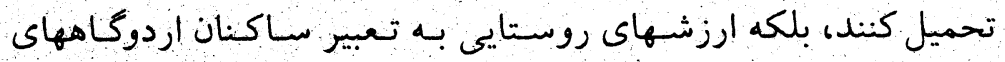

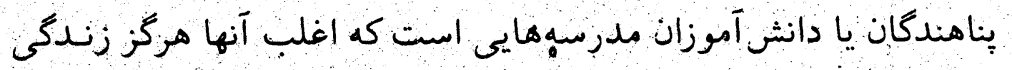

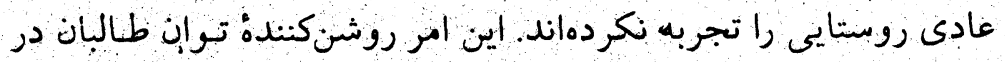
انجام كارهايى است كه تطبيت آنها در يك قرية معمولى افغانستان قابل

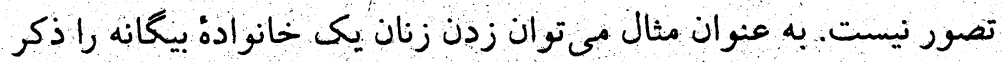
كرد؛ كازى كه معمو لا باعث انتقامكيرى شديد ميكردد. ارزيابي اينكه آيا سنن موزد ادعاى طاللان بيشتر سننى واتعى هستند ليا ناشيى از تصورات

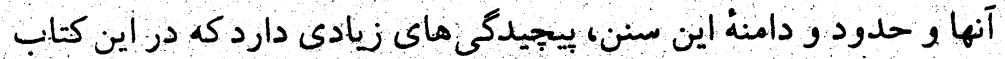
نمى وان به آن يرداخت. اما صرف انعطافِيذيرى مسنت نبايد دور شدن

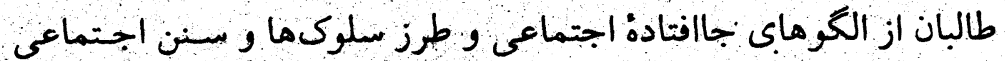

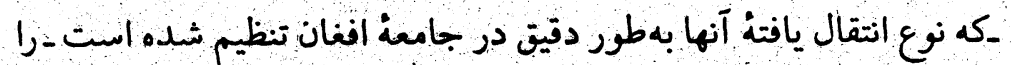
از نظر مخفى دارد

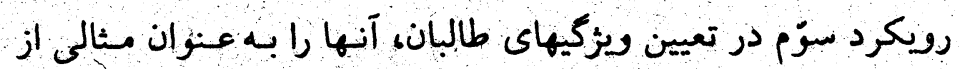
استبداد مطلق العنانى در حال شكلكيرى تلقى مى نمايد. به نظر مي ربـد

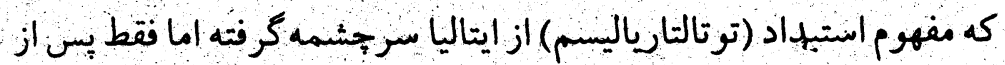

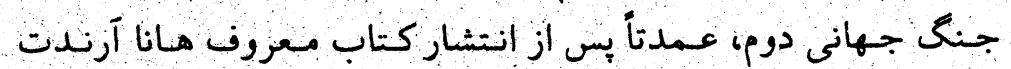
كائ بـ (Hanna Arendt) يافتهاست تحقيق آرندت كه در بحسن اول آن بيستر بـه ضـد مياميتت و

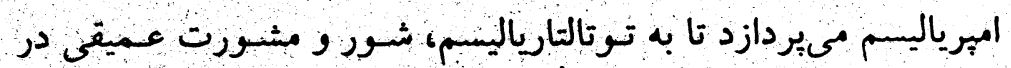
تجربة اروبا دارد تا بذين وسيله ظهور اثبكال مازمانهاي اجتماعى نازى 
كميسيونر اتحادية ارويا براى امور انساني، "(إما بونينو" (Emma Bonino)

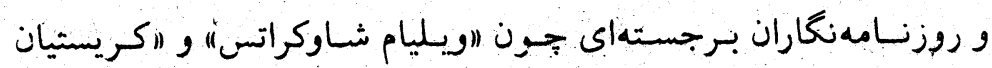

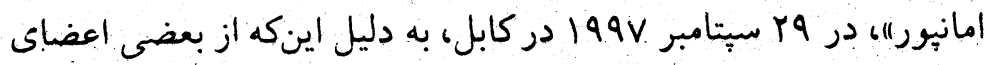

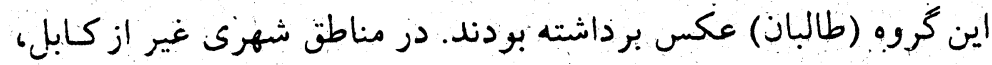

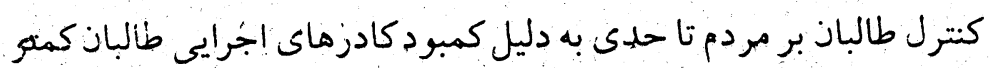

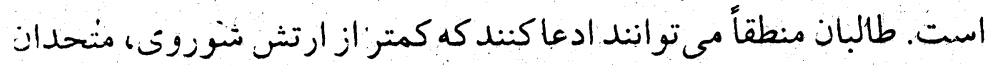
ديكتاتور حزب خلق خفيظاله امين يا حزب اسلامى حكمتيار، مسؤزول

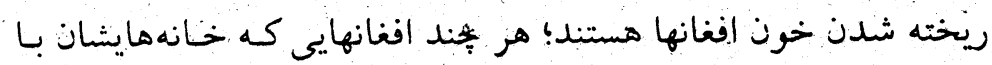

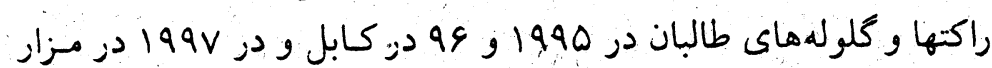

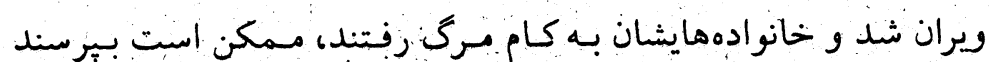

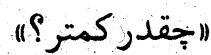

\section{غالبان جيست؟}

در اين كتاب، حجنانكه قبلاً خاطرنشبان كردم، ما قصد نداريم مستقيماً بـه

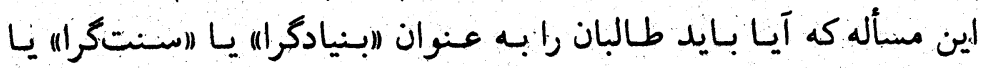

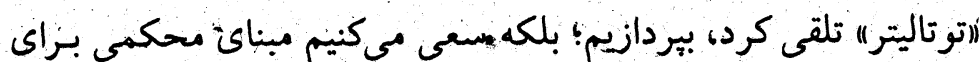

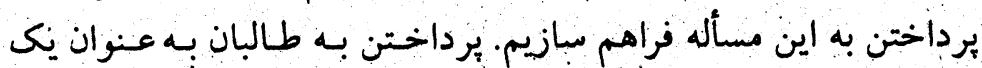

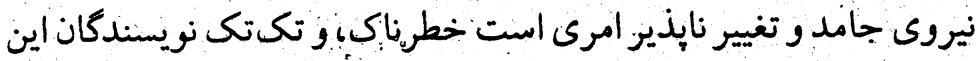

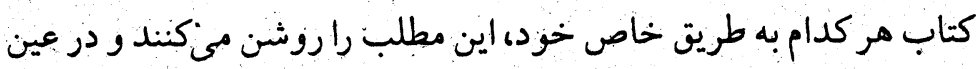

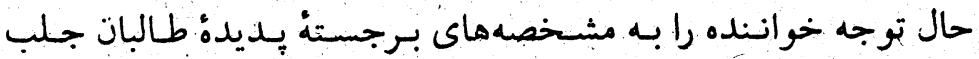
مي دارند. "امـين سبيكله" اينن مسأله را بـررسى مسكند كه جـرا دولت ربـاني
افنانستان، طالبان، و سيخاستهاى جهانى

رسميت نمى شبناسند، از هم متمايز مسىخردند. "ايبزايـاك بـريلين" ققيد،

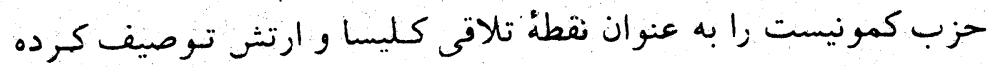

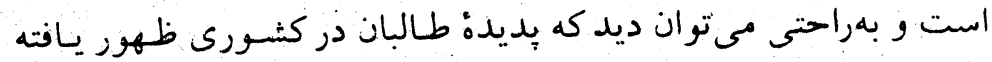

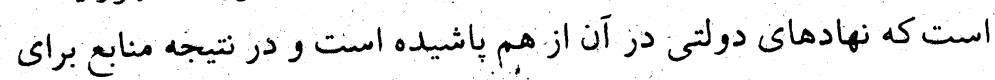

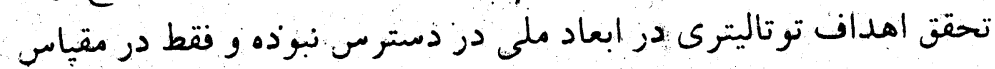

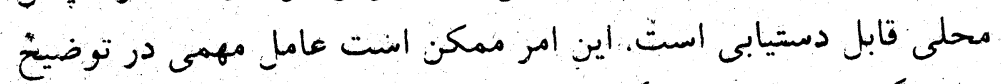
فير فراگير بودن و نأييو ستخى فرمانهائ طالبان باشد.

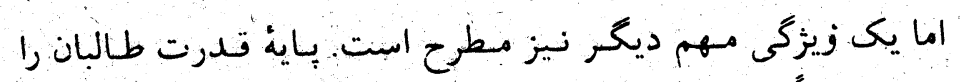

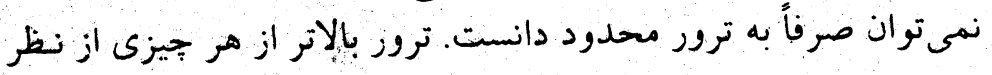

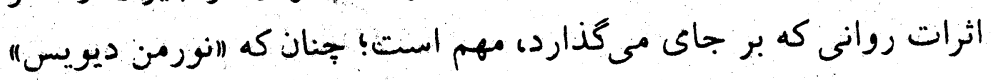

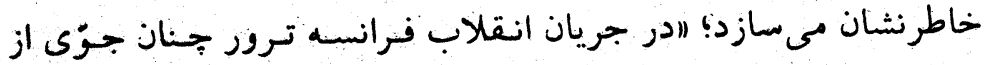

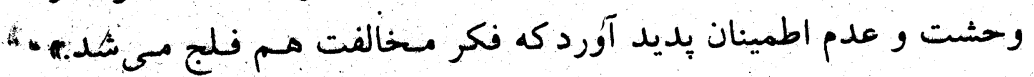

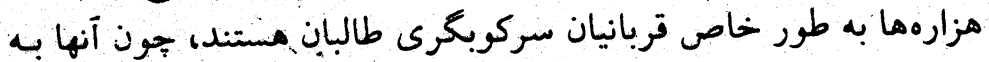

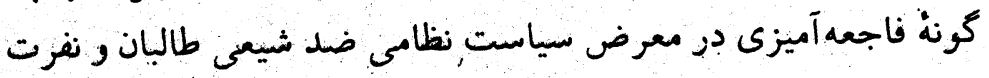

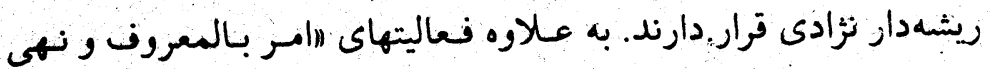

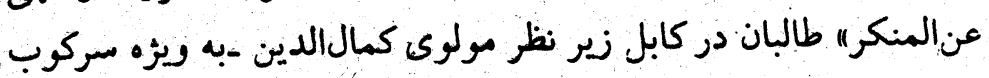

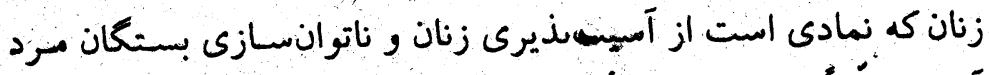

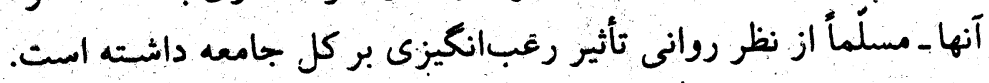

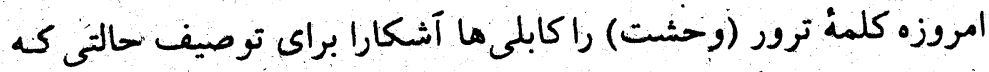

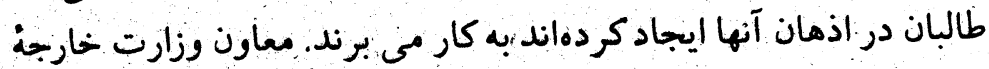

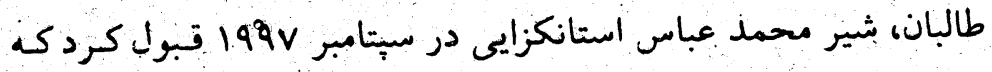

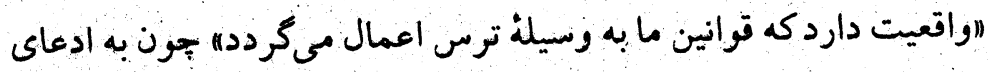

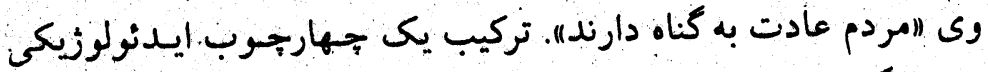
كوبكرانه، يليس مذهبى بى نظم و سختكير و وبنهانكارى زيادي، توبيه

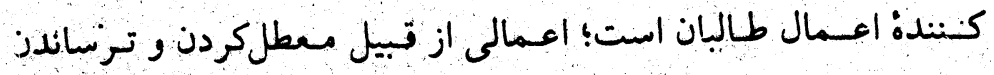


دونه بوتو و برخى ايالتهاى باكستان مطرح مى سازد و نشان مى دهلكه

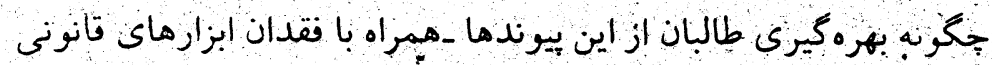

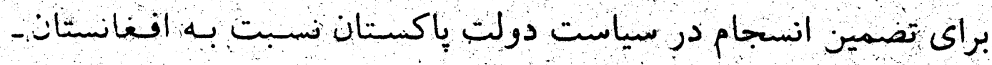
موجب تضعيف قدرت و اعتبار باكستان در ميان بسيارى از افغانها كثتيه

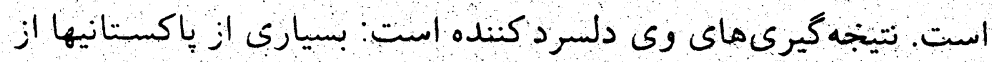

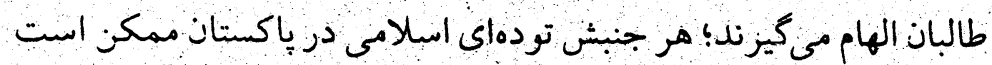

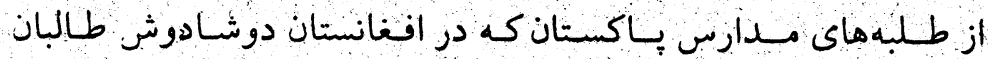
جنجيد اند كمك بخيرد؛ و تهديد ظهور يك انقلاب أسلامى در باكسبتان

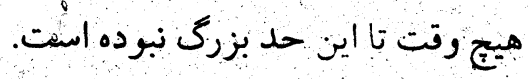

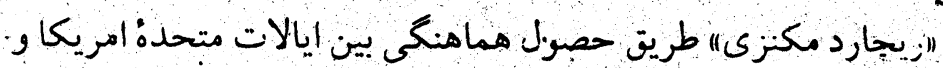

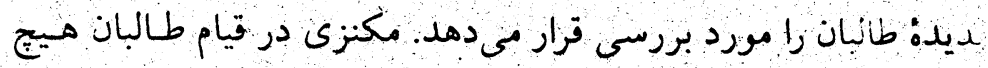

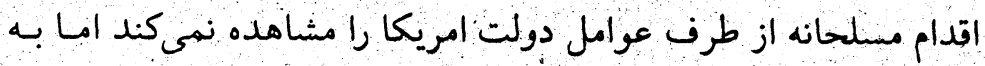

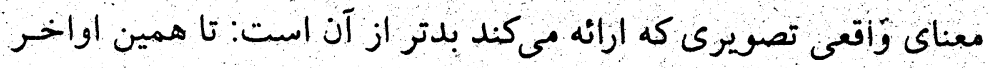

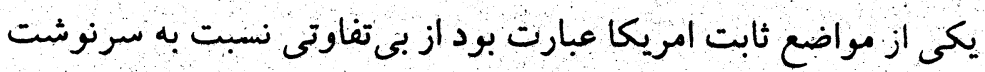

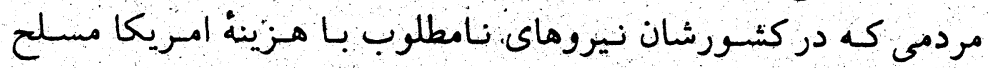

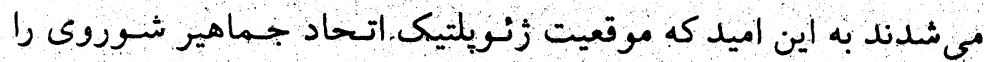

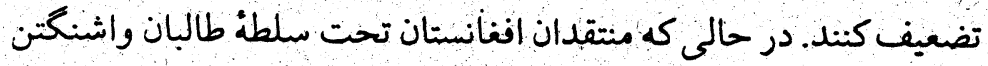
را به عنوان سونغالى (Svengali) طالبان تلقى مى كنند، تحليل (امكنزى)"

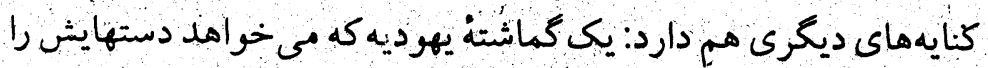

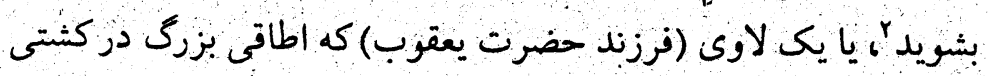

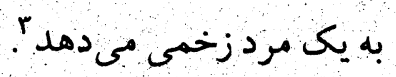

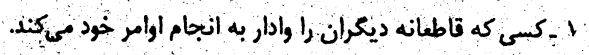

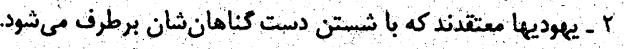

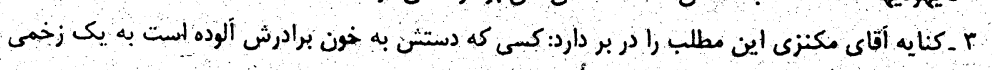

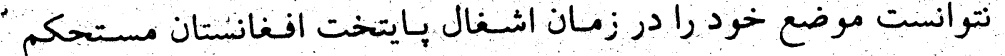

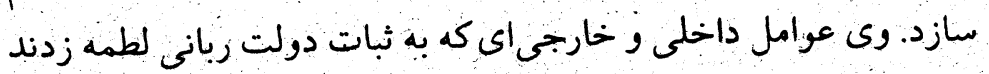

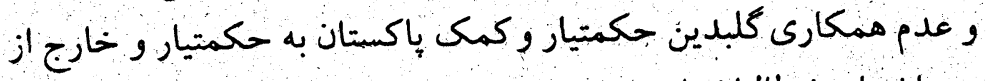

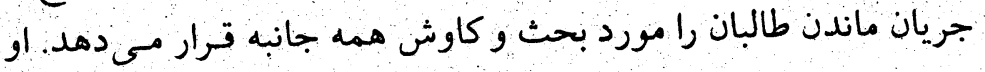

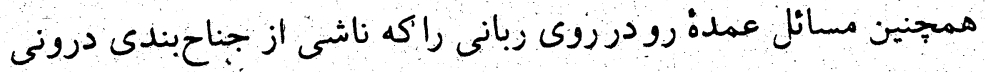

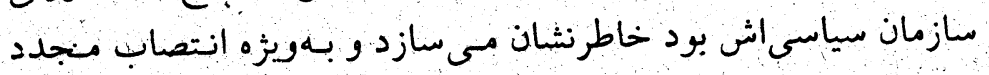

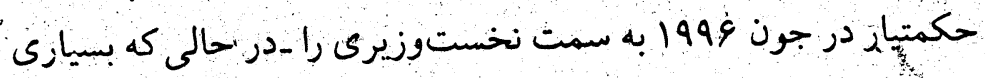

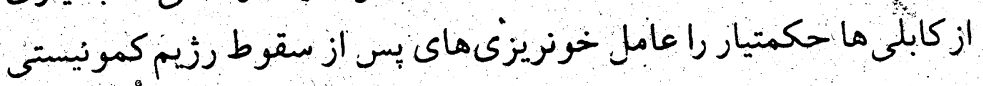

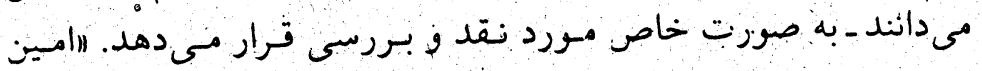

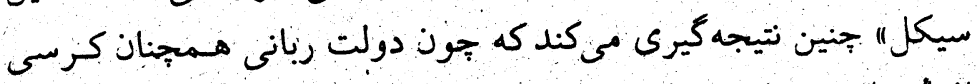

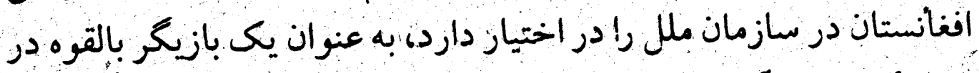
صحخثلة سياسنى آيندةكثور باقى مي ماند.

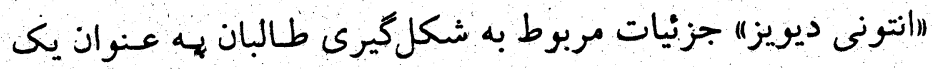
نيروى نظامى را مورد بحث قرار مى دهد. وى مبارزات طالبان در اولينن

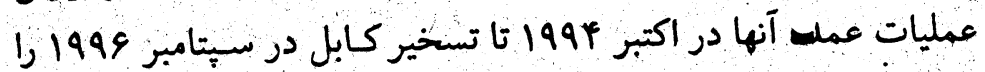
رديايى و بررسى مىكند. اديـويزل| معقتد است عـمليات اوليـة طبالبان، خصومتها و تلفات انسانى زيادى را دربر داشته و به جز قندمار، در تمام مناطق تحت عمليات طالبان، بى قانونى و هوج و مرج حاكم بوده است.

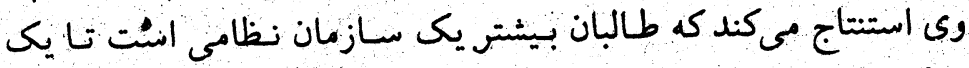

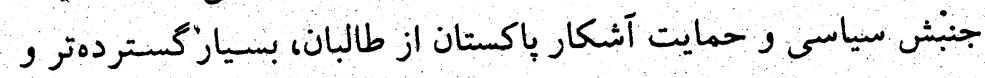
بـلنديروازانهتر از حـمايت سـاير قدرتهاى مـنطقه از كرورههاى سحت جمايتشان بو ده است.

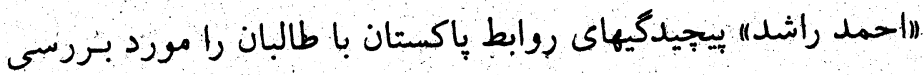

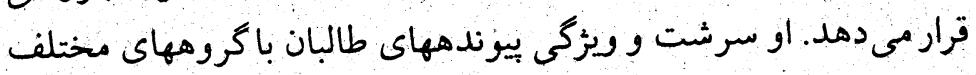

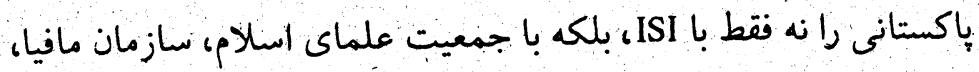




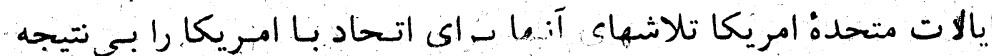

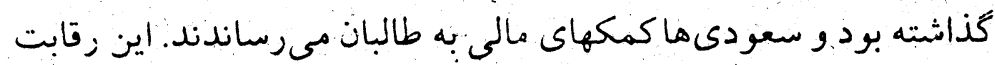

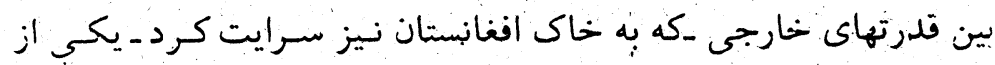

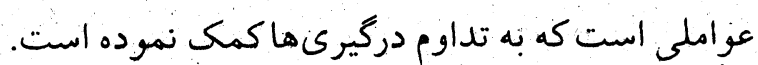

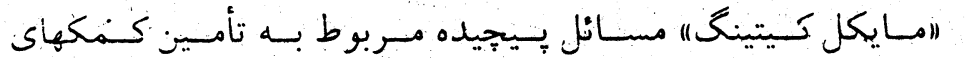

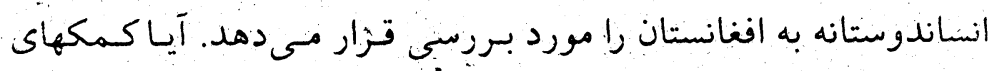

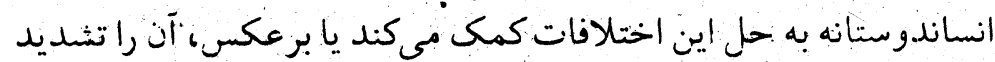

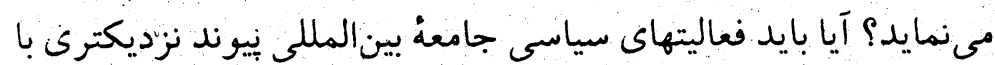

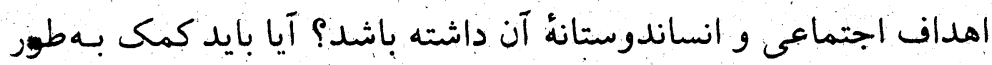

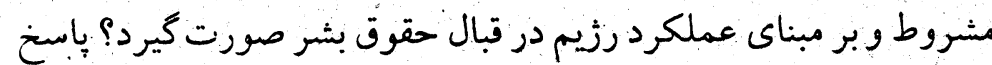

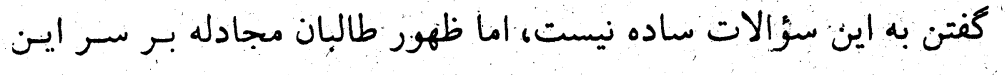

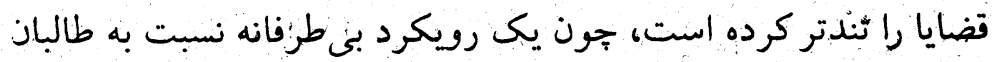

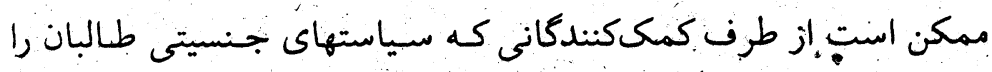

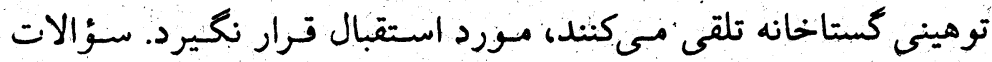

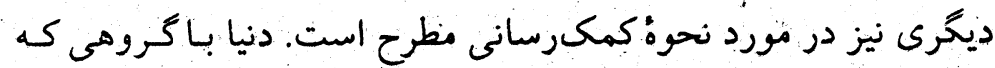

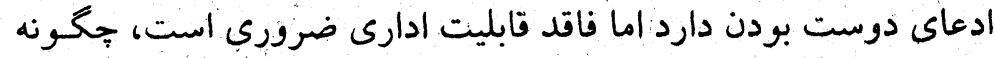

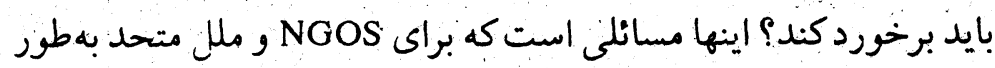
يكسان دردسرآفزين است و سازمان ملل شروع به رسيدكى به آنهاكرده است. نه تنها از طريت اقدامات PEACE (ريشه كنى فقر و تقويت جامعهد)

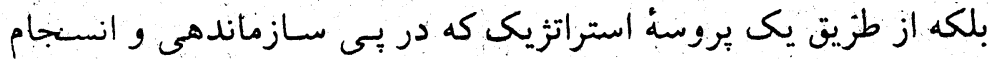
بختيدن به برنامهريزى اين بروزه است.

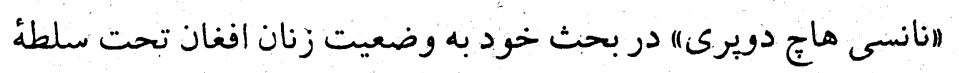

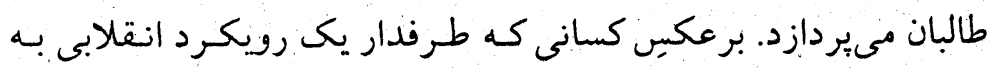

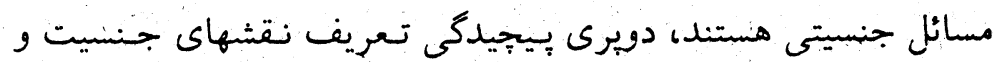

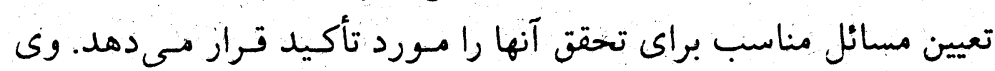

"آنتوني هيمن" واكنش هاى متفاوت روسيه و دولتهاى آسياى مركزى

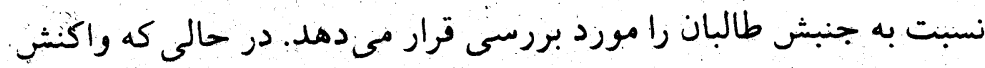

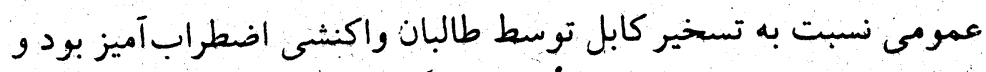

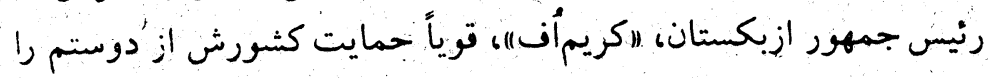

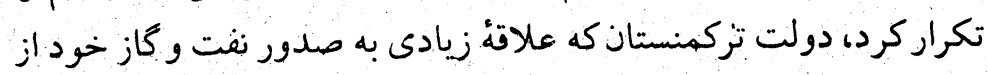

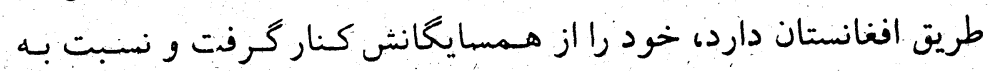

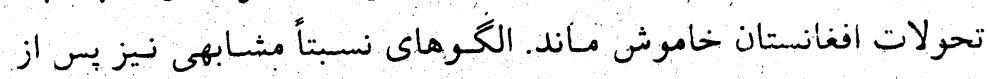

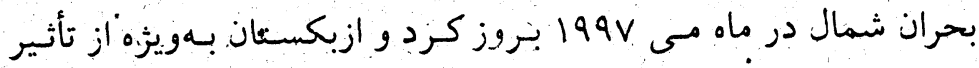

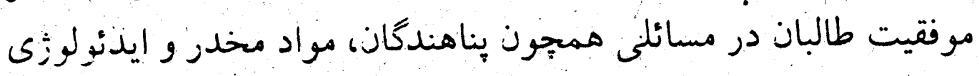
بيشتر ترسيد تا از تهديد مستقيم نظامي از طرف بـ بـاندهاى سـركردان

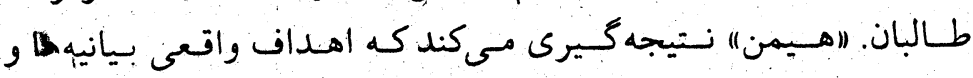

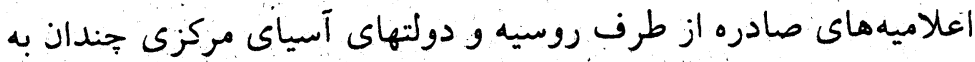

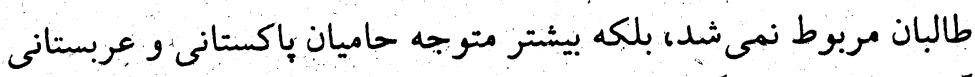

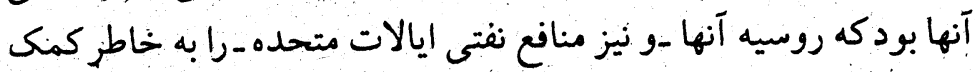
به موفقيت طالبان مورد ملامت قرار مي داد راد.

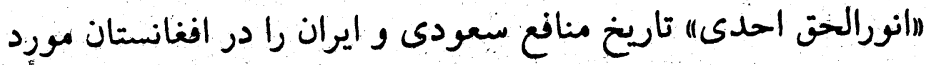

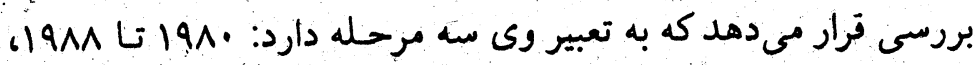

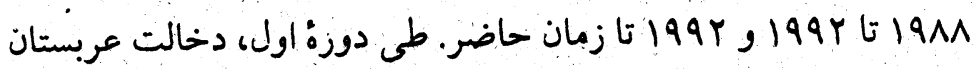

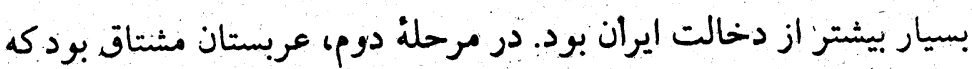

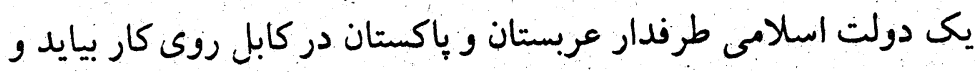
علاقه به حق تعيين سرنوشت خود مردم افغانستان نداشت. اين موضوع

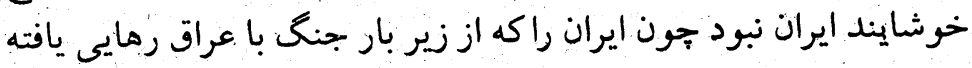

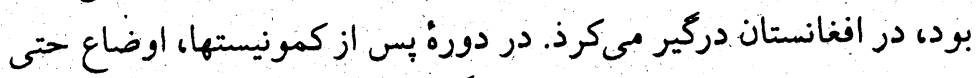

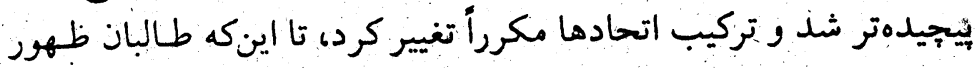

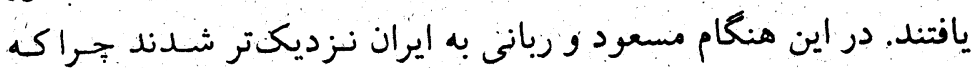


تلاشهاى سازمان ملل متحد نه صرفاً توسط عدم همكارى مباززان افغان فئان

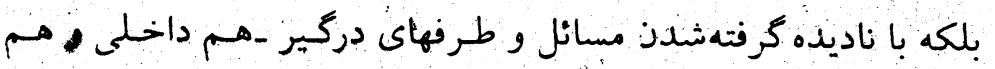

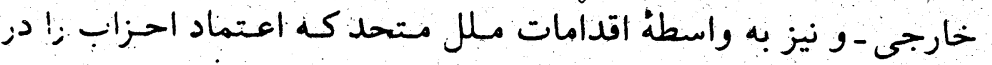

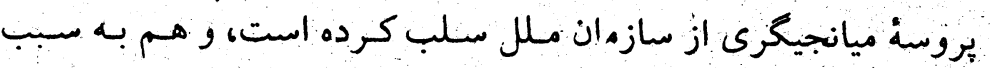

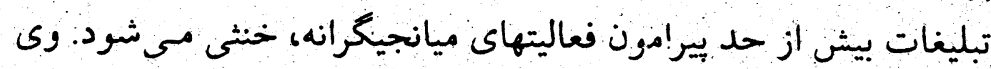

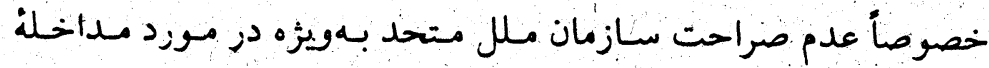

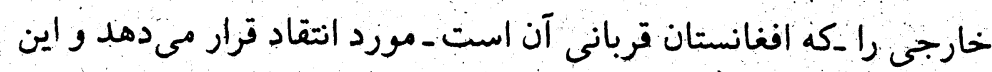

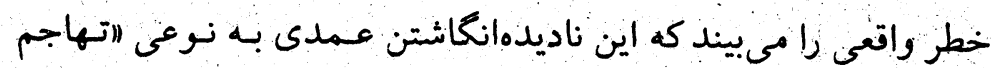

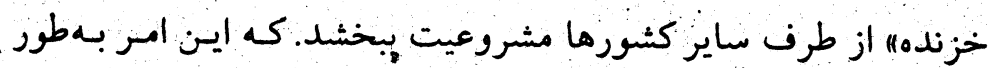

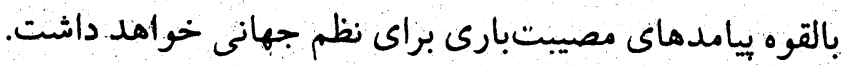

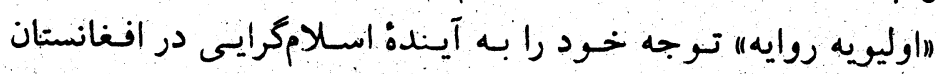
معطوف داشبته است. وى وابستخى درازمدت اسلامخرايي افغانى به ديخً

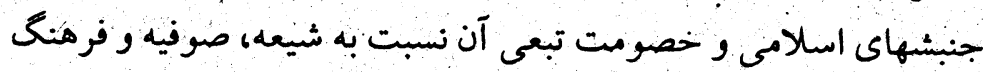

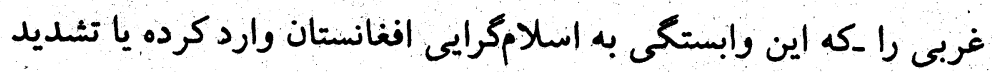

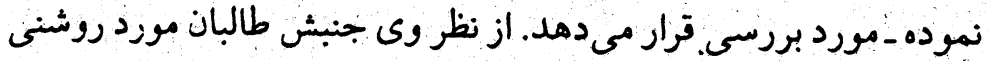

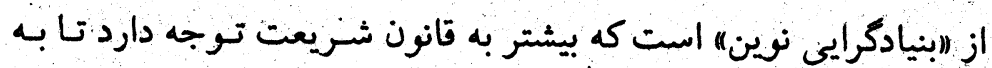

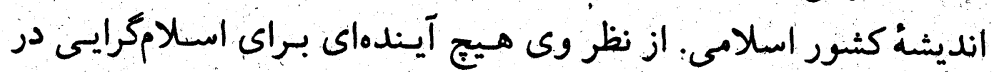

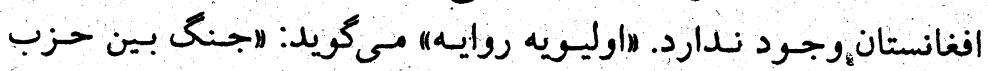

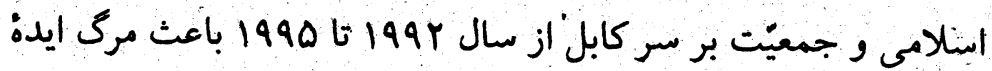

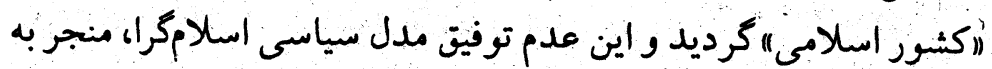

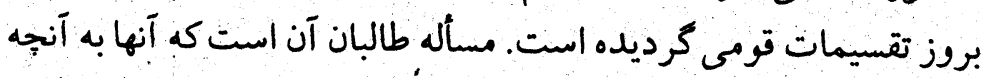

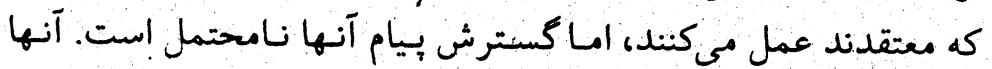

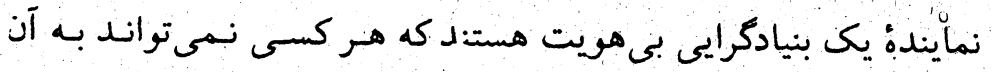
عمل:كند. نماين و نهايتأ، "ام. نظيف شهرانى) آيندة:كشور و حاكميت اجتماعى در

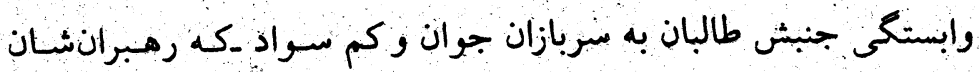

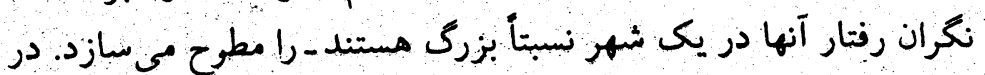

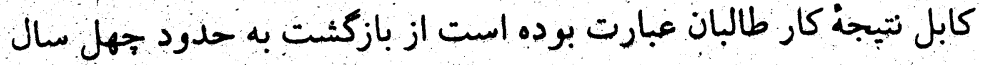

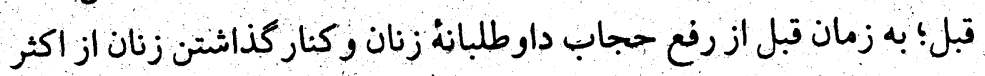

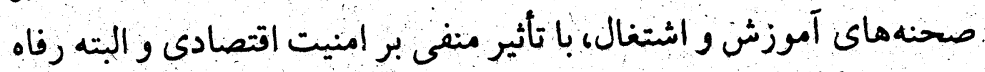

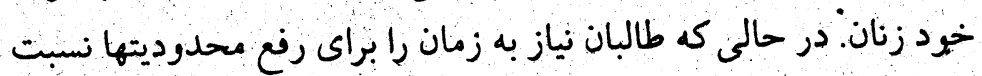

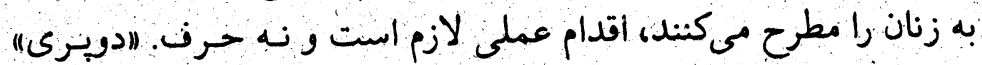

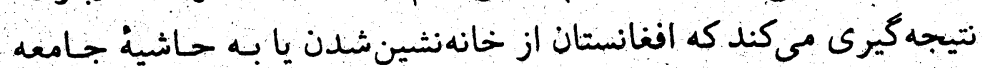

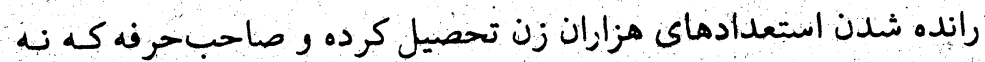

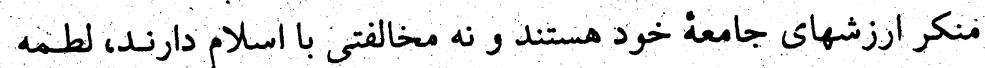

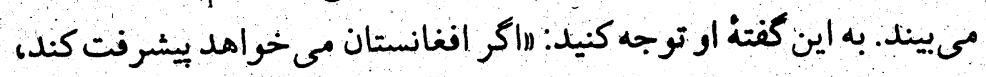

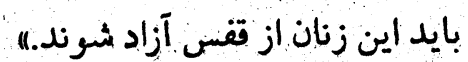

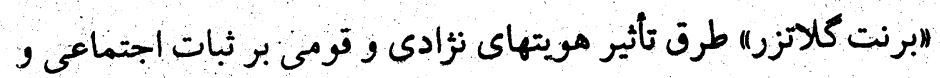

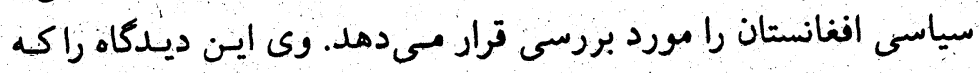

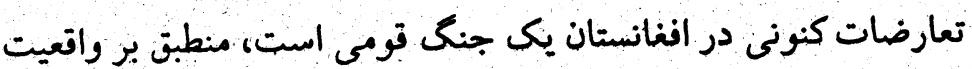

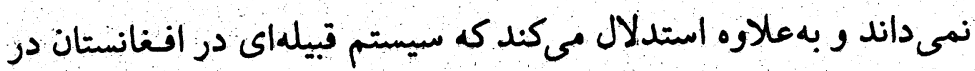

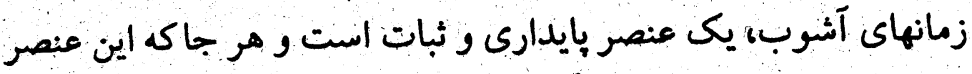

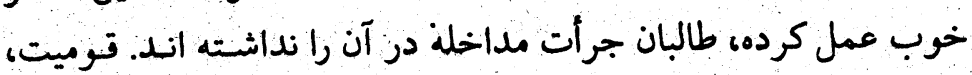

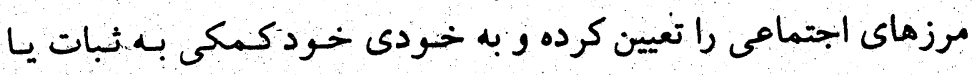

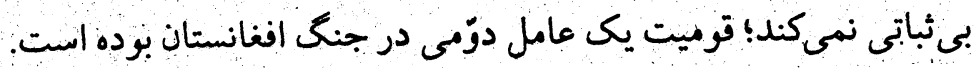

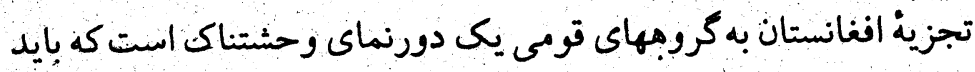

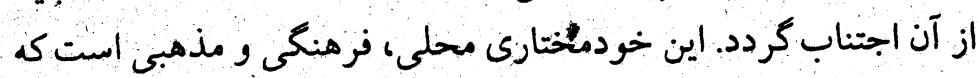
كروهها براى آن جنگ مى كنيند نه تجزينة كثيور.

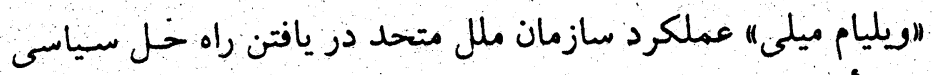

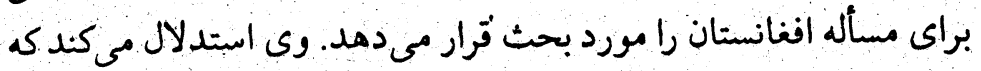




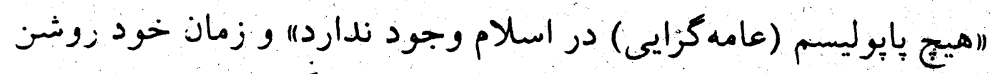

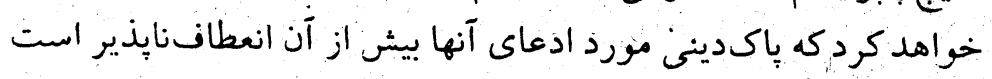

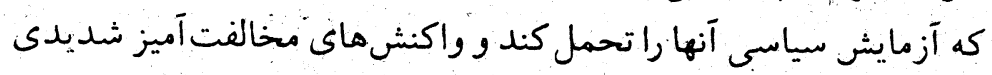

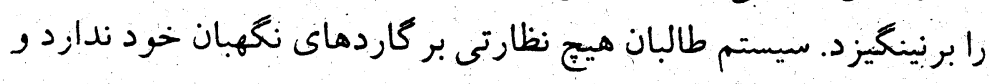

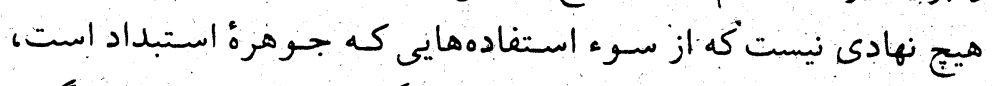

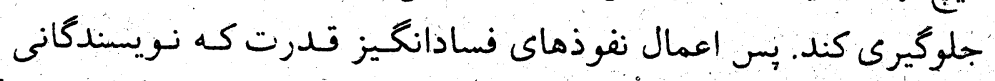

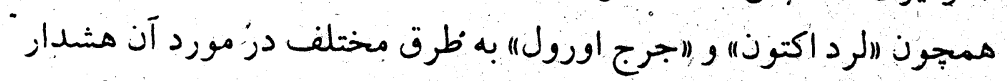

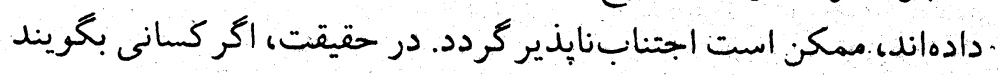

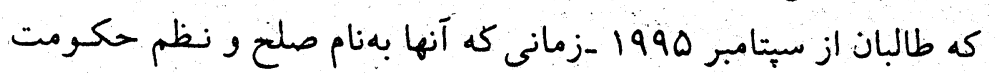

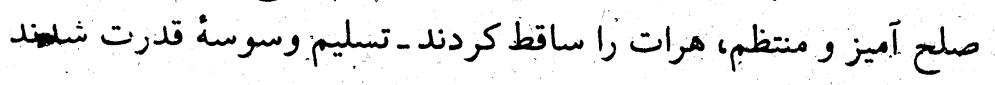
حق دارند.

تجربه طالبان ممكنُ است يك دورة كُخذرا در حيات افغانستان بـاشد.

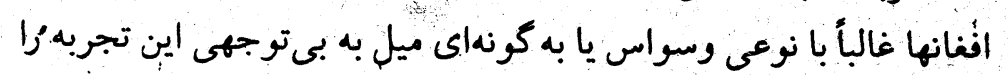

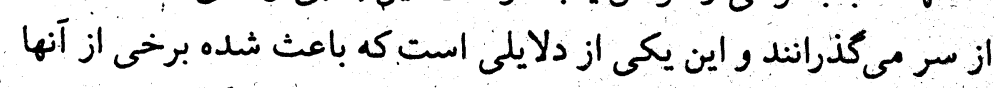

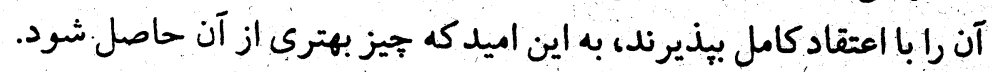

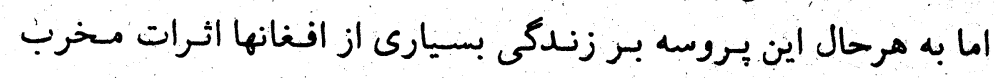

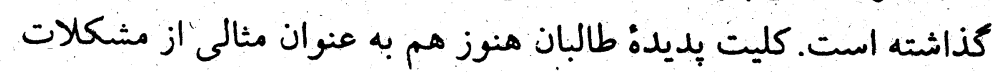

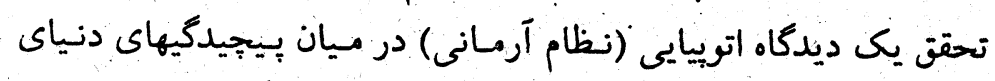

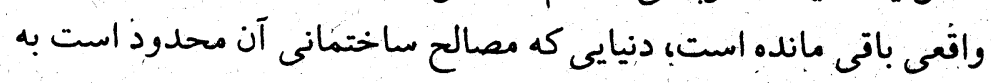

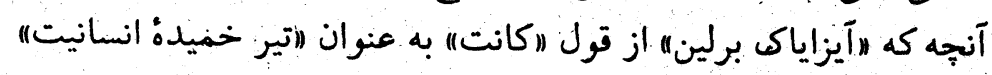

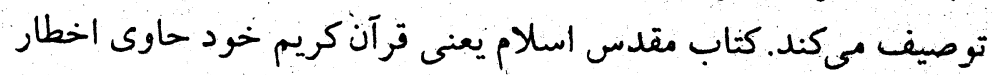

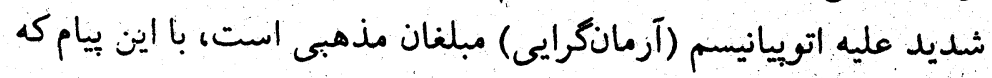

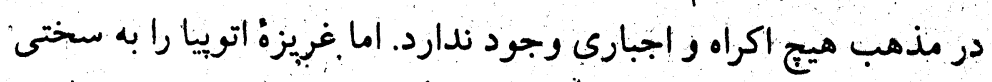

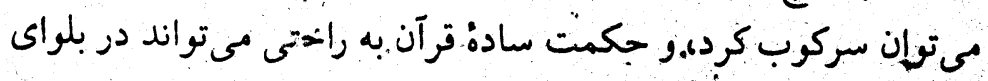

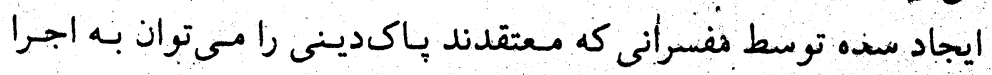

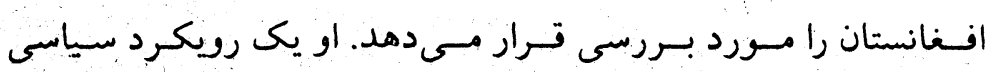

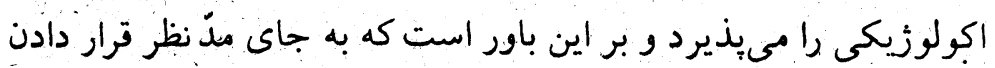

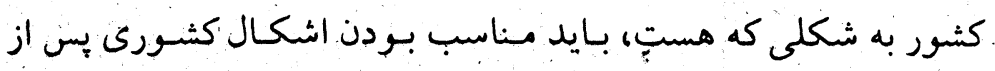

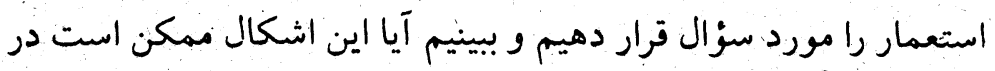

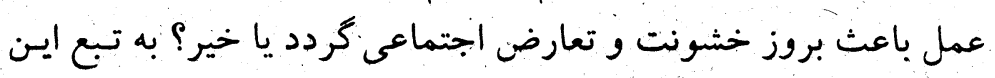

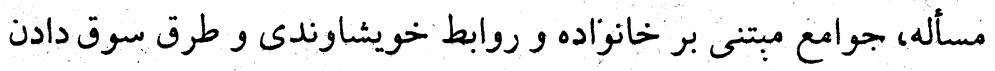

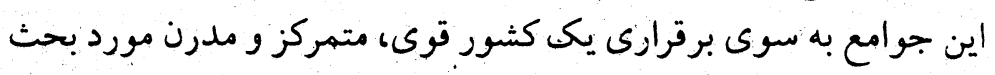

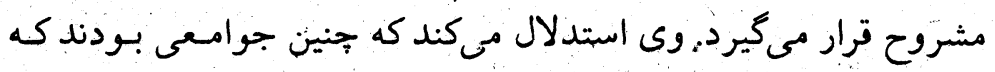

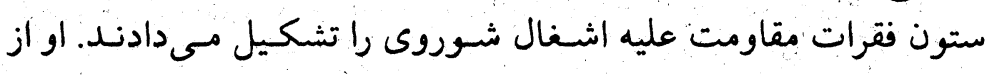

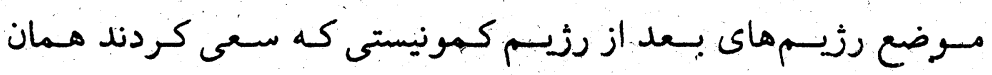

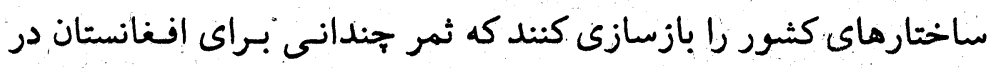

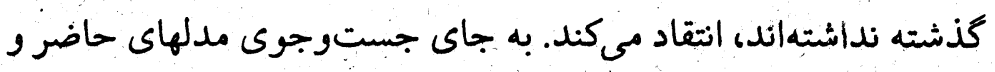

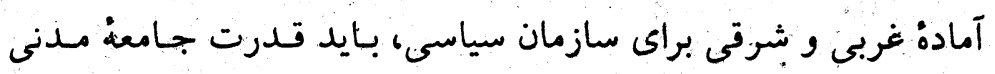

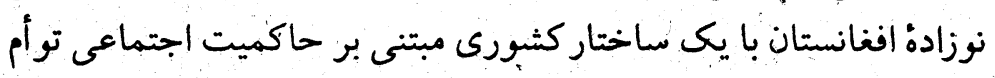

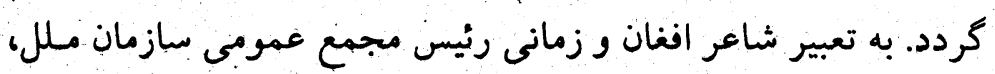

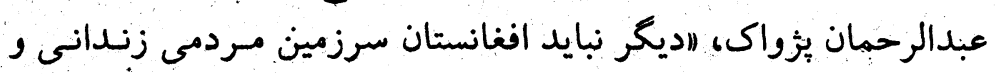

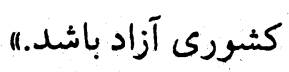
زمانى يك افغانى به يكى از نويسندكان اين كتاب كفت: الشرمى كه

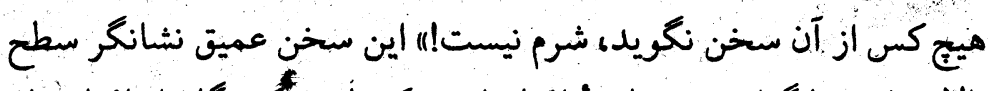

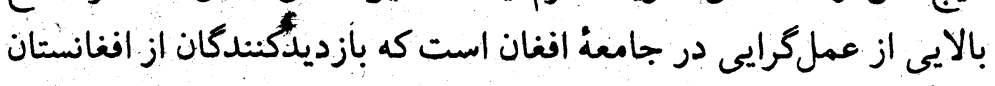

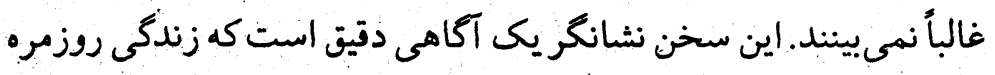

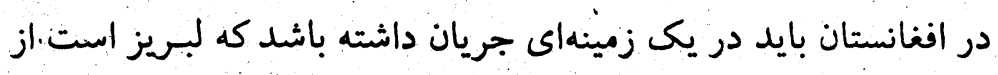

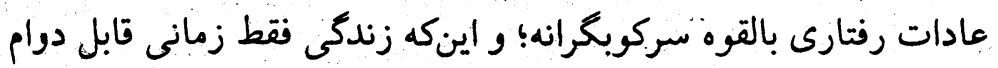

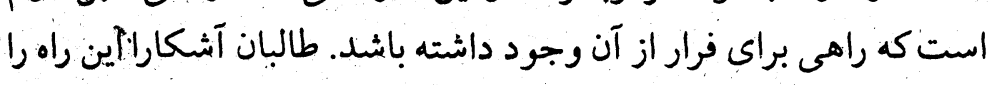

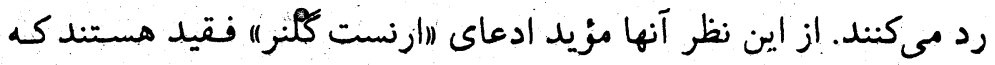


در شرايط محدود بودن رامهاي قانونى و مشروع ابراز وجـود مسياسى،

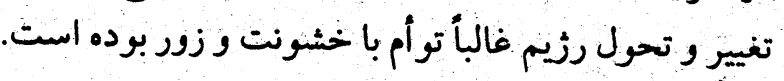

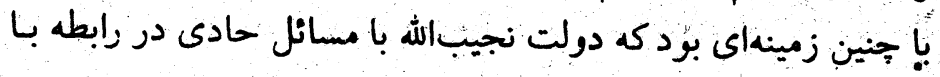

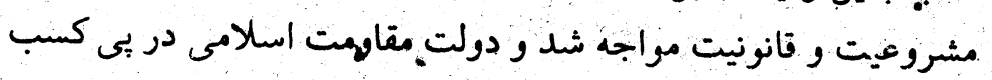
مشروعيت و يذذيرش عمومى بودج.

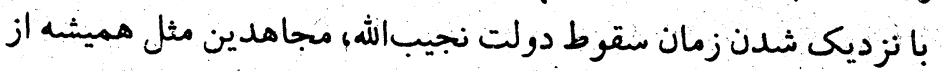

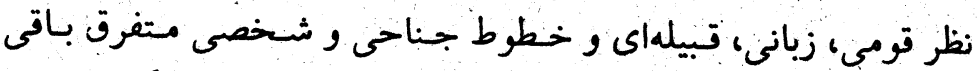

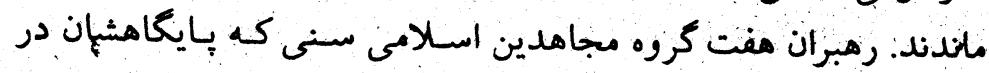

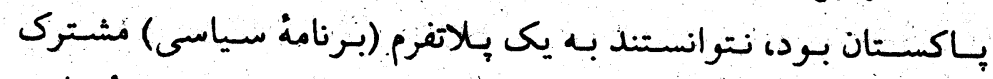

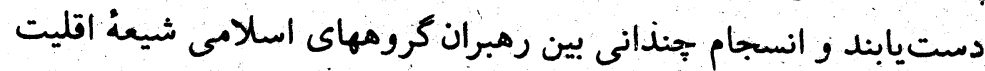

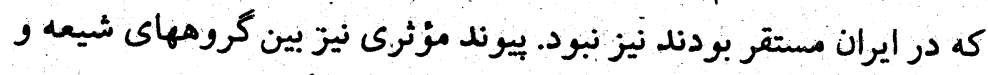

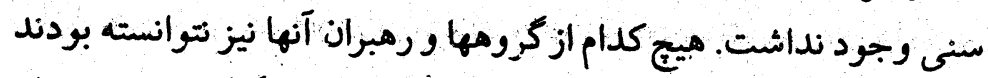

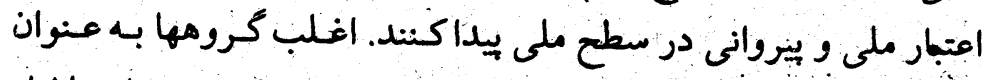

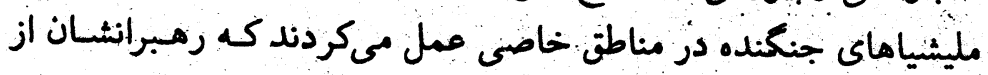

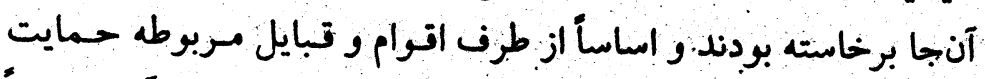

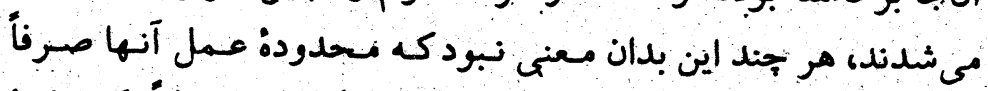

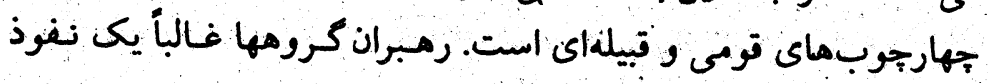

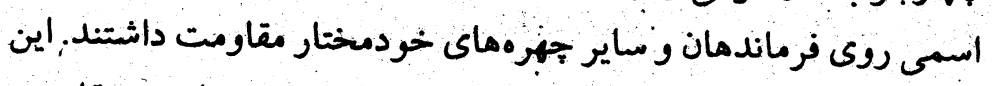

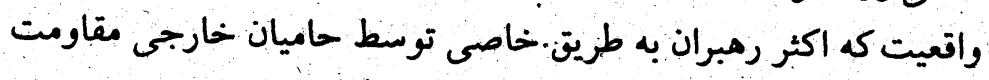

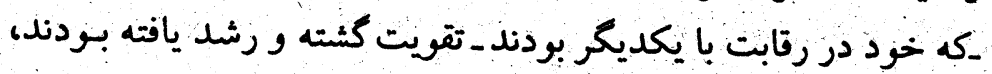

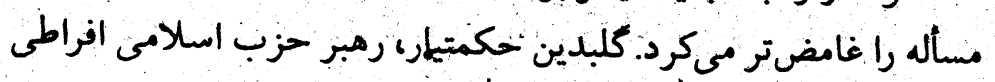

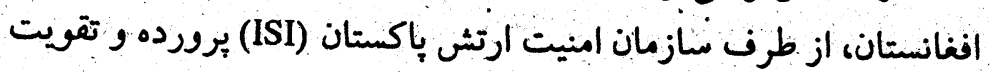

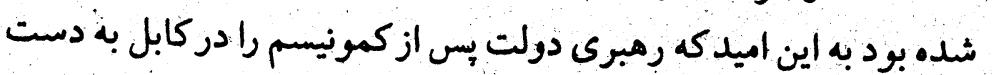

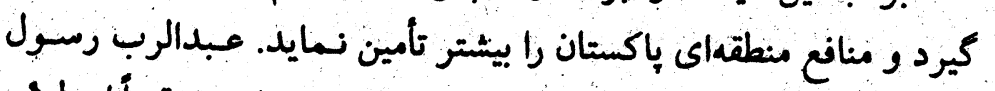

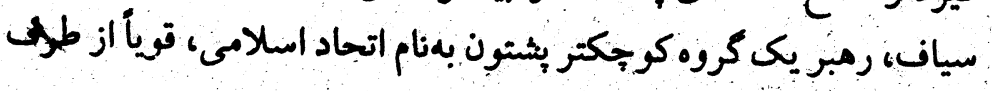

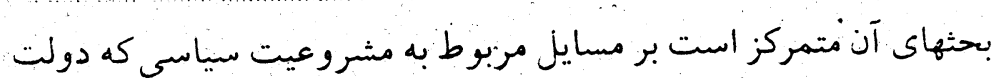

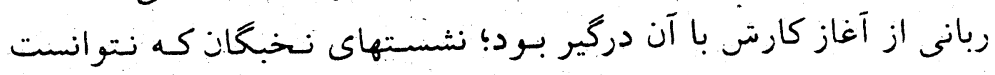

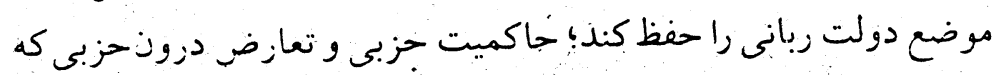

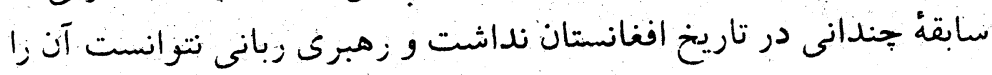

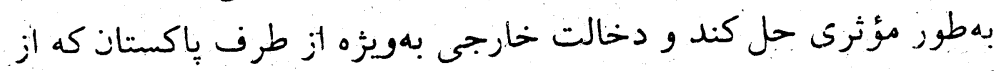

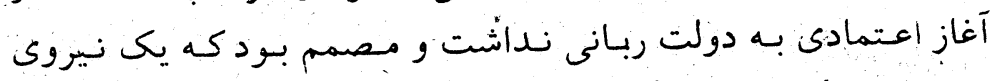

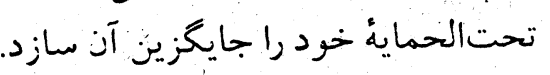

\section{* مشروعنت سياسى}

بروسة مشروعيتى كه دولت ربانى مى خواست ادعاى خود را براى قدرت

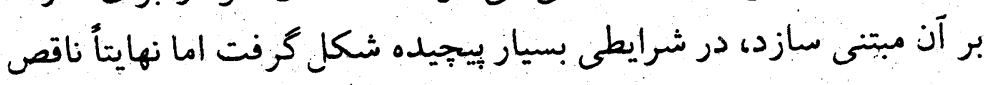

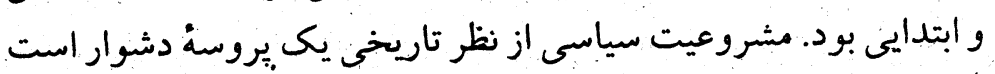

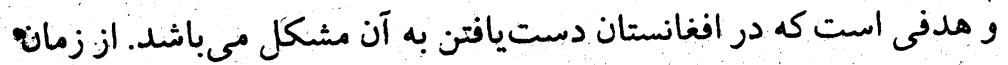

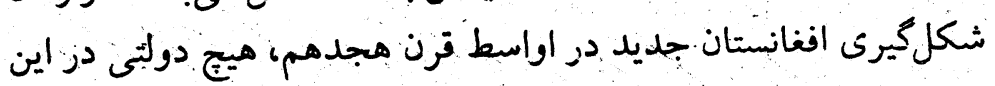

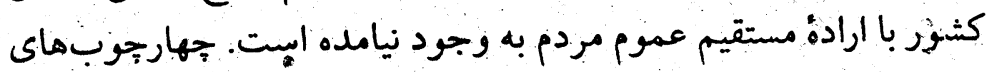

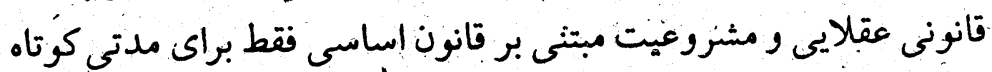

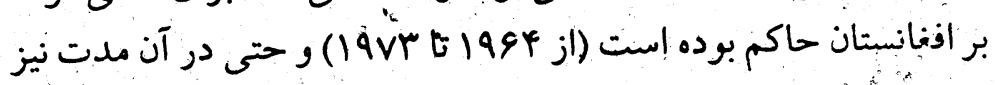

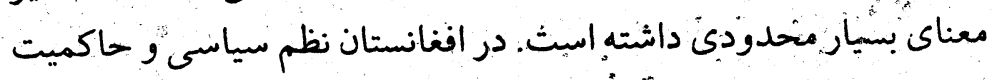

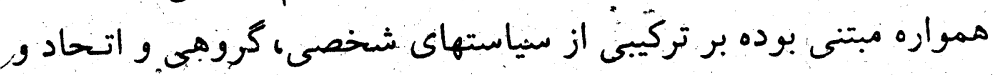

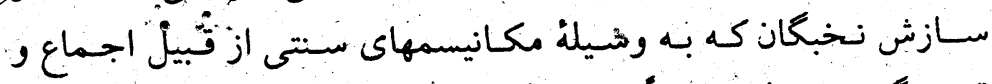

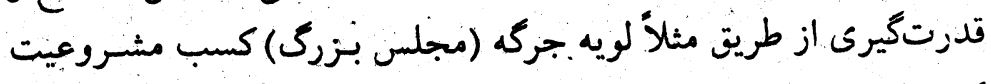

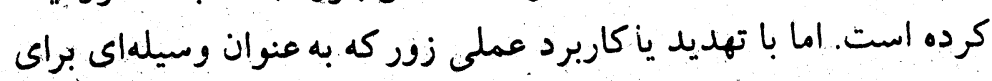

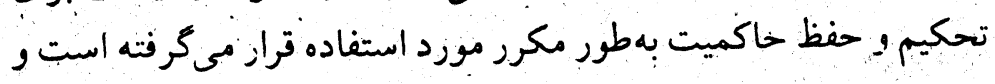


مقاومنت در موقعيتى نبود كه يروسهماى قانونى يا سنتى را براى سعيير

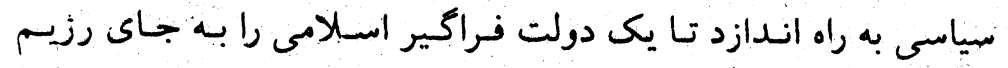
نجيباله بنشاند. در اين شرايط هيج واسطة خارجى نيز قادر نبود نتيجة

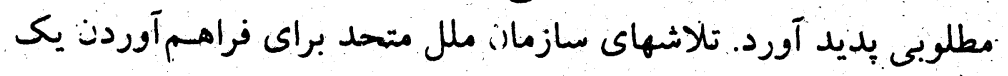

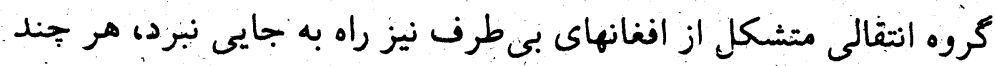

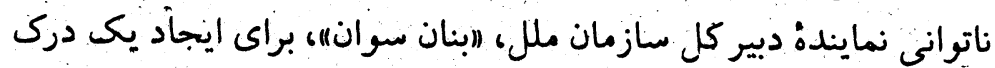

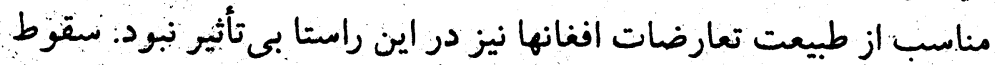

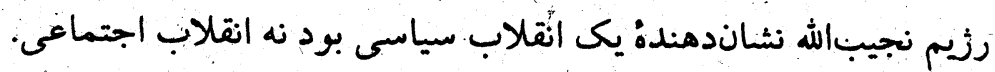

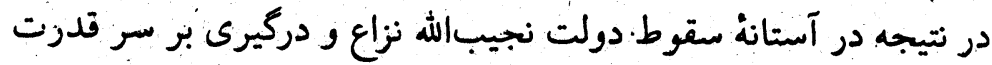
بين رهبران مجاهدين درگز درفت.

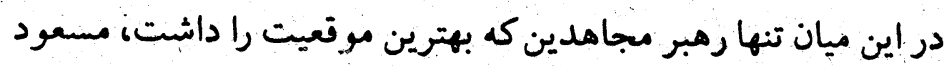

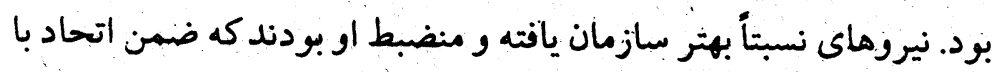

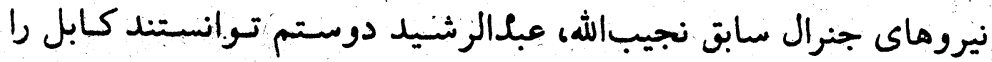

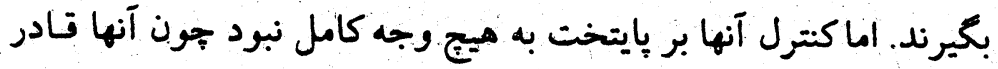

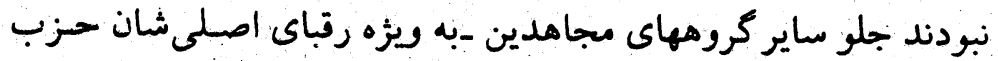

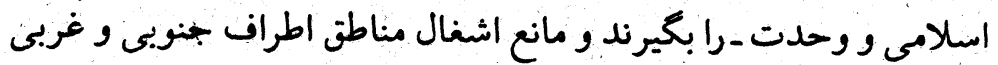

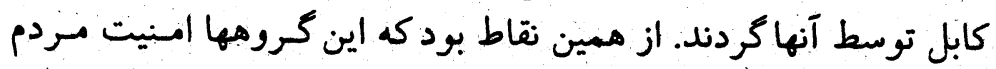

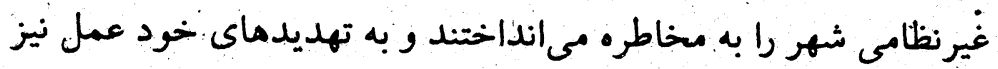

\section{ه راه حل نخبكان.}

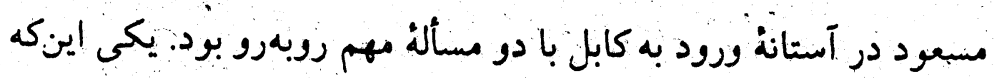

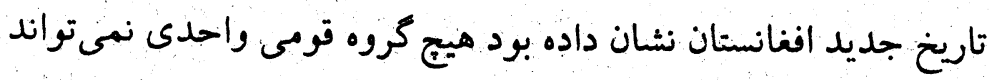

عربستان معودى حمايت مى شدد با اين هدف ته اسلام ومابى ضد ايرانى

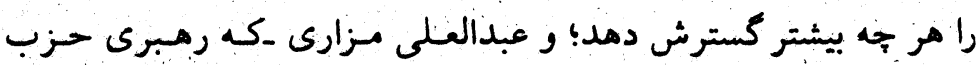

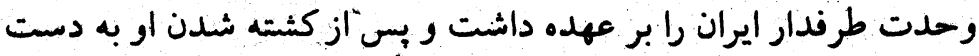

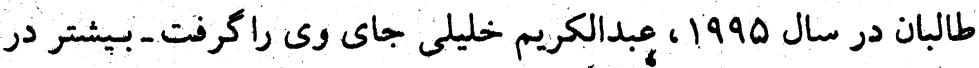
راستاى سياست ايران عمل مىكرد.

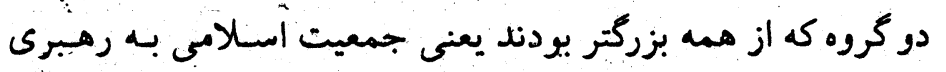

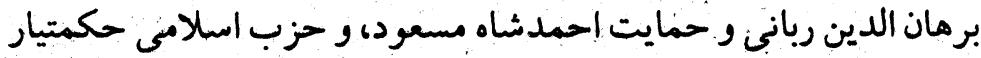

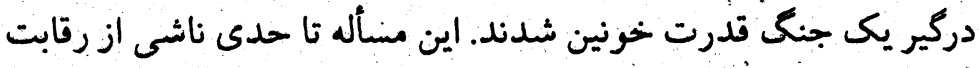

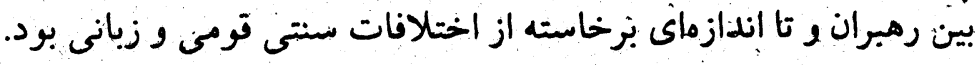

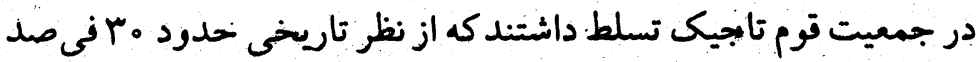

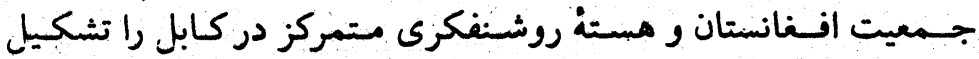

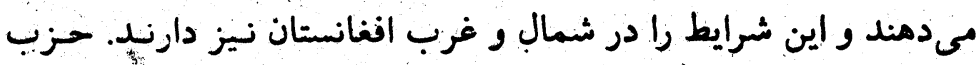

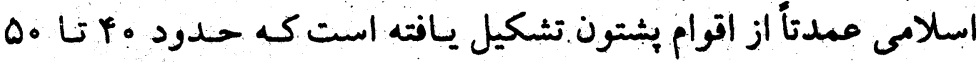

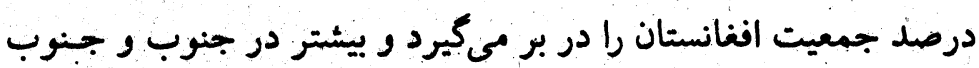

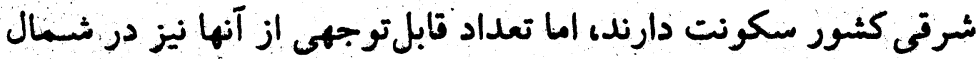
يراكنده مستند. در حالى كه جمعيت فاقد قابليت براى نمايندكى مساير

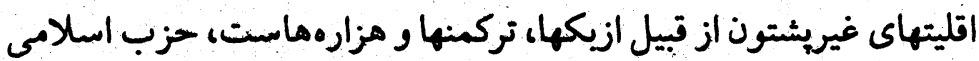

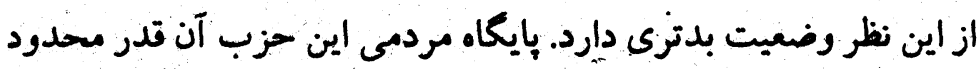

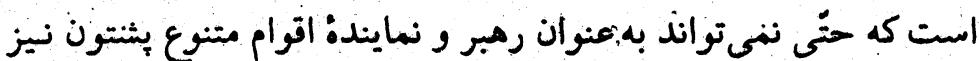

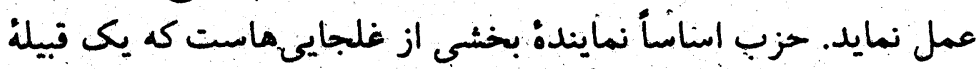

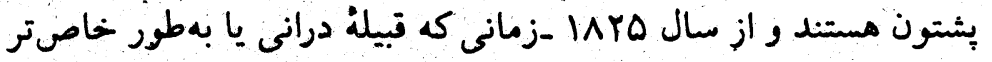

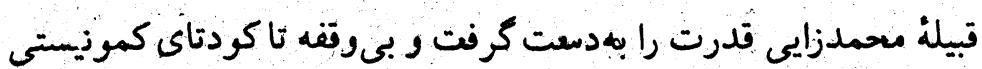

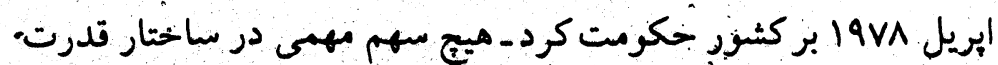

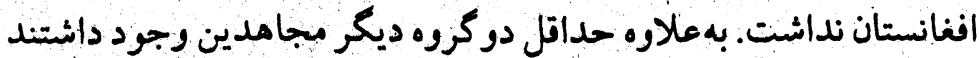
كه براى كسب حمايت غلجايى ها رقابت ميكر دند. 
موقت ر! براى مدت مجده ماه تشيكيل دمد كه زمينهسباز انتخابات باشد.

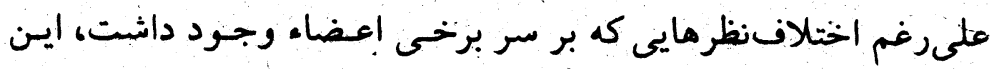

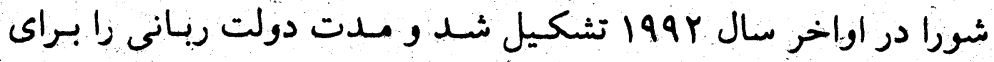

هجده مله تهديد كرد.

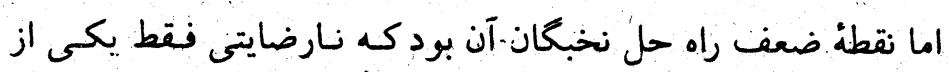
طرفهاى اصلى مىتوانست همه حيز را به هم بريزد و ايسن دقيقاً هـمان نهان

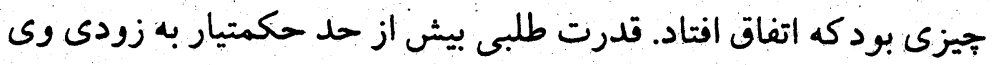

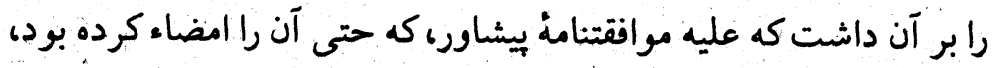

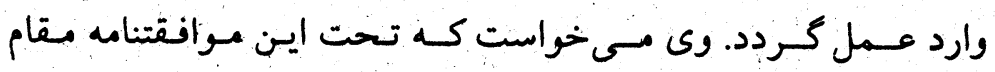

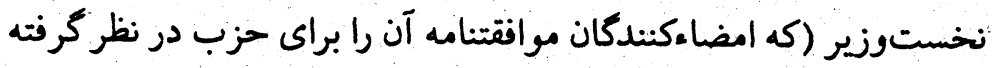
بودند) زير دمبت رئيس جمهور نباشد و مقام وزير دفاع _كه مجددى آن رآ را

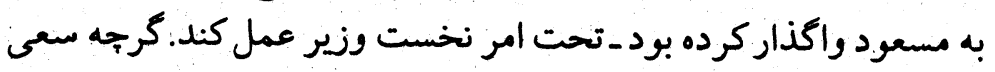

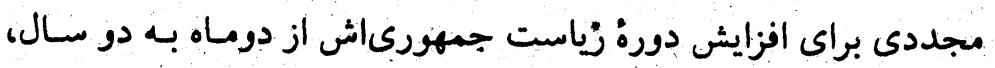

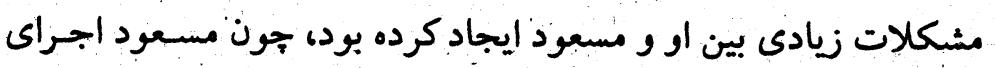

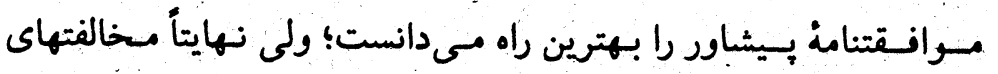
حكمتيار بود كه اين موافقتنامه راكلاًً بي ائر ماخديت.

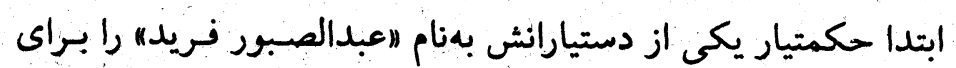

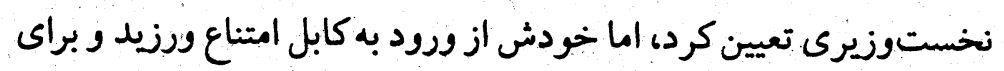

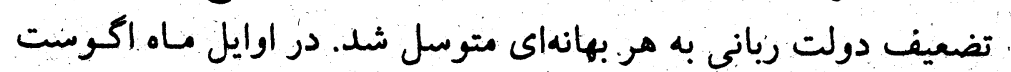

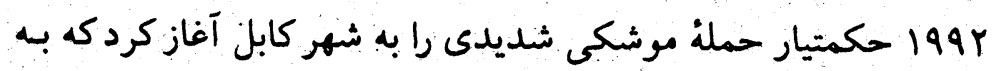

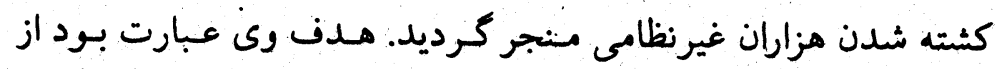

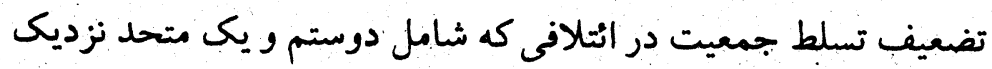

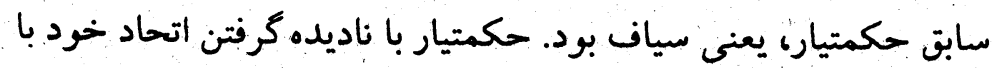

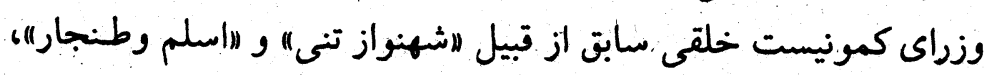

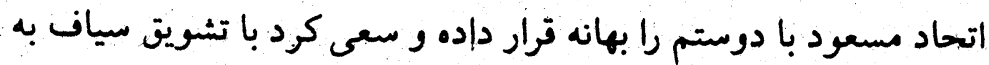

افغانستان، طالبان، و سياستهاى جهانى

به تنهايى بر كُّور حكومت كند و بهترين راه براى حلى اين مسأله عبارت

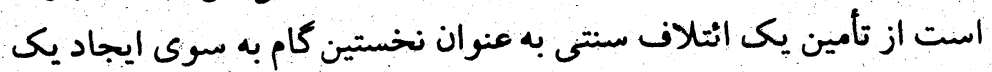

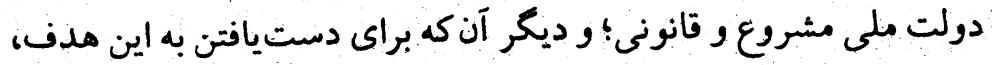

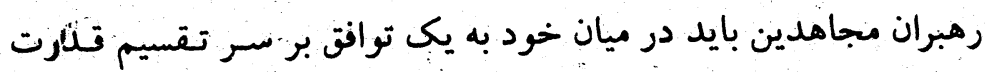

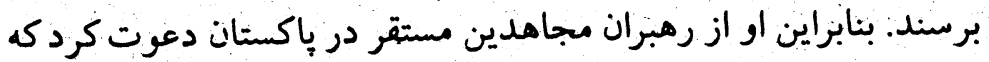

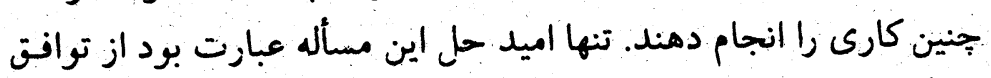

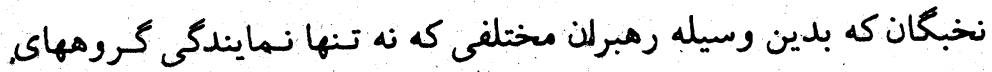

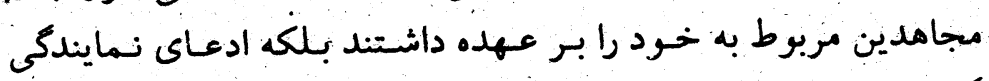

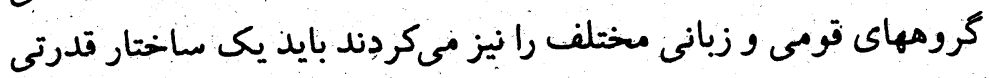

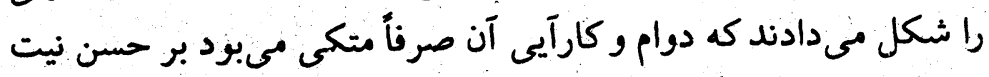

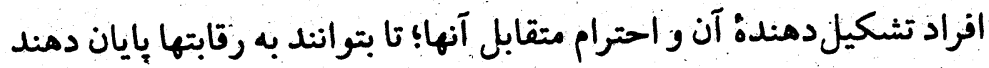

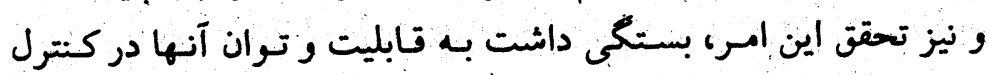
نيروماى تابعة خورد.

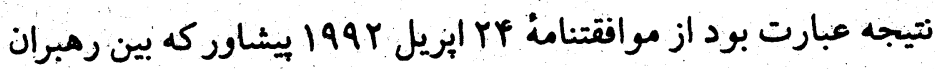

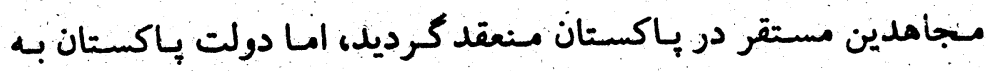
نخستوزيزى نوازشُيف نيز در آن دخالت دابُّت اين موافقتنامه اساساً

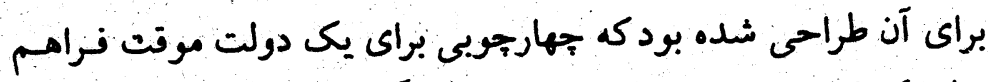

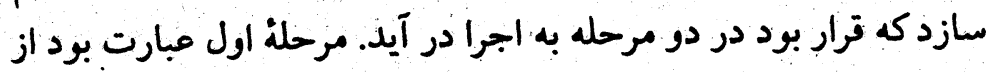

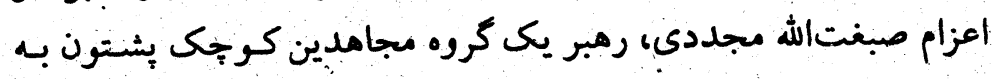

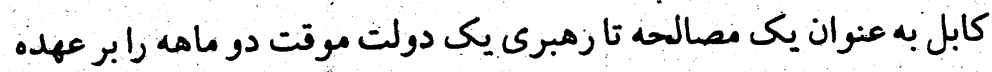

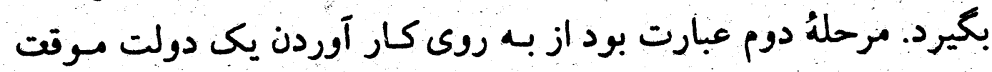

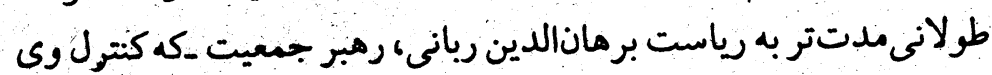

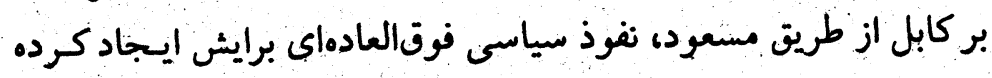
بود ــا رياست دولت موقت را براى جهار ماه عهدهدار كردود.

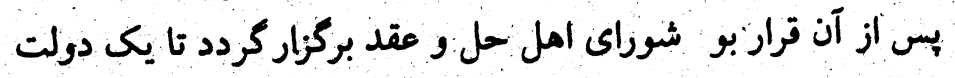


سمدت مليشياى طالبان كه تازه.شهر جتوبى قندهار را تصرف كرده بودند و

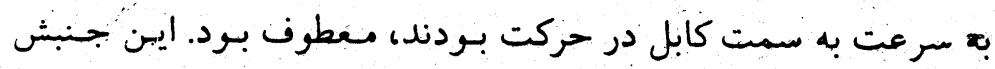

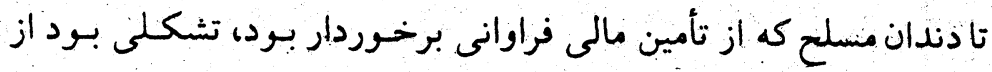

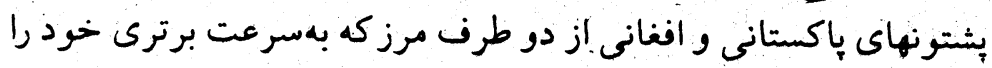

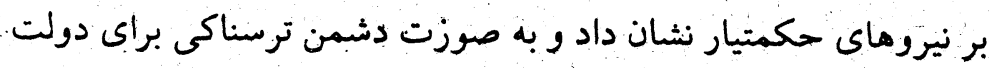

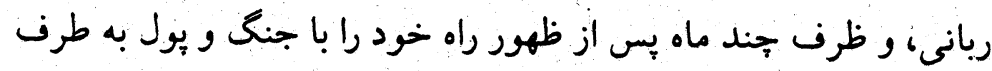

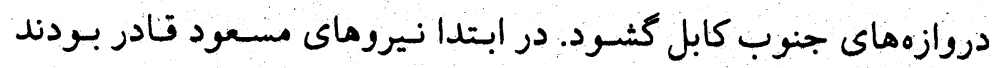

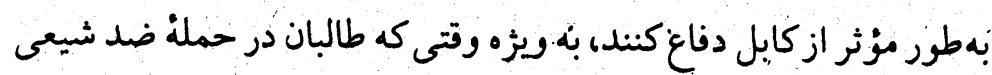

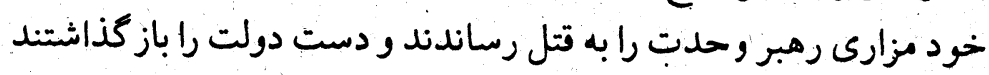

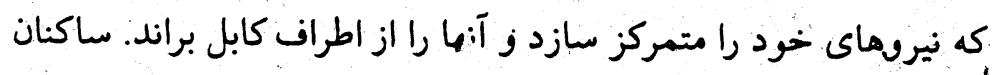

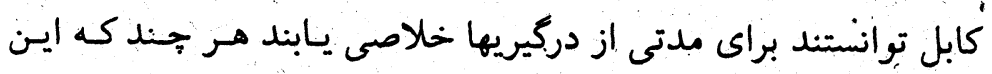

$$
\text { . استراحت طولنى نكشيد. }
$$

\section{| مشكلات درون حزبى}

جمعيت در اصل زمانى از حزب ابلامى فاصله كرفت كه حكمثيار بس از تجاوز شنوروى خود راه خود را جداكرد. ساختار و عملكردهاى جمان جمعيت تحت رهبرى برهانالدين ريانى مدت كوتاهى يس از تبعيد وى به باكستان

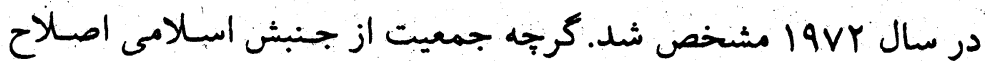

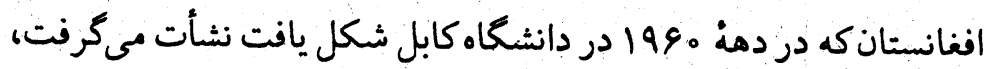
اساساً به عنوان يك انتلاف مقاومت اسلامى مجاهدين غيريشتون تجديد

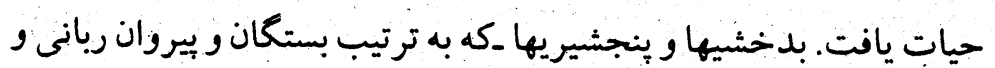

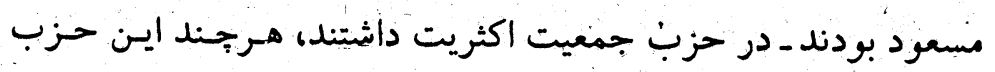

مخالفت شديد با آنها، تضاد بين جمعيت و وحدت را تشديد كند تا بتواند

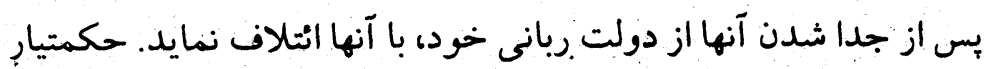

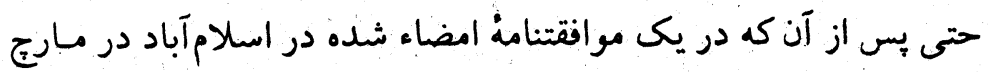

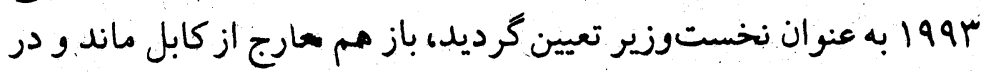

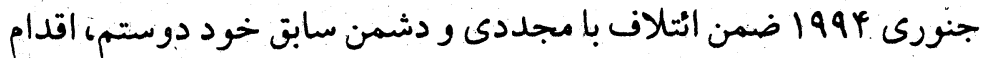

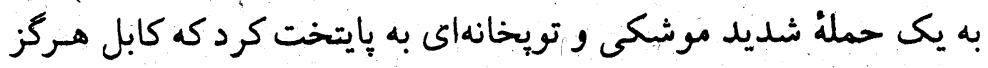

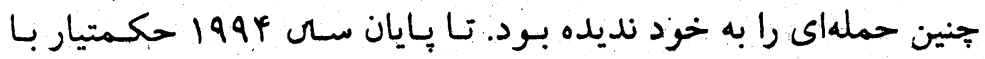

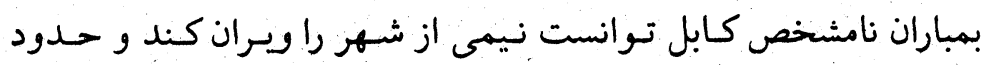

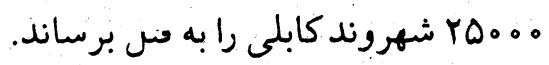

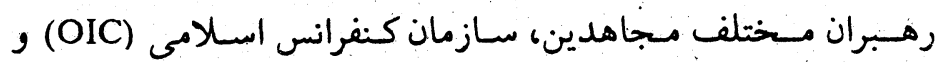
سازمان ملل متحد كـوششهاى زيـادى بـراى بـرقرارى صـلح كـردند كـهـ.

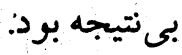
حكمتيار در تمام عملياتهاى خود سـه هـدف را دنبال مسكرد.

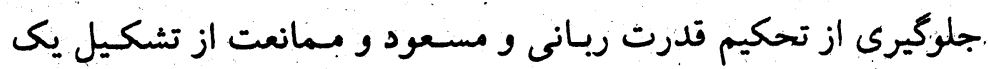

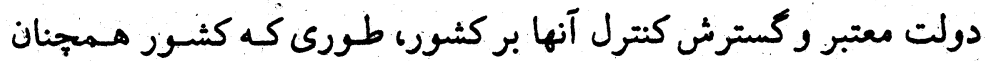

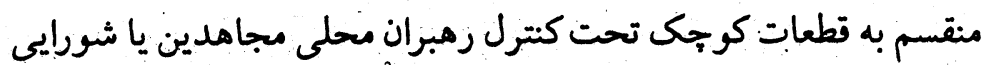

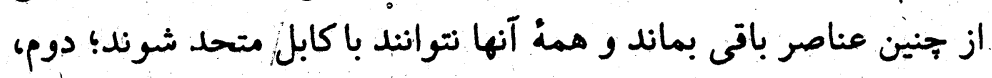

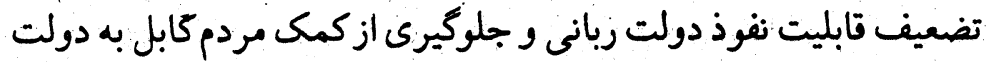

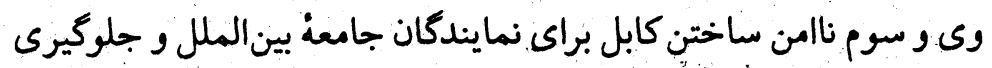

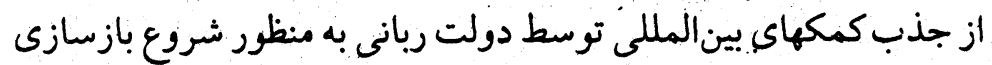
كثور يس از جنگ و ارتقاء سطح فعاليتهاى اقتصادى براى بالا بردن اعتبار

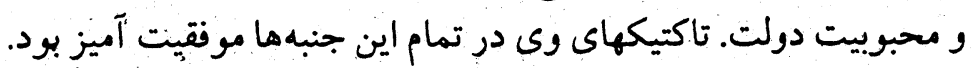

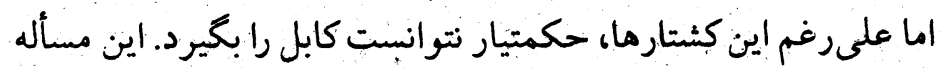

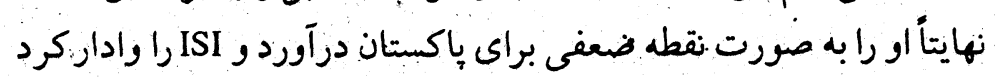

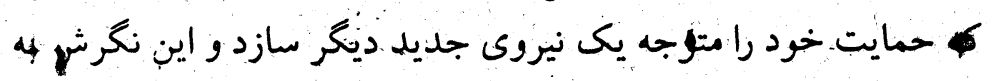




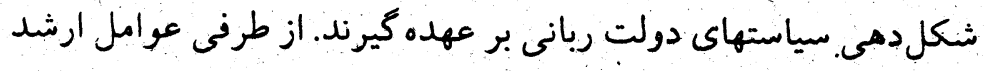

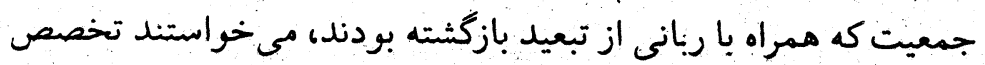

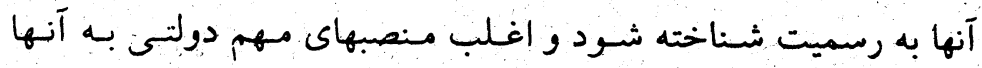

عـاملـ دوم عـبَارت بـود از قوميتكرايسى در هـر يك از جـناحهاى

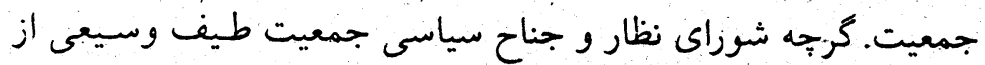

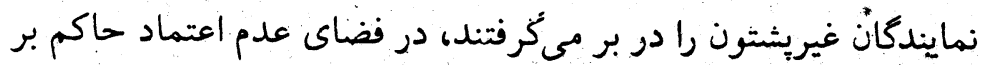

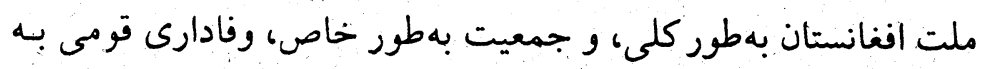

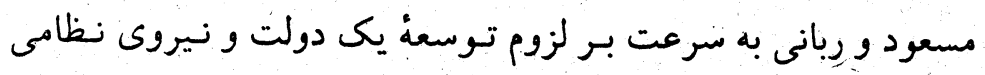
جند قومى تُلدم يافت.

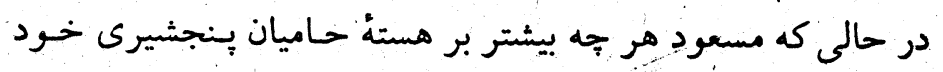

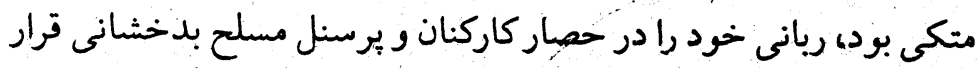

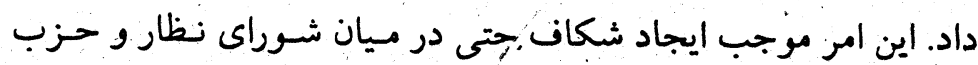

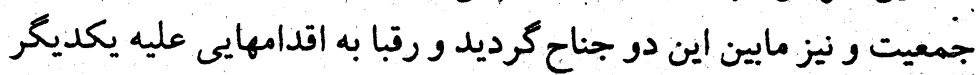

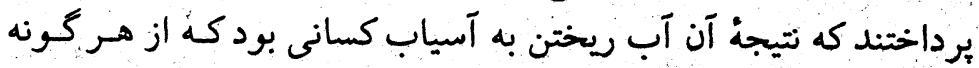

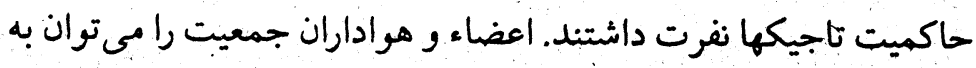

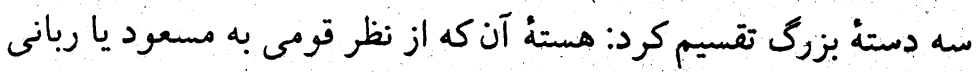

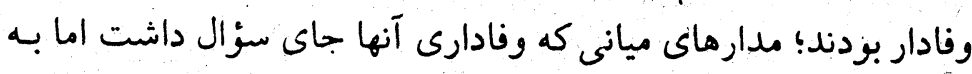

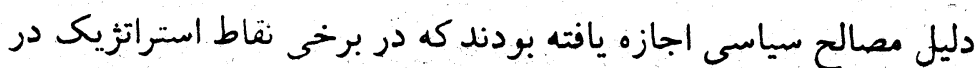

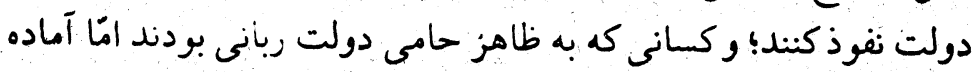

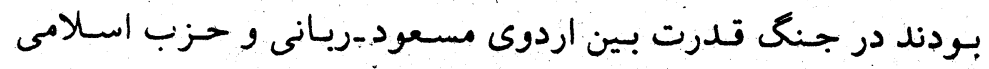

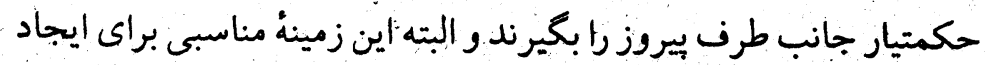

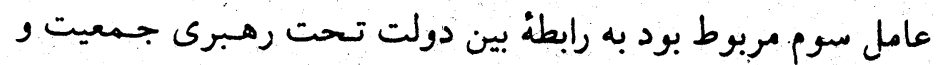

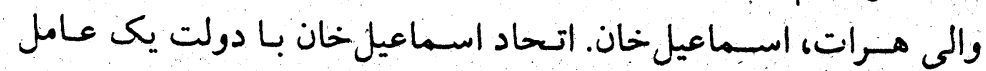

عناصرى إز بشتونها و بهويزٔه بنستونهاى شمال را نيز در بر مى دكرفت.

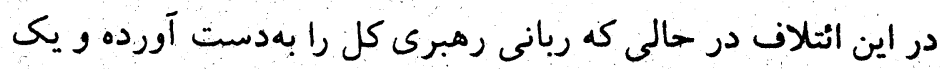

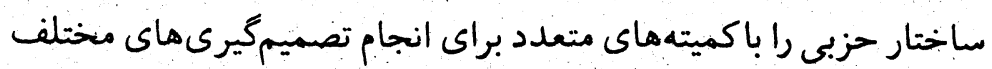

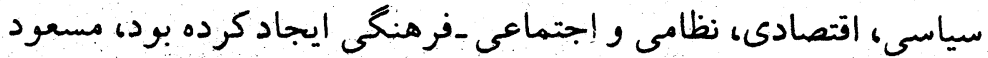

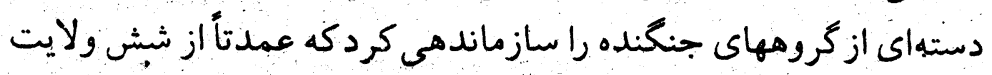

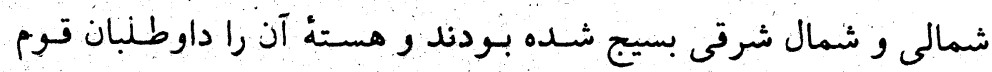

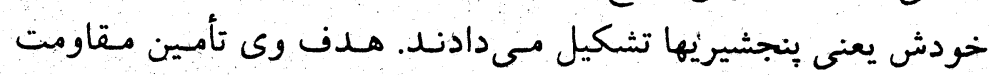

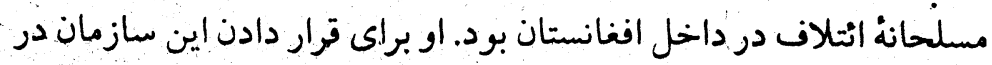

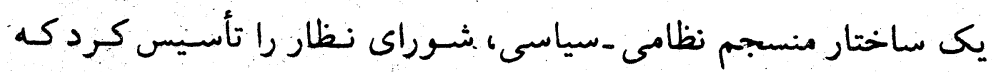

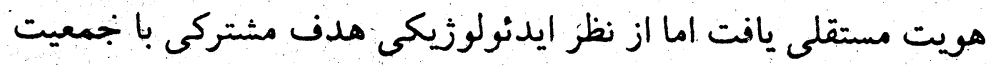

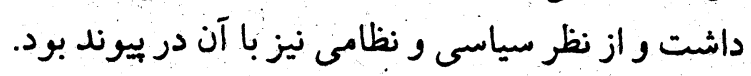

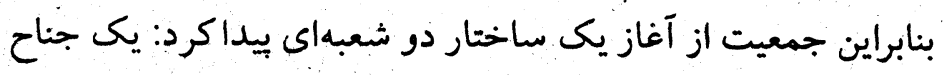

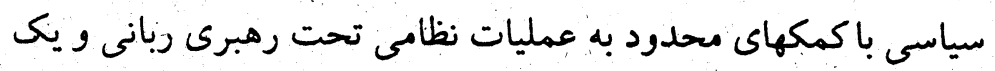

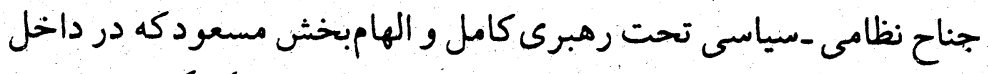

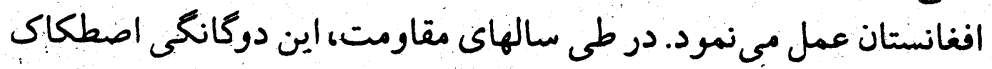

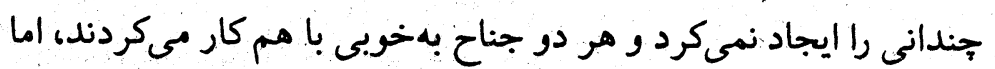

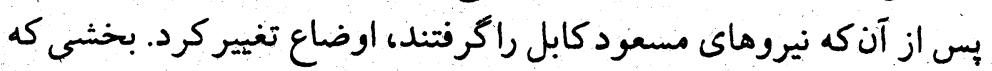

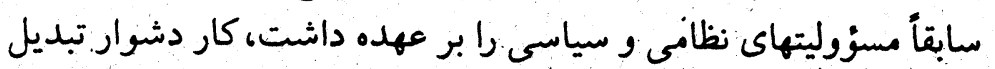

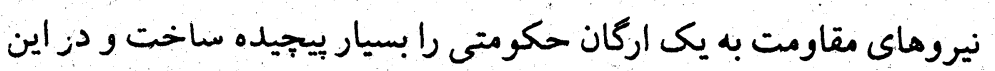

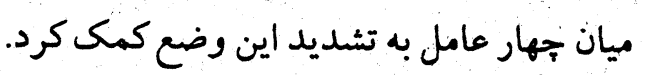

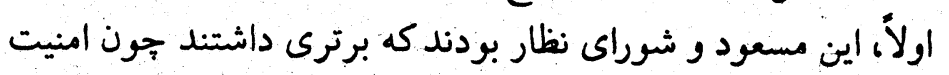

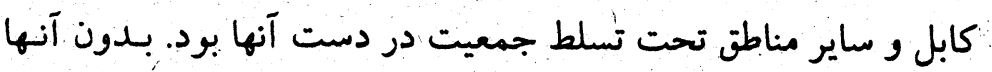

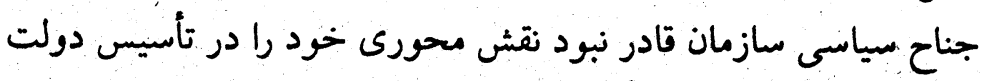

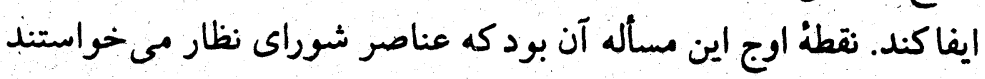

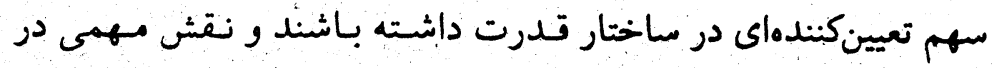


كند، لنيا امتعفايش از ريانت جمعيت دو ييامد بيش بينى نشده داشت. از

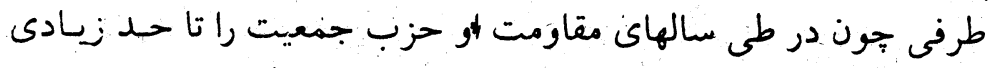
متكى بن شخص خود كرده بـود، ايـن امـر سـردرگمى زيـادى دز مهيان

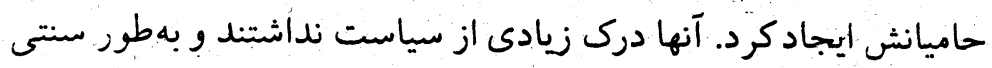
به شخعى كردن امور سياسى عادت كرده بودند: از طرف ديخر، إيـ كار

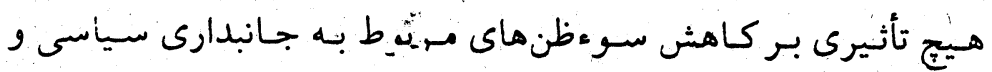

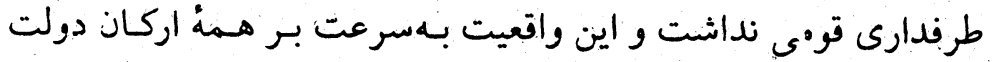
رباني تأثير گذاشت قون.

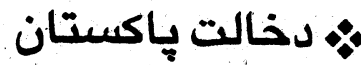

سياست باكستان نسبت به افغانستان از زمان تهاجم شوروى يك سياست.

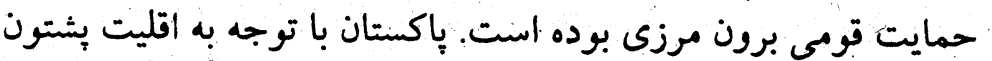

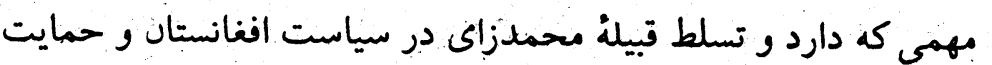

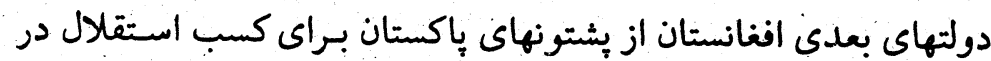

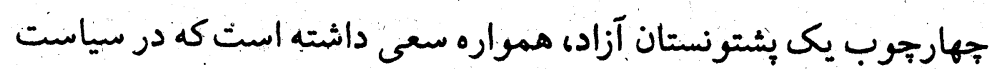

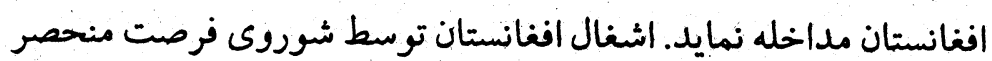

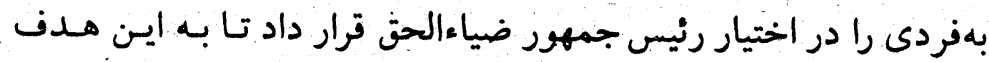

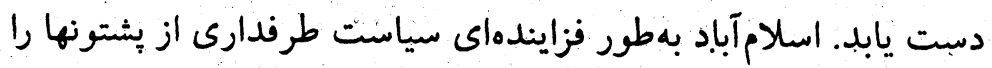

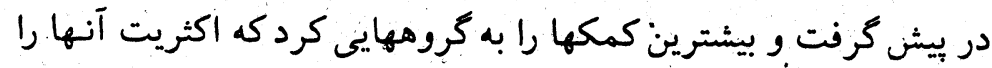

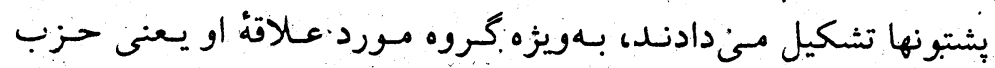

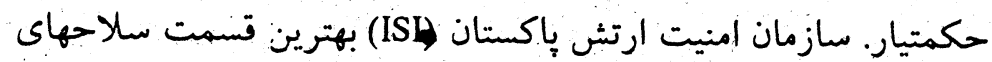
امريكايى و ديخر كمكهاي خارجنى ارسالى براى مجاهلين رإ در اختيار
آسودكى خاطر رباني و مسعود بود ولى از سويى ديغر افزايش قدرت او

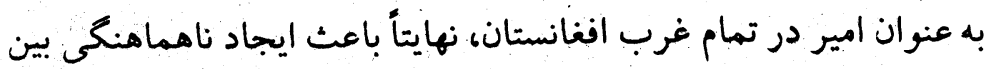

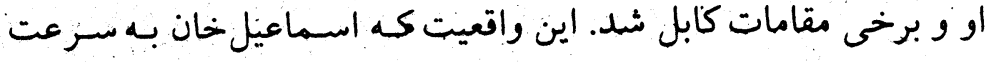

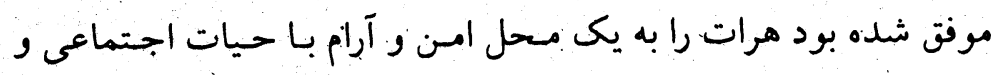

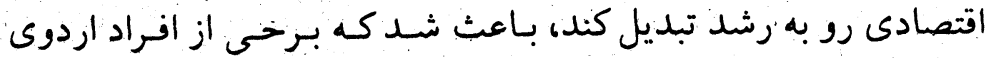

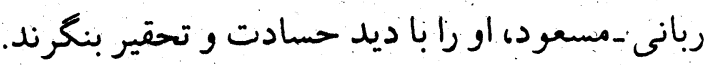

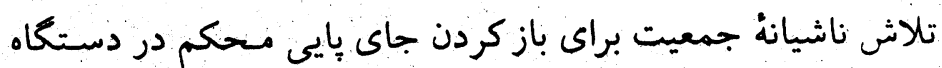

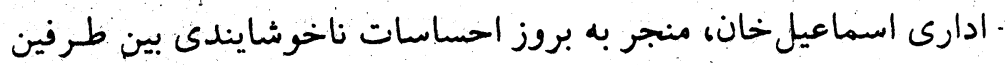

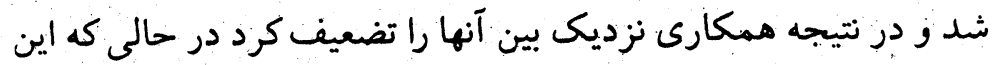

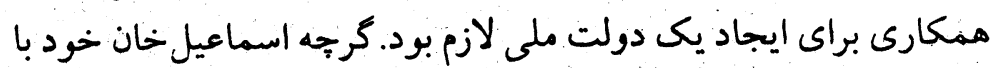

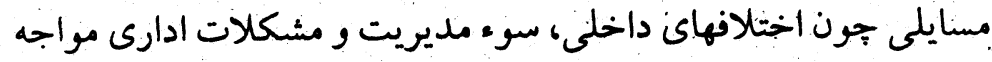

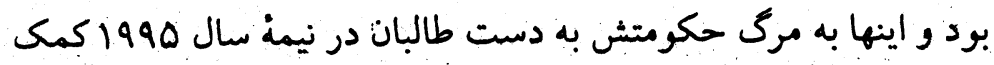

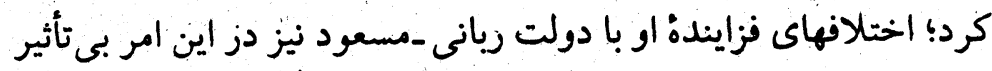

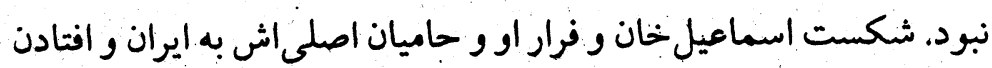

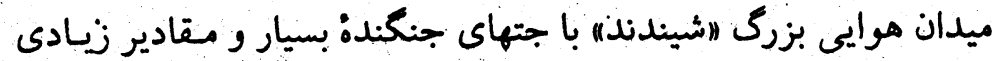

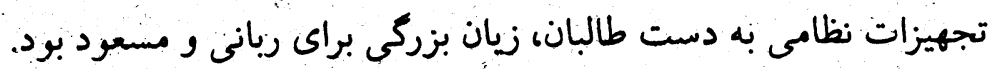
اين حادثه تأثير روانى و مادى سختى بر نيروهاي آنها داشت و و تسلطشنان

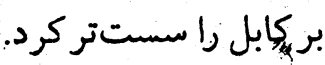
عامل ديكر، ناشى از اين واقعيت بـزبد كه ربـانى بس از كسبت مـقام

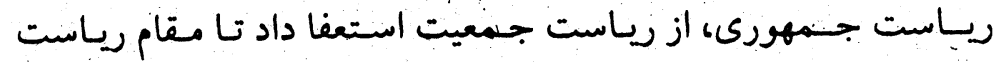

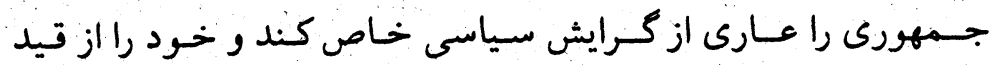
محدوديتهاى حزبى و سوءظنهاي مربوط به جانبدارى سياسى از حزبى

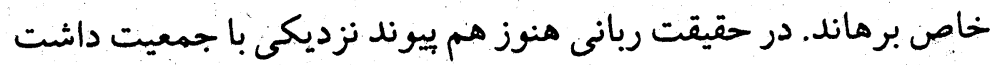

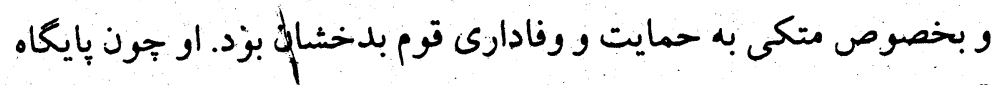

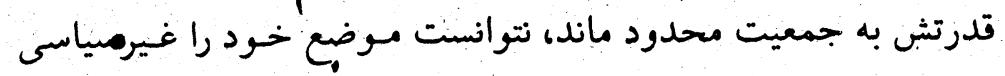




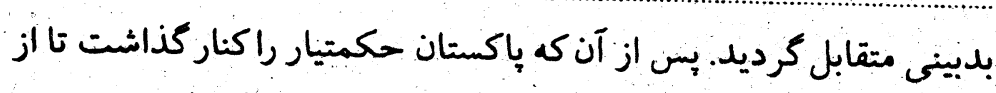

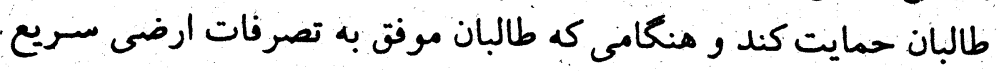

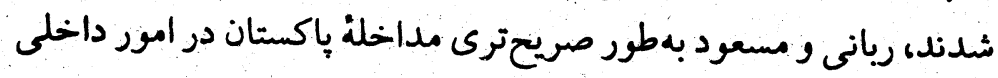

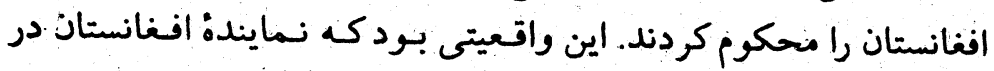

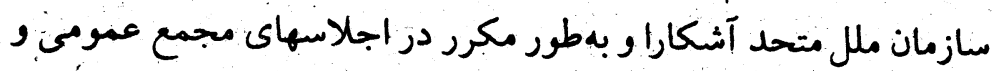

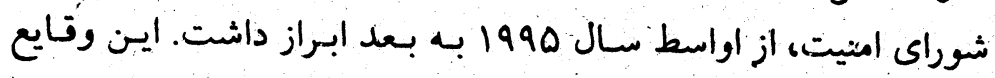

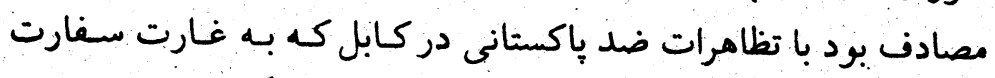

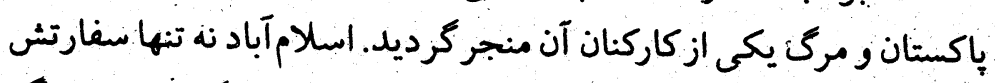

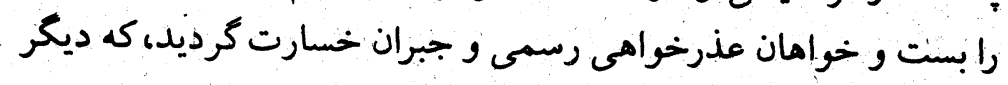

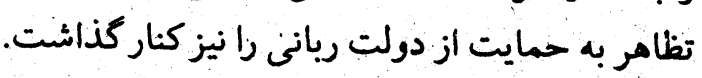

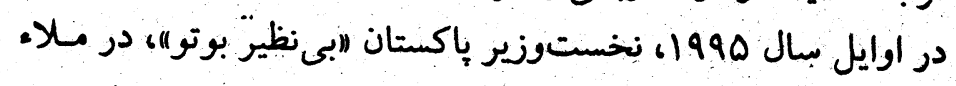

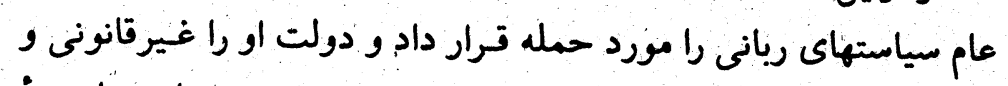

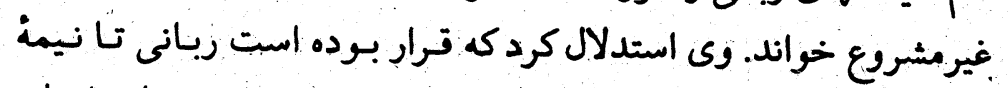

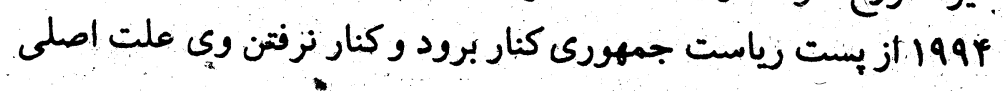
جنكهاى داخلي اففانستان است.

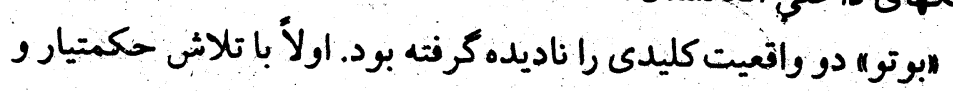

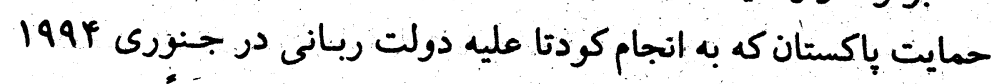

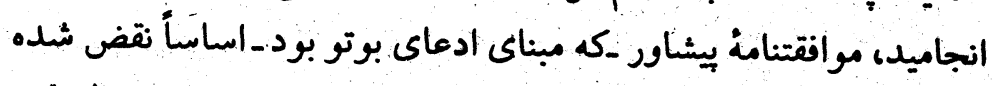

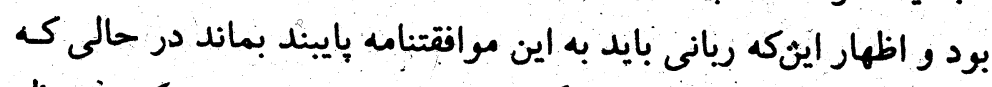

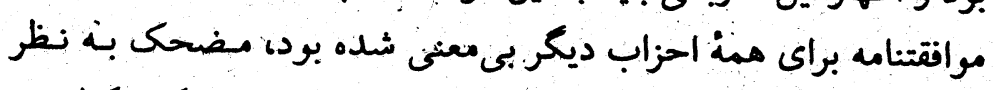

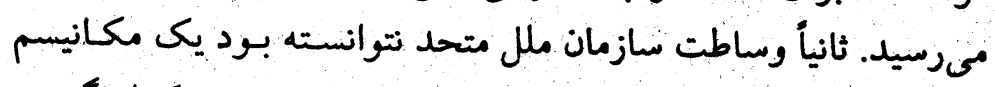

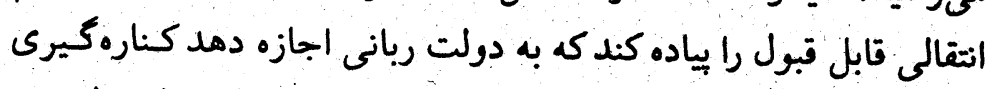

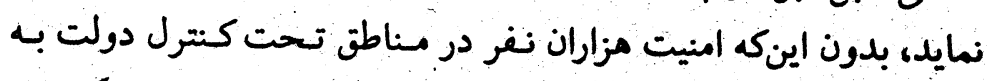

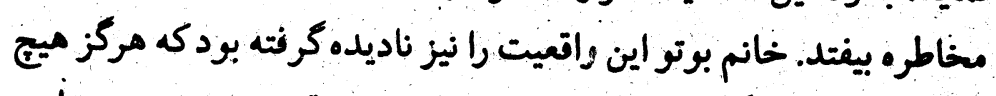

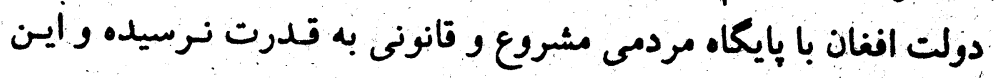

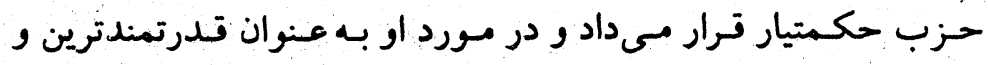

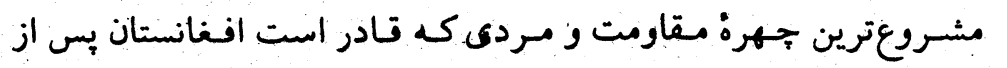

$$
\text { كمونيسم را رهبرى كند، تبليغ مىكردئ }
$$

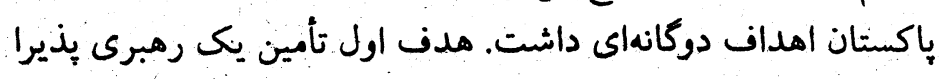

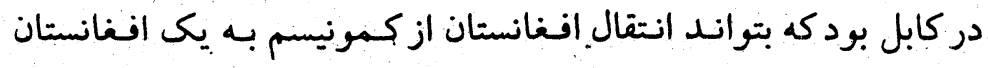

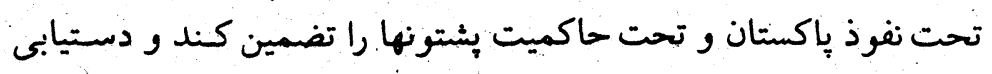

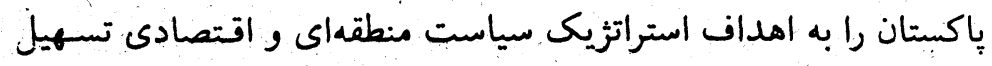

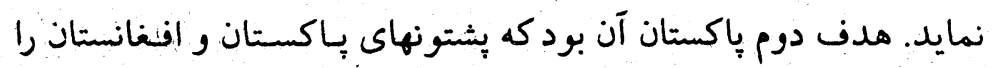

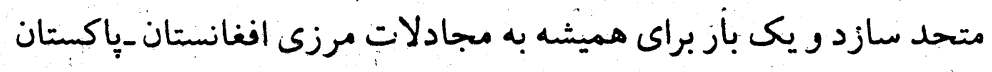

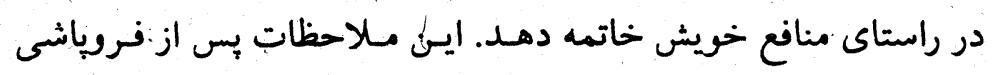

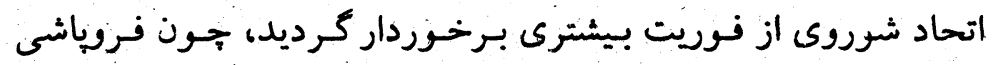

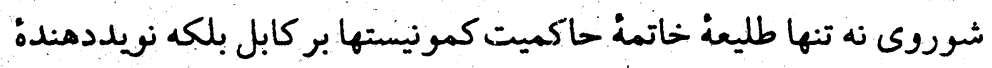

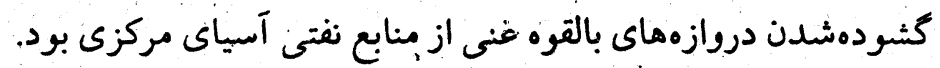

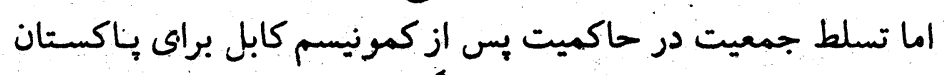

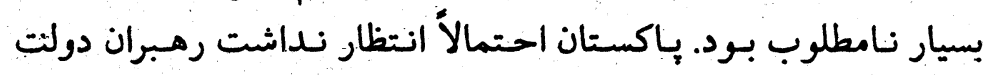

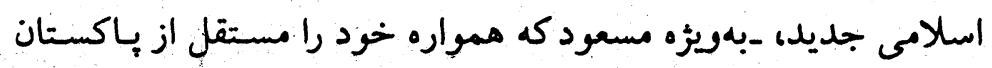

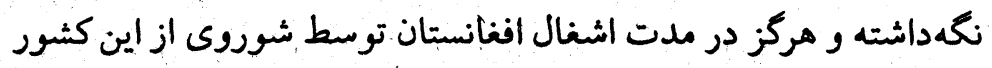

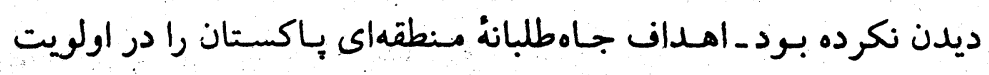

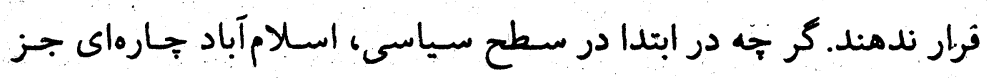

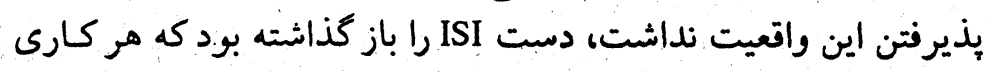

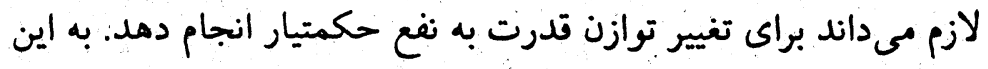

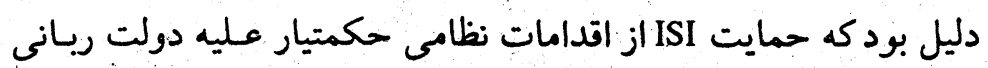

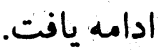
ناسازكارى ريانى و مسعود با ياكستان و بالاخره ابراز نكرانى آنها از

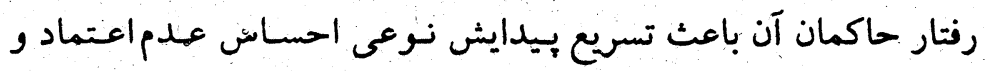




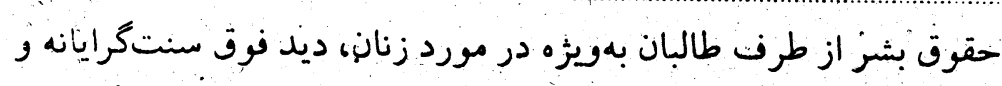

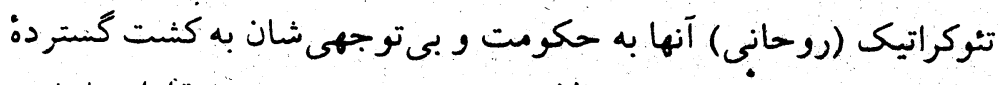

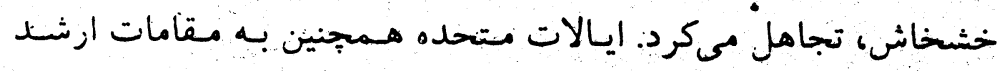

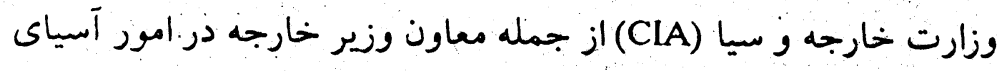

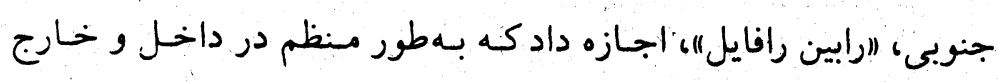
افغانستان با رهبران طالبان ديدار كنيد.

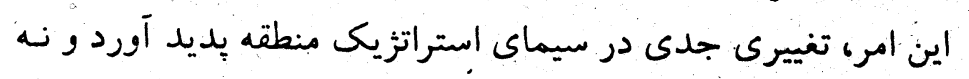

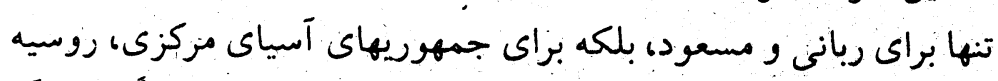

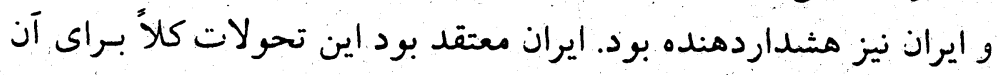

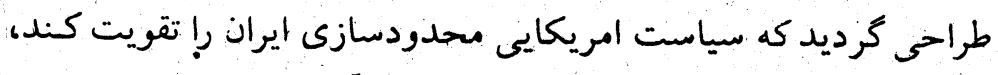

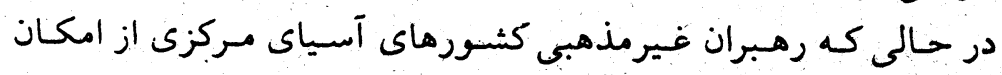

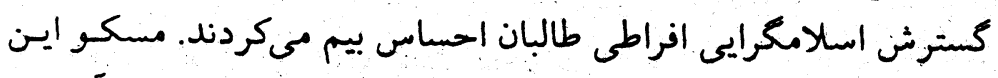

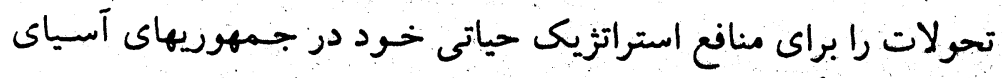

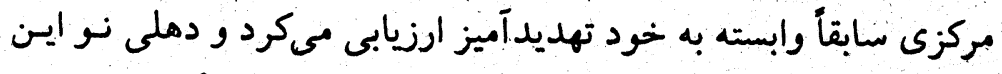

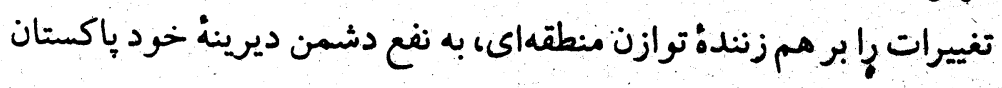

كرجه تا اين زمان رباني و مسعود از هركونه بيوند نزديك با رزيم ايران

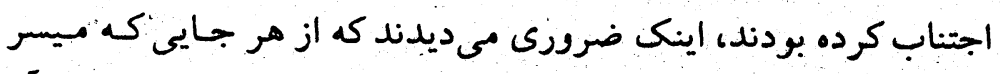

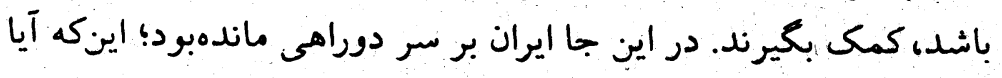

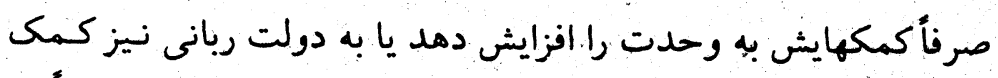

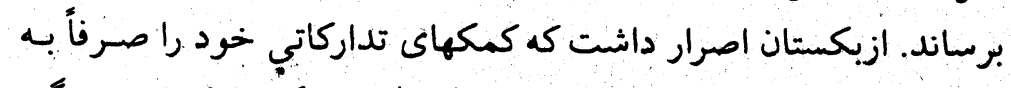

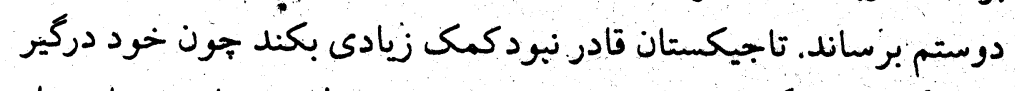

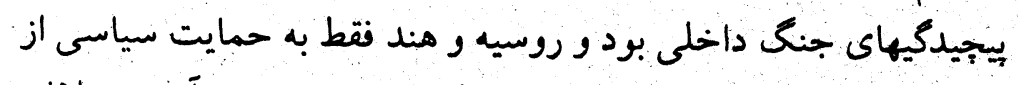

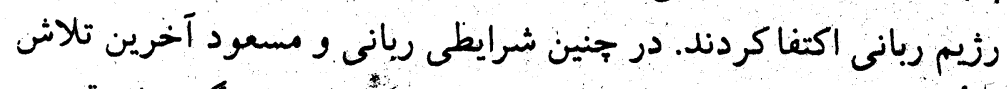

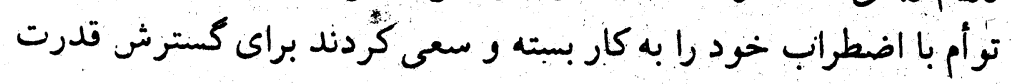

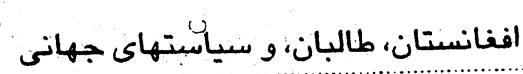

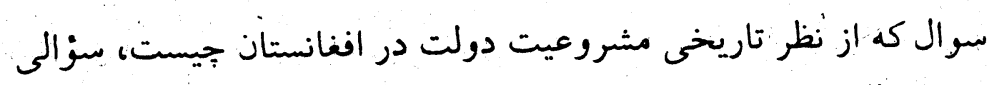
بسيار علمى مىباشد.

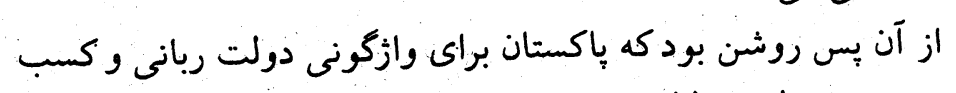

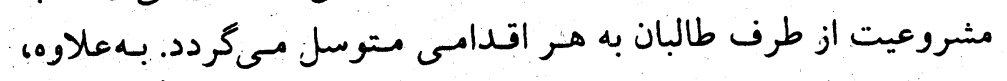

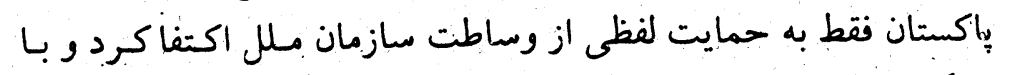

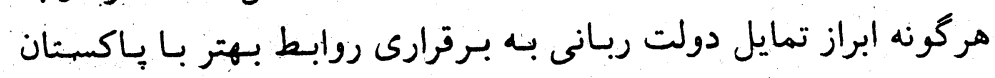

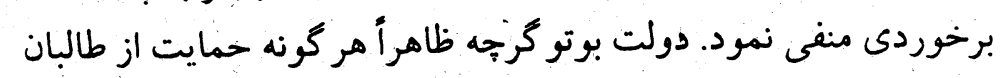

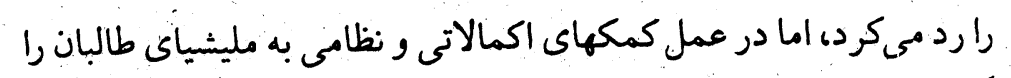

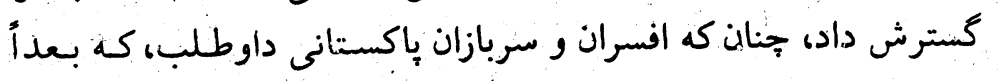

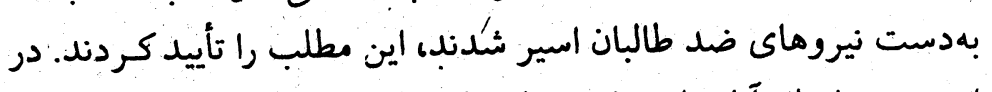

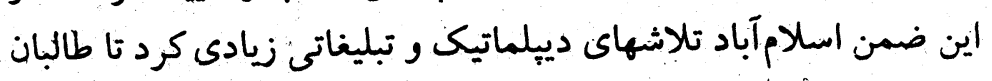

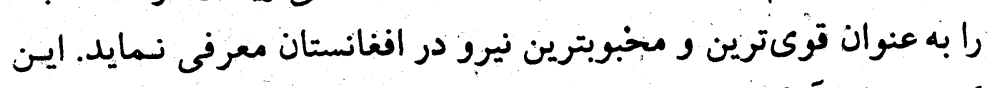

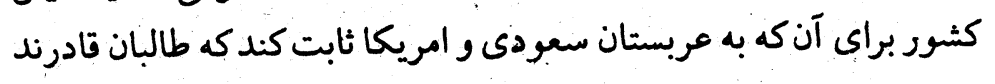

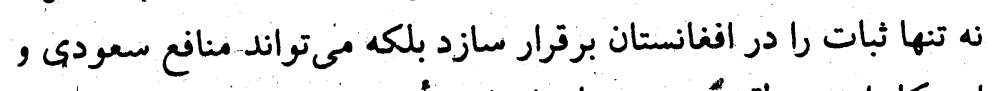

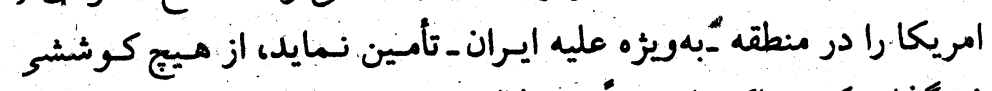

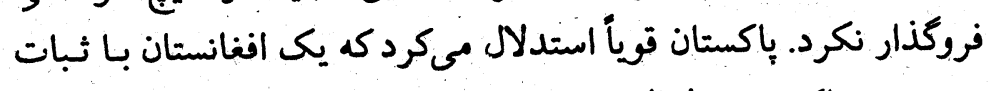

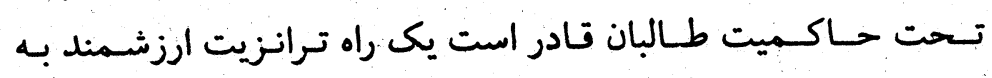

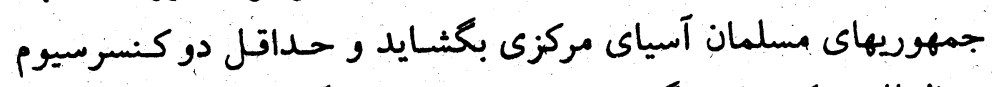

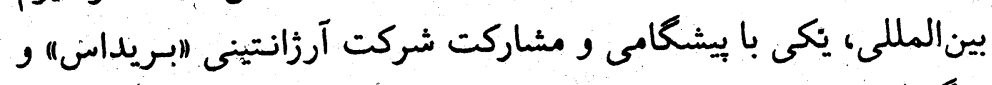

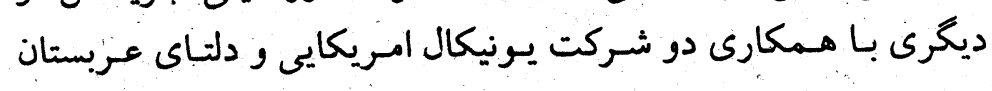

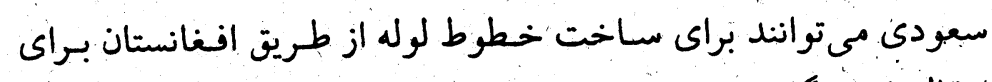

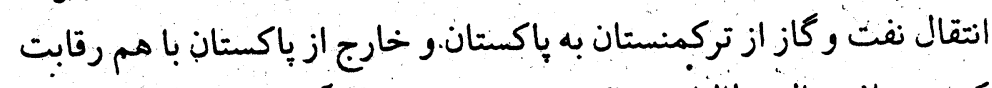

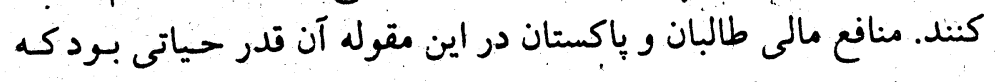

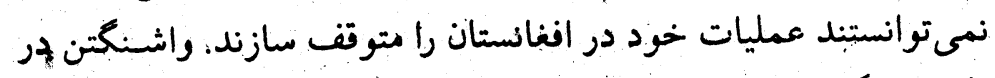

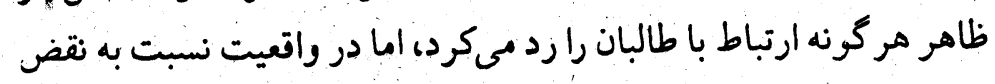


افغانستان در قرن نوزدهم و شُوروى در دهه •191 آشنا هستند.

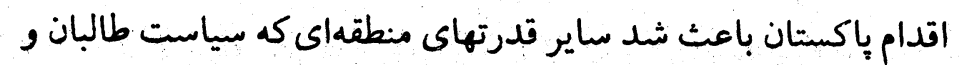

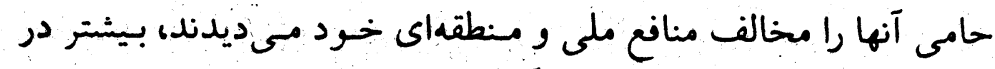

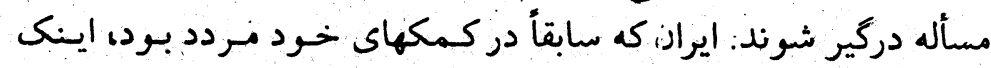

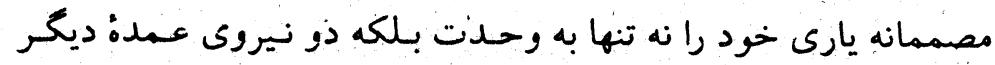

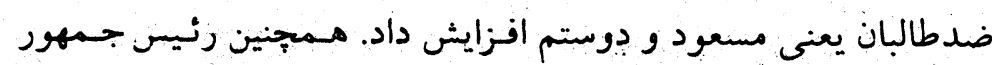

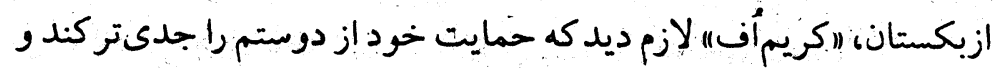

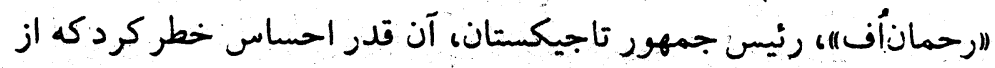

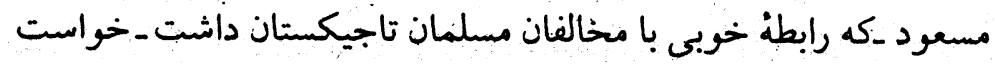
كه نقش مهمى در تسريع خاتمه جنك داخلى تاجيكستان إيفا كند و در

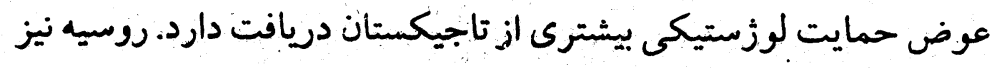

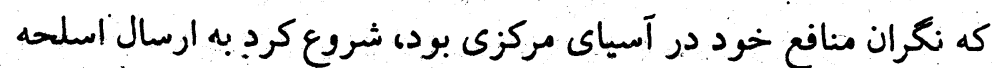

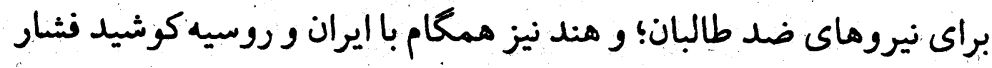

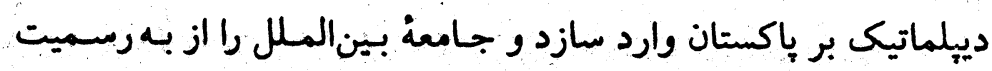
شُناختن طالبان باز.دارد.

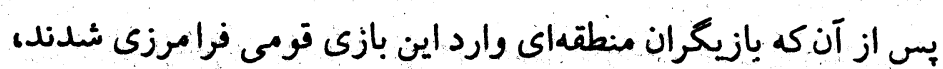

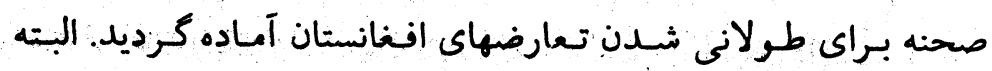

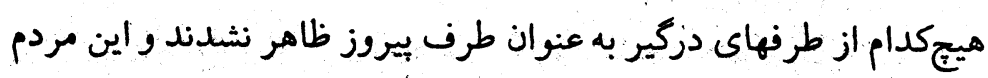

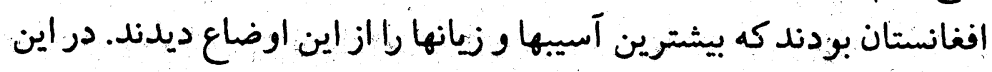

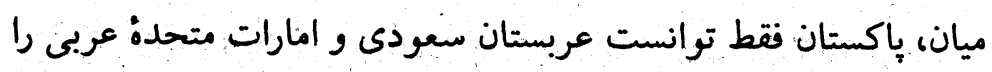
براي شناسايى ديخلماتيك طالبان با خود همراه كند. دولت ربانى همجنان فيسان

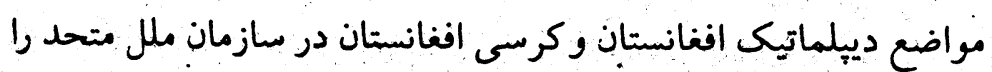

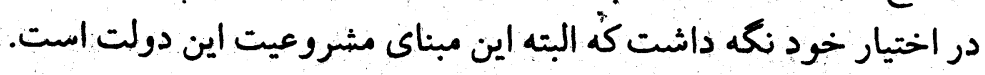

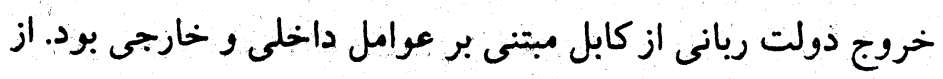

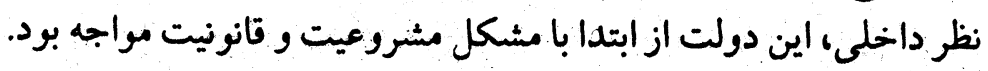

دولت خود نه تنها با وحدت كنار بيايند، بلكه حكنتيار بشتون رادر دولت

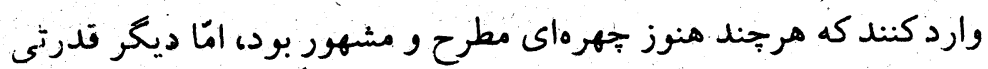

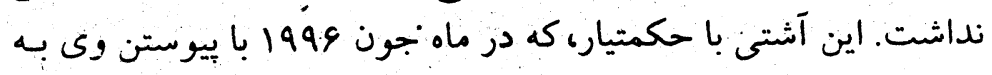
سمت نحستوزير به دولت تثبيت شد، شايد بدترين خطاى استراتزيكى بود كه رهبران جمعيت مرتكب شبدند، يك مدحاسبة غلط كنه بيـامدهاي

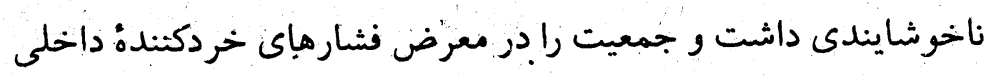

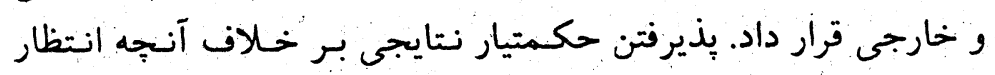

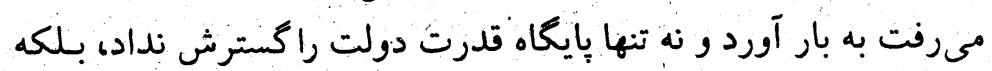

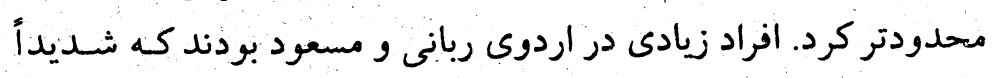

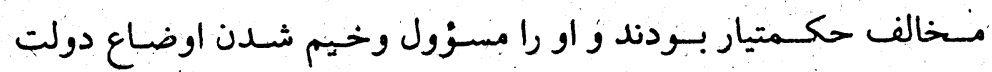

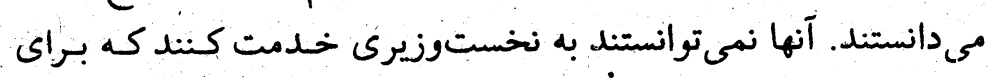
نابودى آنها به هر كارى دست زده انه بودي

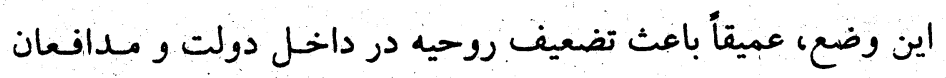
نظامى شد و نتيجة نهايى آن مصيبتبار بود. وقتى طانبان آخرين حسملية

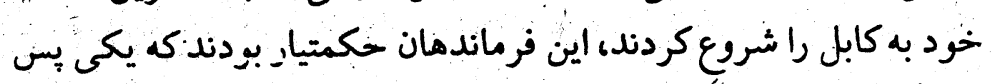

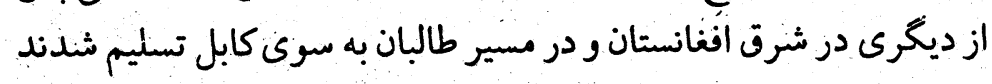
و نيروهاى مسنعود نتوانستند جلو سدى راكه شكسته بـود، بخكيرند. تـا

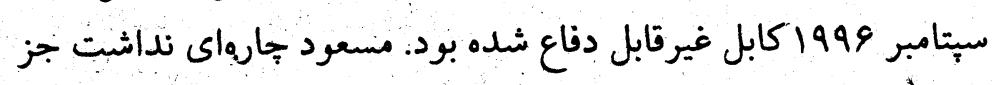

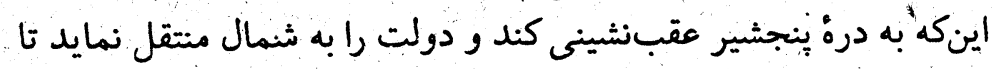

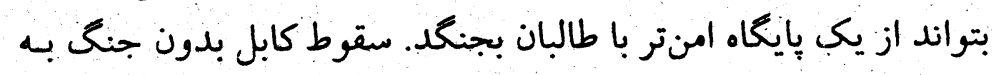

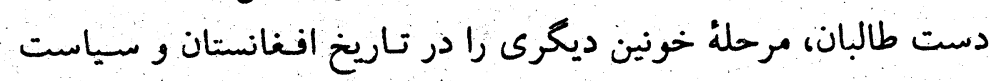

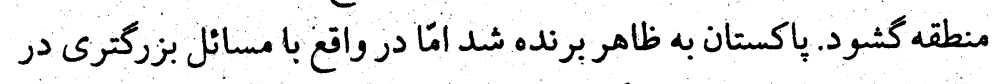

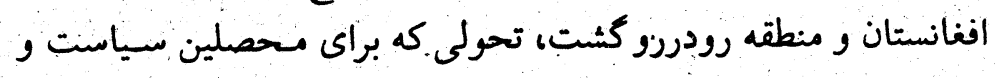

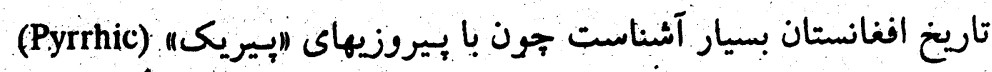

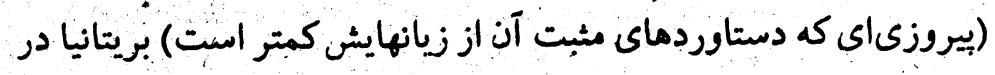




\section{نحوة شكل ئيرى كروه طالبان

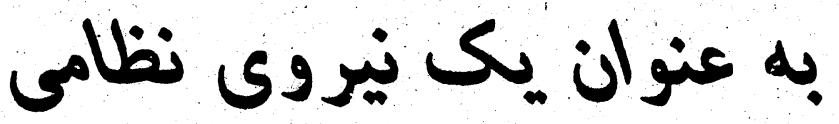

هانتونى ديويز

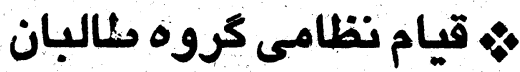

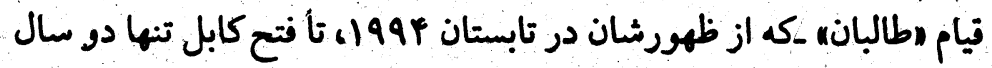

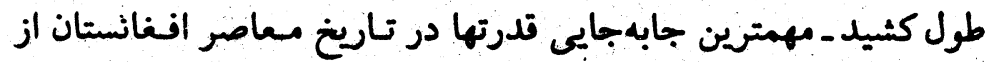

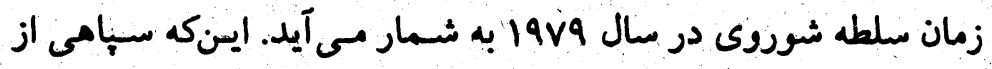

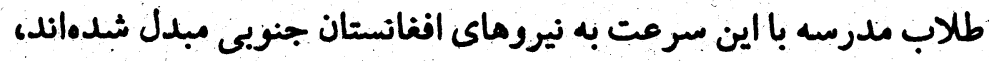

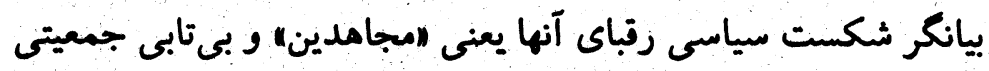

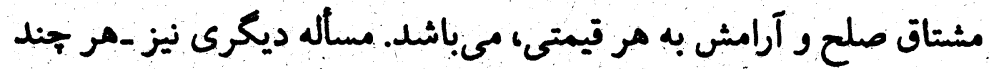

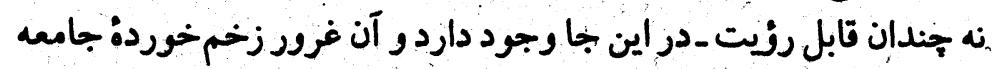

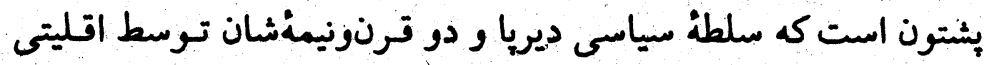

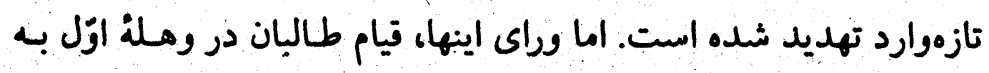

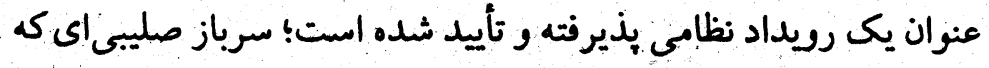

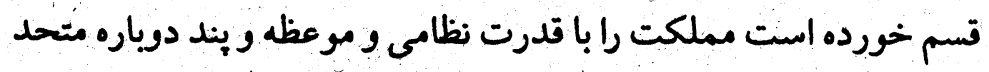

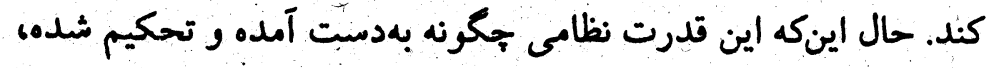

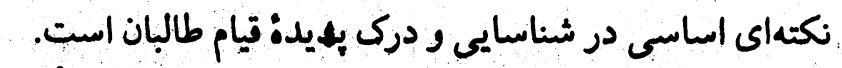

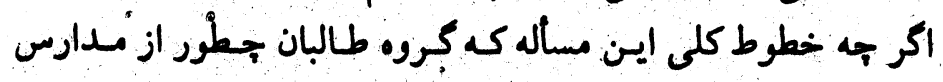

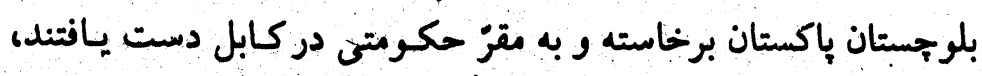

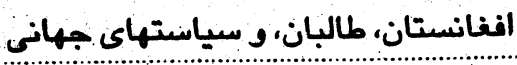

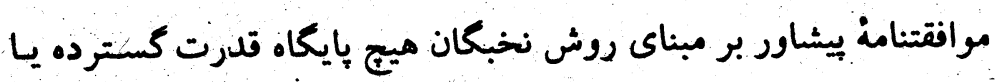

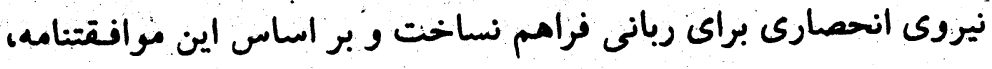

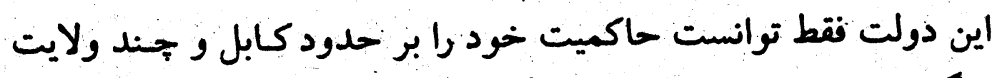

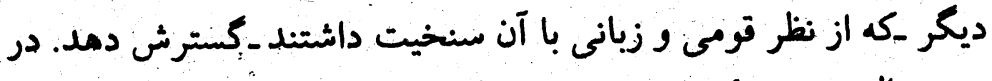

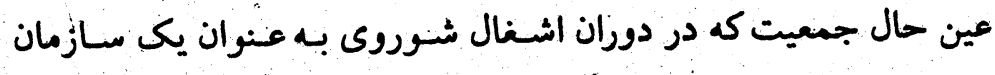

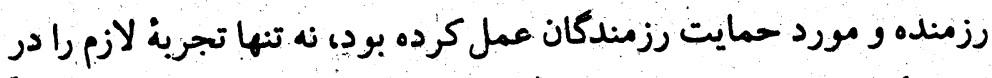

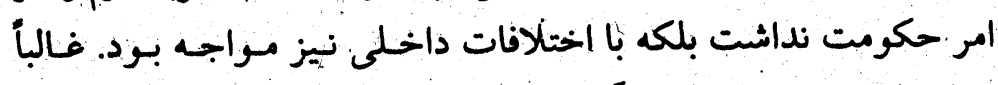

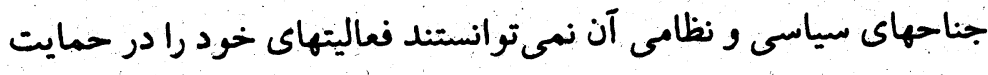

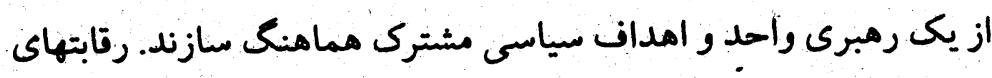

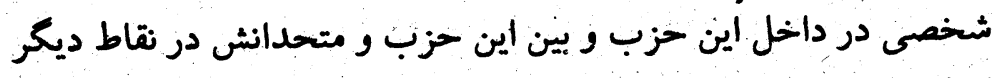

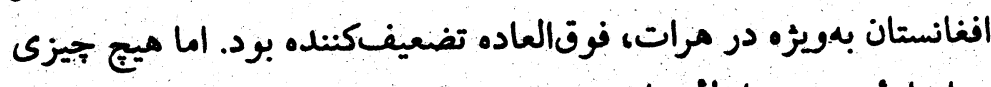

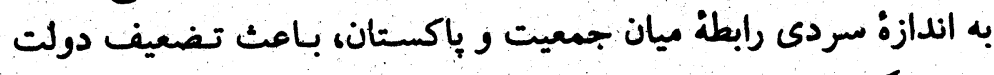
ربانى نكرديد. مخالفت باكستان با دولت ربانى به عنوان دولتى كه حاضر نبود تسليم

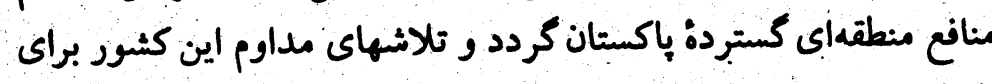

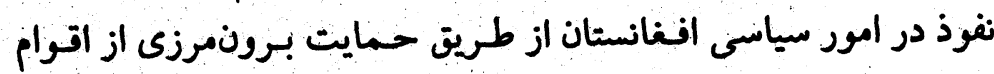

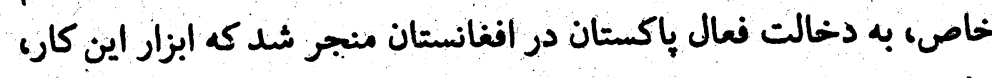

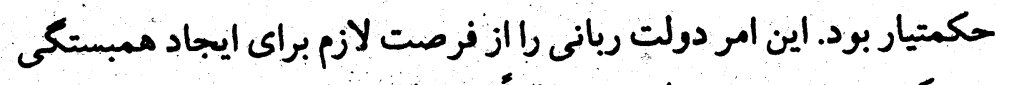

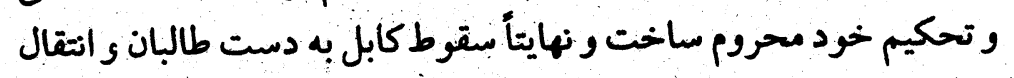

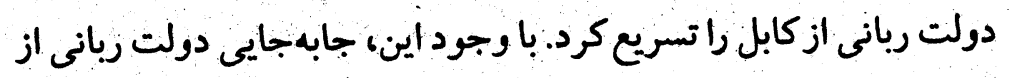

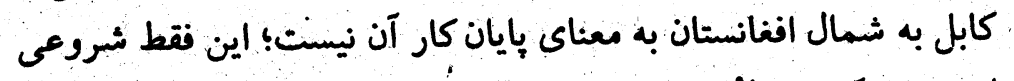

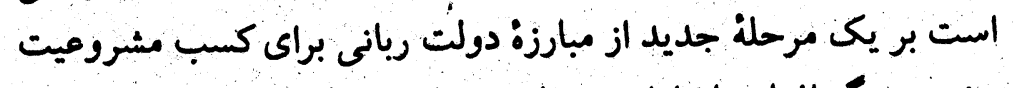

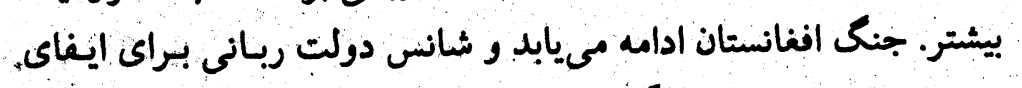
نقش در تعيين سرنوشت آيندة افنغانستان نيز نداوم دارد. * * * * 


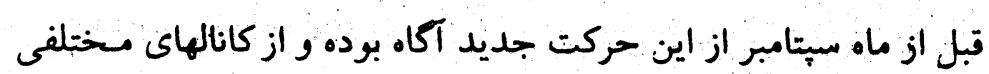

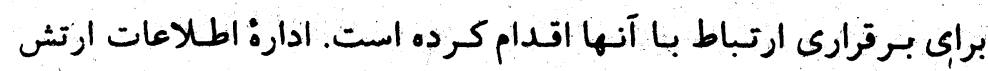

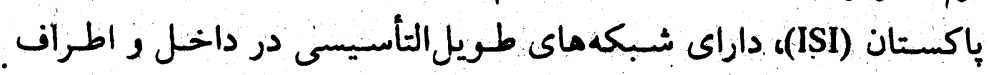

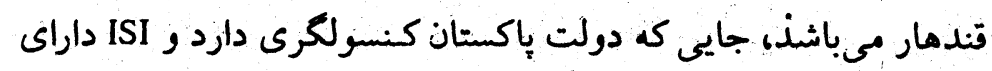

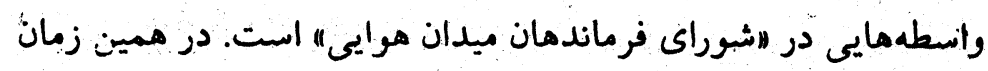

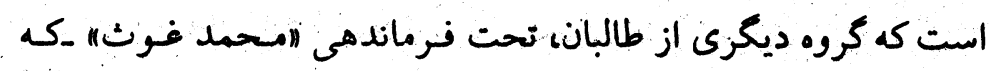

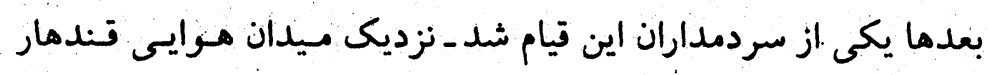

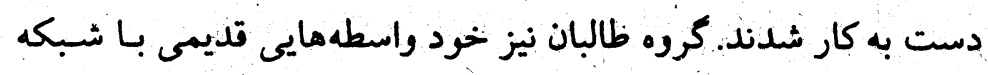

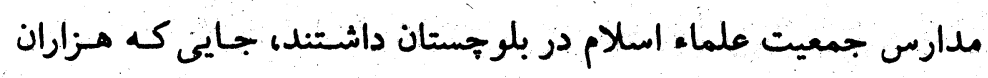
جوان مهاجر و تعدادى از دانشجويان افغانى مشغول تحصيل علوم قرآنى دئي

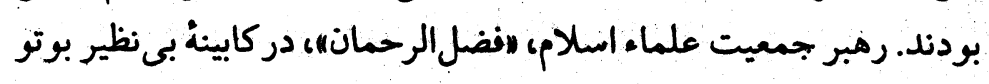

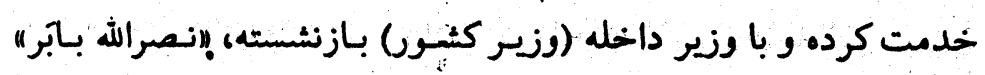
مبكارى داشته است.

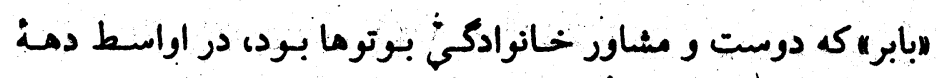
19V.

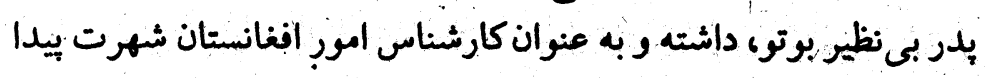

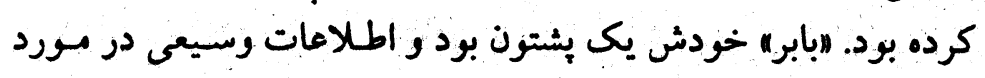

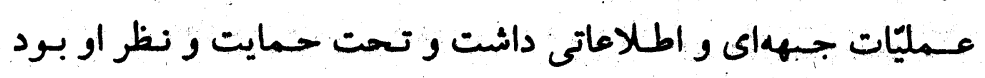

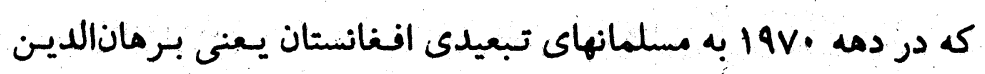

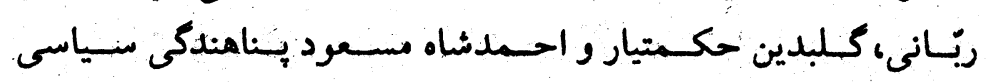

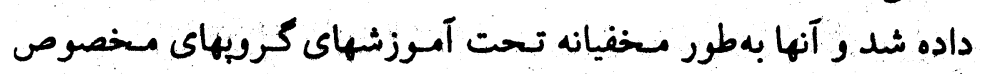

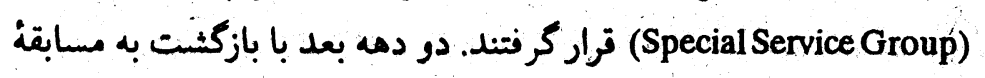

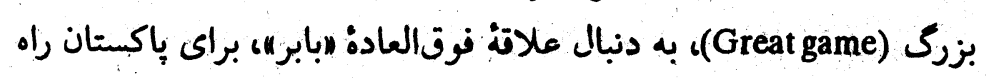

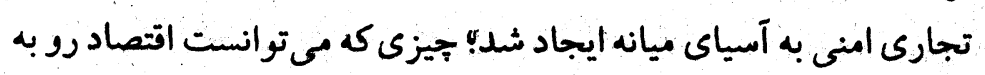

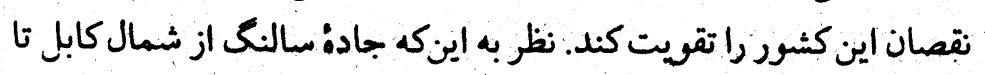

كاملاً روشن و واضح است؛ امًا ريشهماى اين حركت هنوز مبهم ماندهاند.

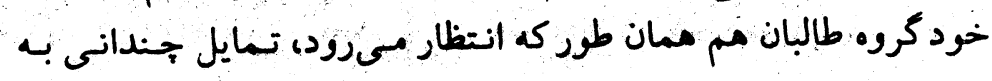

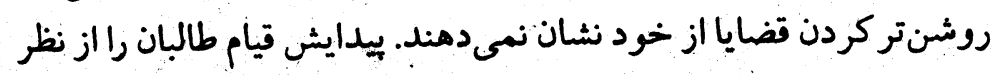

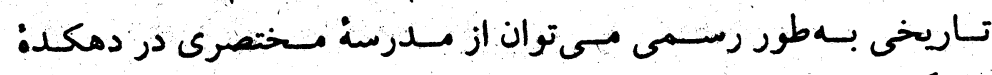

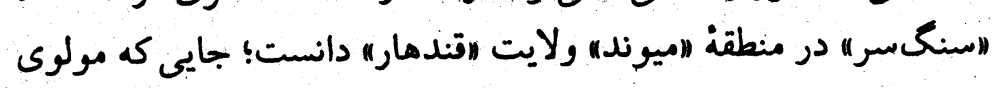

محمدعمر يكى از مجامدين ييشين مشغول تحصيل بوده است.

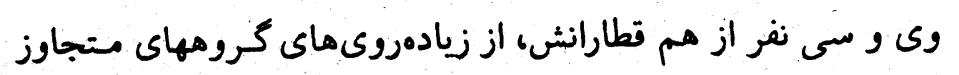

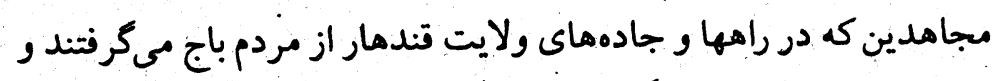

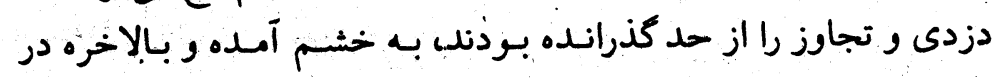

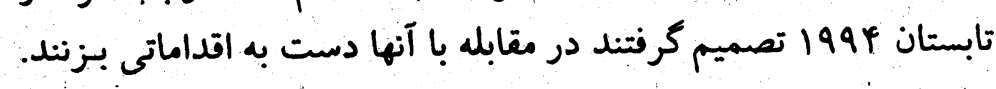

قيام با ضميمه شدن موج خِشم مردم از ممين نقطه آغاز شد.

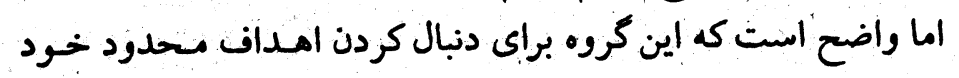

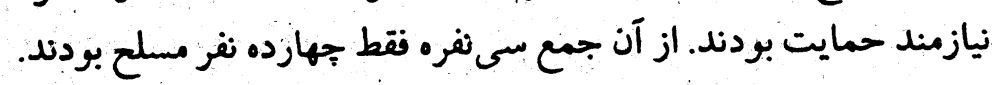

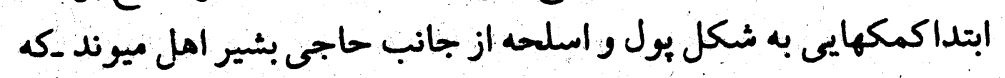

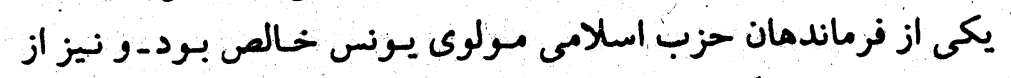

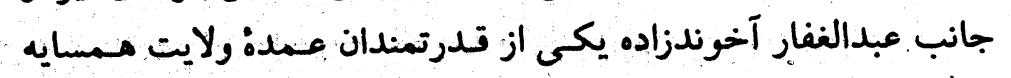

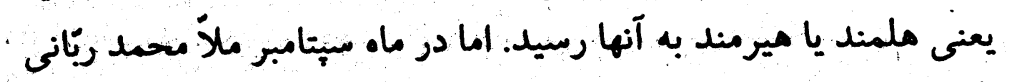
يكى از ياران نزديكى مولوى محمدعمر با جندين نفر از ممراهان به كابل

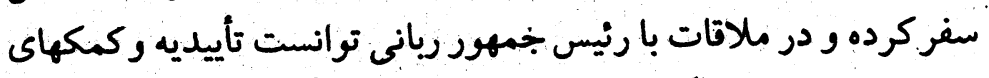

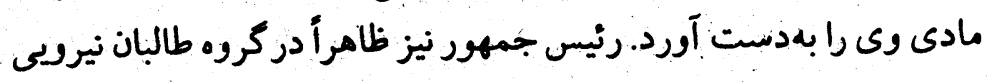
ديده بود كه ممكن بود عليه حزب اسلامى كلبدين حكمتيار به كارش آيد،

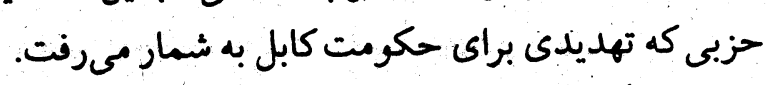

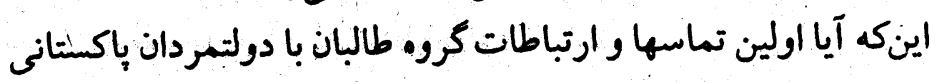

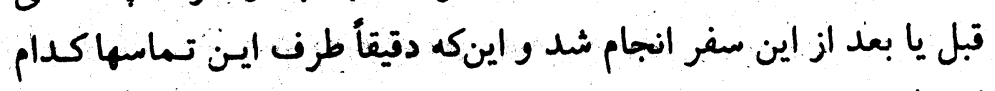

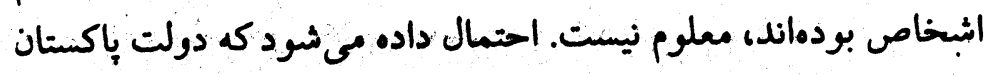


در بيشتر موارد در كرومهايى كه بهطور اخص به عنوان طالبان شـناخته

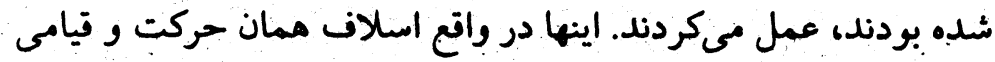

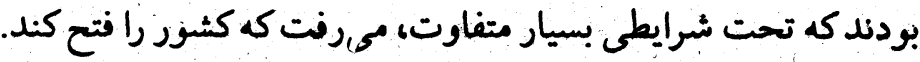

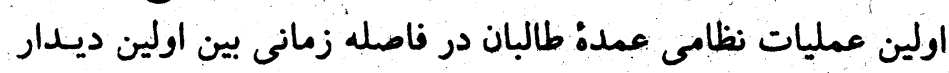

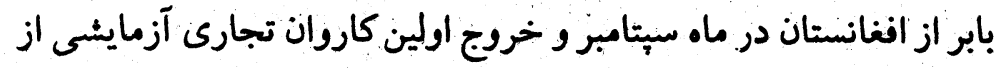

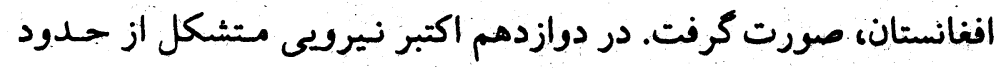

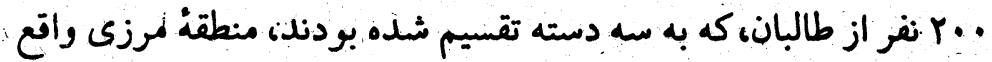

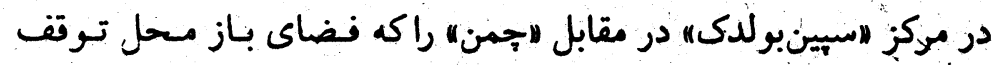

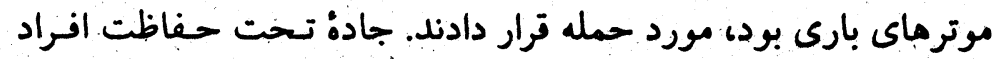

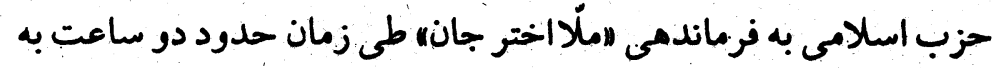

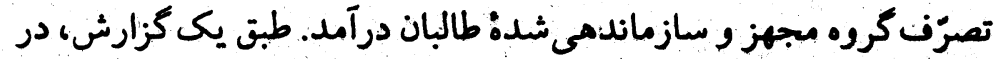

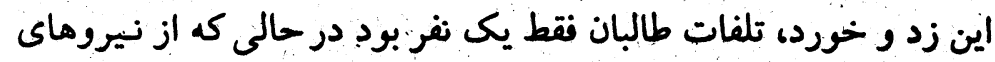

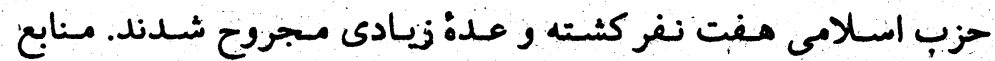

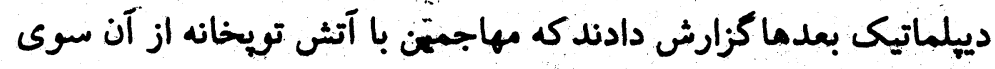

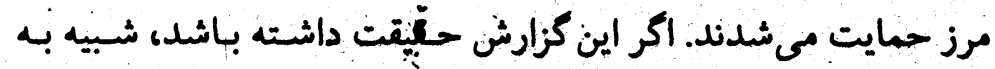

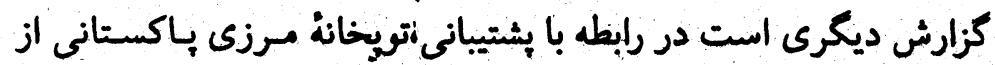

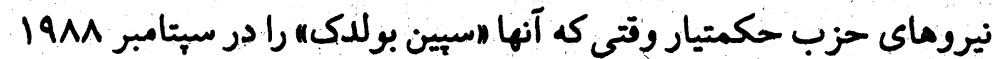

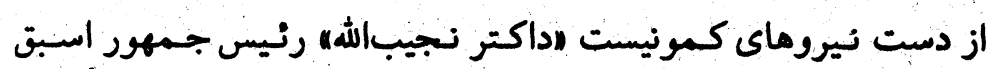
افغانستان در آوردند.

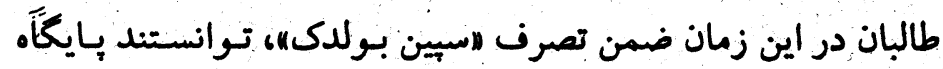

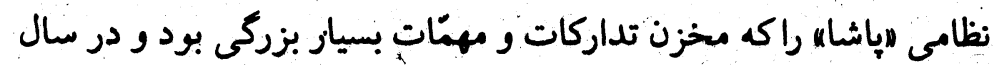

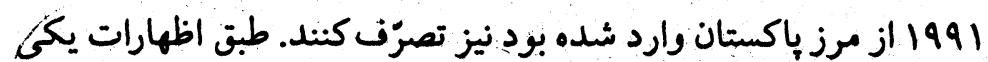

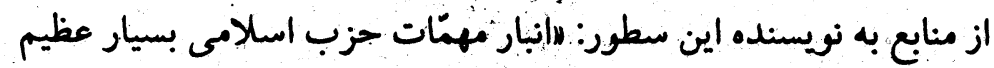

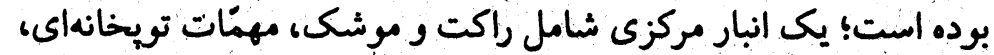

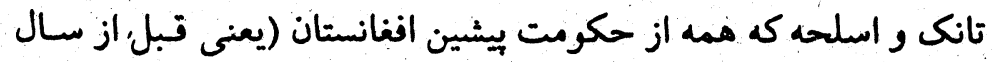
ازيكستان به دليل جنك بسته شده بود، بابر در يكى از جلسات دولت در

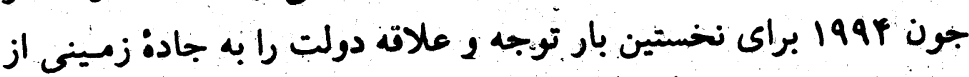

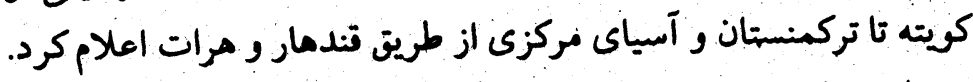

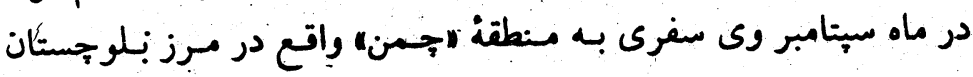

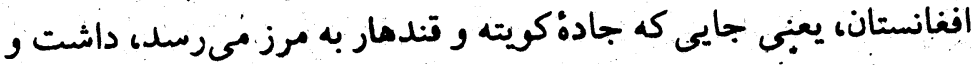

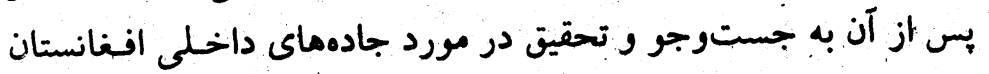
وى در بازكشتش به اسلامآباد، در اراخر ماه مستامبر أعلام كرد كه.

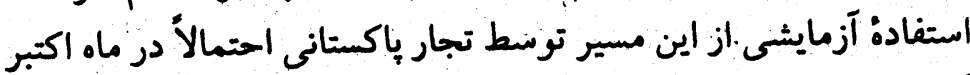

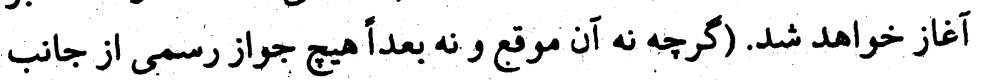
حكومت وقت افغانستان دريافت نشد.

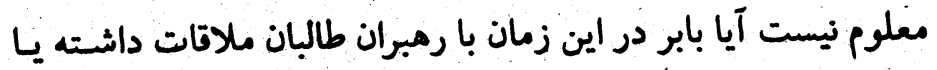

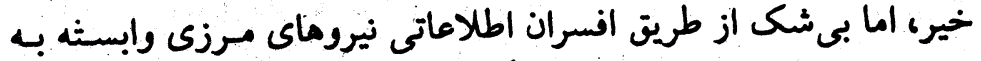

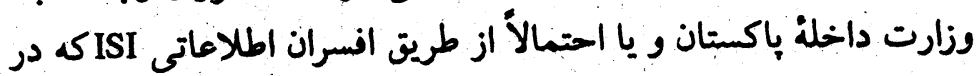

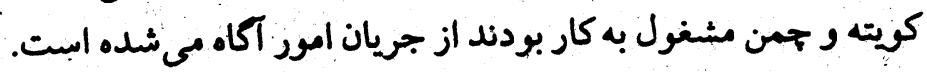

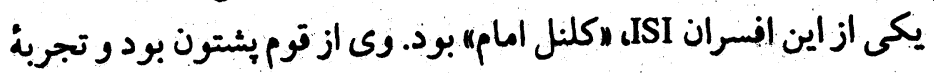

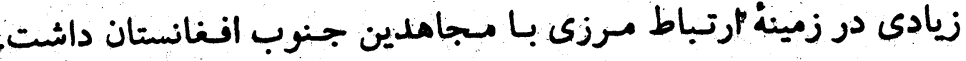

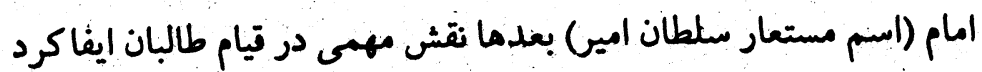

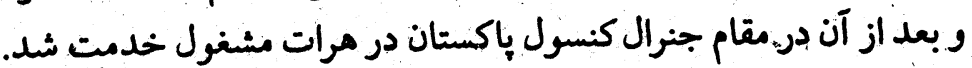

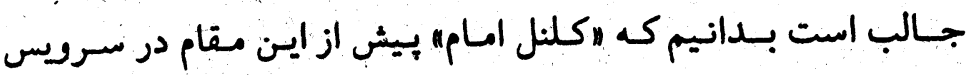
Special Service Group

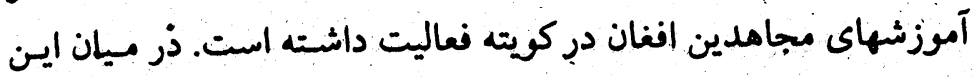

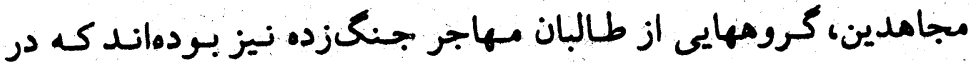

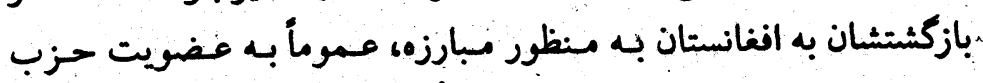
اسلامى يونس خالص و حركت انقلابِ مولوى محمد نبى درآمدند، اما 
سمت قوماندانى فرقه منصوب شده و از اينرو در قنذهار جهره مهـم و

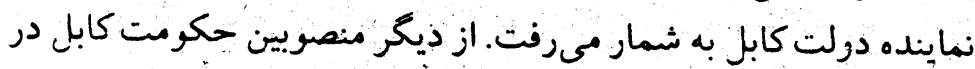

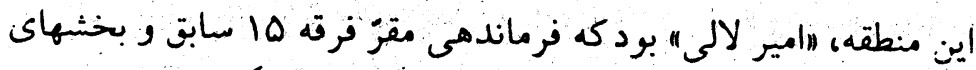

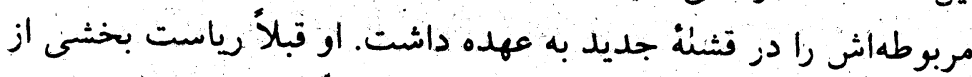

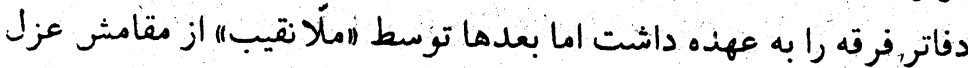

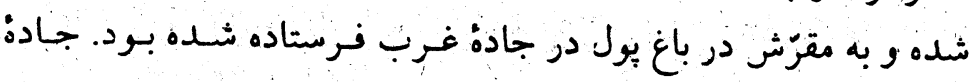

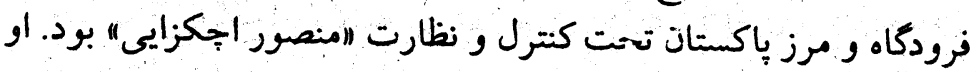

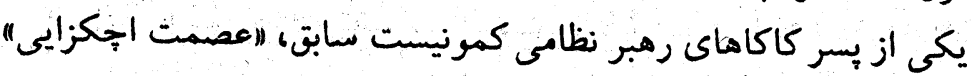

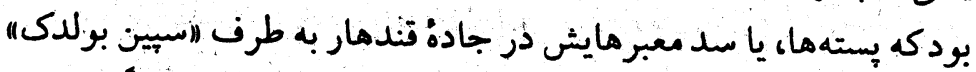

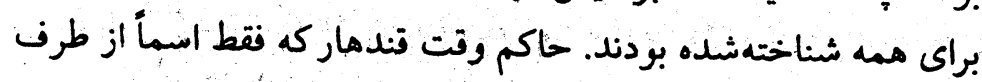

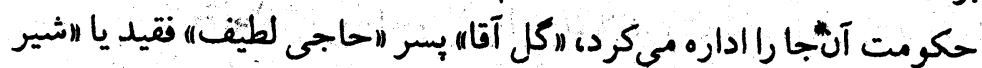

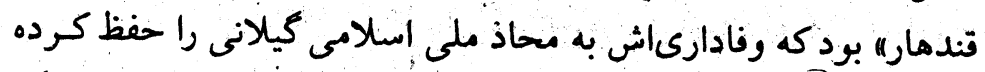

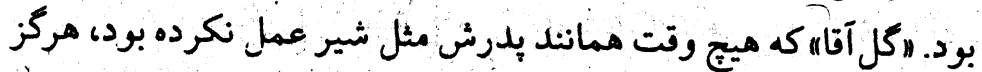

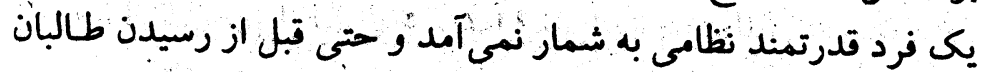
بدون هيج مقاومتى از قندماركريخت.

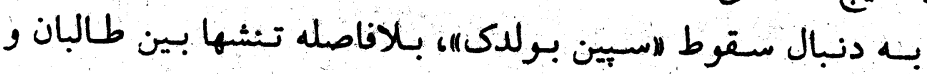
فرماندهان قندهار بالا كرفت. سردمداران قندهاز معتقد بودند كه طالبان از موى مقأمات پاكستانى حمايت مى شوند و مىترسيدند كه اين طلاب مقاصد بزركترى در سر داشته باشند. آنها بالاخص بيم داشتند كه مـبادا

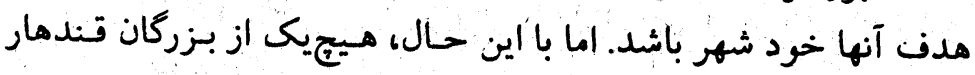

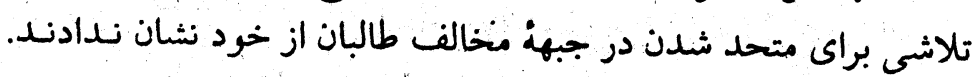

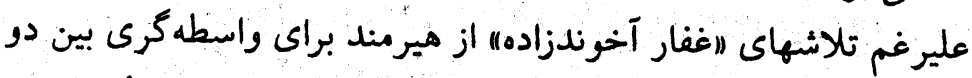

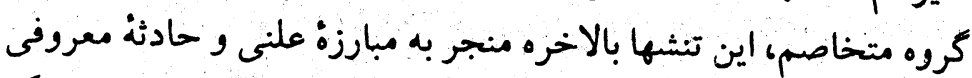

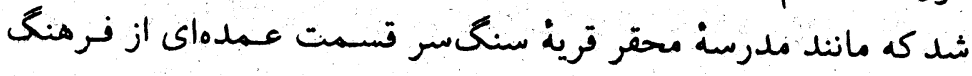
طالبان را تشكيل داد.
مه 199 باقى مانده بود. به عقيده من اين مهمات براى تأمين مقاصد آنها تا

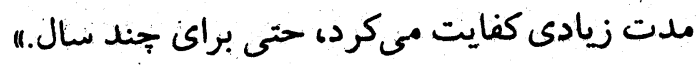

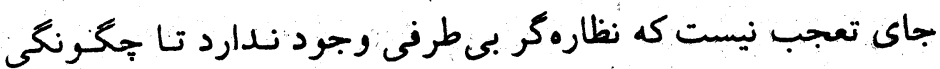

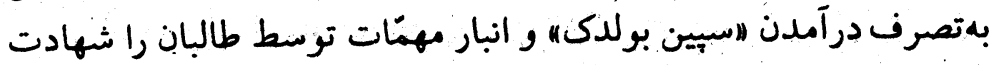

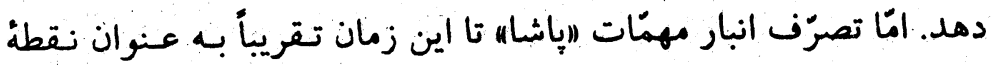

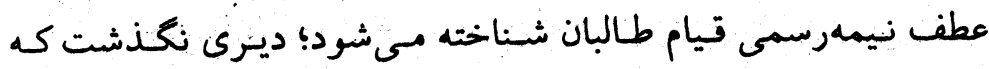

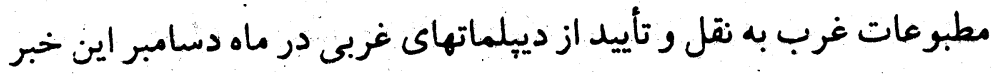

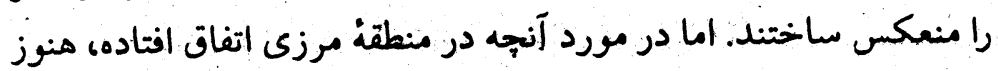

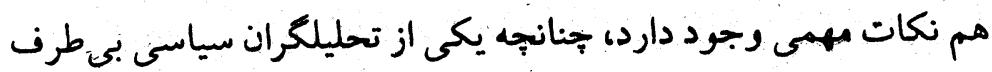

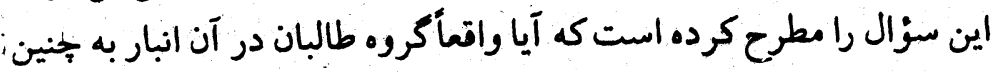

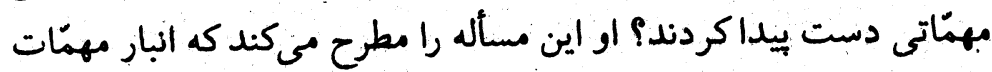
"إياشال مدتها تبل غارت شده بوده است: آنجه در بس اين شعك و و ترديدها

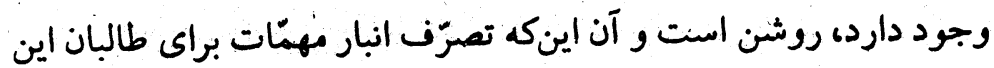

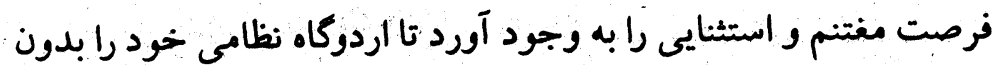

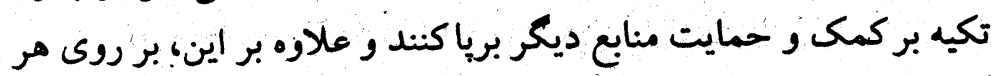

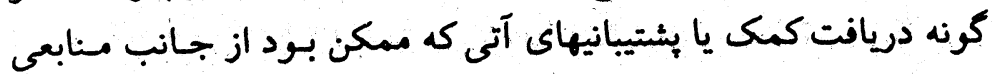
صبورت كرفته باشل برده بيوشانند.

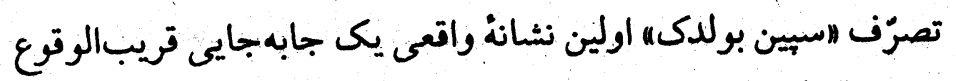

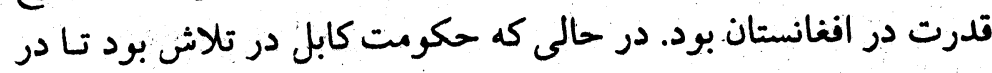

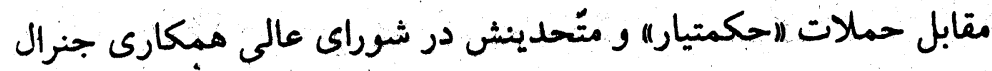

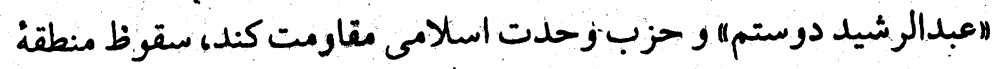

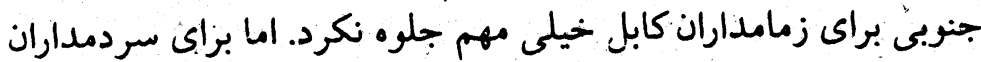

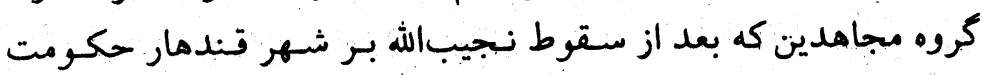

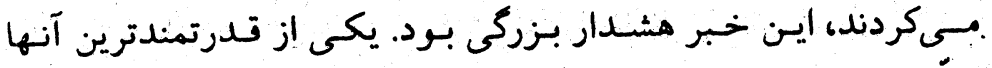

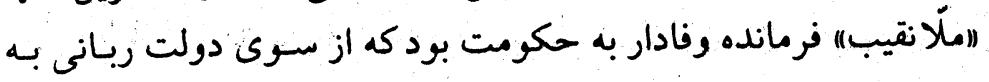




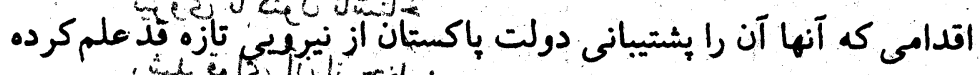

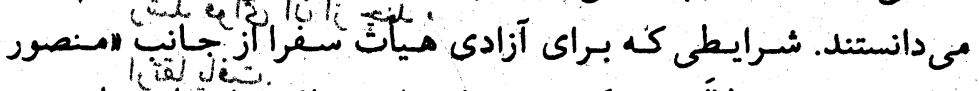

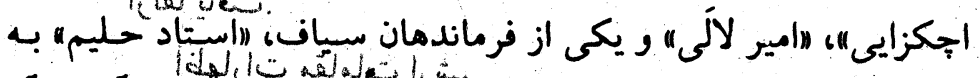

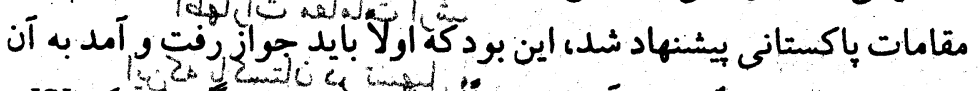

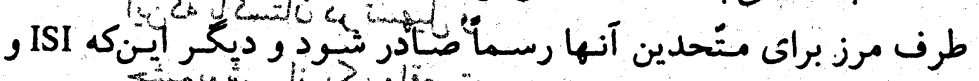

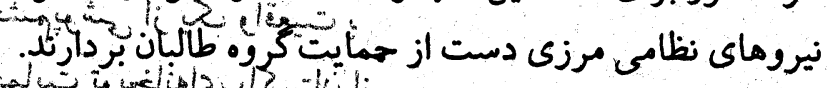

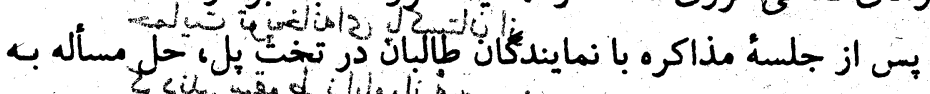

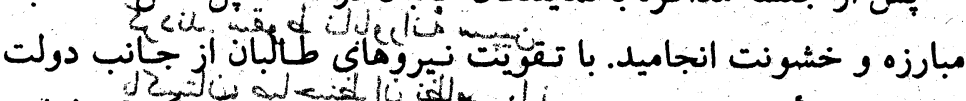

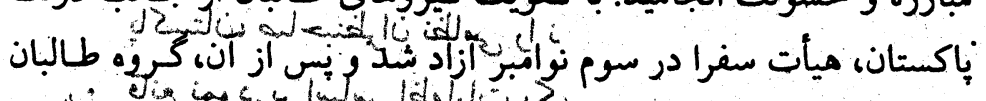

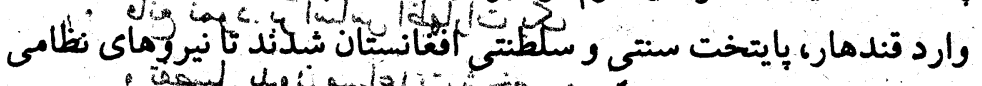

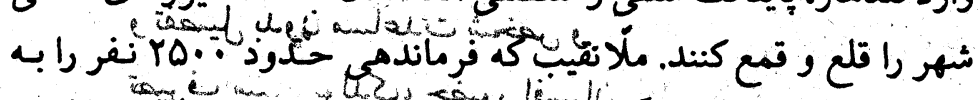

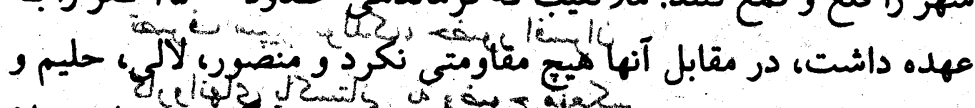

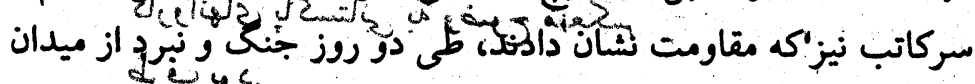

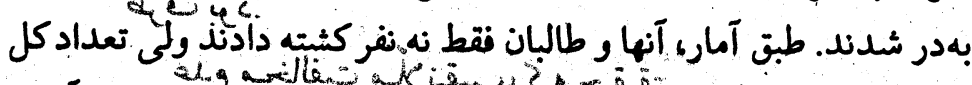

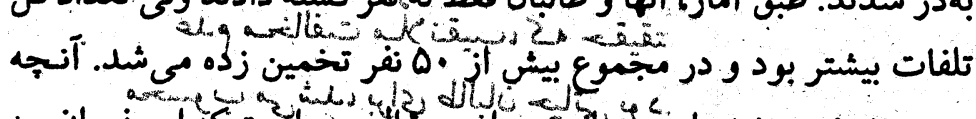

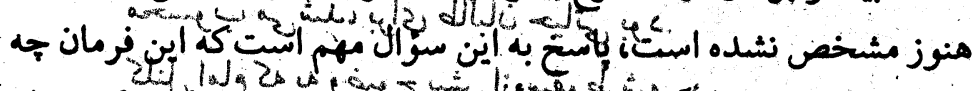

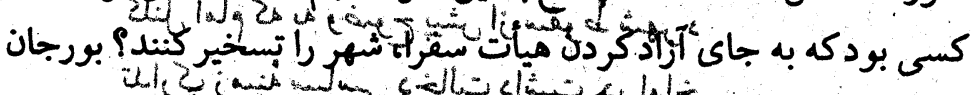

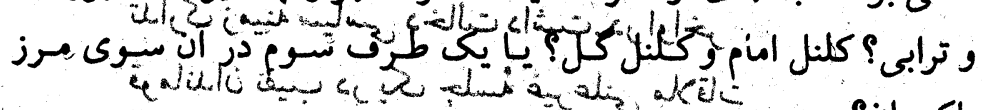

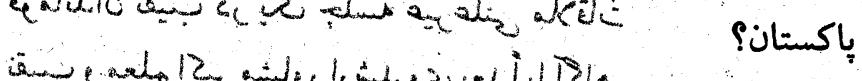

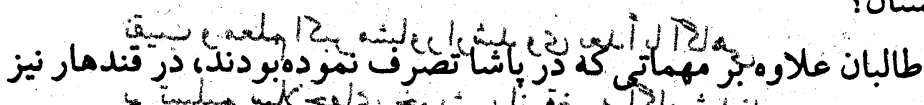

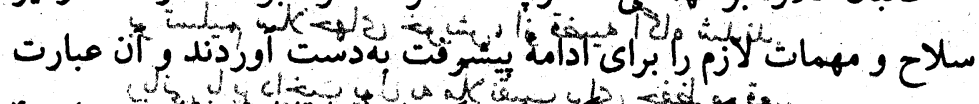

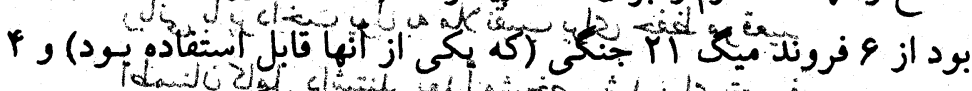

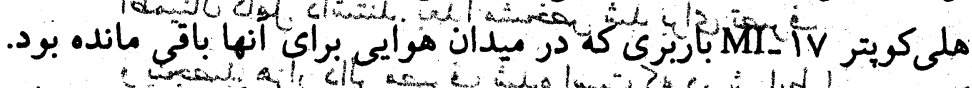

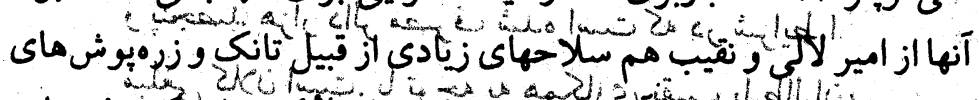

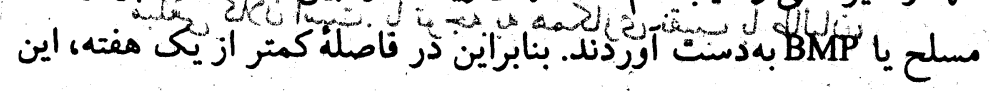

افغانستان، طالبان.................................. - ove

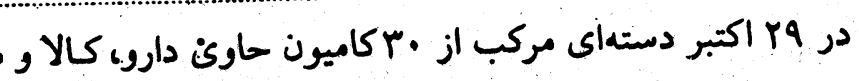

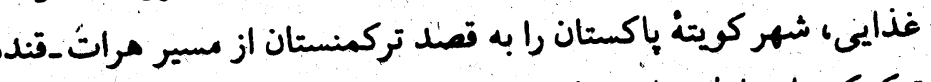

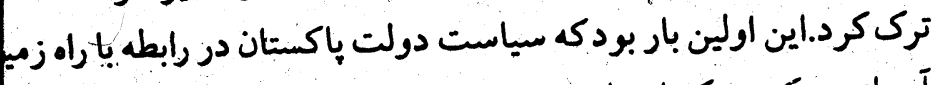

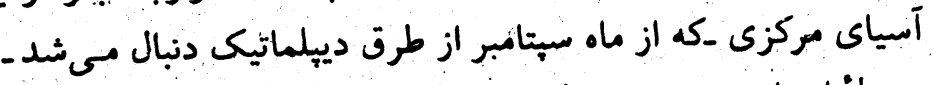

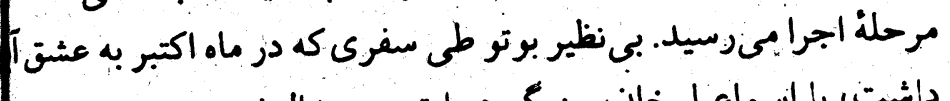

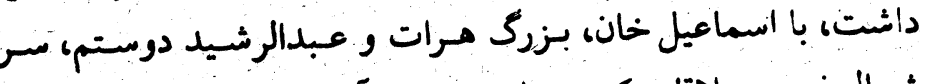

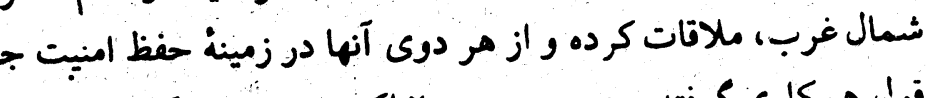

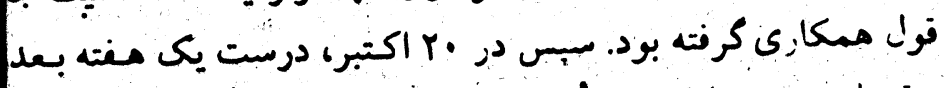

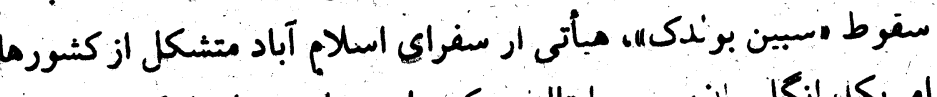

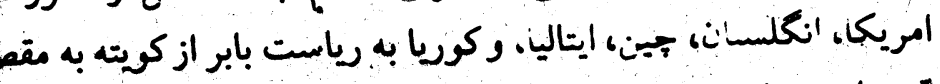

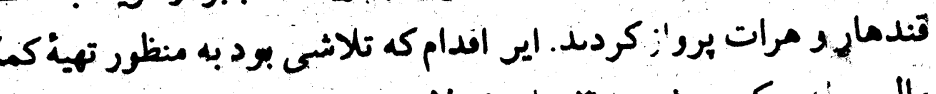

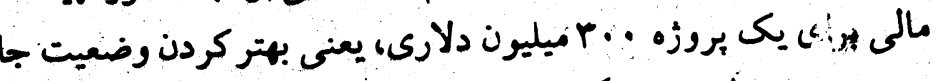

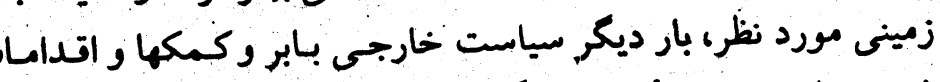

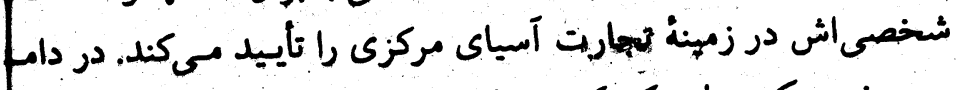

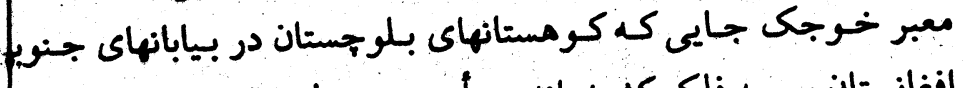

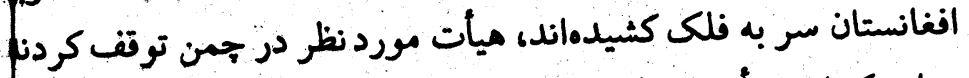

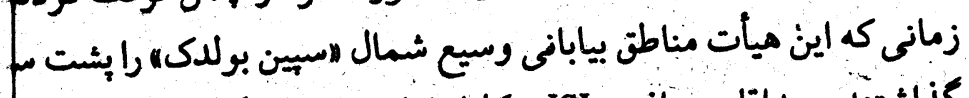

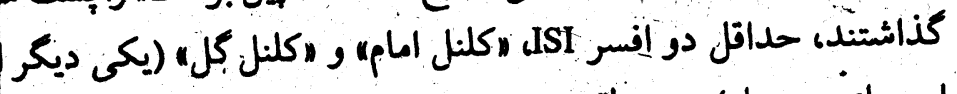

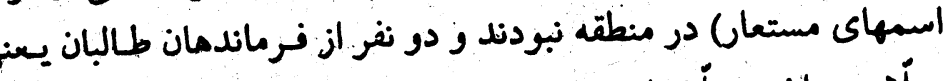

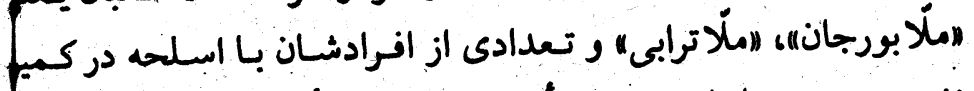
نشسته بودند. بنابراين ورود ميأت به قندمار به تأخير افتاد.

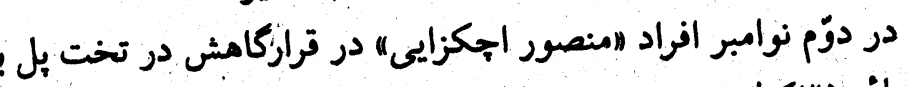

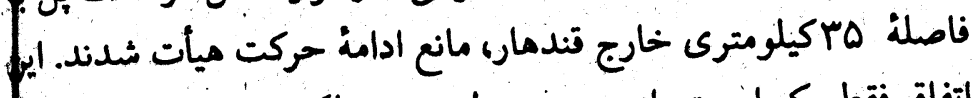

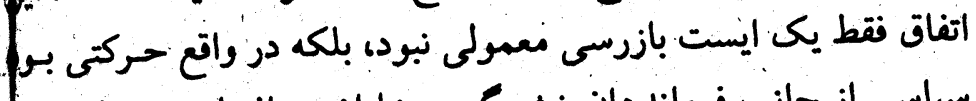

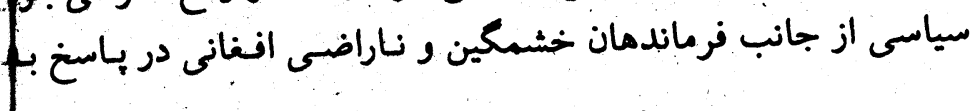




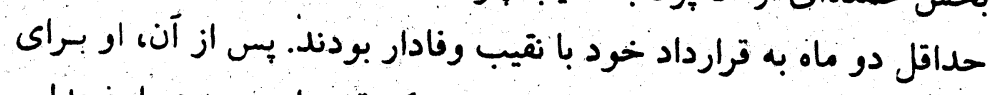

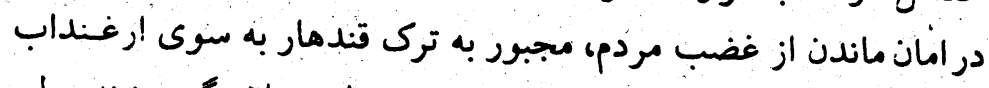

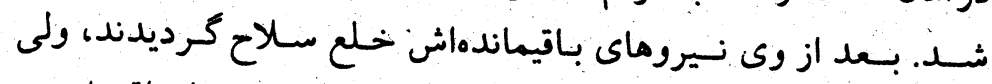

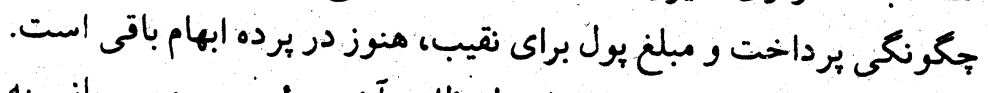

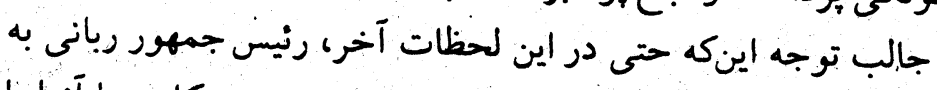

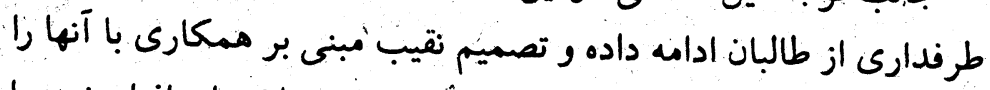

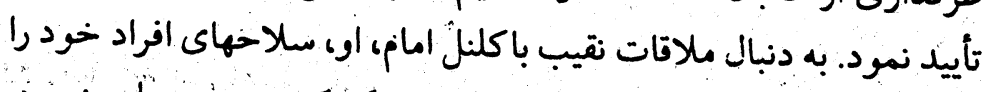

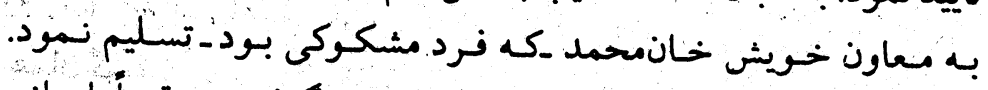

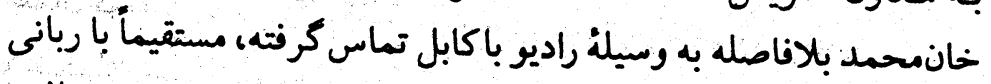

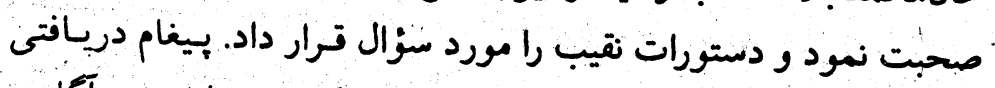

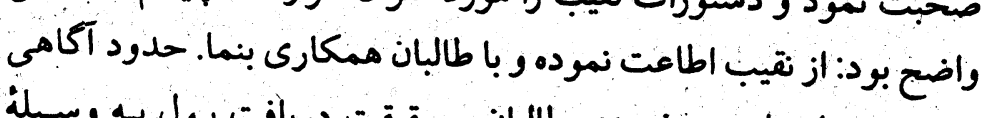

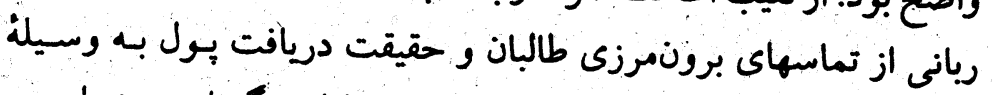

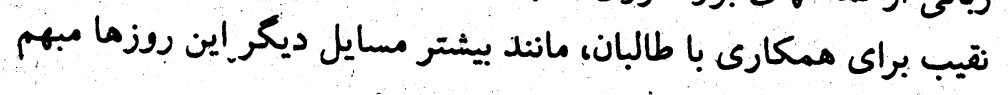
باقى مانده است. قابل توجه اين است كه بيشتر طالبان شركتكننده در تصرف قندهاره به مالاحهاى مدرن مسلح بودند؛ به خصوص تفنكهاى تهاجمى از نسوع

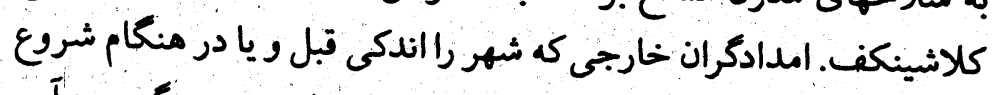

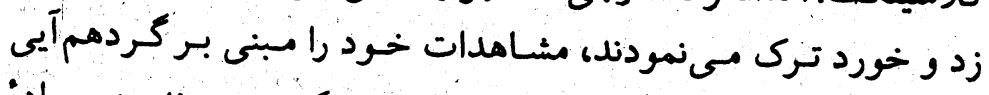

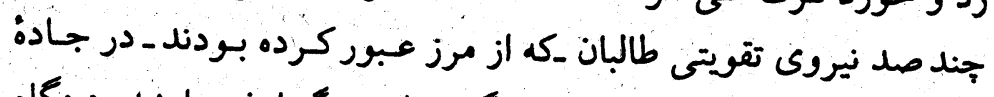

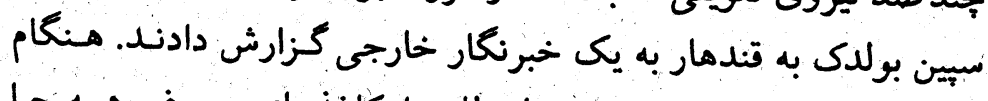

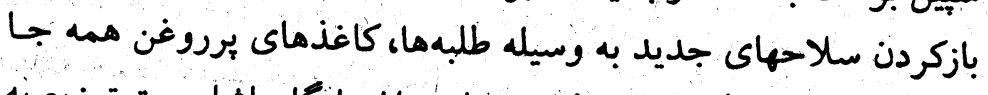

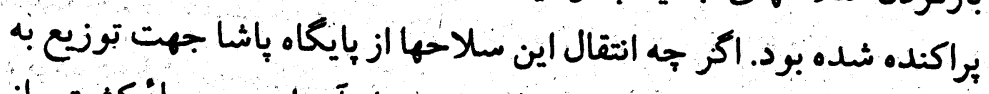

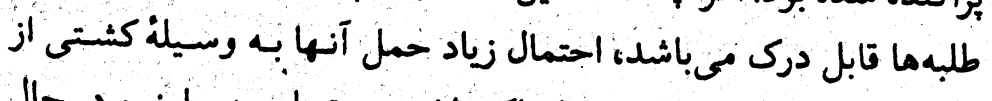
انبار (سلاح كوت) هاى ISI داجل باكستان جهت تسليم به مبارنبين در حال

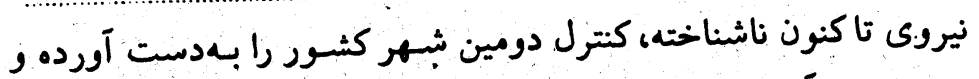

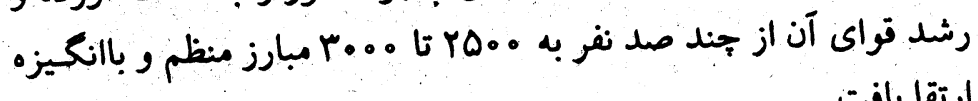

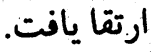

اظهارات مقامات ارشد اسلام آباد از قبيل نخست وزير و... مبنى بسر.

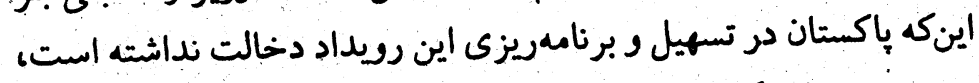
جشميوشى از يك واتعيت بود. دييلماتهاى غربي در اسبلام آباد و كريته

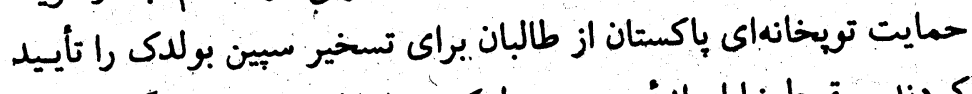

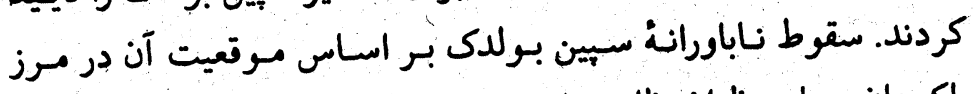

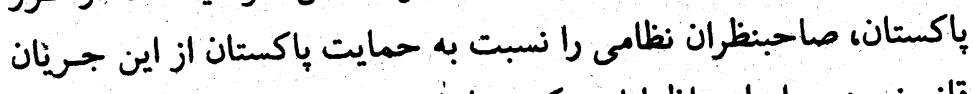

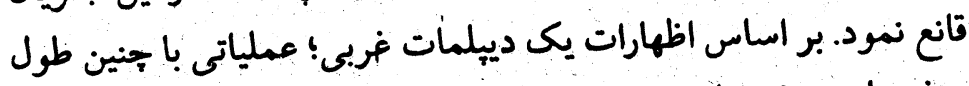

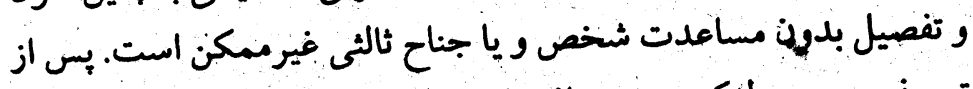

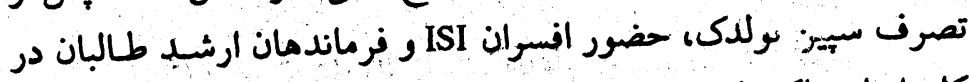

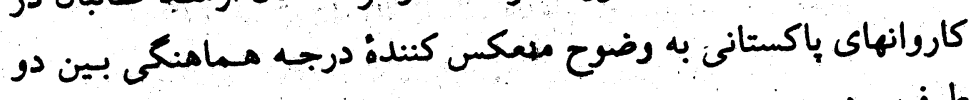

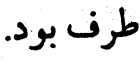

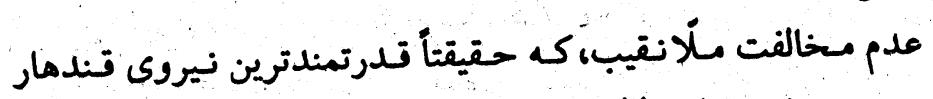

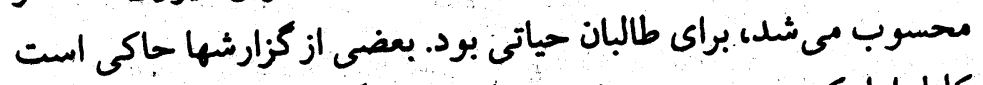

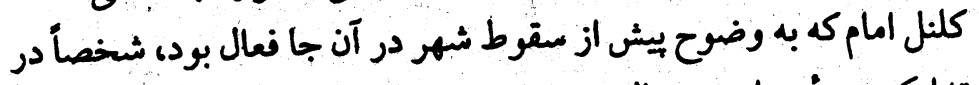

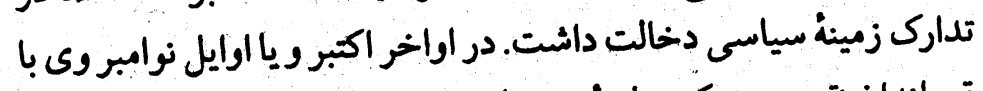

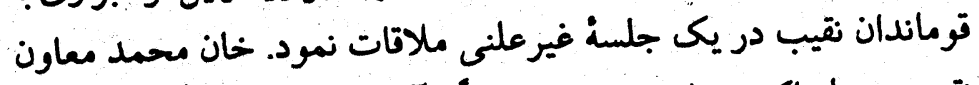

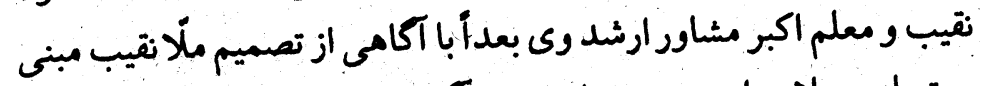

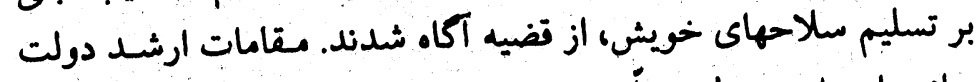

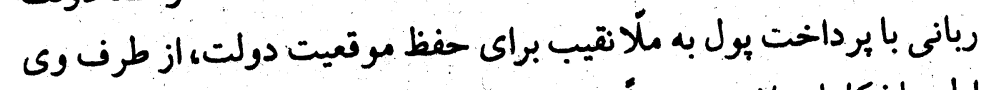

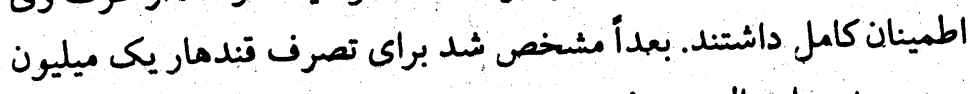

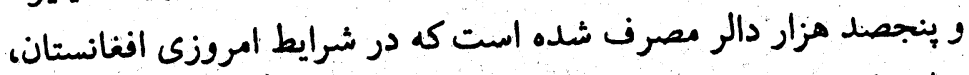

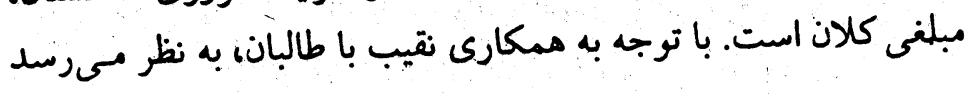




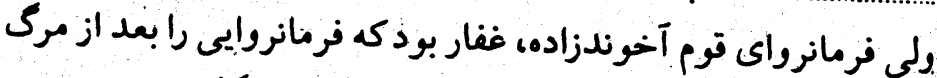

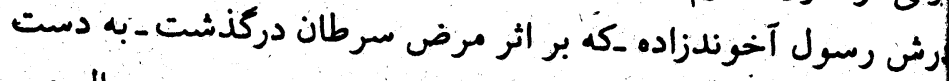

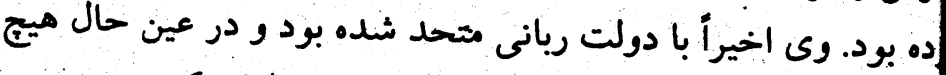

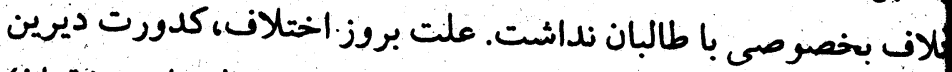

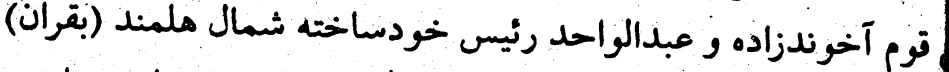

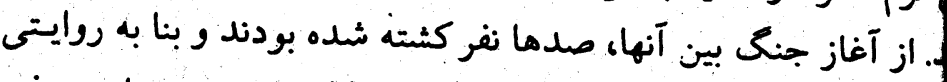

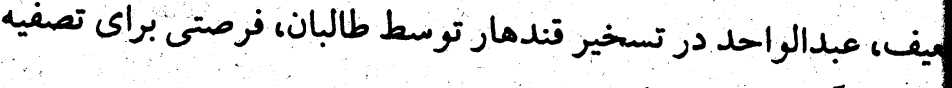
حركت به داخل افغانستان نيز وجود دارد. در اينكه تعداد كثيرى از طالبان

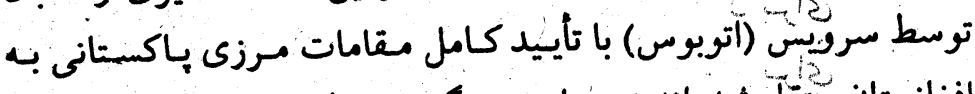

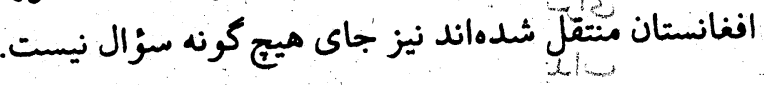

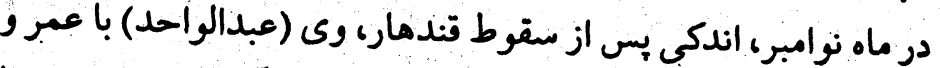
دراب با آخوندزاده بيدا نمود.

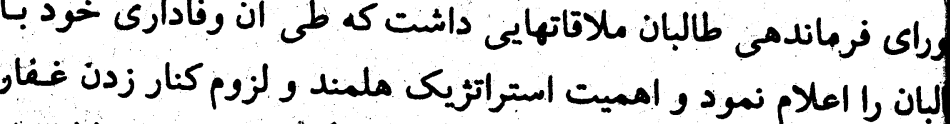

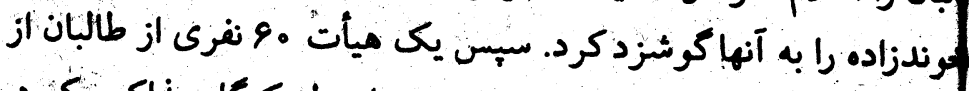

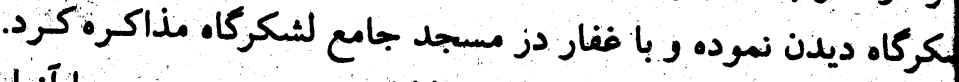

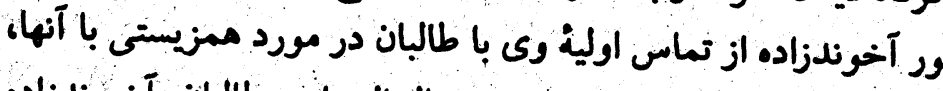
لكى بعد با شكست موزاجه مُد. به دنبال إلتياتوم طالبانن، آخـوندزاده

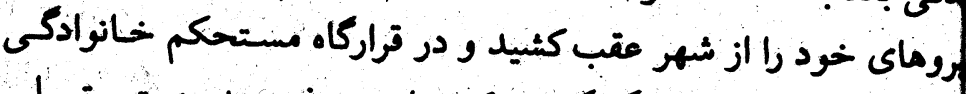

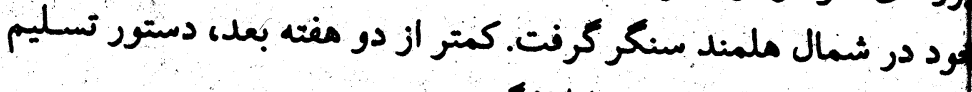
لكاح از طرف طالبان به وى ابلاغ كرديد.

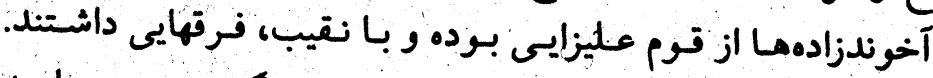

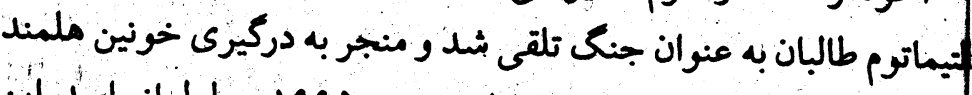

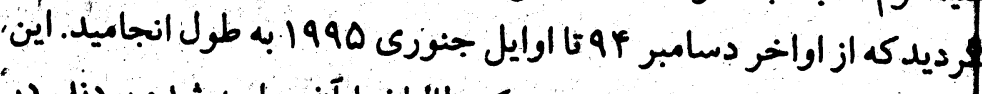

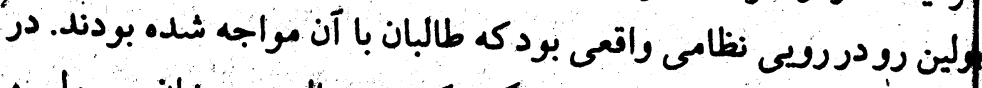

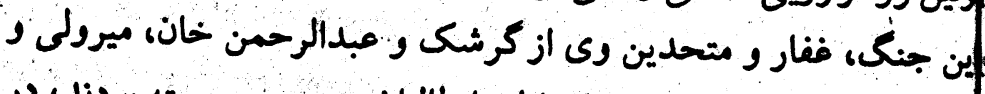

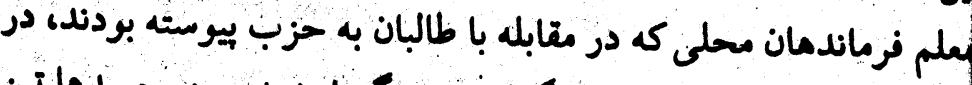

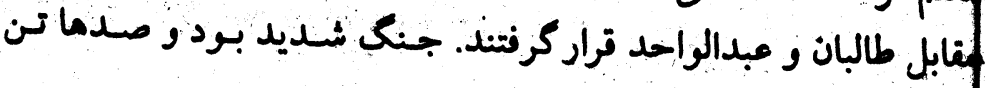

4

هنوب

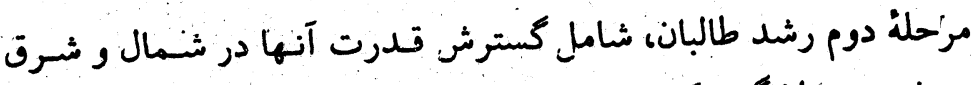

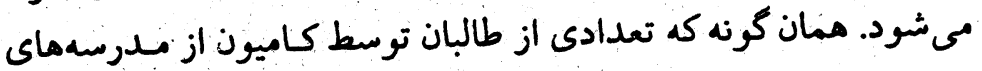

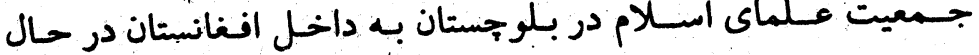

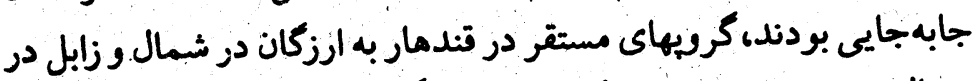

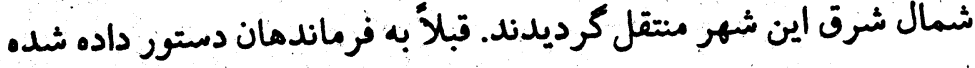

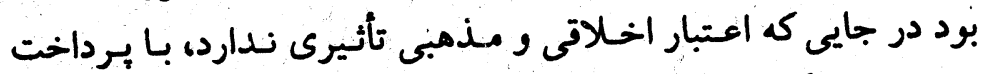

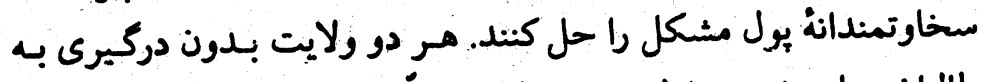

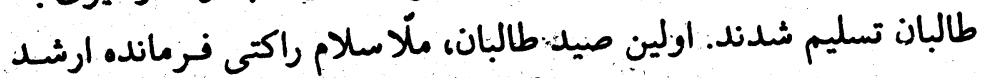

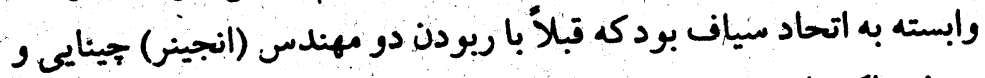

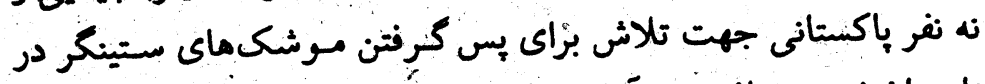

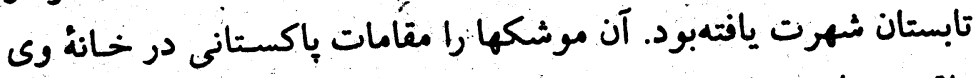

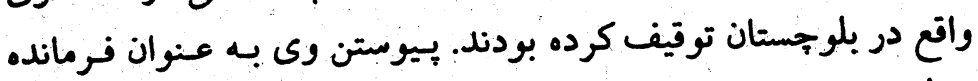
منطقه زابل، به طالبان كمك زيلوح ديادى كرد.

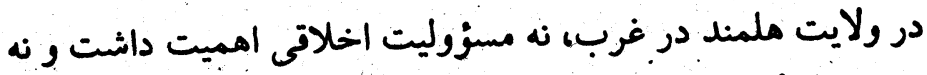

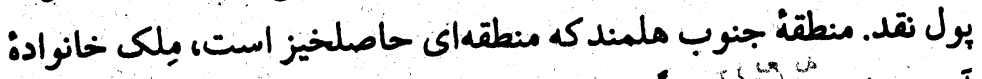

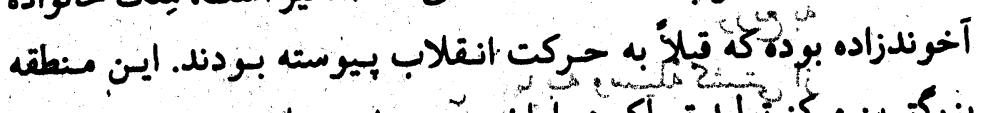

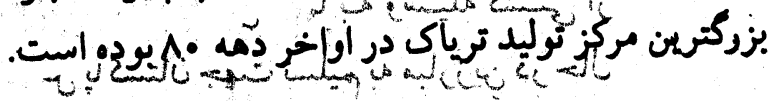




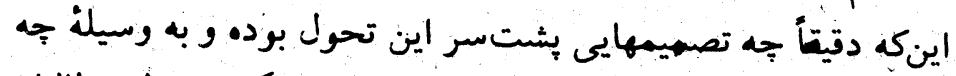

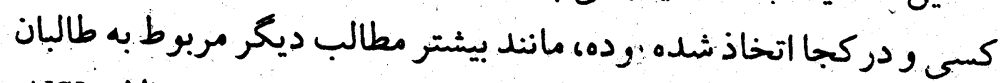

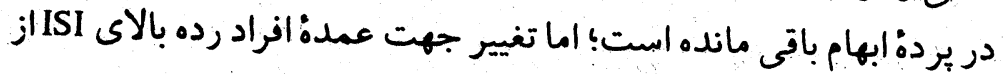

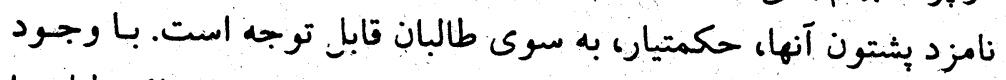

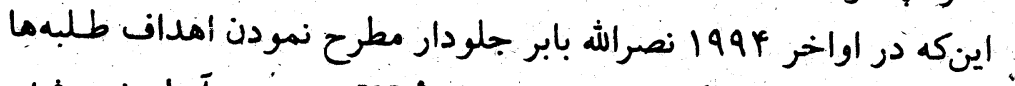

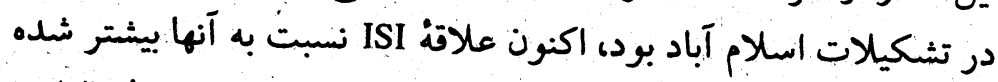

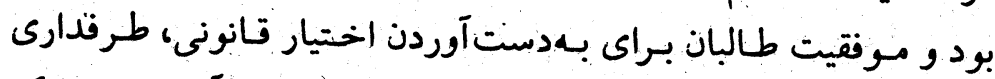

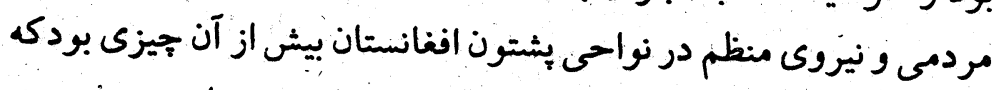

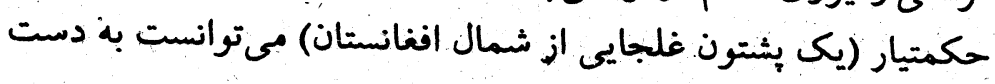

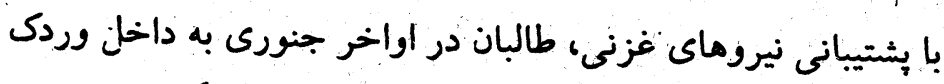

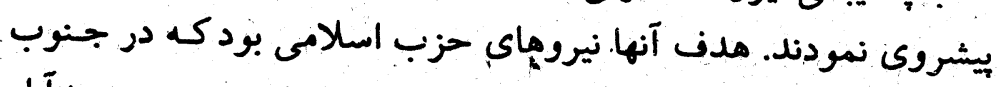

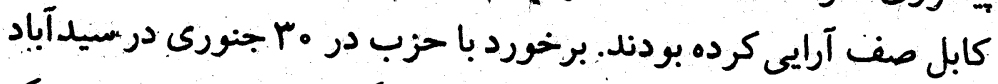

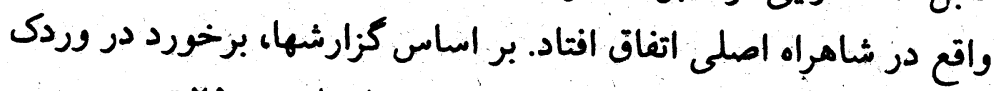

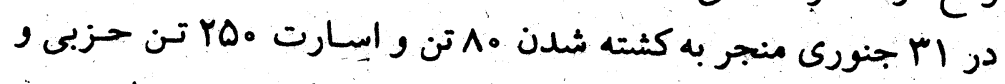

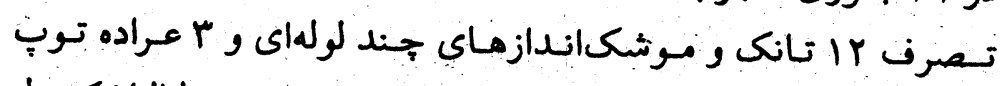

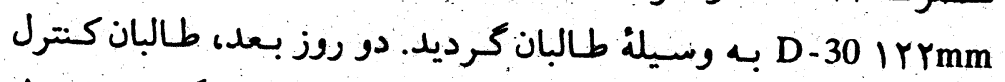

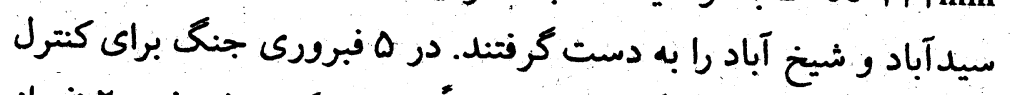

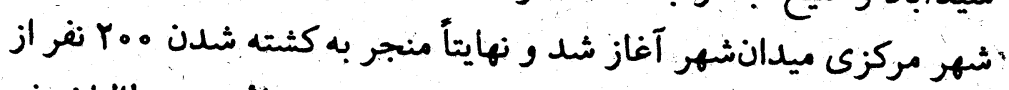

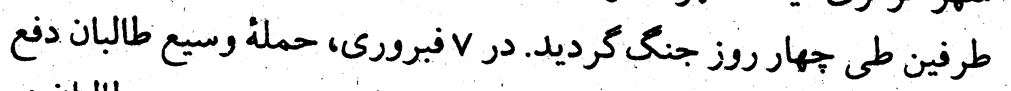

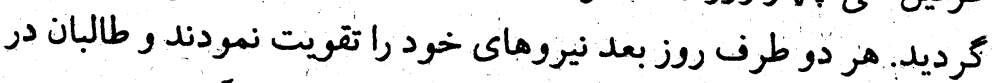

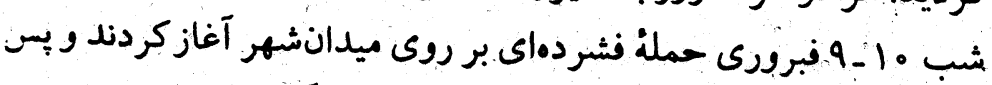

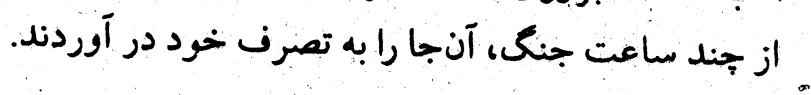

افغانيتان، طالبان، و سياستهاى جهانى

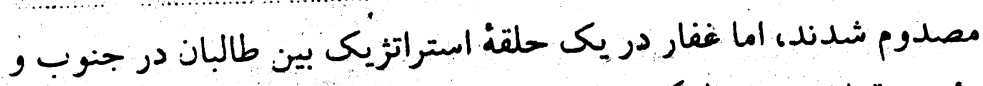

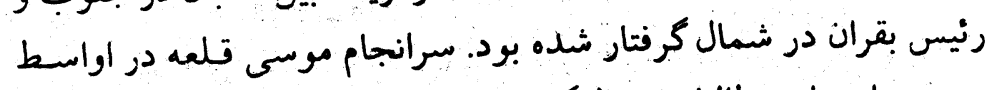

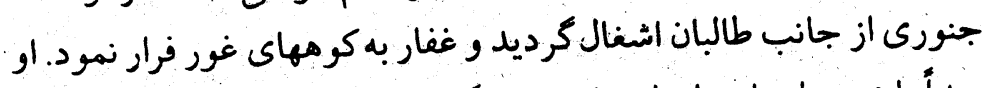

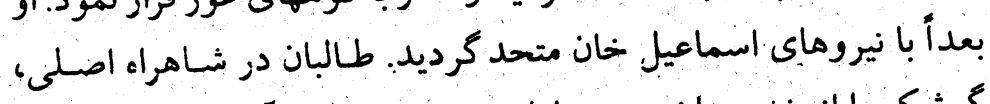

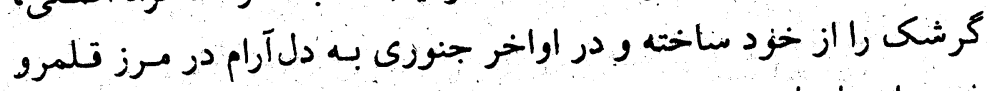
غربى اسماعيل رسيدند.

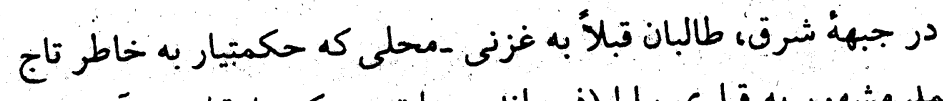

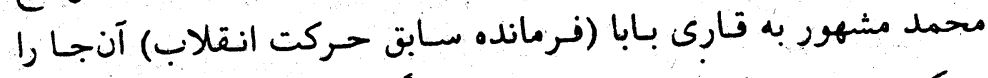

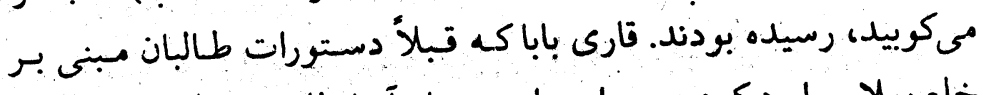

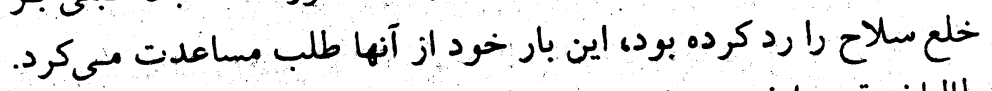

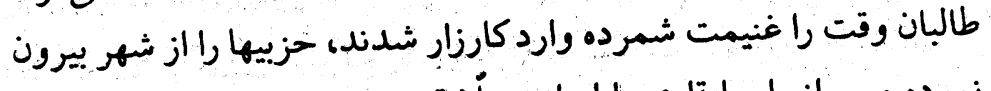

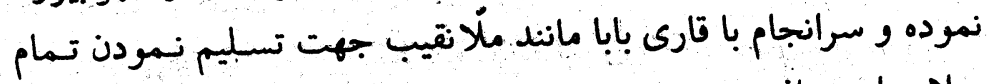
سلاحها به توافق رسيدند. فتح غزنى جنبة حياتي داشت و نقطة تحولى برائل براي طالبان محسوب

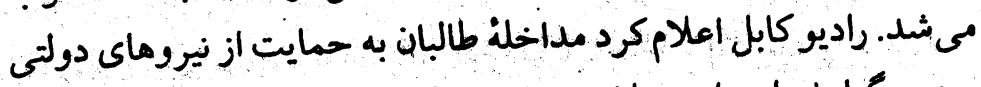

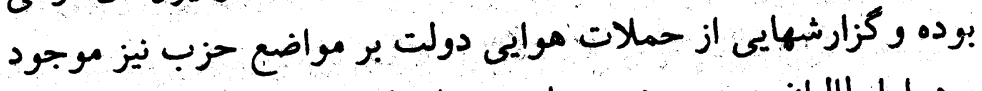

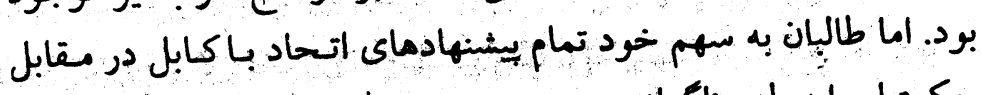

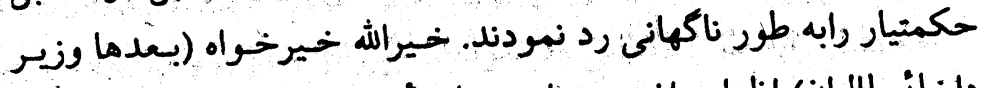

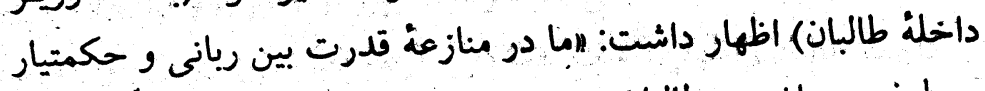

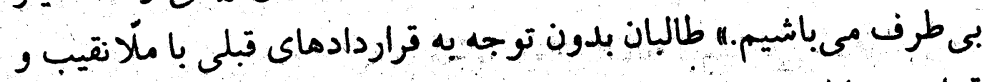

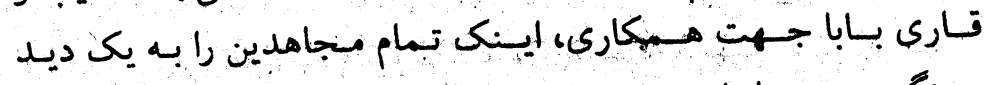

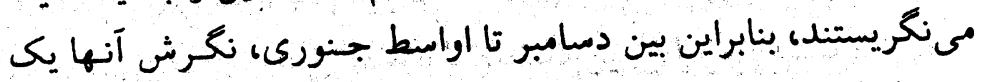

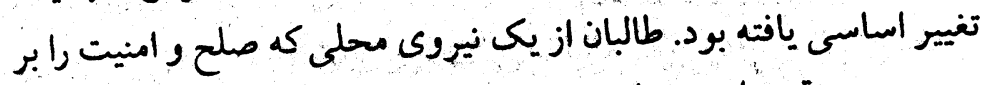

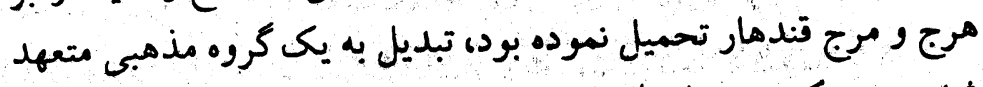

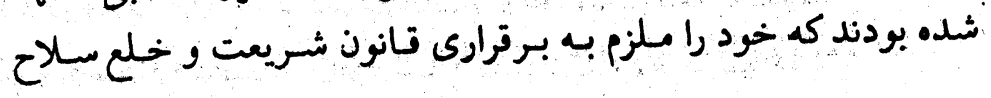


نتيجهاى مي شد.

اين امن ممكن است تا حدى ناشنى از اين واقعيت باشد كه تا جنورى

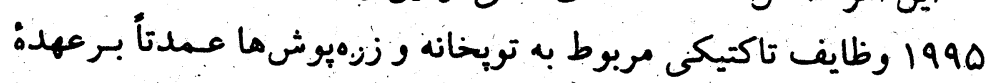

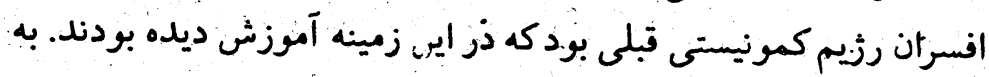

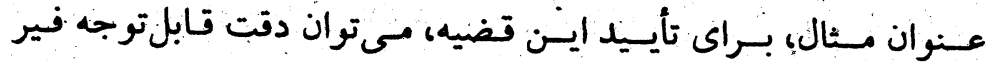

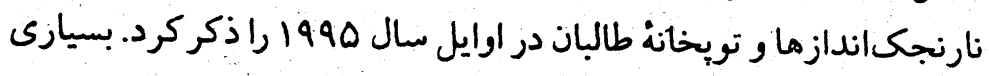
از اين افسران كه از طالبان حقوق دريافت مىكردند، اعضاى سابق جناح يشتون دز حزب دمكراتيك خلق افغانستان و برخى از آنها وفادار به وزير

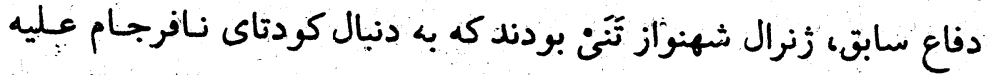

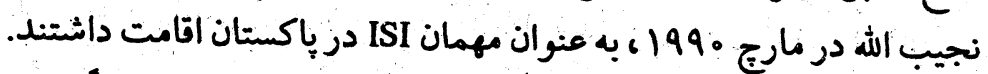

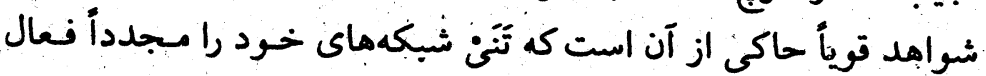

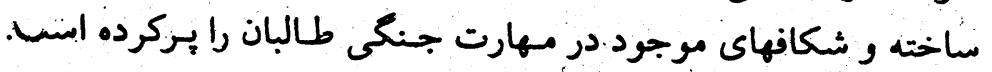

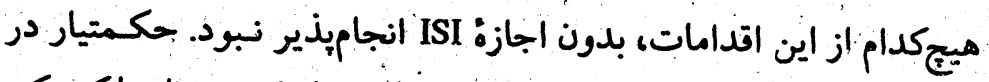

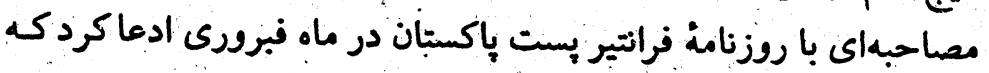

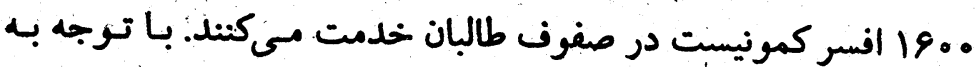

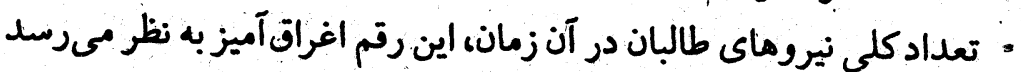

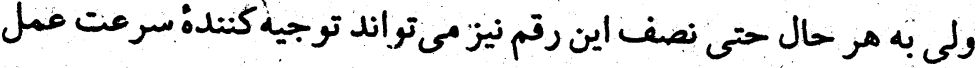

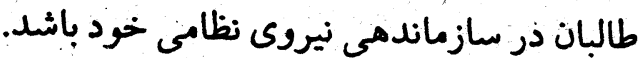

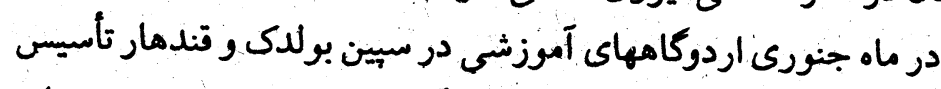

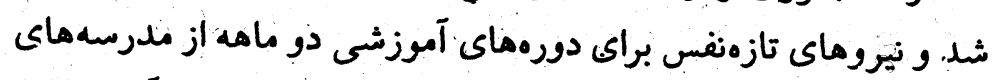

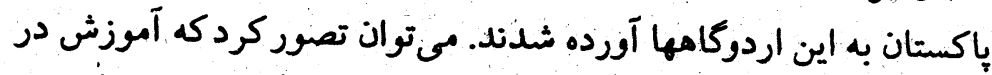

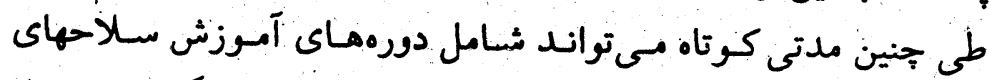

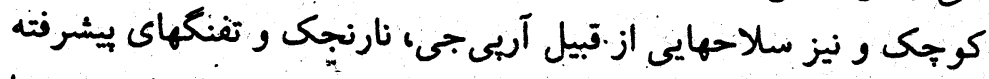

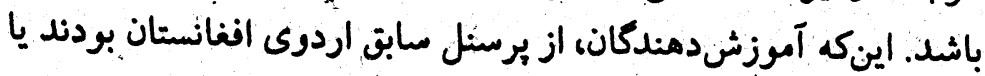

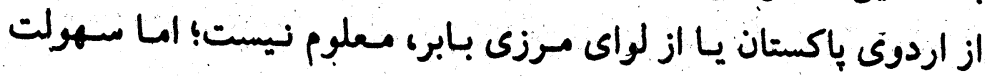

اين نبرد، بزركترين و مهمترين يروزى طالبان بود و آنها را بلافاصله

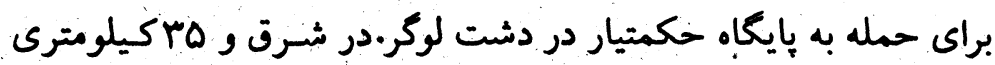

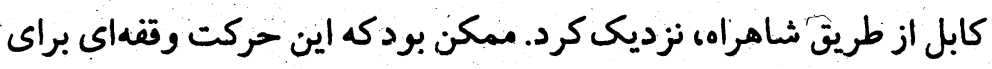

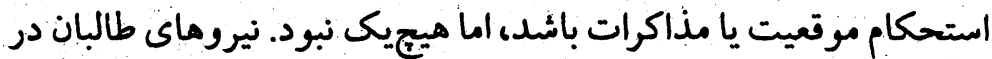

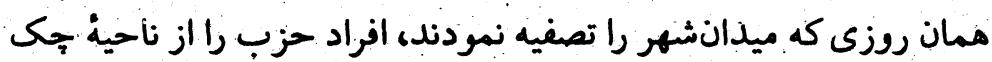

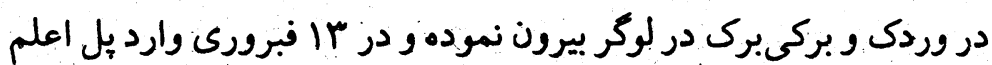

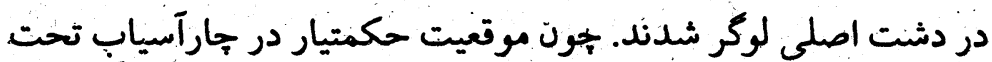

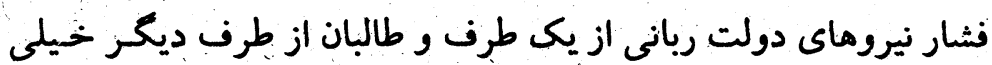

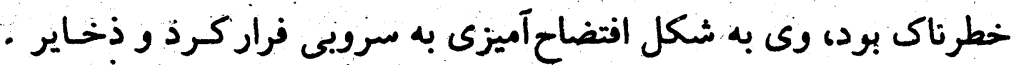

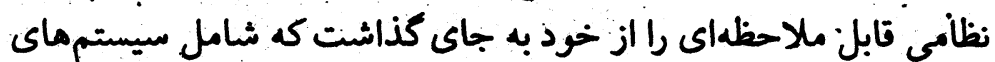

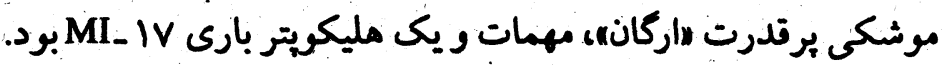

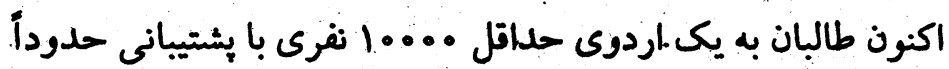
صد تانك و AVF مبدل شده بودند. مهارتهايى كه در عمليات مسالهاى

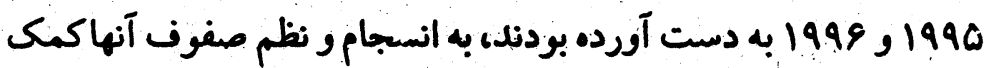

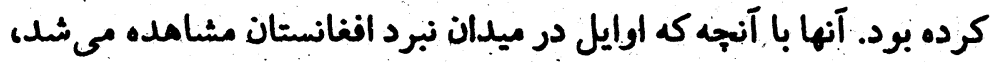

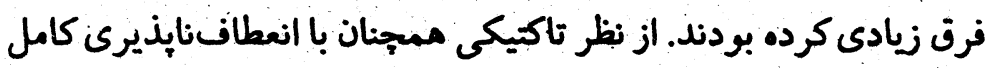

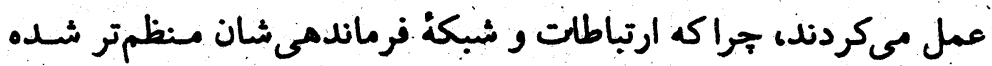

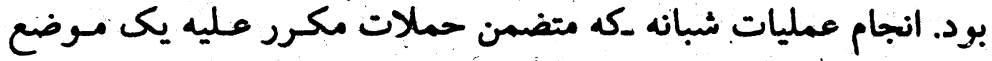

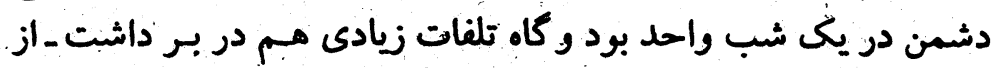
جمله خصوصيات نظامى طالبان بود. جنين حمالتى با هجومهاى امواج

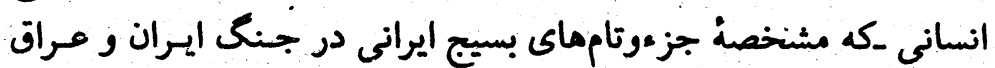

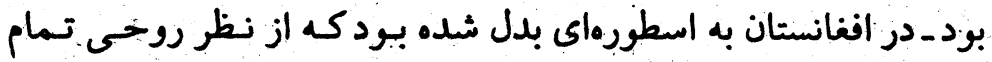

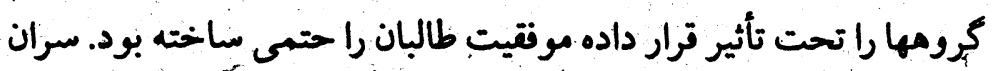

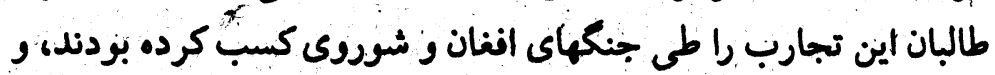

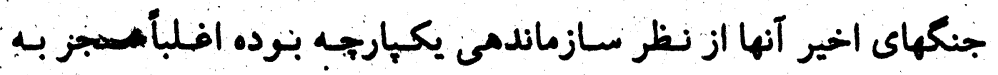


جنكيدن كشودند و وارد جاهايى شدند كه در آرامش به سر مىبردند و در

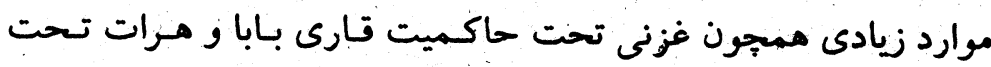

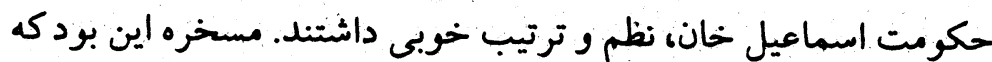

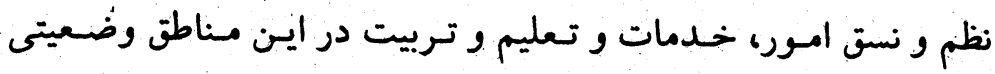

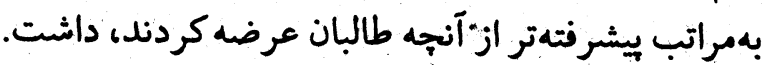

كابل

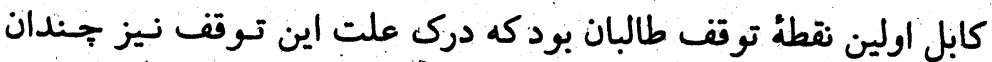

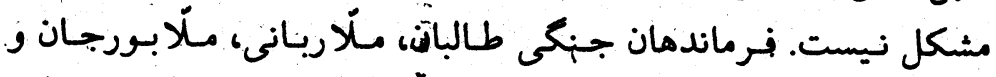

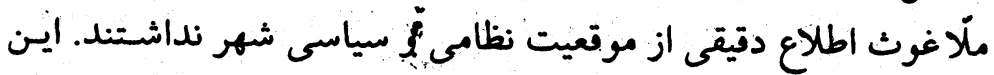

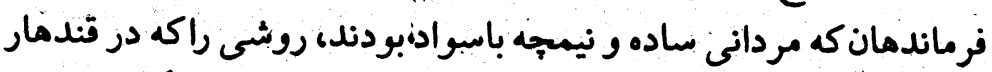

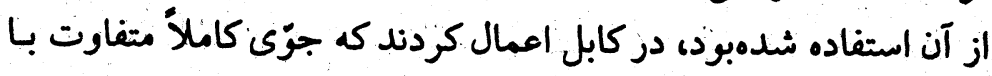

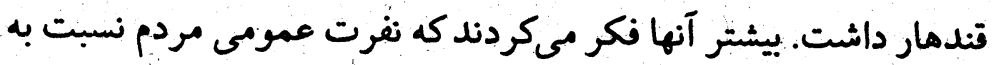

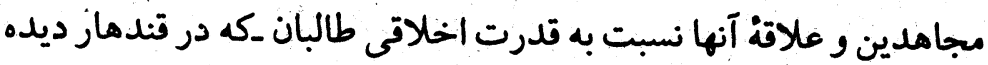

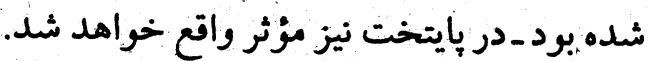

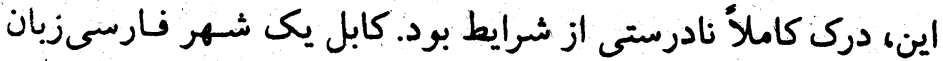

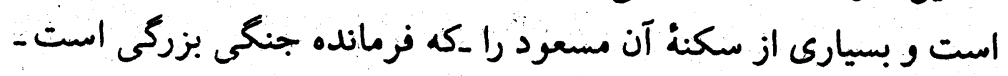

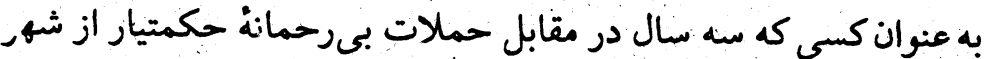

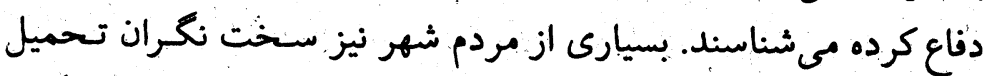

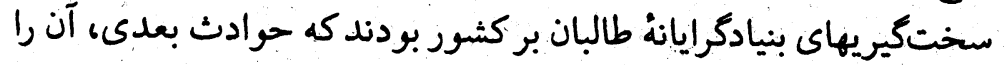

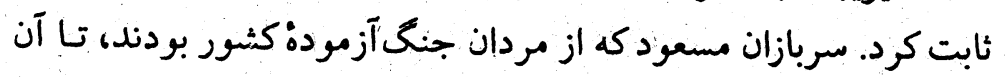

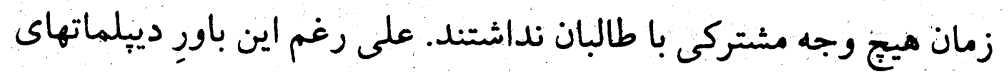

ريشكذاشتن بشتونهاى بإكستانى و يوشيدن بيرامن و تنبان توسط آنها و

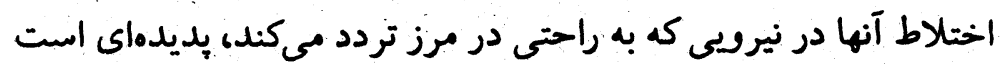

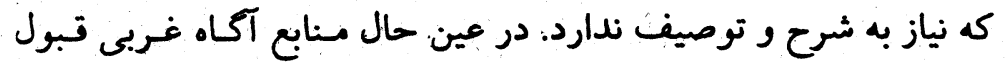

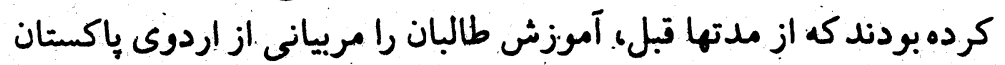

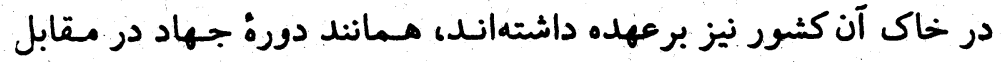
كمونيستها. تا اوايل مـال 1990، نيروى طلالبان بـ ايسن ترتيب يك سـاختار

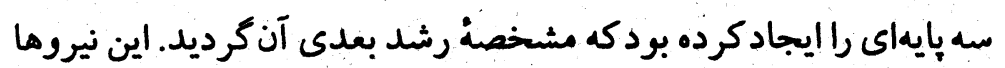

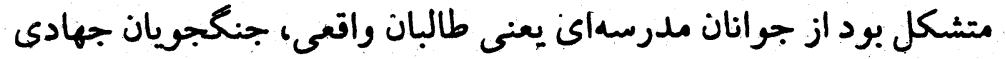

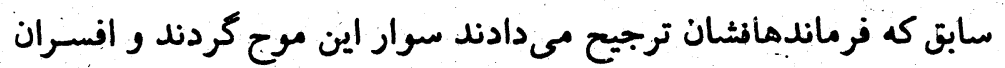

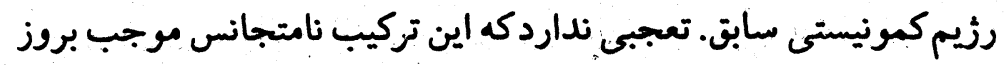

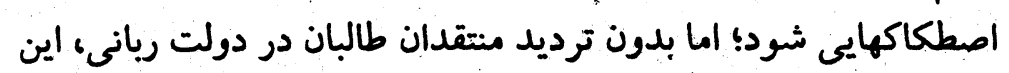

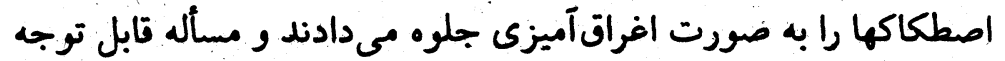

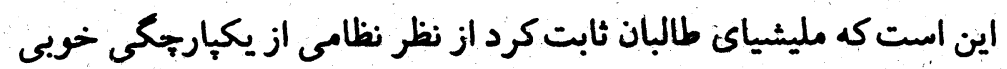
برخوردار است.

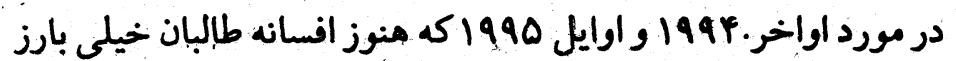

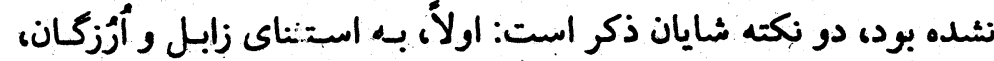

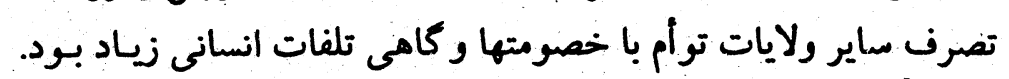

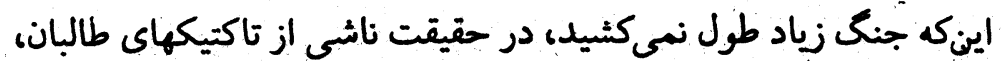

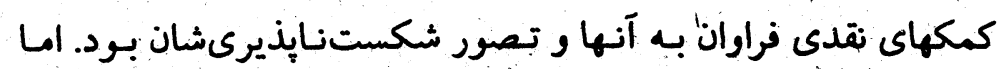

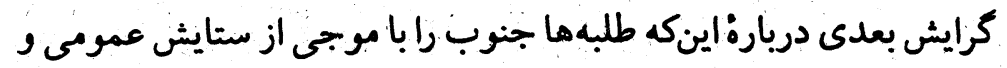

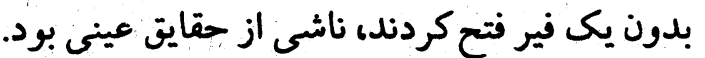

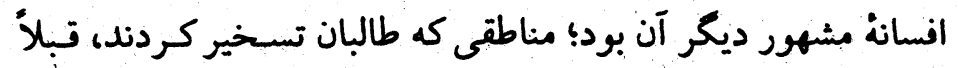

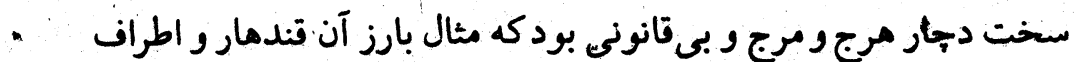

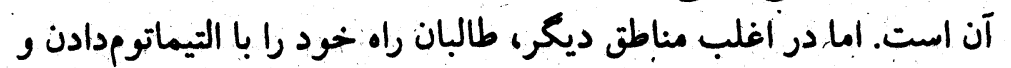




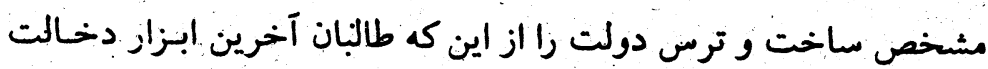

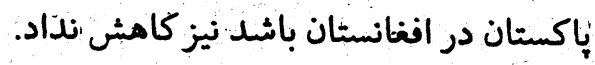

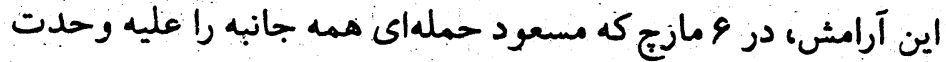

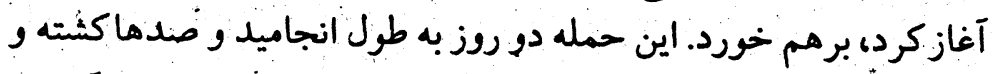

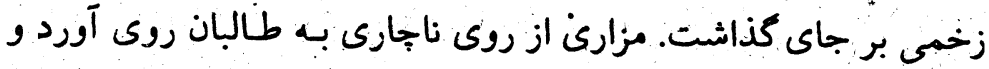

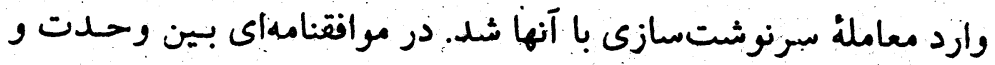

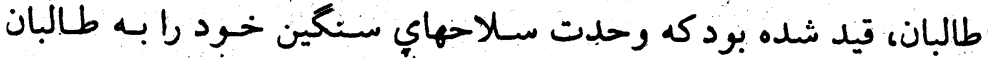

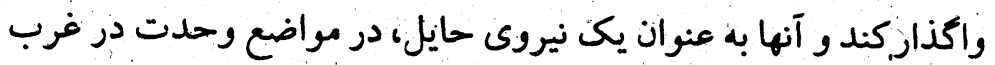

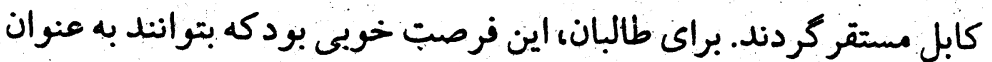

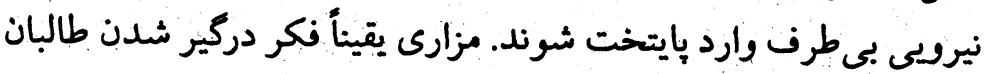

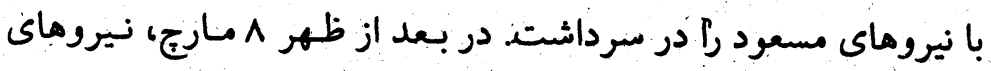

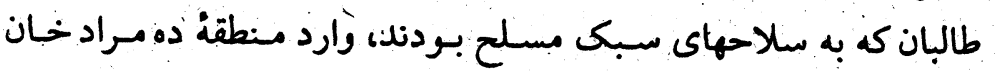

$$
\text { بُدند. }
$$

تنشهاى شديد در جنهة جنظ، اوضاع را وخيمتر مساخت. سـربازان

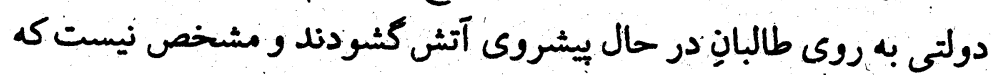

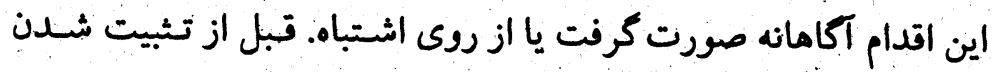

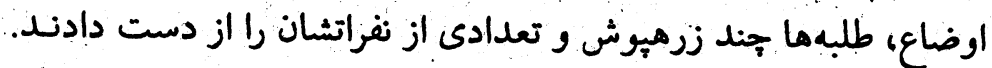

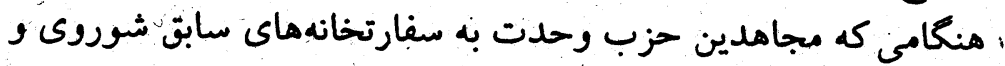

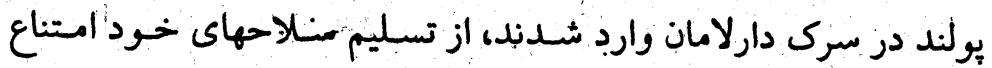

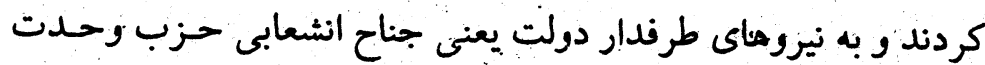

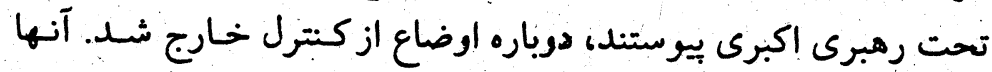

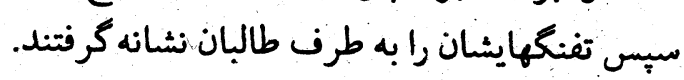

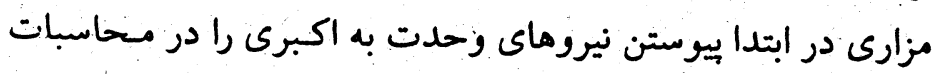

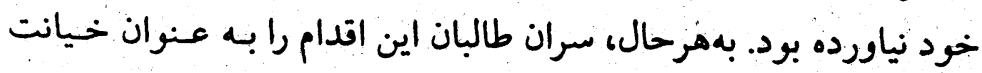

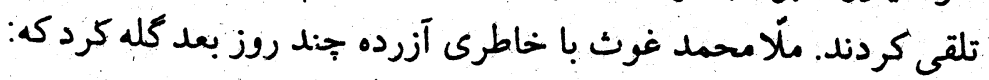

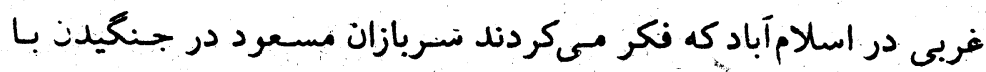

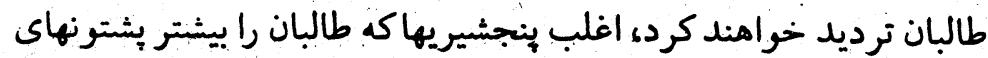

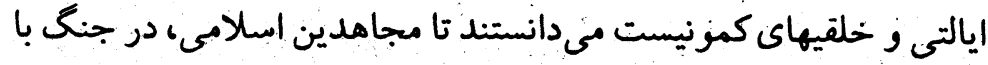
آنها هيج ترديدى نداشئندائ.

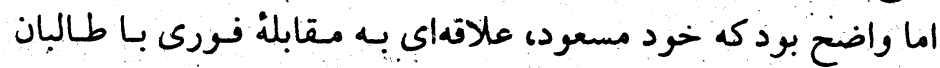

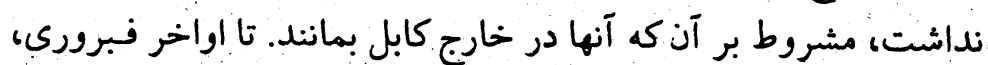

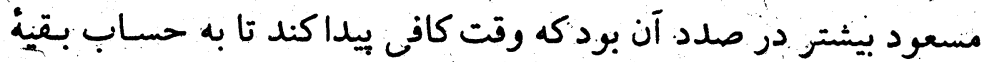

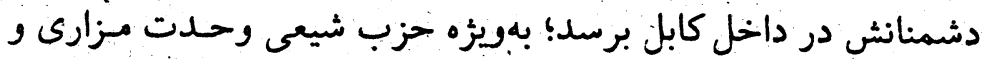

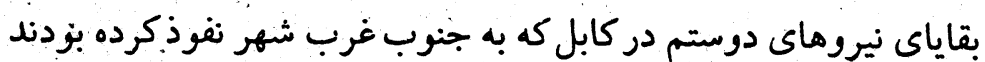

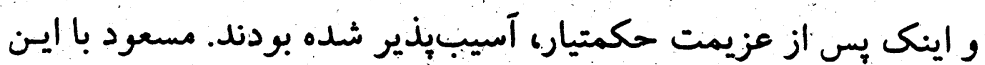

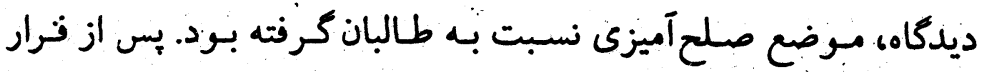

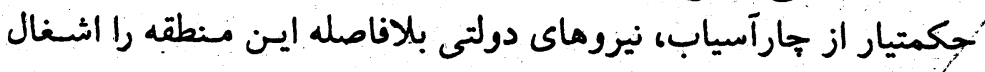

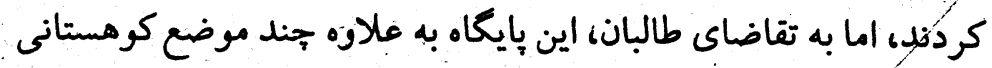

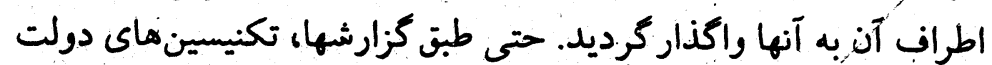

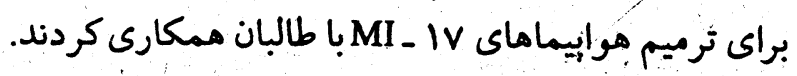

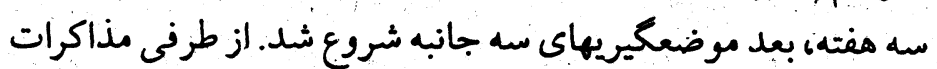

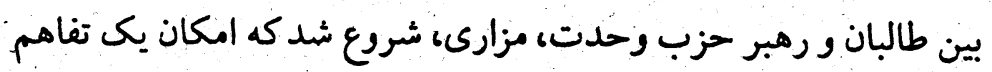

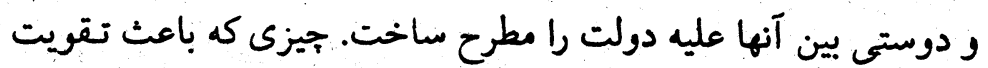

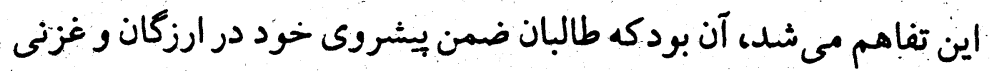

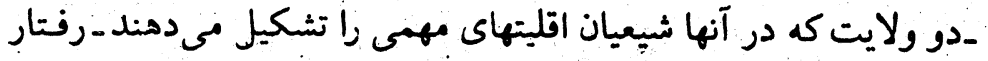

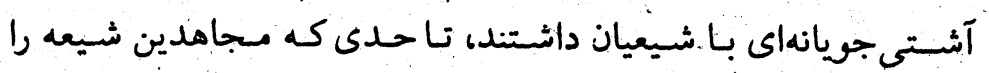

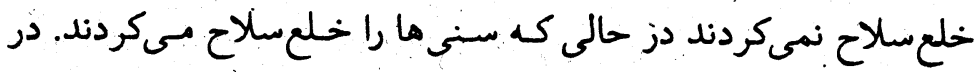

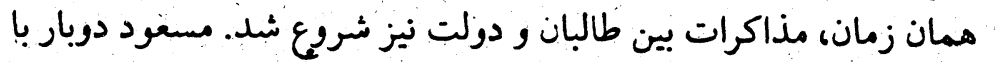

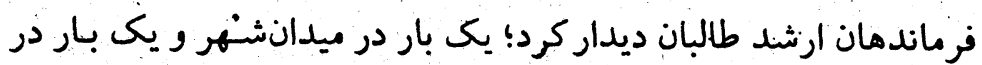

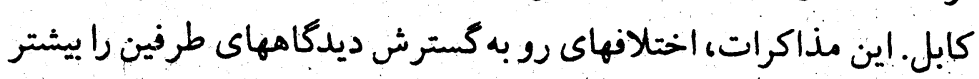




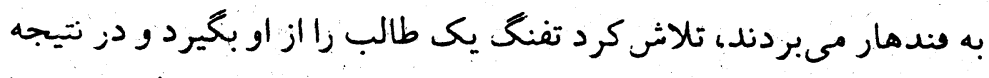

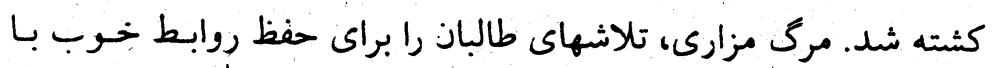

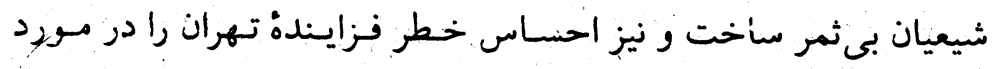

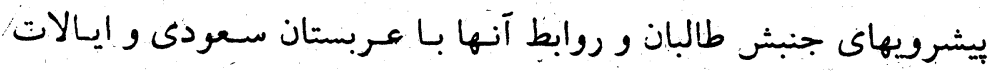

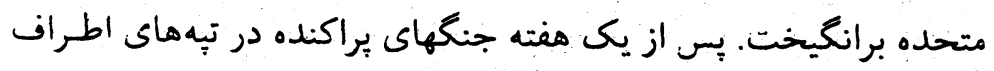

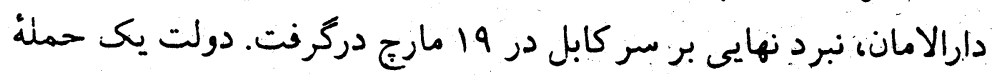

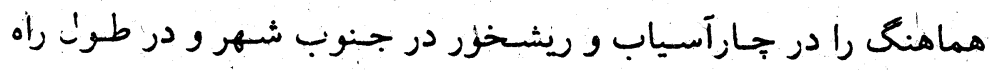

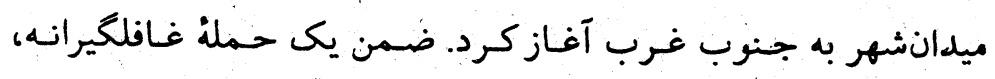

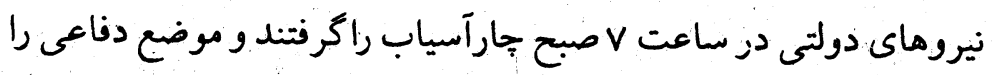

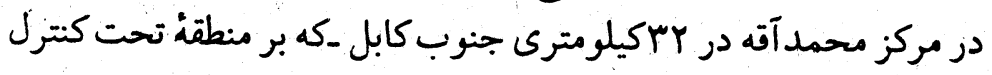

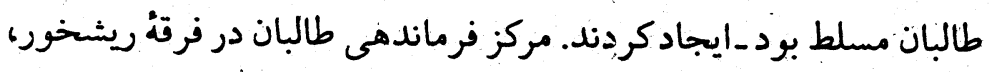

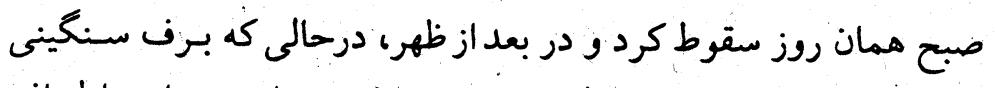

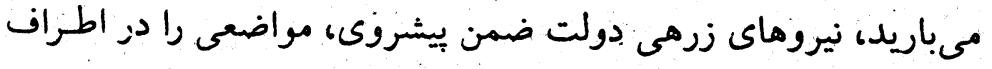

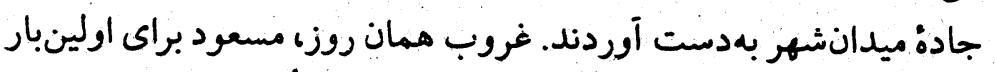

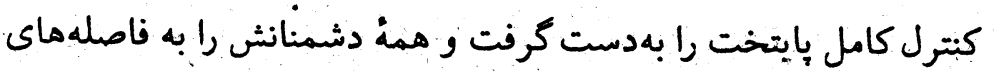
بسيار دور از كابل عقب راند.

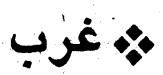

طالبان در همان زمانى كه از كابل رانده مى شدند، بيروزيهان جشمخيرى

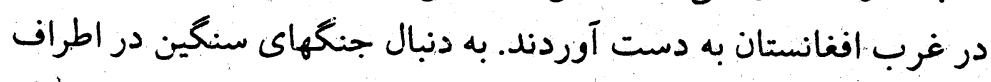

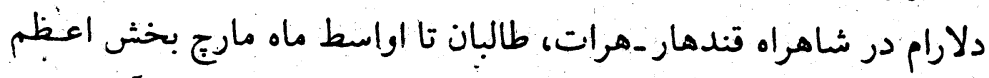

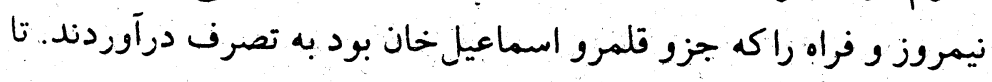

افغانستان، طالبانب، و سياستهاءى جهانى

"ادر دو روز اول جنظ (و و vنارج) مسعود و وجدات هر دو هيأتهايى نزد

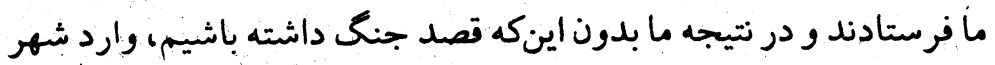

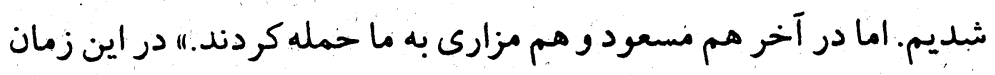

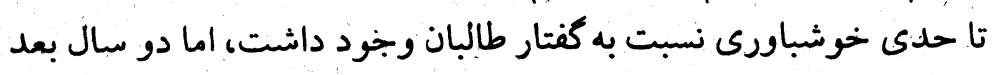

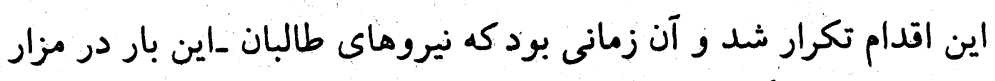

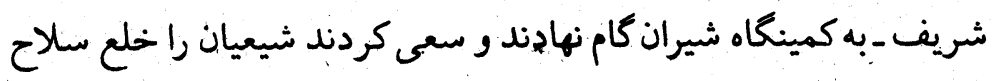

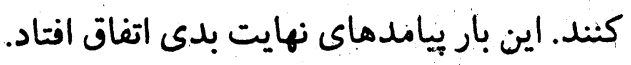

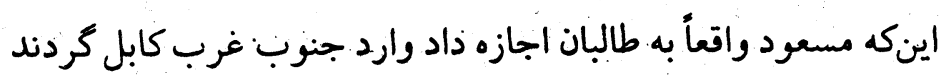

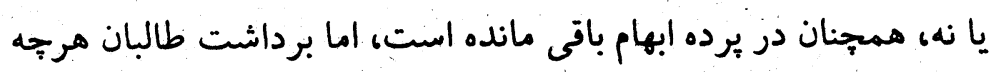

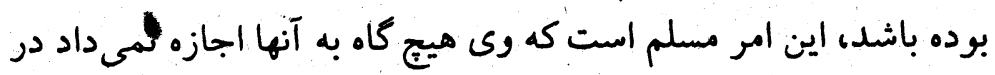

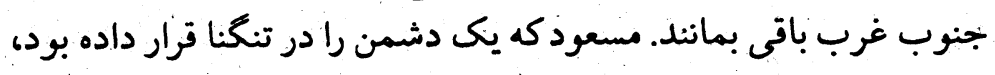

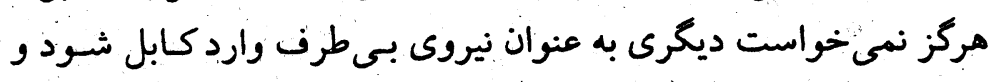

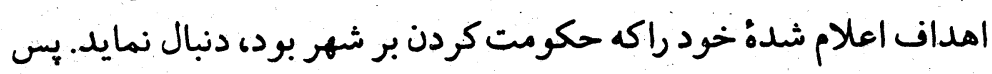

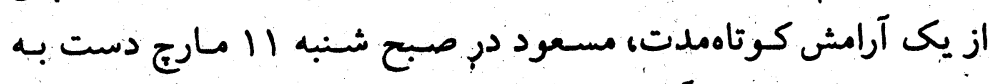

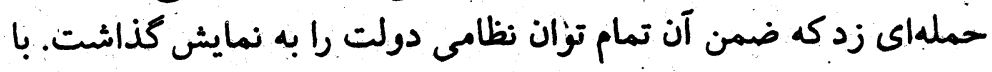

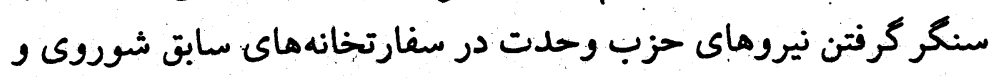

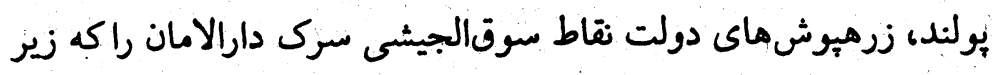

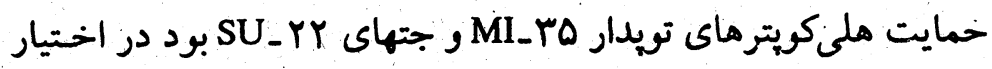

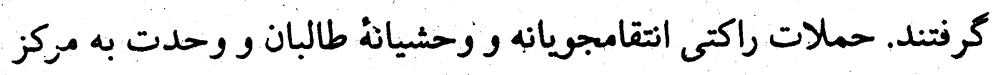

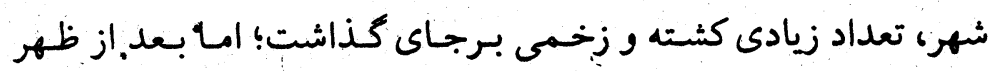

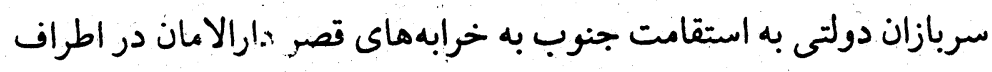

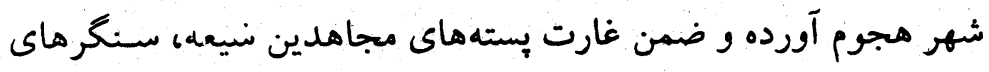

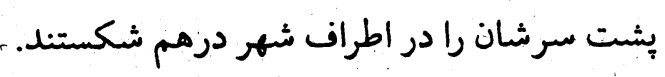

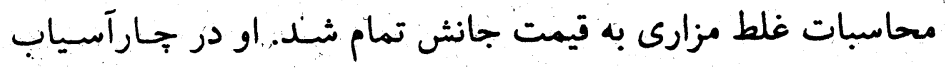

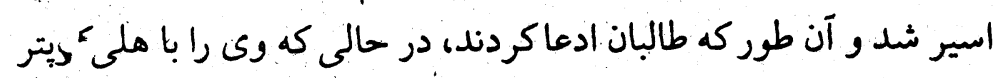




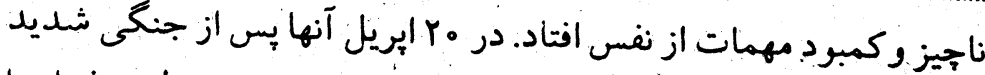

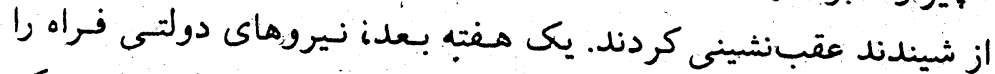

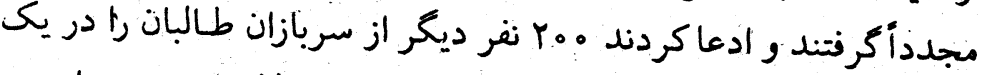

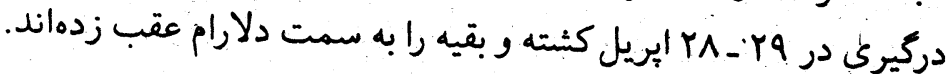

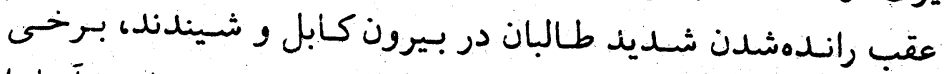

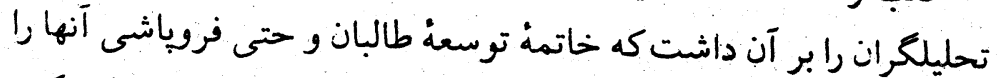

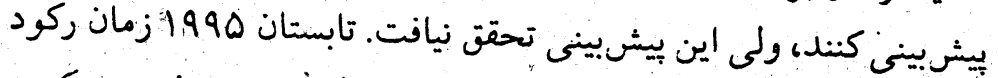

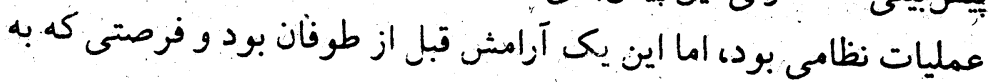

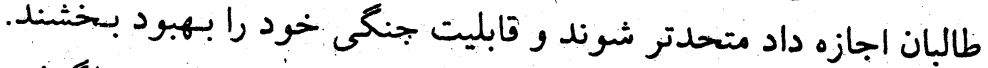

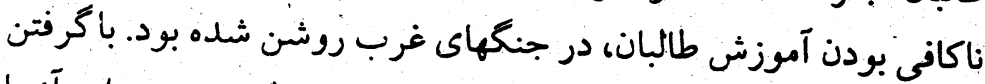

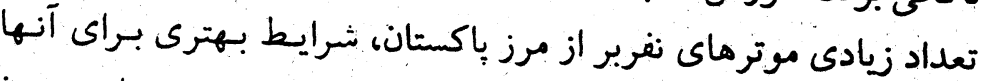

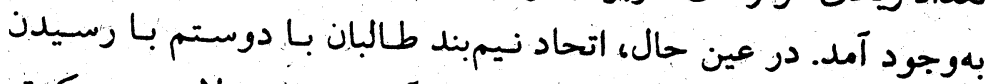

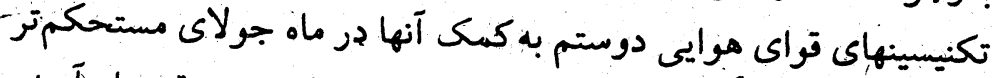

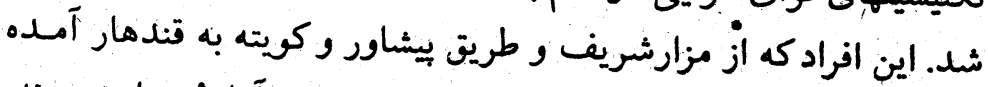

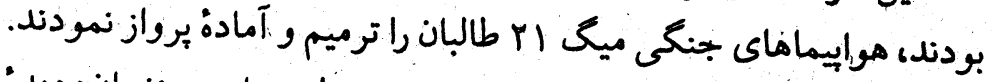

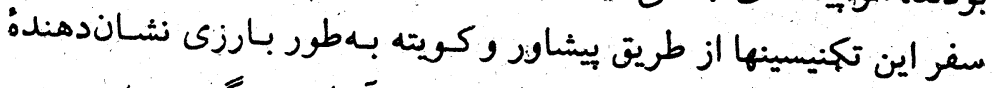

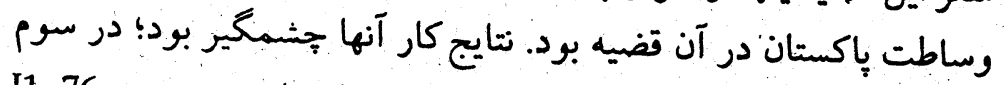

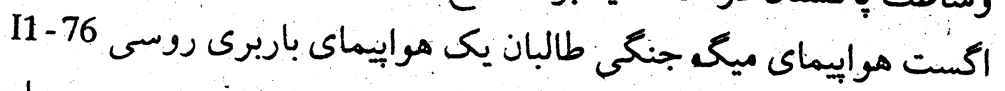

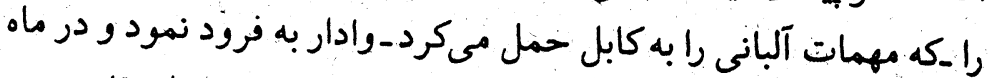

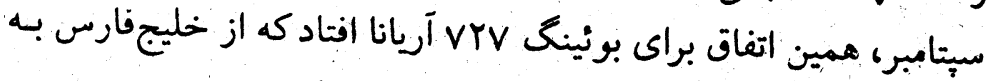

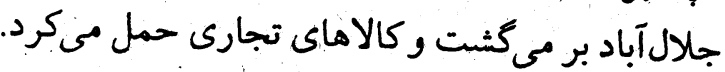

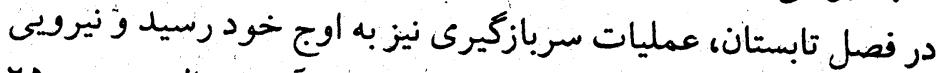

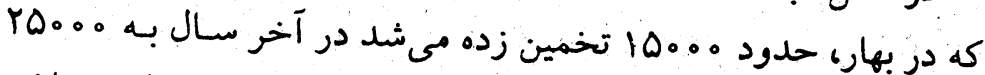

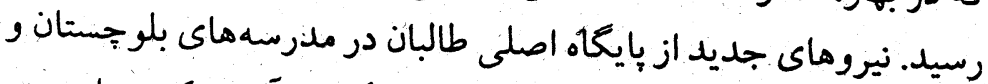

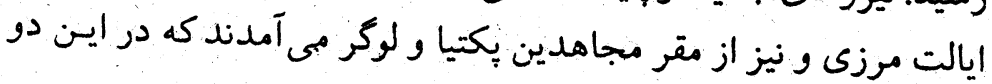

اواخر مارج؛ روشُن شد كه على رغم ترديلهاى محافل امنيتى باكستان در

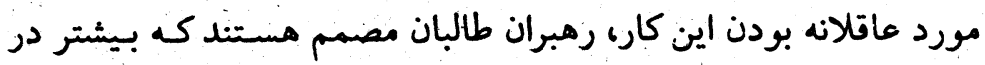

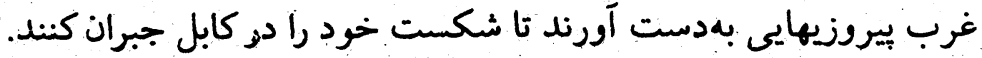
هدف أنها هرات بودئ

شكست و ييوستن متحذين بُستون اسماعيل خان به طالبان در نبمروز

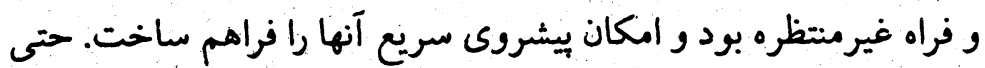

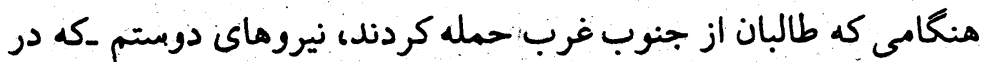

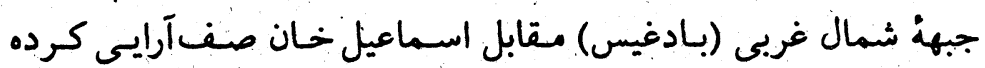

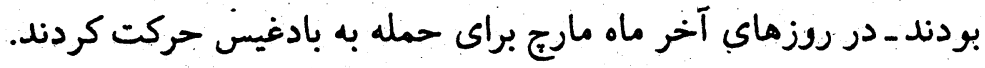

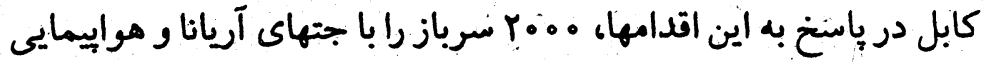

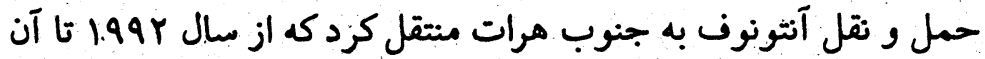

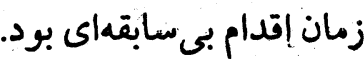

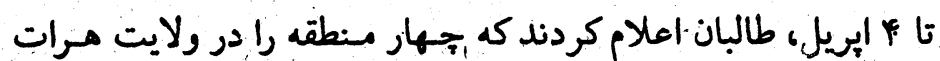

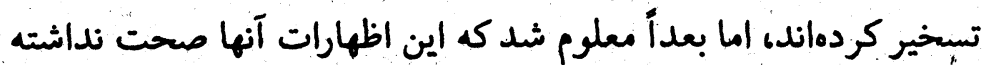

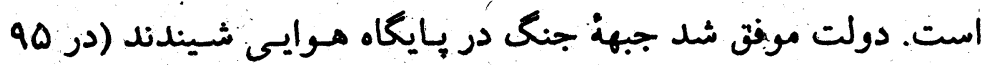

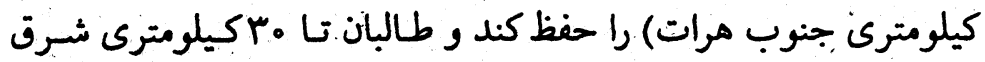

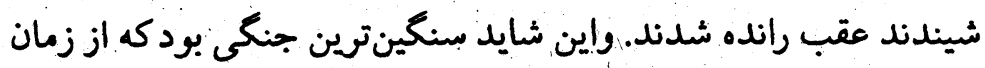

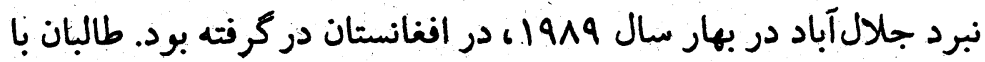

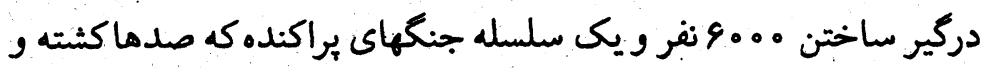

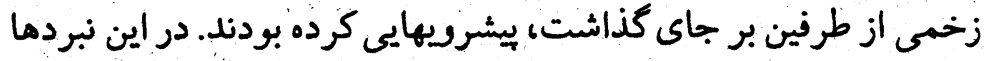

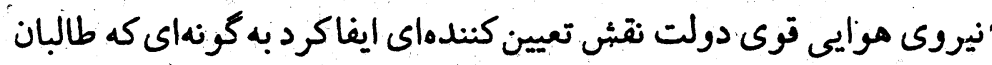

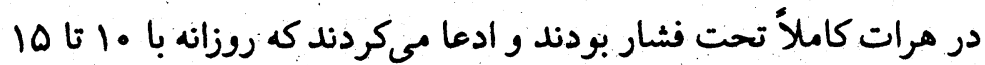

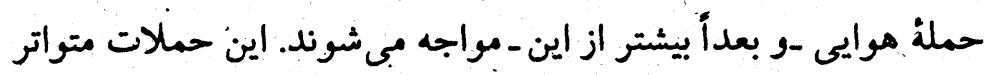

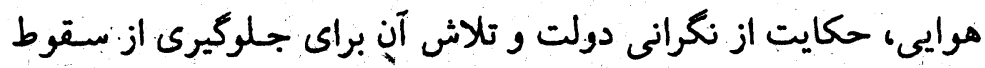

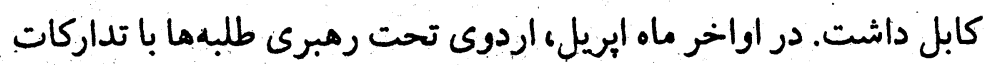




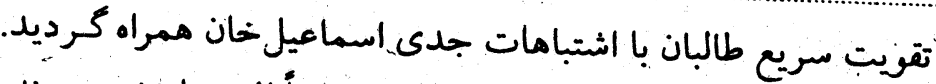

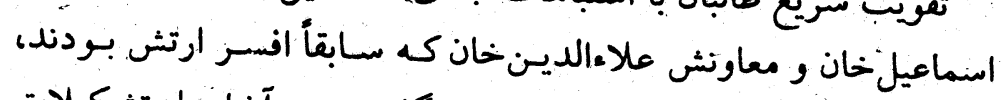

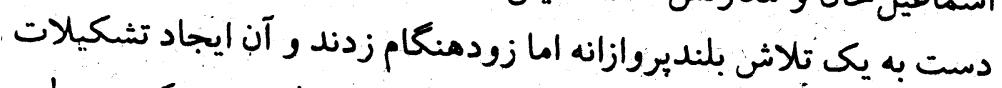

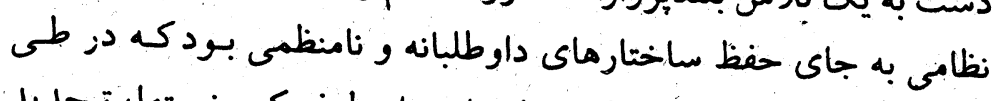

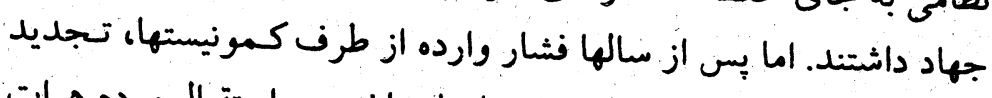

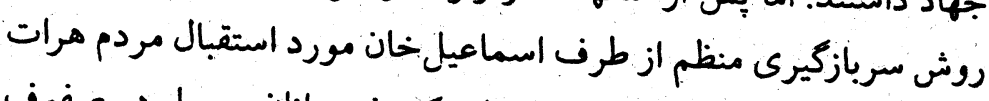

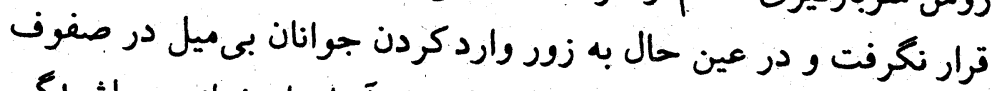

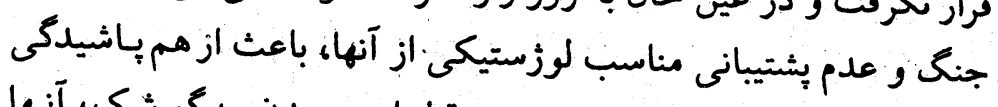

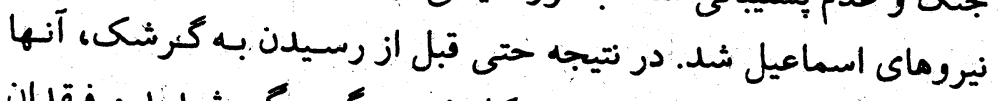

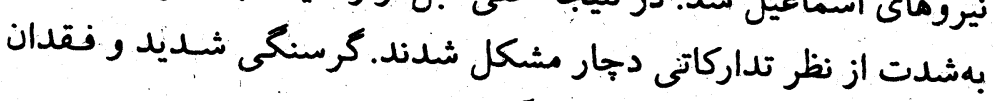

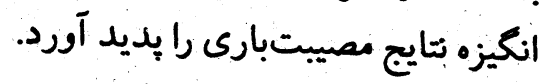

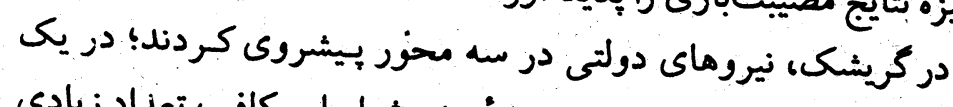

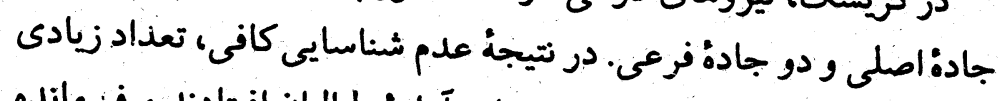

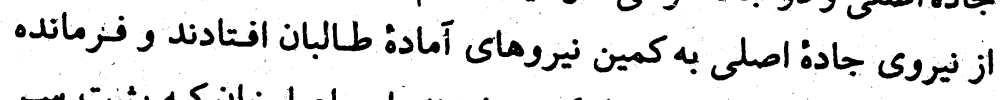

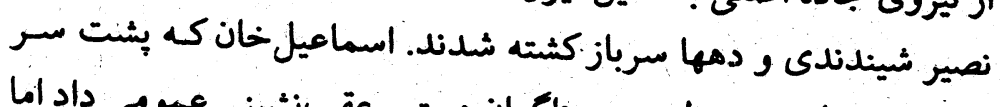

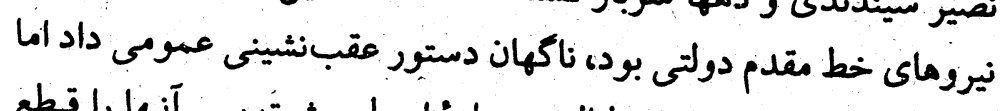

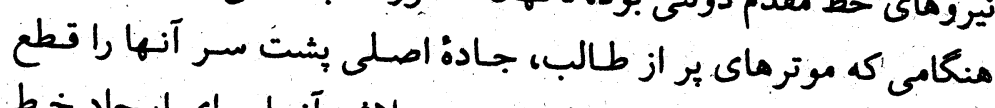

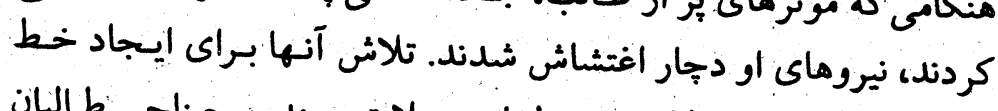

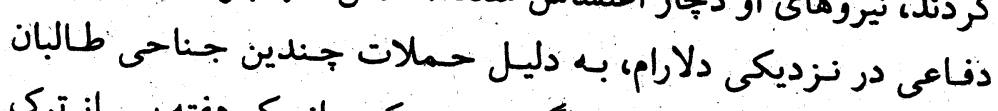

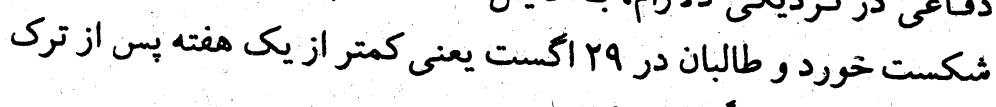

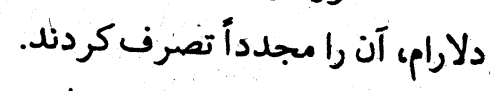

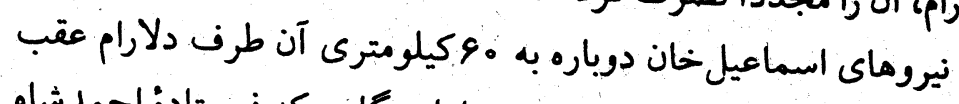

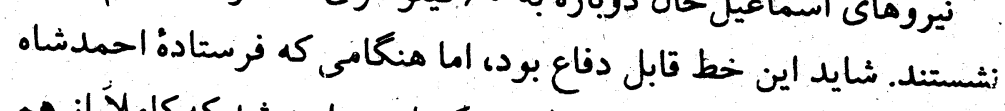

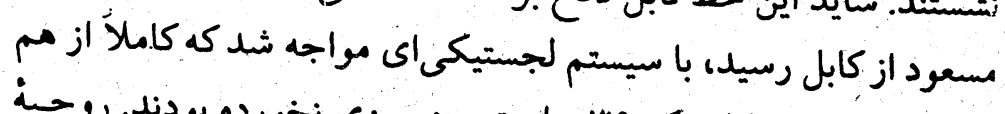

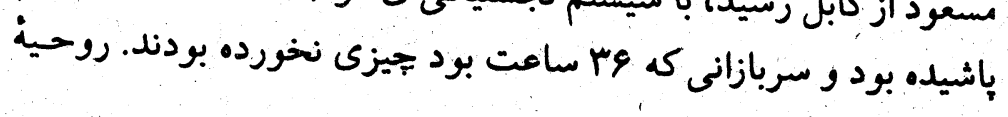

منطقه در ماه سبتامر سربازكيرى عمدهاى صورت كرفت. تجت حمايت

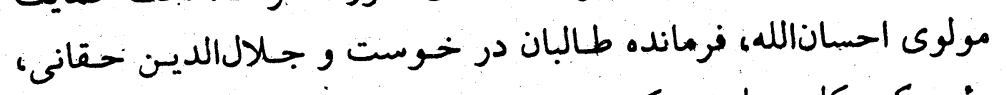

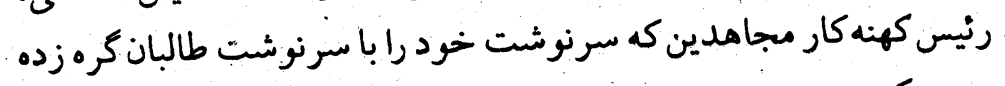

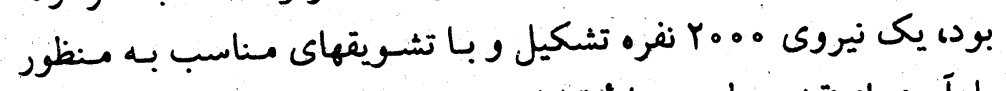

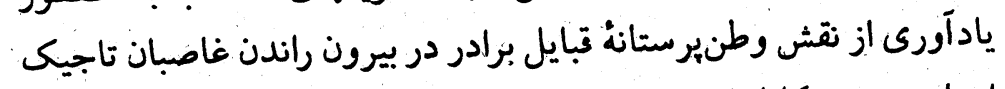

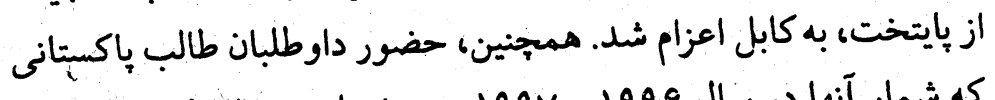

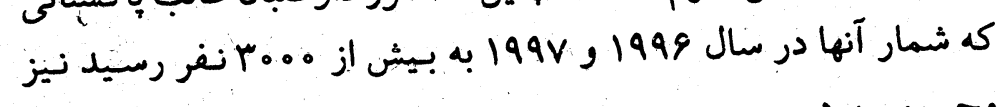

محسوس بود. در ماه اخست، دولت كه نياز به بيروزيهايى داشت و. مشتاق بود از فشار

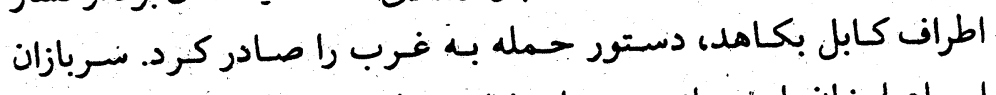

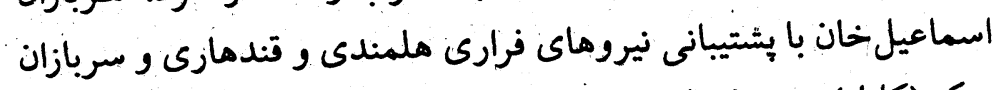

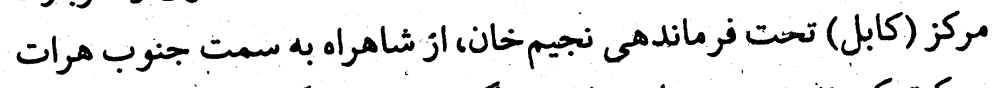

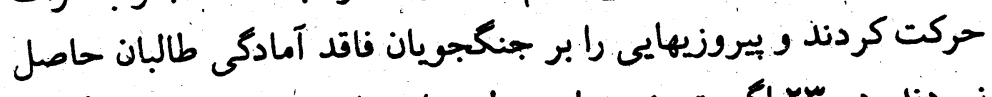

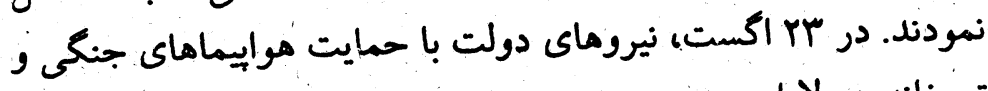

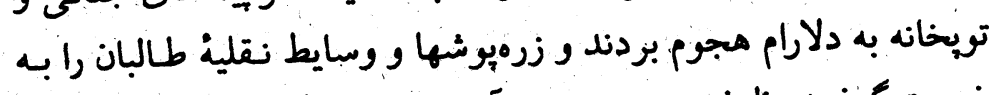

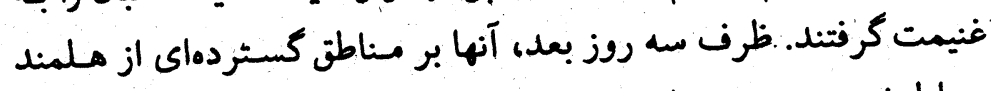

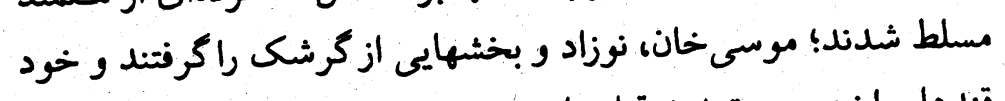
قندهار را نيز مورد تهديد قرار دادند.

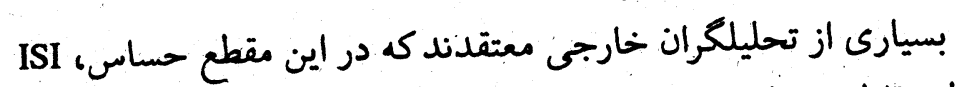

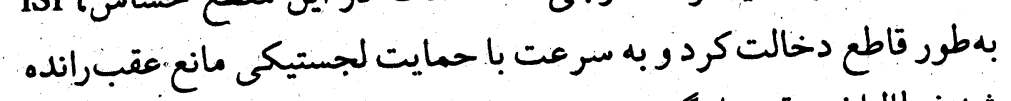

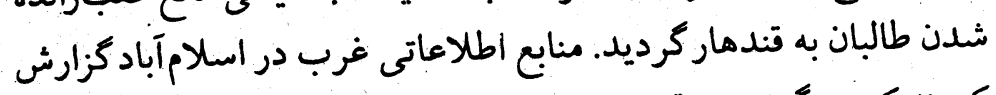

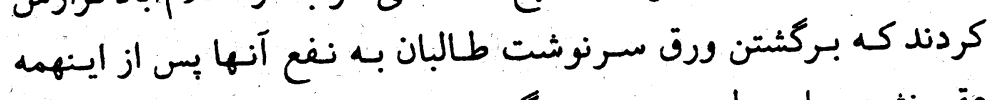

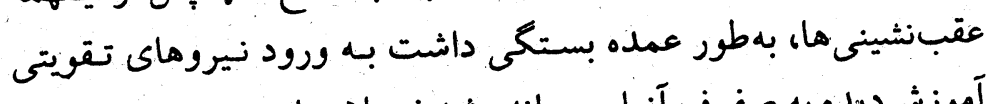

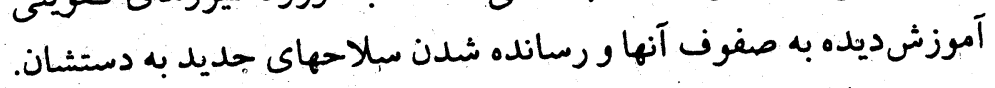

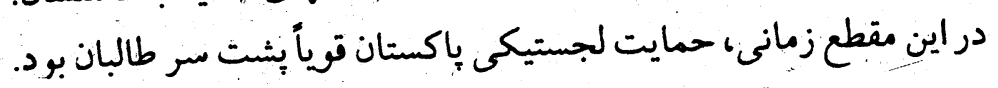




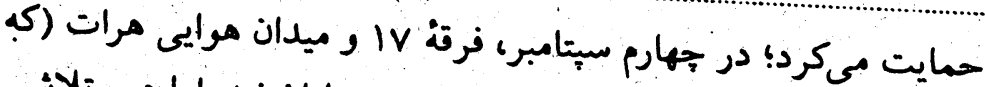

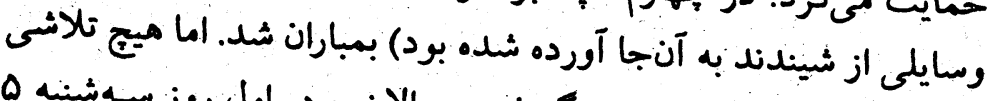

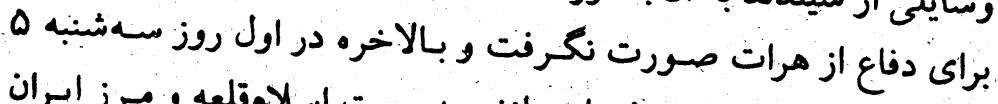

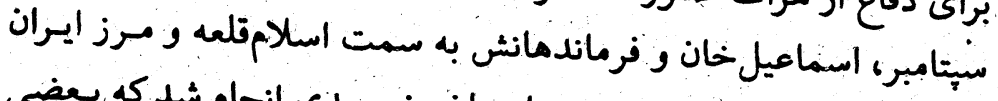

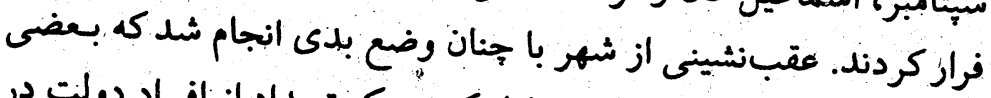

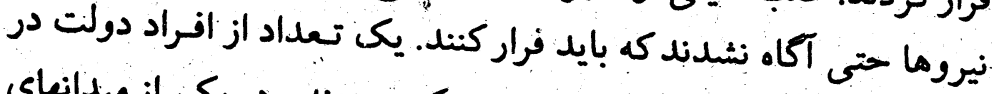

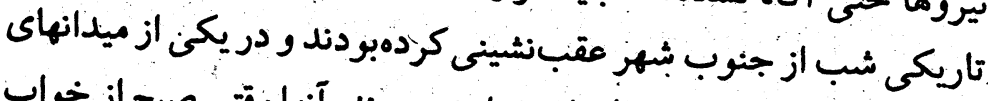

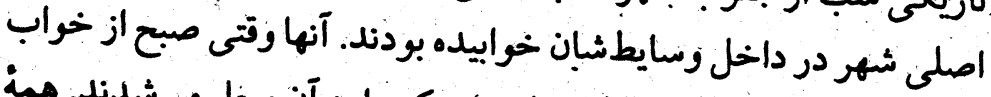

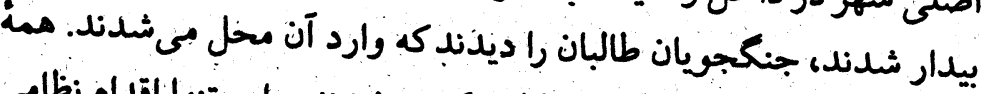

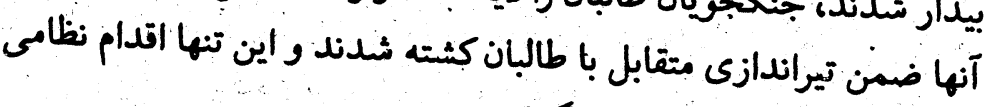

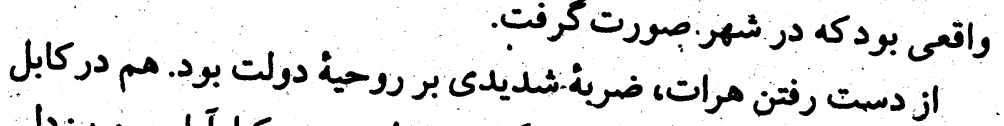

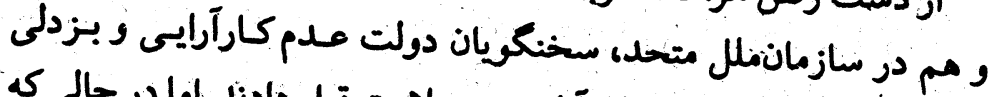

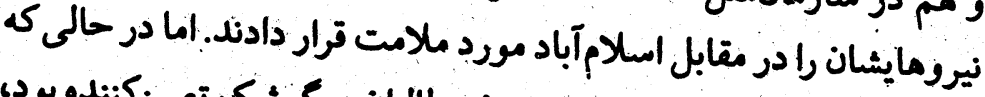

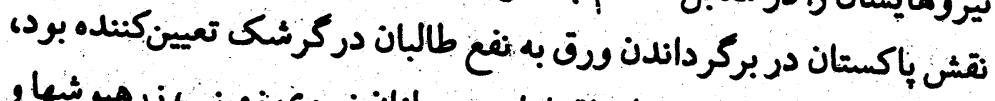

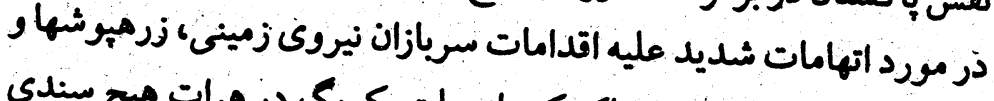

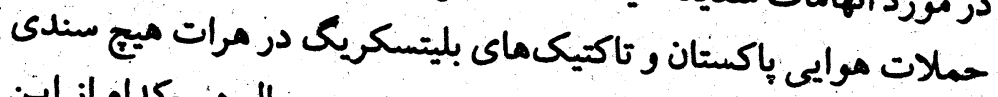

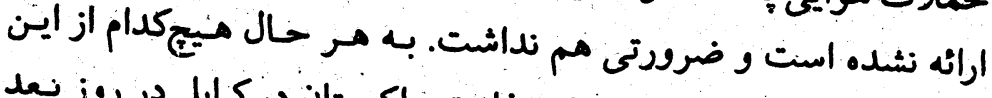

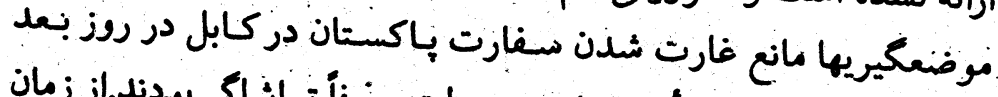

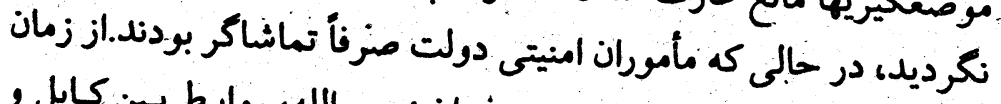

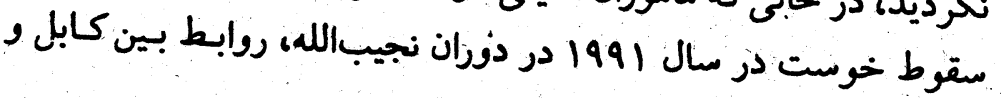
اسلام آباد ميجوقت تا اين حلد خراب نشده. بود.

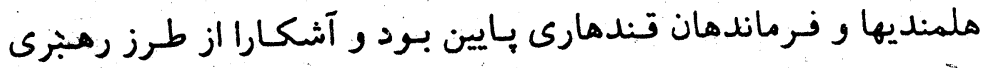

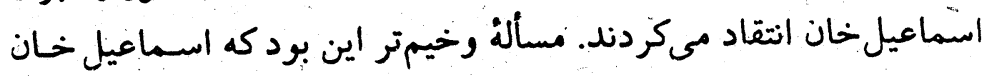

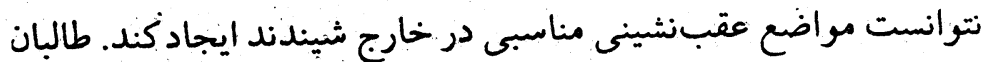

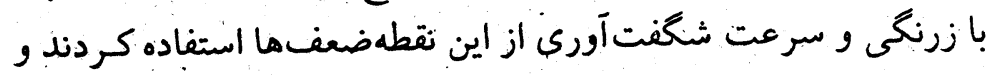

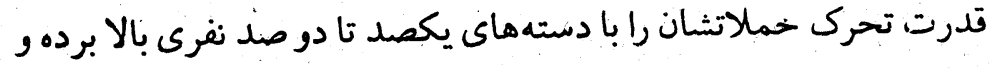

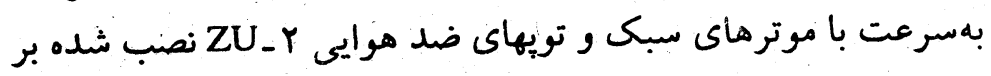

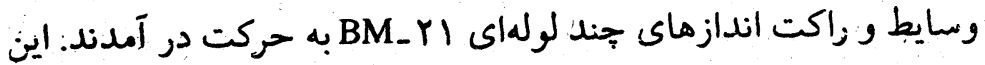

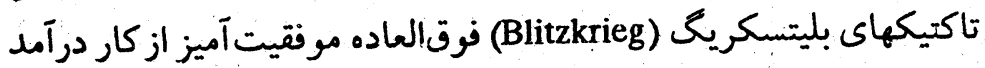

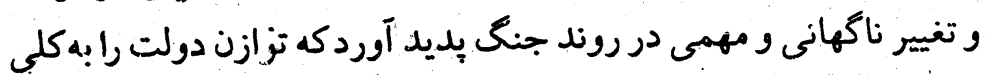
بر هم زد.

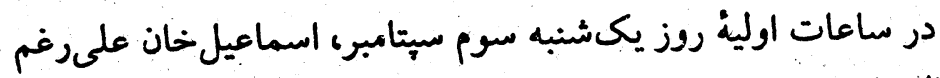

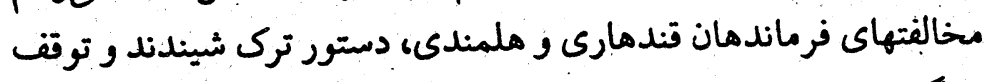

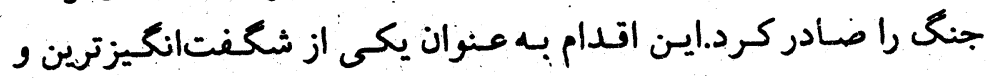

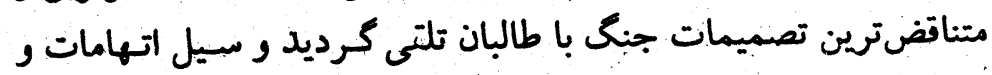

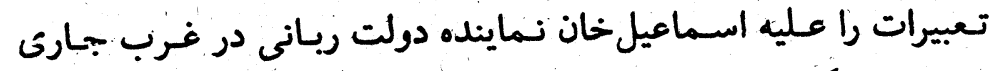

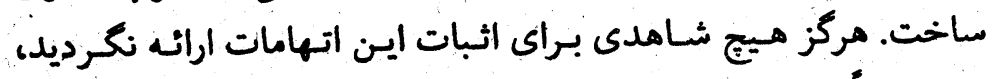

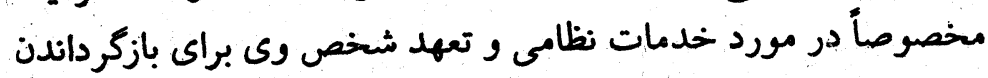

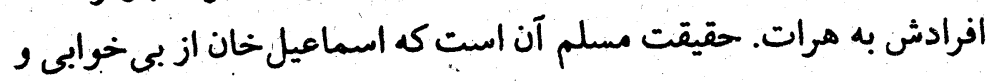

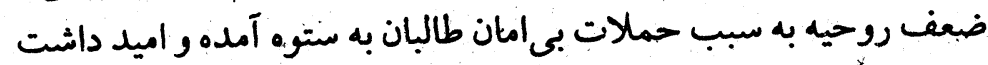

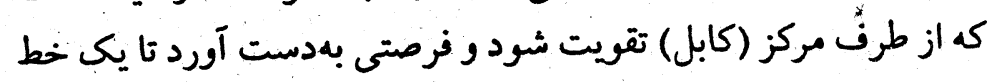

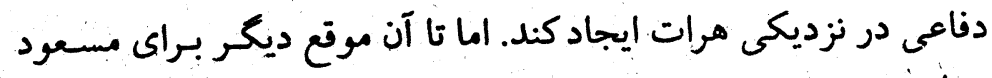

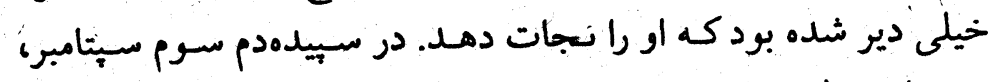

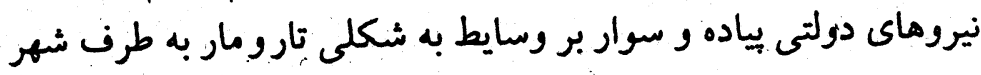
هرات در حال عقب نشينى بودند.

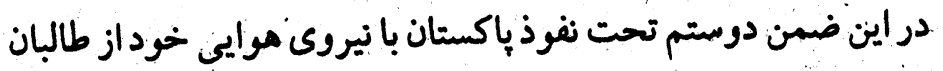




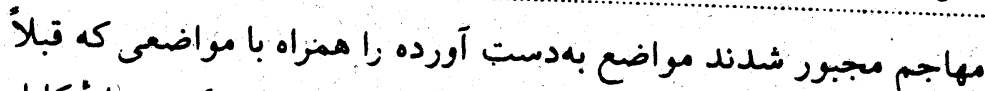

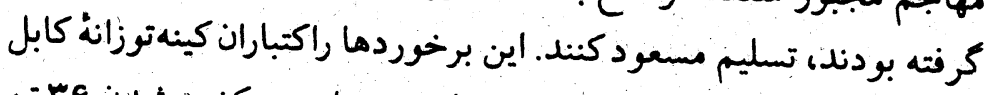

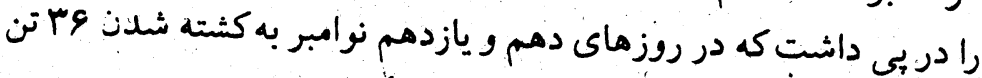

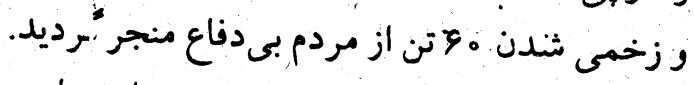

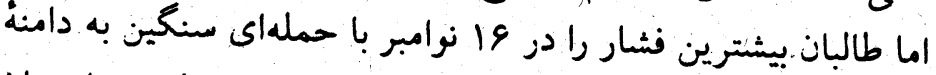

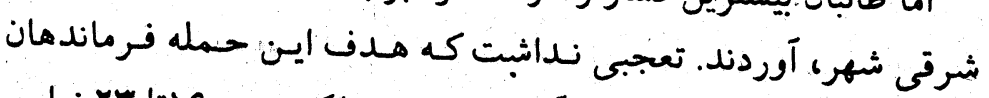

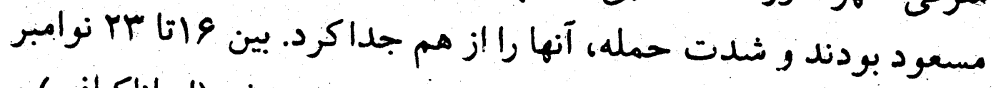

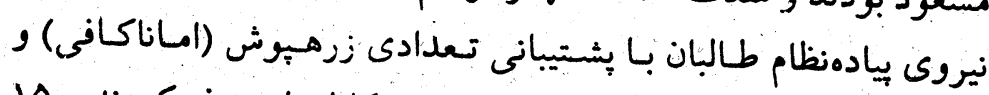

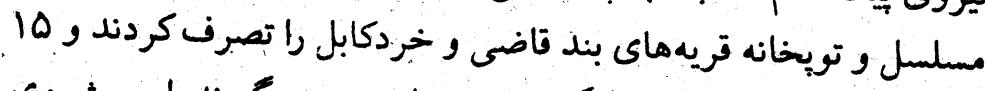

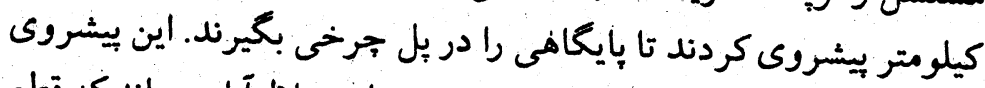

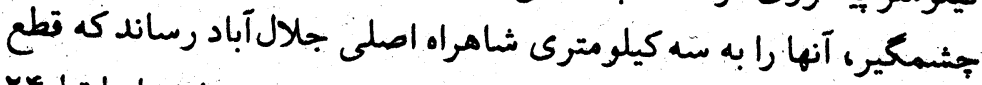

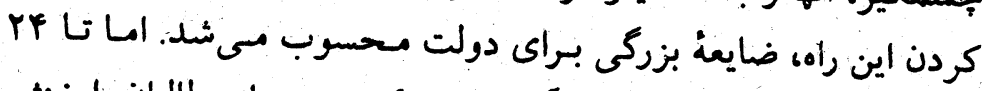

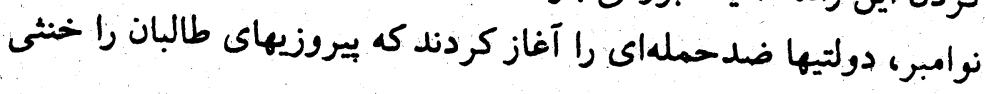

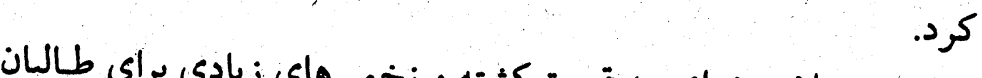

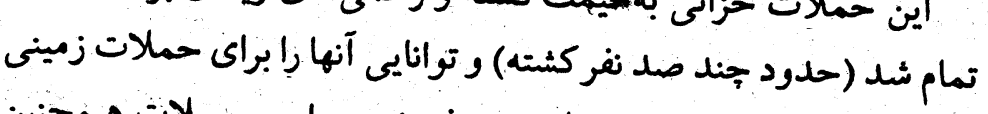

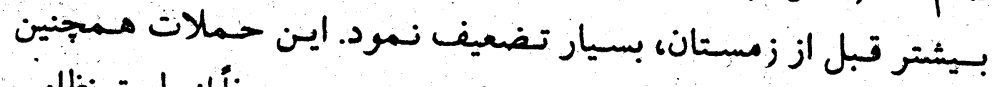

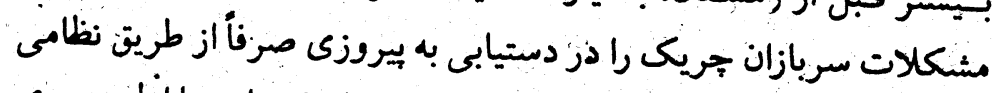

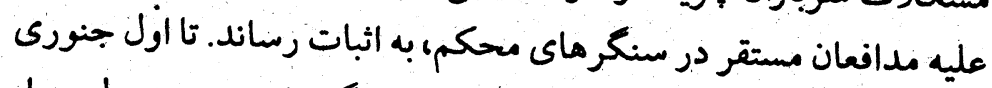

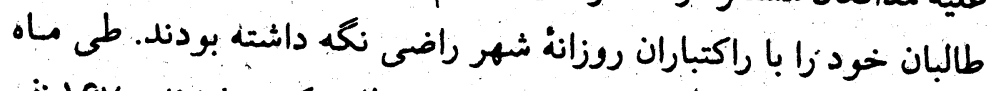

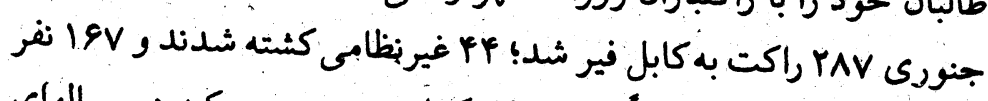

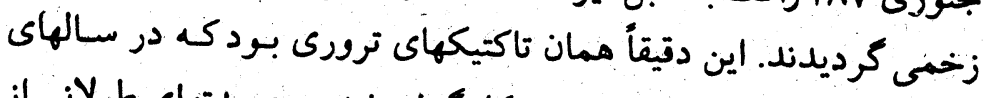

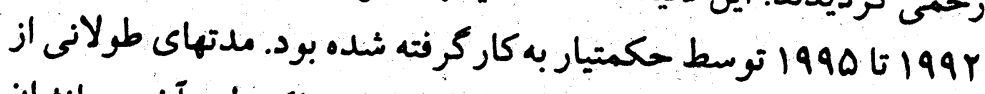

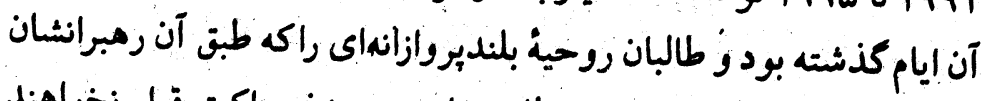

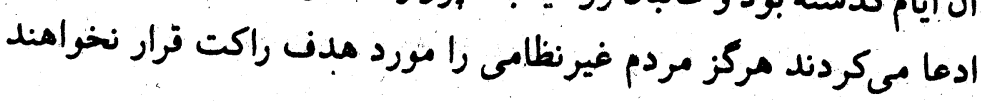

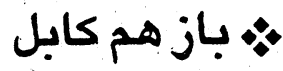

طالبان در خالى كه خرب افغانستان را در اختيار داشتند، به سرعت تلاش.

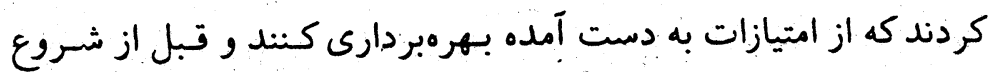

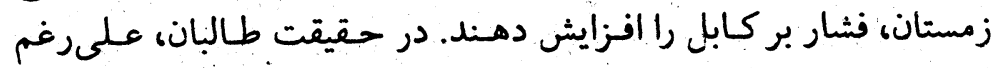

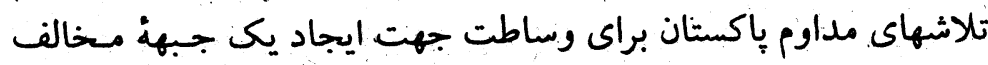

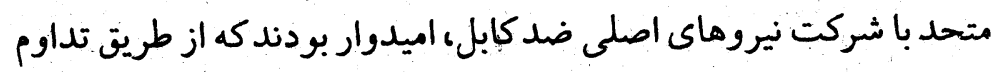

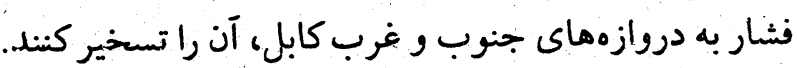

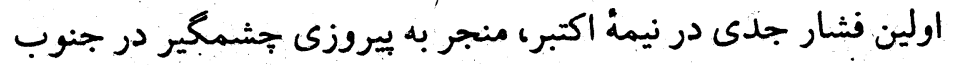

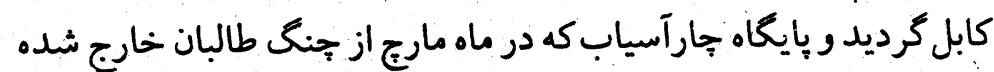

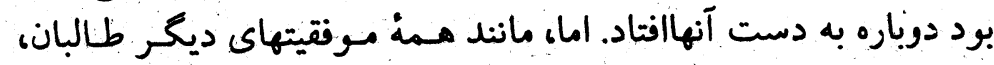

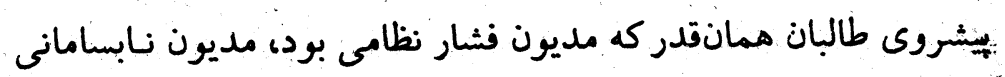

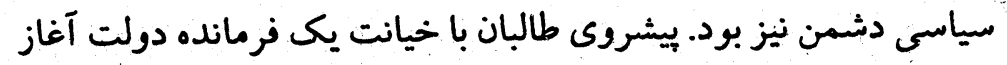

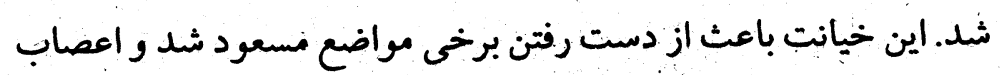

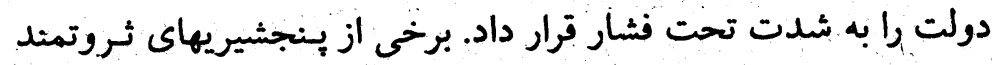

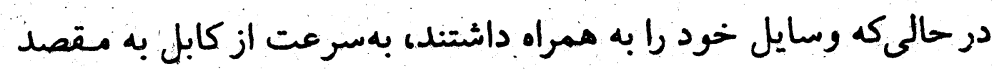
درة بنجشير كريختند.

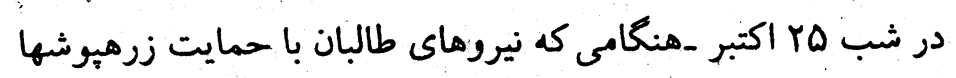

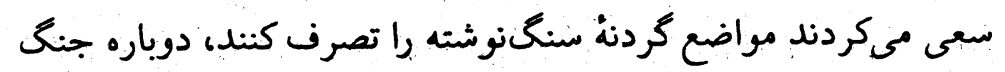

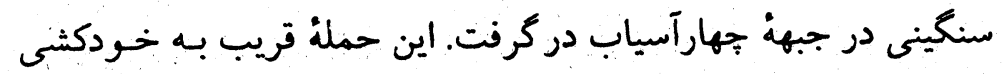

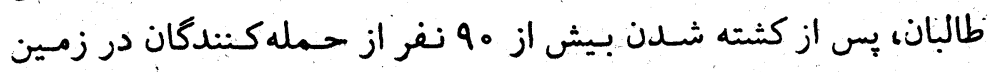

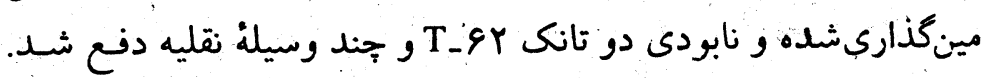

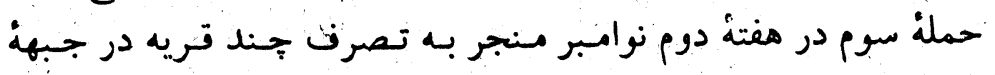

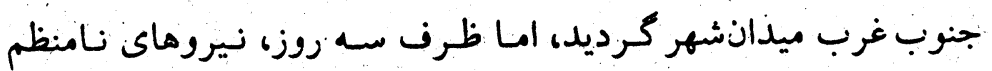




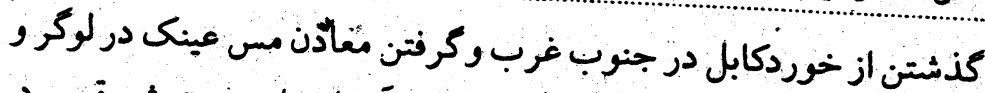

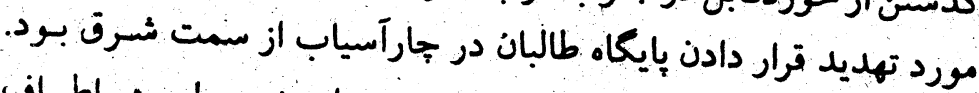

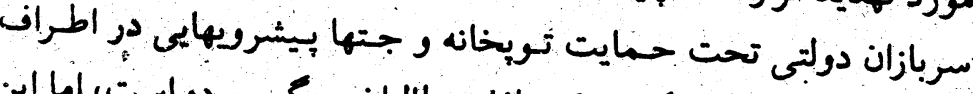

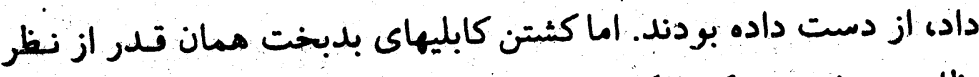

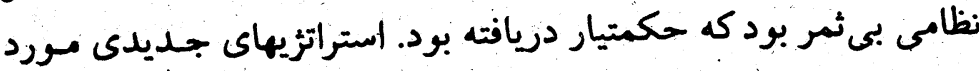

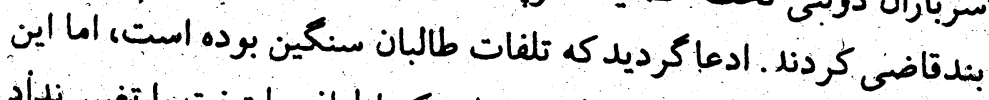

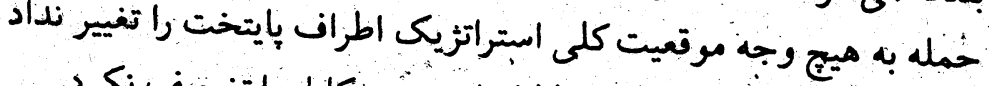

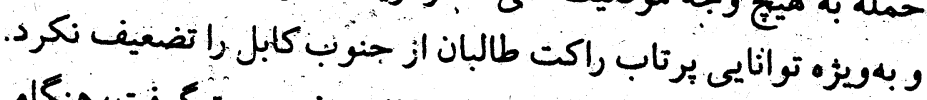

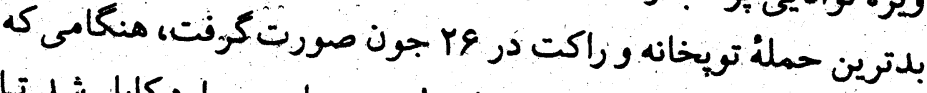

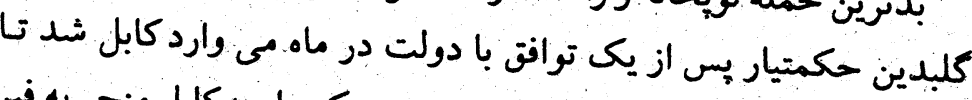

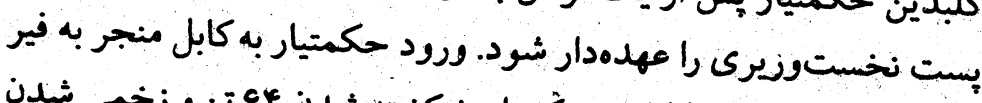

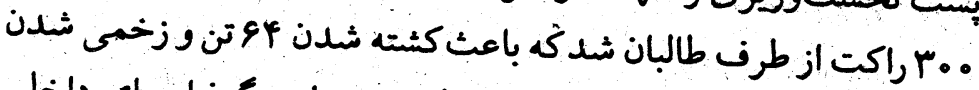

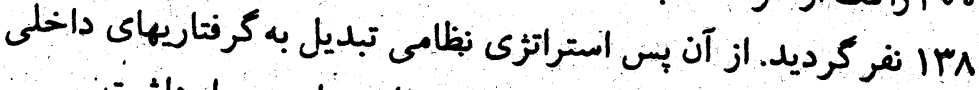

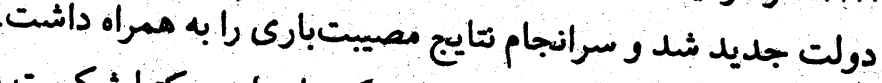

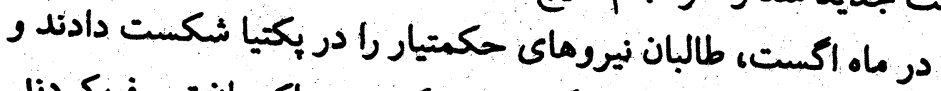

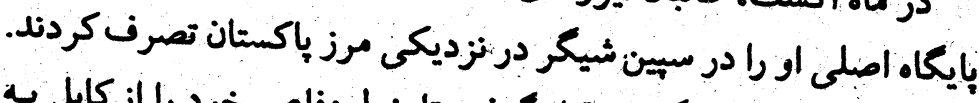

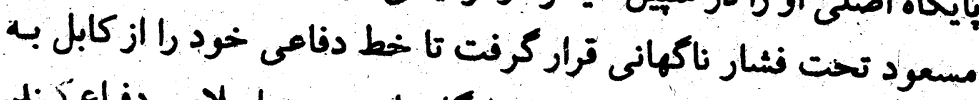

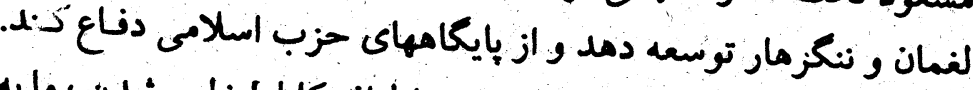

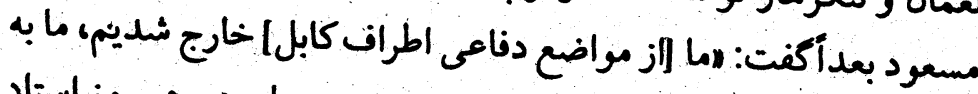

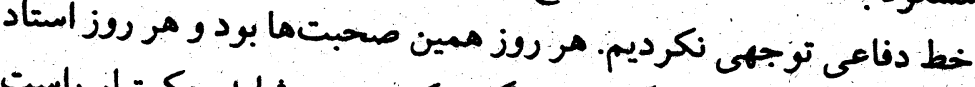

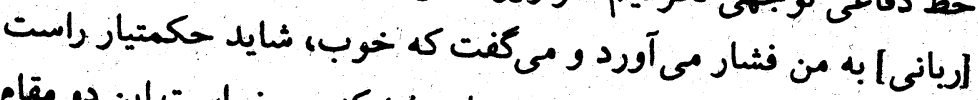

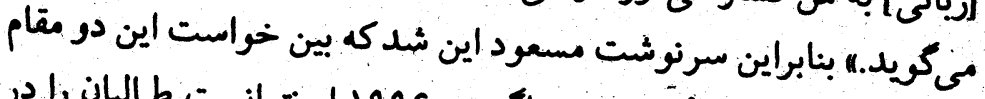

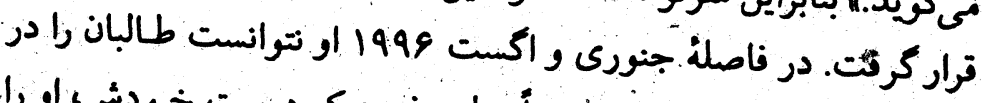

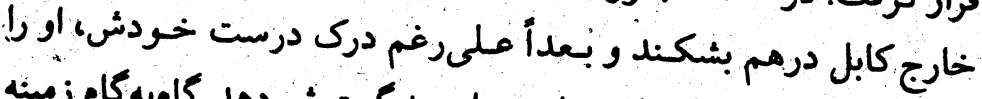

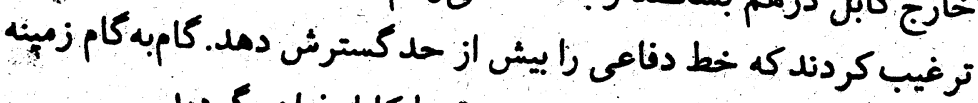
براى شُكست سخت ماه سبتامبر و مبقوط كابل فرامب كرديد.

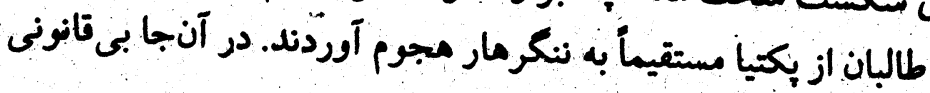

\section{. - مشمكش در شرق و تسخير كابل}

بس از وقوع اين حوادث، مىتوان استدلال كرد كه يكى از بزركترين

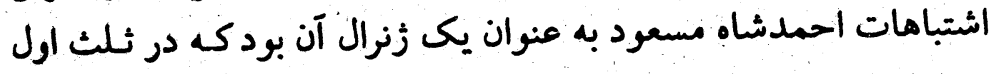

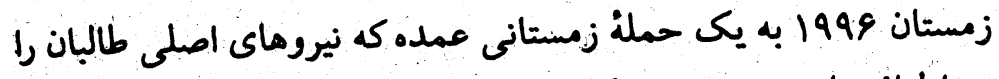

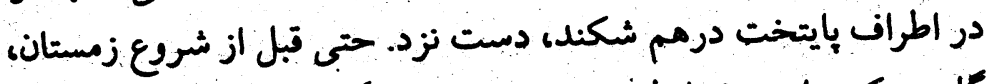

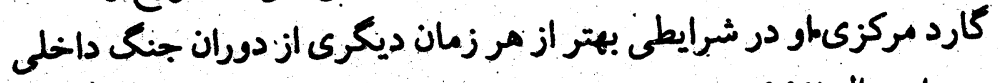

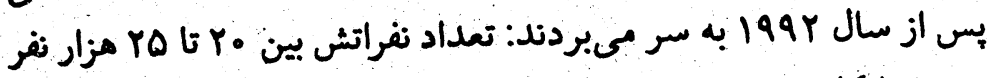

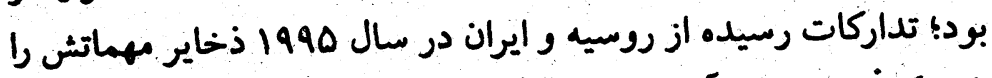

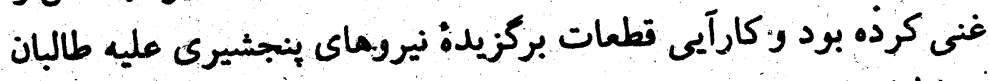

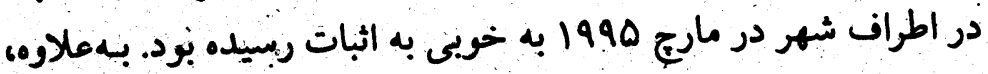

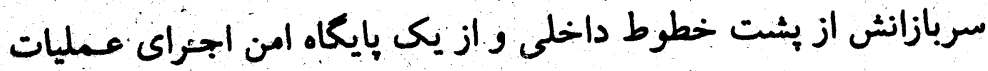

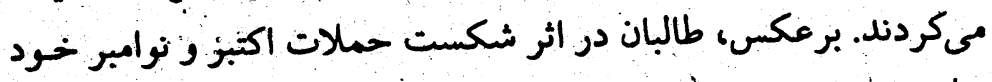

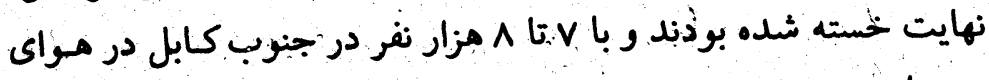

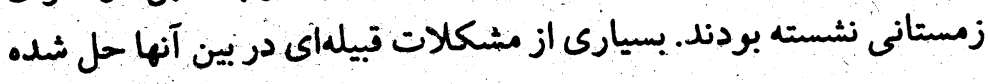

مسعود كه ماند مفيشه محتاط بود، در زمستان ميج اقدامى نكرد و

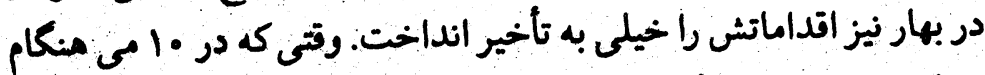

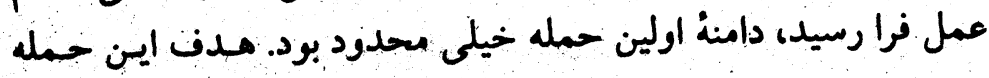




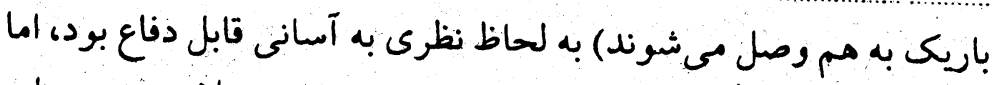

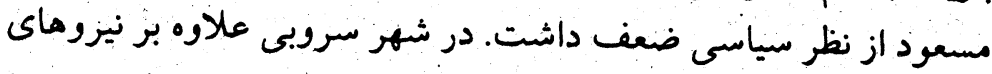

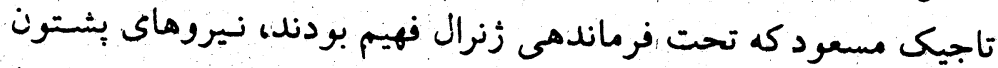

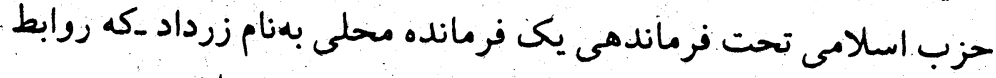

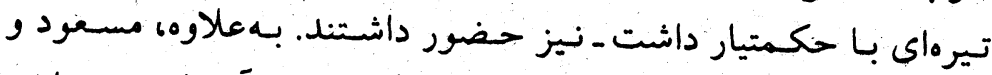

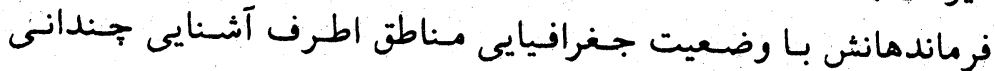

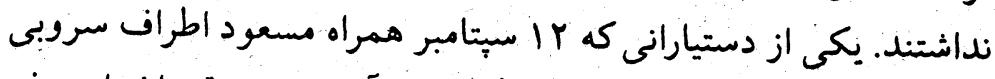

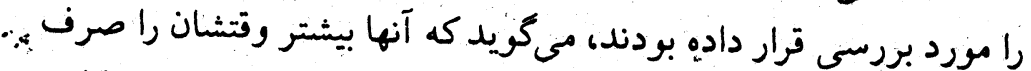

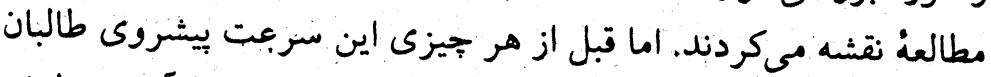

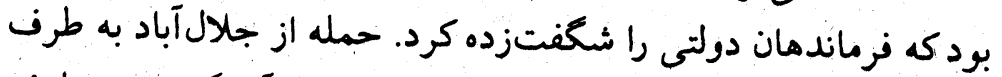

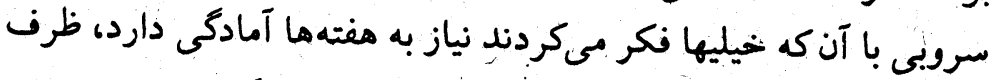

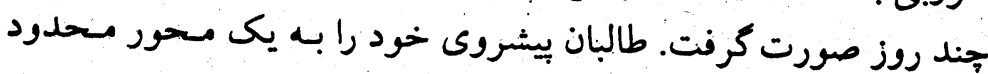

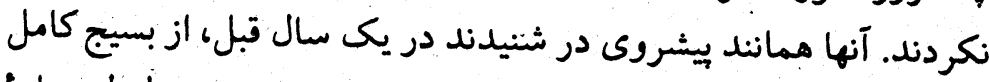

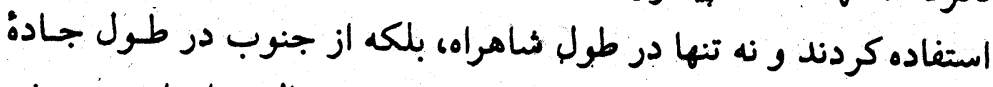

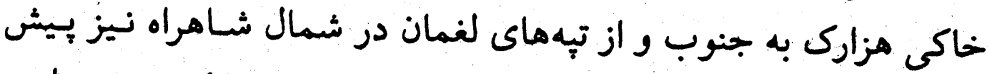

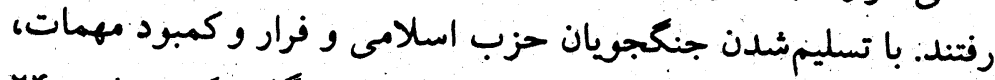

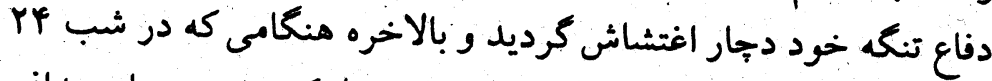

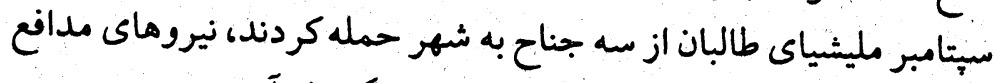

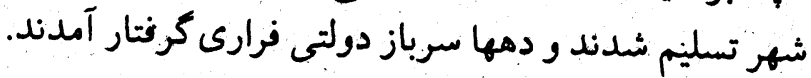

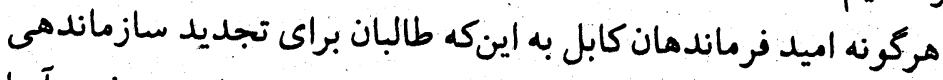

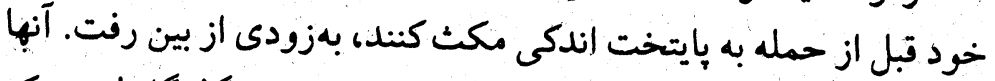

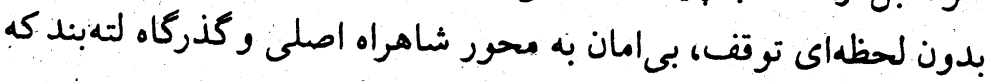

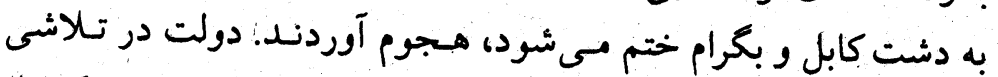

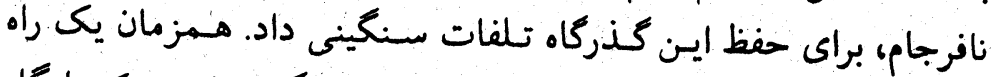

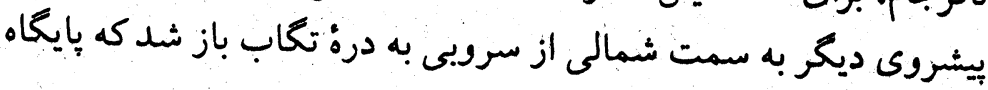

مجاهدين و يولهاى طالبان كار خود:ثُ راكرد. در هفتهُ اول سيتامبر آنها

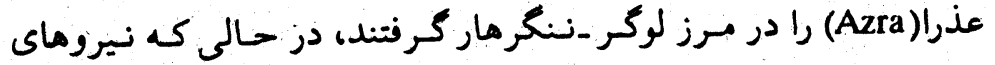

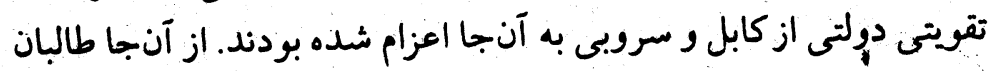

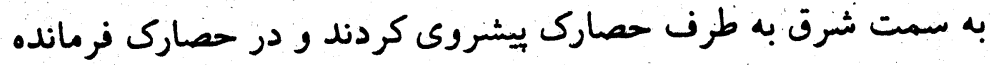

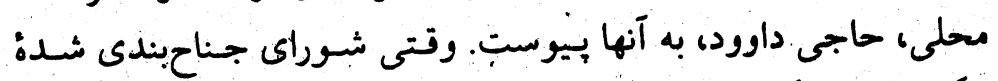

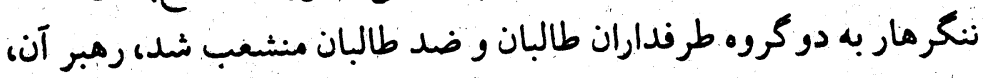

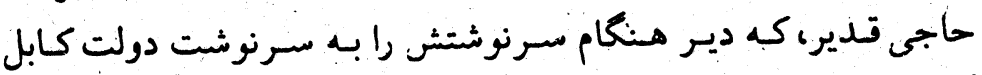

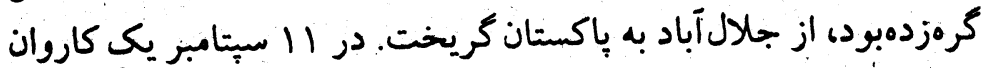

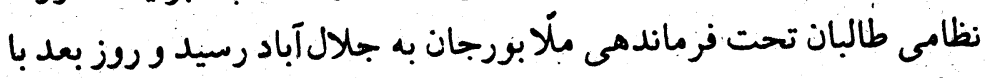

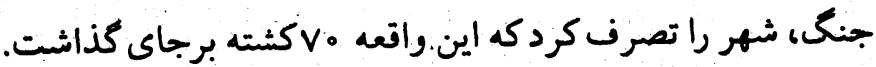

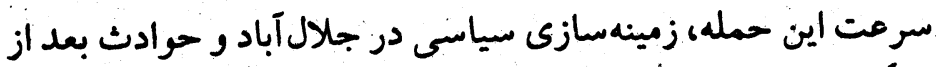

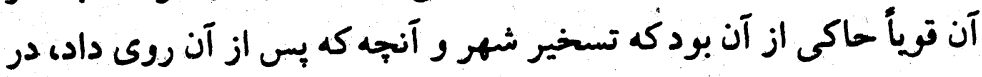

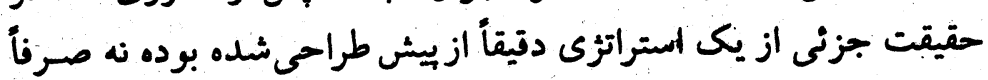

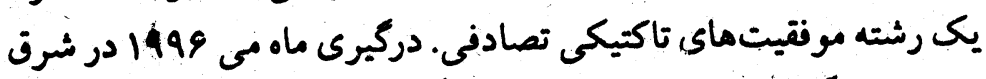

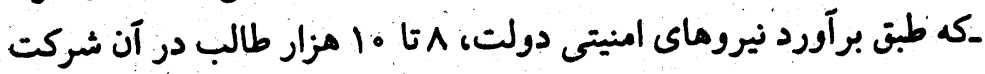

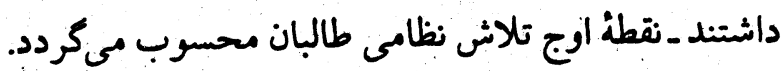

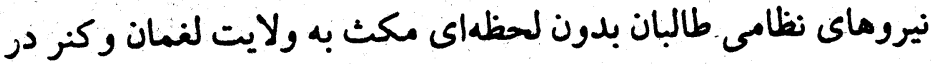

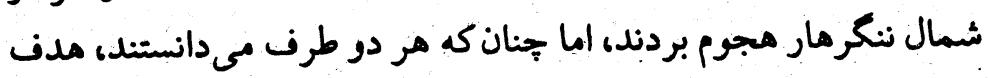

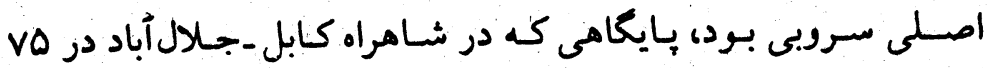

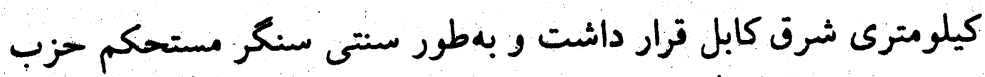

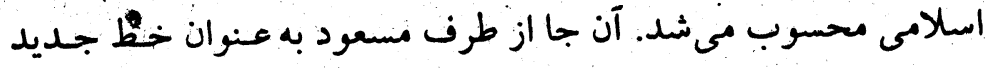

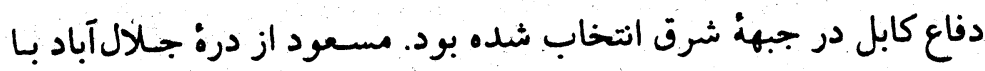

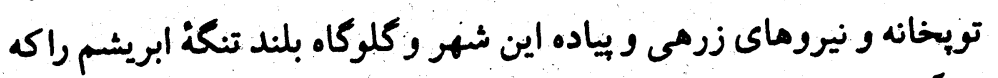

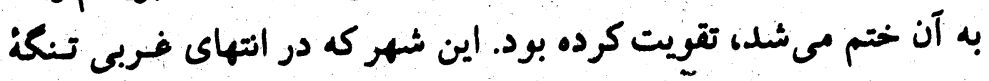

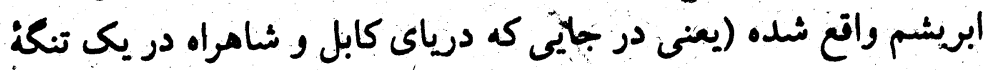




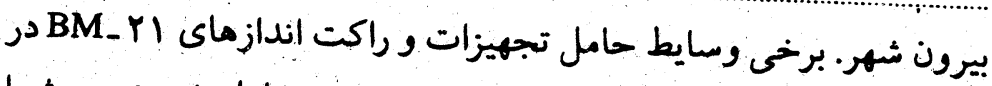

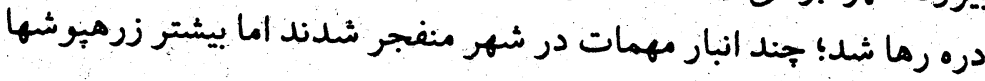

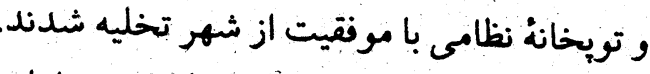

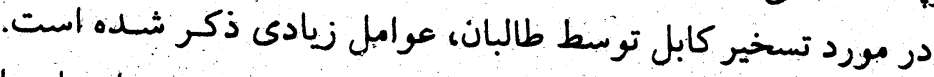

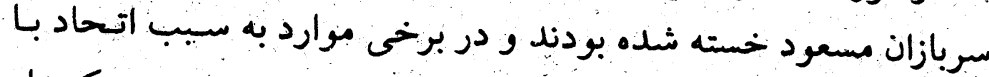

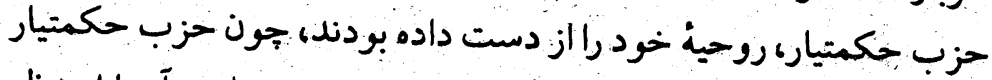
جهار سال بود كه دشمن كينهتوز آنها تلقى مى شد. بهعلاوه آنها از نظر

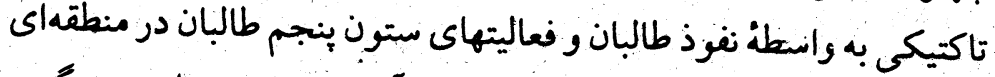

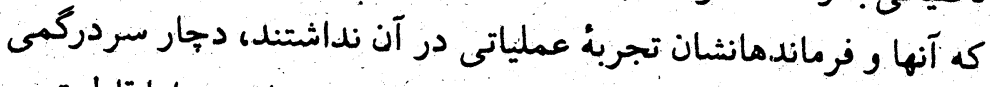

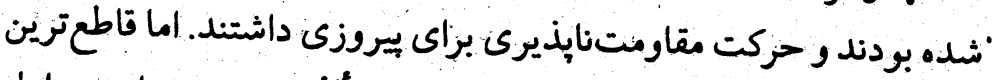

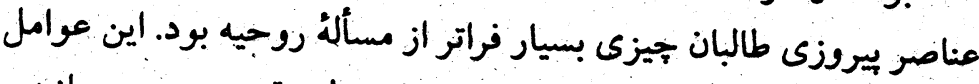

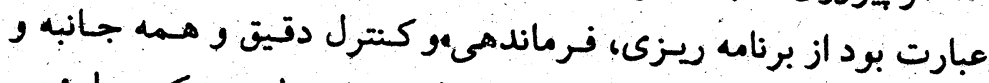

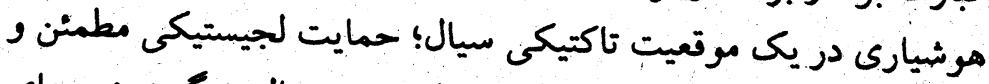

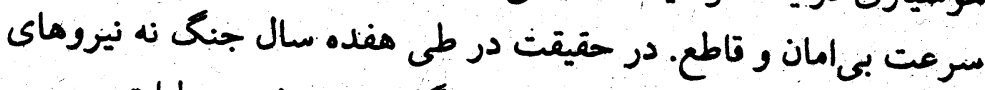
دولتى و نه نيروماى مخالف دولت هيجكاه جنين رشته عمبليات سريع و

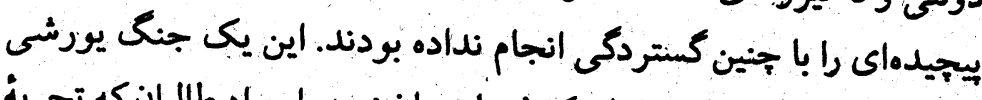

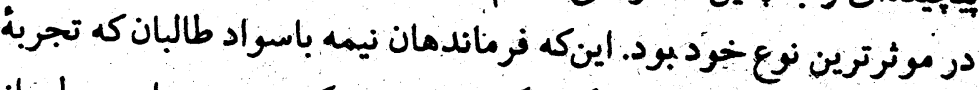

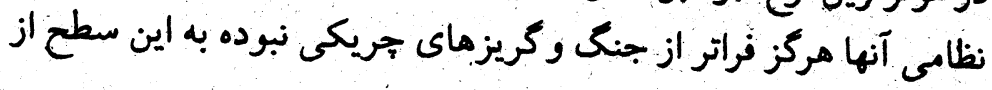
برنامهريزى و اجرا رسيده باشبند، باوركردنى فراتي أنيست.

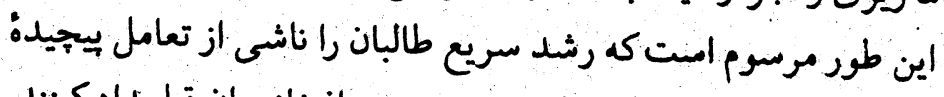

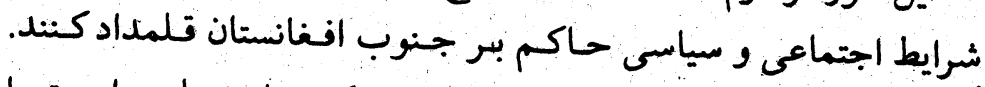

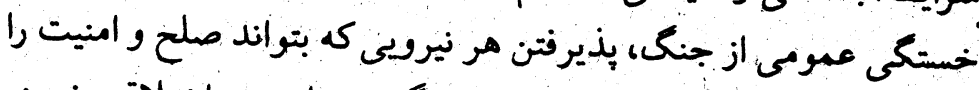

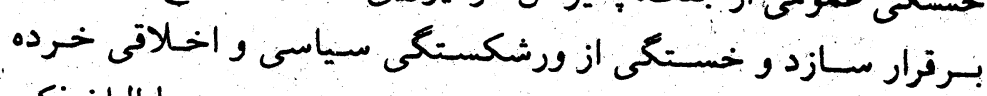

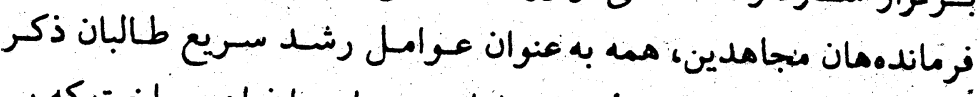

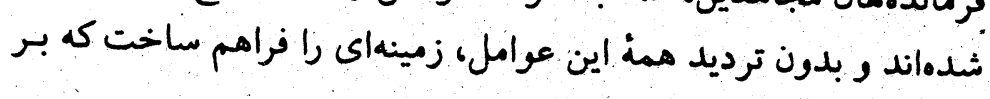

افغانستان، طالبان، و سيابستهاى جهانى

Ol.

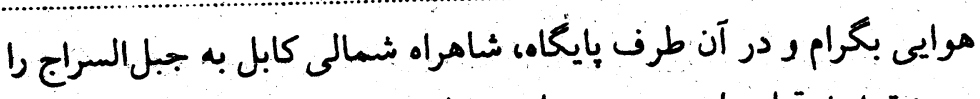

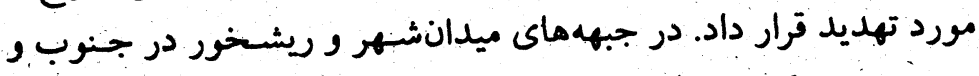
جنوب غربى كابل، تطعات نظامى دولتى در معرض حمالات طالبان ميكه

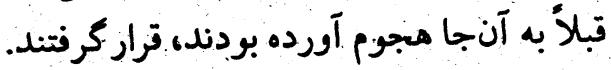

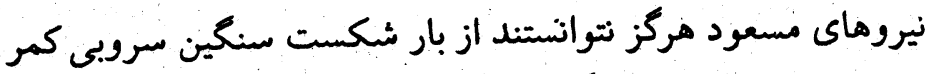

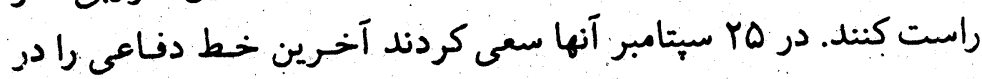

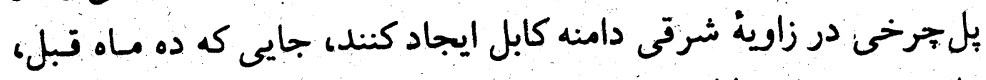
مانع بيشرويهاى طالبان شده بودند. الما حملات هوايى و هلى يكويترهاي

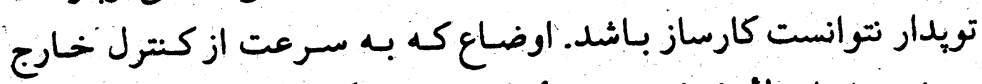

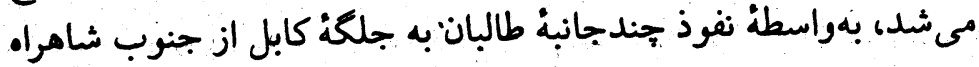

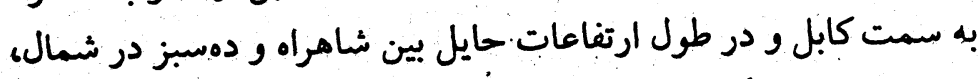
بيشتر به وخامت كراييد.

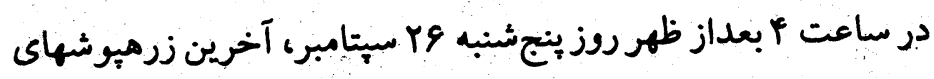

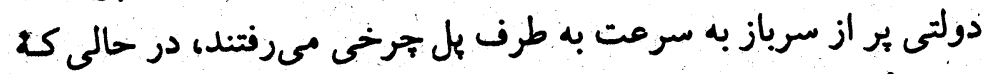

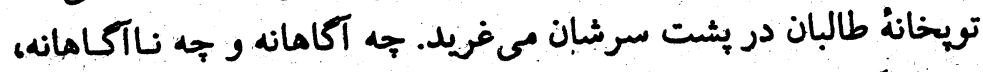

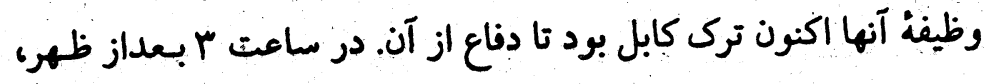

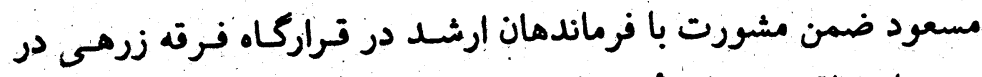

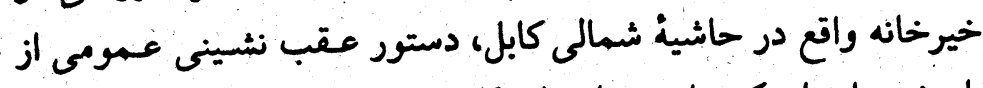

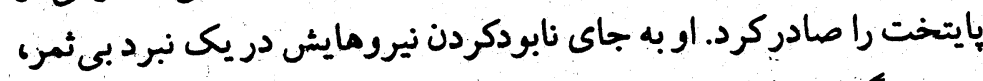

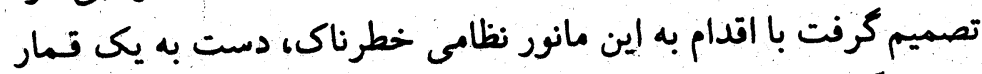

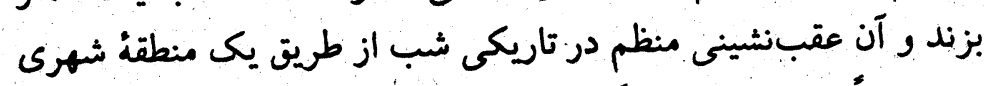

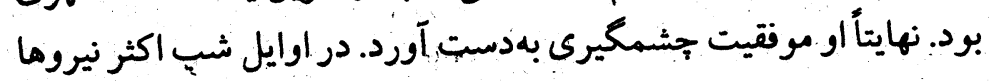

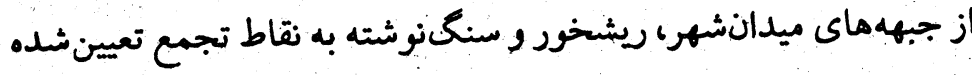

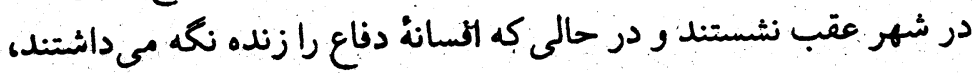
شروع كردند به حركت از جادههاى مختلف به سمت گذركاه خيرخانه در 


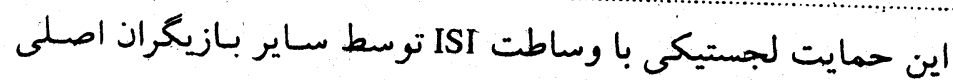

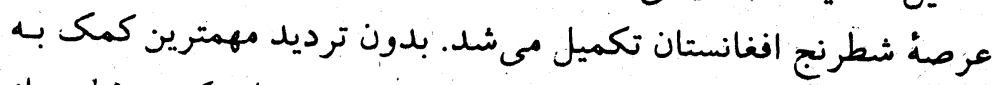

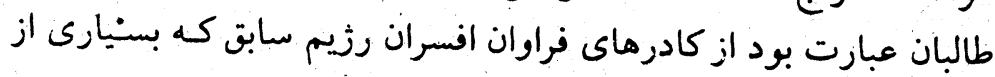

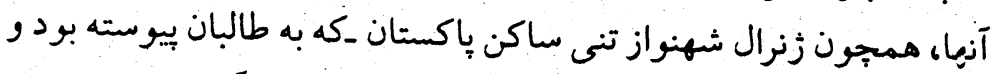

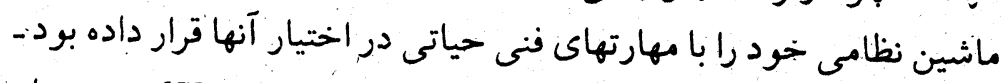

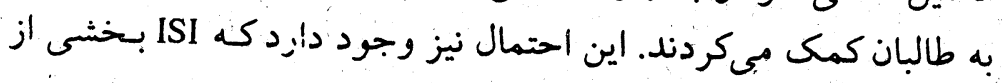

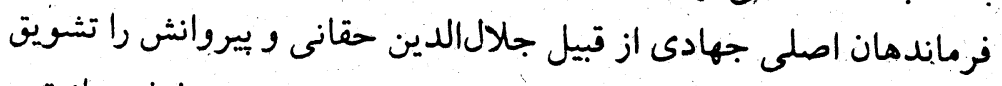

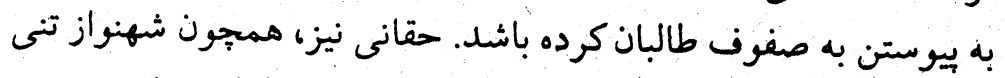

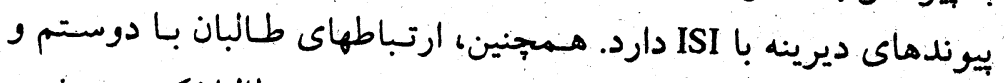

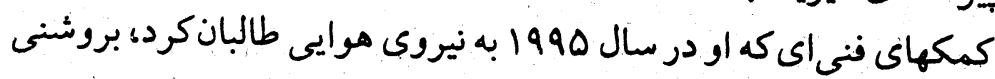

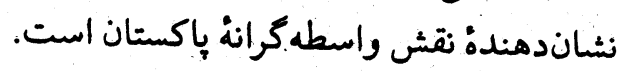

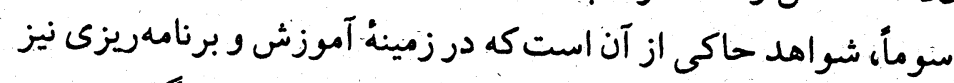

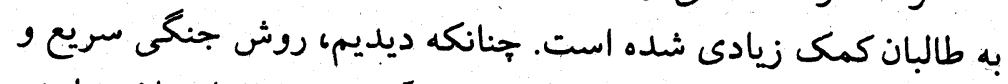

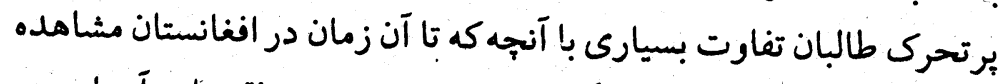

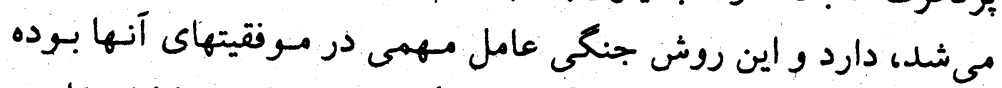

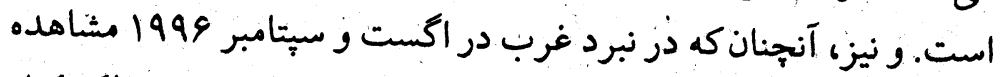

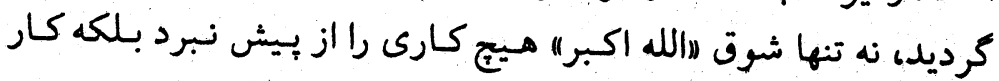

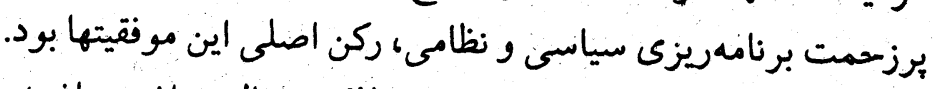

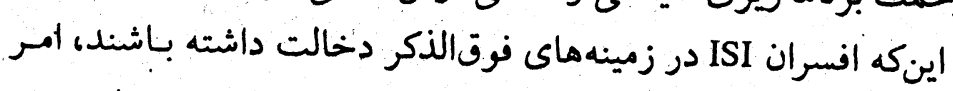

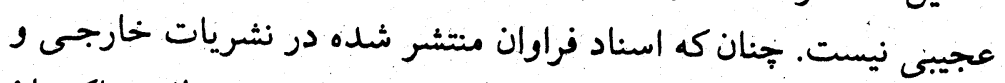

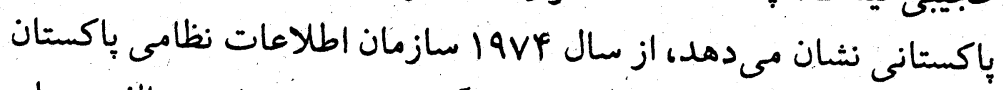

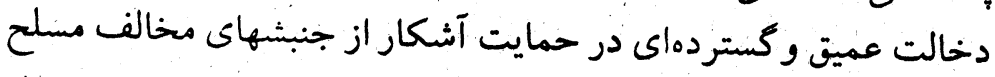

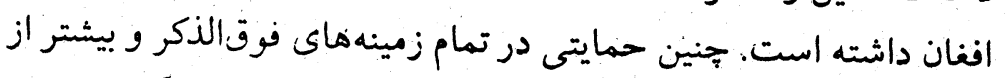

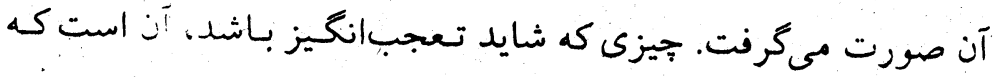

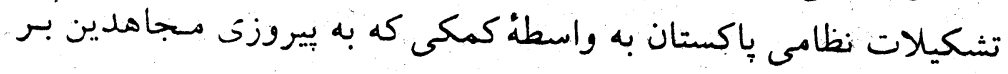

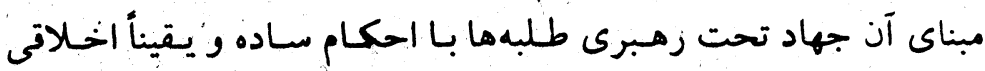

$$
\text { توإنست به سرعت رشد كند. }
$$

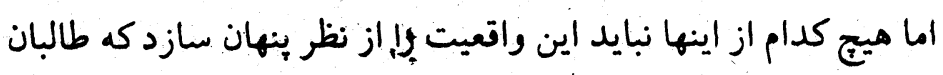

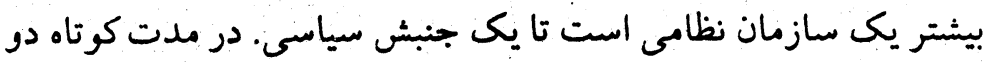

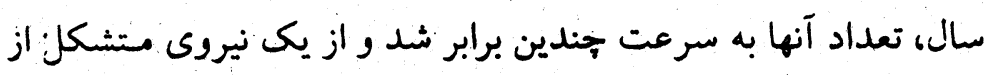

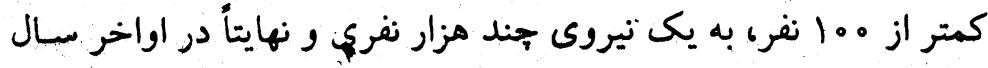

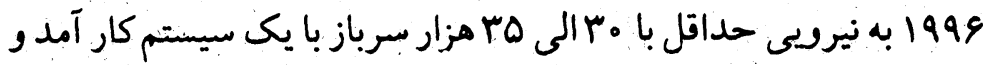

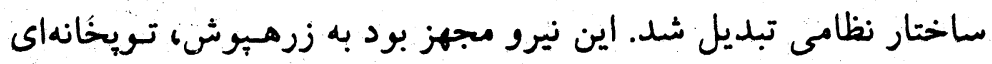

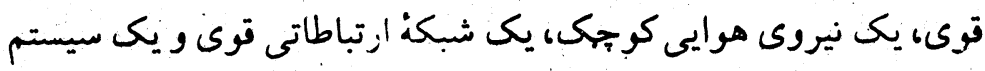

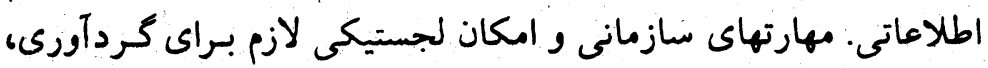

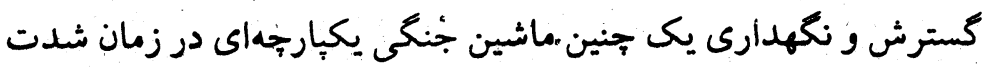

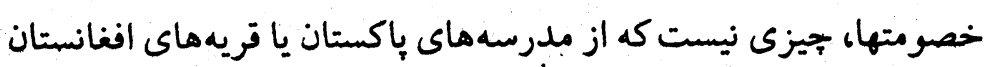

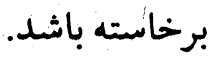

جمايت آشكار ياكستان، تأثيرى اساستى ذر كسترش طالبان و تبديل

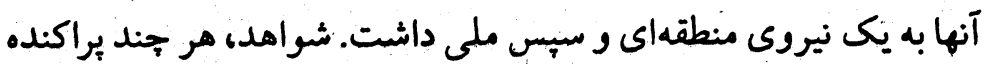

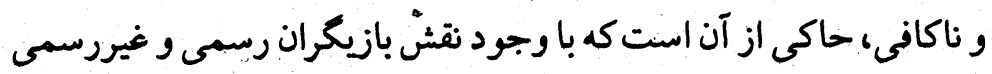

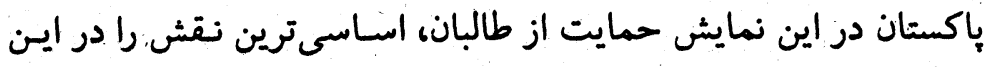

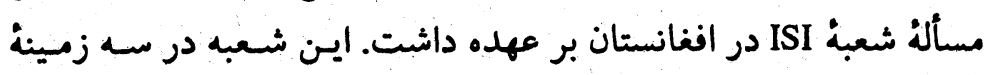
متمايز فعال بوده است.

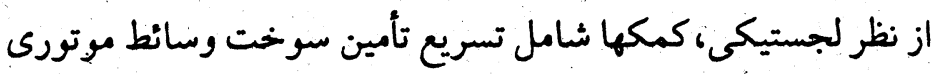

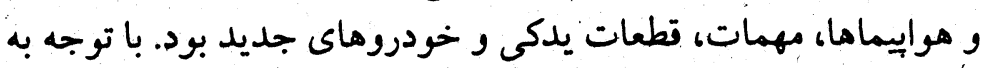

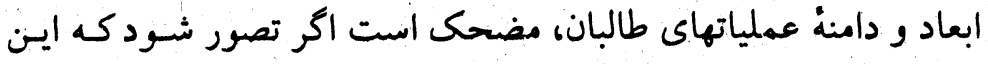

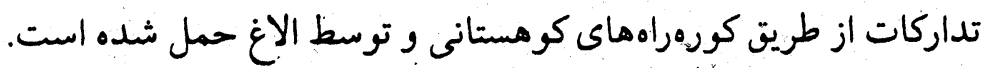

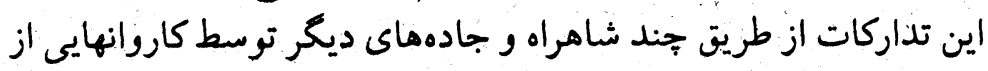

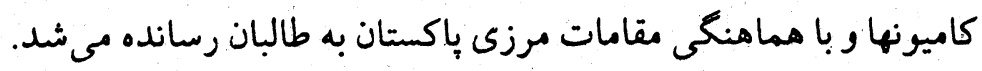




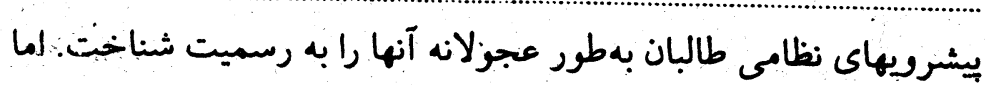

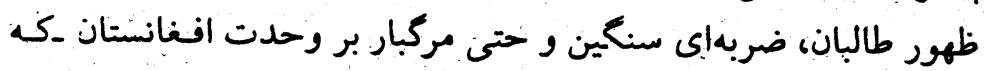

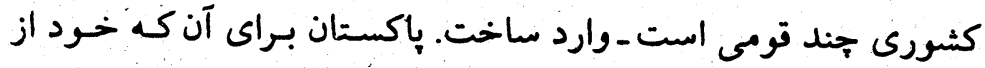

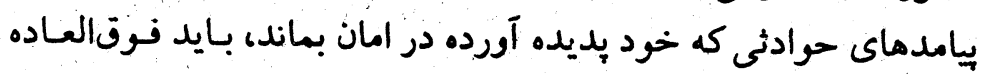
توجه داشته باشد.
رزيم دستنبشاندة مسكو كرده، اين حق را براى خود قائل است كه در

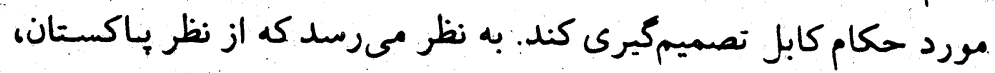

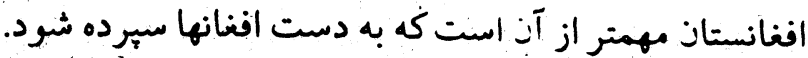

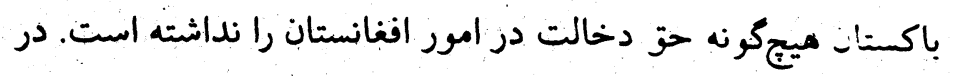

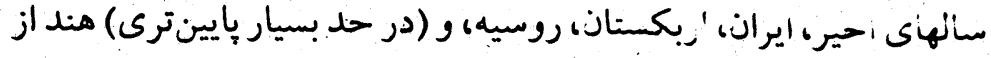

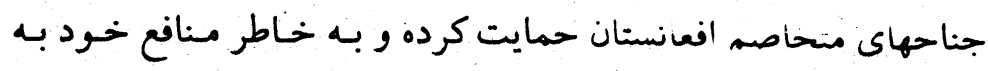

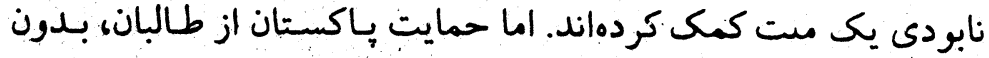

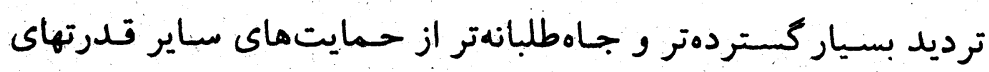

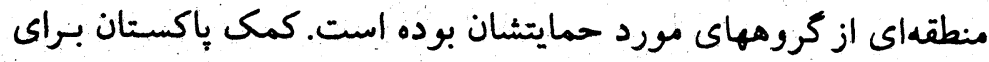

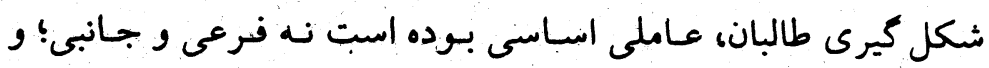

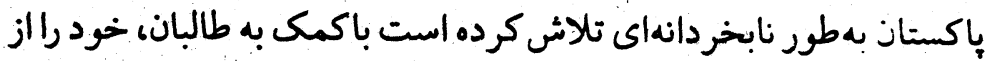
راه نظامى بر يك ملنت، تحميل كند.

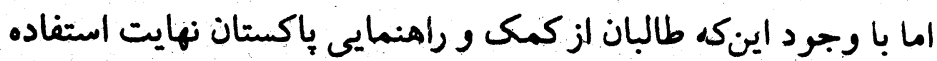

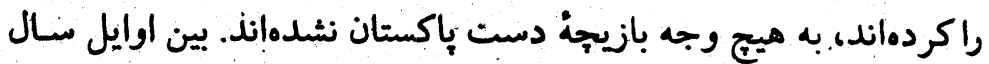

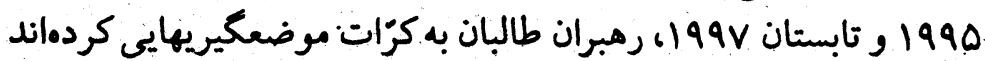

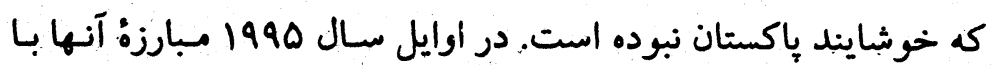

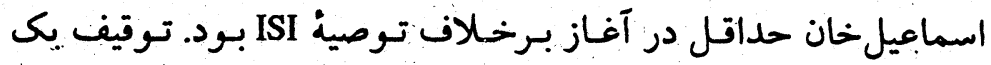

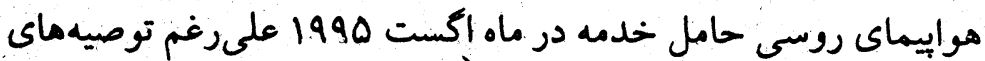

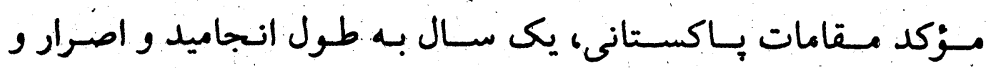
انعطافنايذيرى طالبان در مسائل اجتماعى و زنان، مخالف توصيهماي باى عاقلانهتر حاميان بإكستانى آنها بوده است استان.

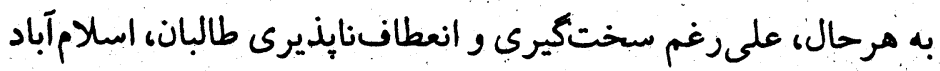
به جفظ يك نيروى حافظ سياست خودش دلخوش بوده است. باكستان

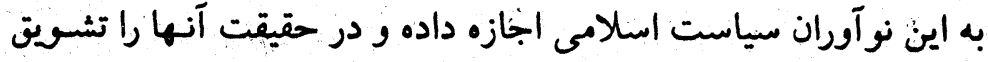

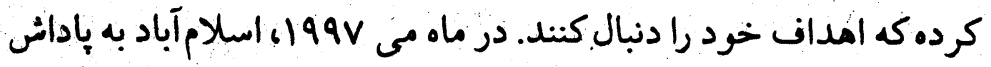




\section{صِاكستان و طالبان}

\section{هاحمد راشد}

طالبان درمت جند ماعت بس از آنكه شهر قندهار رادر \& نوامبر

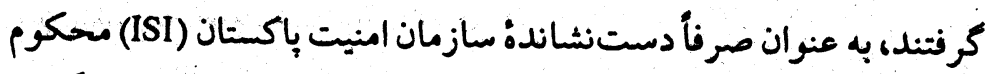

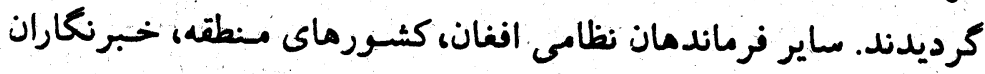

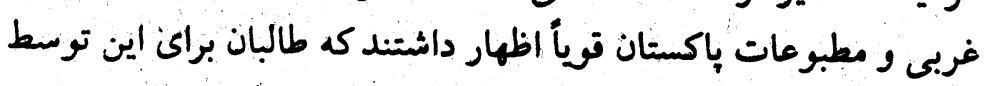

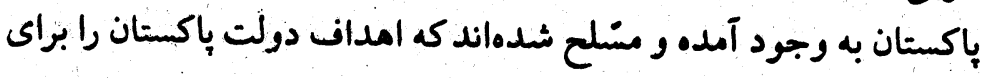

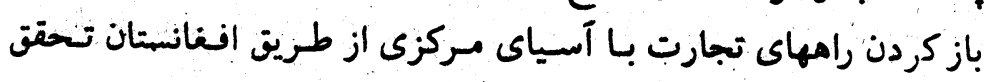

بخنسند.

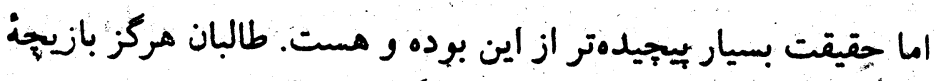

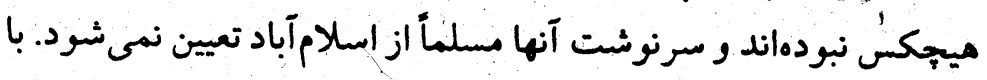

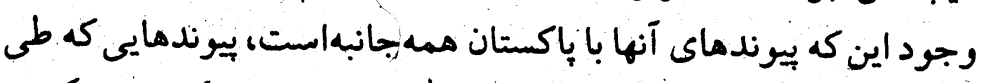

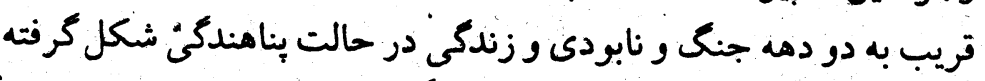

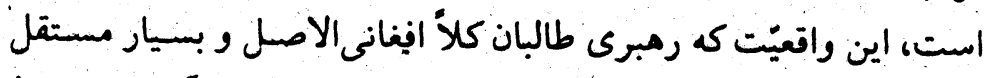

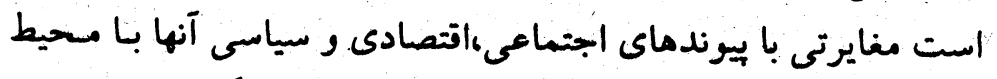

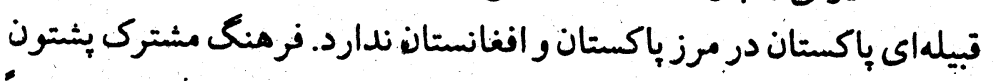
در اين منطقة مرزى مركز آنجنان كه در بديدة طالبان انعكأس يافته قبلاً منعكس نشده بود.

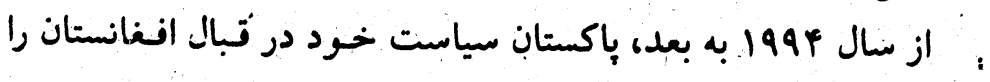




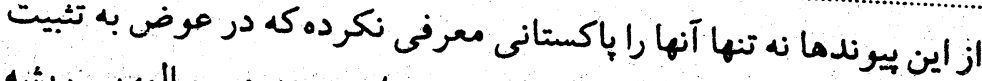

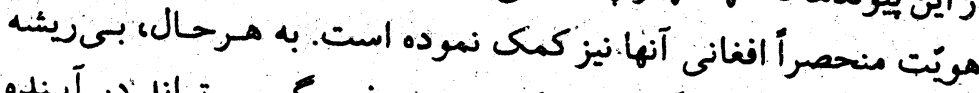

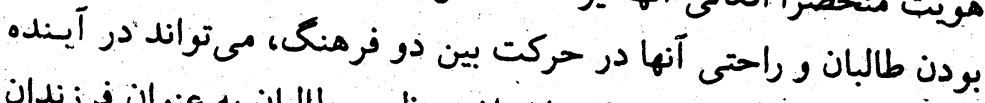

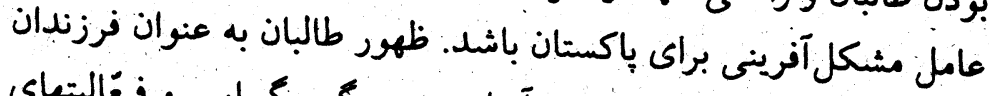

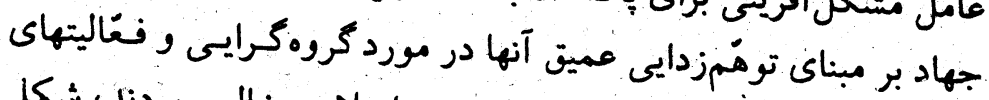

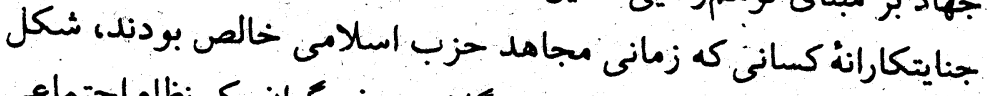

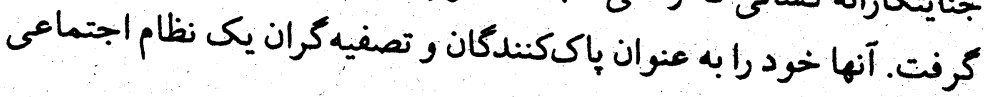
روبه كمرامى مى ديدند. بيشينة تاريخى طالبان تيز به آنها اجازه مي داد كه ارتباط بسيار نزديكى

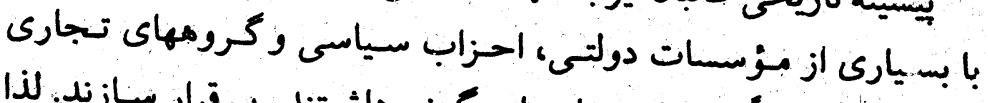

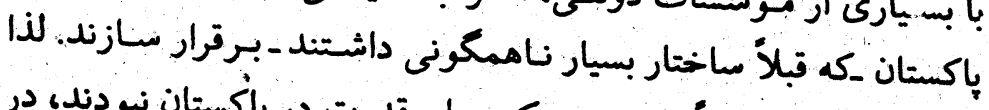

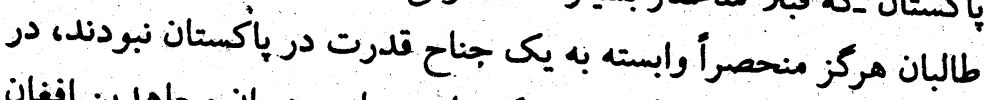

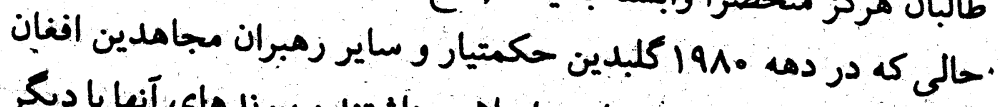

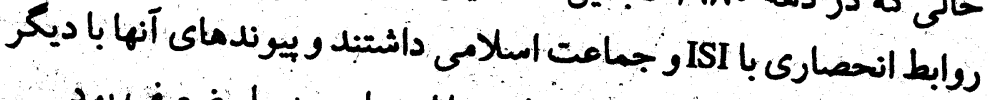

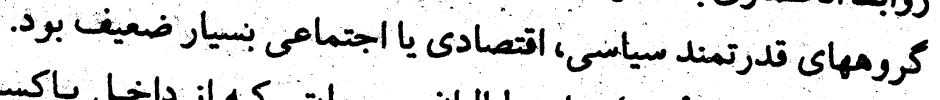

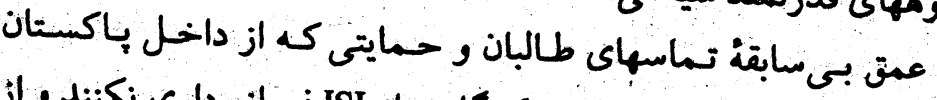

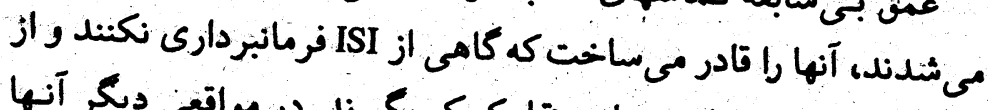

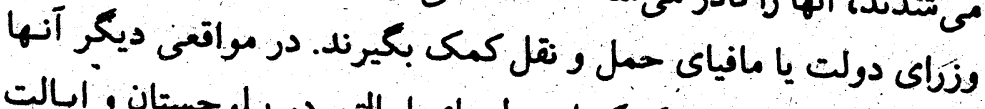

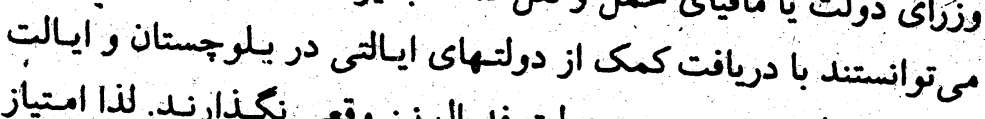

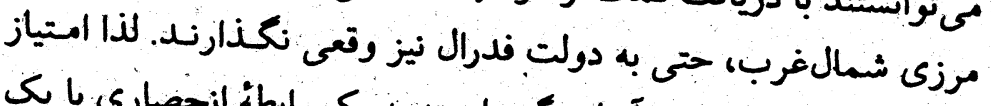

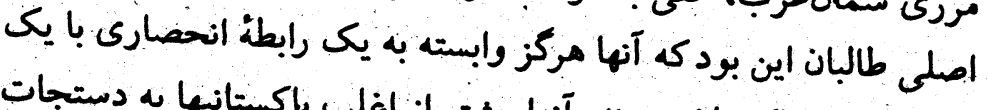

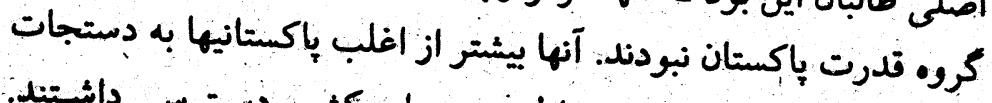

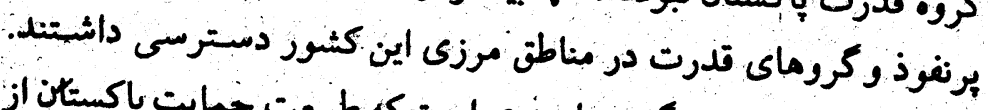

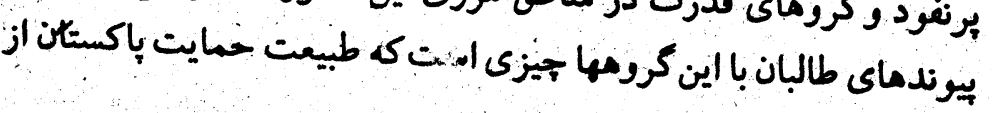
آنها راروشن مئمسازد.
افغانستان، طالبان، و سياستهاى جهانى

011.

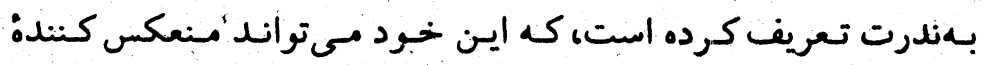

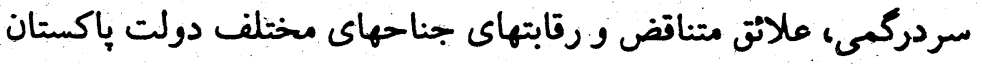

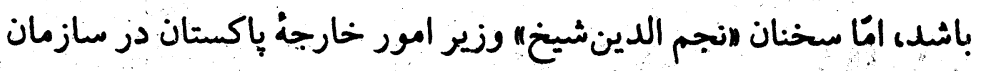

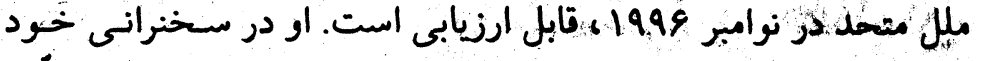

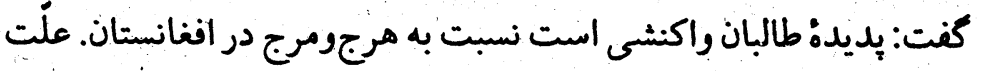

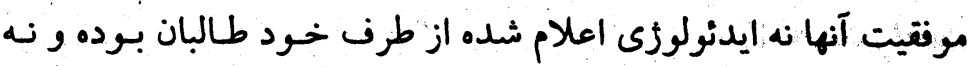

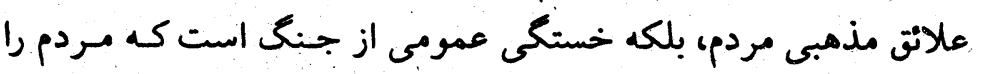

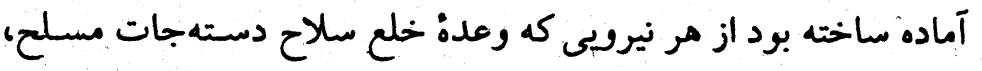

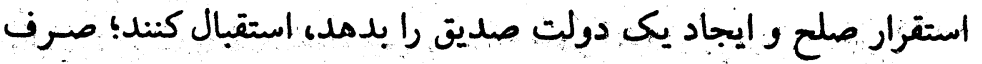

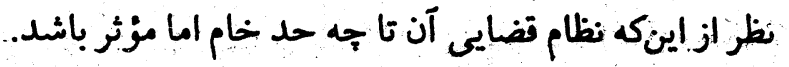

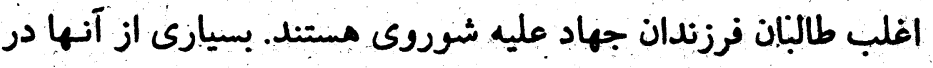

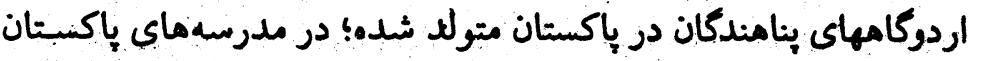

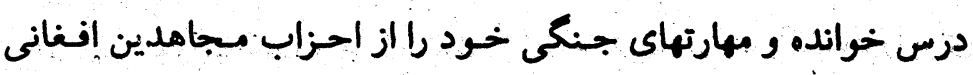

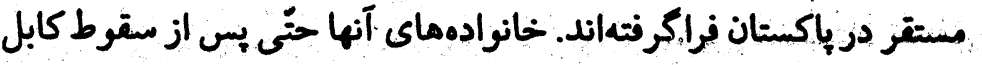

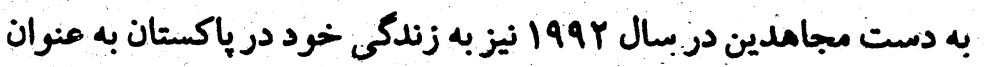

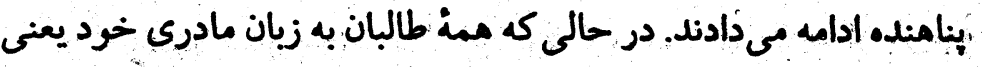

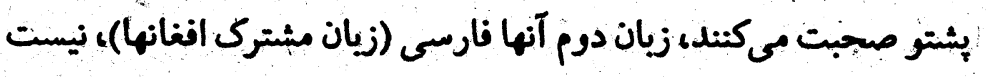
وزيان اردوى باكسئان استب.

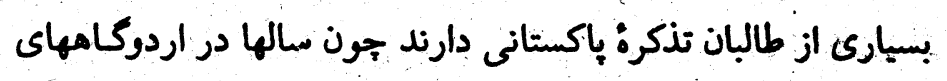

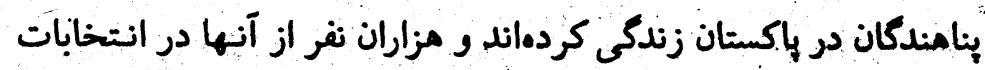

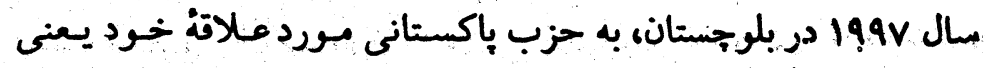

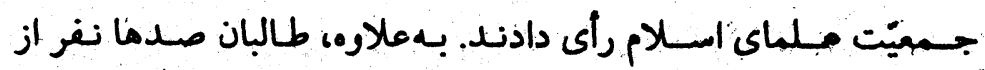

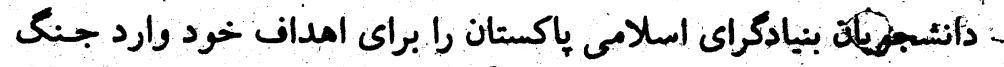

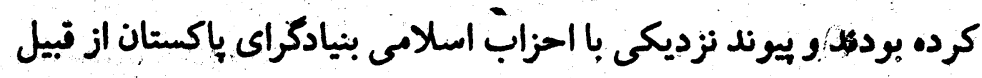

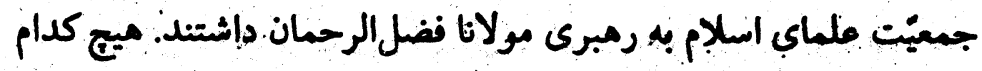




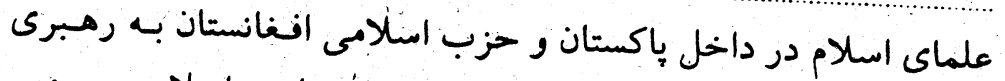

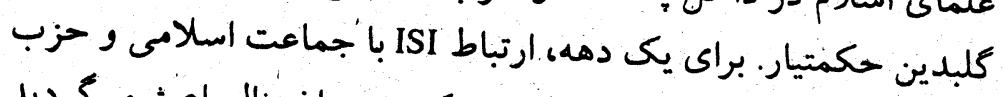
اسلامى، ابزار اصلى سياست دولت بود كه به عنوان مثال باعث مئى برديد

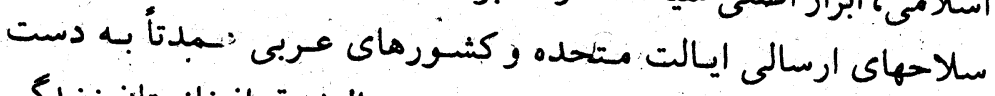
جنگجويان بشتون غلجايى كه در مركز و شمالشرق افغانستان زنداكى إنى

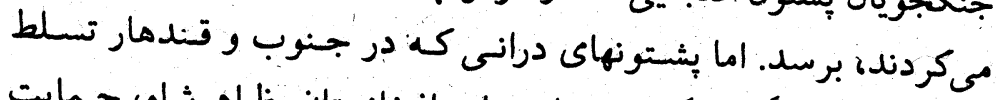

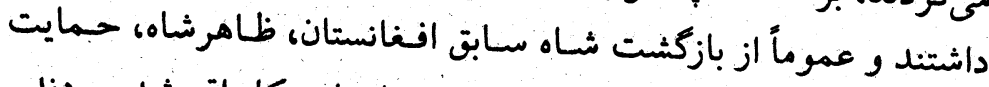

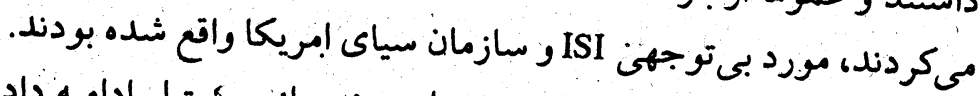

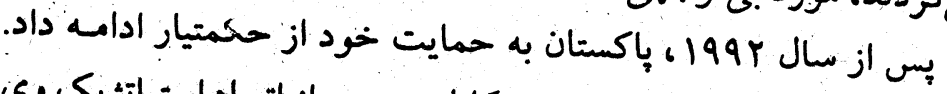
نخست از مخالفت حكمتيار با رثيم كابل و سبي از اتحاد استراتئيك وى دئ با زنرال دوستم در سال به9 199 حمايت كرد كه به حماتلات خونين دوماله

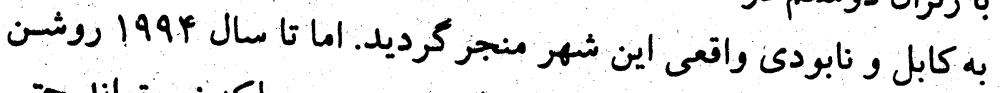

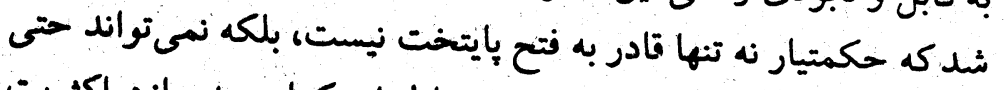

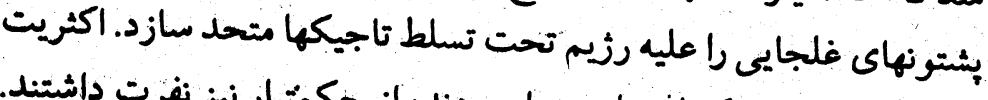

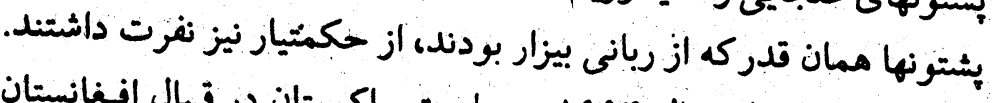

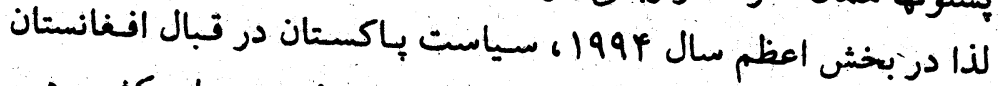

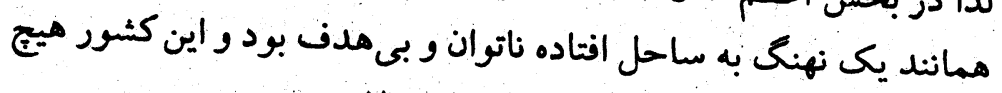
نماينده قدرتمندى نيز در داخل افغانستان نداشت ئه

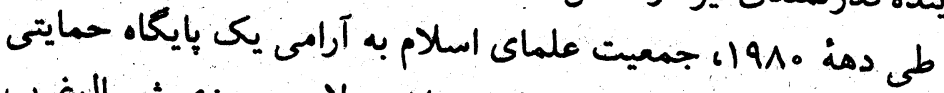

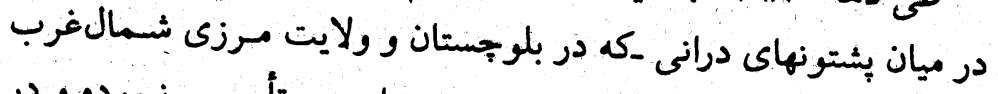

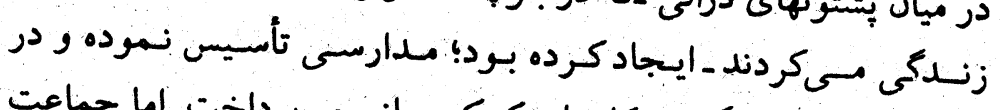

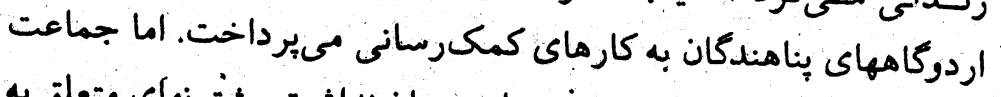

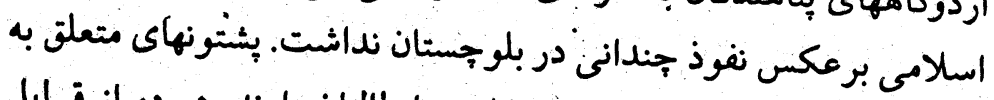
جمعيت علماى اسلام مشتركات زيادى با طالبان دارند. هر دو از قبايل

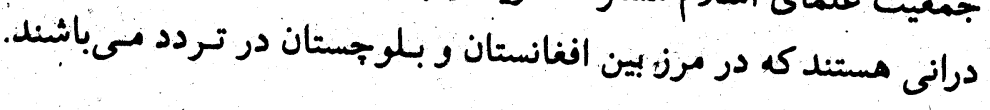

\section{مالبان و جمعيت علماى اسلام}

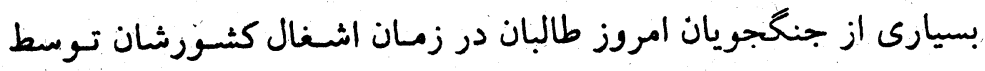

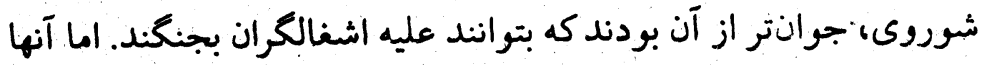

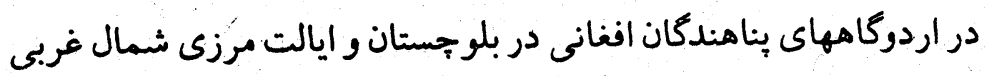
رشد يافتند. تعدادى از رهبران طالبان از قبيل محمدعمر، در مـراحل

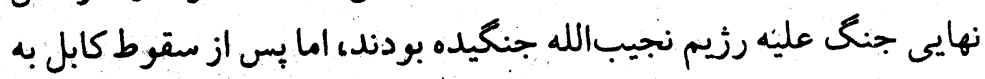

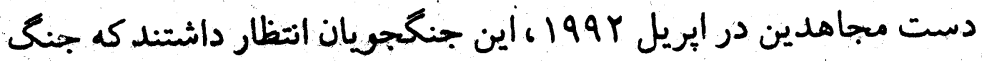

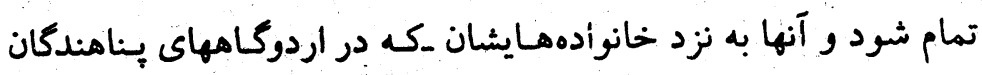

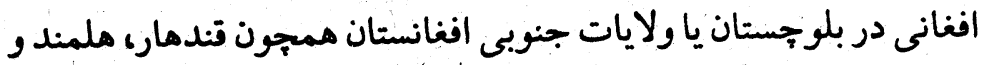
ارزخان زندكى مىكر دند - باز كردند.

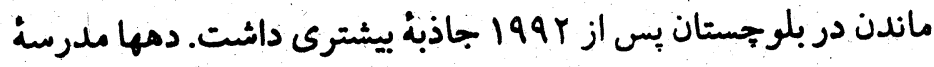

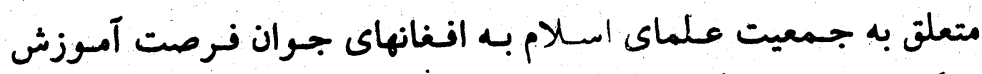

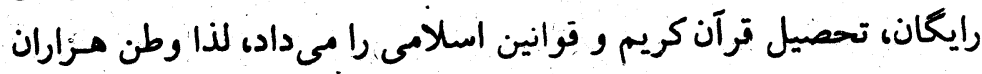

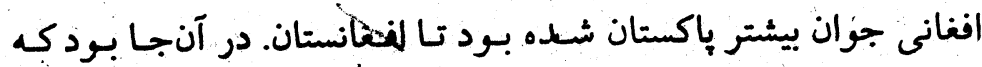

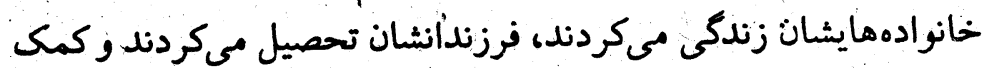

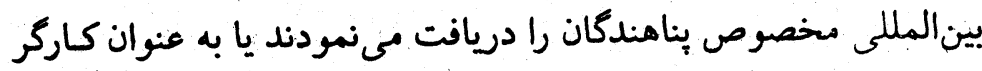

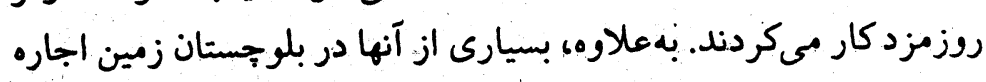
كرده بودند تا براى رممهمايثشان علوفه كشنت كنند.

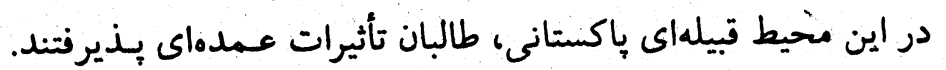

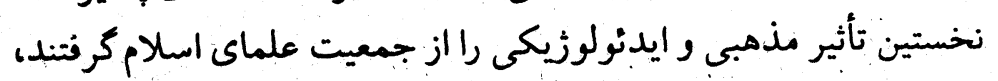

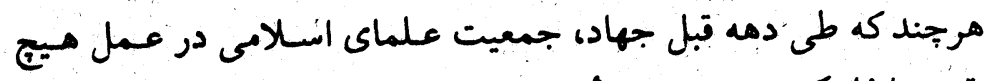

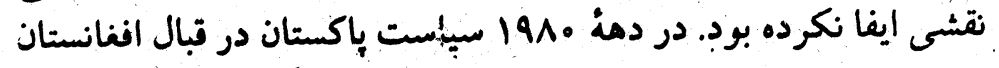
منحصر بود به كمك كردن به جماعت اسلامى، رقيب اصلى جسمعيت 
حزب مردم باكستان به رهبرى بى نظير بوتو ـكه به بـيروزى رمسيدهبود -

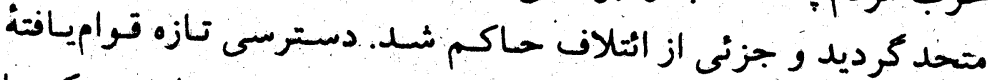

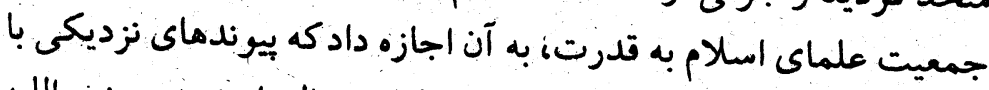
ارتش، SI' و وزارت خارجه تحت مسؤوليت زنرال بازنشسته، النشرالله

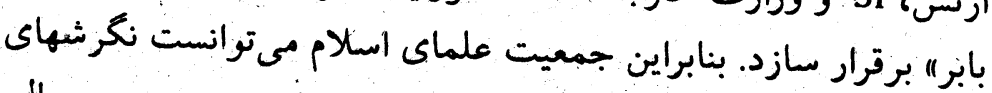

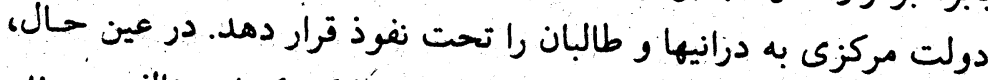

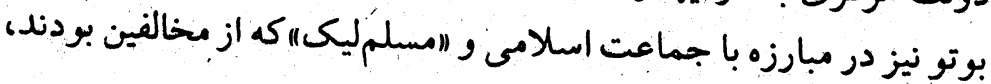
يك متحد اسلامى بيداكردهبود.

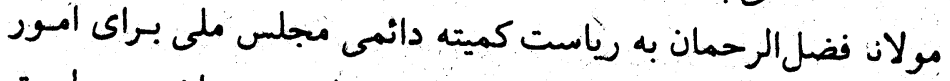

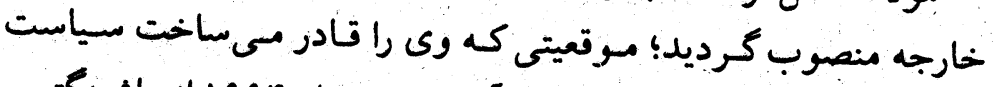

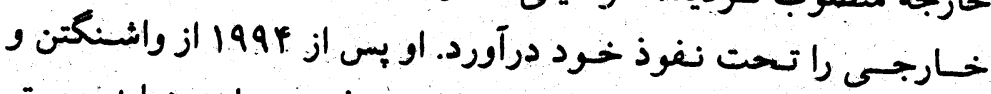

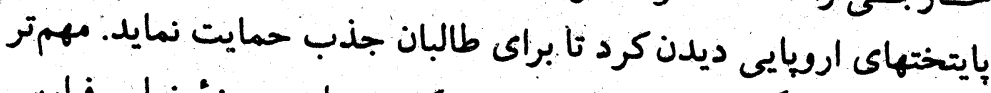

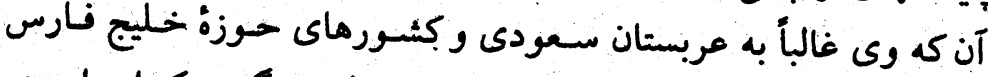
مىرفت تا از آنها براى طالبان كمى مالى ورئى و نظامى بكيرد، كه اين امر در

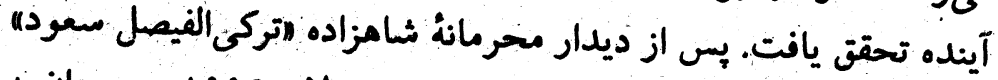

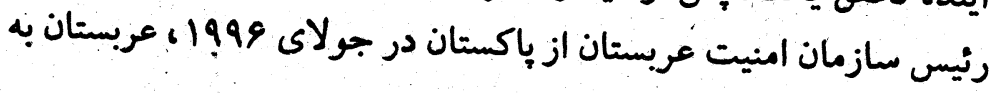

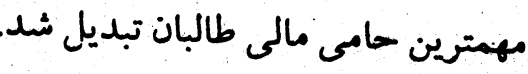

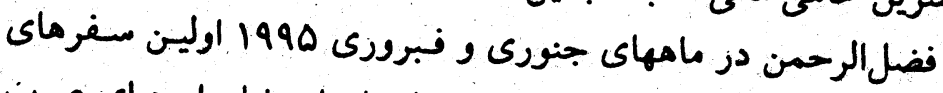

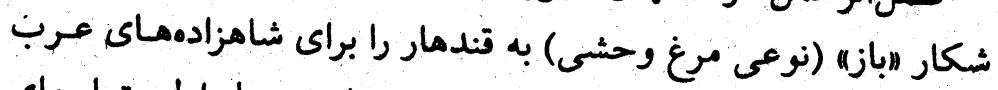

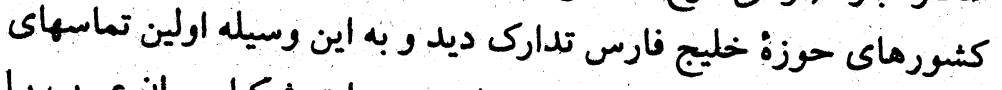

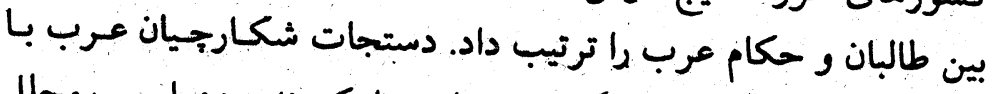

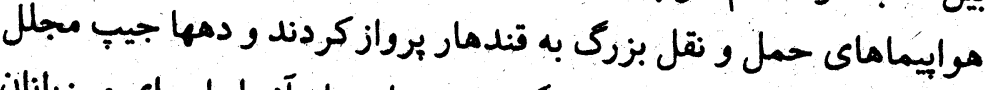

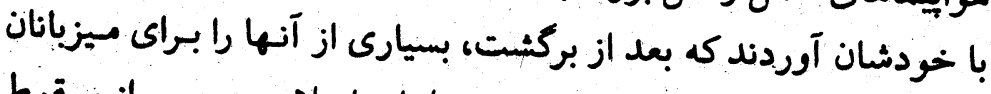

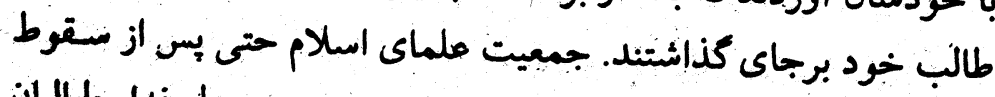
دولت بؤتو در نوامبر 1999 نسيز بـه عـنوان صسريحتوين طبرفدار طالبان

فعالين جمعيت علماى اسلام، ديوبندىها. هستند كه بيسروان, يمي كروه

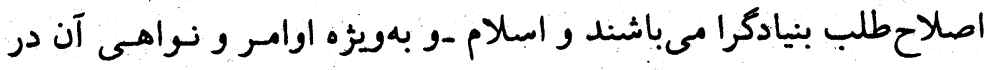

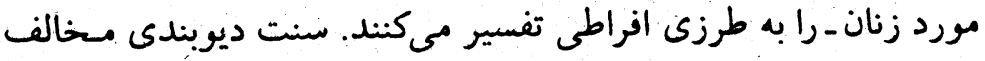

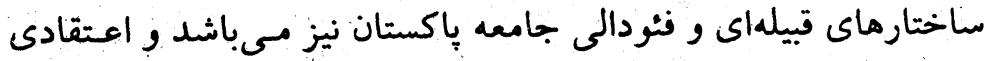

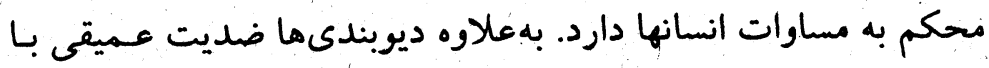

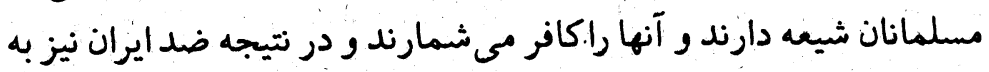

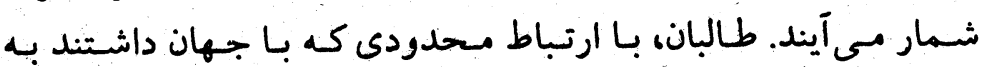

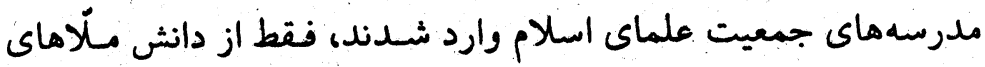

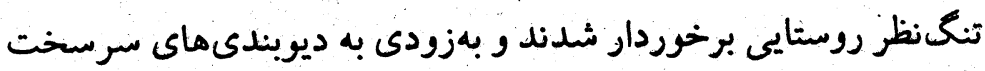
و متعصب مبدل كُشتند. لذا تفسير طالبان از اسلام با حال و هواى بشتونوالى ـكه رمز قبيلهاى

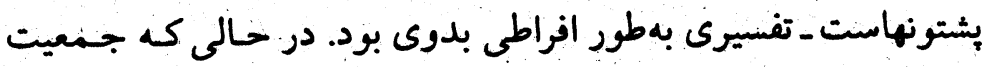

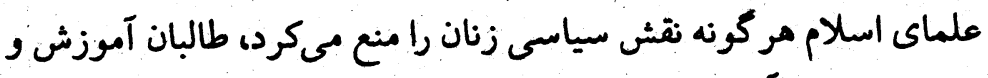

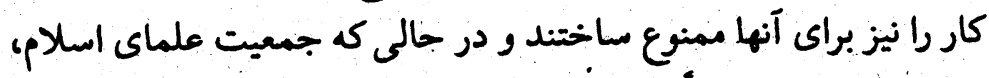

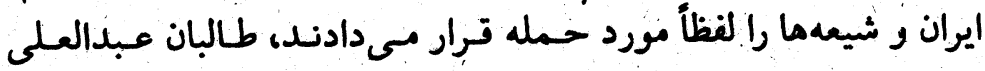

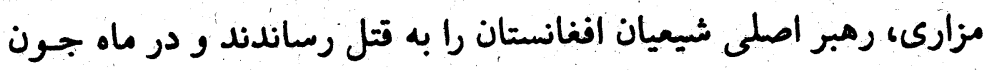

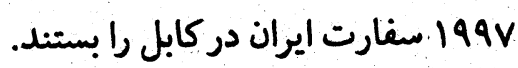
درباواخر دمه •191ه، نفوذ جمعيت علماى اسلام بر بشتونهاى درانى

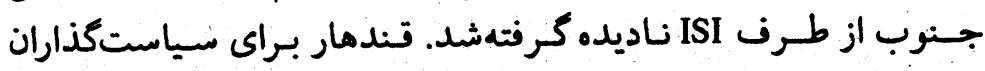
ياكستانى به صورت يك مرداب باقى ماند و اين امر باعث شد كه دهها

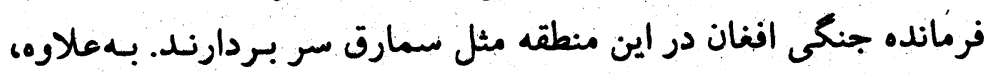

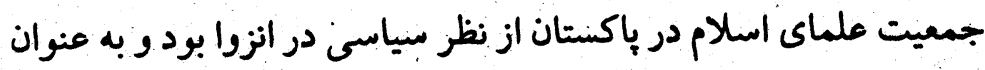

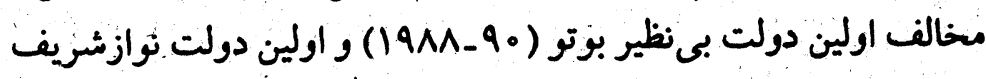

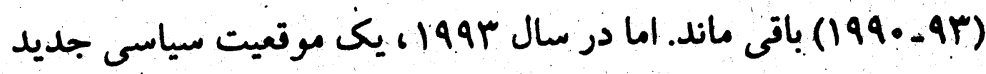

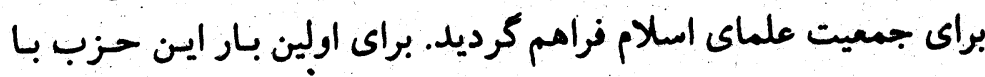




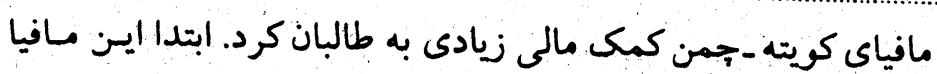

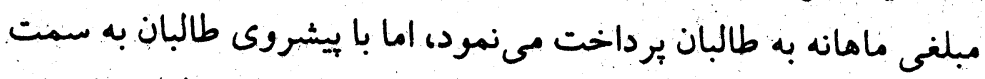

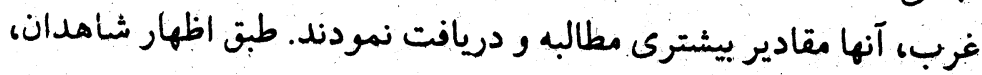

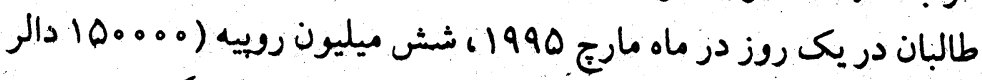

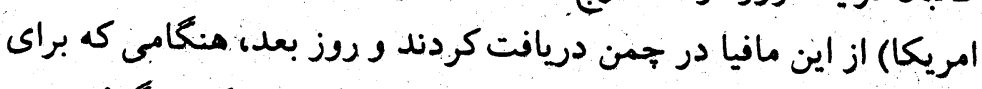

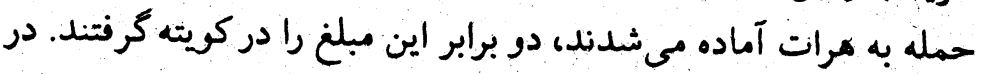

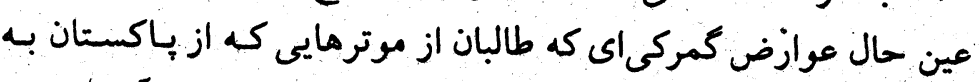

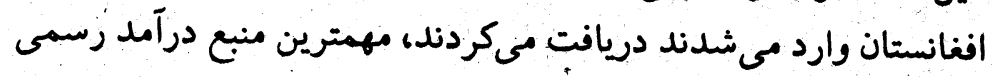

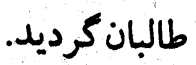

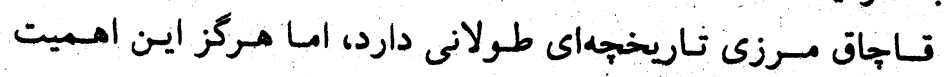

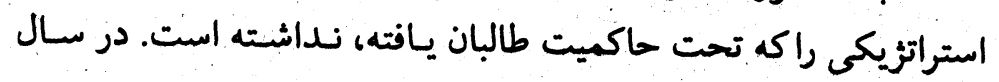

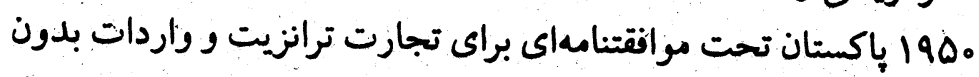

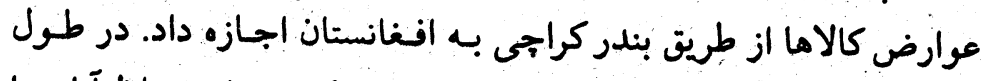

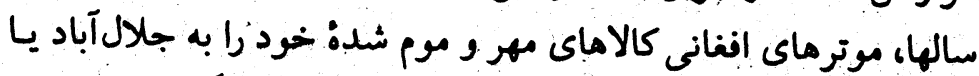

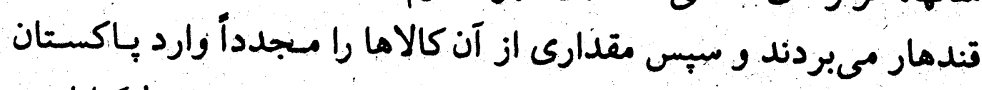

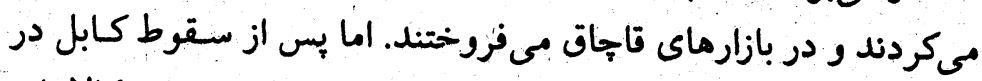

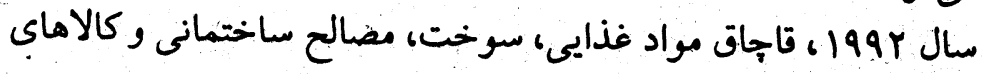

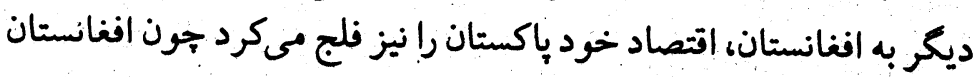

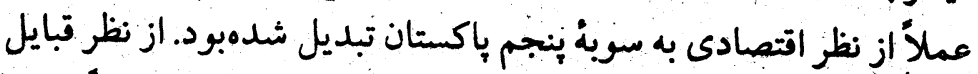

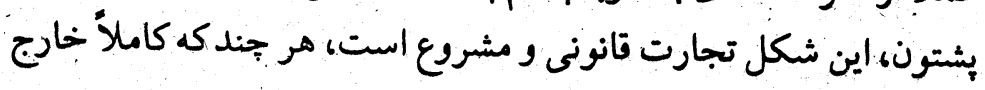
از از حوزه قانونى دولتى باشند.

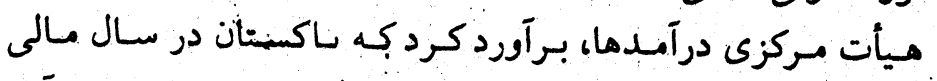

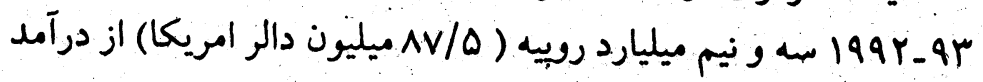

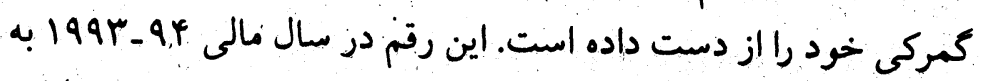

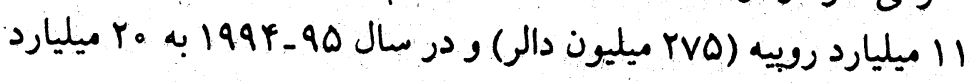

افغانستان، طالبان، و سياستهاى جهانى

باقى ماند و نخستوزير، نوازشريف راتحت فشار قرار داد كه طالبان رابه

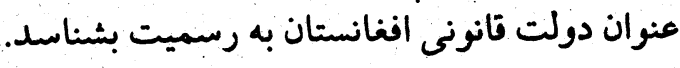

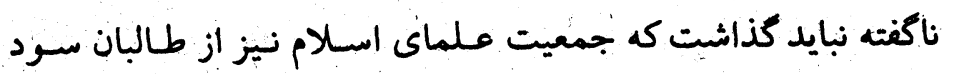

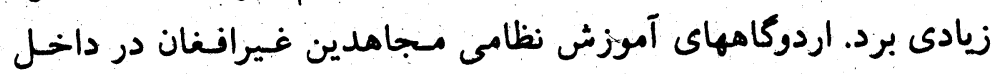

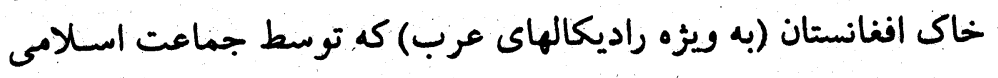

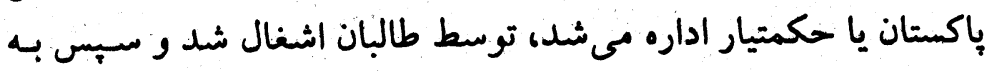

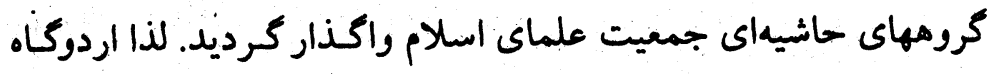

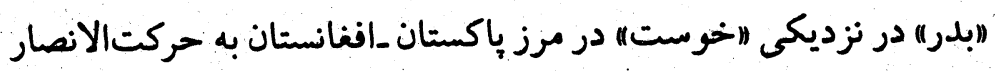

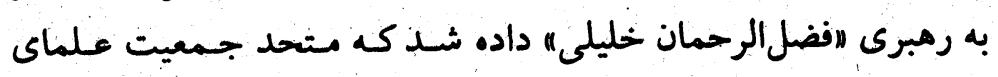

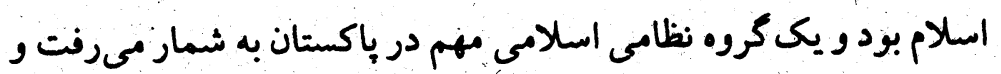

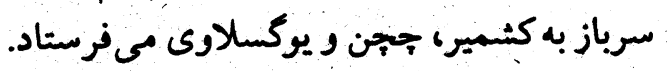

\section{• طالبان و مافياى حمل و نقل ·}

يك نفوذ عمدة ديكز باكستان بر طالبان، عبارت بود از مافياى فاجاق حمل

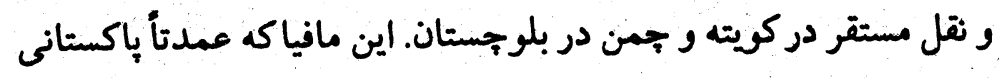

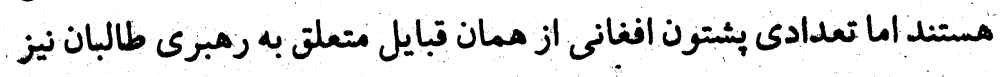

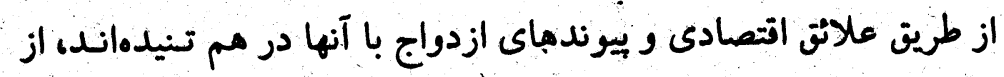

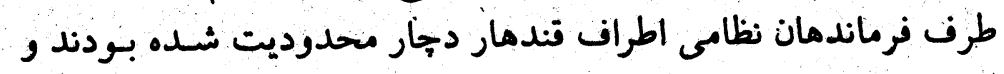

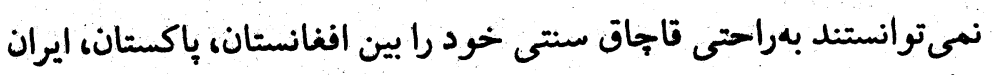

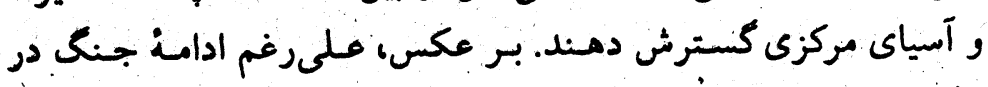

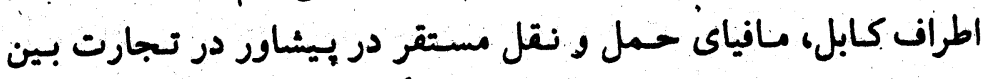

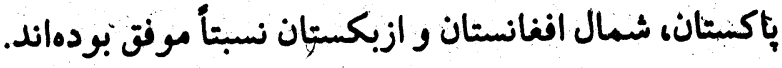




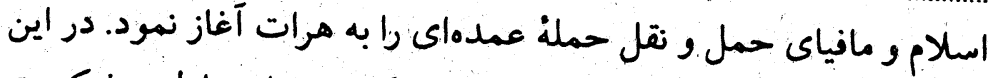

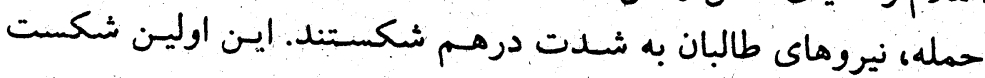

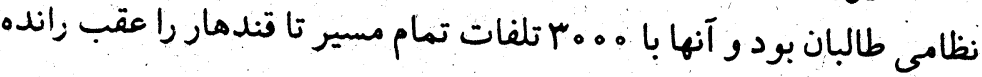
شدند.

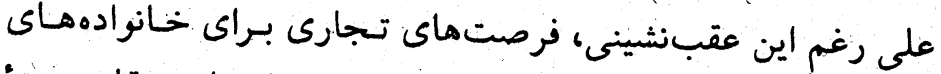

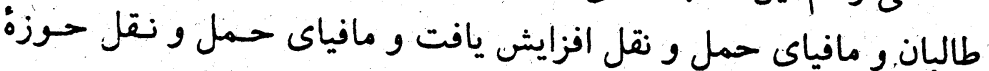

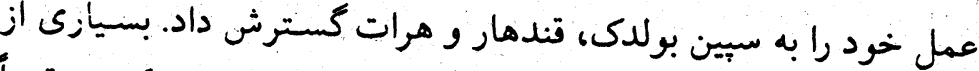

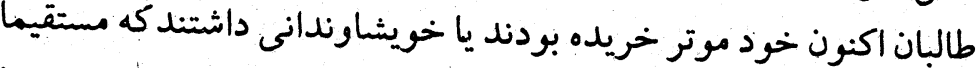

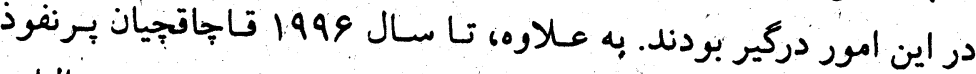

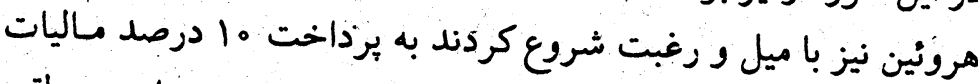

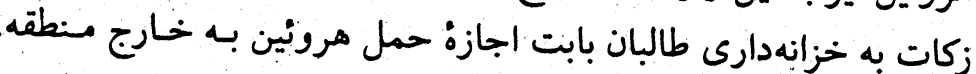

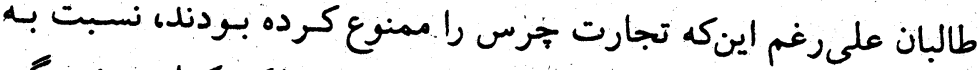

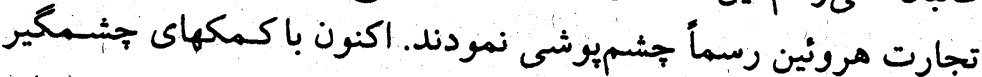

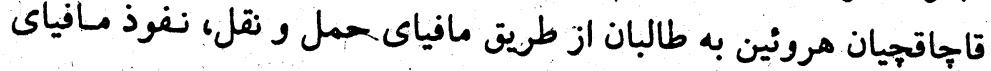
حمل و نقل مستقر در باكستان كسترشّ عظيمى يافته بود.

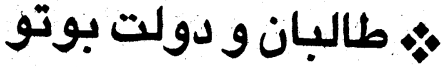

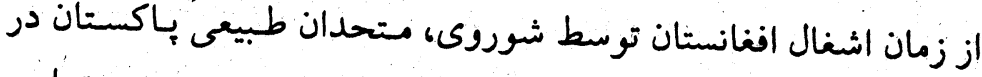

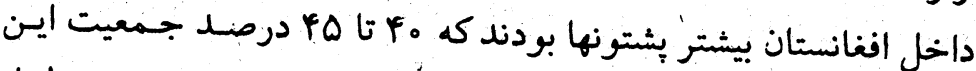

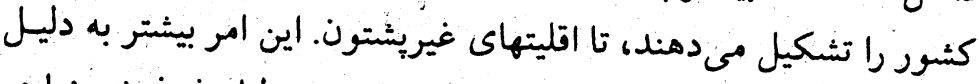

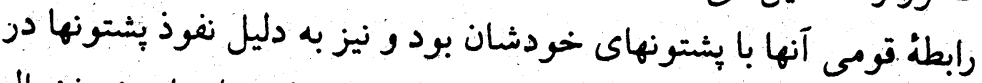

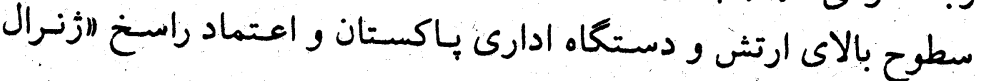

روييه (0.0 ميليون دالر) رميد كه يك افزايش اعجابانغيز است: اما به نظر مىرسد كه اين ارقام فقط نوك كوه يخ است الته

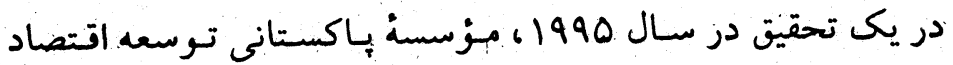

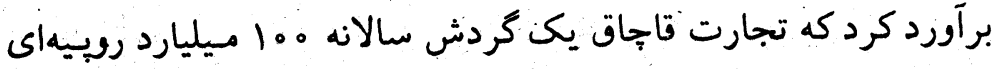

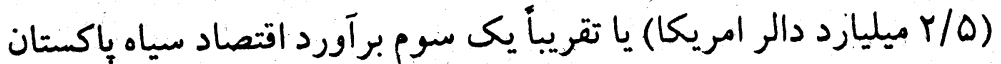

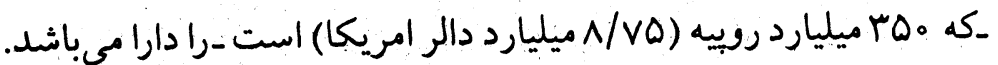

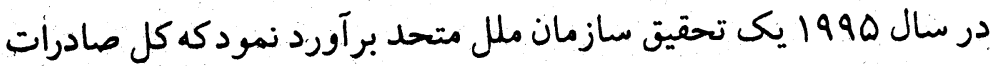

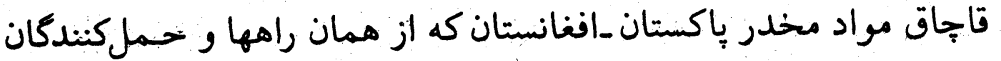

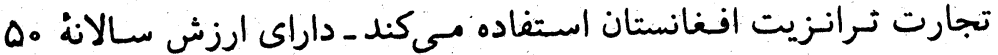

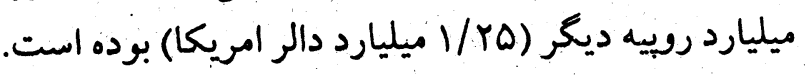

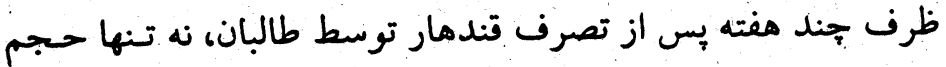

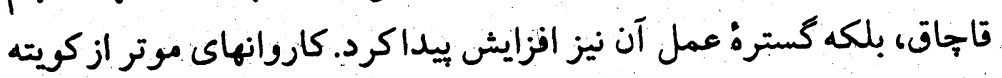

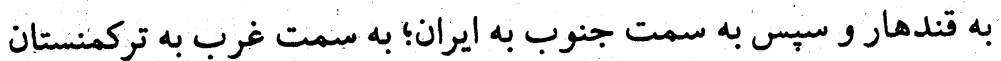

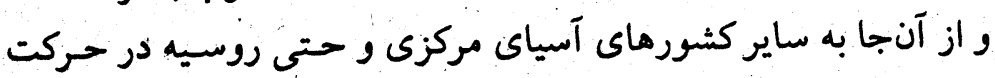

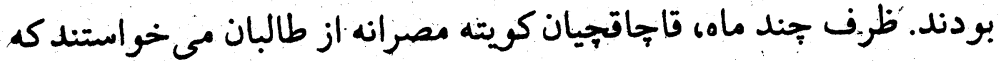

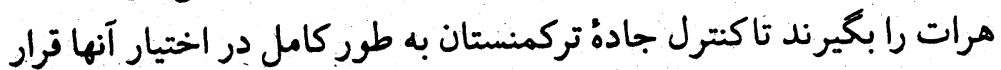

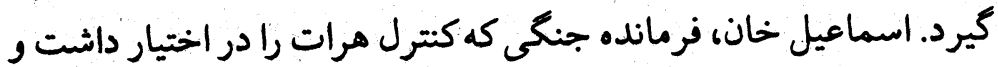

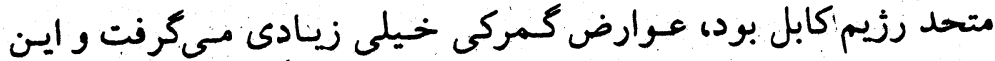

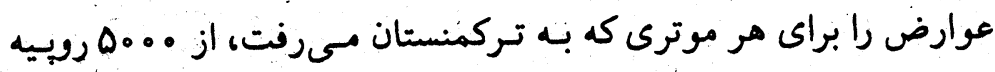

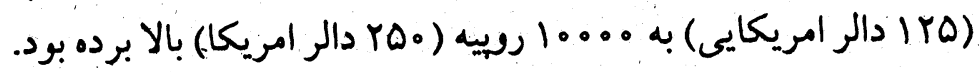

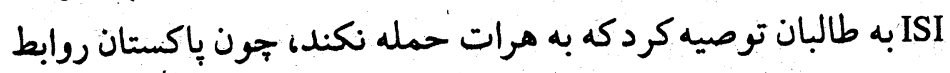
نزديكى با اسماعيل خان برقرار كرده است و اميد دارد كه او عليه دولت بردات

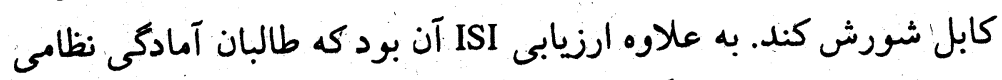

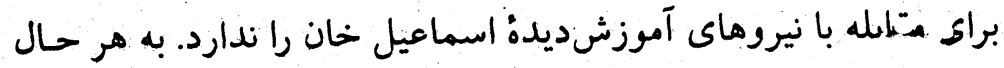

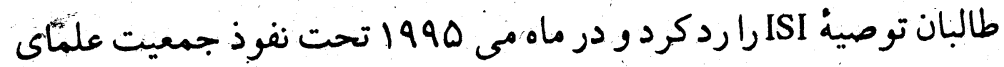




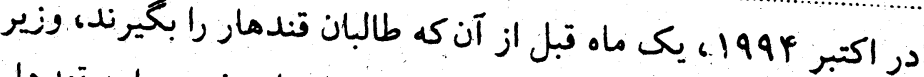

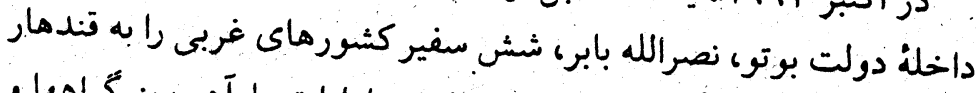

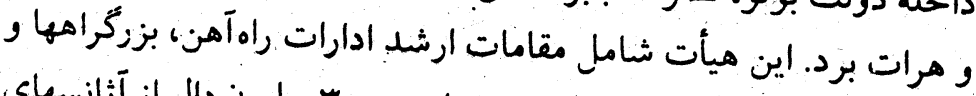

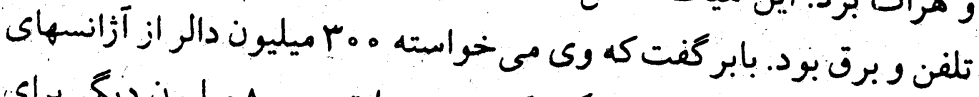

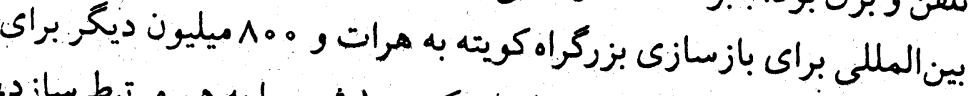

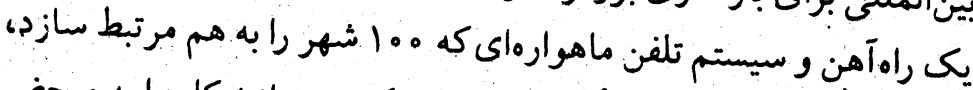

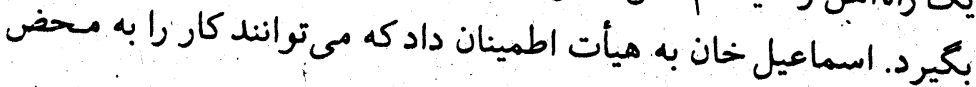
برقرارى صلح و امنيت شروع كنيد.

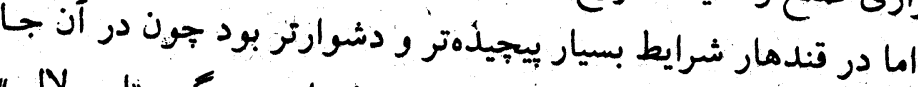

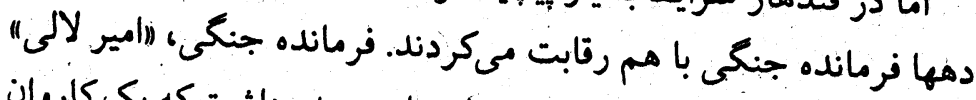

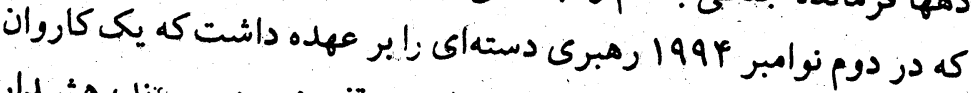

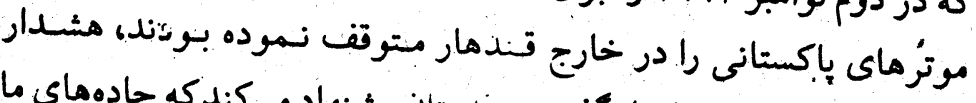

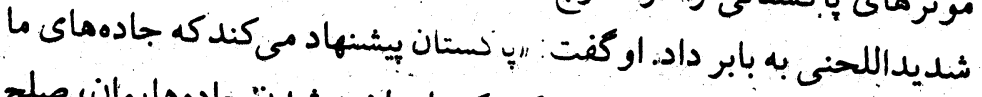

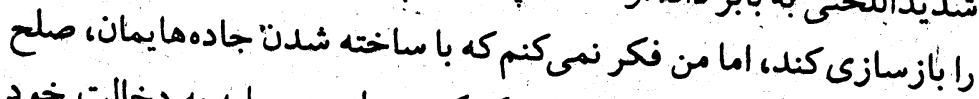

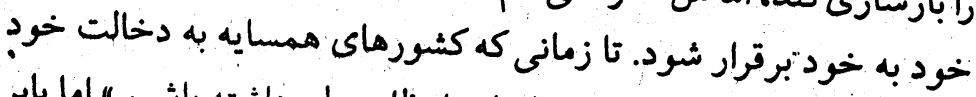

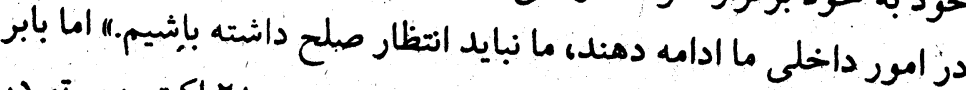

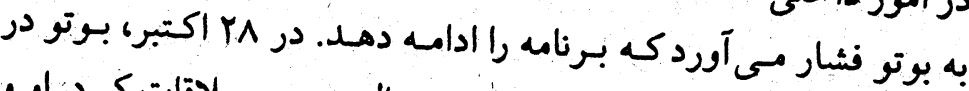

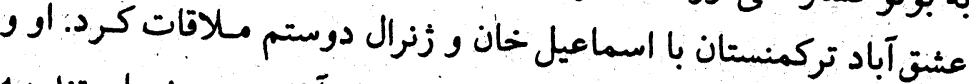

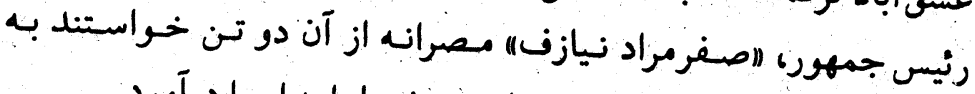

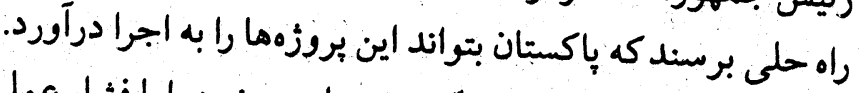

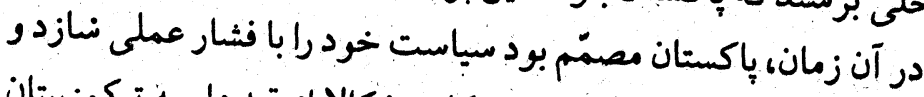

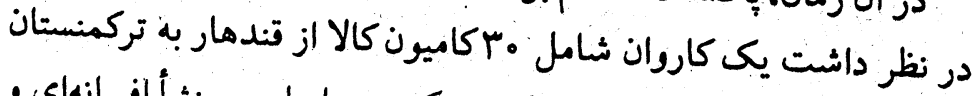

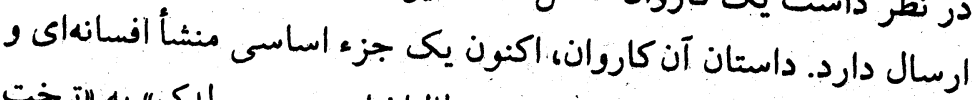

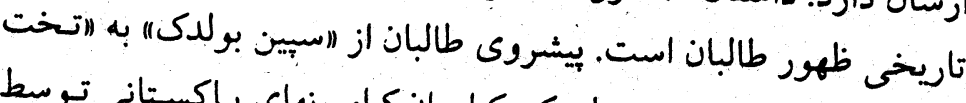

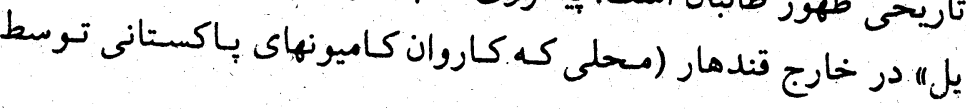

افغانستان، طالبان، و وسياستهاي جهاني

olr.

ضياةالهق" به إين كه جـماعت اسـلامى تقاضا براى يك إيشتونستان

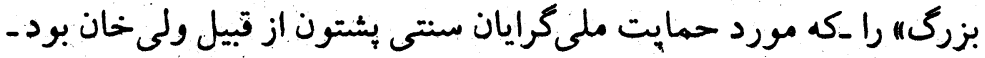

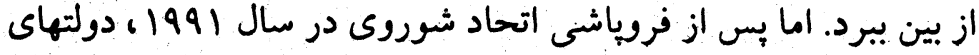

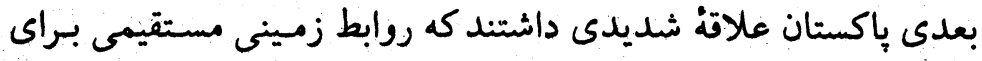

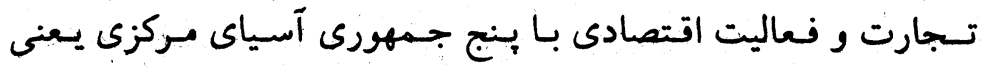

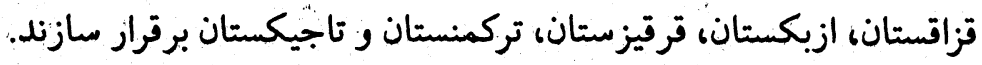

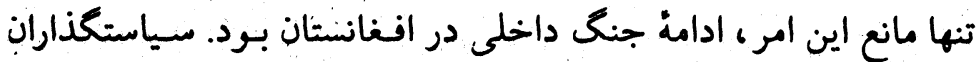

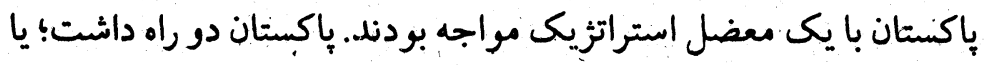

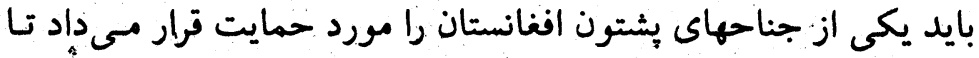

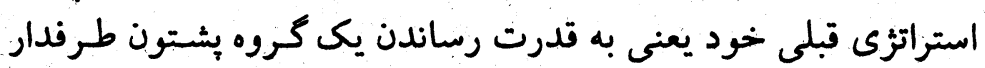

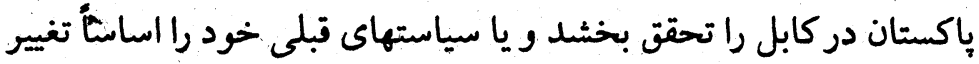

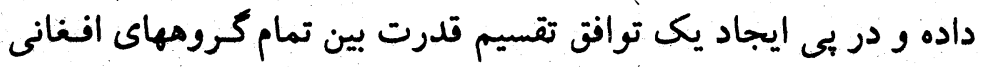

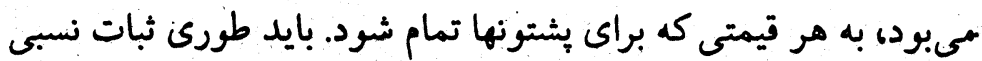

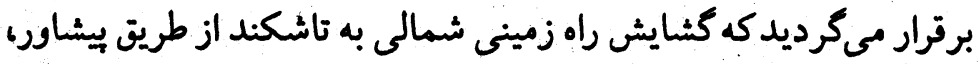
كابل و مزارشريف امكانيذير كردد.

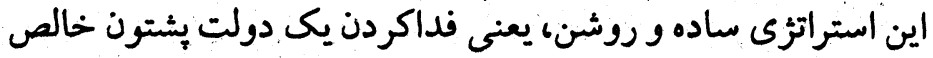

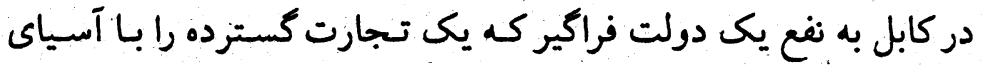

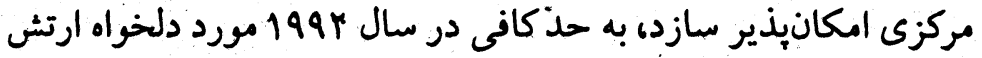

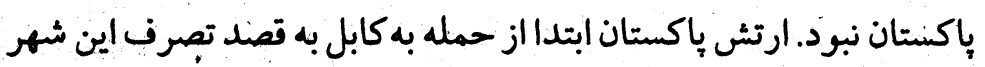

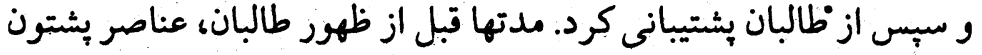

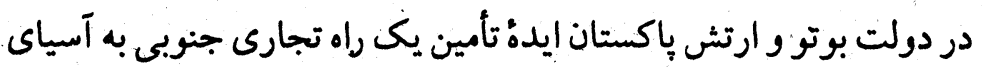

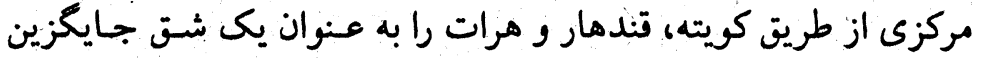

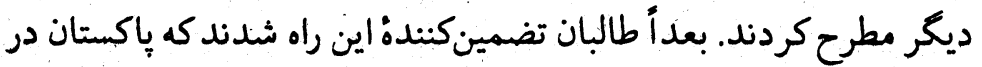

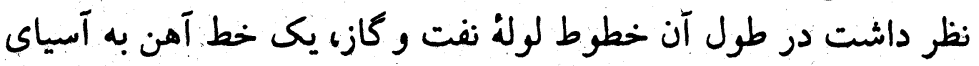
مركزى احداث كند. 


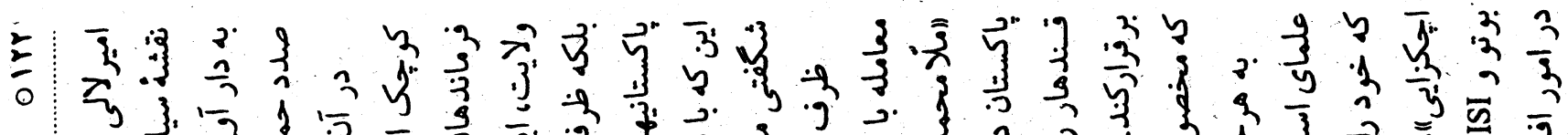
4.

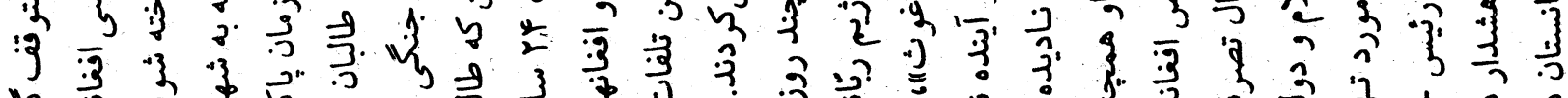

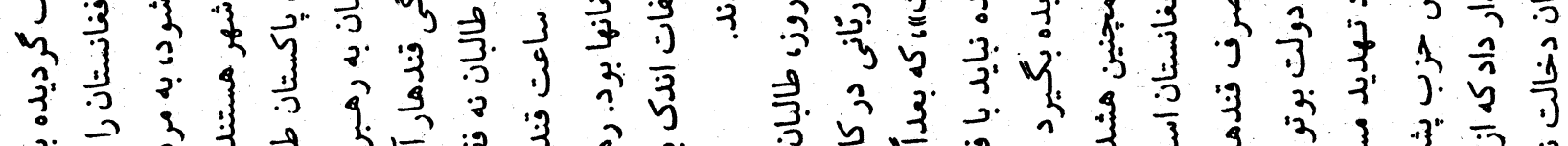

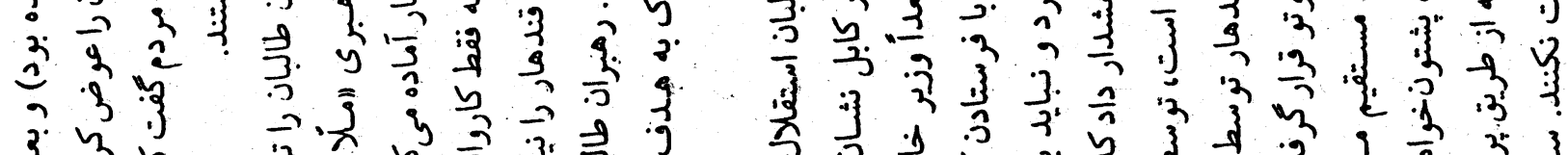

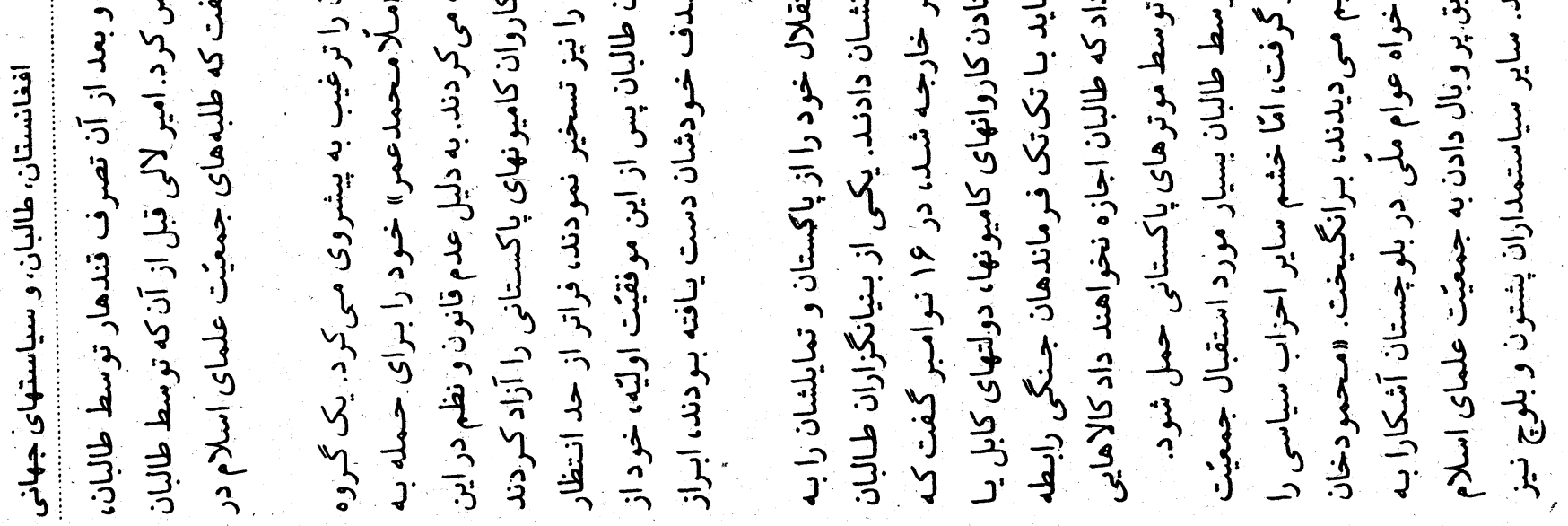

0
2

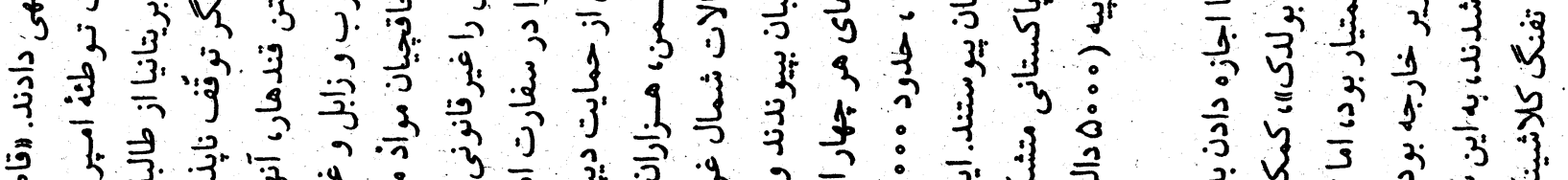

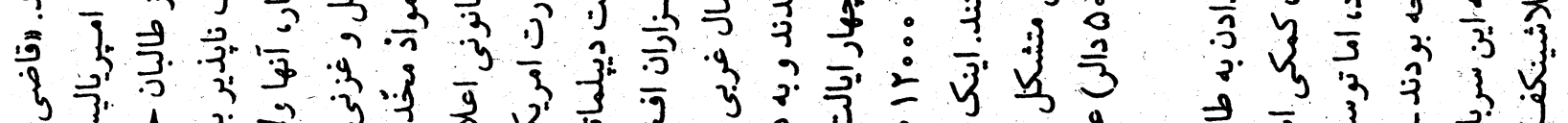

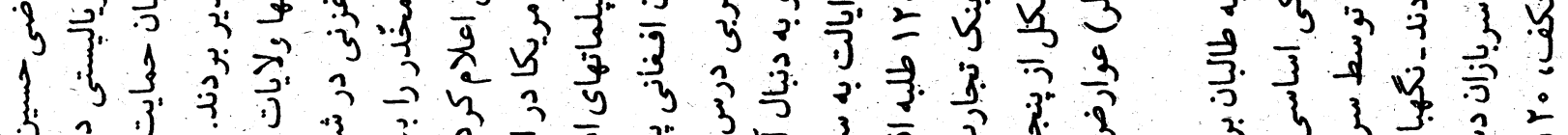

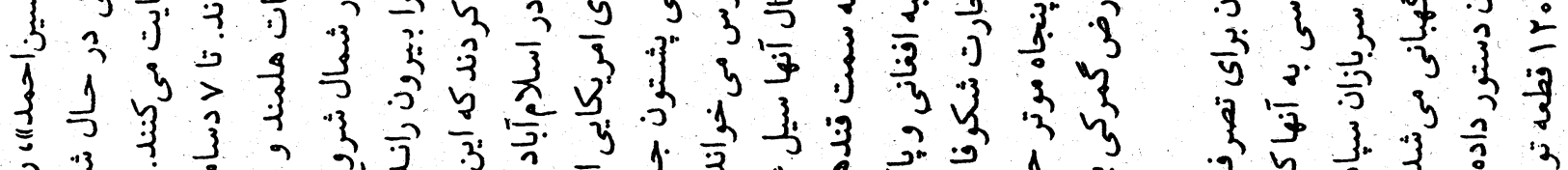
3.

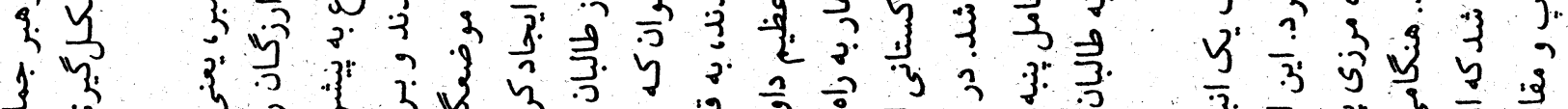
3 , 3.

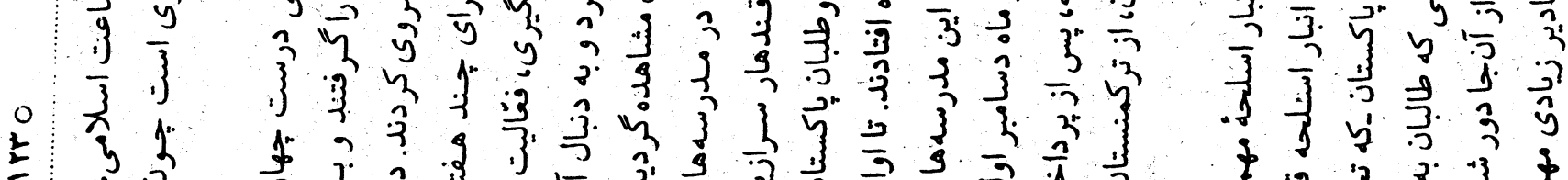

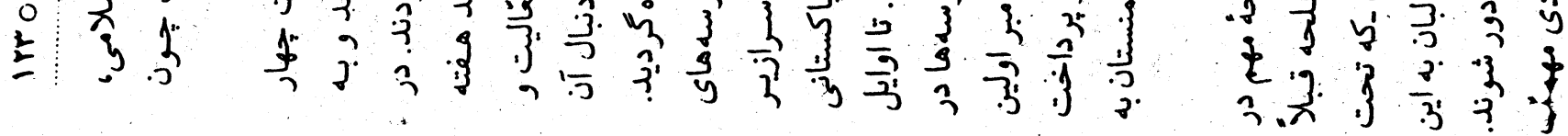




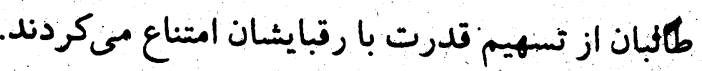

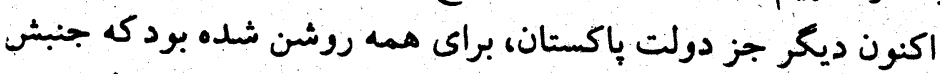

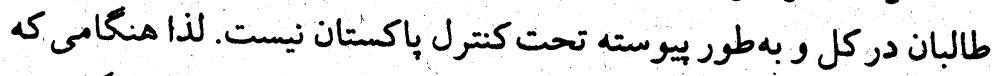

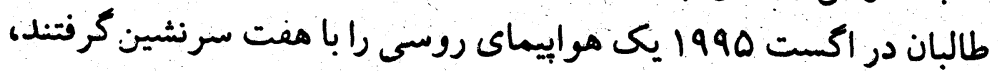

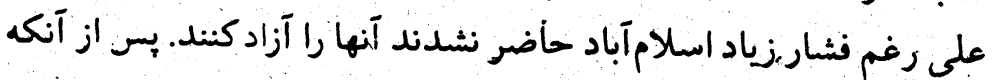

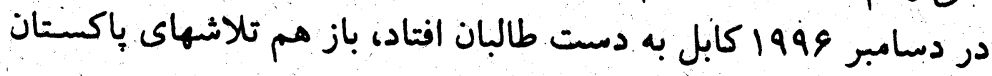
براى ترغيب طالبان به اتحاد با دوستم به بـكست انجاميد.

\section{هالبان و هكومتهاى ايالتى باكستان}

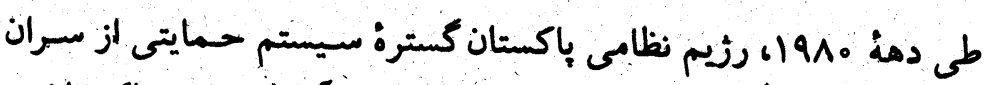

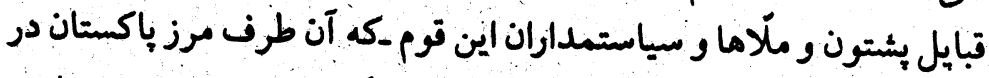

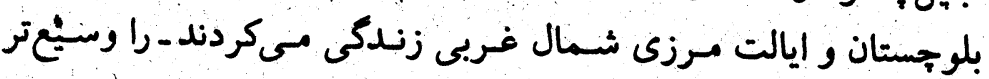

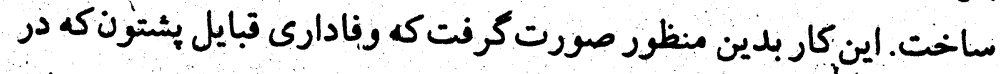

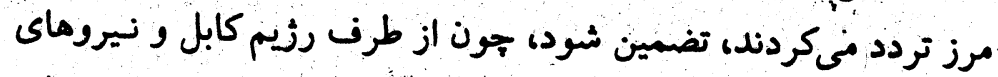

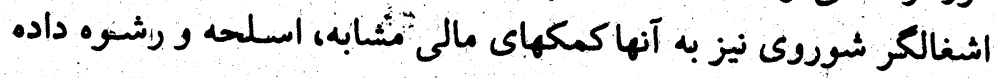

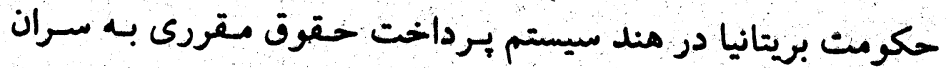

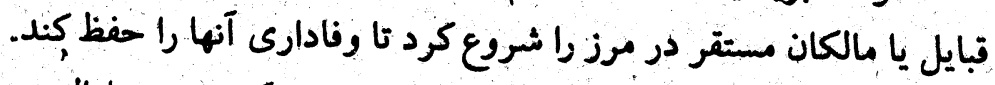

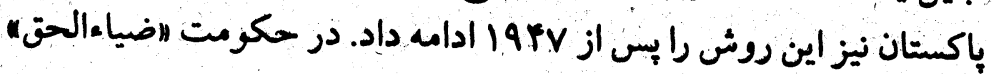

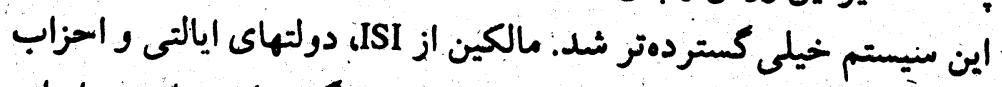

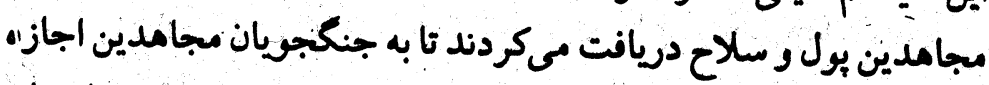

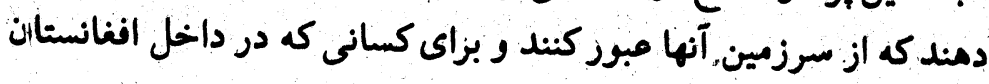

به. دست طالبان افتاد.

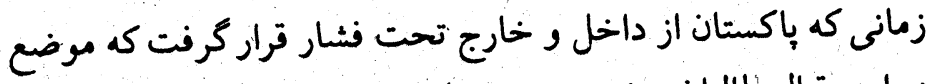

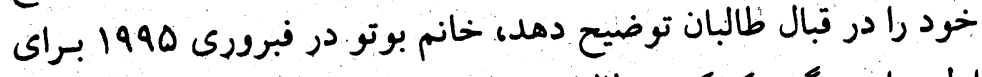

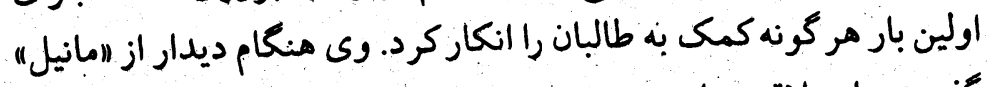

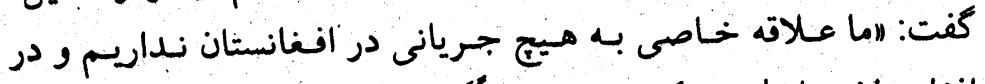

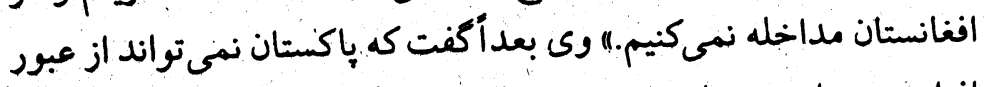

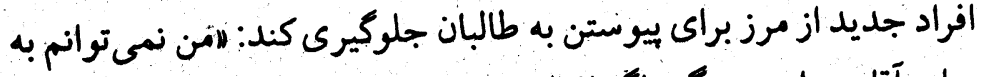

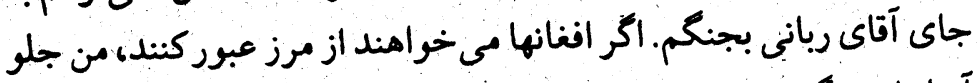

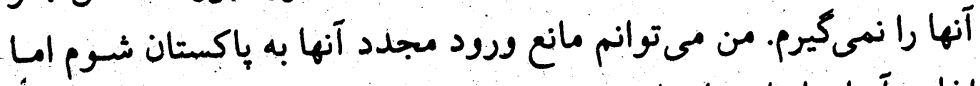

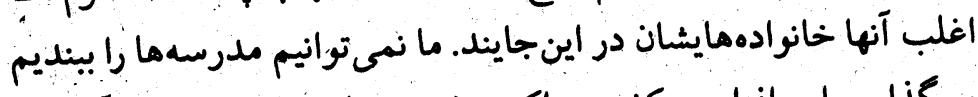

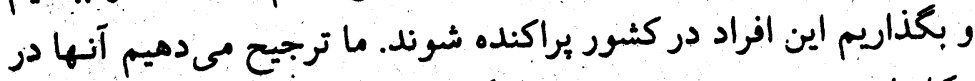

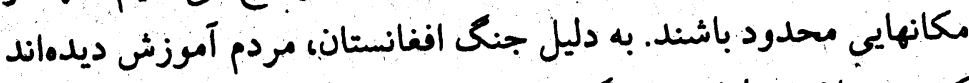

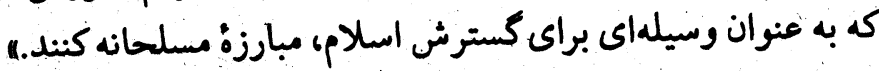

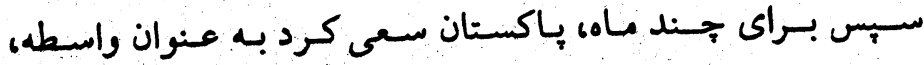

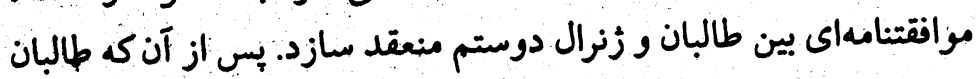

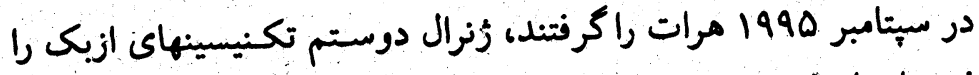

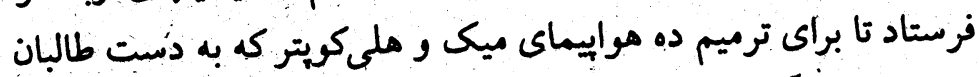

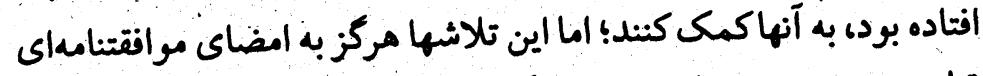

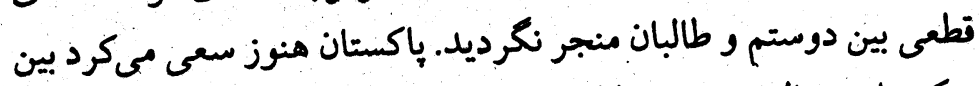

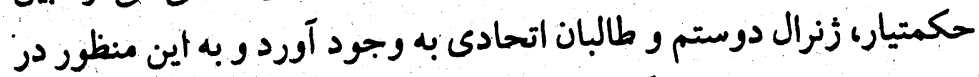

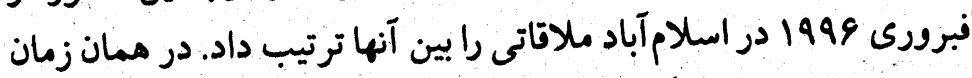

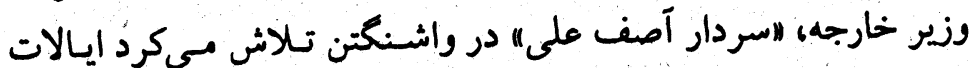

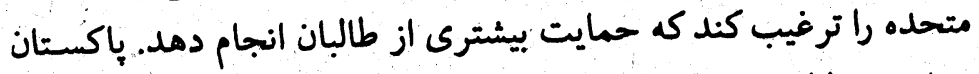

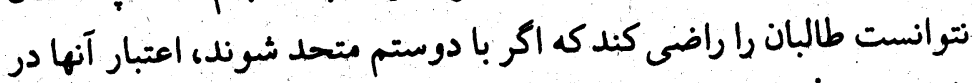

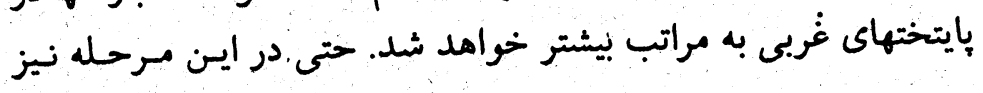




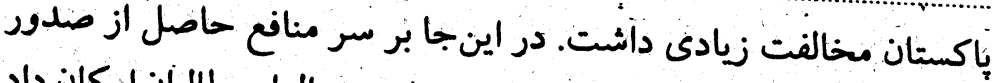

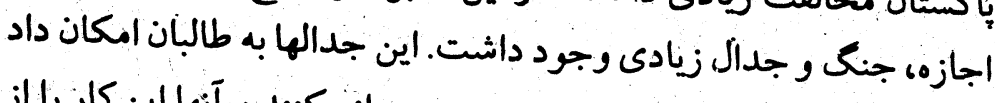

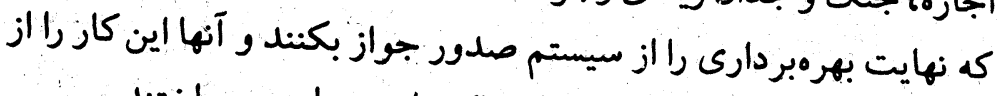

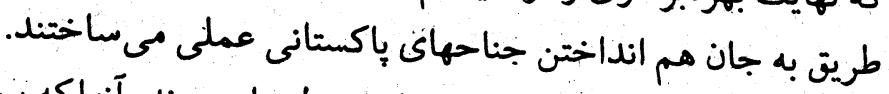

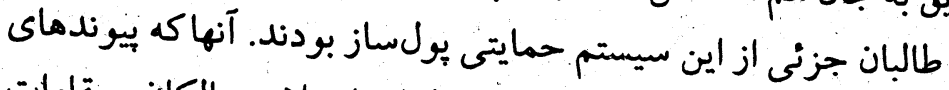

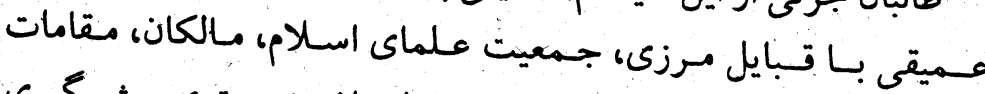

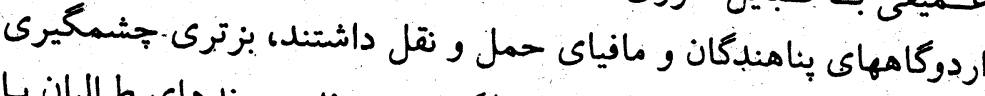

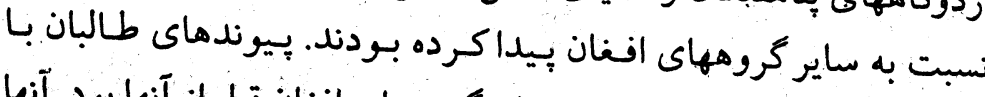

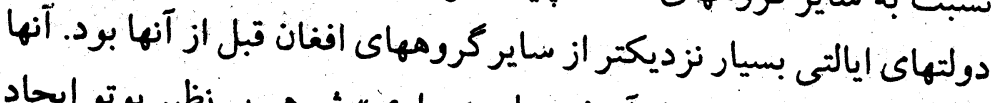

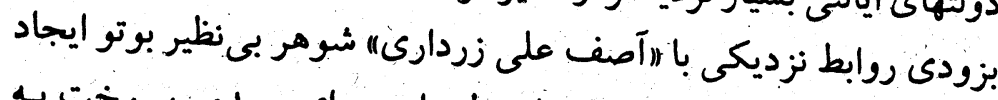

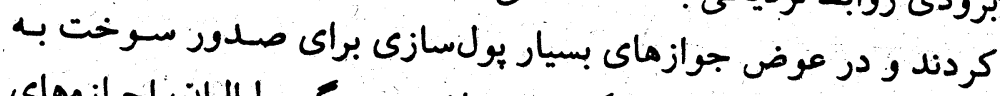

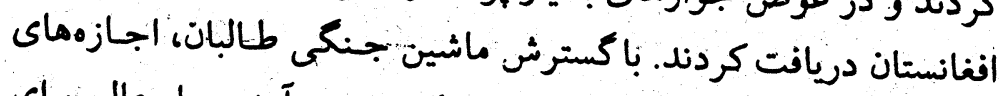

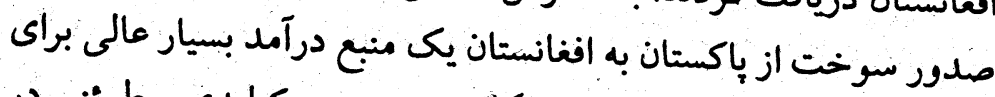

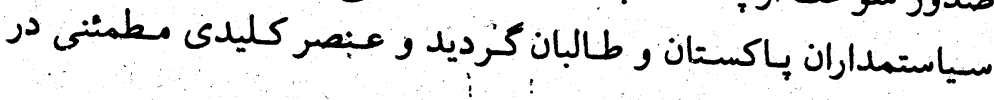
موفقيتهاى نظامى طالبان شُد.

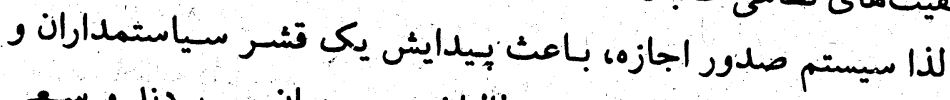

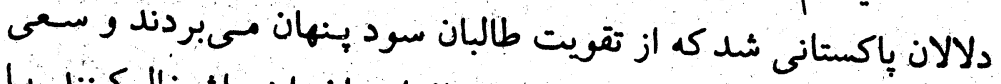

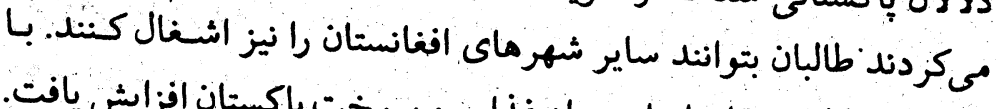

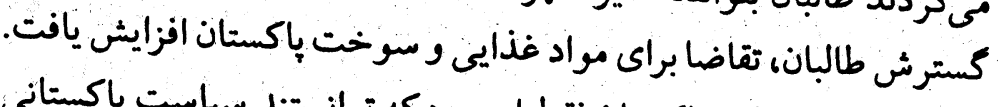

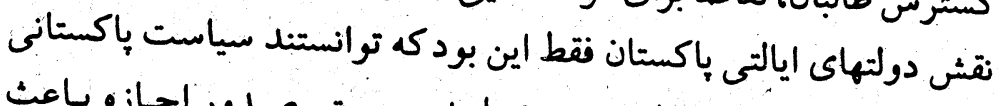

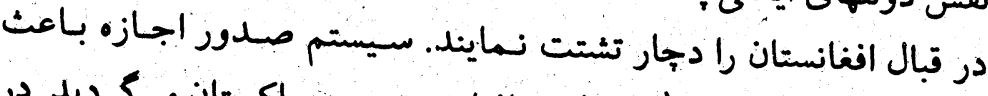

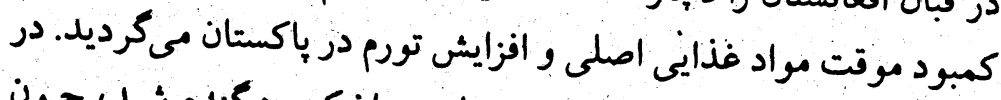

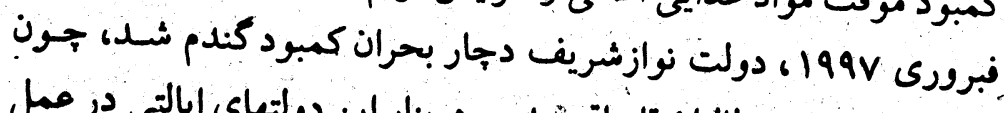

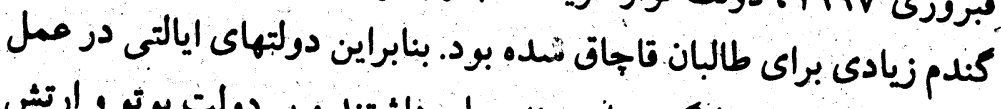

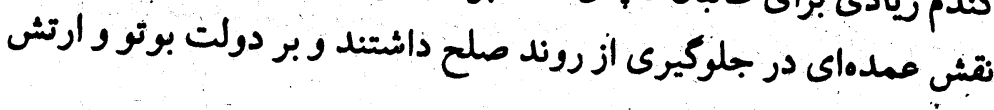

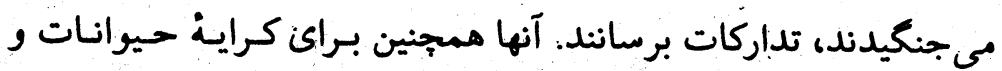

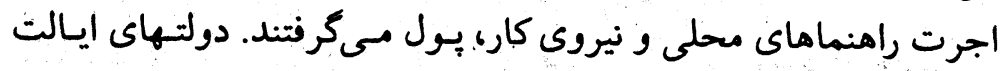

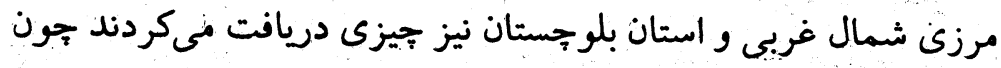

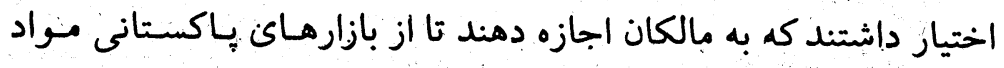

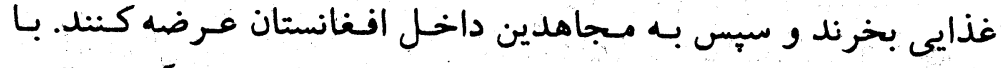
بإيانيافتن جنگتخليه شبوروى در سال

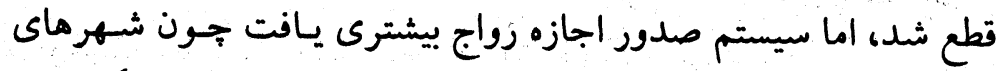

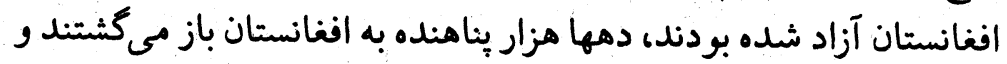

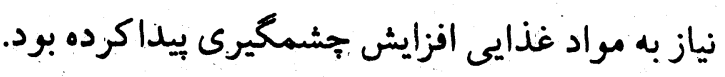

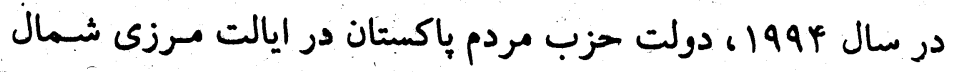

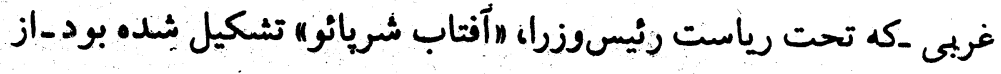

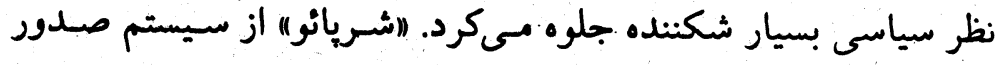

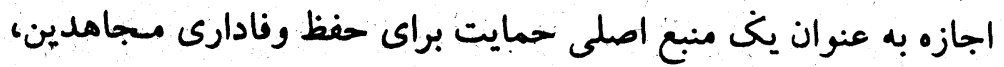

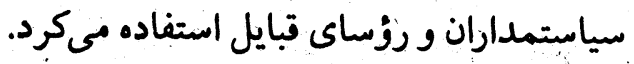

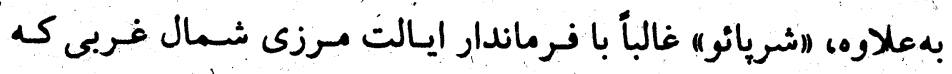

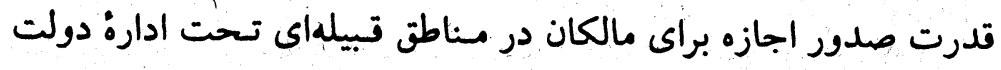

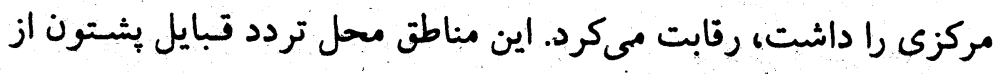

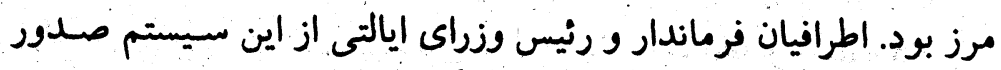

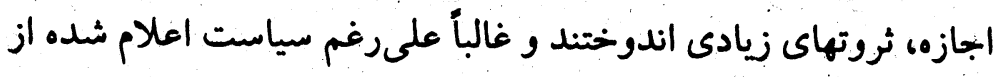

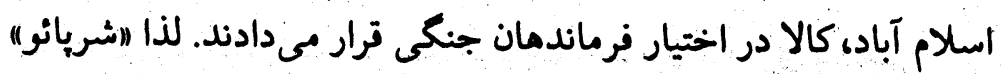

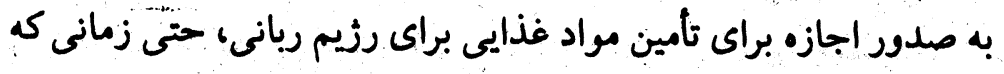

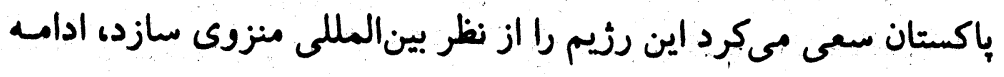

داد.

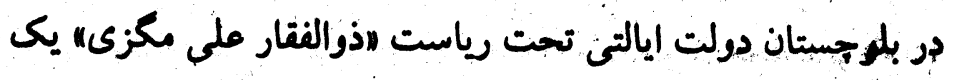

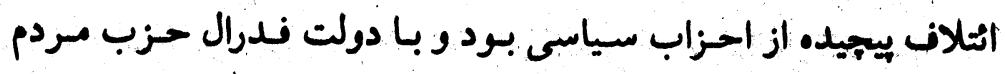




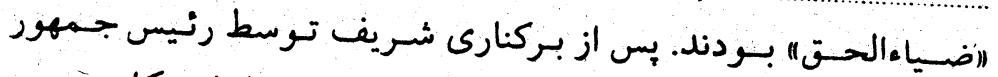

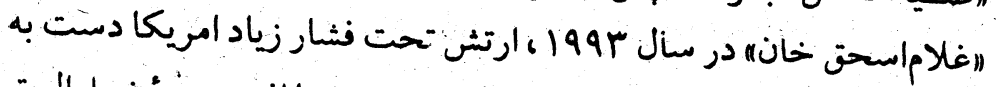

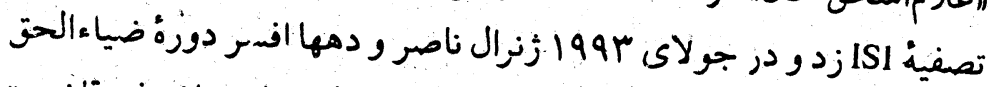

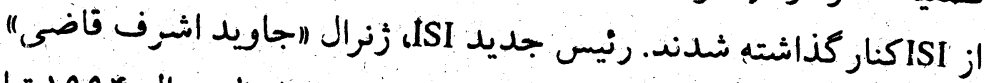

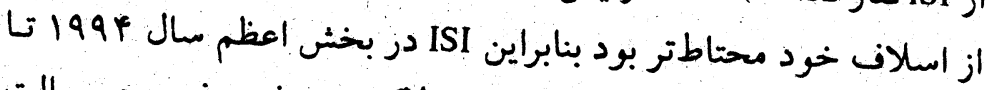
اعمال نفوذ مىكردند كه از طالبان حمايت كنند. "اداكتر نجببالله لفرايى"

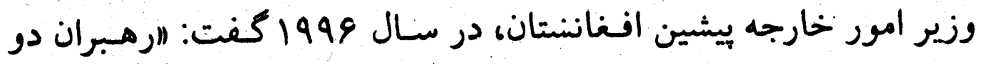

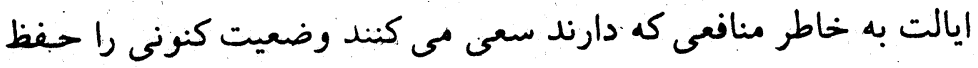

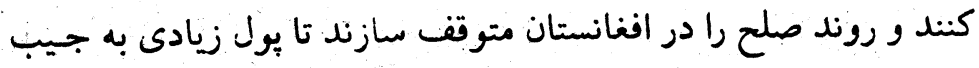
بزنتد.11) آنجا كه به افغانستان مربوط مى شده، در لاكى خود فرو رفته بود. حسالت

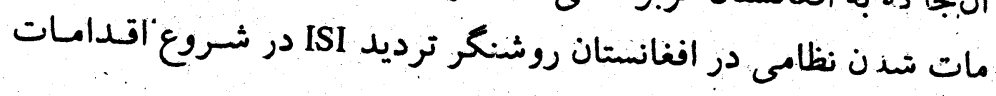

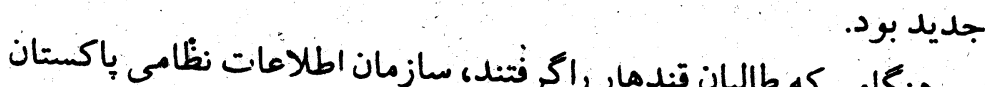

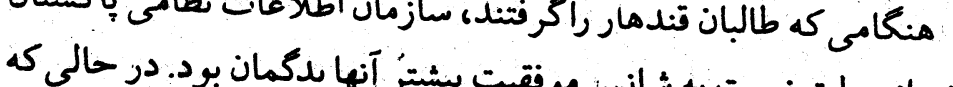

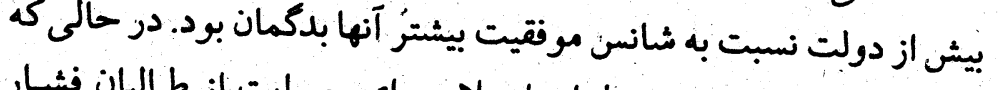

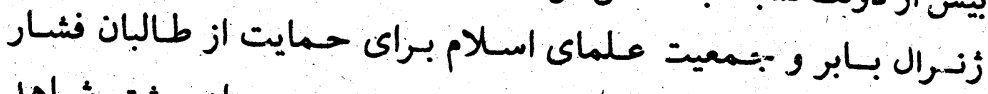

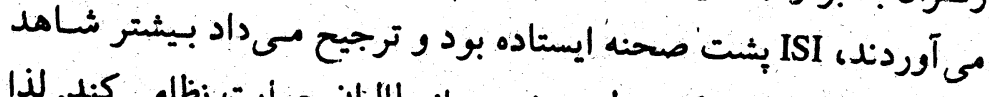

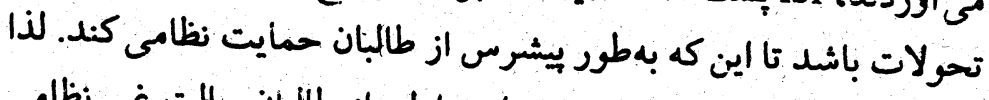

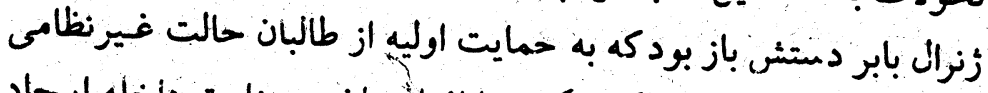

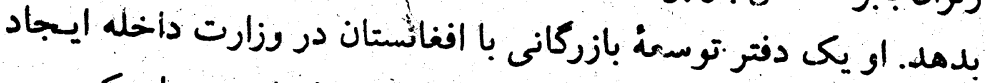

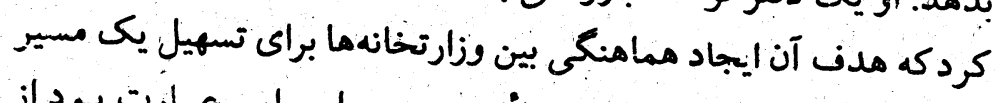

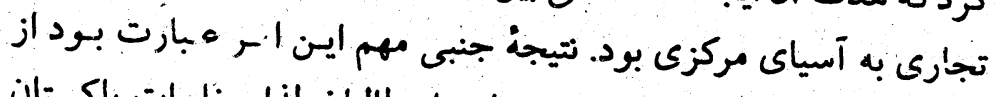

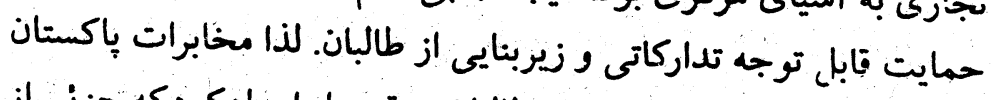

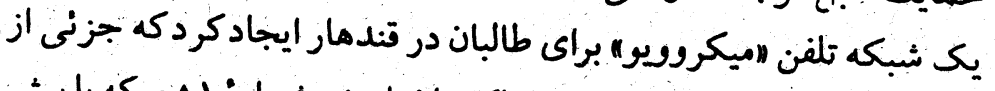

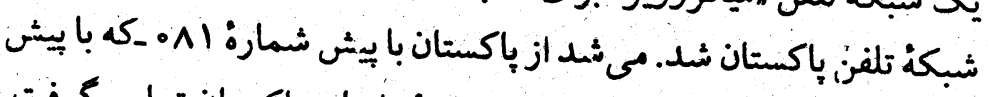

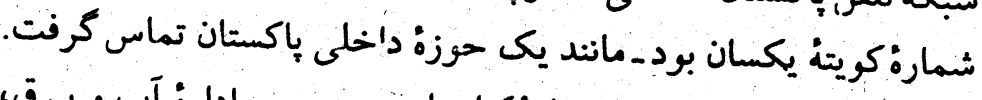

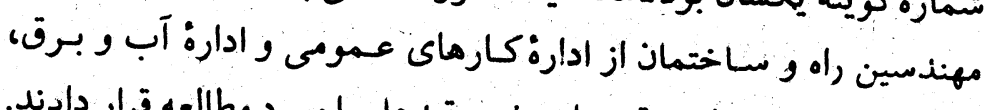

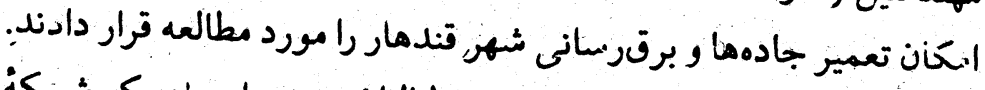

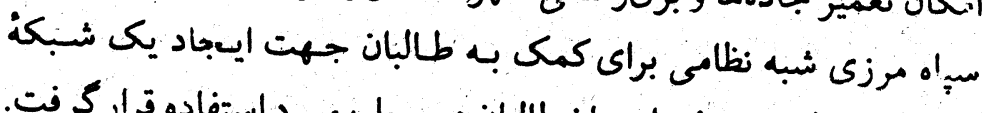
بى ميم داخلى براى نرماندهان طالبان در محل، مورد استفاده قراركرفت.

\section{ISI طالبان و}

قبل از تصرف قندهار توسط طالبان در سال 1994) سياست باكستان و

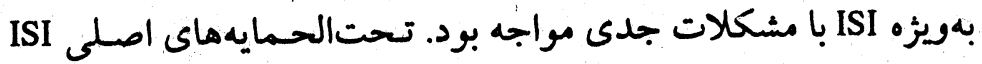
يعنى حكمتيار و دوستم نتوانسته بودند كابل را بنكيرنذ و نهايتاً مشخص

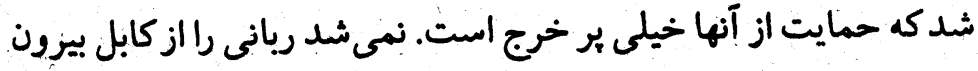

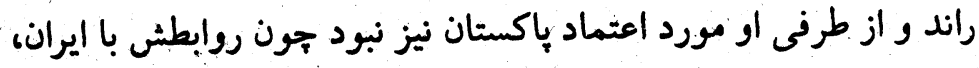
روسيه و هند هر روز رو به كسترش بود. بهعلاوه از زمان خـاتمهُ جـنك نيك

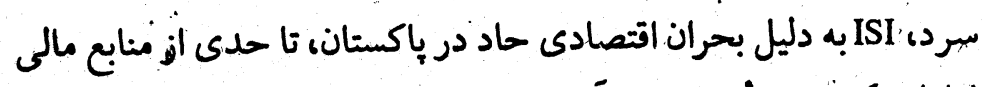

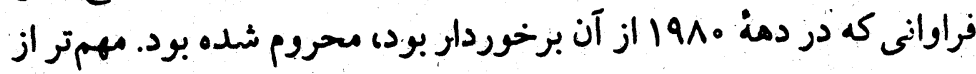

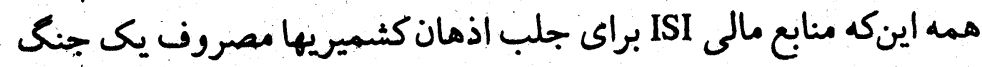
فرمايشى ديخر عليه هند شده بود.

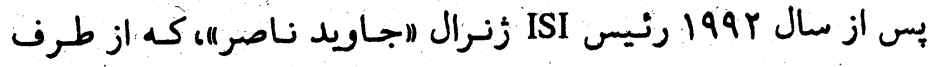

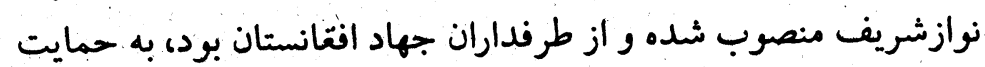

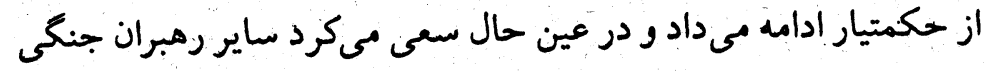

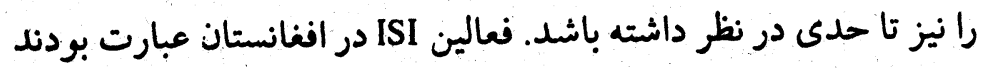
از افسران بنيادكراى اسلامى و بشتون كه بازماندكان رزيم نـظامى زُنرال 


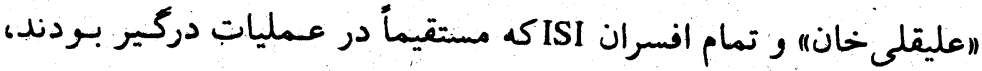

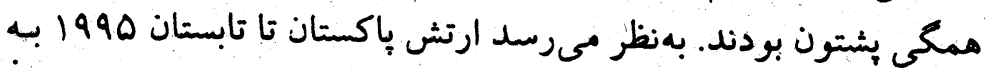

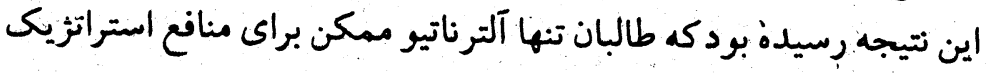

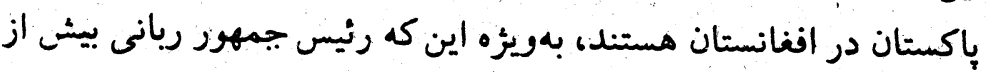

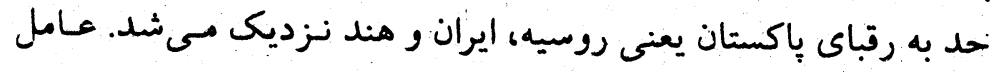

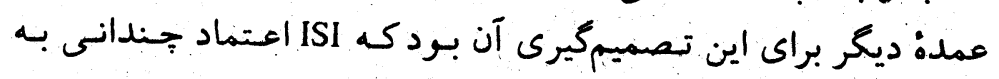

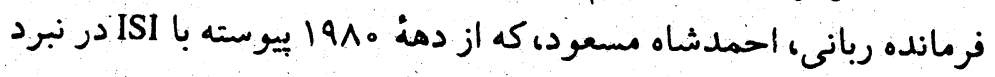

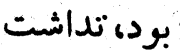

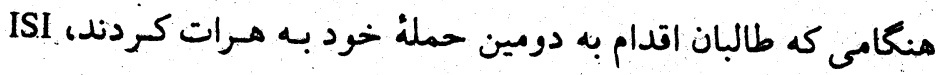

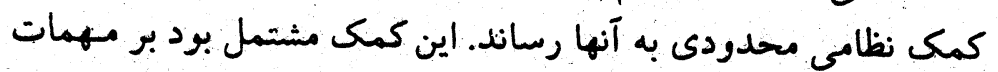

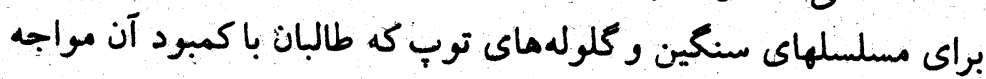

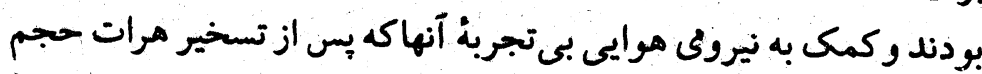

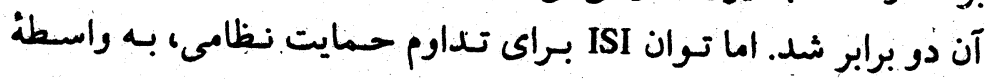

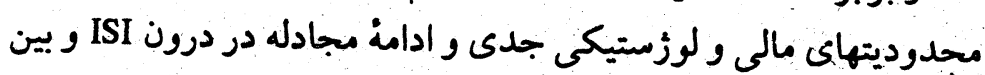
IISI

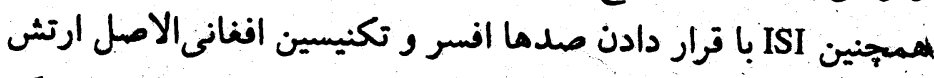

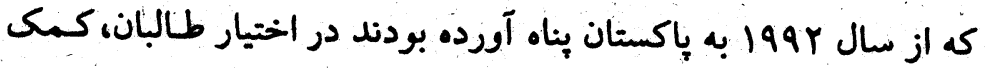

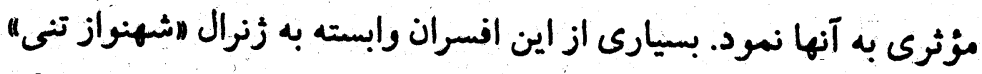

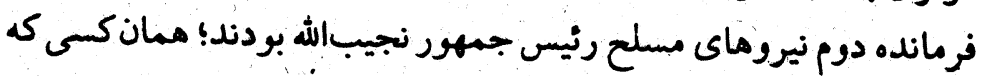

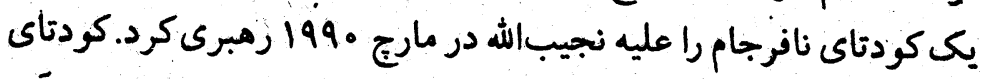

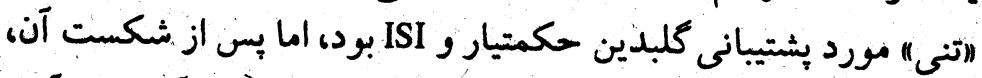

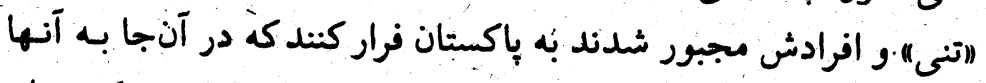

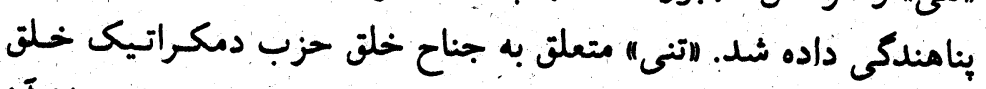

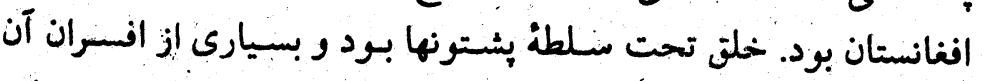

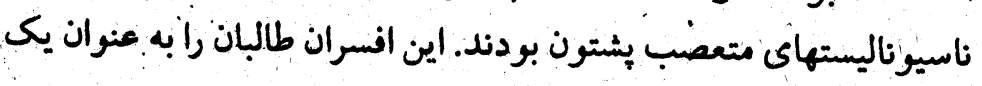

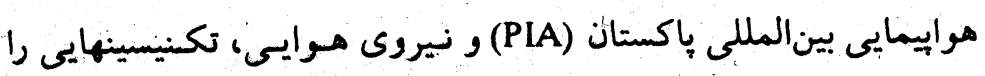

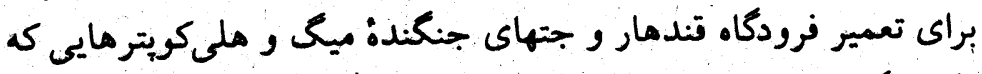

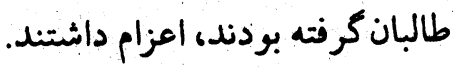

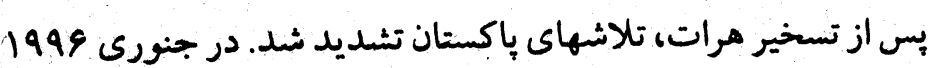

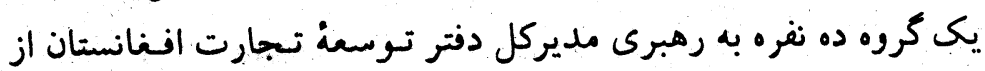

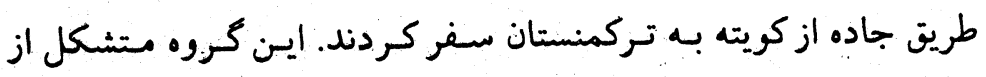

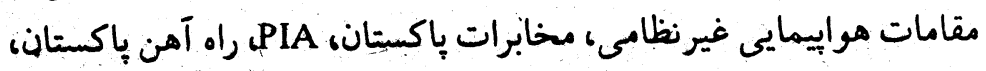

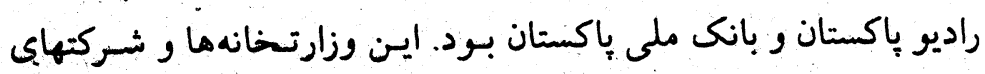

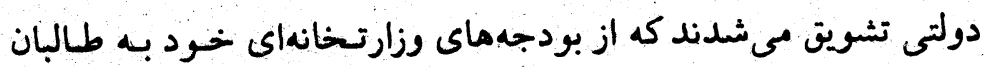
كمك كنند. بس از آن كه دز سنال

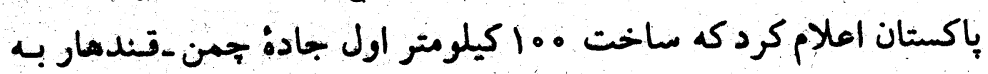

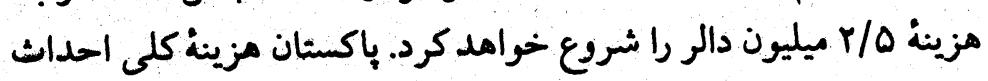

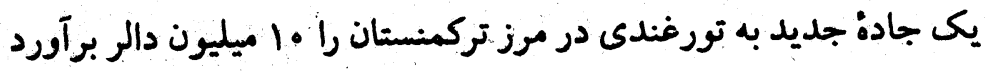

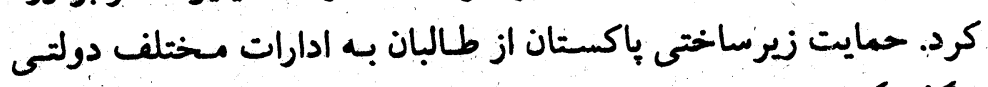
واكذار كرديد.

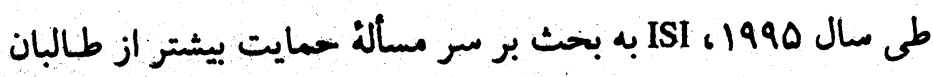

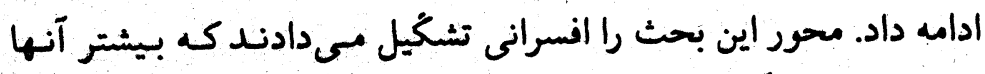

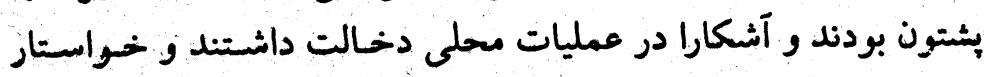

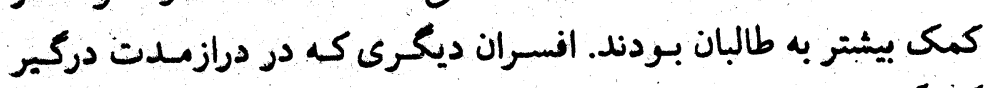

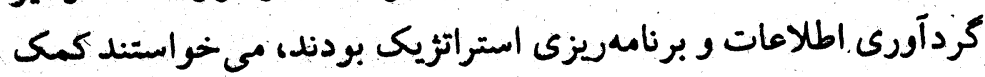

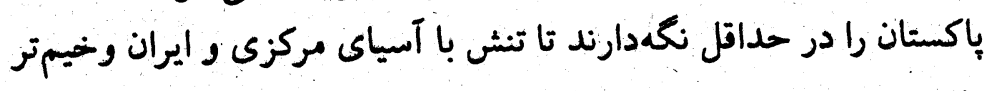

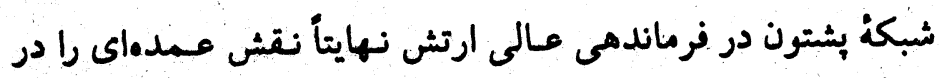

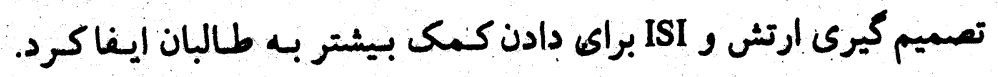

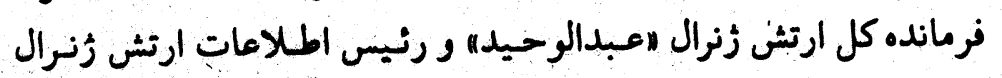




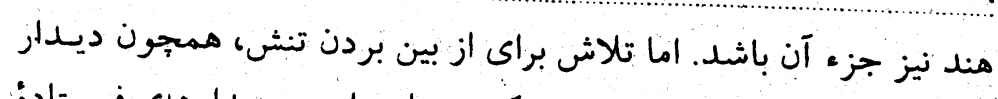

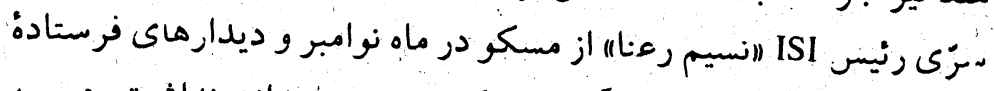

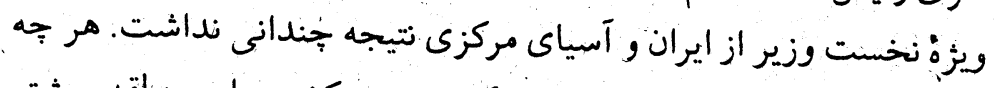

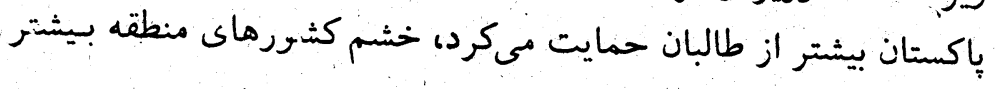

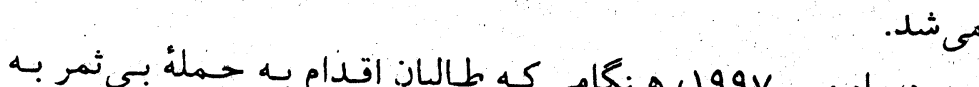

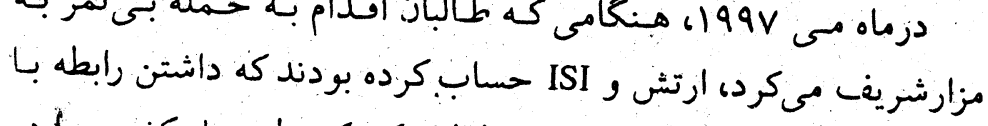

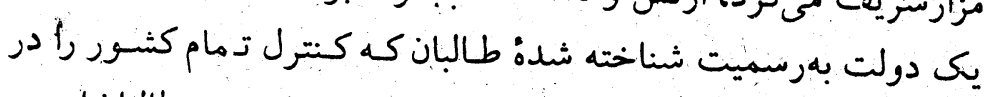

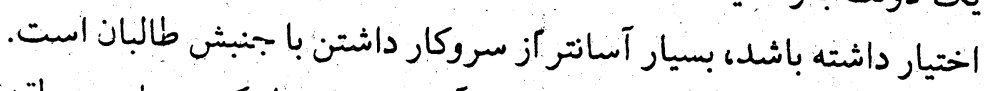

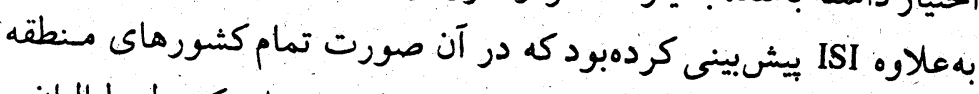

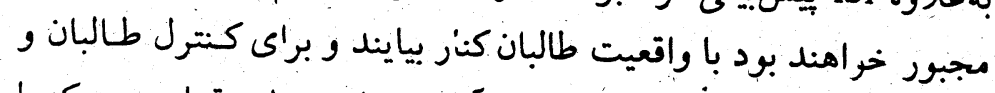

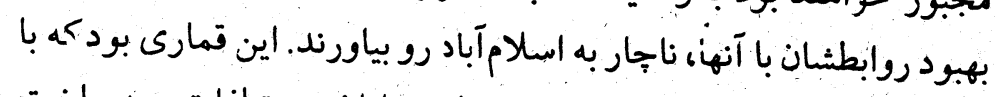

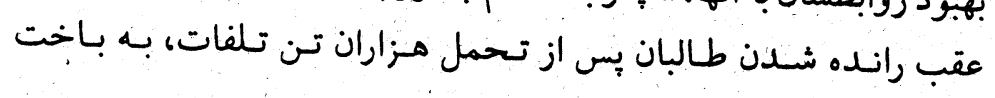
انجاميد.

به نظر بسئرى از كارشناسان داخل و خارج دولت ياكستان ـبه ويزه

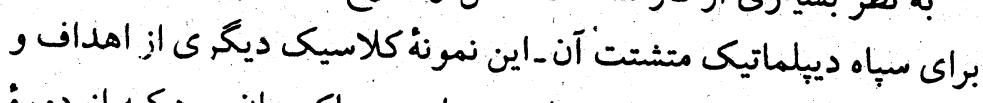

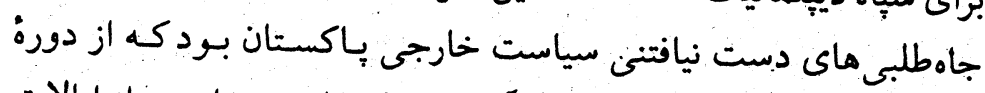

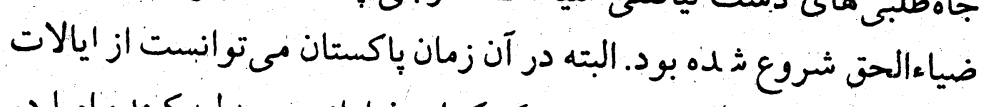

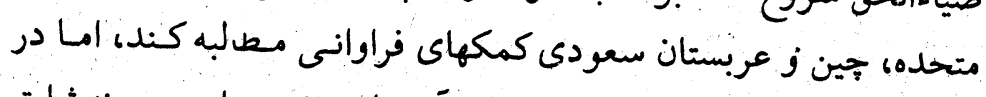

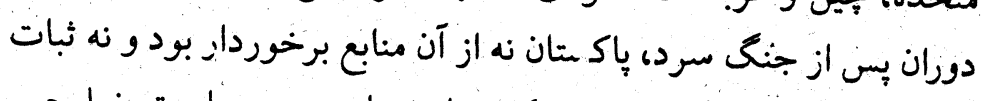

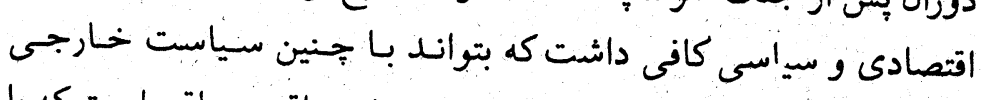

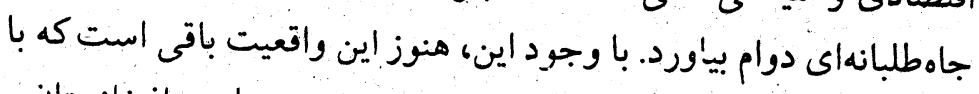

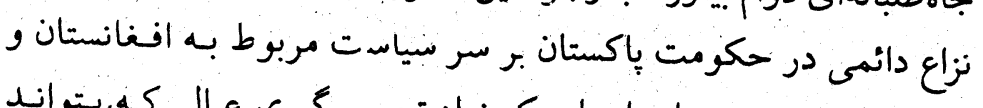

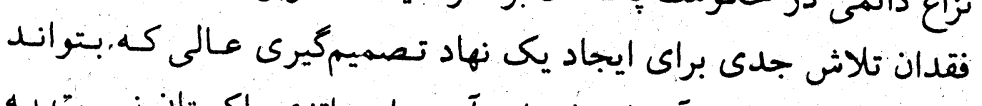

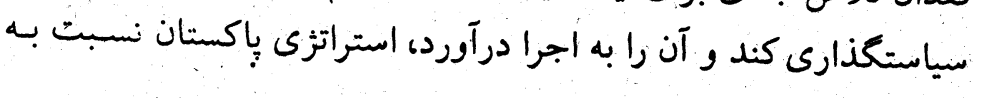

افغانستان، طالبان، و سياستهاي جهانى

olrr

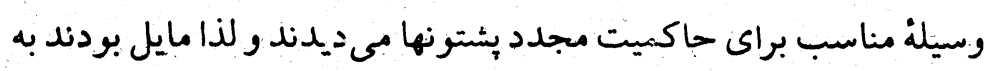

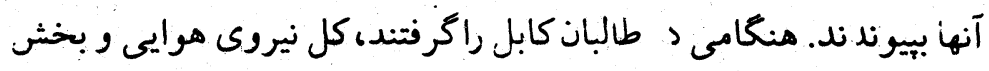

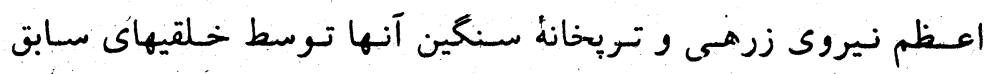

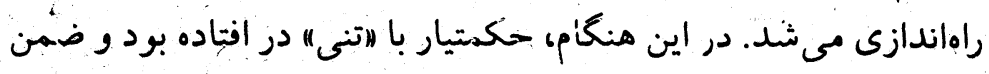

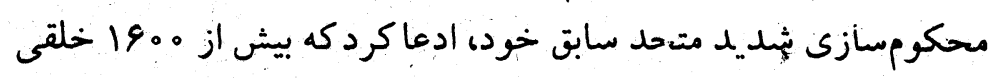

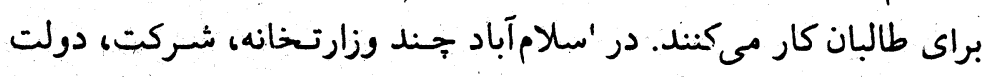

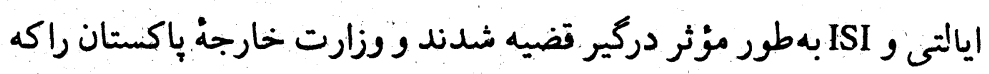

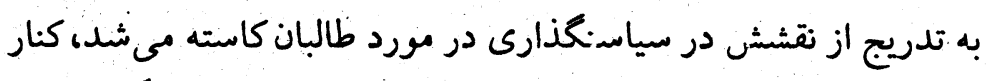

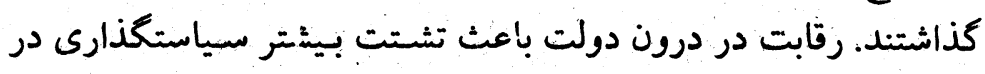

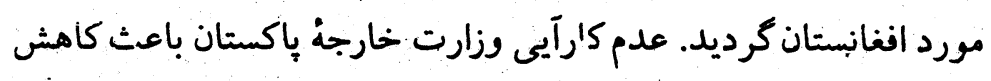

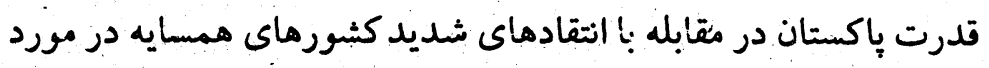

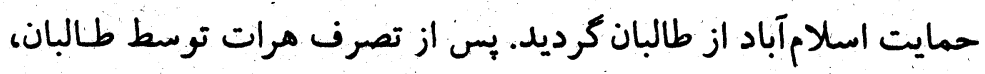

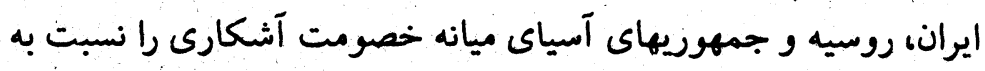

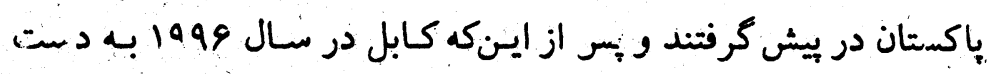

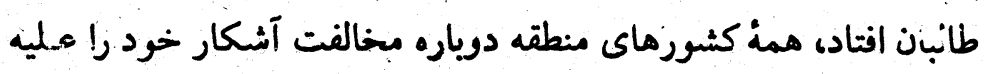

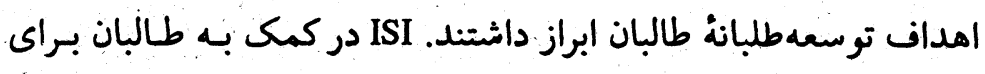

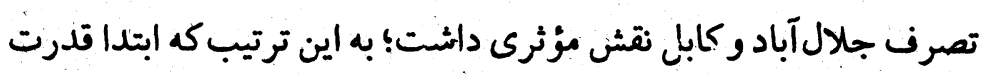

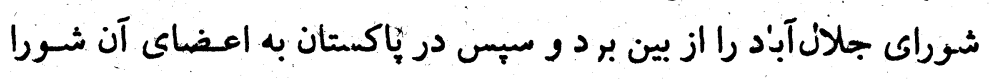

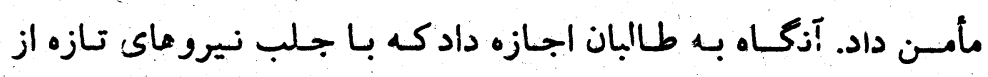

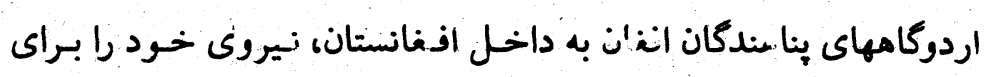

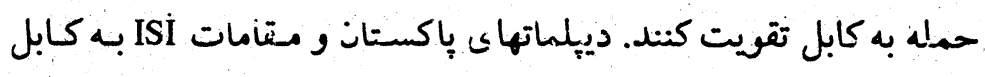

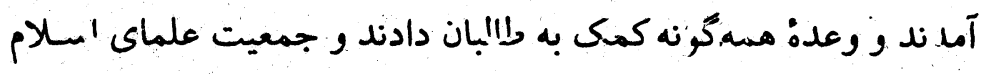

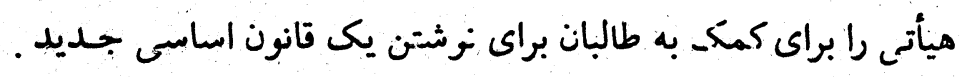
كابز فردتاد. ISI 


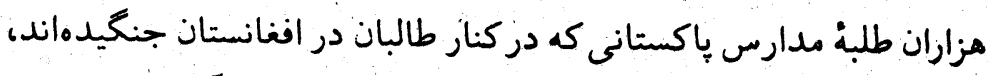

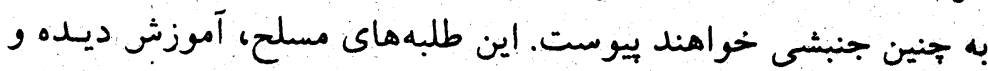

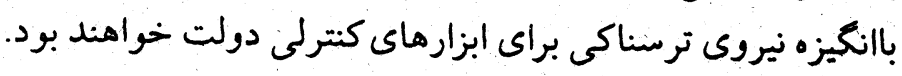

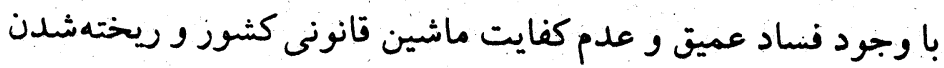

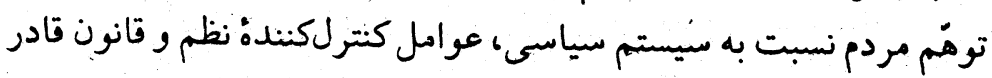

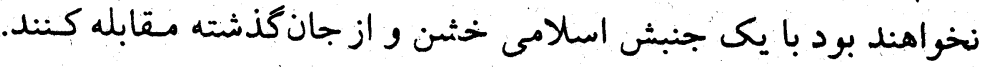

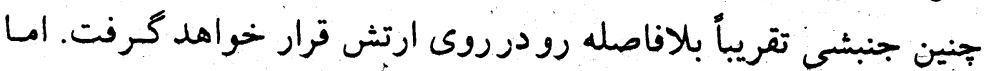

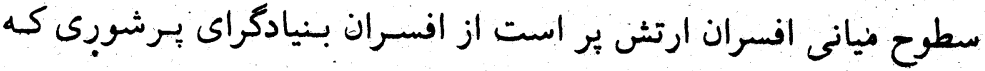

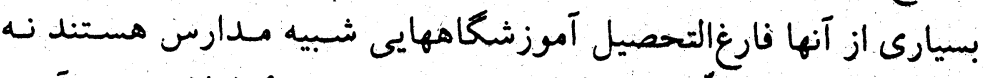

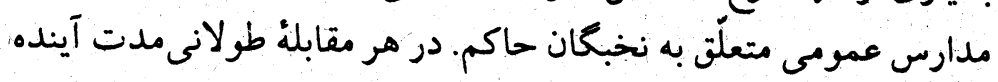

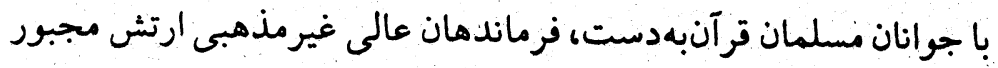

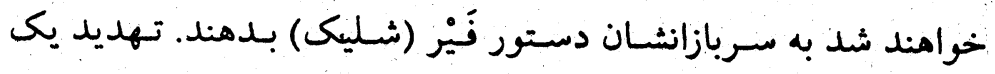
انقلاب اسلامى در باكستان هيج وقت تا اين حد جدى نبودهاست.

\section{施䊎次}

طالبان بيشتر متزلزل بوده تا قطعى. بر سياست اسلامآباد بيشتر فساد،

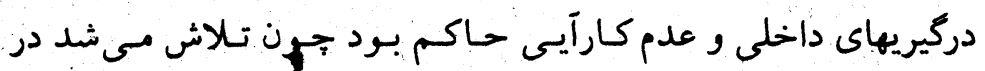

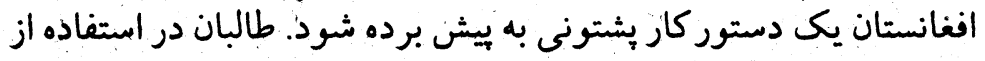

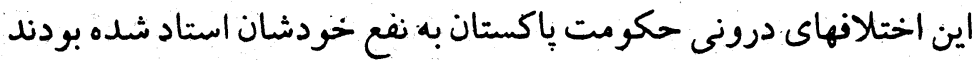

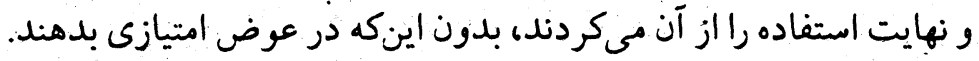

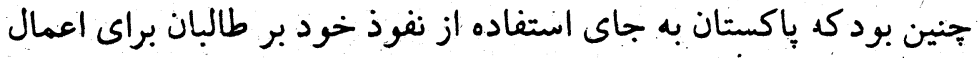

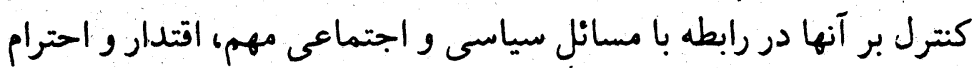

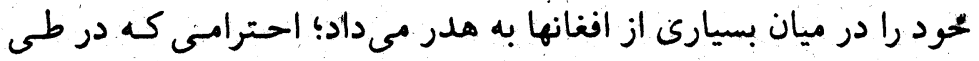

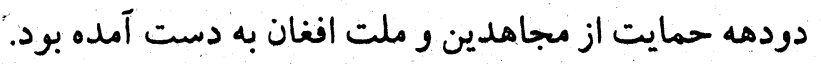

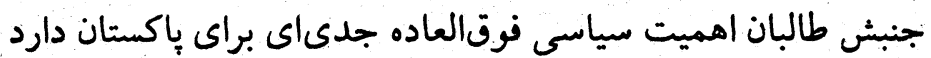

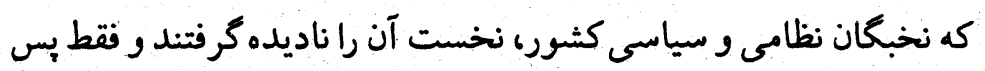

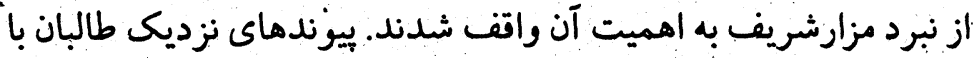

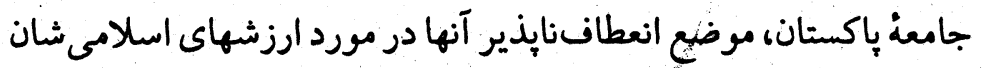

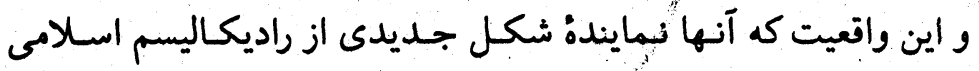

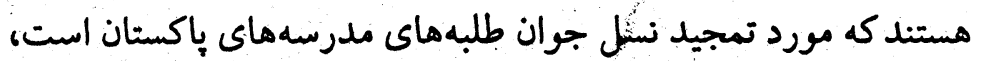

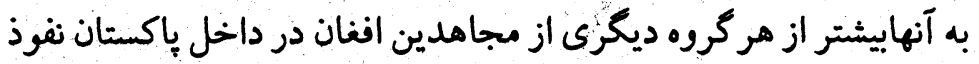

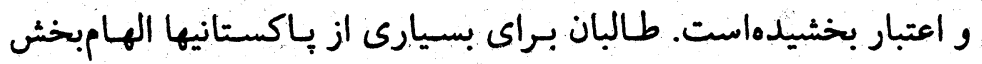

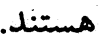

بهلهلاوه بس از نبرد مزارشريف، طالبان عملاً حمايت تمام احزاب

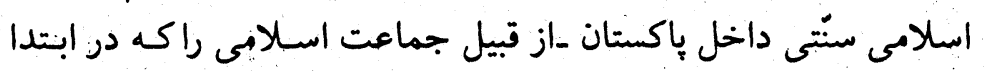

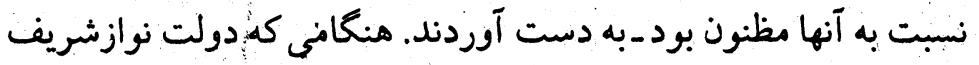

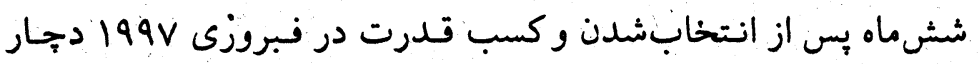

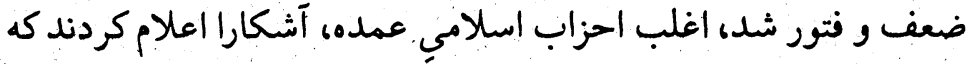

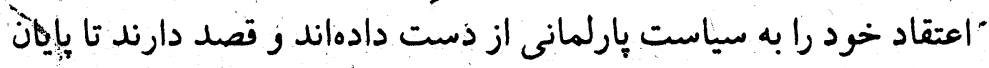
سال اقدام به بسيج يك جنبش تودماى براى انقلاب اسلامى كنيد. مسلماً 


\section{إيالات متحده و طالباني}

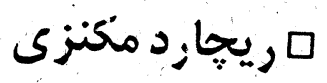

وزير خارجه ايالات متحده، المندلين البرايت)، كه خود سابقاً يك، بـار از واز

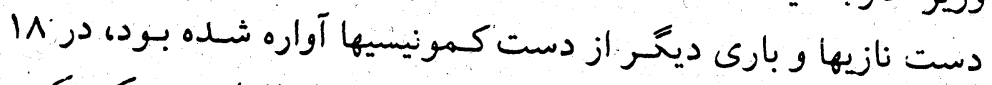

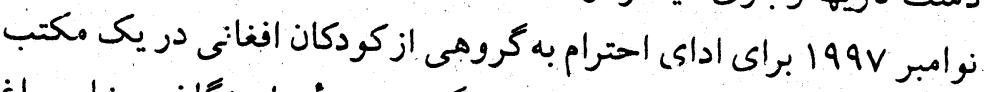

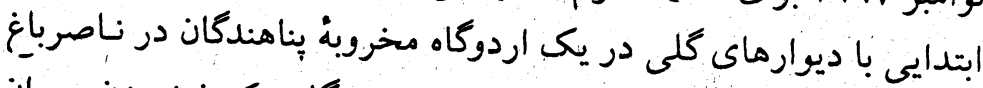

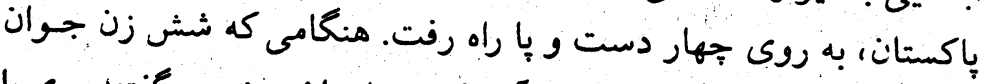

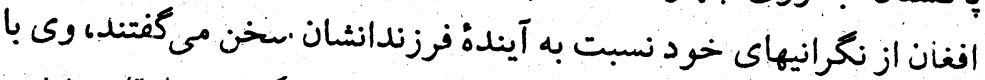

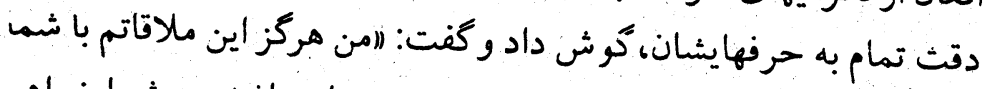

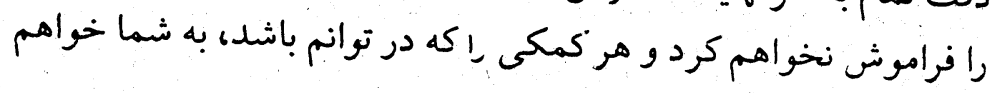

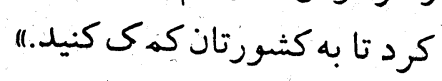

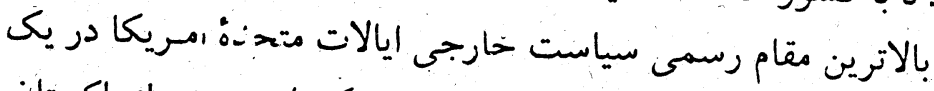

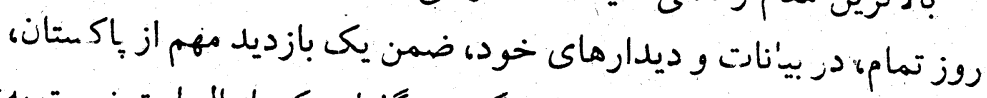

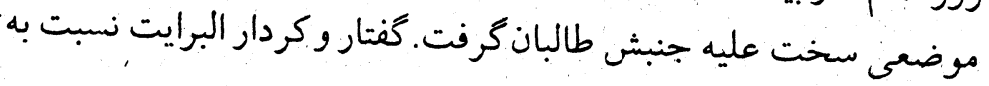

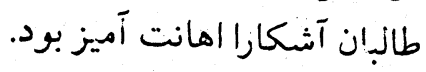

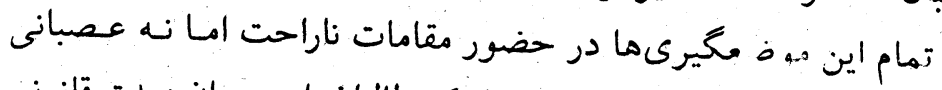

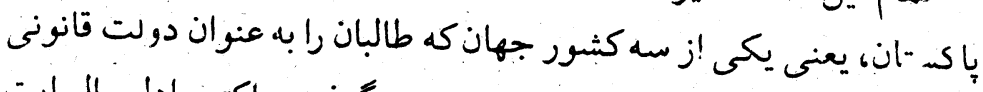

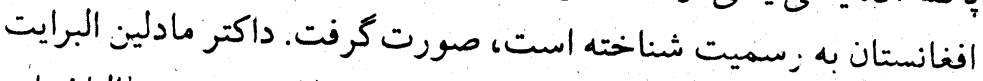

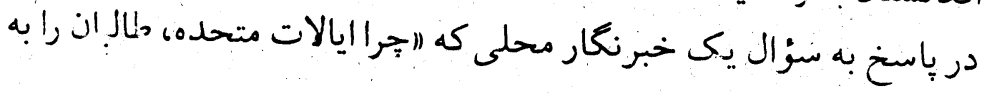




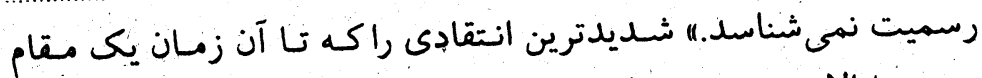

مقامات ايالات متحده از مذاكرات اوليـه بـا رهبران طالبان و حستى

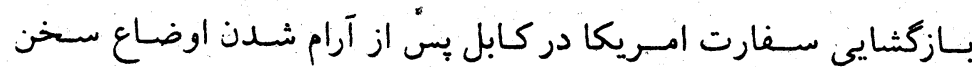

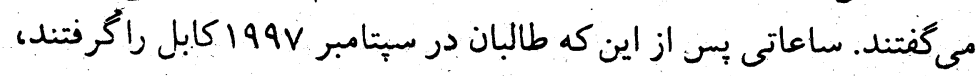

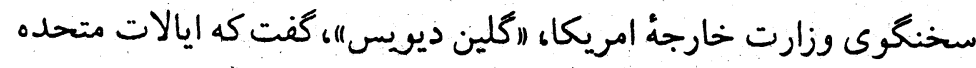
در رابطه با قوانين اسلامي اى كه طالبان بر مناطق تحت كنترل خورد خود تحميل

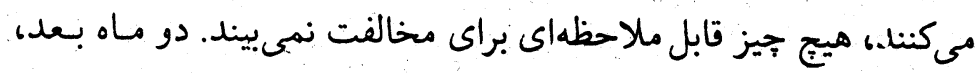

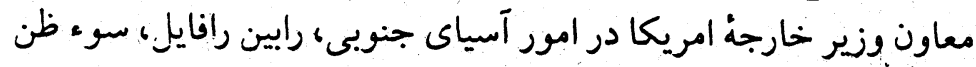

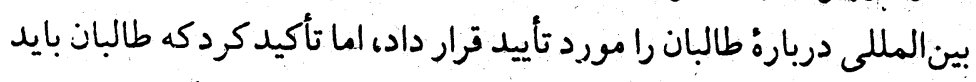

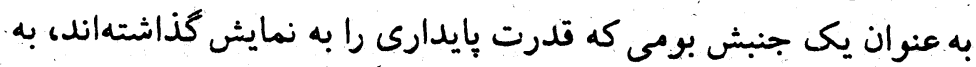

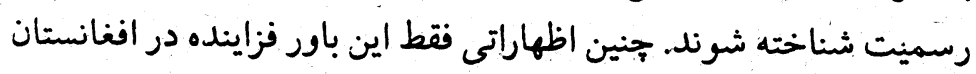

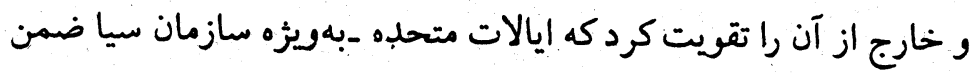

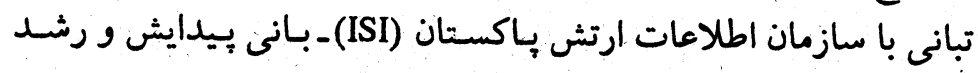

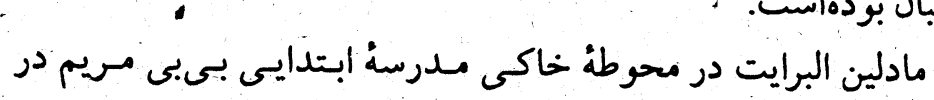

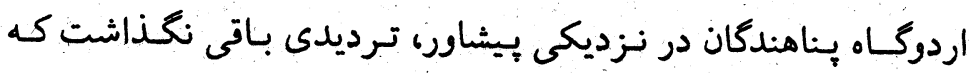

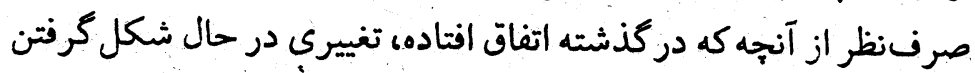

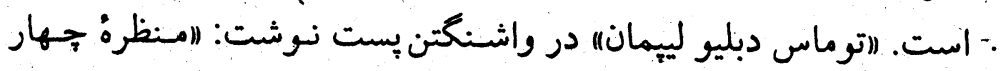

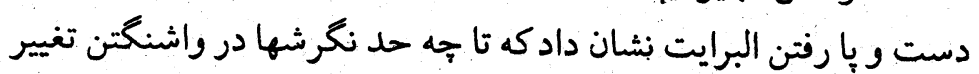
كرده است. "ماليها لودهى" (Maleeha Lodhi) سـردبير روزنامه و سفير سابق

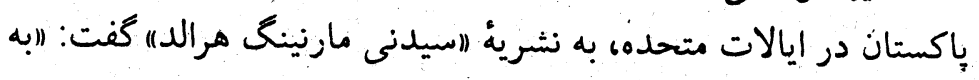

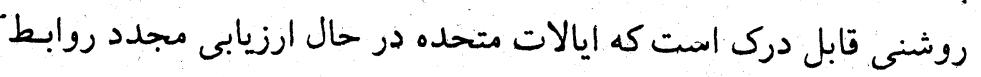
خود با هند در اين بخش از جهان است." درديت

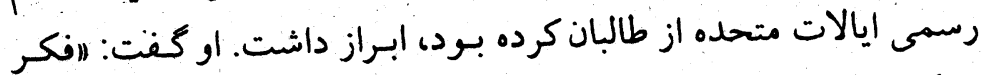
مىكنم علت مخالفت ما با طالبان روشن است. به دليل عملكرد منفى آنها

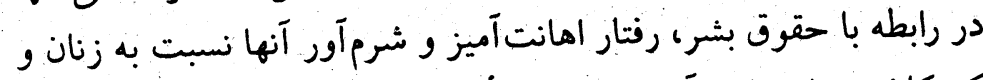

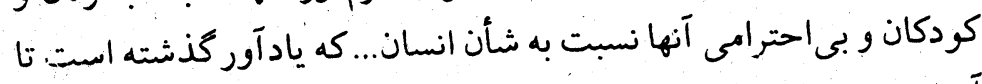
آينده. (1)

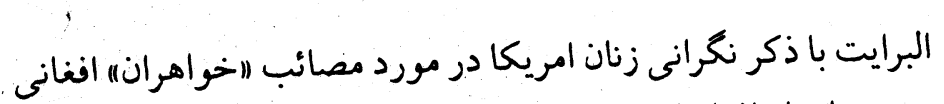

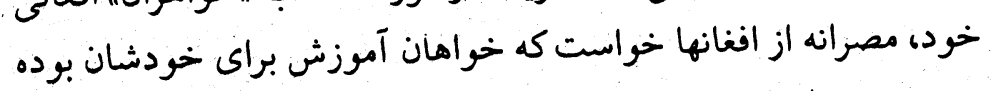

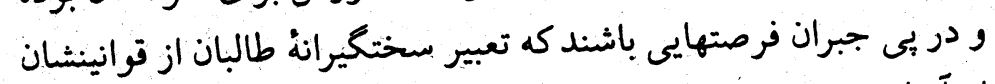

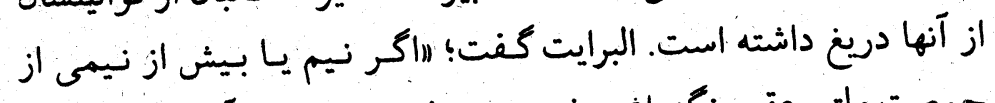
جمعيت ملتى عقب نگهداشته شود، بيشرفت و نوسازى آن ملت ناممكن

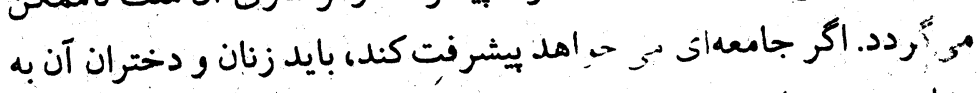

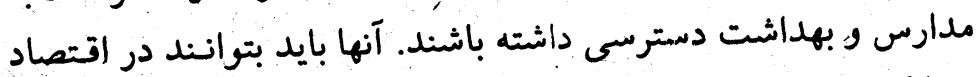

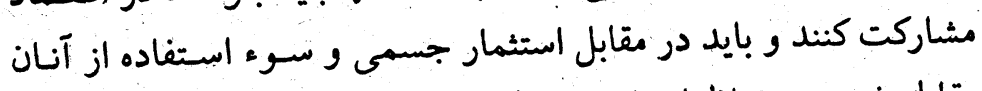

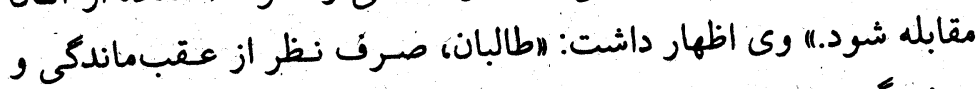

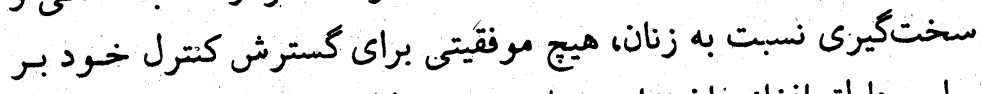

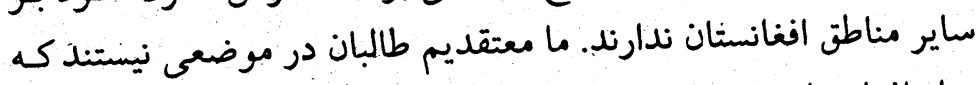

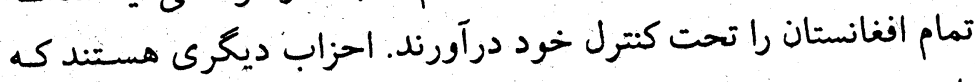

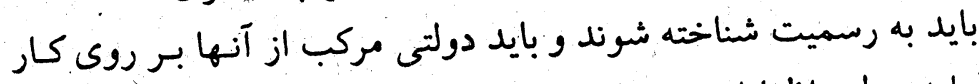

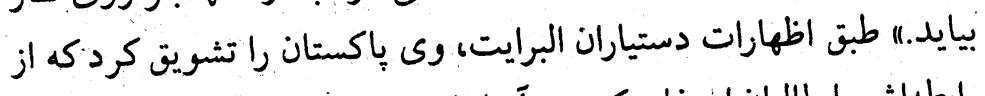

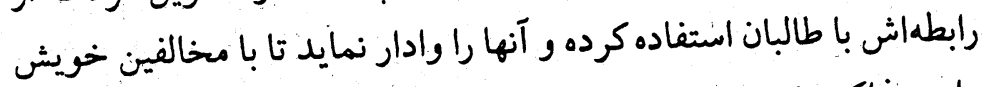
وارد مناكره شوند. آيا اين همان دولت ايالات متحده است كه هنخام ورود طالبان به كابل با آن لح: خوشبينانه سخن مى كفتب؟ طبت اظهارات مفسر بريتانيايى، التيم

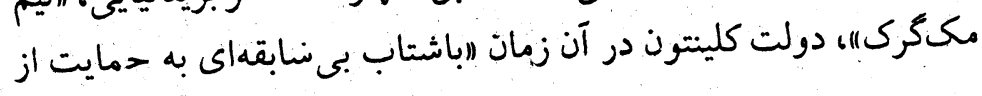


منوط است به فنار مسابل ديگر در يك زمان خاص، و اينكه آن قضيه

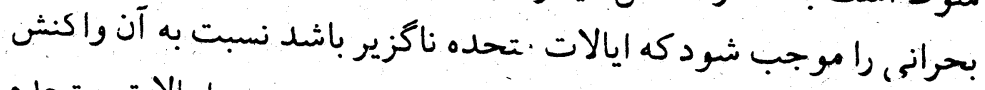
* شكل شيرى سياست ايالات متحده

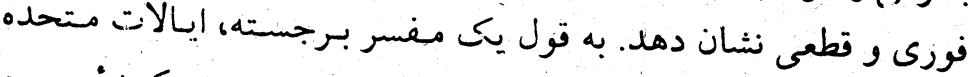

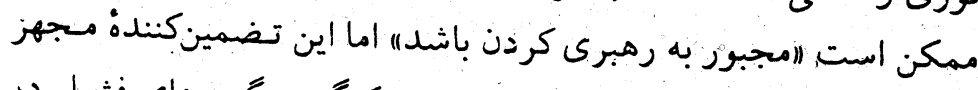

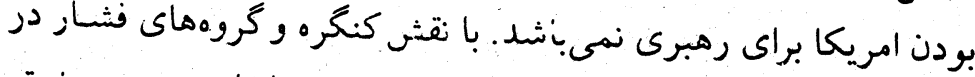

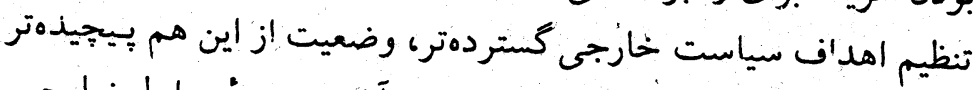

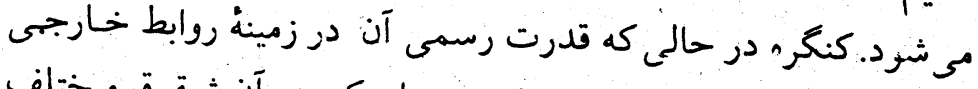

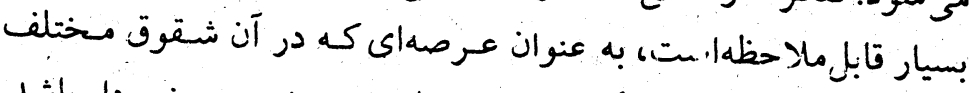

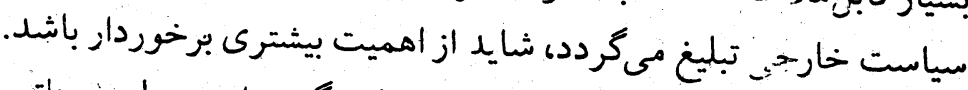

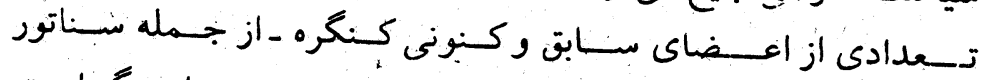

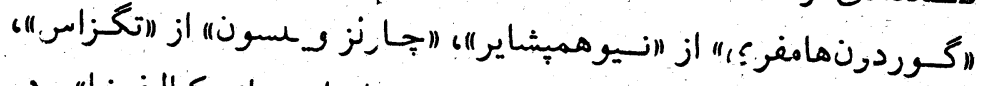

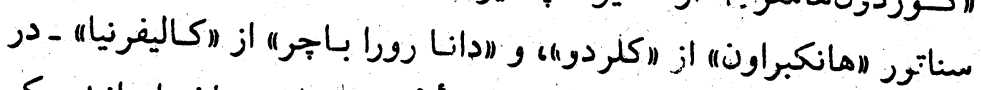

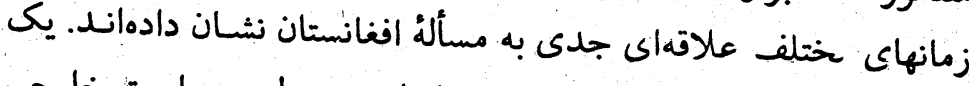

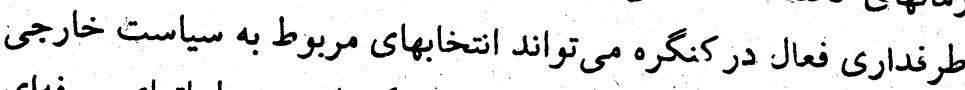

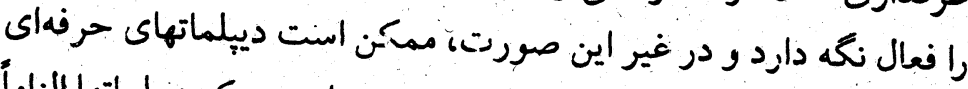

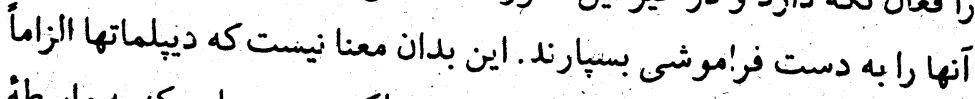

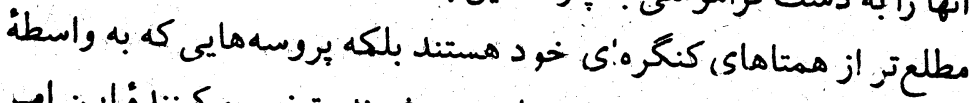

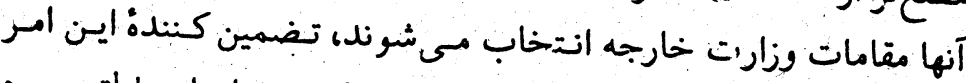
نيستند كه إفراد انتخاب شـده متحخصص در كثـورها يـا مـناطق مبورد

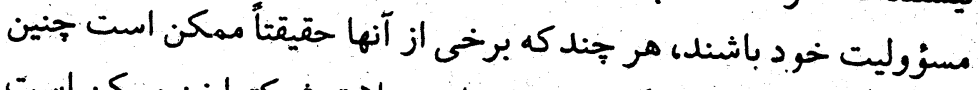

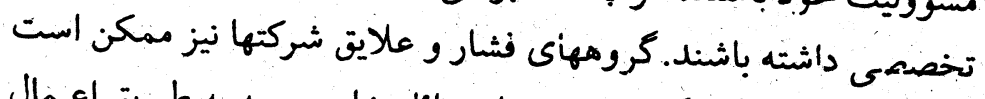

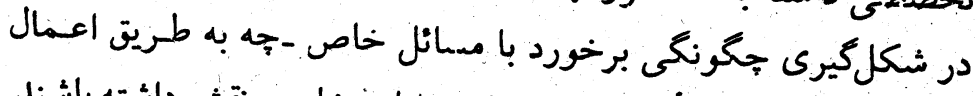

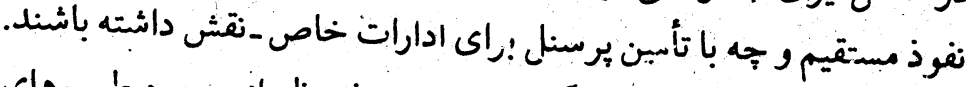

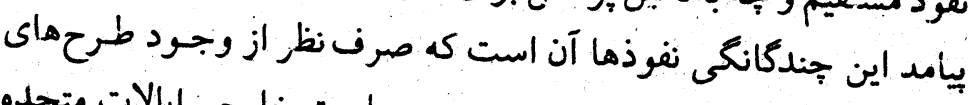
خوب، به ندرت يك فرد هوشمند بشت سياست خارجى ايالات متحده

امبا فقط سأدهانديشترين افراد باور كردند كه دلسوزى شخصى البرايت يا

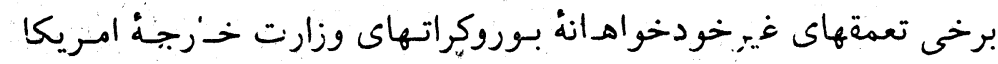
منجر به رويكردى جديد خواهد شد. در واقع اين آخرين جريانى بود كهو

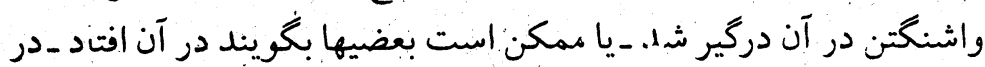
يك بُازى بزرگ قرنبيستمى كه عبارت بود از رقابت ديبلماتيك نظامى بين

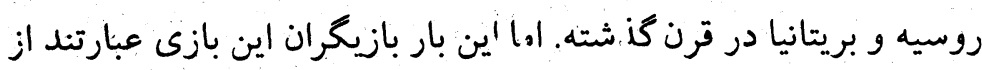

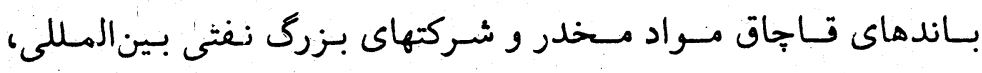
تروريستهاع مدرن و مسافران جادههاى تجارى كمهن. ايـالات مستحده

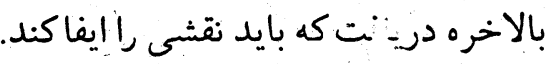

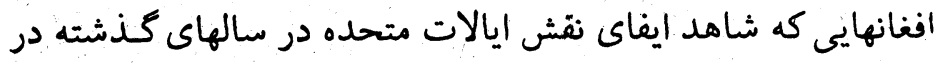
افغانستانبودهاند، حق دارند از تغيير سياست ايالات متحده سردركم و خحتى حيران شوند. يكى از دلايل اين اهر آن است كه بروسهوناي تعيين سياست خارجيَ

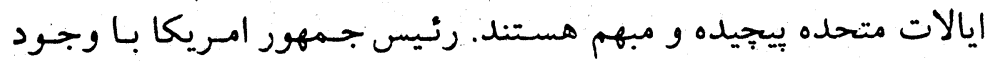

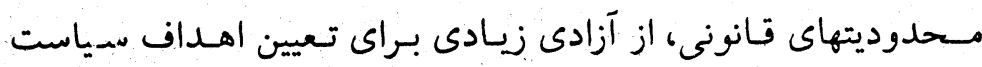

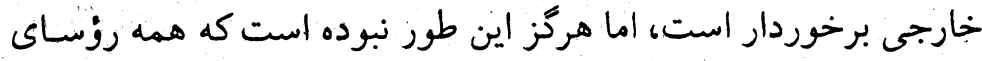
جمهور اين كشور علاقهُ زيادى به امور خارجه داشته بانشند؛ يا آنهايى كه.

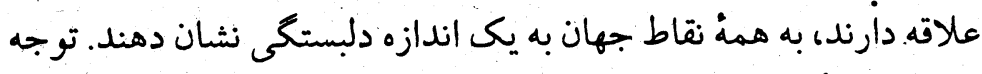

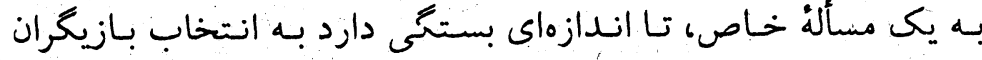

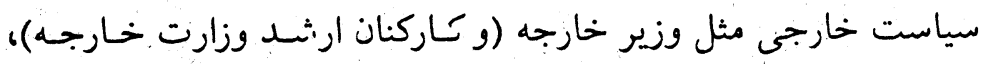

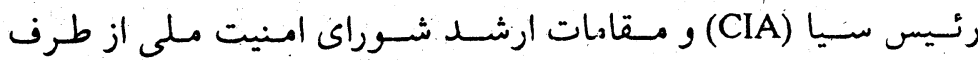
رنيس جمهور و اينكه آن س أله توجه آنها را جلنب كند. اما بيشتر اين قضيه 


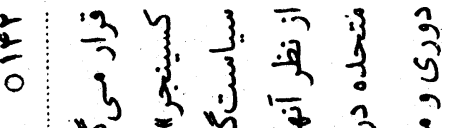
?

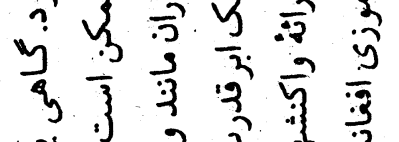

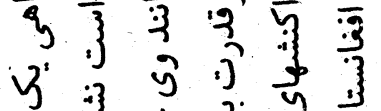

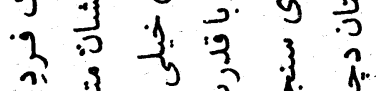

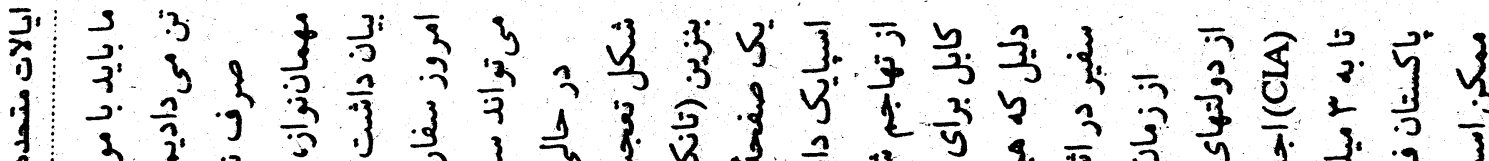

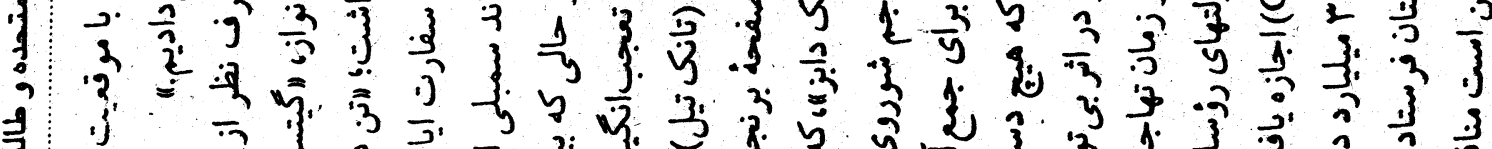

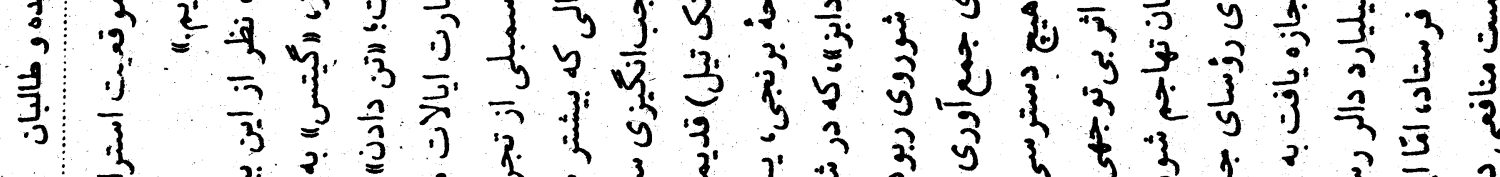

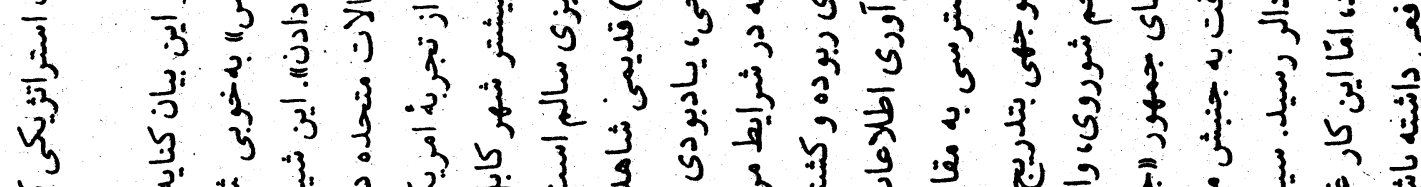

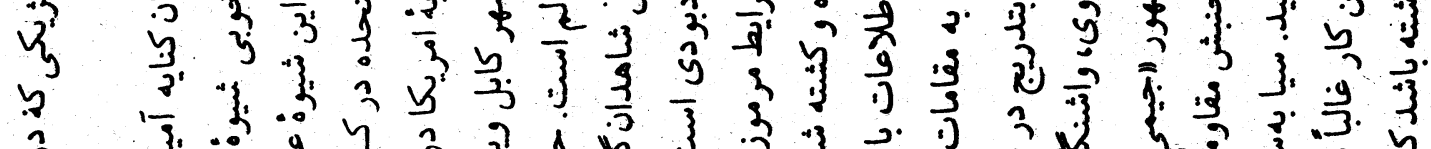

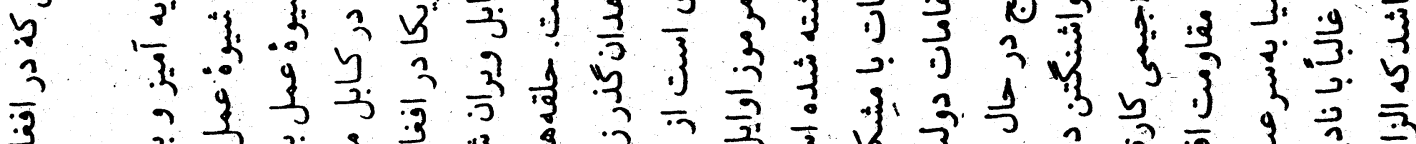

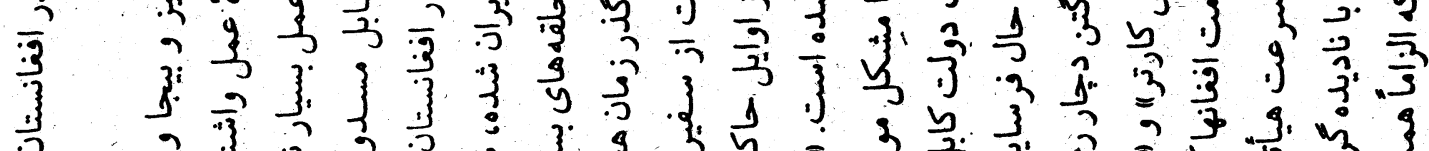

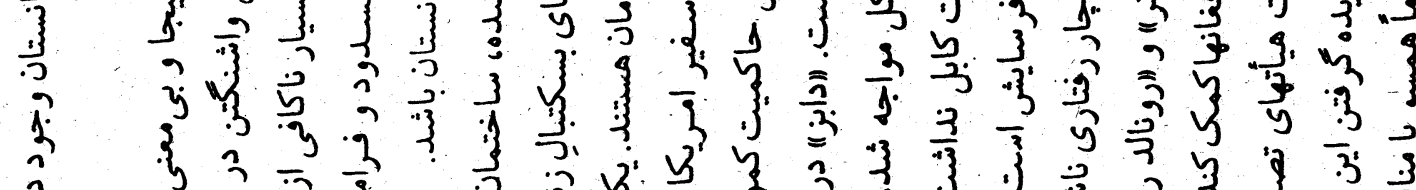

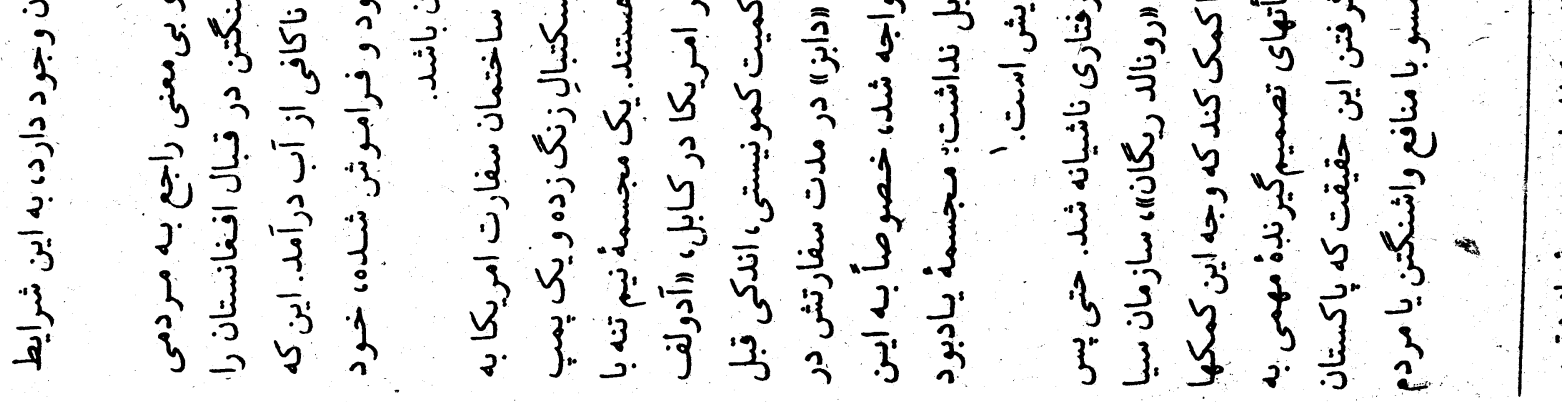


همين مقطع زمانى طالبان در حال رشد و تكامل بودند. ظهور مرموز اين

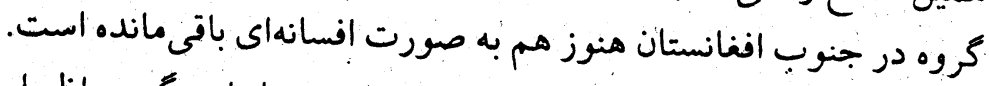

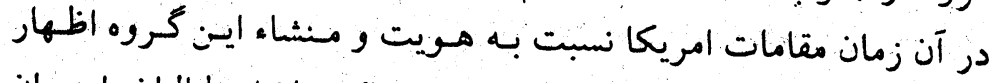

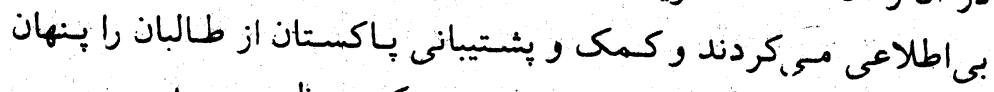

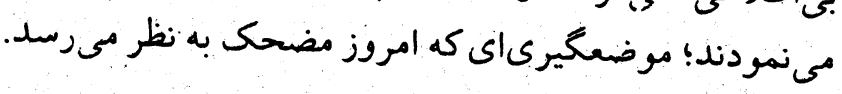

\section{. منافع 'يالات متحده و طالبان}

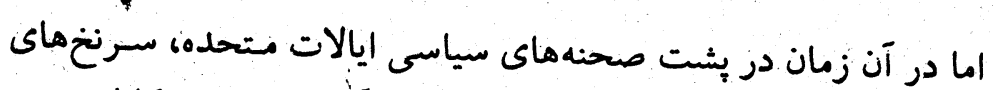

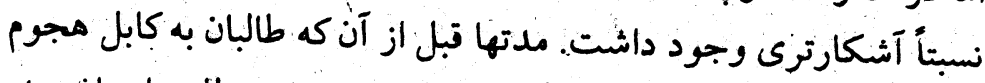

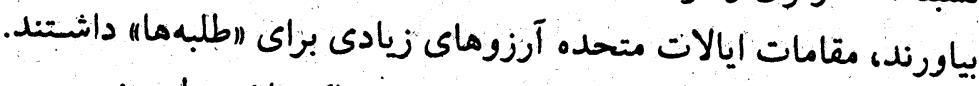

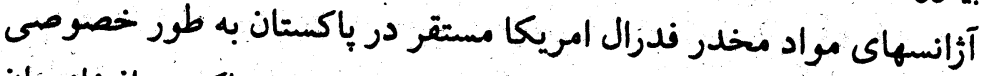

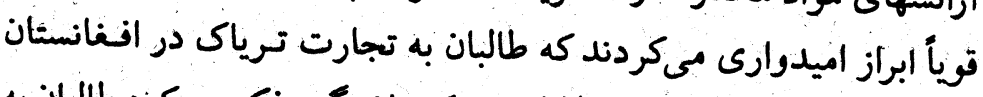

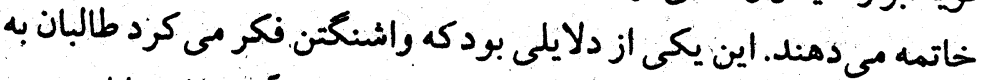

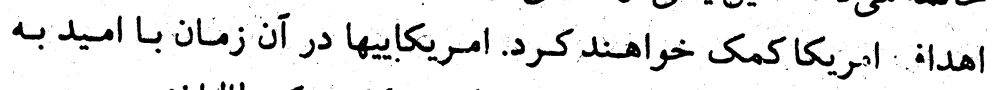

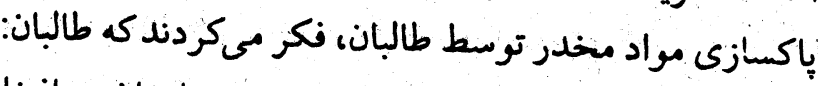

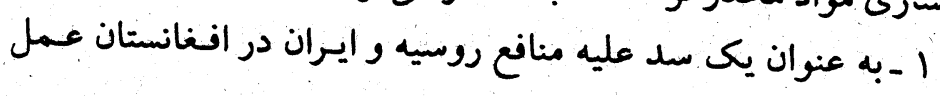

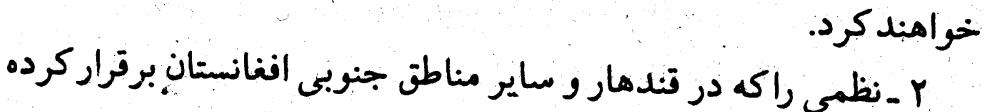

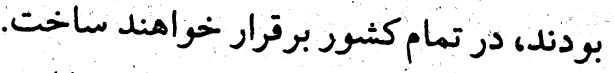

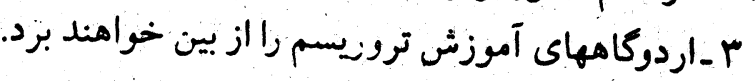

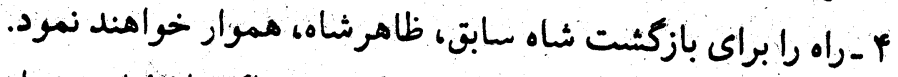

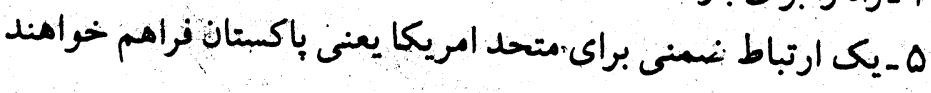

افغانستان، طالبان، و سياستهاى جهانى

olff

افغانستان نباشد، صورنت گرفت. اولين مصداق اين عدم موفقيت عبارت

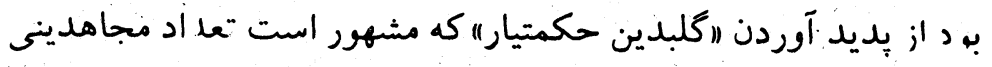

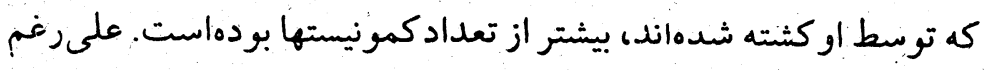

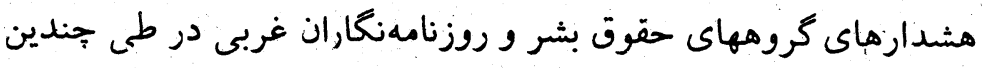

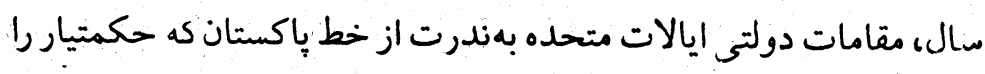

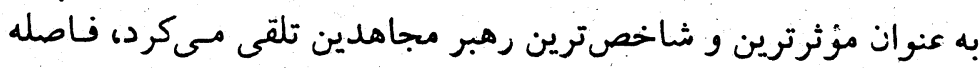
كرفتند.

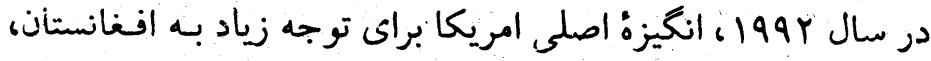

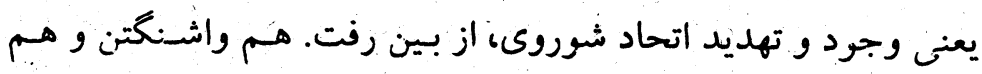

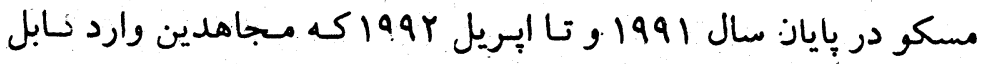

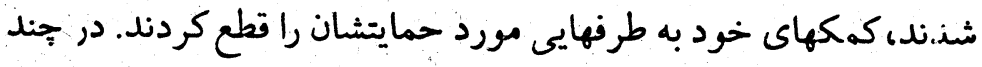

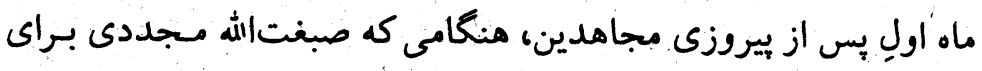

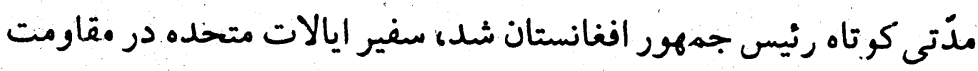

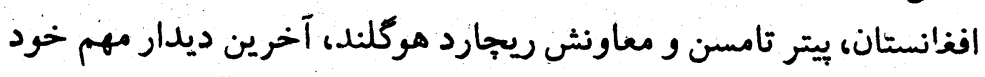

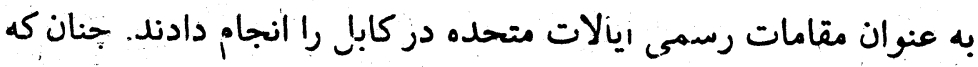

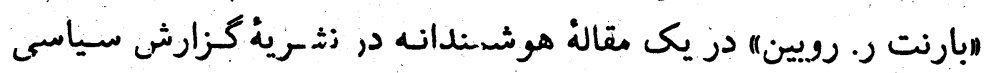

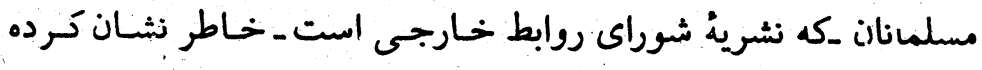

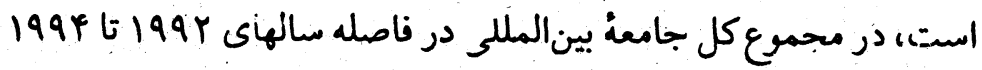

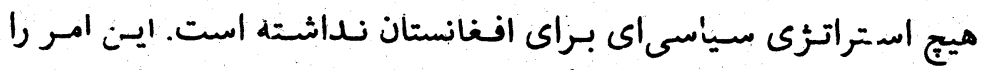

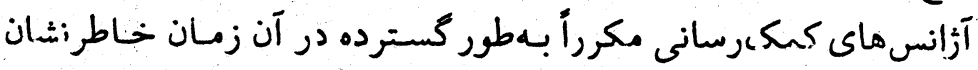

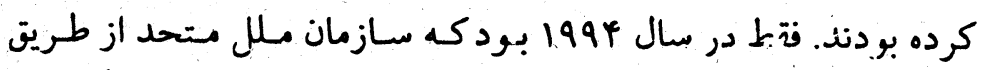

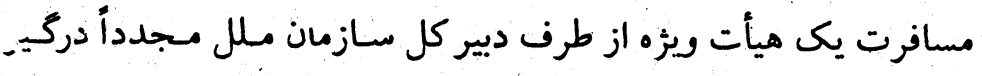

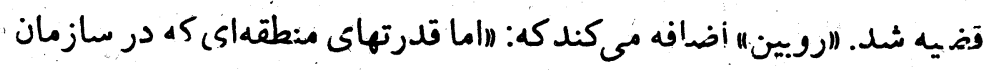

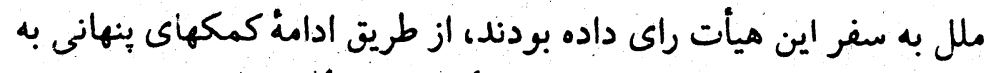

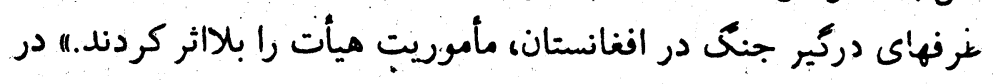




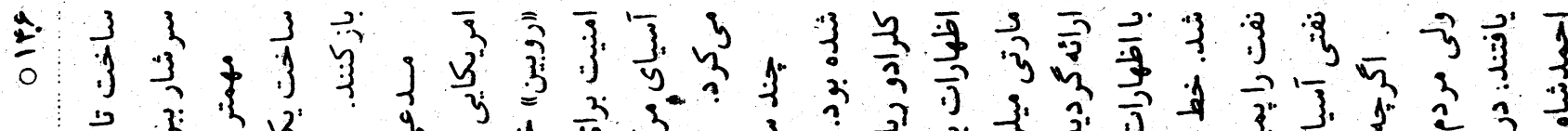

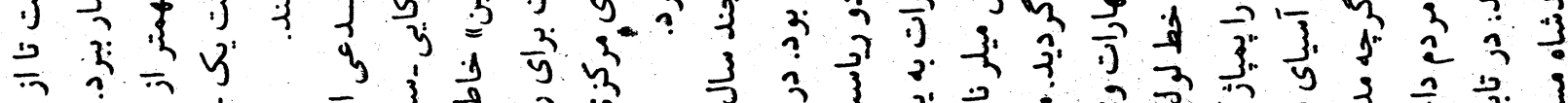

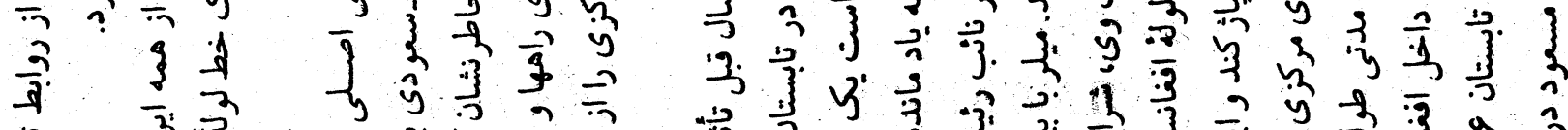

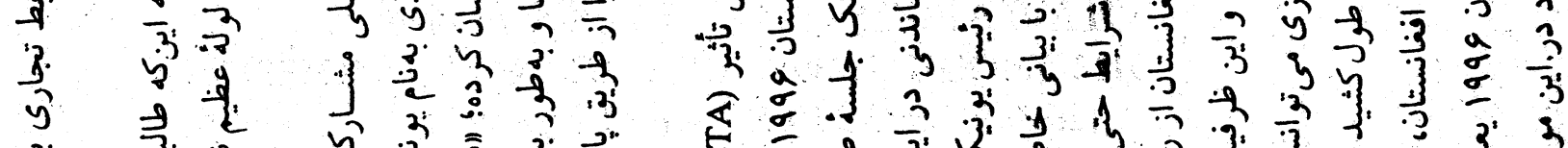

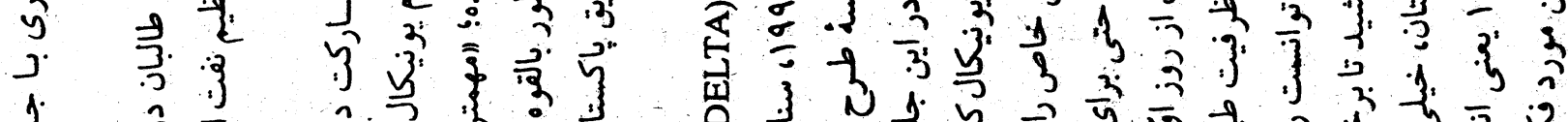

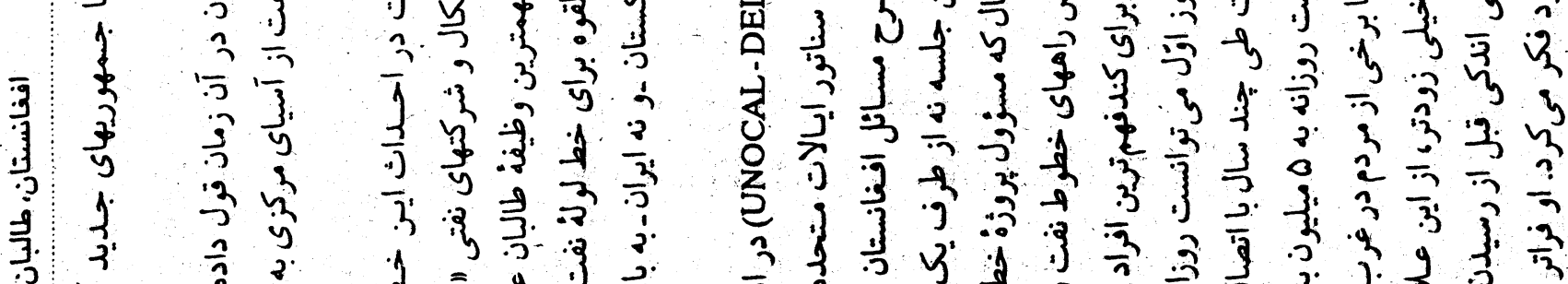
2. 1. 303

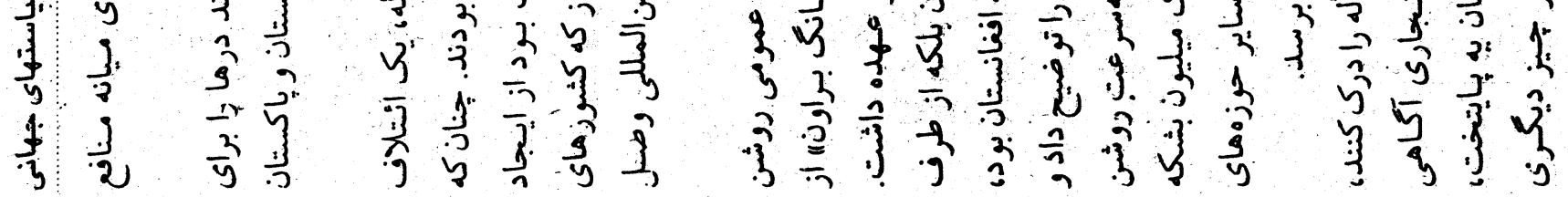

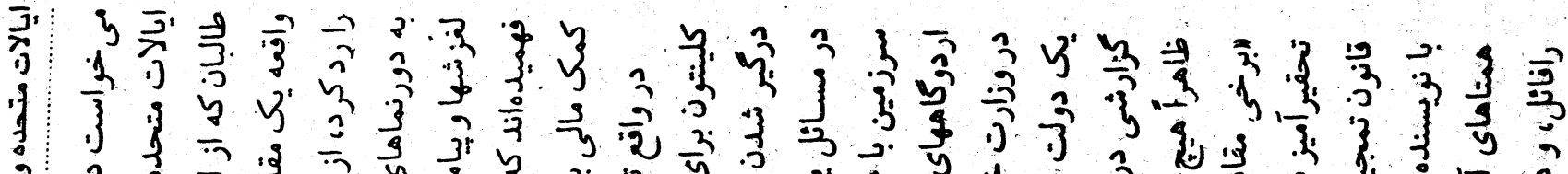
3. 等

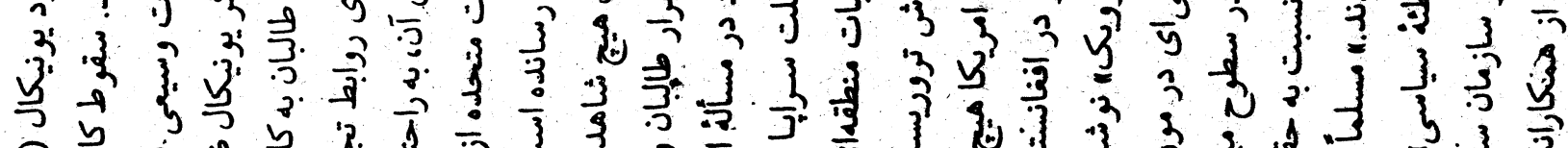

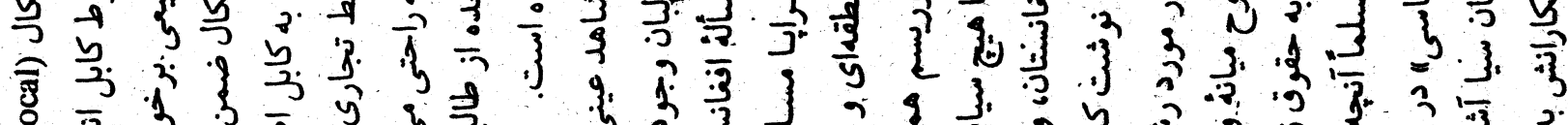

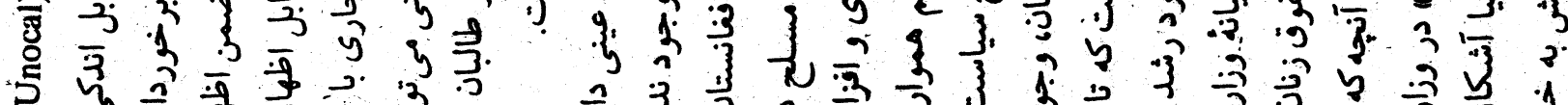

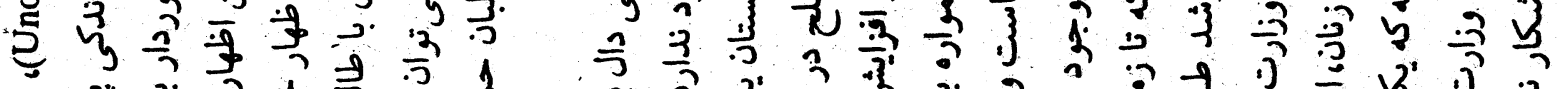

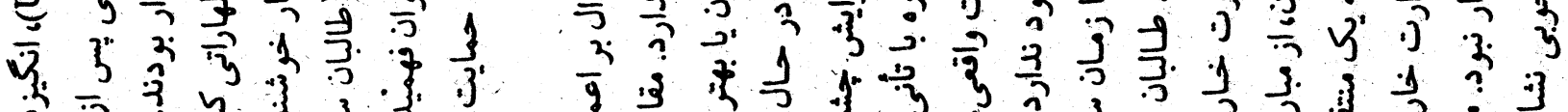

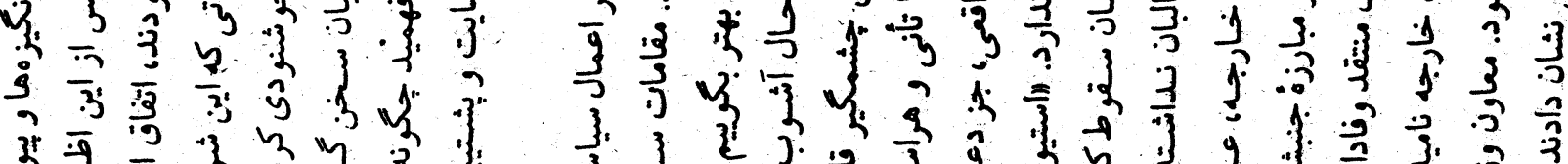

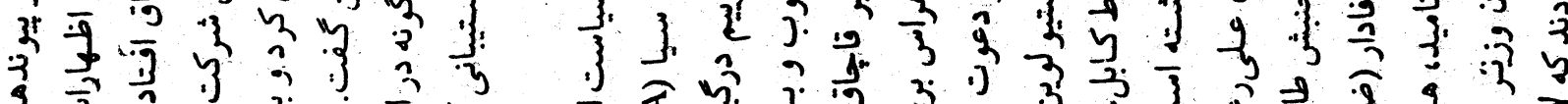

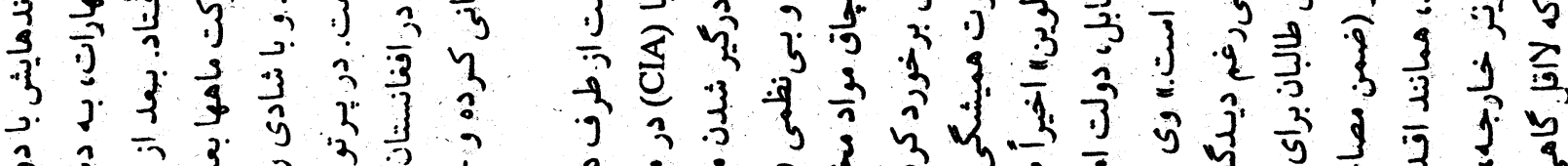

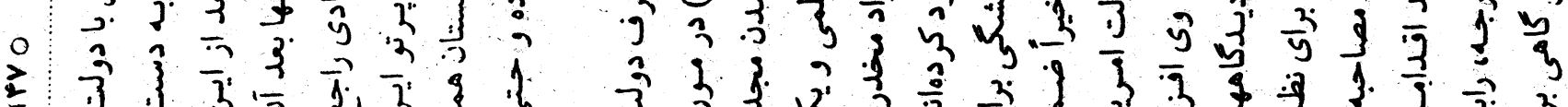

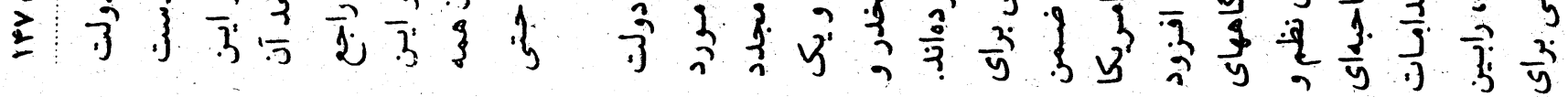


플. 콕.

ล

मे $\overline{3}$.

?)

i $2 \overrightarrow{1}$ iे

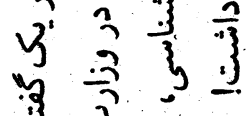

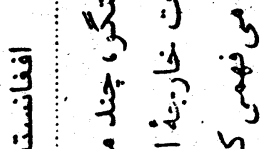

$3 \div \frac{3}{3} y$

3. $3 ; \mathrm{V}^{2} \cdot \frac{9}{3}$

:

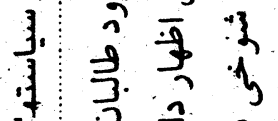

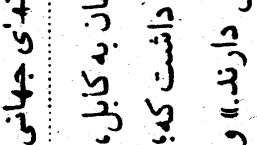

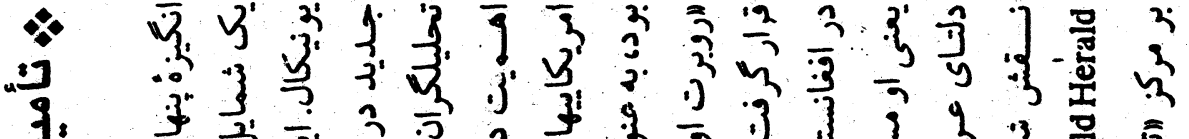

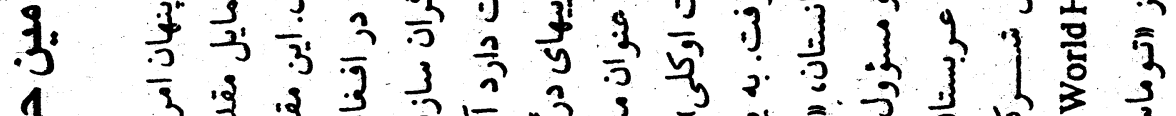

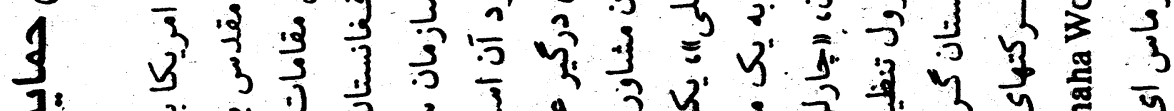

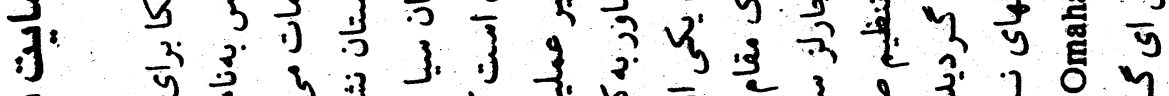

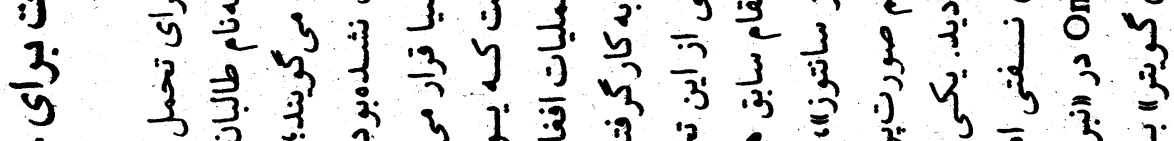

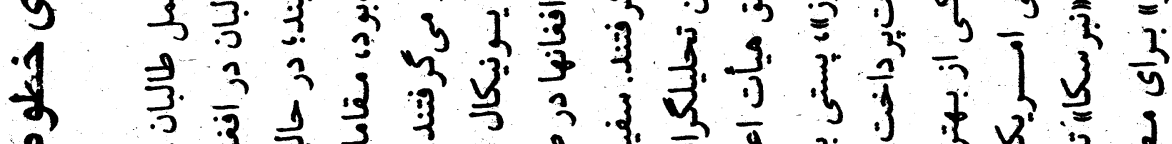

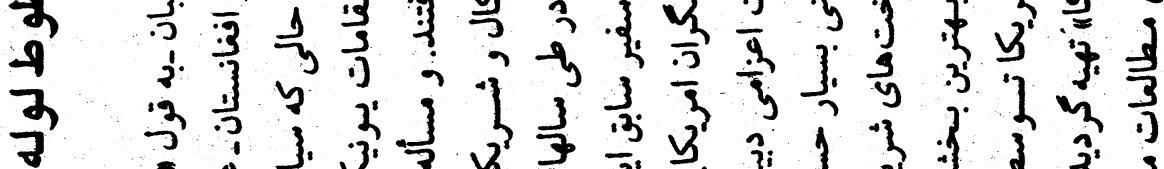

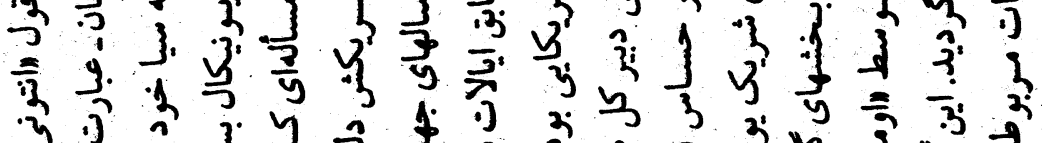

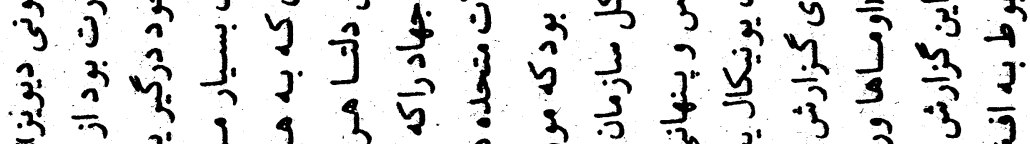

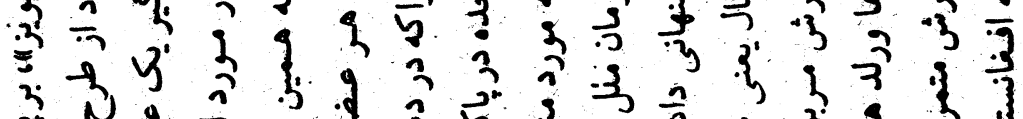

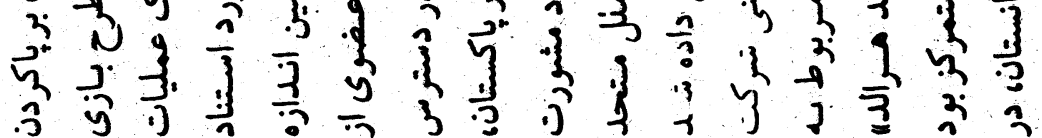

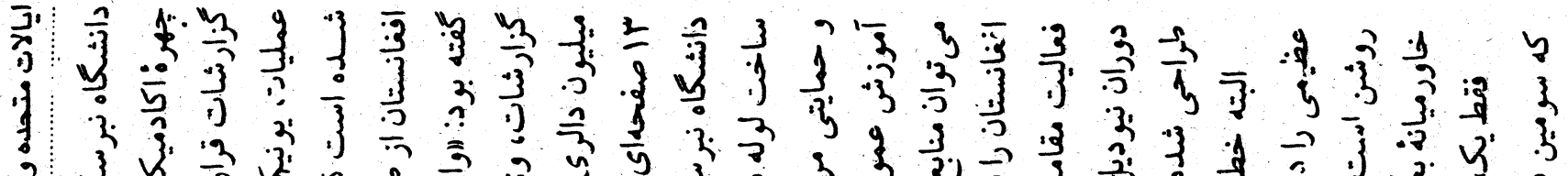

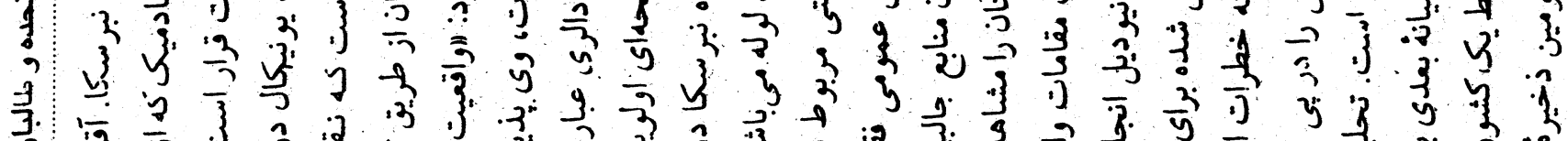

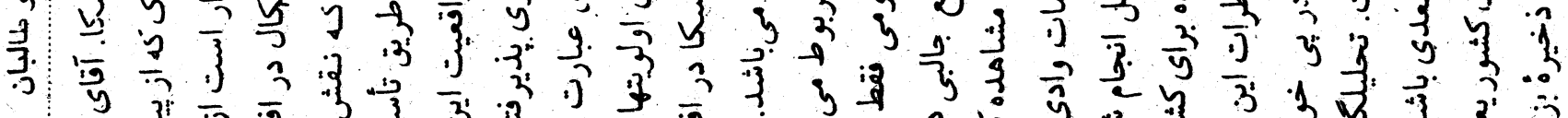

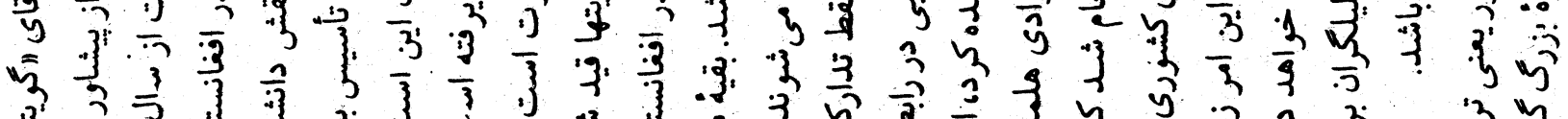

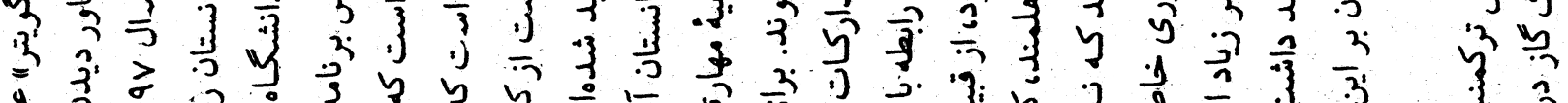

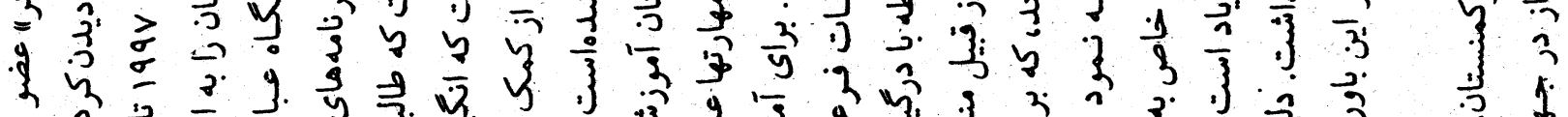

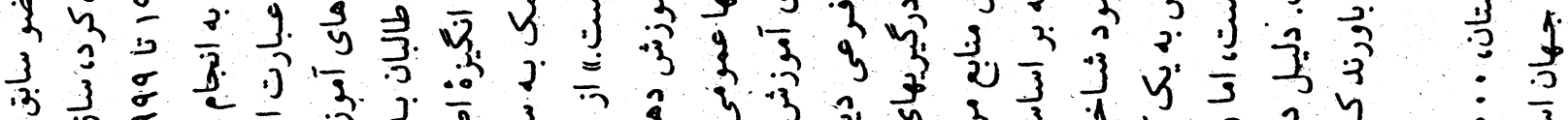

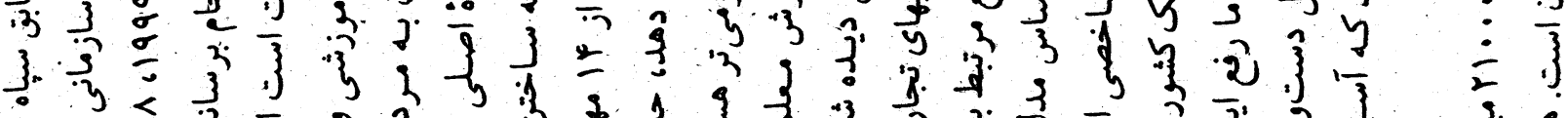

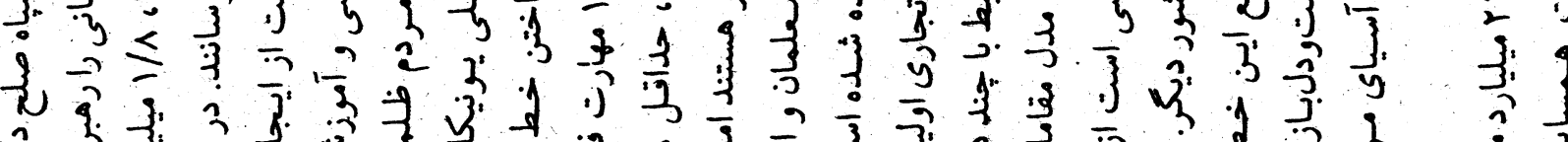

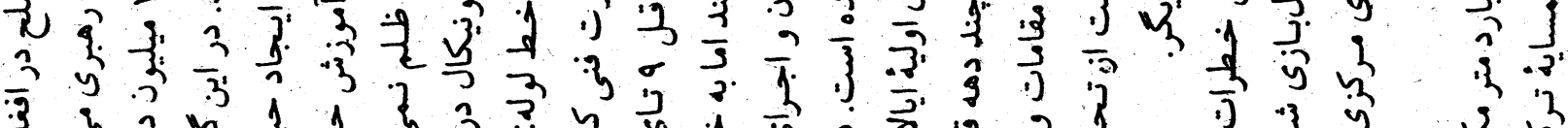

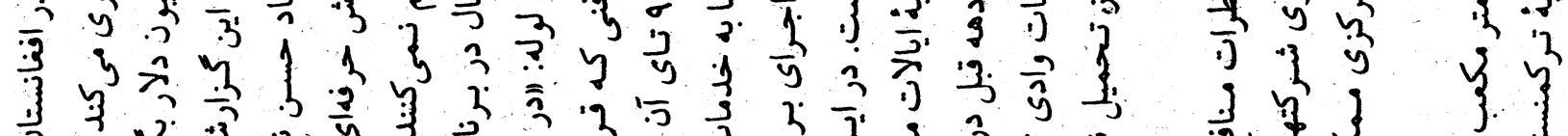

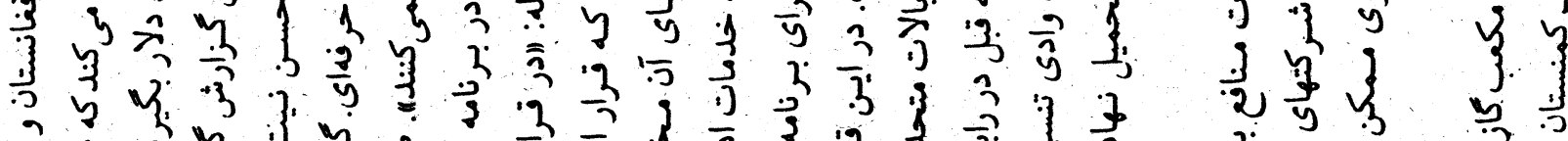

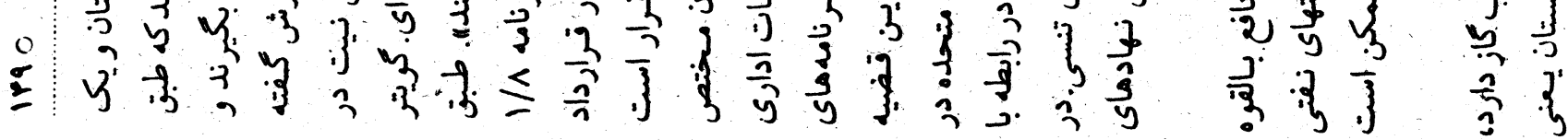




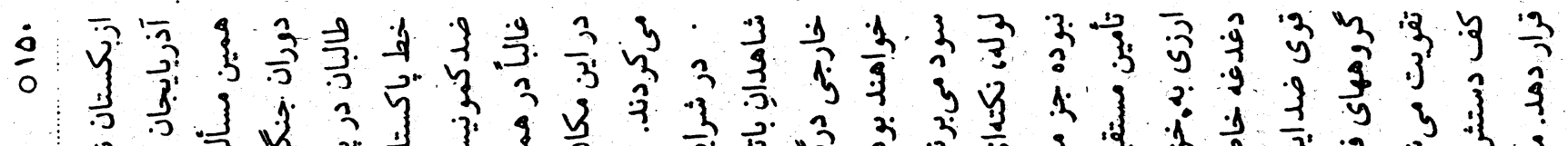

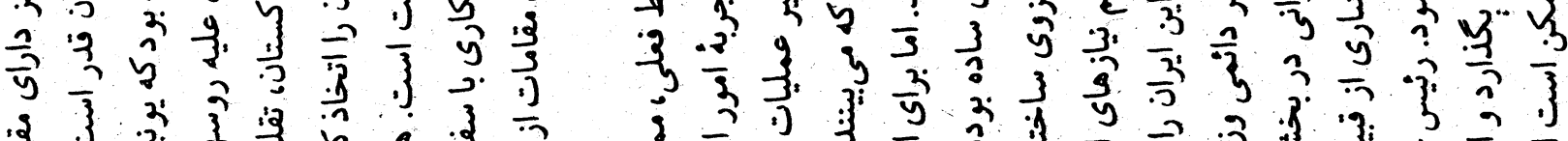

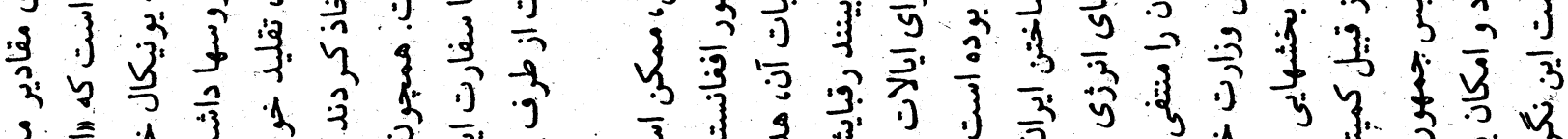

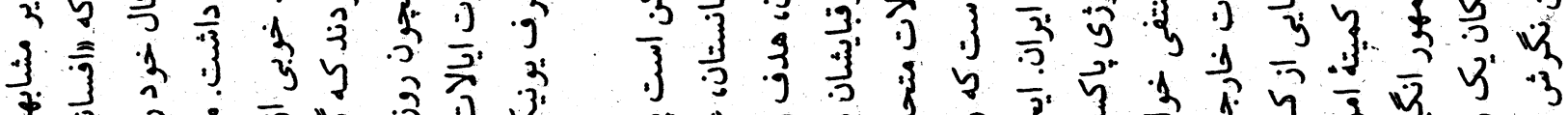

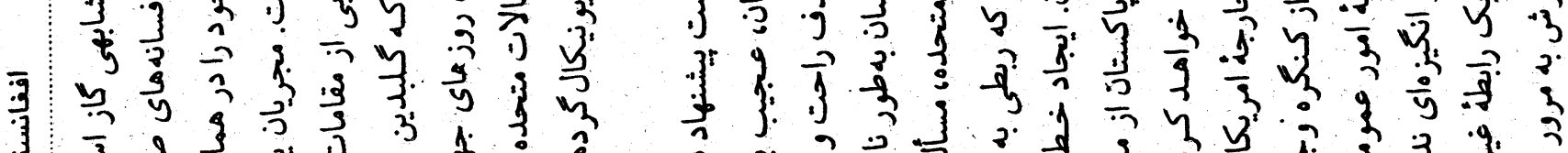
- 3$\}$

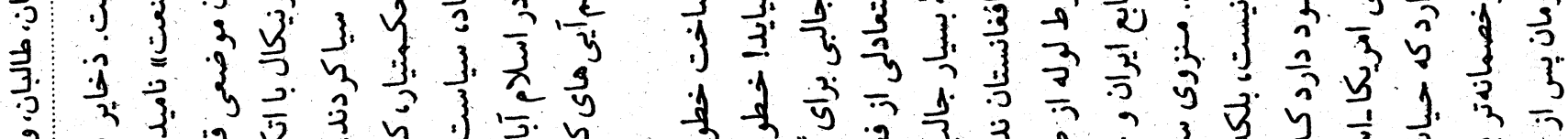

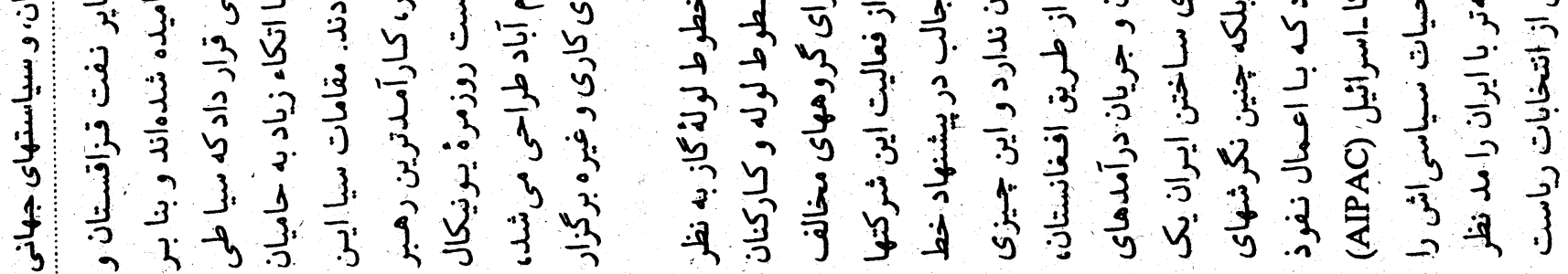

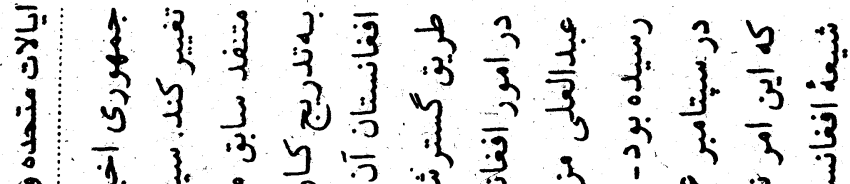
: 130

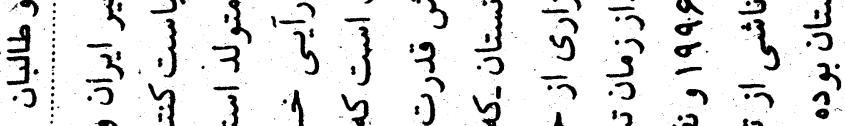

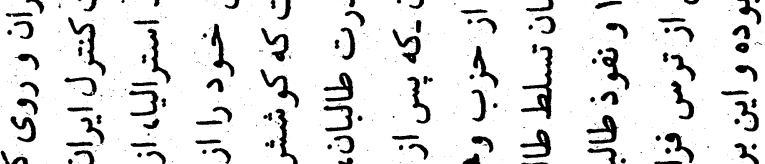

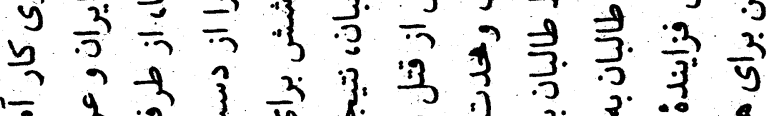

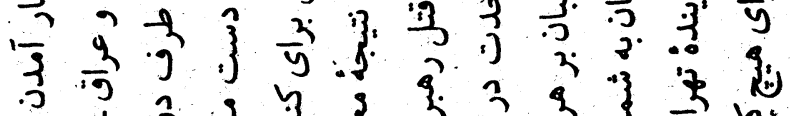

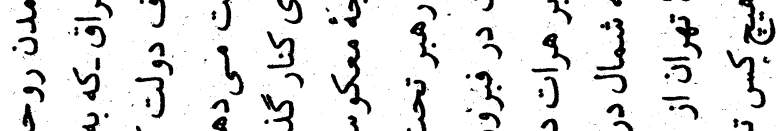

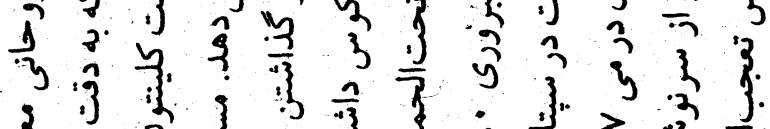

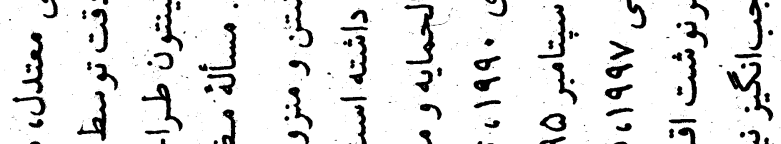

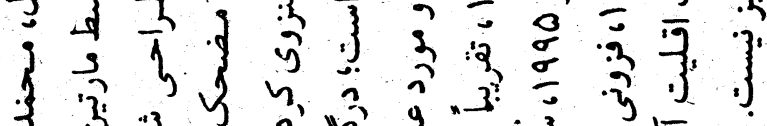

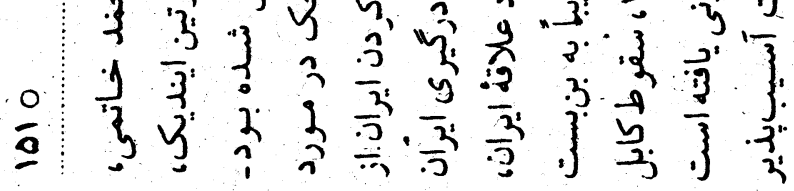

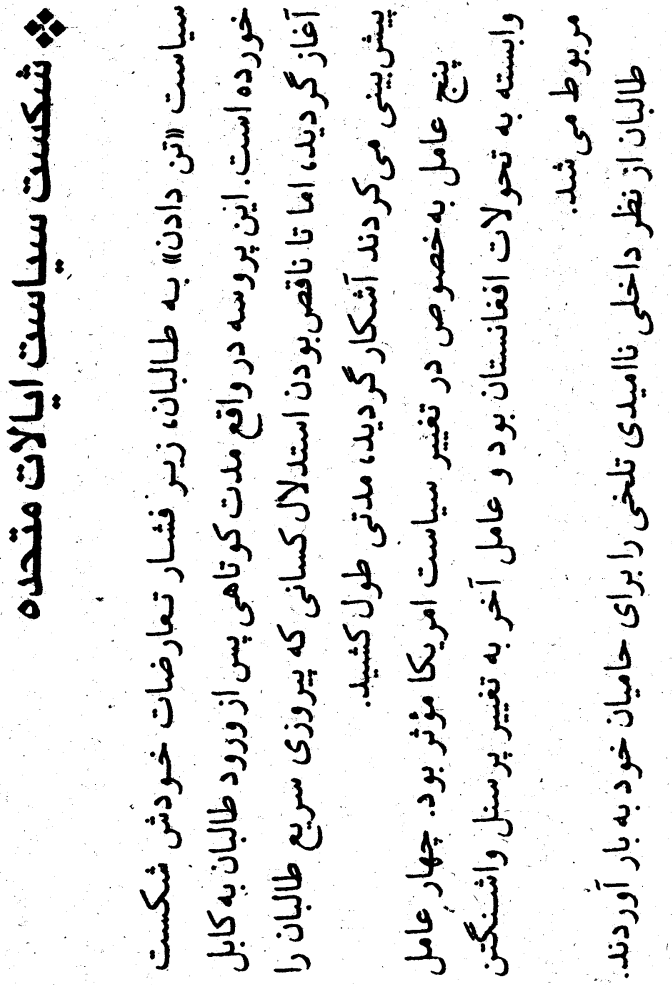




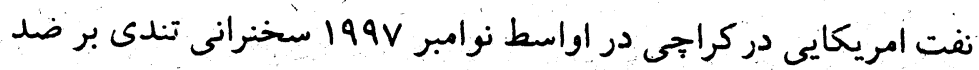

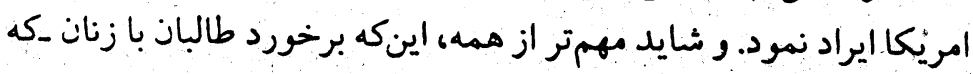

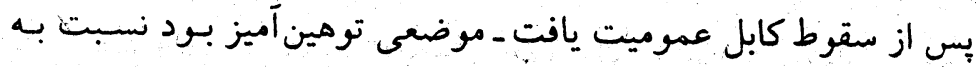

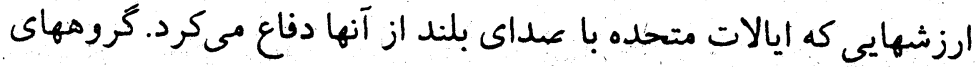

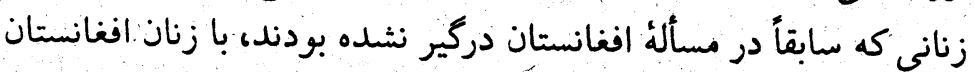

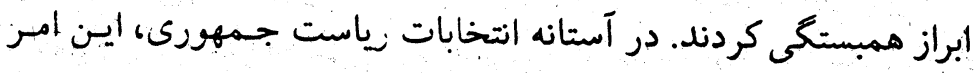

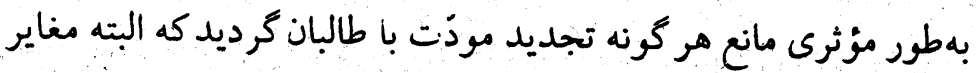

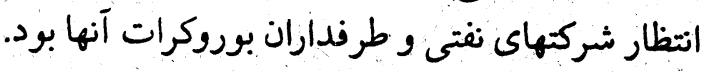

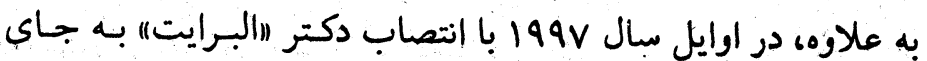

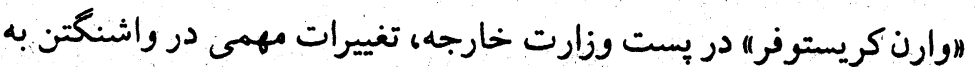

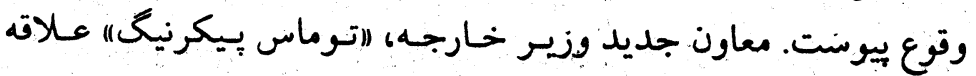

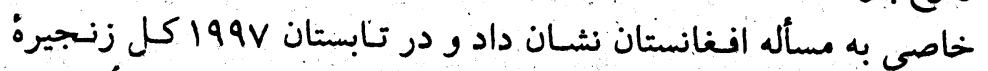

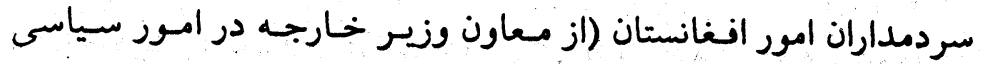

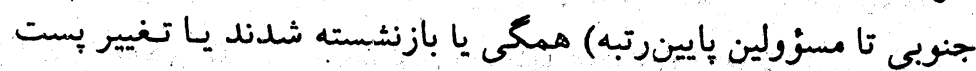

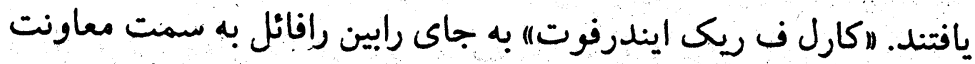

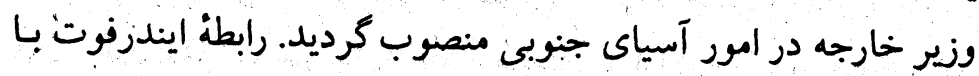

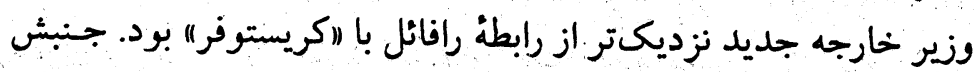

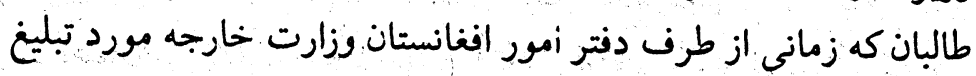

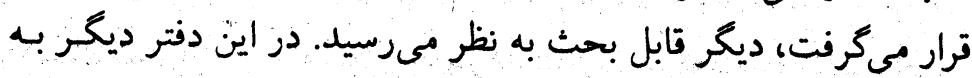

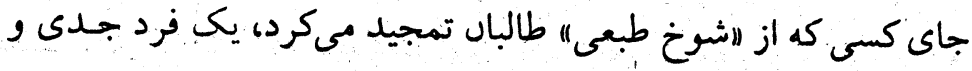

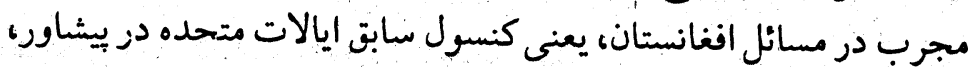

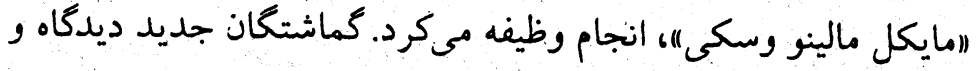

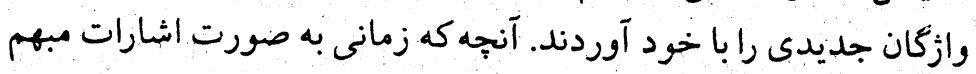

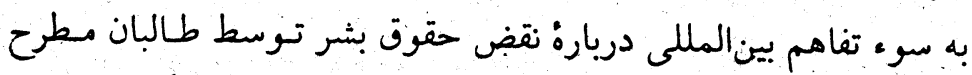

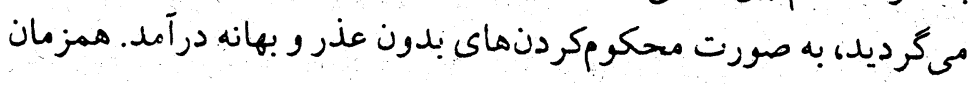

ثابت شُد كه آنها قادر نيستند كنترل خود را به نسرعت بر تمام افغانستان

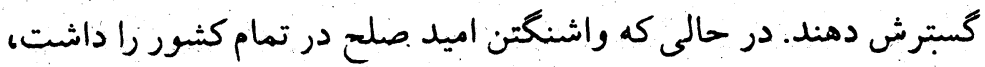

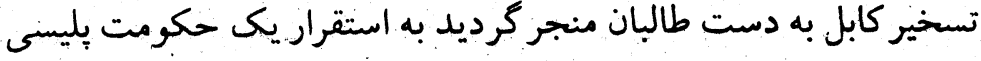

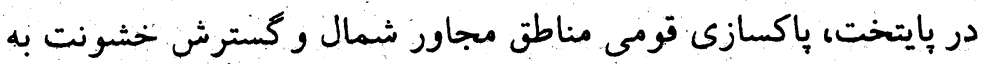

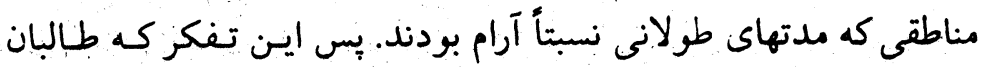

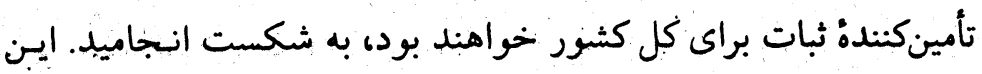

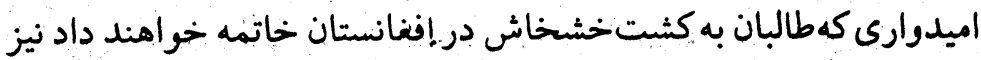

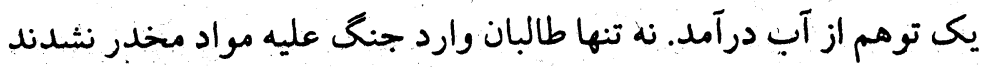

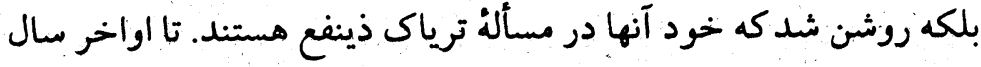

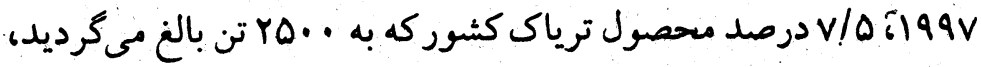

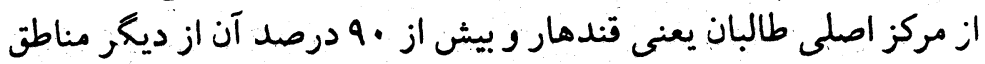

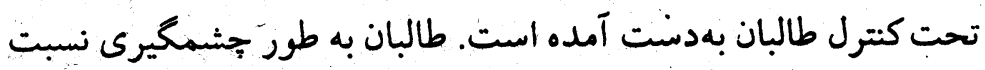

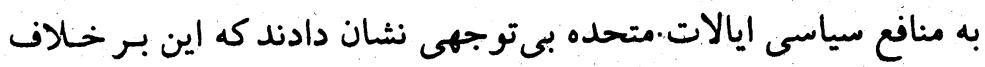

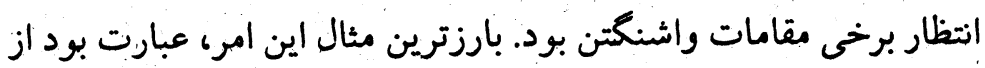

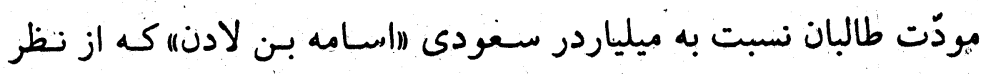

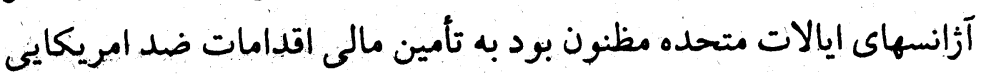

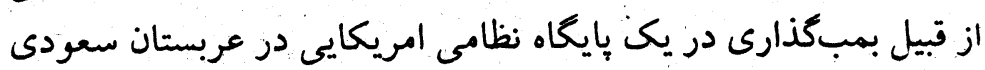

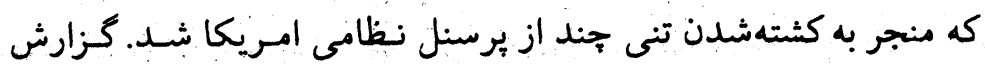

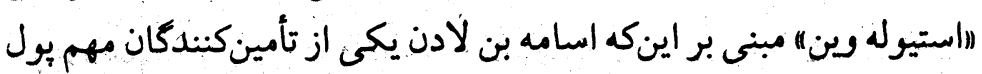

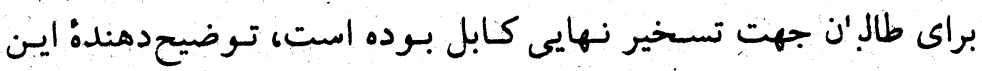

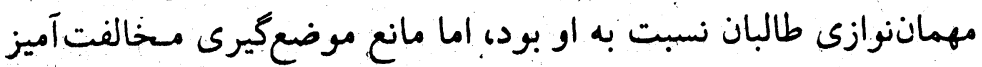

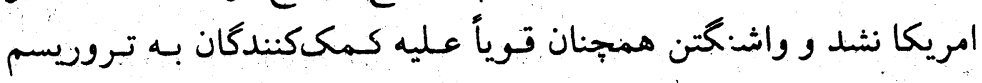

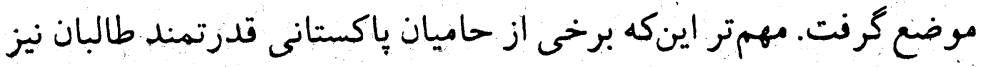

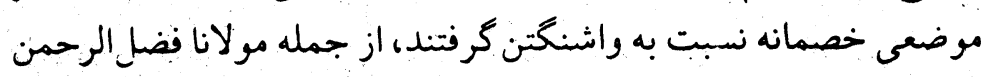

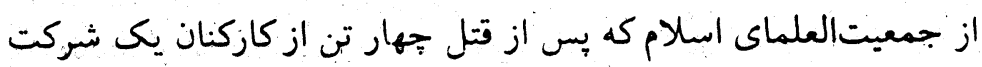




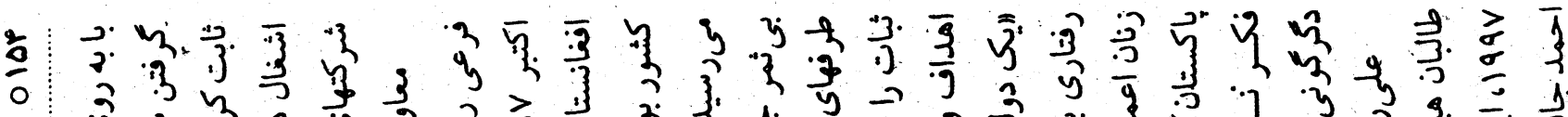

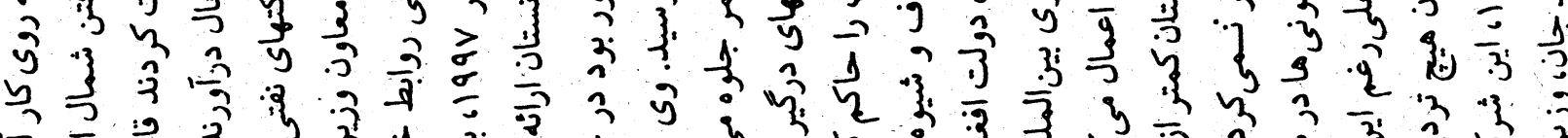

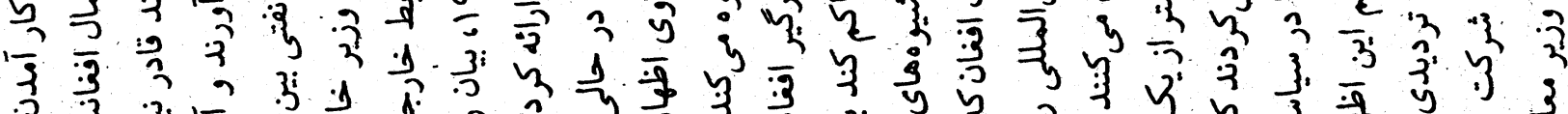

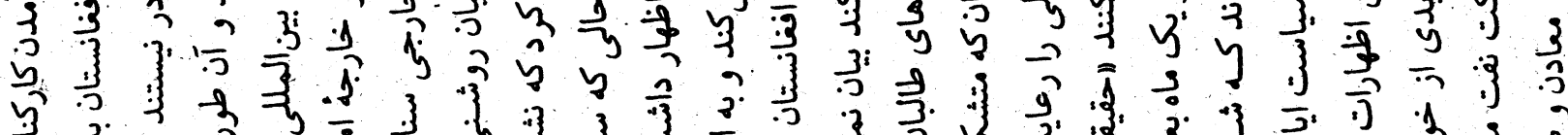

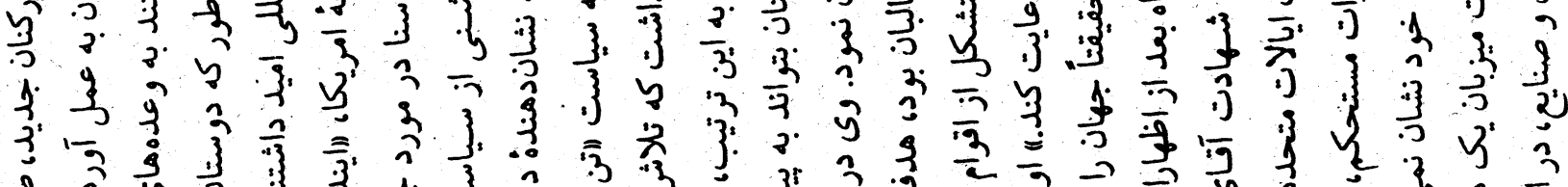

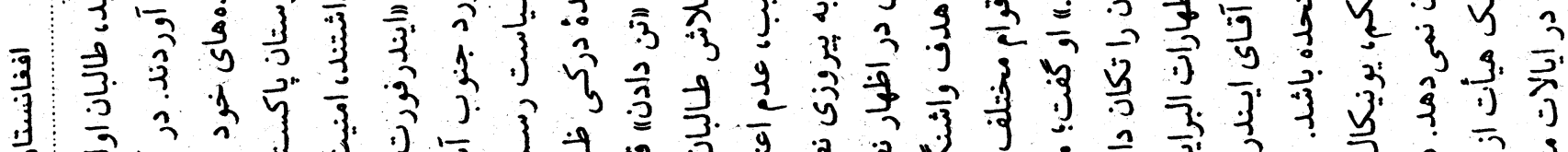

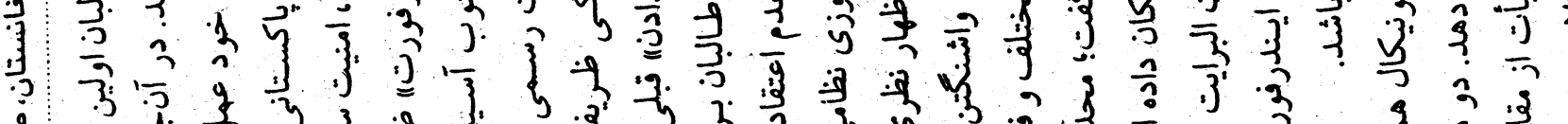

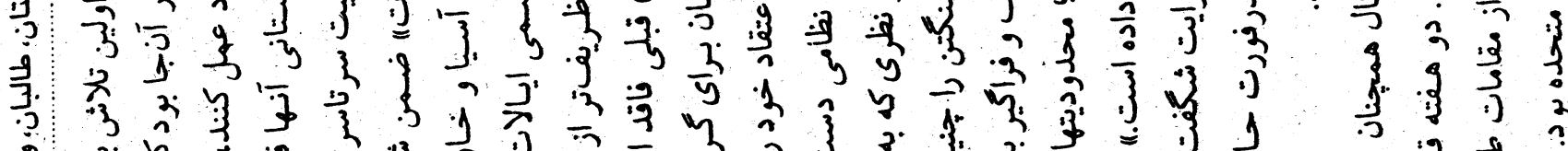

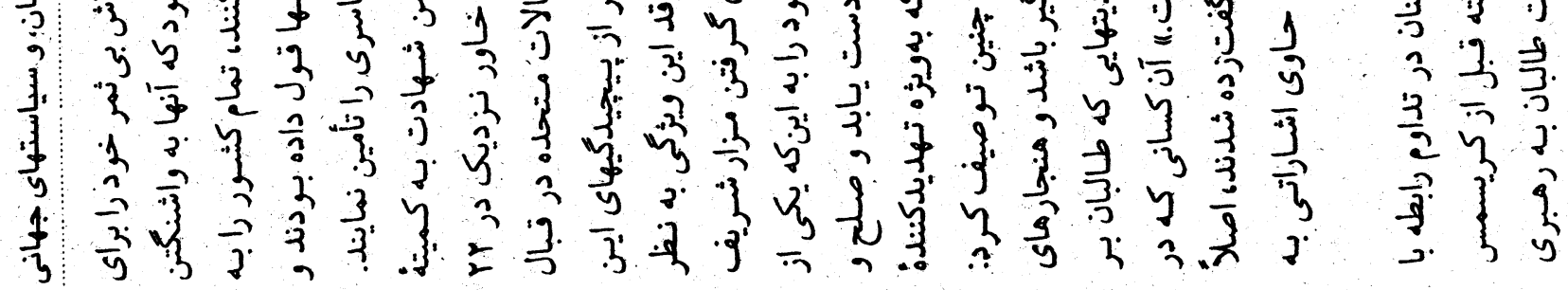

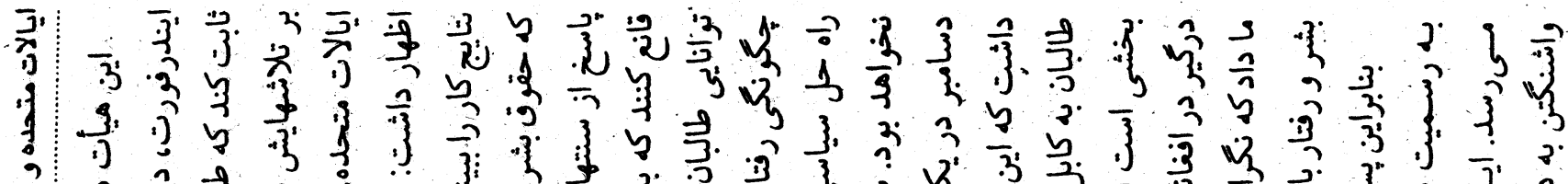

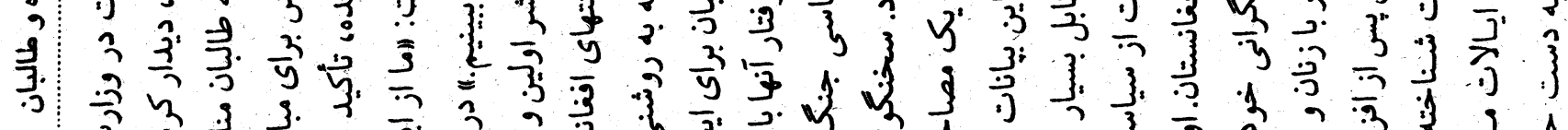

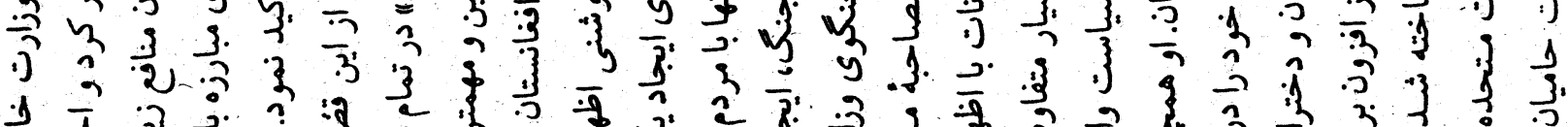

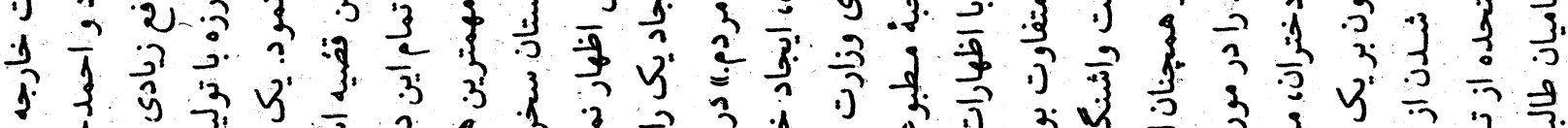

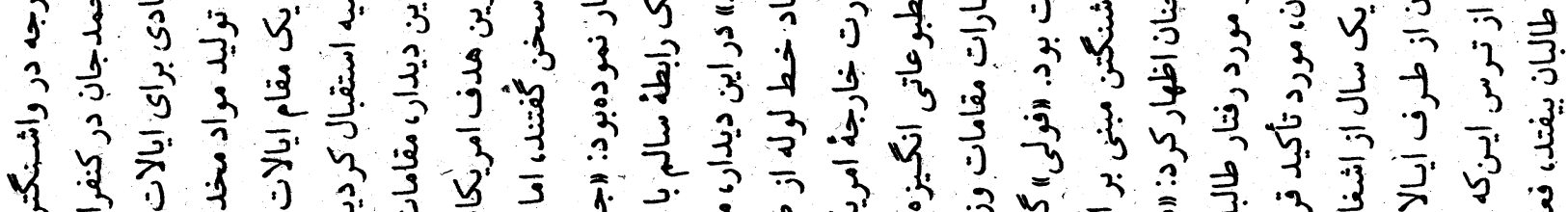

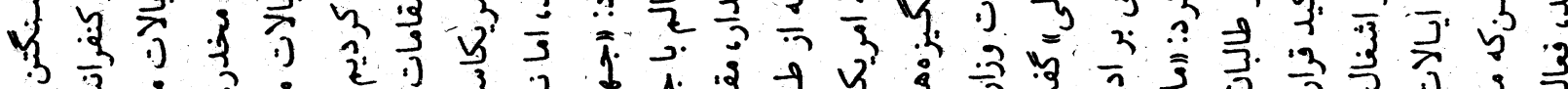

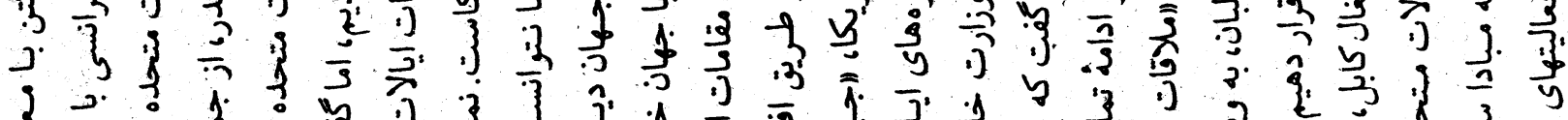

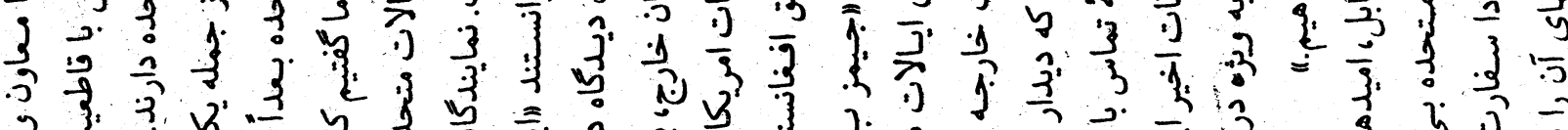

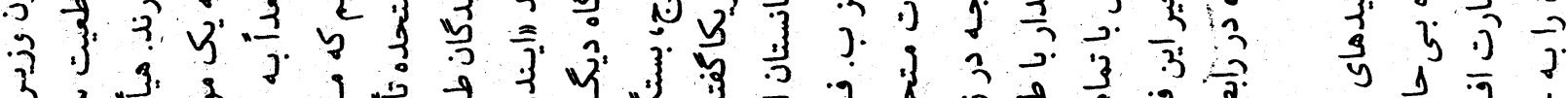

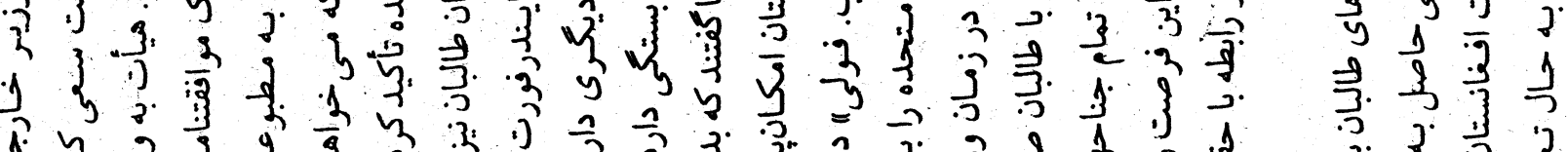

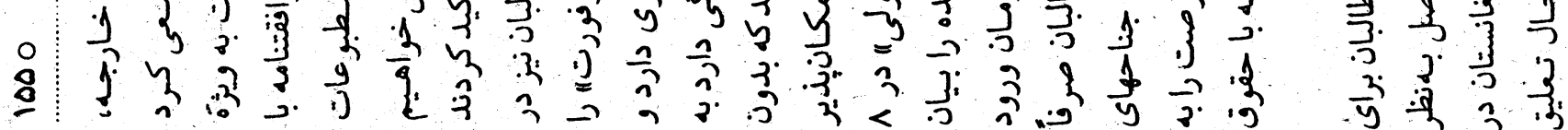




\section{عربستان سعودى، إبران

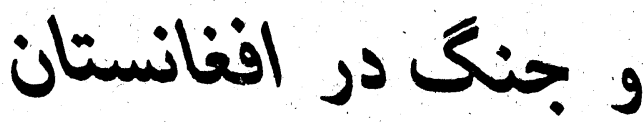

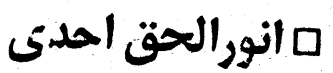

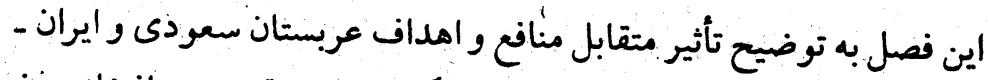

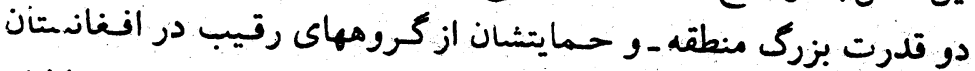

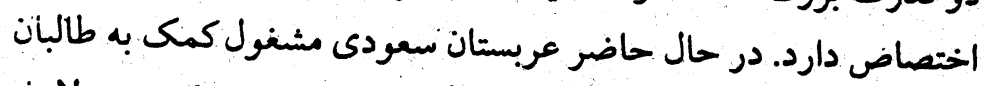

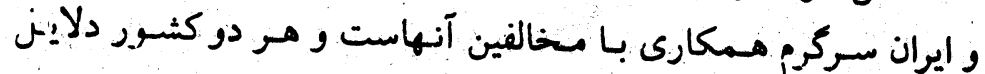

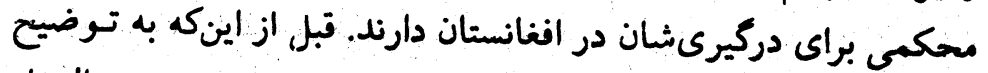

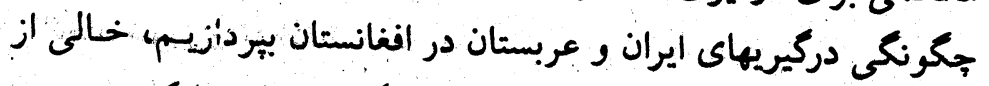

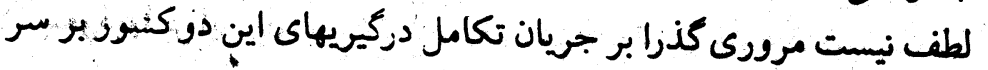
موضوع افغانستان داشته باشيم. بردير

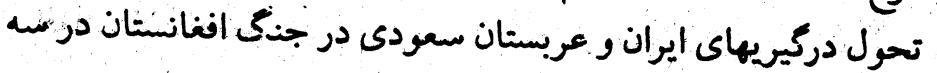

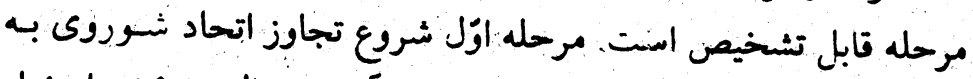

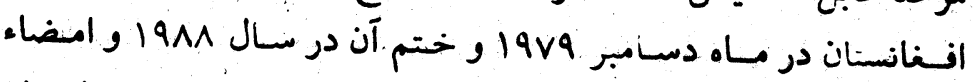

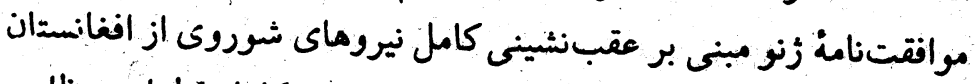

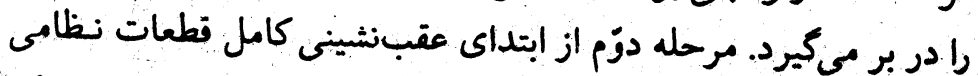

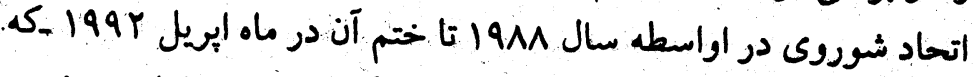

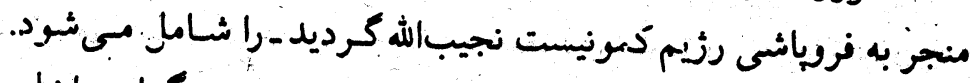

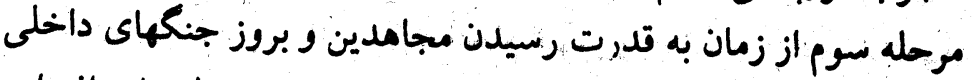

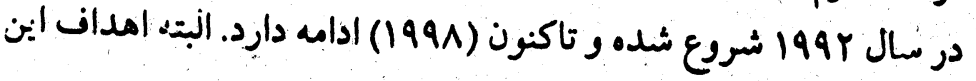

افغانستان، طائبان، و سياستهاى جهانى

درآورده است و جنان كه مادلين البرايت با حملهماى لفظى خود به به طالبان

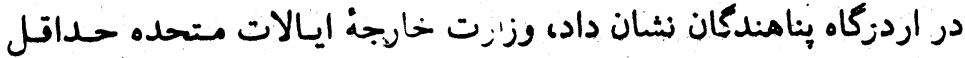

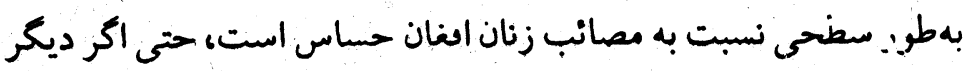

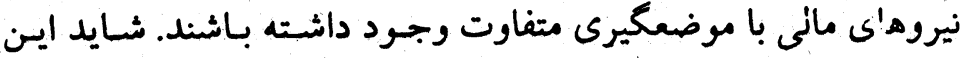

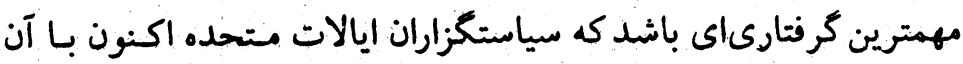

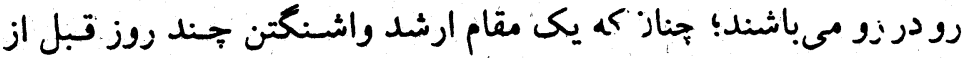

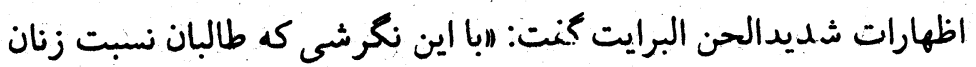

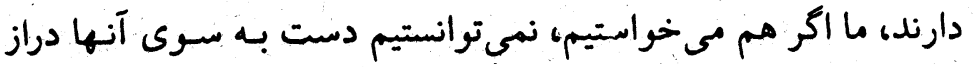




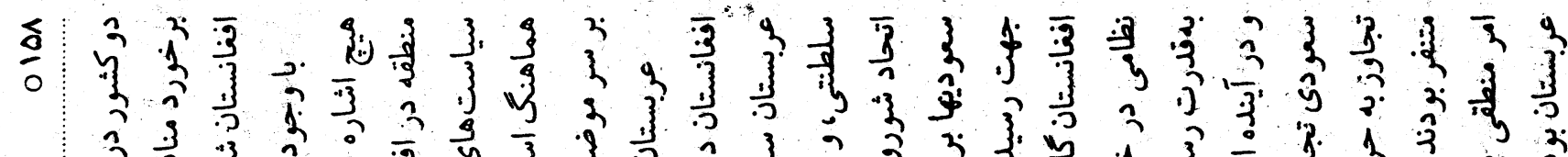

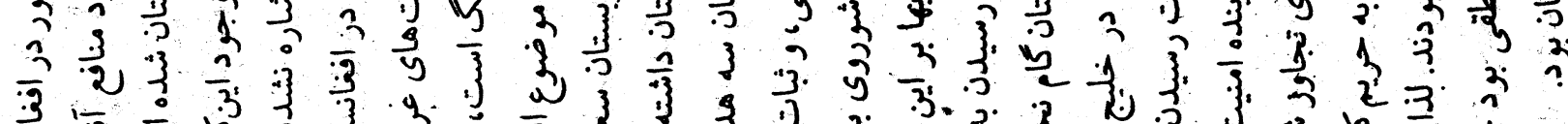

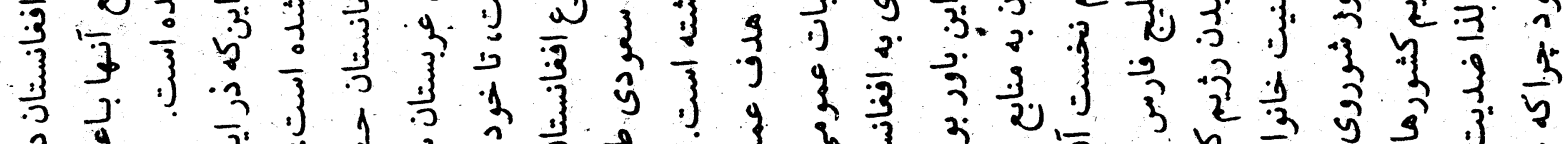
$\frac{2}{3}=3$

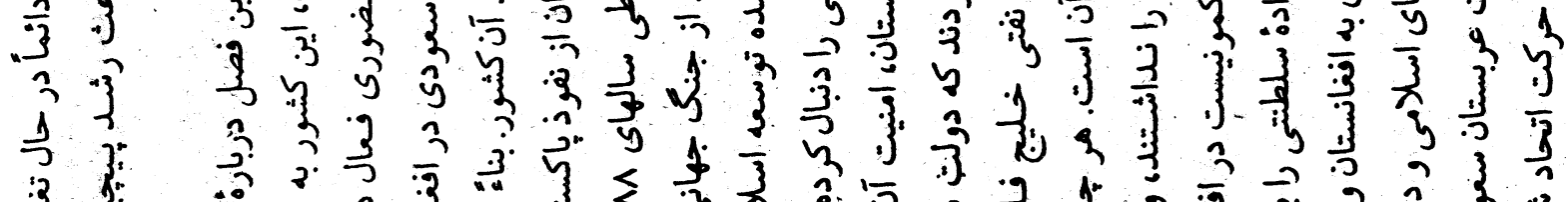

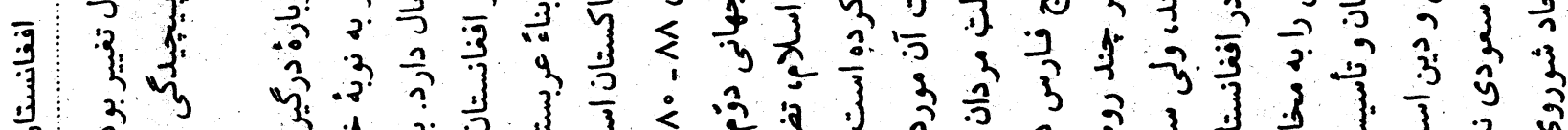

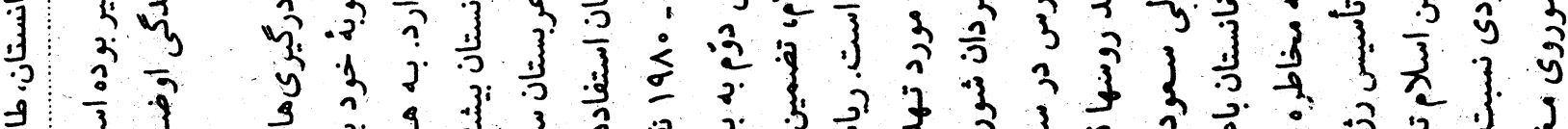

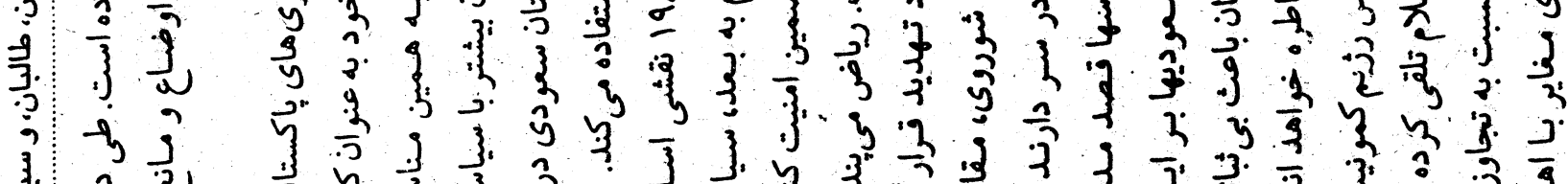
. की

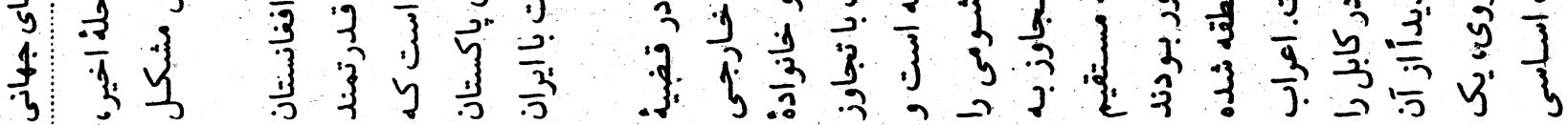

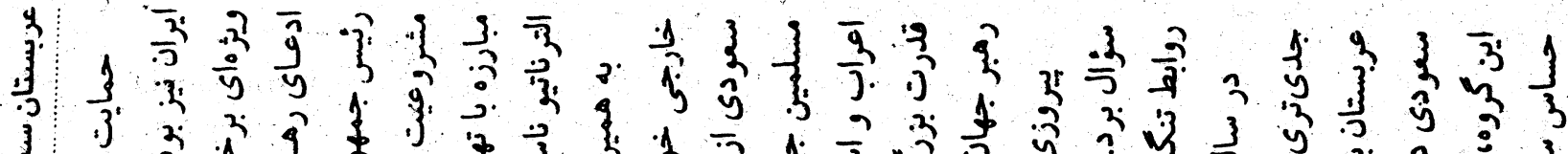

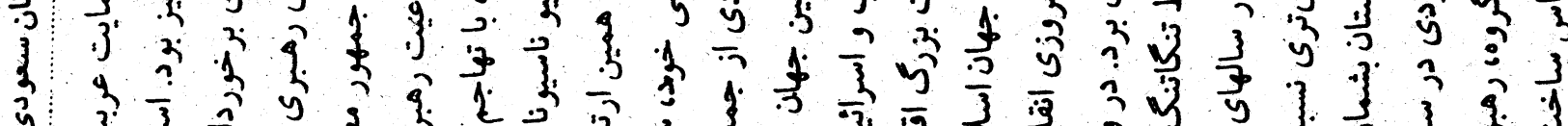

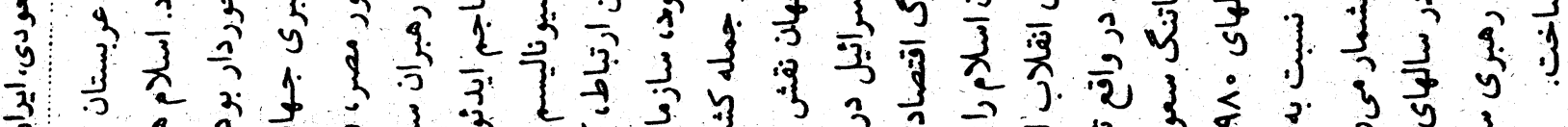

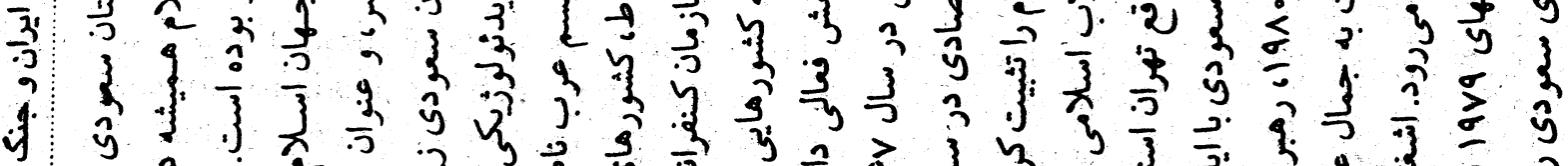

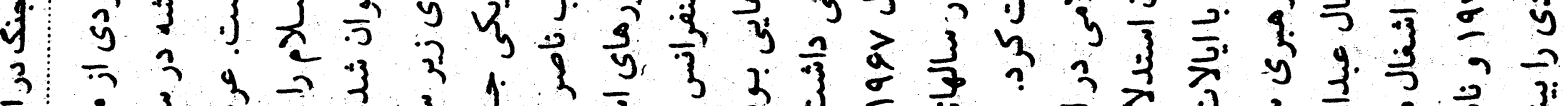

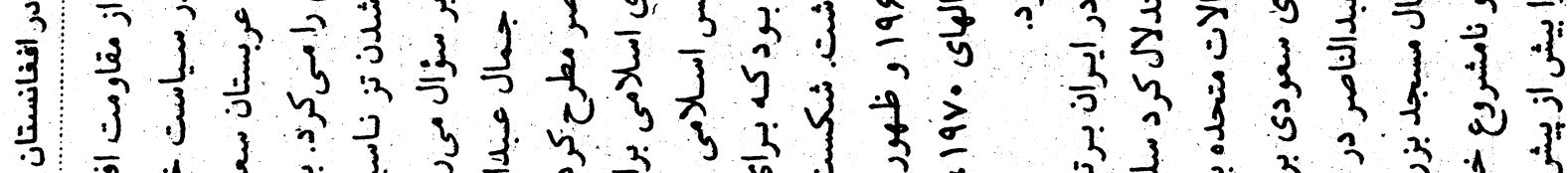

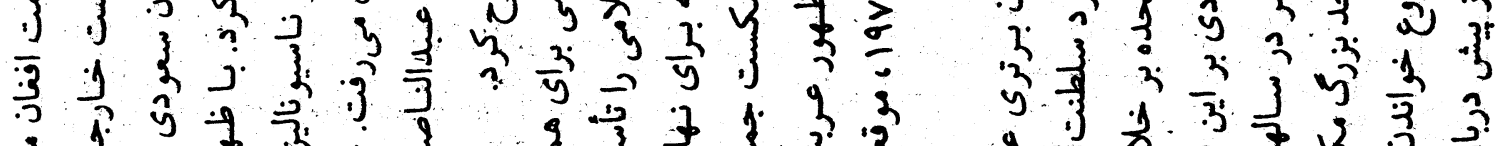

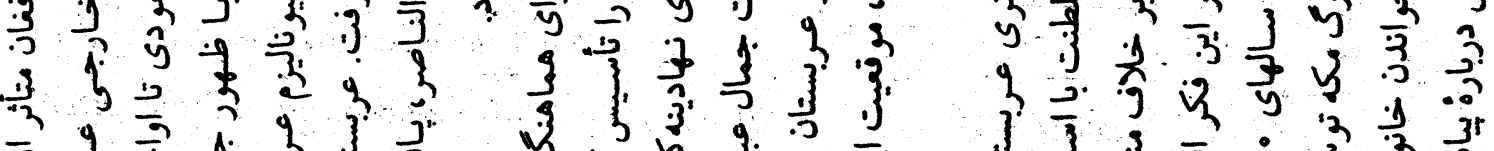

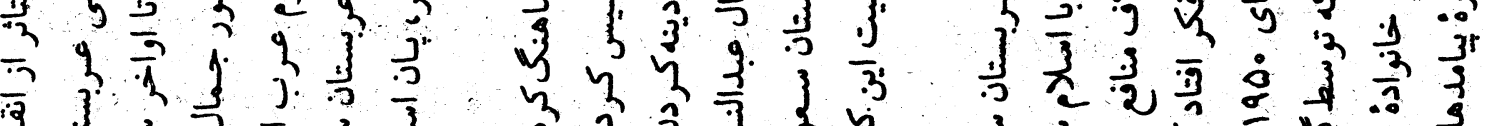

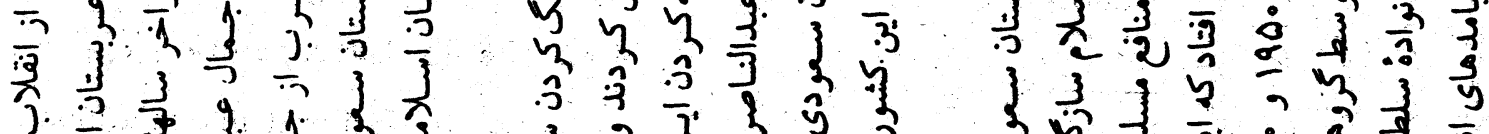

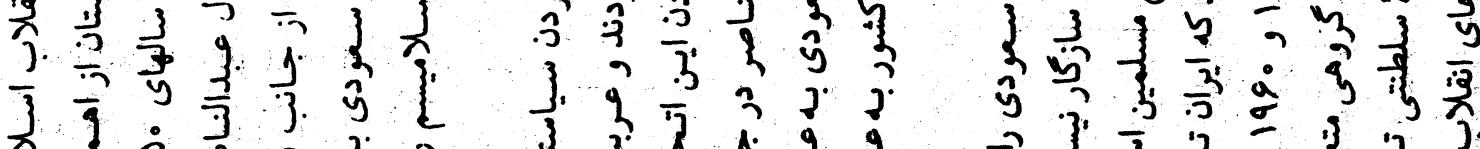

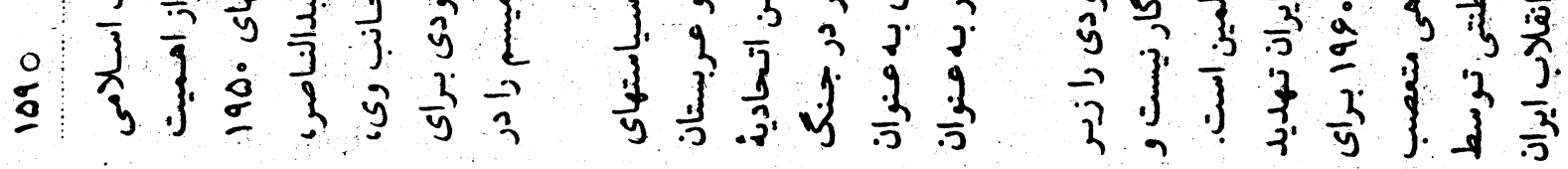




\section{1_ 1994 دوره دوّم}

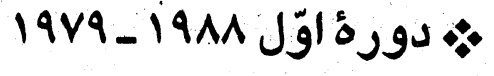

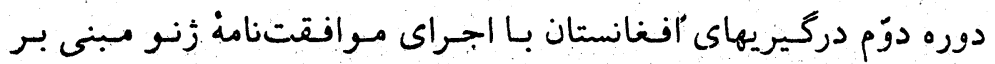

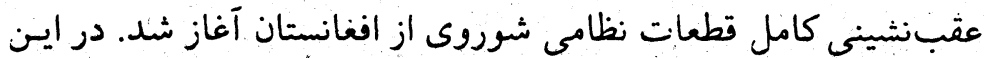

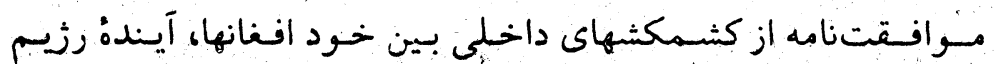

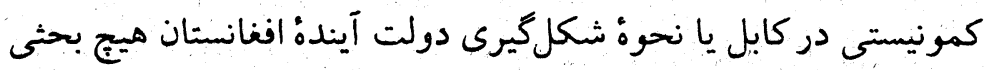

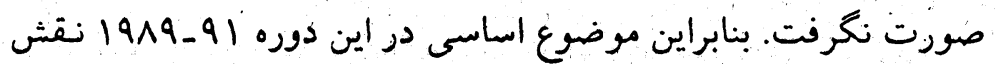

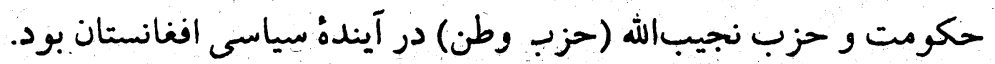

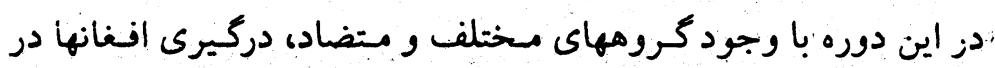

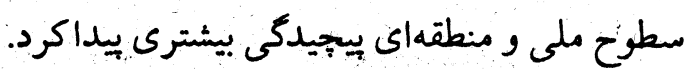

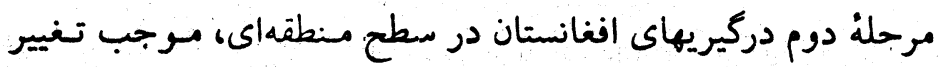

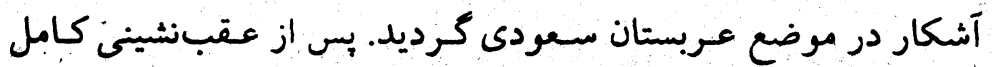

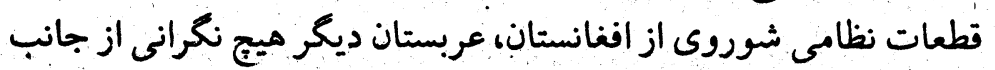

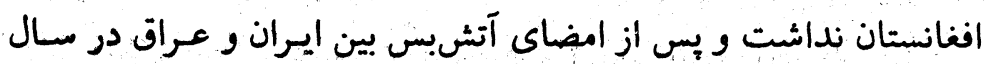

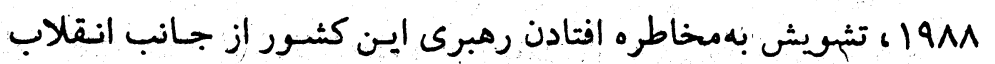

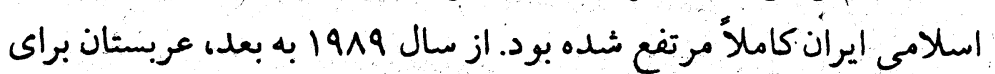

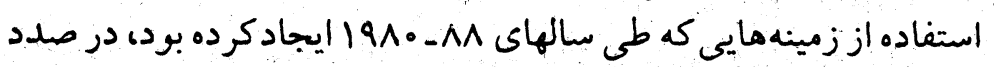

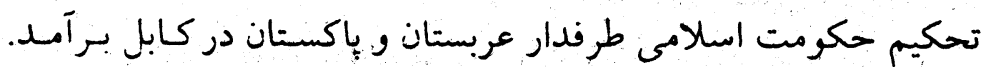

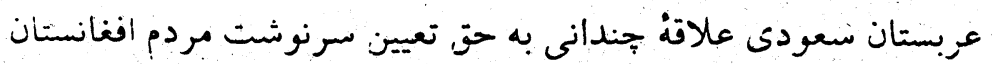

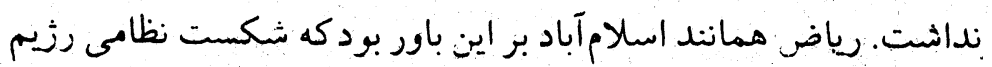

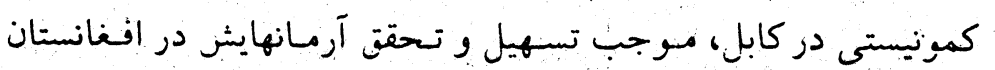

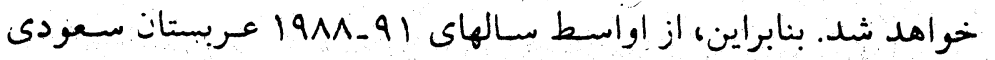

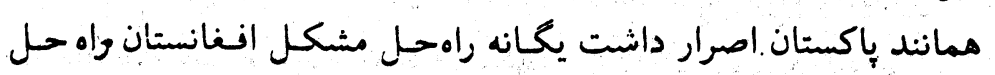
نظامى است.

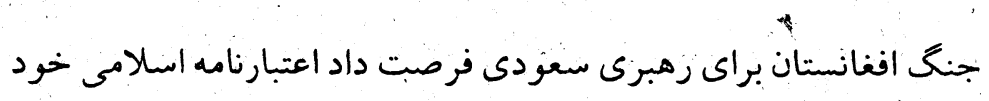

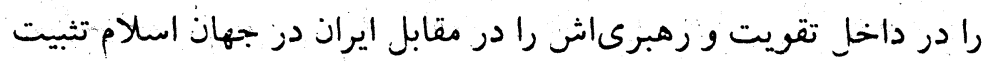

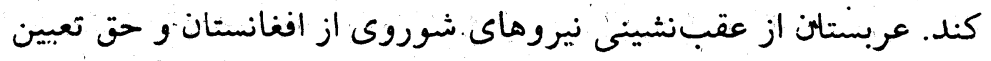

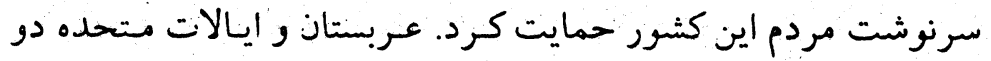

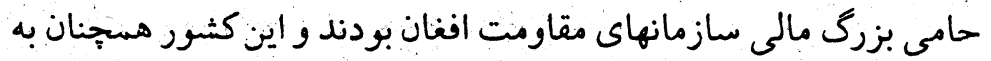

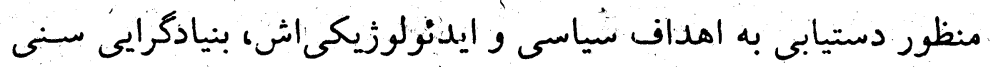

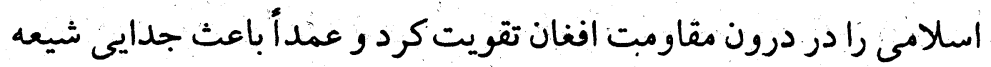
و سنى در اسلام شند.

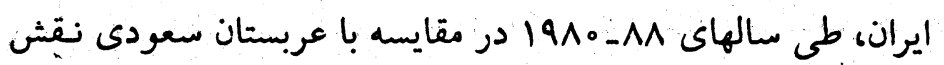

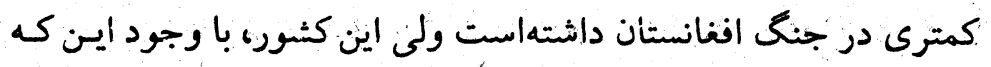

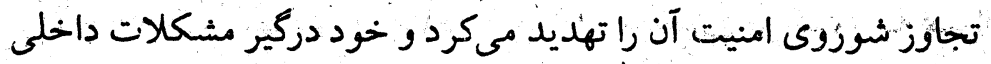

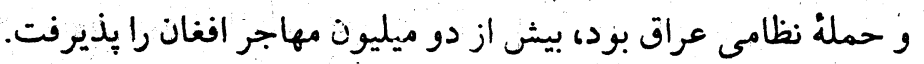

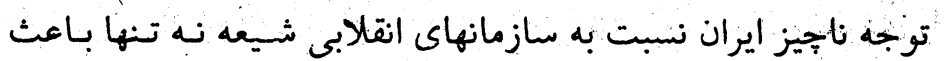

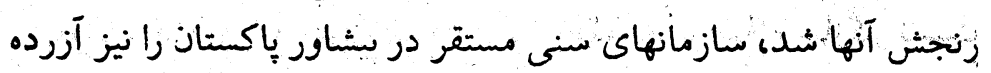

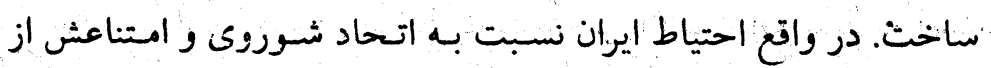

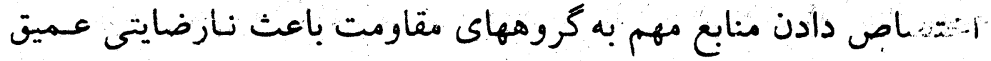

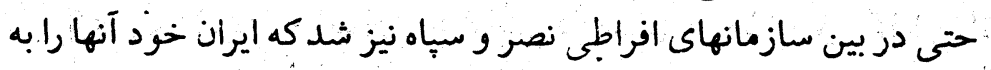

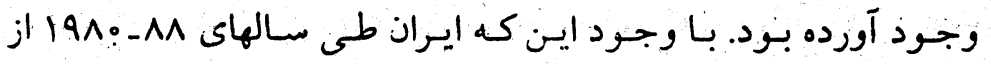

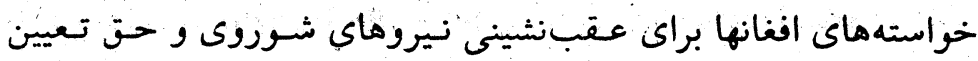

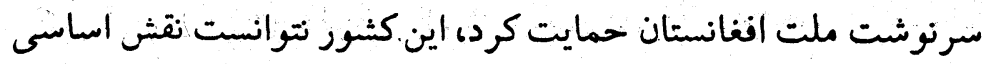
در جهت تحقت بخشيدن اين اهداف داشته باشد. 
شد. ايني كثوز كمكهاى مالى خود به مازمانهاى افغاني را قطع نموده و

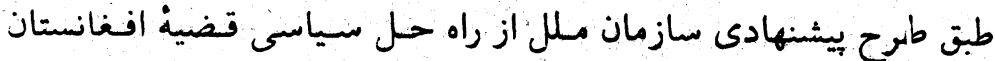
حمايت كرد.

داررة دوم درگيريهاى افظانستان همراه بود با تحول شخرف در سياست

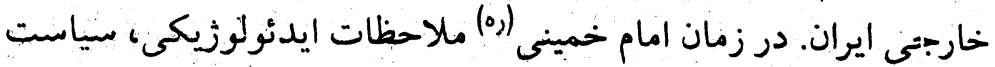

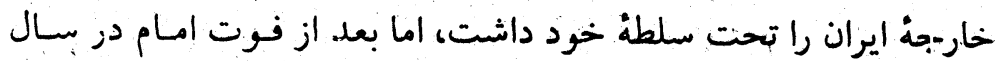

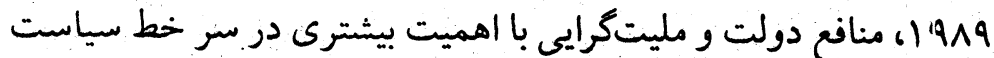
خار.جه ايران قرار گرفت. اين تحول، تأثير عميقى دور رابطه با تصميمكيرى

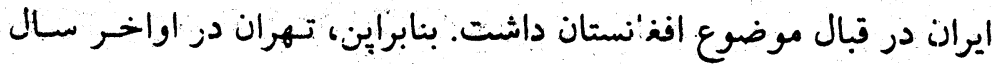

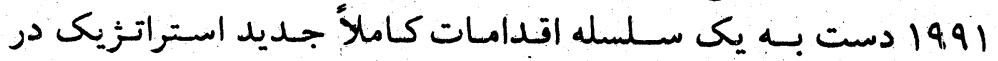
افغانستان زد. براى ايران مشخص بود تـاكيد مـنحصر راجبع بـه حفوق

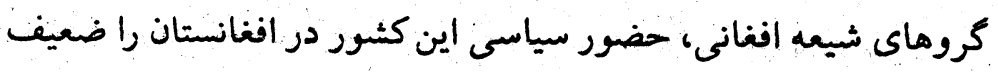

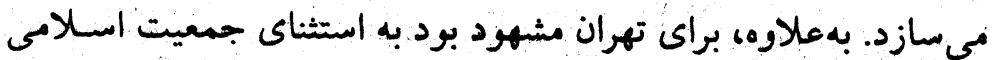

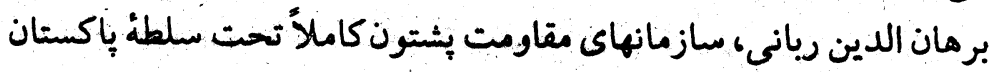

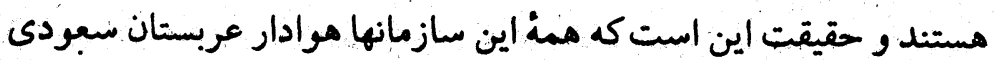
بودند. ايران براى تقويت نفوذ خود در بين فارميى زبانهاى منيى در ارواخر

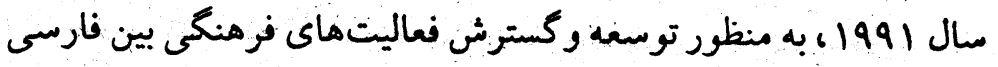

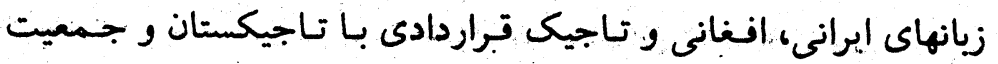

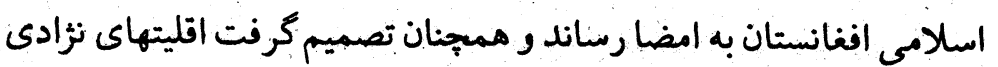

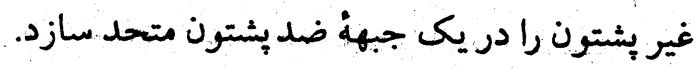

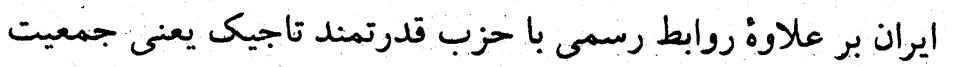
اــالامى، با شيعيان اسماعيلى و ازبكهاى افغانستان نيز ازتباط قائم كرد.

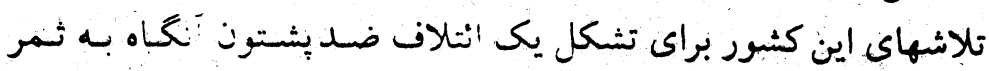

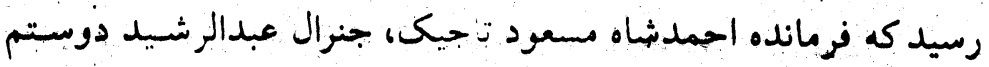

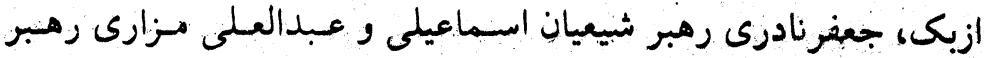

اين تغييرات در مواضع عربستان مسودى و باكستان با مخالفت شديد

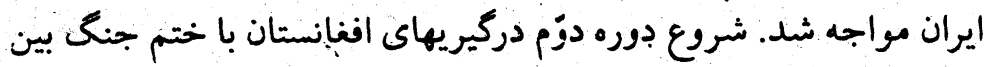

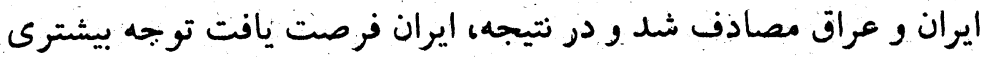

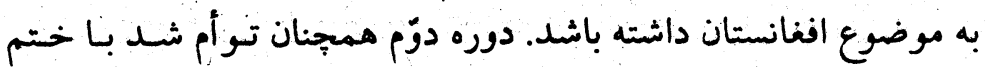

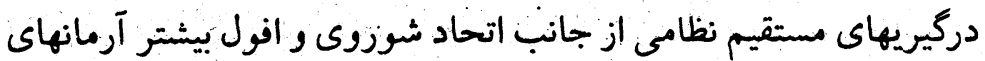

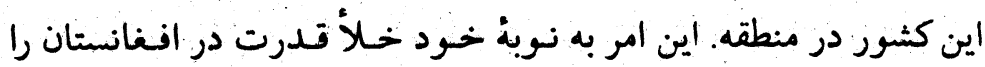

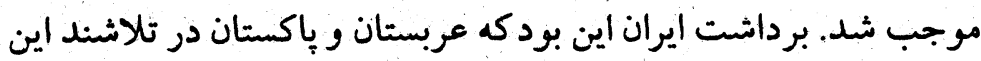

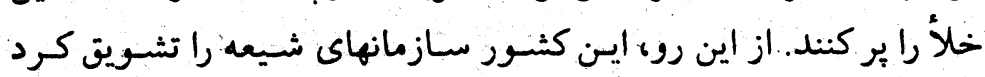

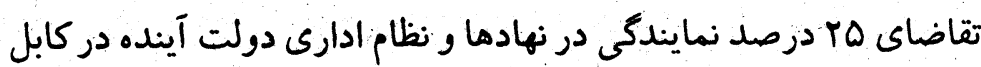

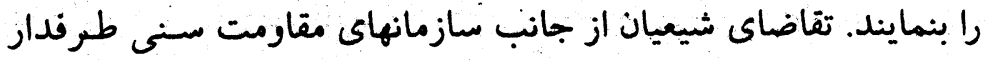

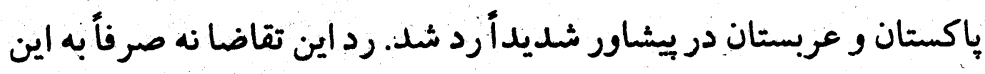
دليل كه شيعيان در حلود با درصد از كل جمعيت افغانستان را تشكيل مى دمند صورت كرفت، بلكه رمبران سنى امتدلال ميىكردند شيعيان در جنگ با روسها سهمى فعال نداشتند و بناء مستحق نيستند در دولت آيندة:

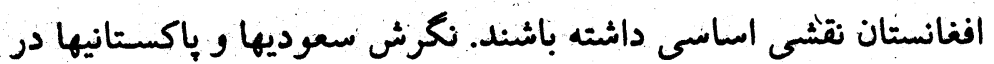
رابطه با تلاثنهاى ايران براى نفوذ در افغانستان، يكسيسان بـود. ايـران و

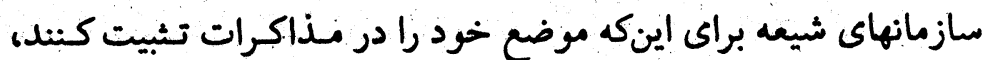

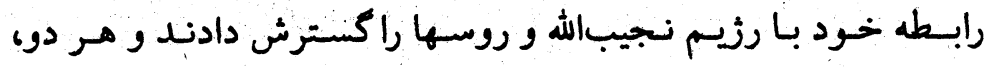

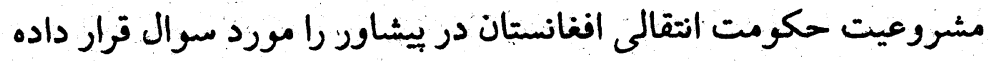

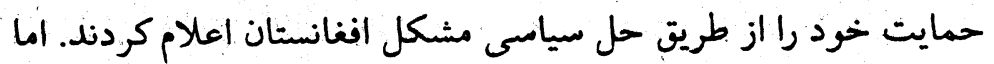

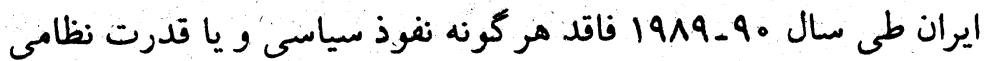

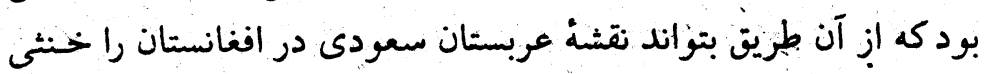

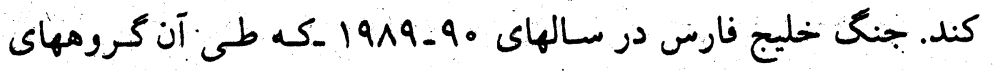
مَقاومت افغان تحت حمايت منعودى، بيشتر از فراق بشتينبانى كردند تا از

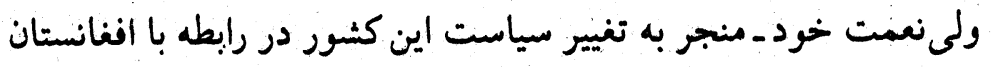


مجاهدين كه جانشين رزيم كمونيستى شد، تأثير آنى كذاشت. مسعود و

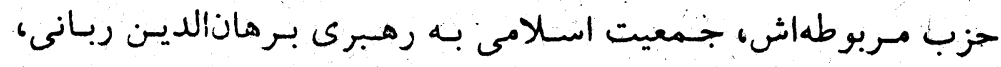

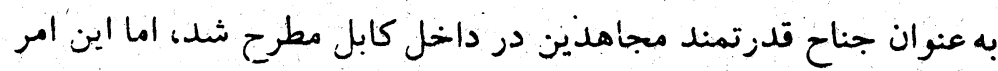

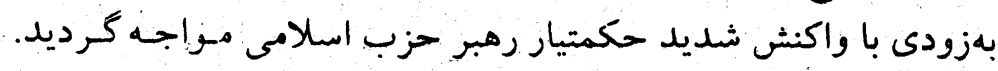

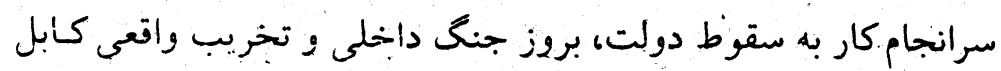
كشيدهشند. علاوه بر رقابت شديدگروههاى افغان بر سر قدرث، زقابتت ودرگيرى

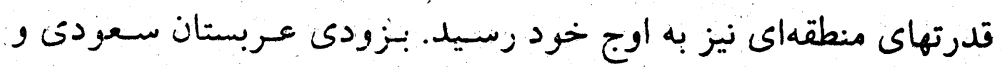

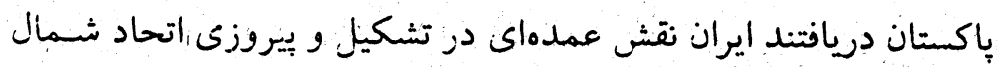

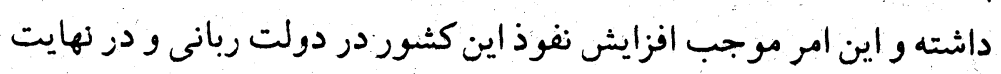

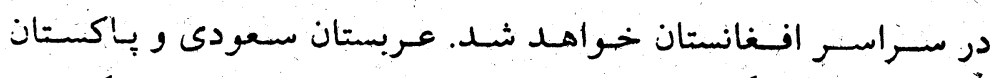

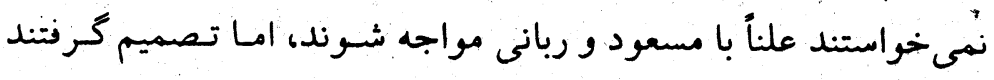

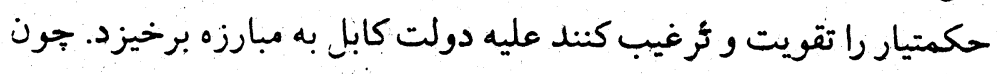

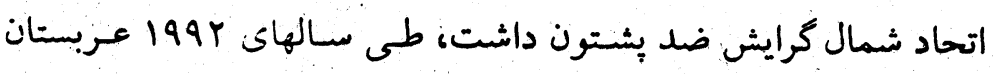

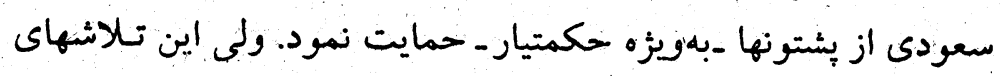

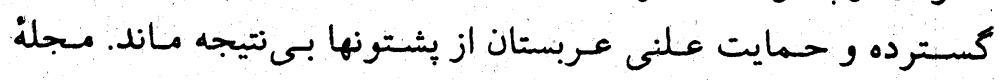
Middle East

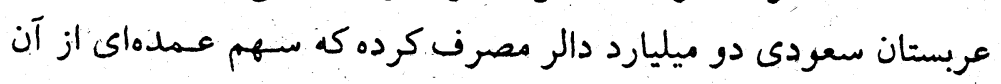
نصيب حكمتيار شده است. در همين دوره، ايران همزمان كمكهاى قابليل

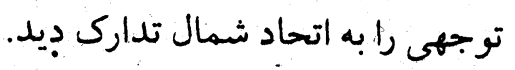

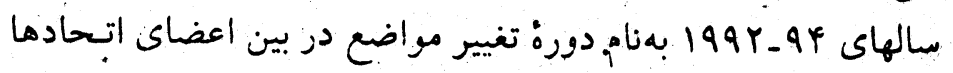

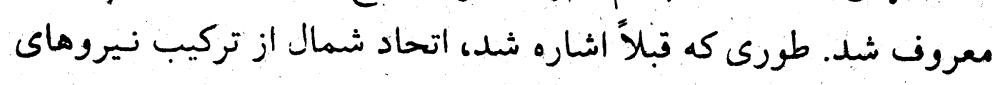

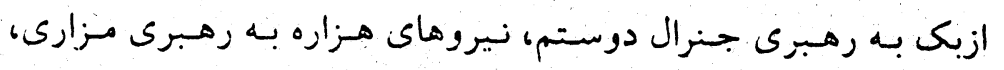

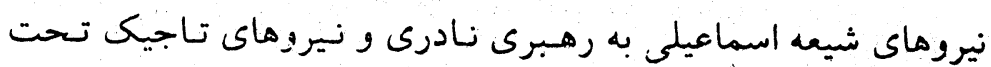

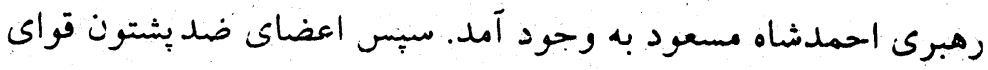

حزب هزاره وحدت، اتحاد سمت شمال را به وجود آوردند كه إين اتحاد

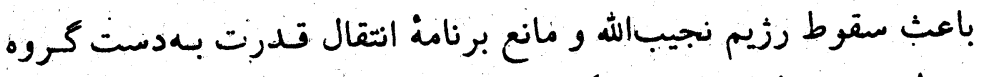

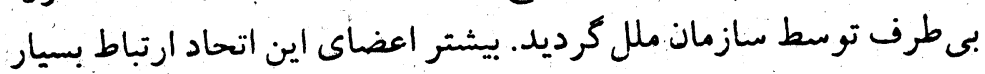

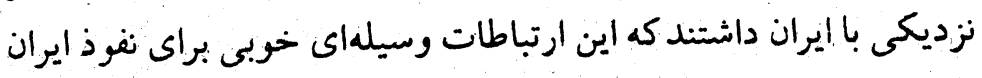
در امور افغانستان بود.

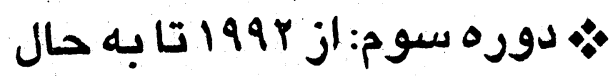

دوره سوم دركيريهاى افغانستان همزمان با سقوط رذّم كمونيستى در ماه

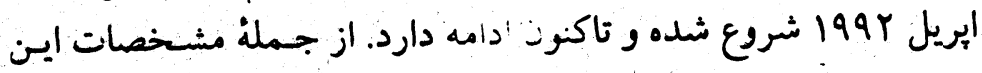

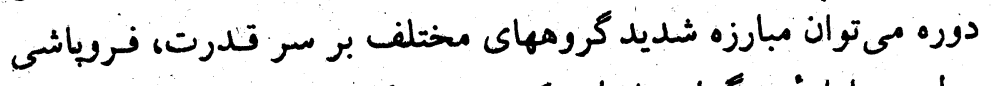

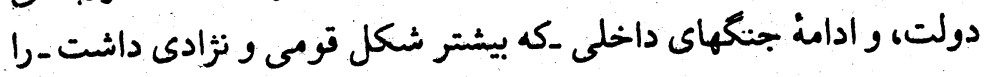

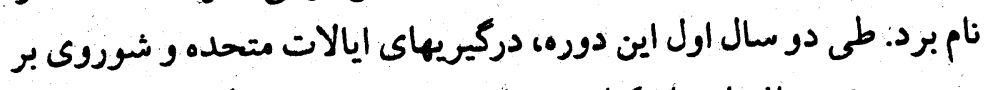

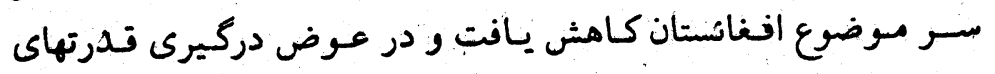

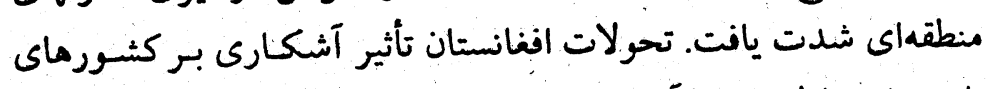
تازه به استقلال رسيدة آسياى ميانه داشت. طى نسالهاى

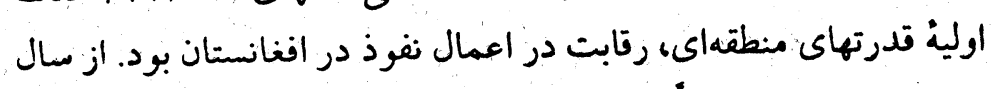

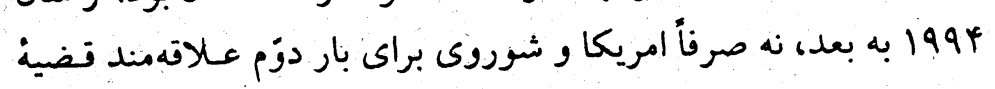

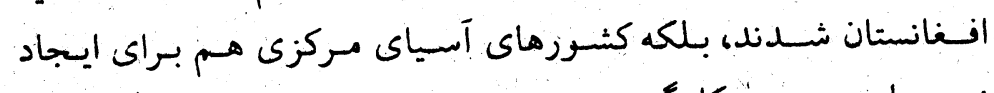
زمينه هايى دست به كار كرديدند.

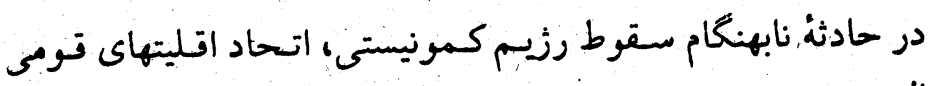
شمال تحت رهبرى فرمانده احميش شاه مسعود در صحنه قذرت حسفور

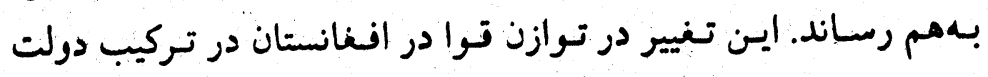




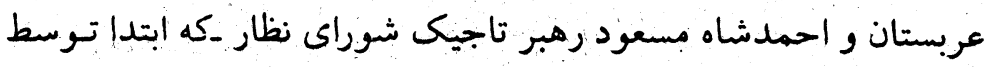

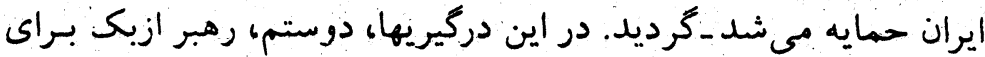

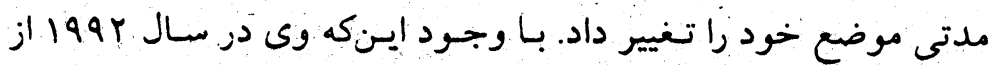

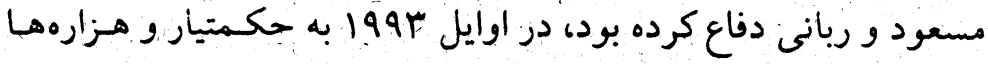

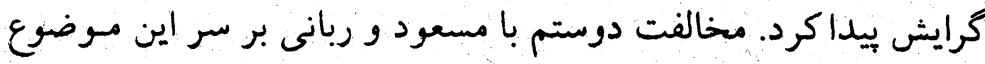

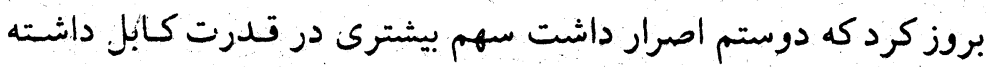

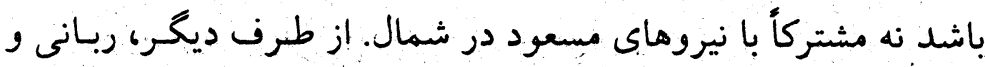

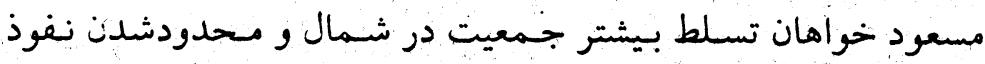
دوستم در كابل بودند. در جـنورى 1994 دومستمه، حكمتيار، منزارى و

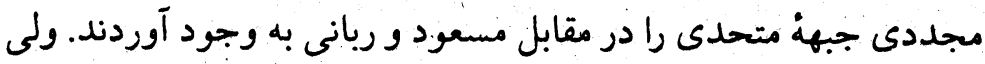

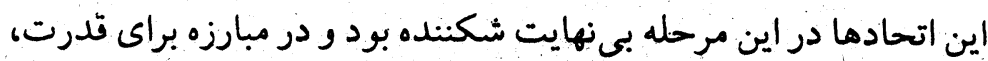
بيشتر طرفها، موقعيتها رابر آرمانگرايى ترجيح مي دادئ دادند.

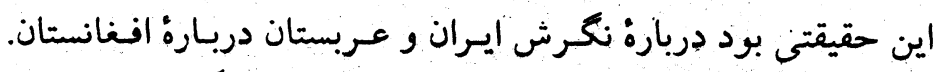

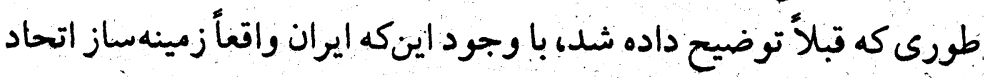

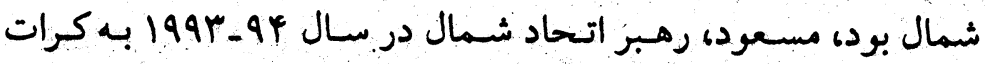

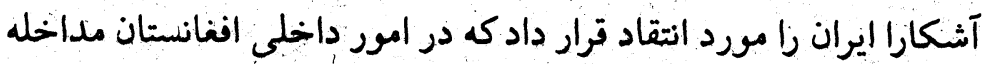
مى كند. على رغم اينكه قبل از بروز اختلاف بين مسعود و هزارهها، إيران

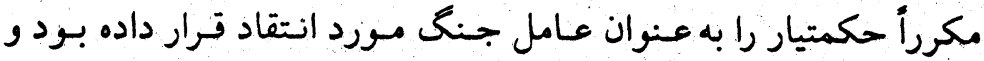

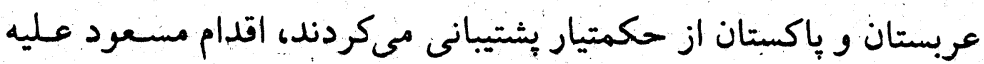
هزارهها، باعث نزذيكى ايران و حكمتيار شند. ايران در ابتداى فروياشى ئسي

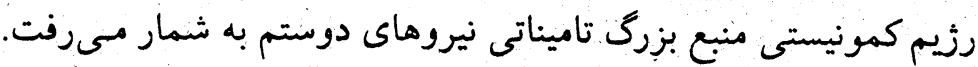

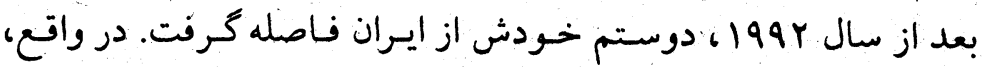
مسعود براى مدت كوتاهى استراتيزّى ضدايران و ضد بنيادكرايى داشت آنست

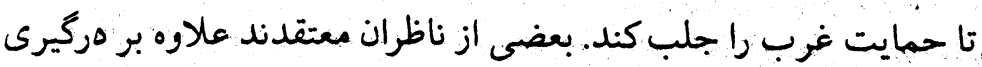

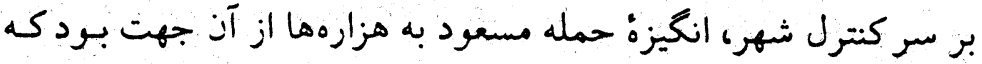

مسلح و حزب وطن نجيبالله به اين اتحاد ييوستند. بسياركى از هزارهماى

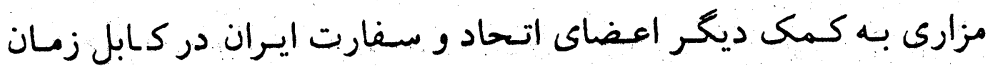

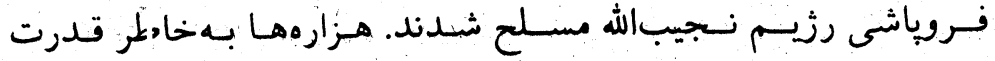

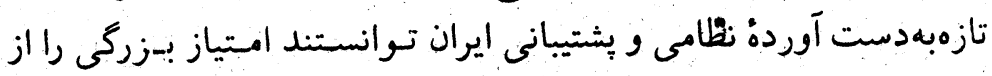
صبنتالله مجددى، اولين رئيس دولبت انتقالى مسجاهدين كمهاين كسند.

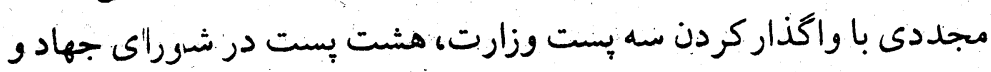
يكى بِست در شوراى رهبرى براى هزارهما موافقت كرد و آنها توانستسند

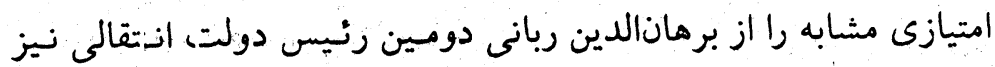

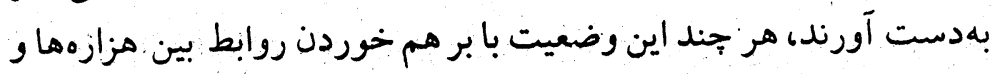

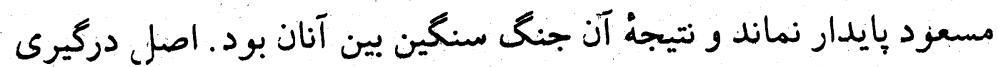

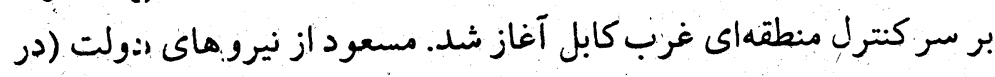
واقغ نيروهاى خودش شوراى نظار) خواست كنترل منطتئه غر بـ كابل را

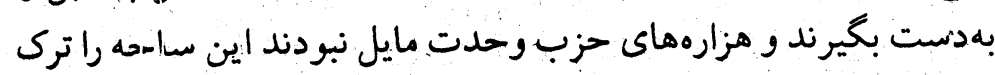

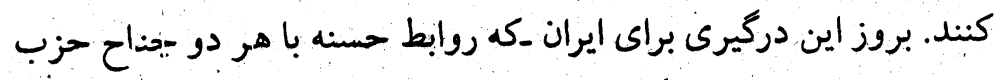

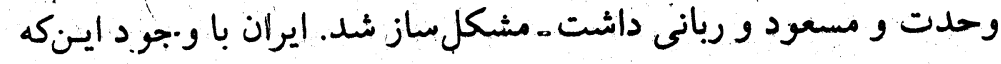

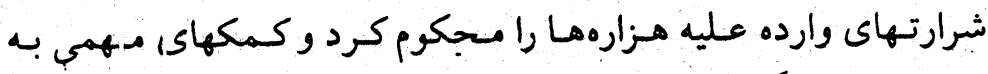

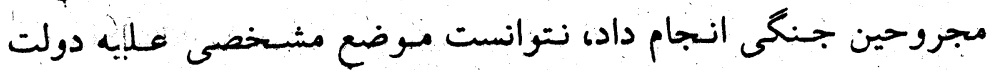
رباني _مسبود اتخاذ كند.

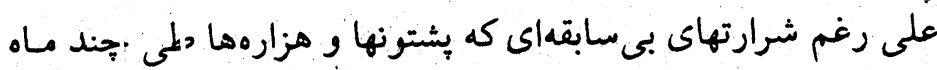

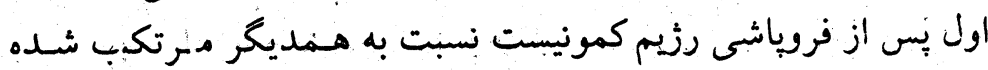

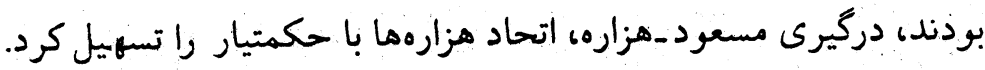

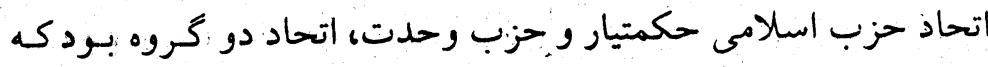

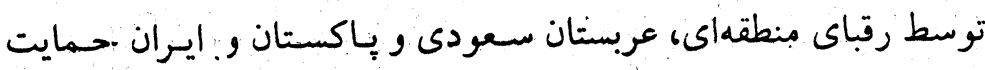

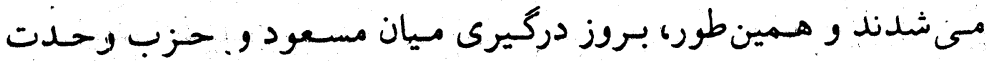
زمينه بباز اتحاد يين عبدالرب رسول نسياف، رهبر اتحا د اسلامى هوادار 


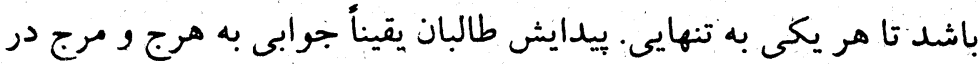

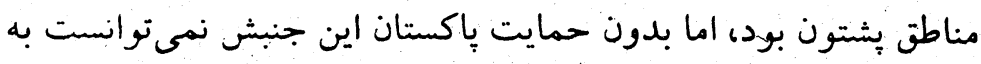

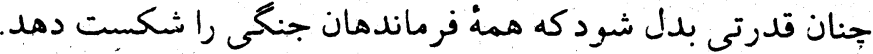

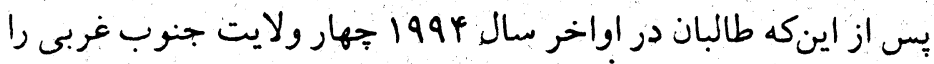

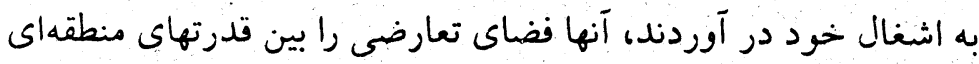

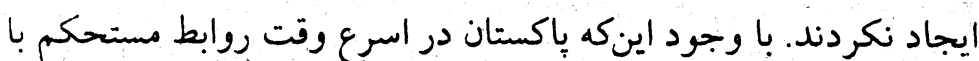

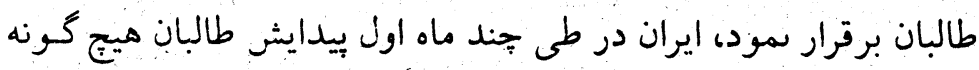

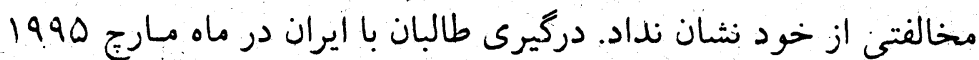

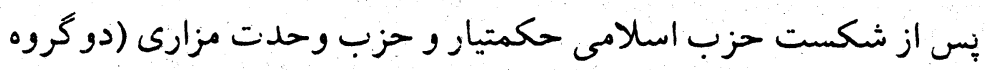

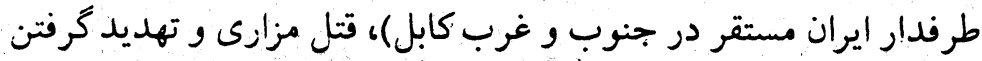

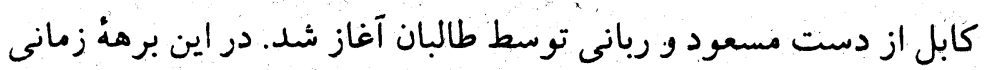

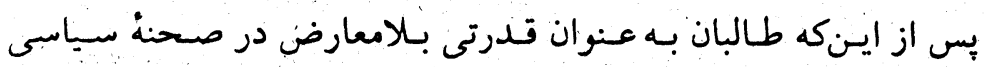

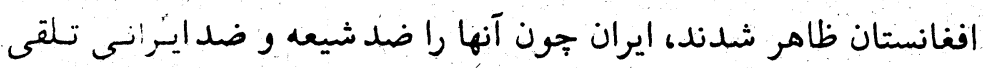
مئكرد، از خود حساسيت نشان داد فران.

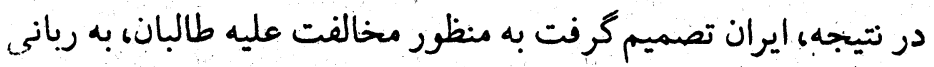

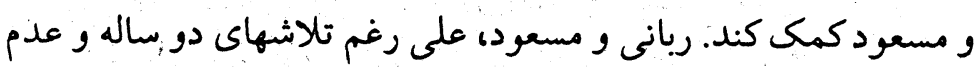

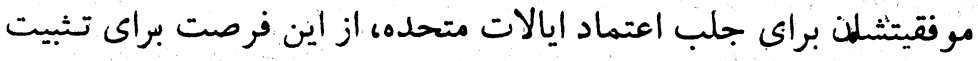

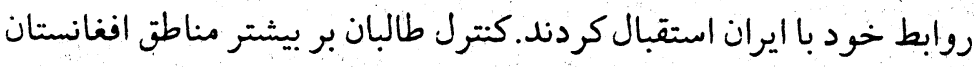

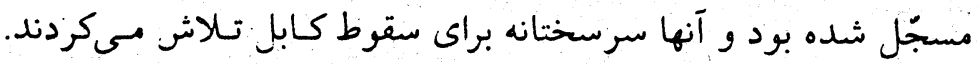

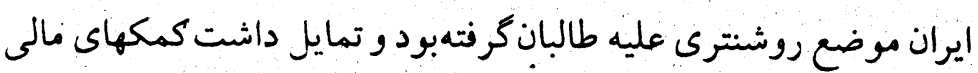

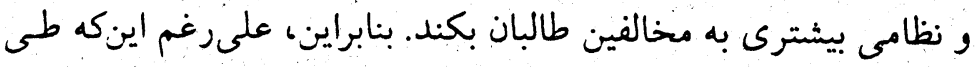

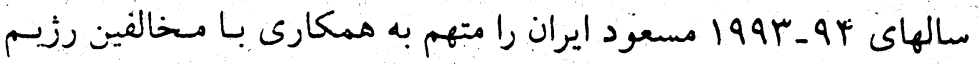

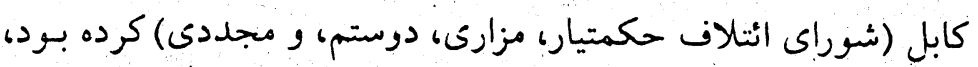

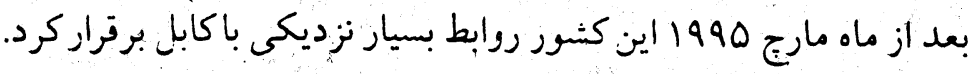

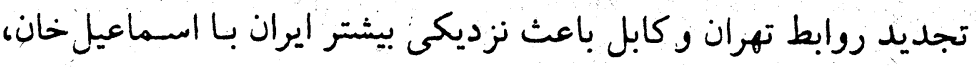

مي خواست خود را به عنوان خهرة ضد بنيادگرايسى و ضـد ايسران مـعرفى

همينطور، عربستان سعودى براى اينكه نفوذ خـود در افغانستان را

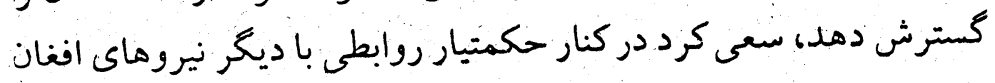

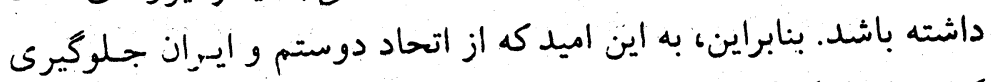

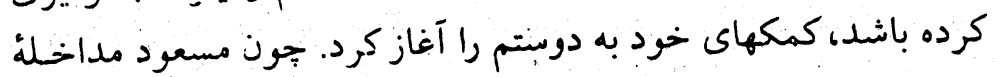
ايران در امور افغانستان را مورد انتقاد قرار داده بود؛؛ روابطه عربسنتان بـانسا

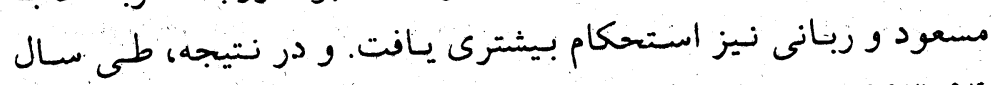

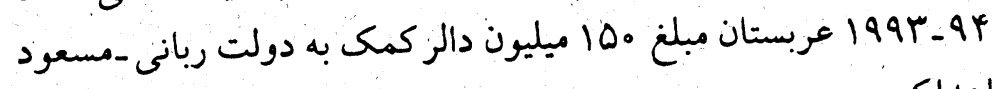

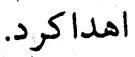

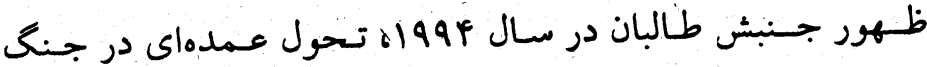

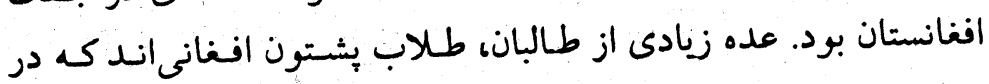

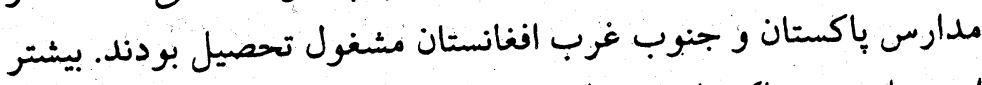

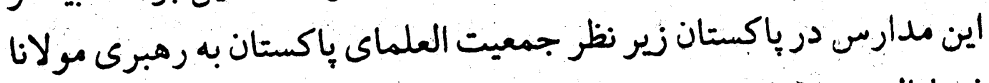

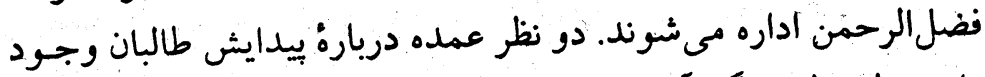

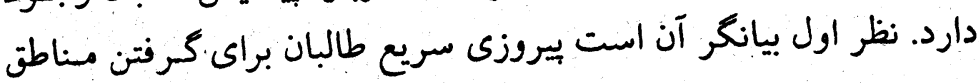

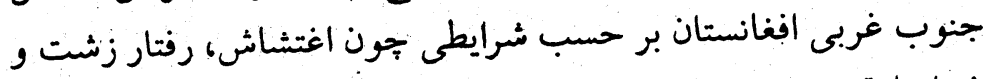

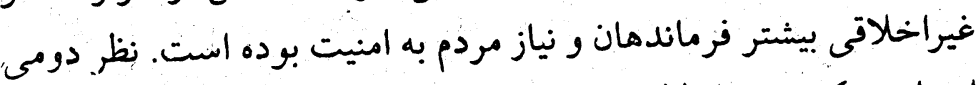

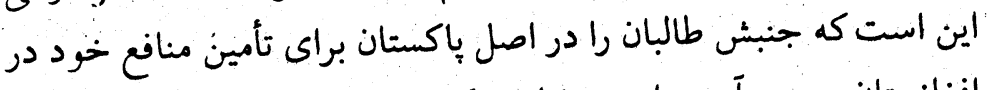

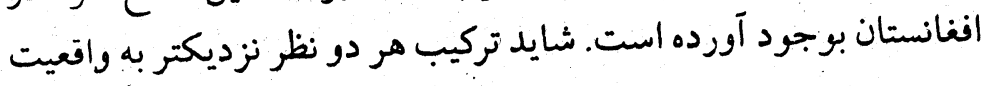

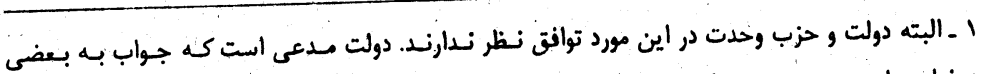

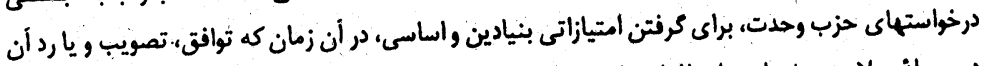

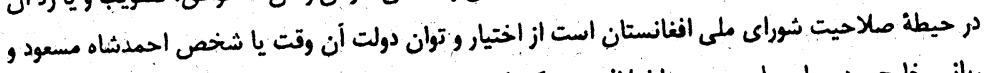

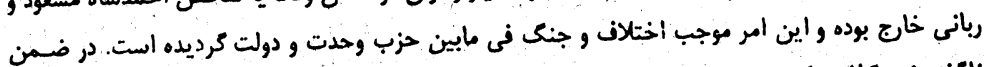

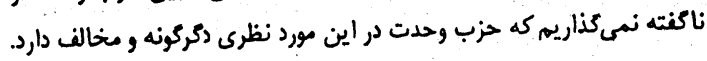




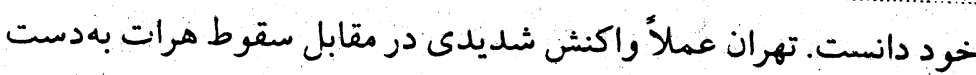

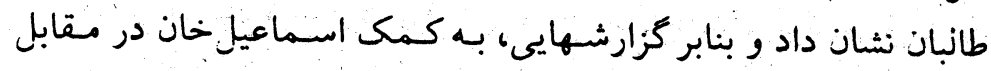
فرمانده حوزة جنوب غرب كه اين كثور قبلاً نيز از او بشتيبانى مىكر.د،

با از دست دادن هرات توسط نيروهاي طرفدار ايران و بالاكرفتن موج

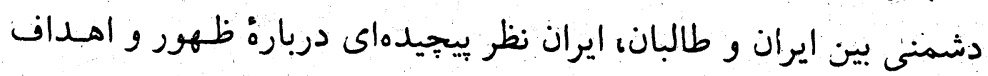

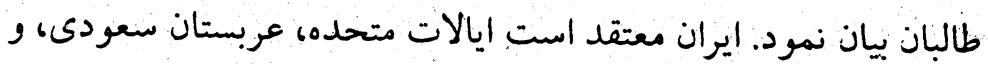

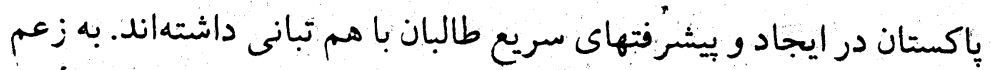

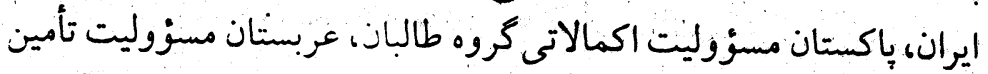

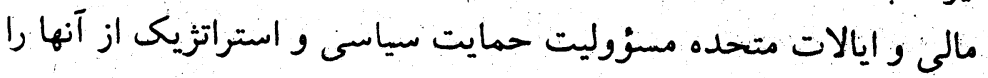

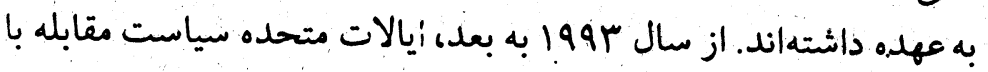

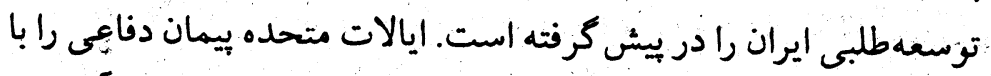

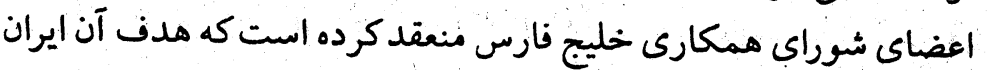

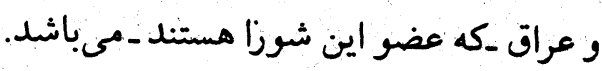

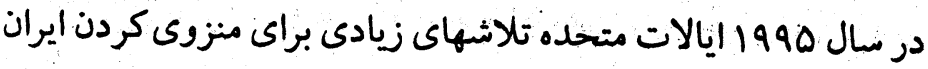

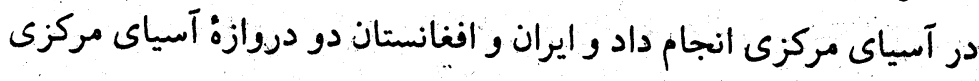

\section{ه. تغيير منافع و استراتيزّىها}

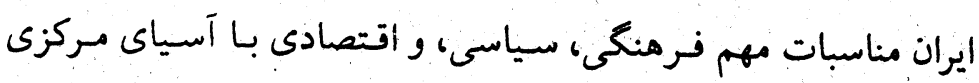

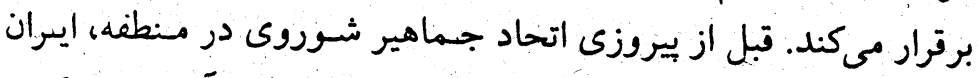

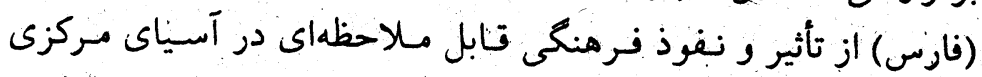

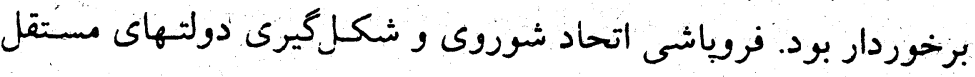

اسماعيل خان عضو سازمان جـمعيت آتاى ربانى و جـز تشكيلات

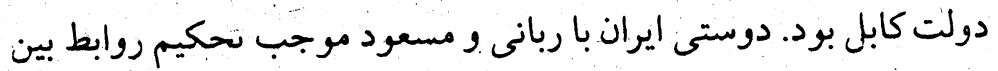

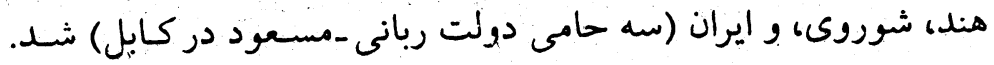

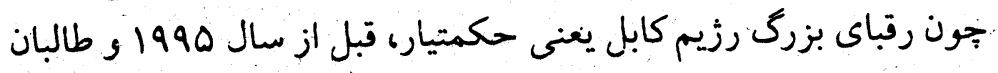

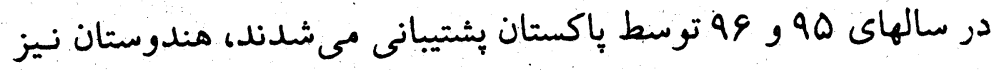

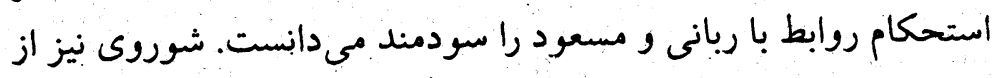

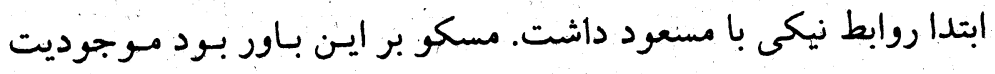

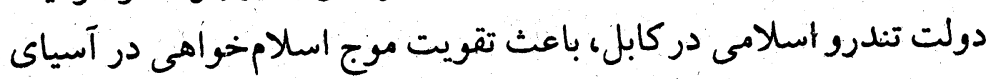

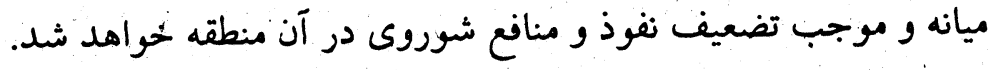

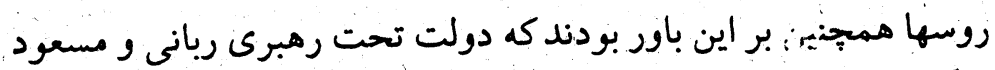

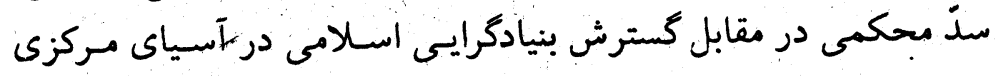

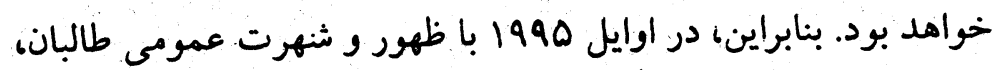

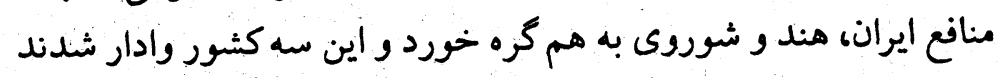

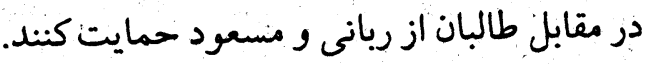

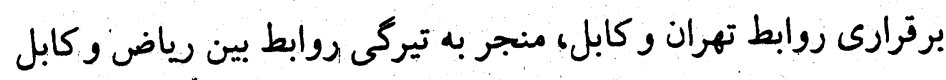

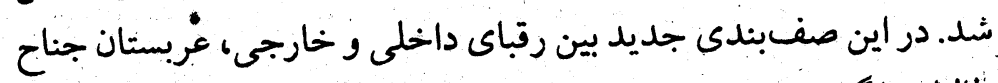

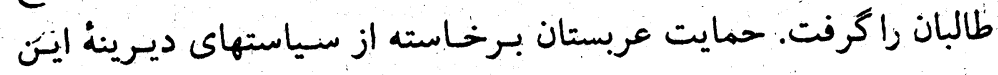

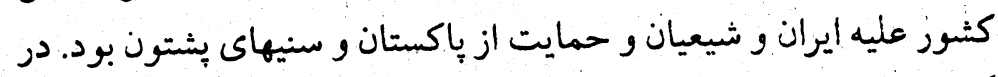

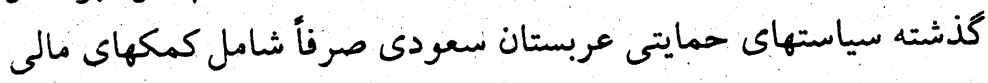

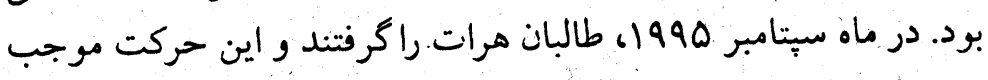

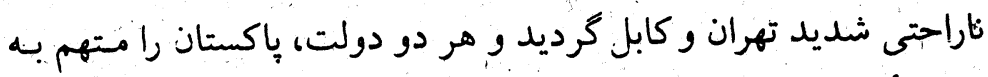

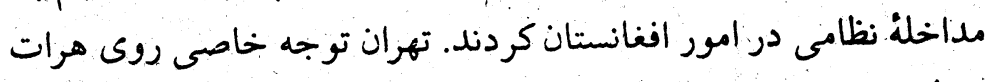

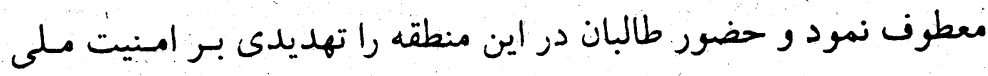


تركمنستان به باكستان و بازارهاى جهاينى به امضا رسانده است. شركت

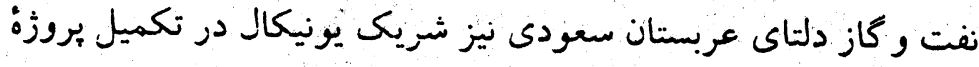

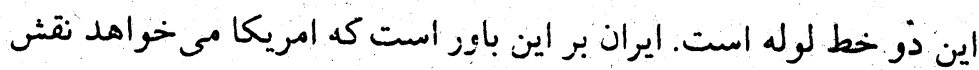

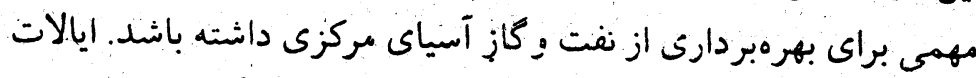

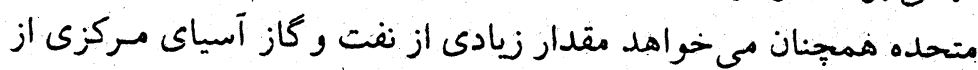

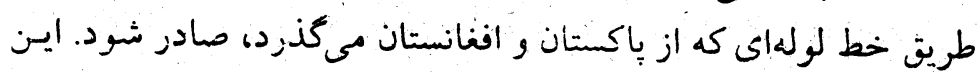

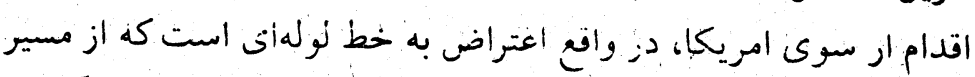

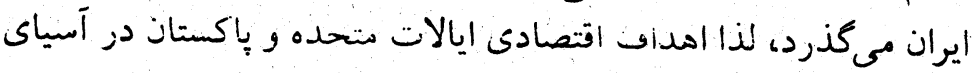
مركزى با هم تلاقى كرده است. با وجود اينكه عربستان سعودى هيسج

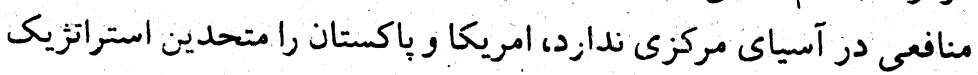

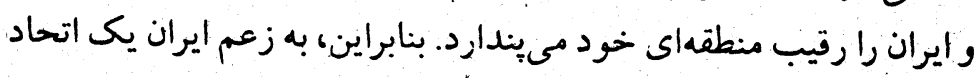

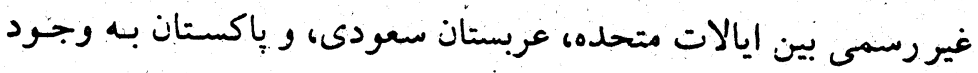

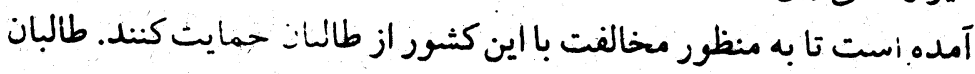

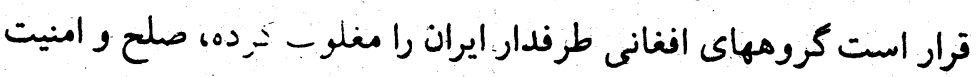

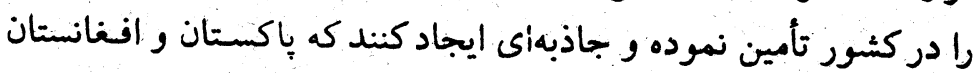

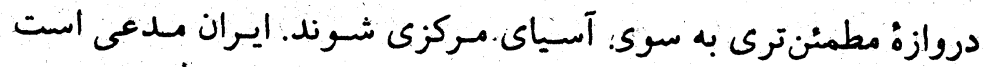

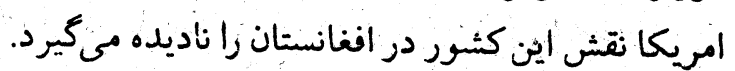

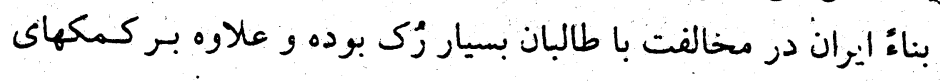

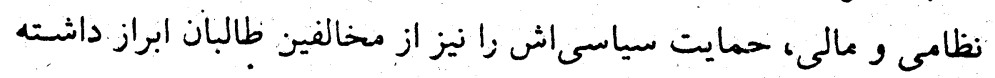
است. همين طور، بس از سقوط هرات بهدست طالبانه، ايران بـا بـرقرار

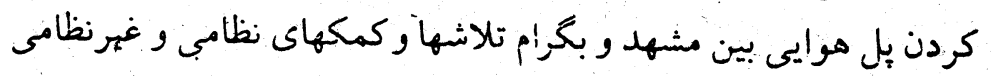

خود را به منظور تقويت دولت رباني را دو برابر ساخت.

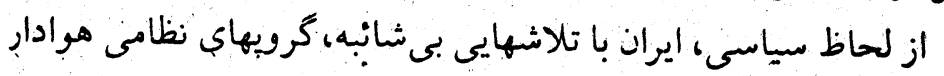
خود را وادار كرد با دولت ربانى و مسعود در كابل همكارى كنند. جنانجه

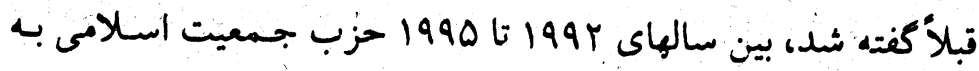

آسئاى مركزى، بانى احياى مجدد نفوذ فرهنگى و سياسى ايران در اين

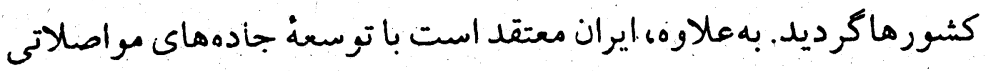

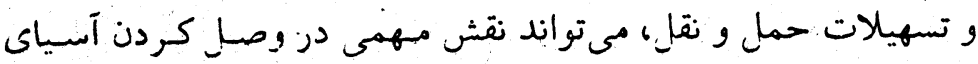

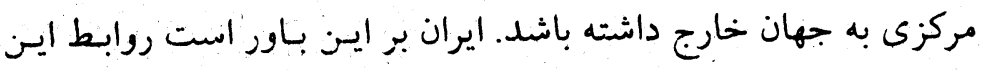

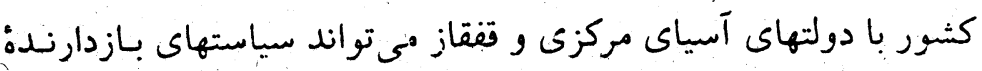

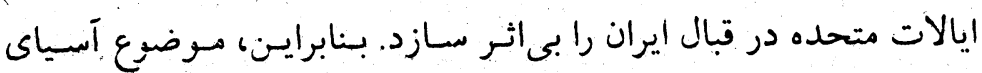

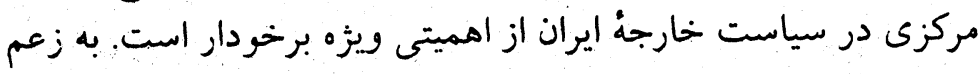

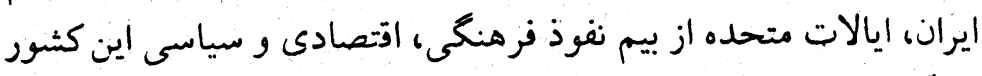

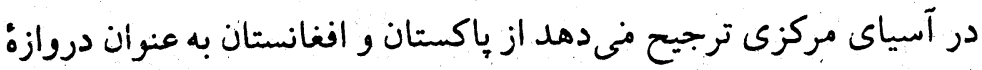

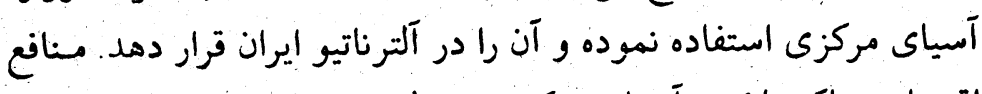

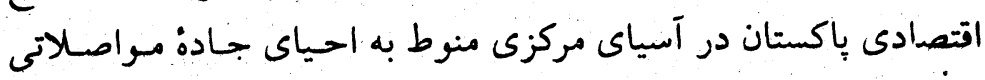

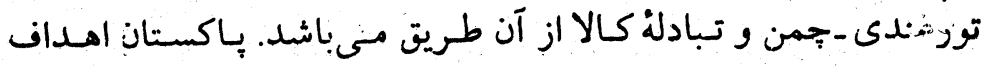
اقتصادى ديخرى را دز آسـياى مهركزى در نظر دارد. ايسن كثسور تبلاً

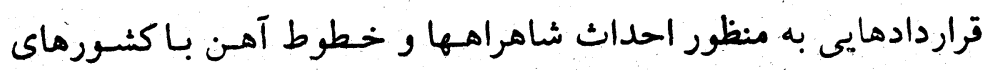

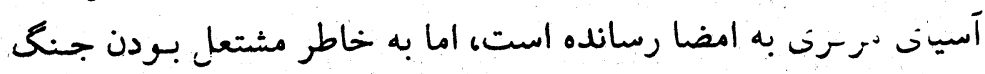

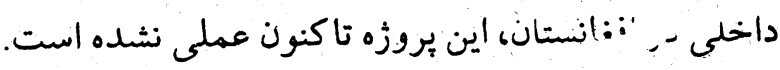

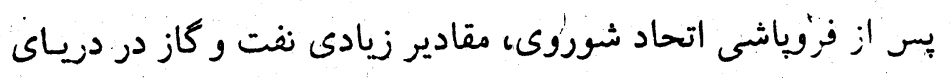

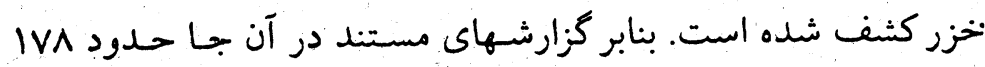

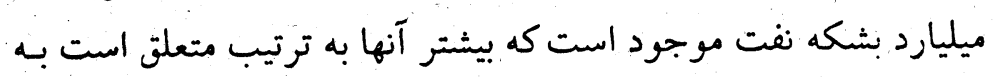

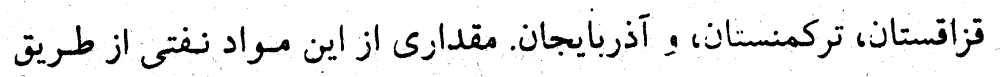

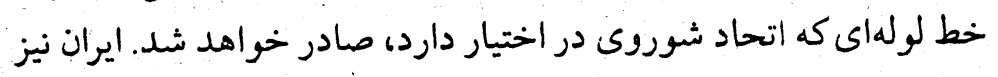

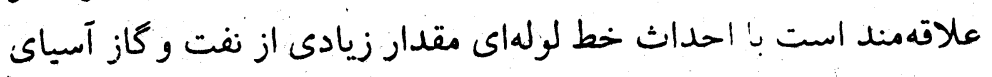

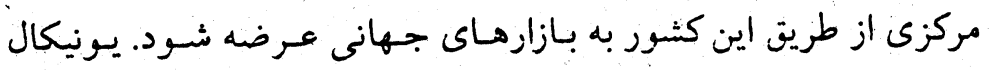

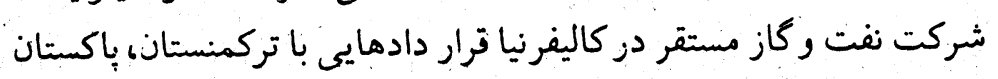

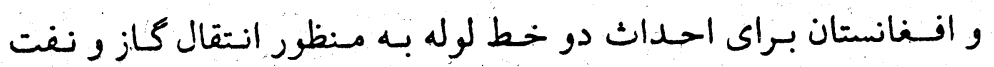




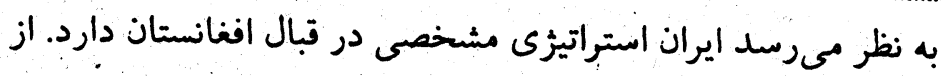

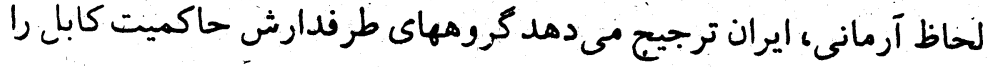

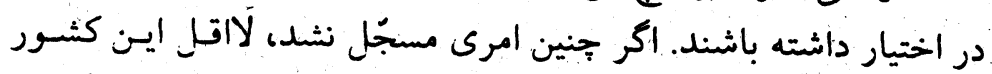

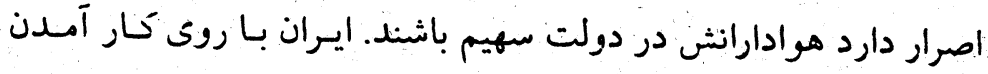

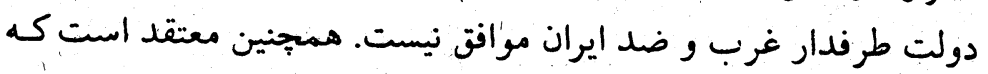

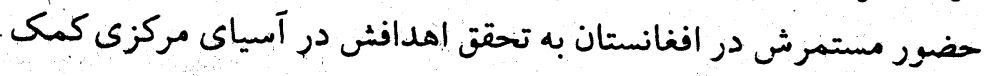

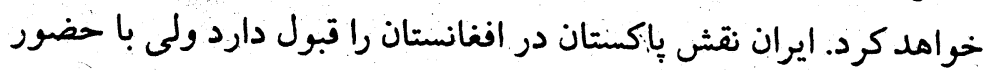

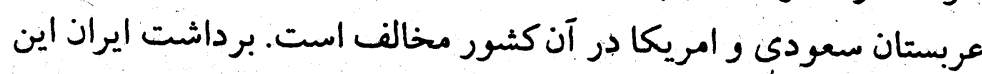
بود كه دولت ربانى و حكمثيار بـا اهـداف و مــافع ايـران در افـغانستان سازگار است.

هنوز بيش از جهار ماه از عمر حكرمت ريانى -حكمتيار نظذشُته بود

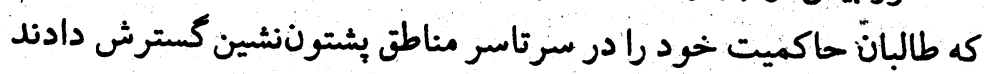

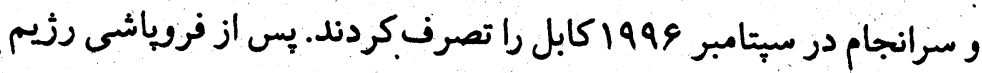

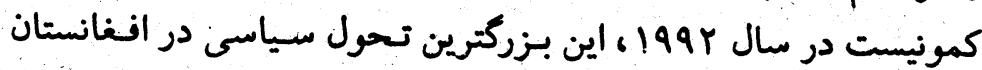

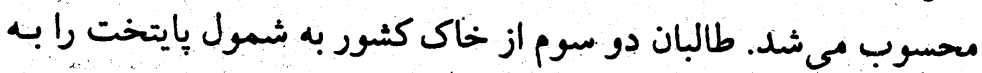
كنترل خود در آوردند و مخالفين خويش را تا فاصله ماى ببسيار دور از كابل عقب راندند تا حدى كه اين شهر ديخر در تيررس موشكها و تويخانه

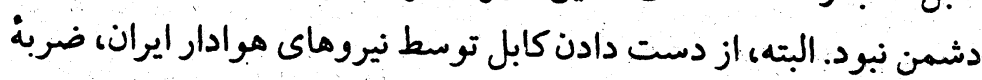

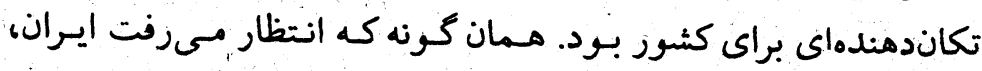

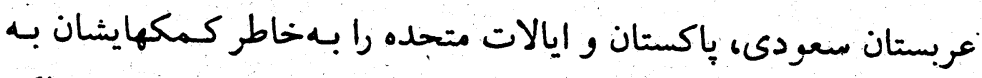

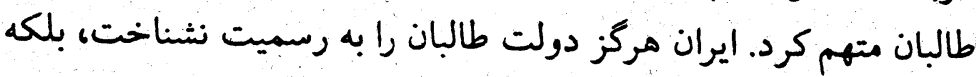

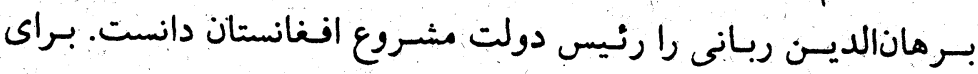

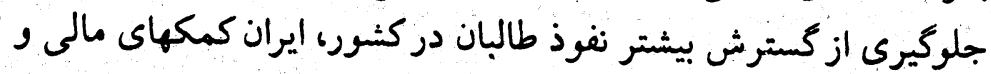

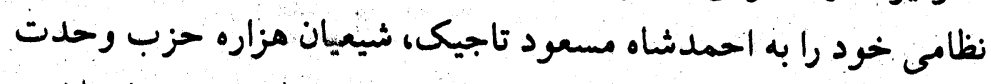

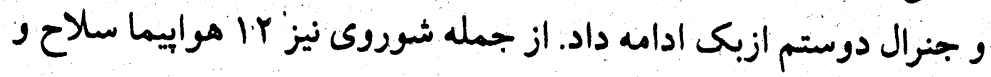

رهبرى ربانى و حزب اسلامى به رهبرى حكمتيار دو رقيب عمده براى

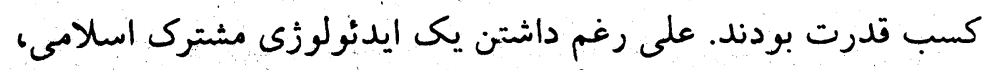

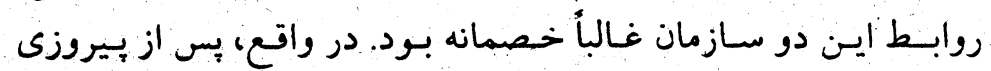

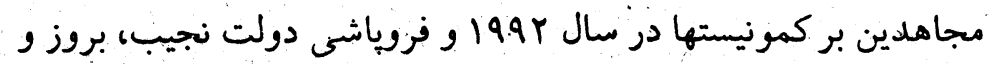

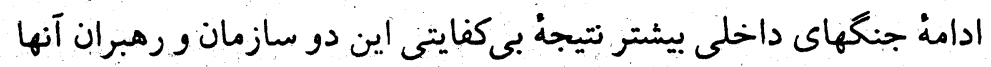

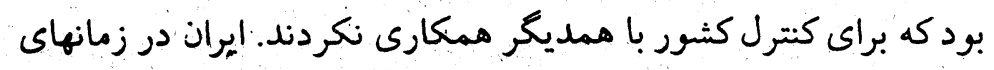

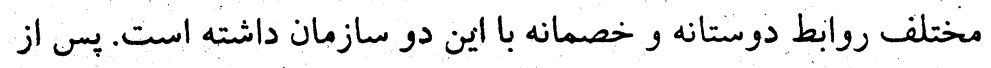
فتح هرات به دست طالبان، ايران تلاشهاى زيادى بـراى نزديكتر كردن دون دون ربانى و حكمتيار كرد.

سرانجام، تلاشهاى، ايران در اوايل مال 1999 ، زمانيى كه حكسمتيار

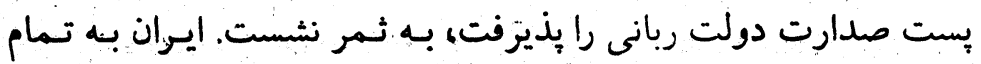

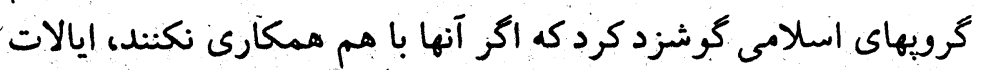

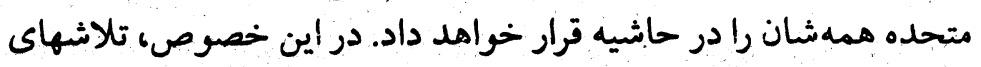

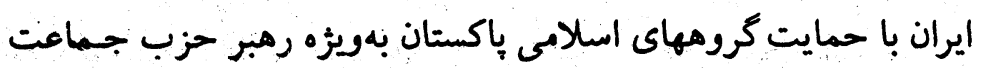

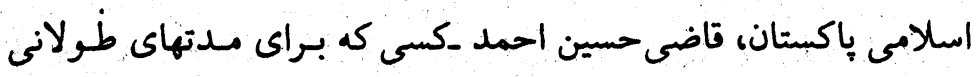

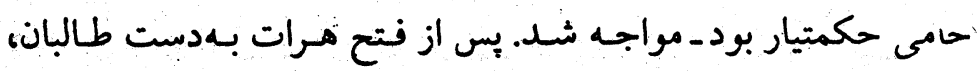

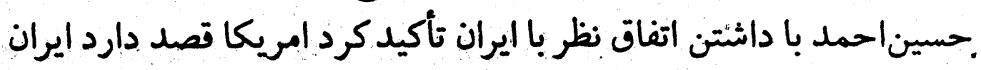
و تمام كروبهاى اسلامى منطقه را منزوى كند و طالبان براى تأمين. اهداف

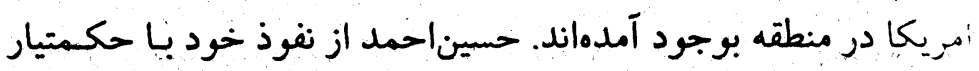

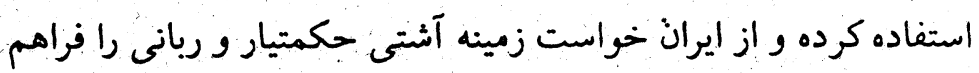

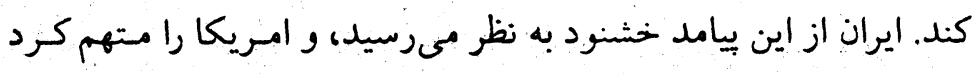

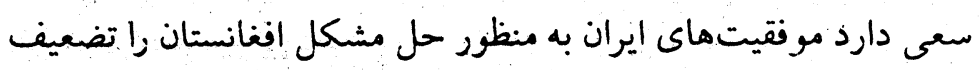

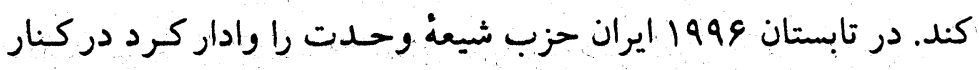
دولت قرار گيرد و گزارشها حاكى از آن بود كه جنرال دوستم نيز مـمكن است با دولد"، جديد كناز آيد. 


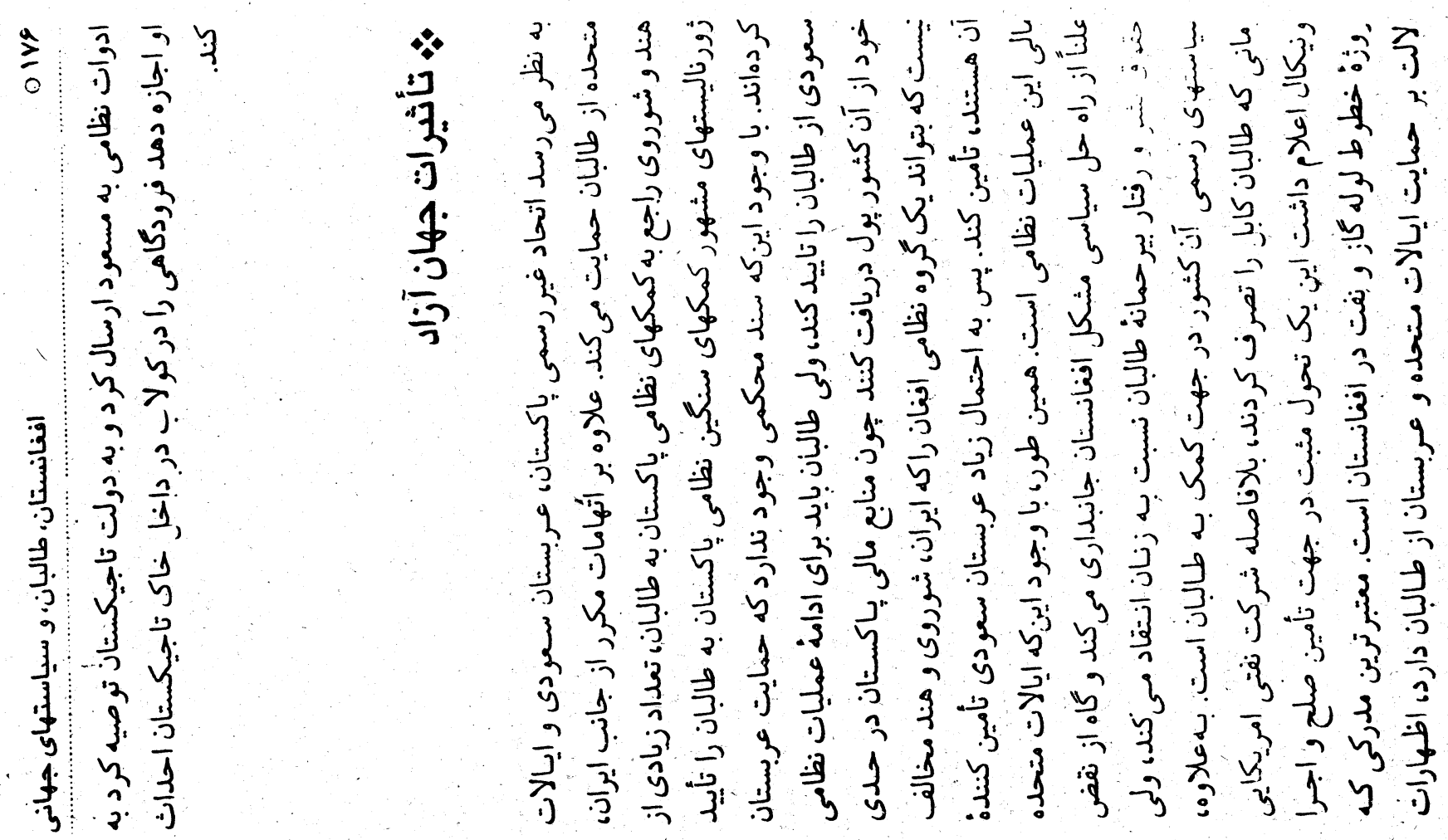

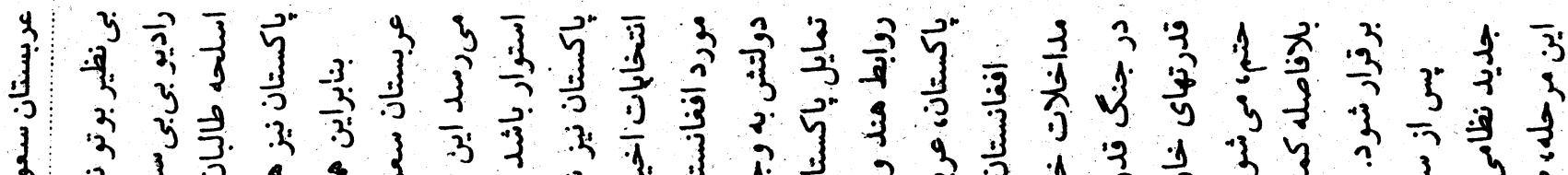

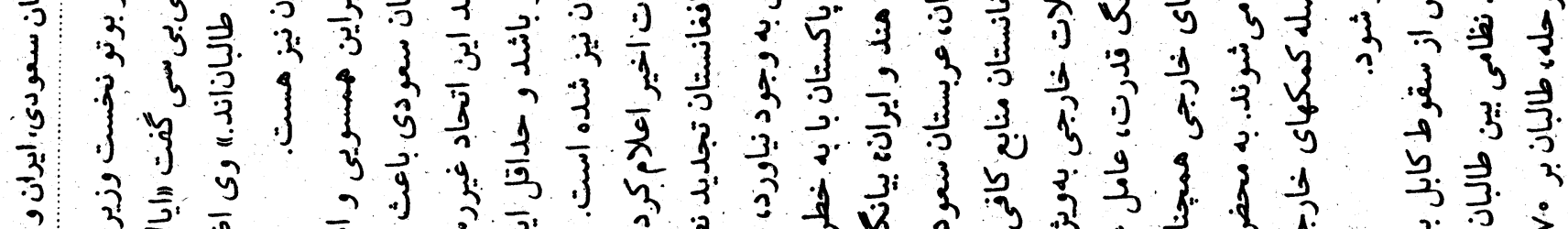
वे

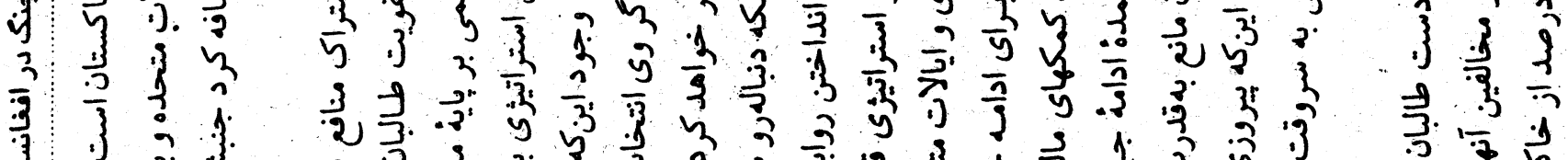

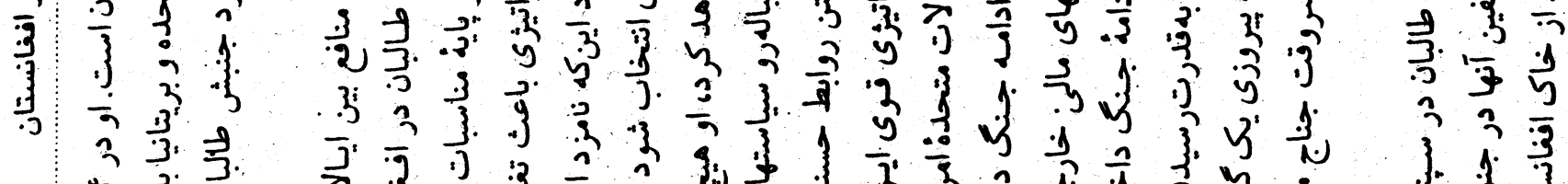

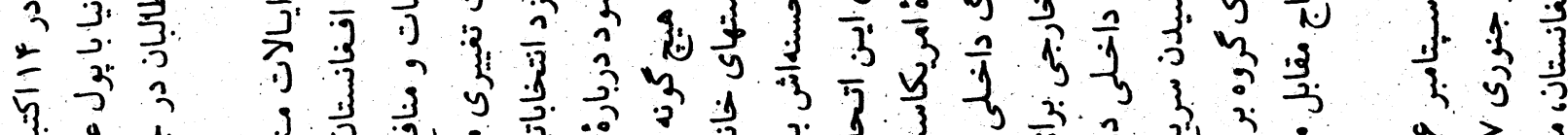

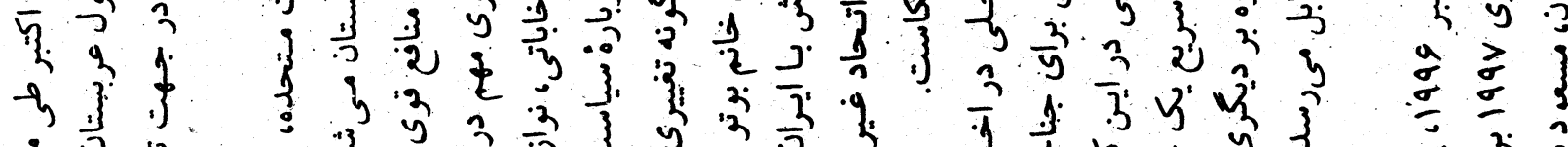

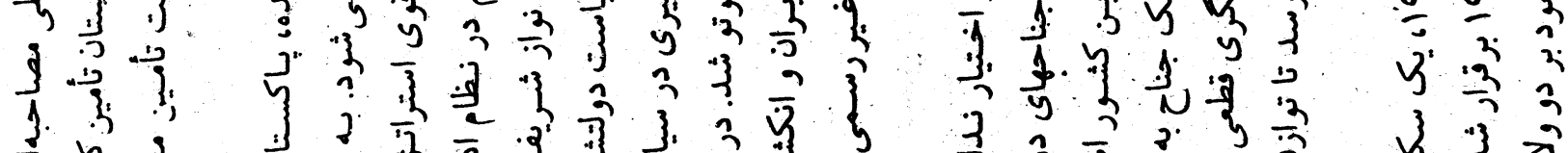

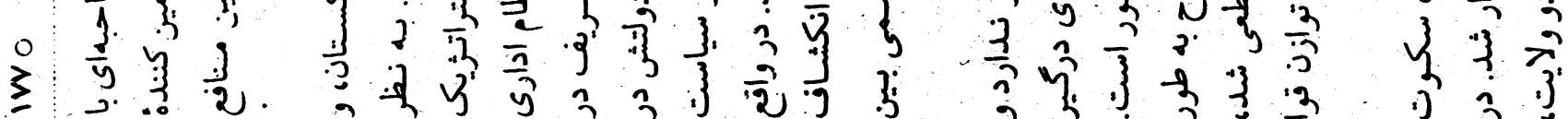


كشته و اسير جنكى بجا كذاشتند. اين بزركترين شكست نظامى طالبان حزب وحدت بر يك ولايت و جنرال دوستم بر همهة ششر ولايت شمال

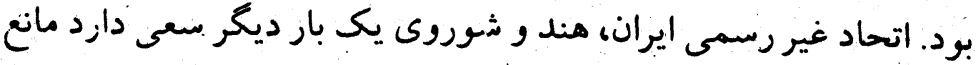

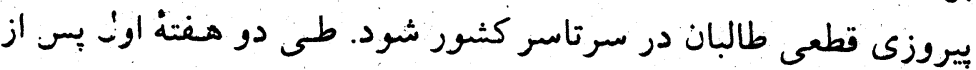

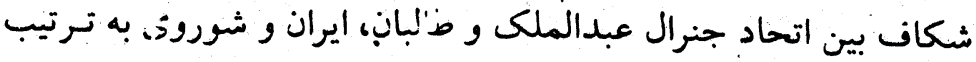

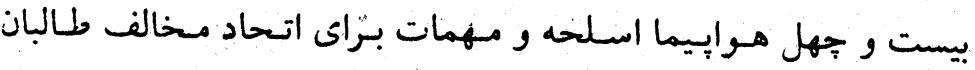
فرستادند. بنابراين تا هنوز عـلائق زيـادى بـراى مـداخـله و مسرمايهگذارى در

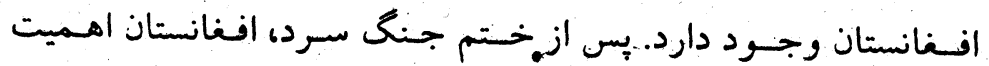

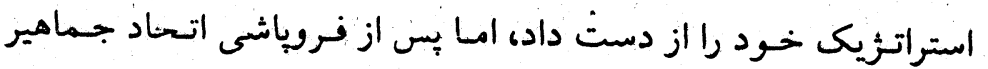

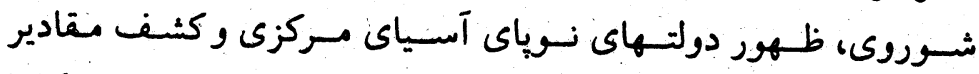

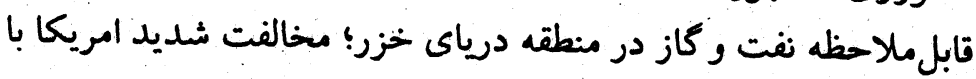

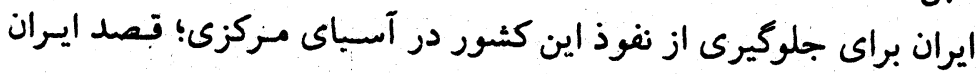

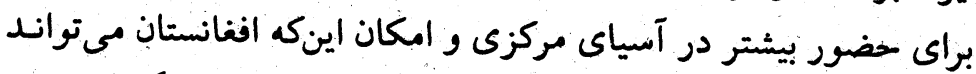

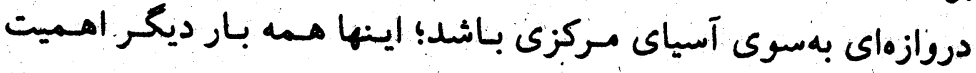

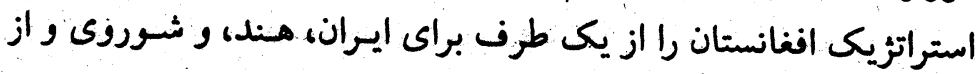

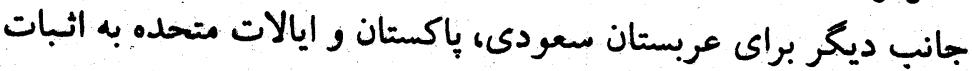

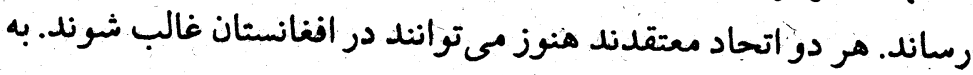

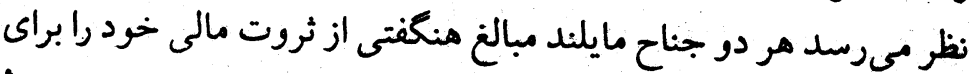

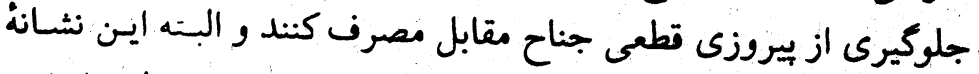

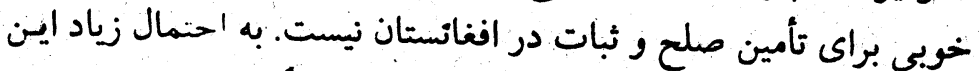

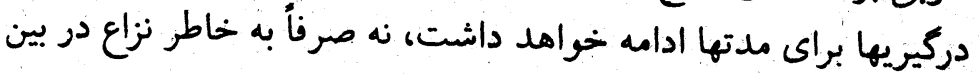
خود افغانها بلكه به خاطر رقابهاى شدئد بين قدزتهاى خارجى بر سـر

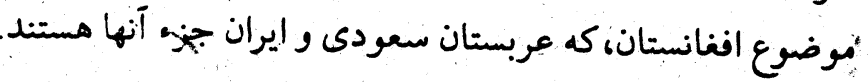

* * *

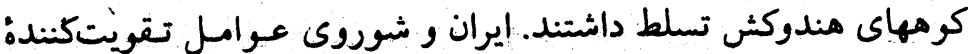

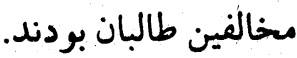
اين سكوت در 19 مي 199V 19 زمانى كه جنرالل عبدالملك از دوستم

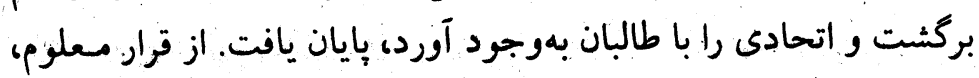

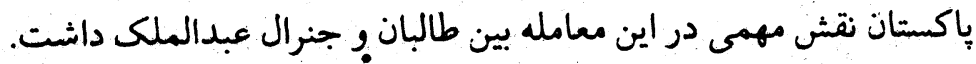

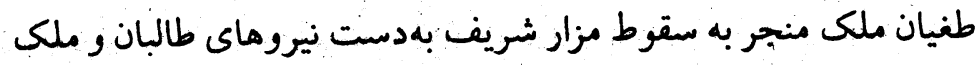

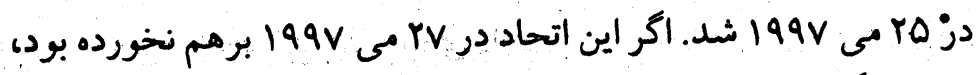

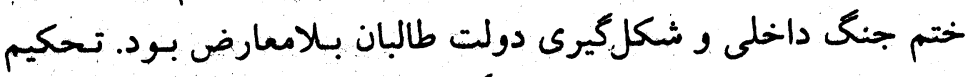

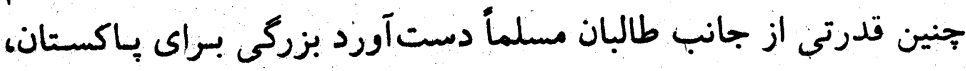

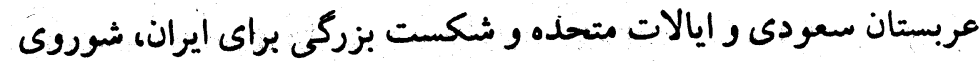

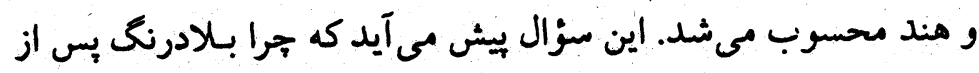
سقوط مزار شريف بهدست نيروهاى طالبان و ملك، ياكستان، عربستان

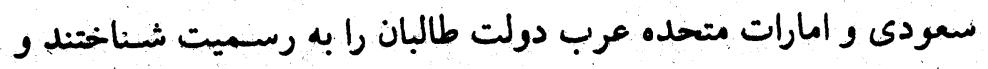

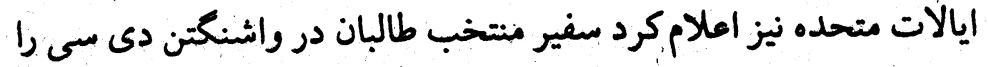

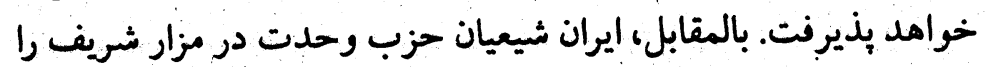

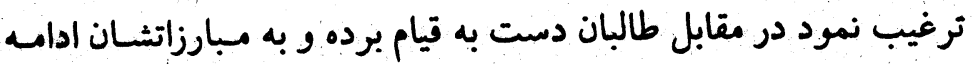

دهند.

زمـانى كه اتساد مـلك نـا طـالبان درهـم شكست، إيسران در خـارج افغانستان وبسيلة ايجاد انتلاف بين نيروهاى ازبك جـــرال عبدالمـلك،

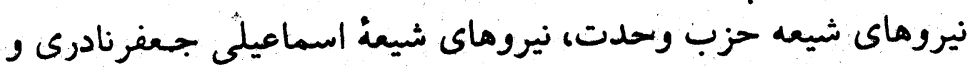

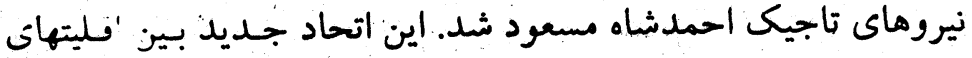

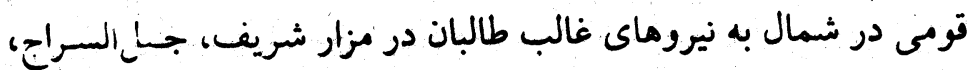

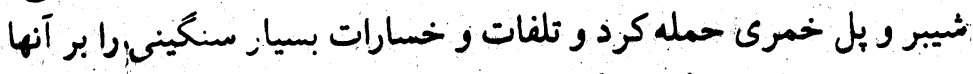

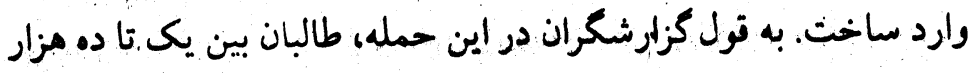


روسيه، آسياى مركزى و ظالبان

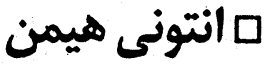

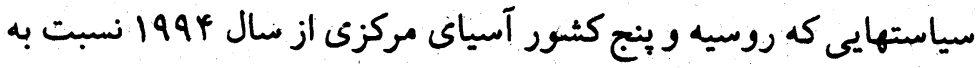

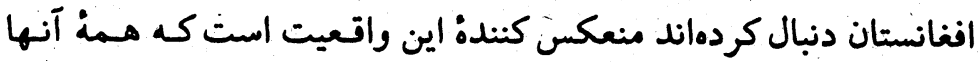

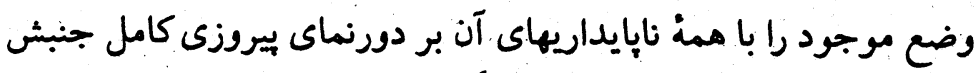

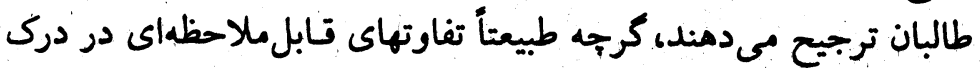

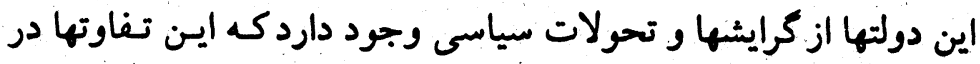

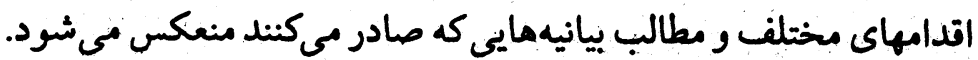

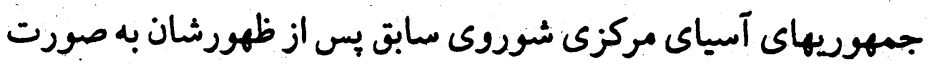

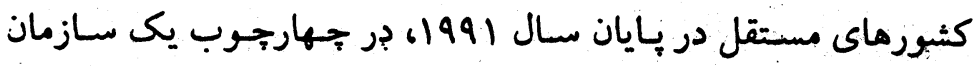

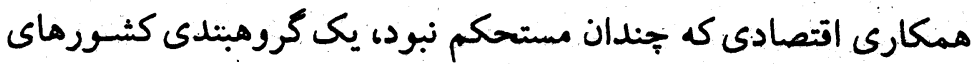

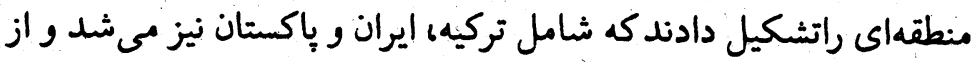

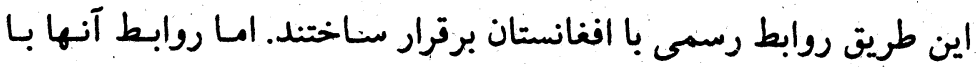

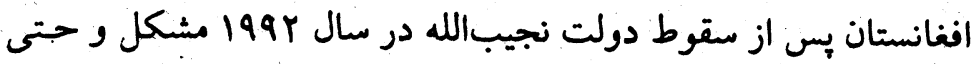

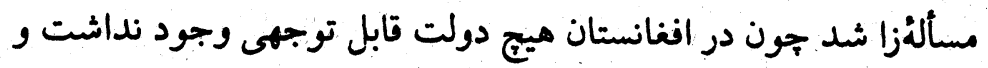

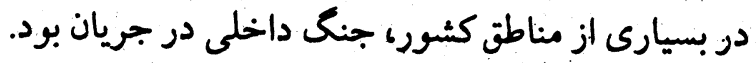

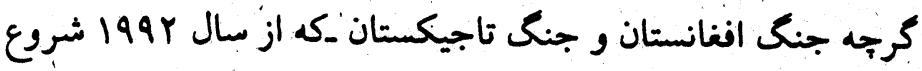

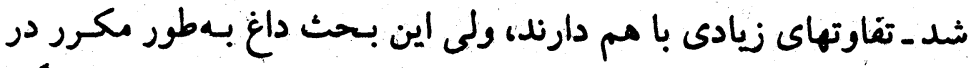

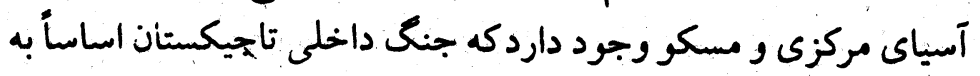




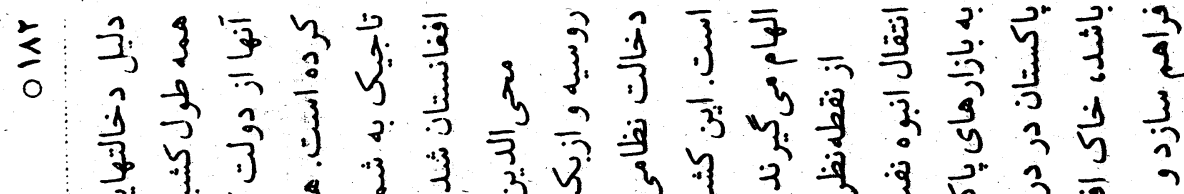

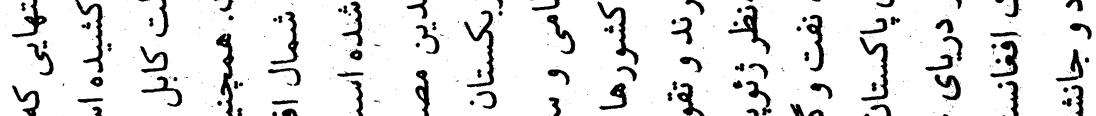

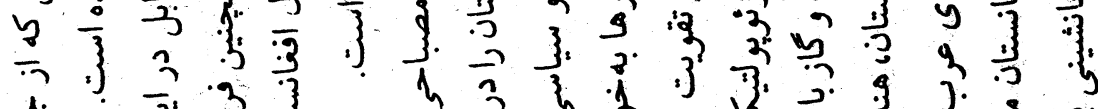

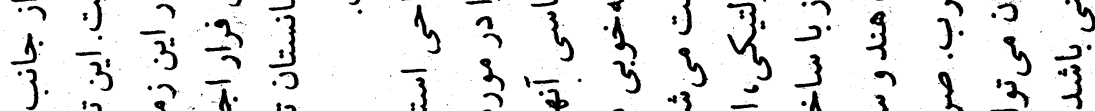

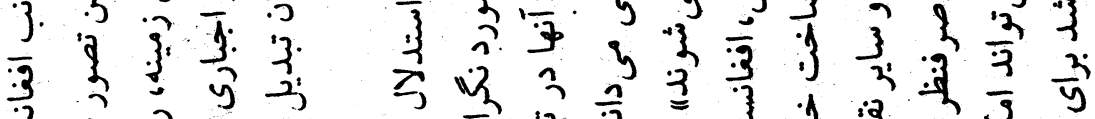

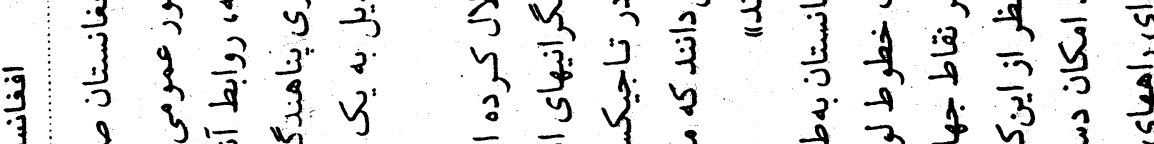

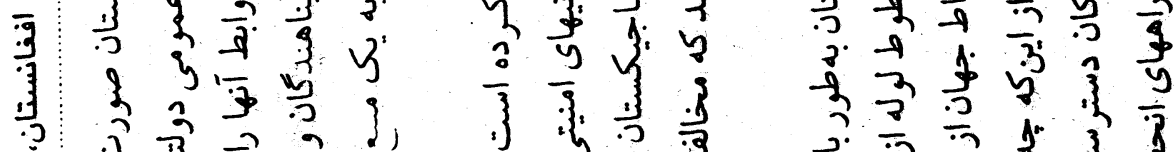

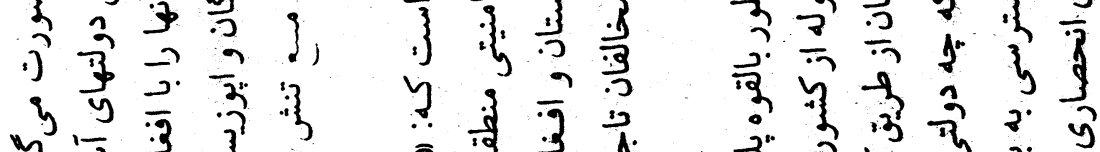

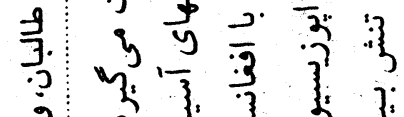

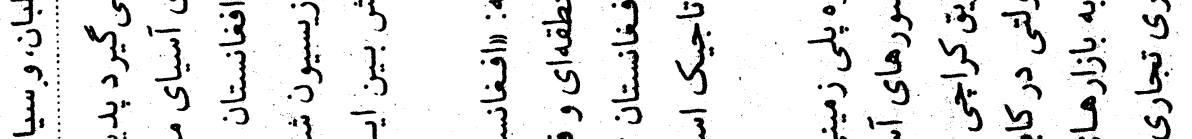

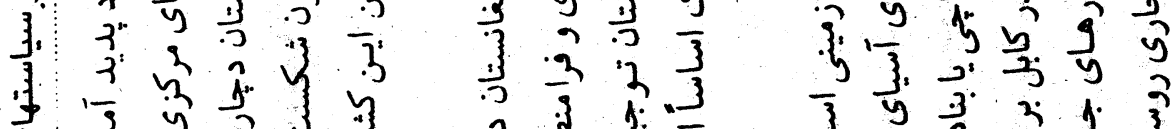

-

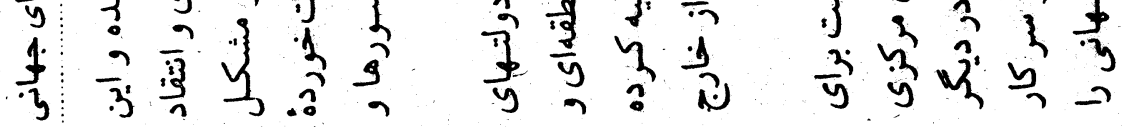

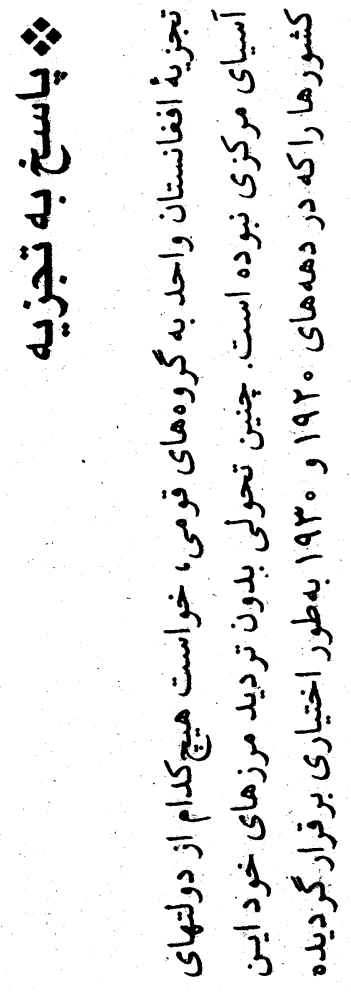

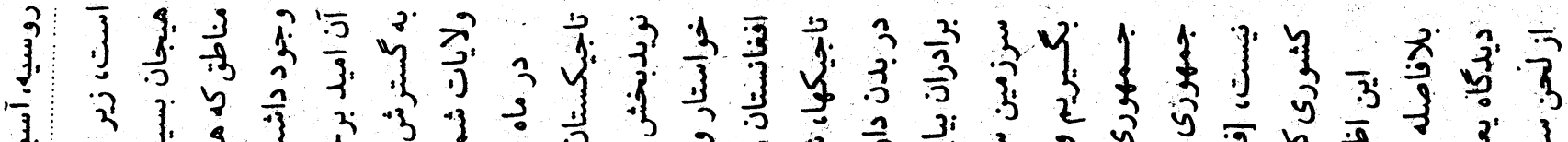

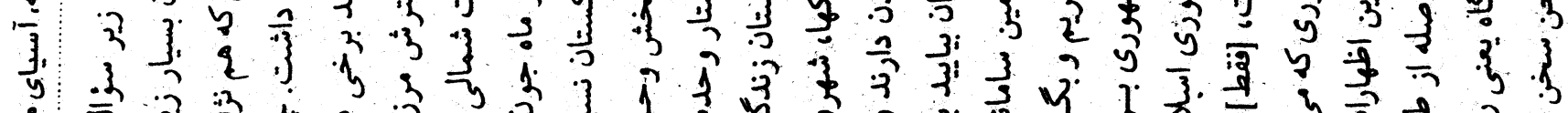

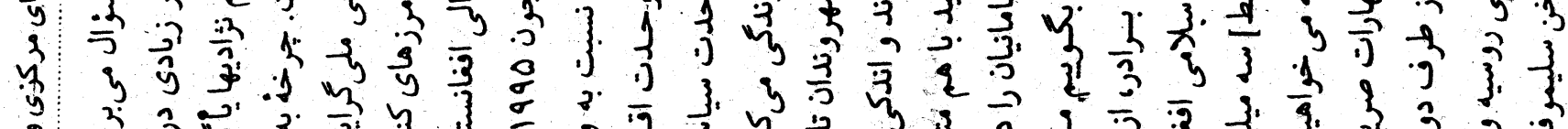

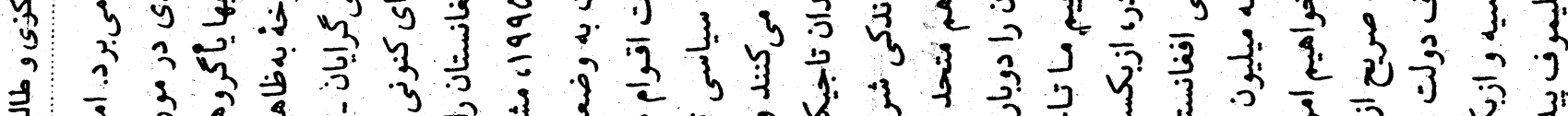

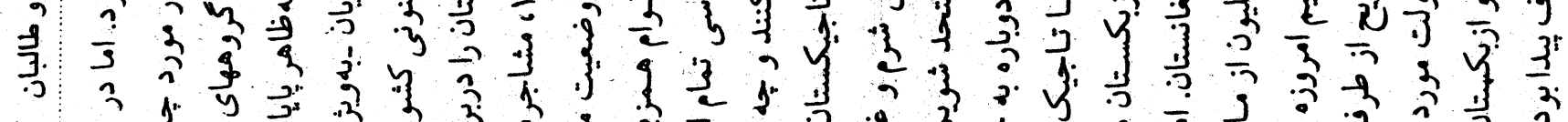

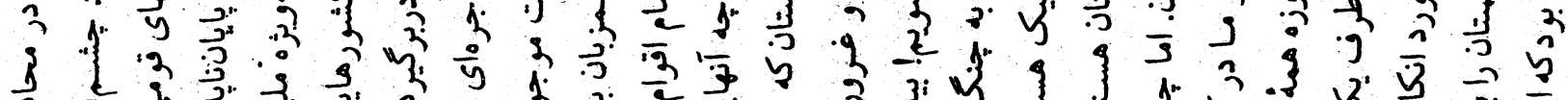

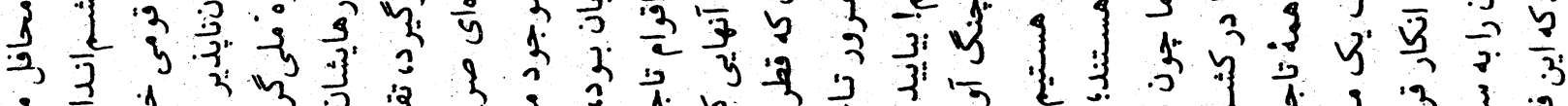

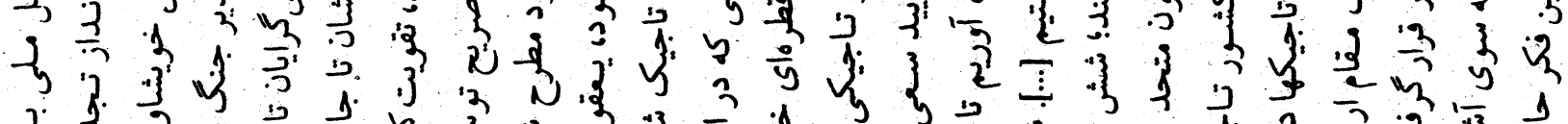

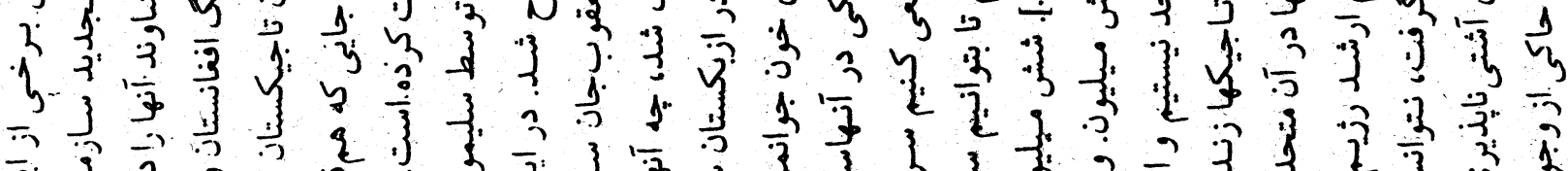

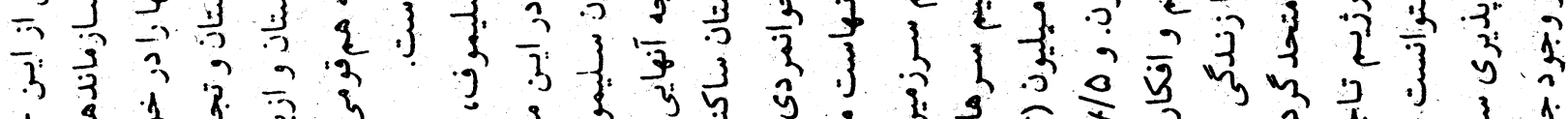

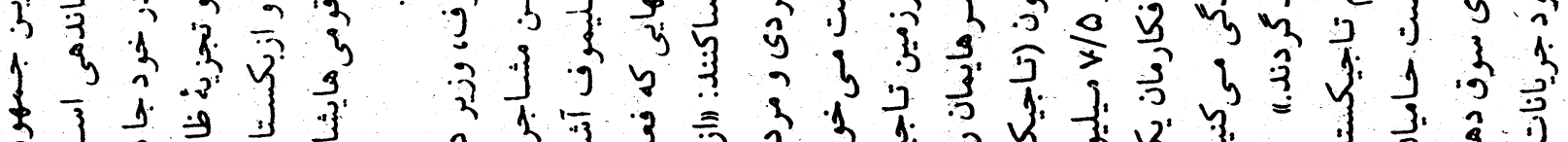

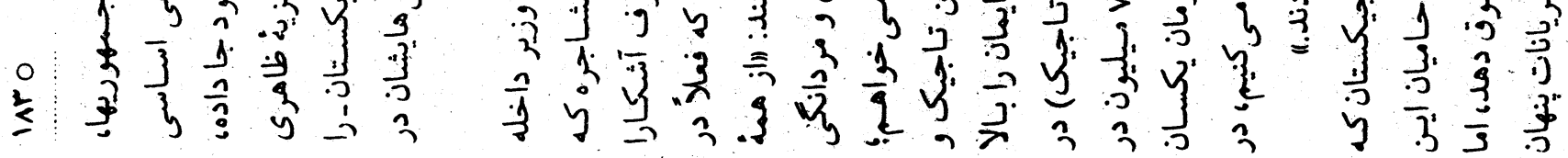




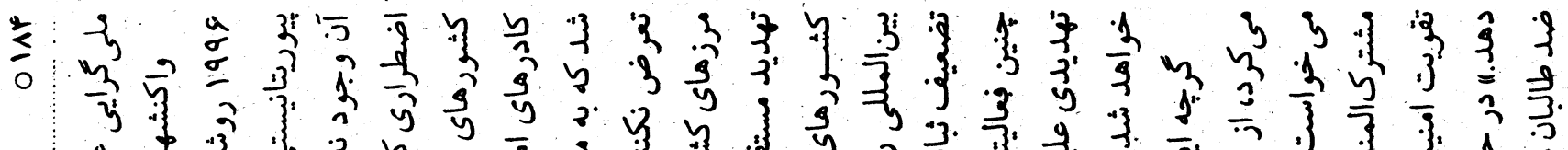

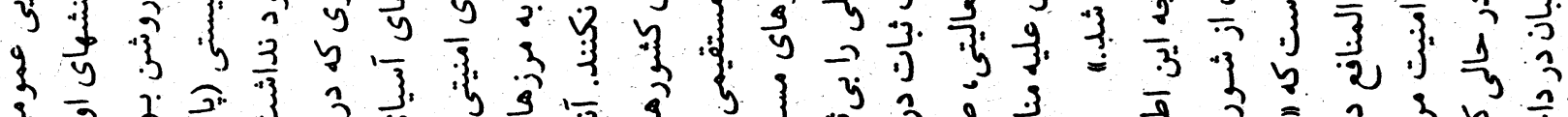

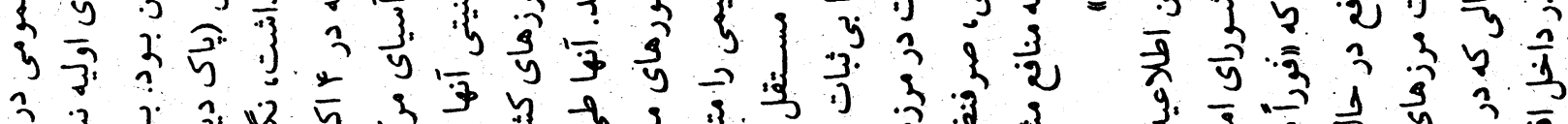

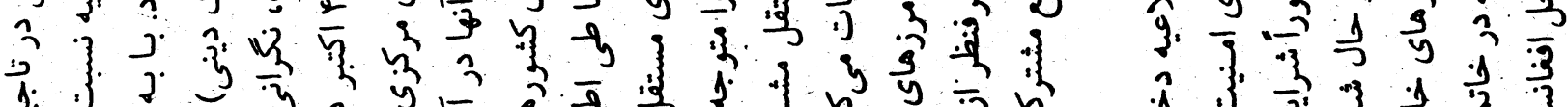

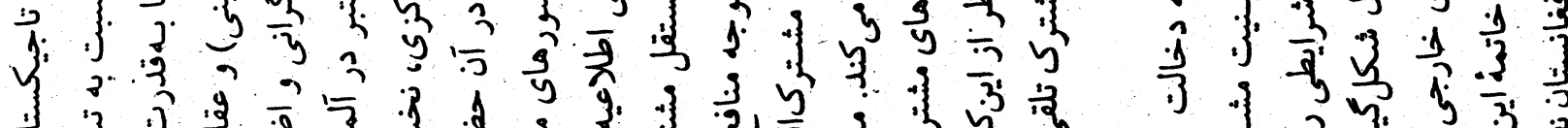

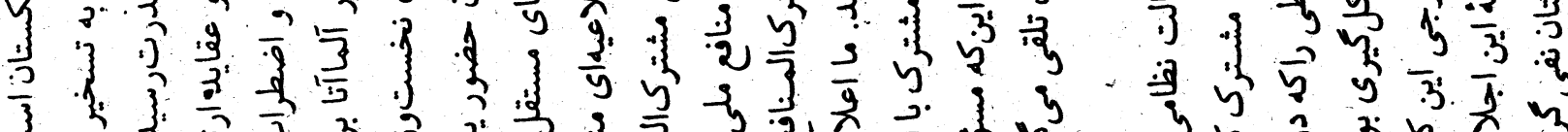

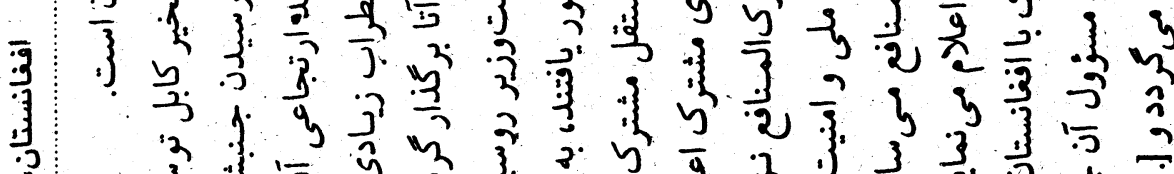

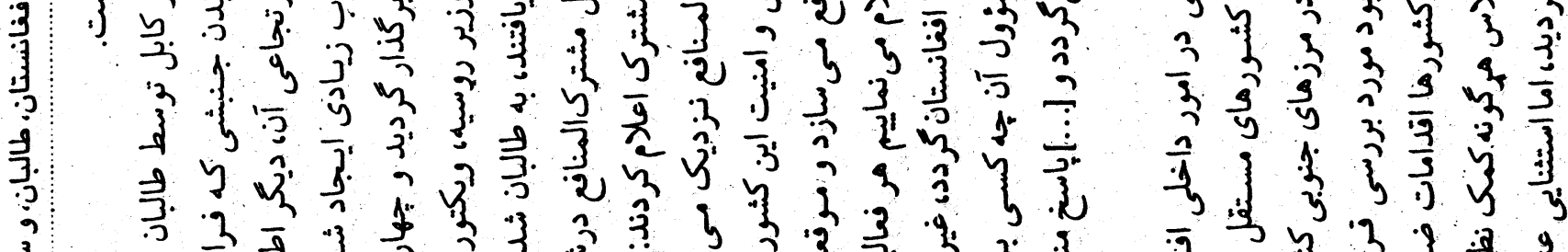

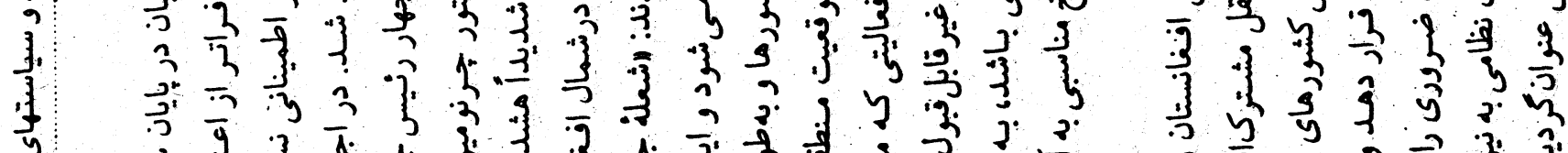

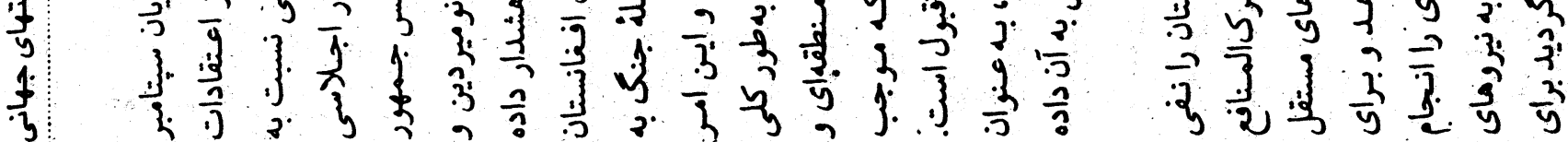

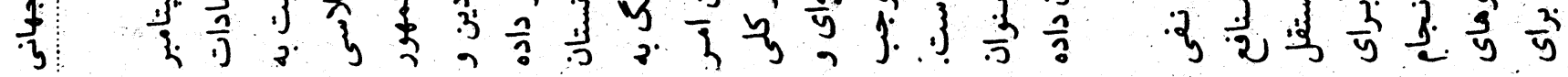

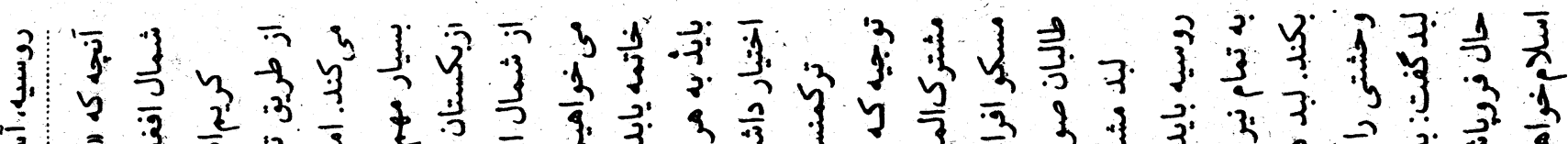

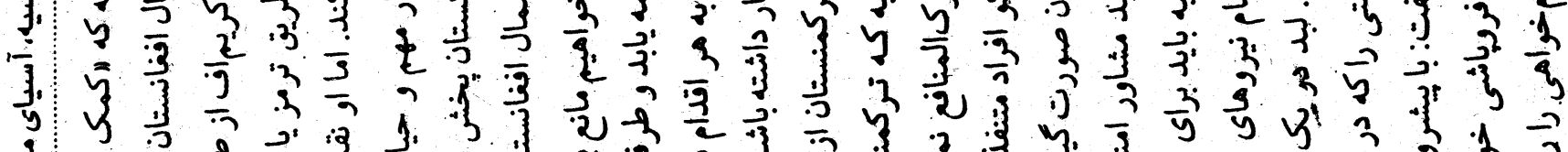

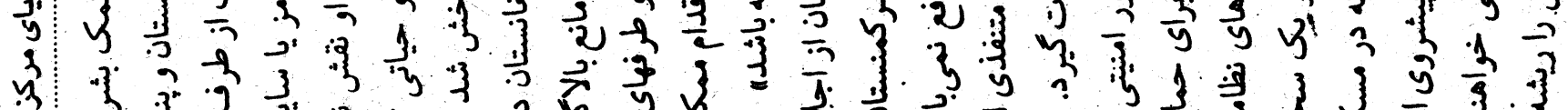

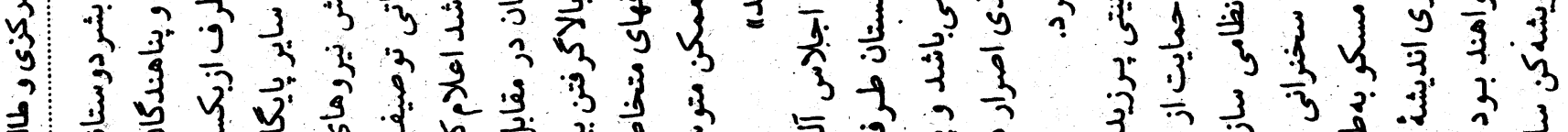

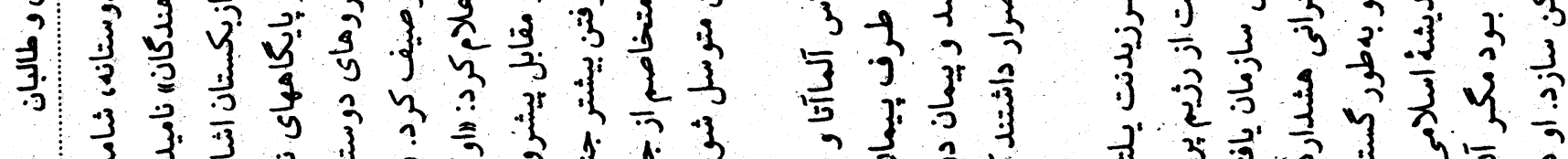

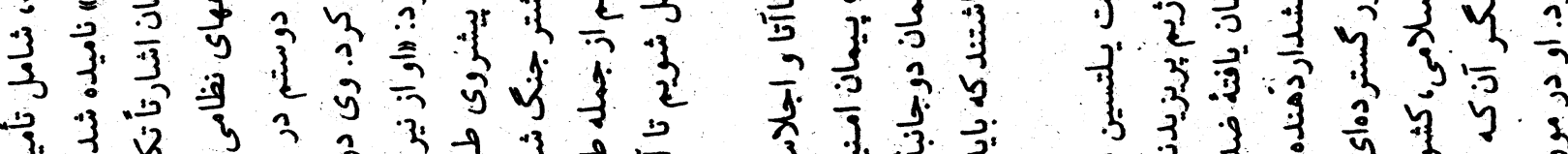

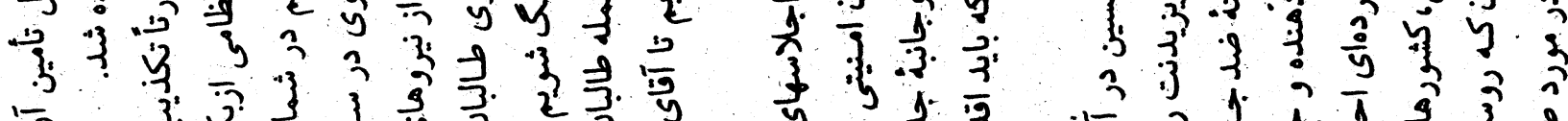

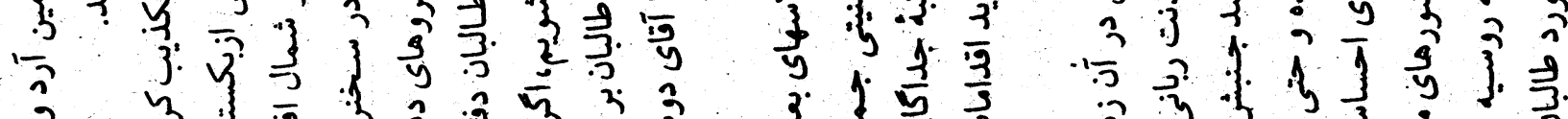

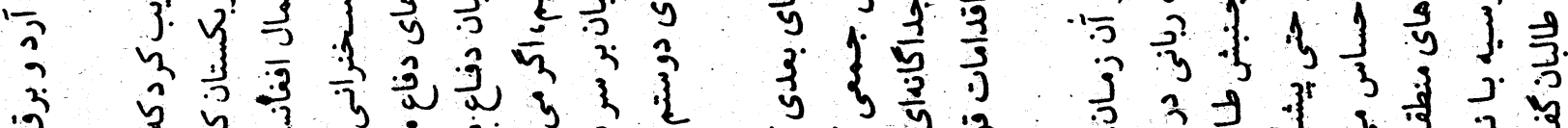

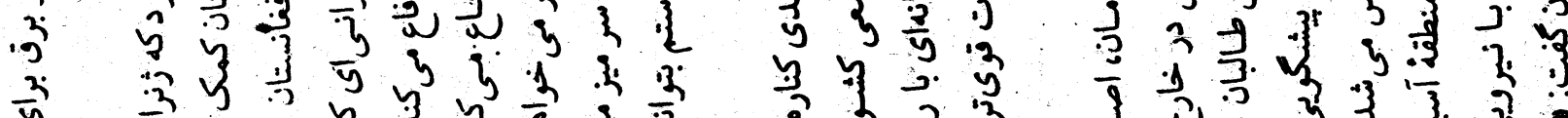

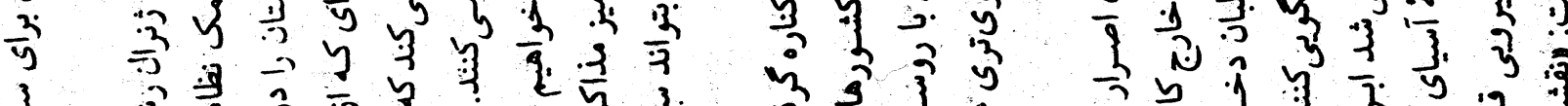

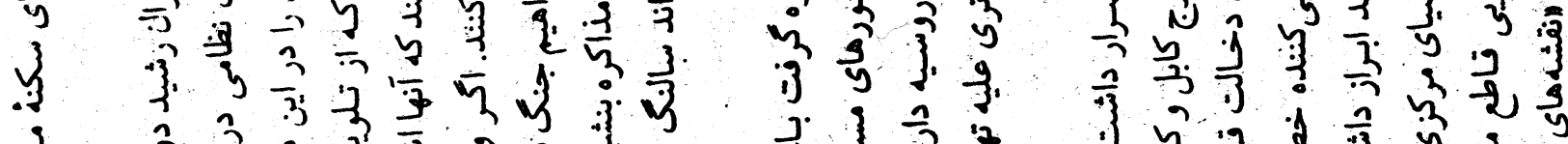

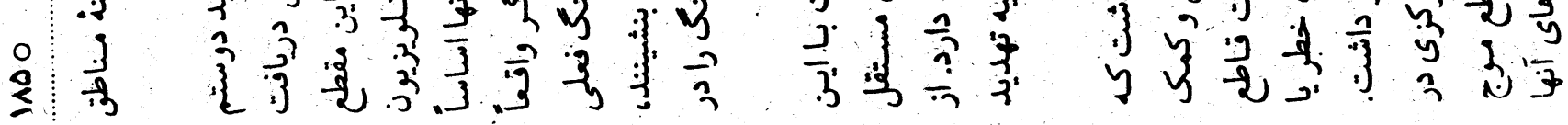




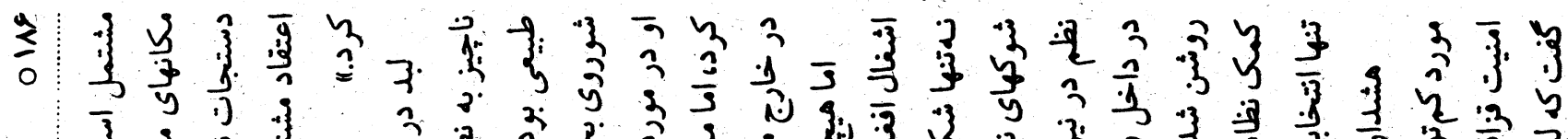

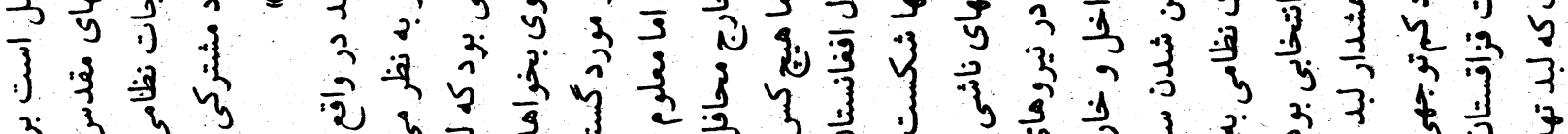
य)

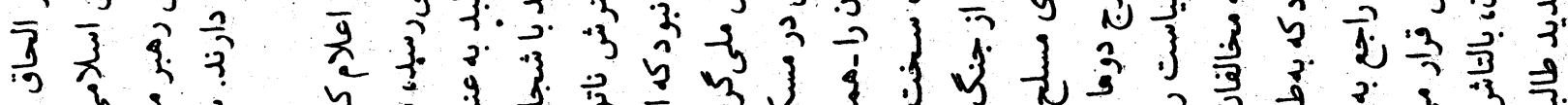

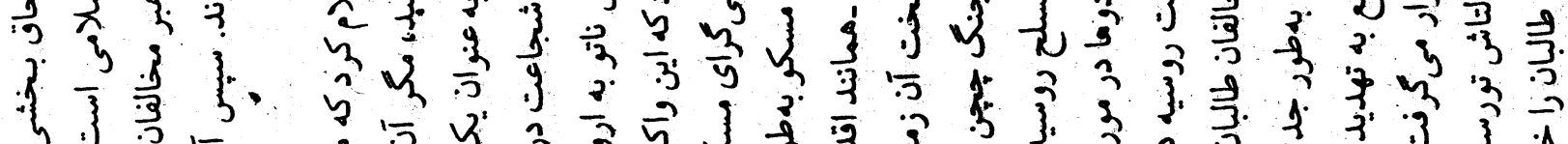

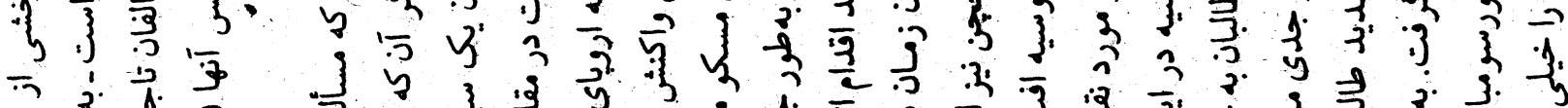

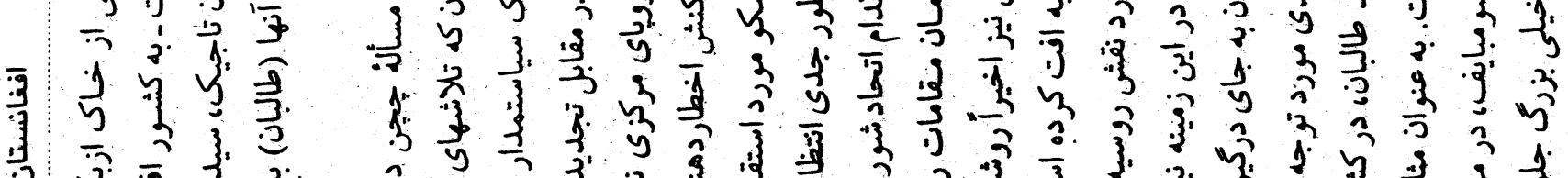

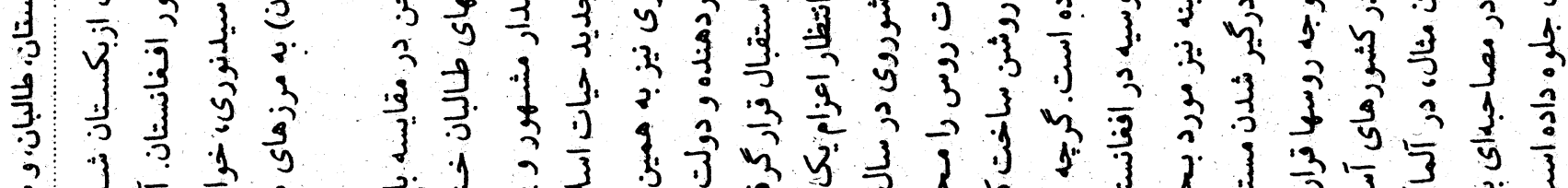

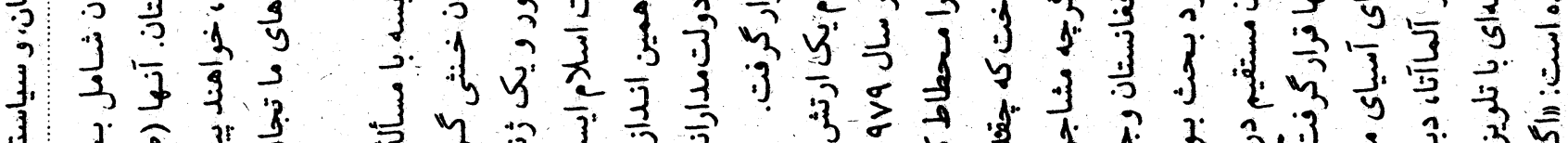

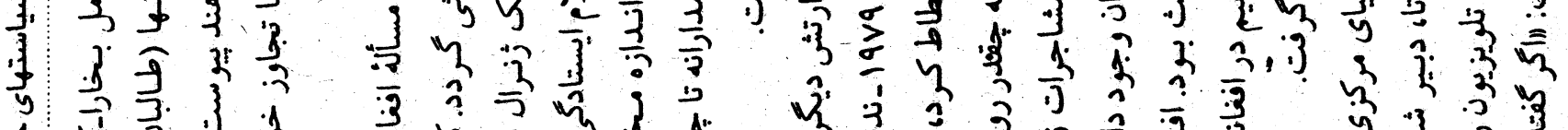

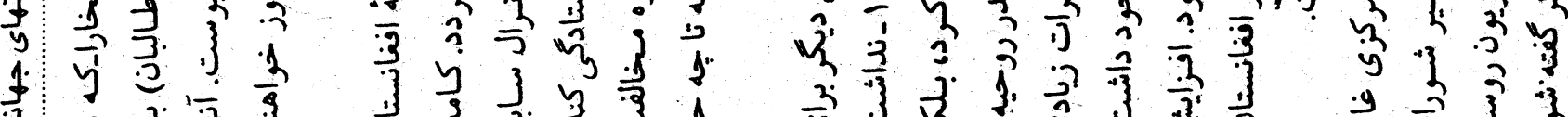

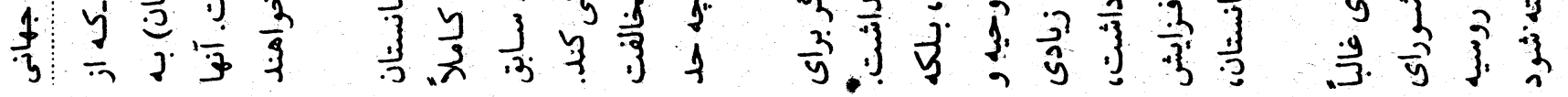

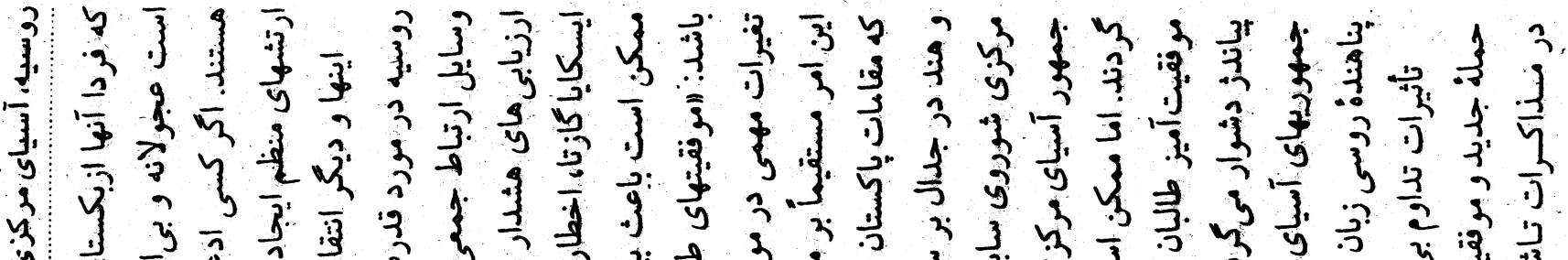

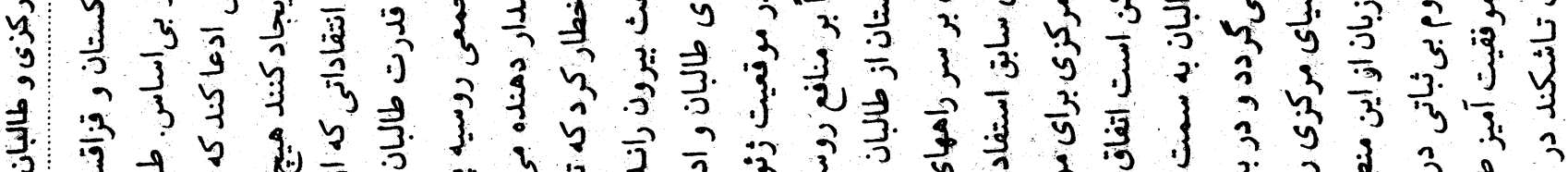

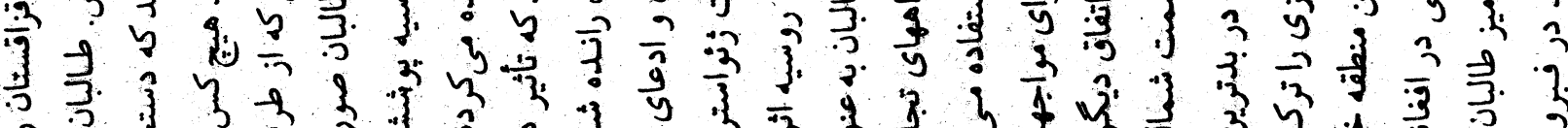

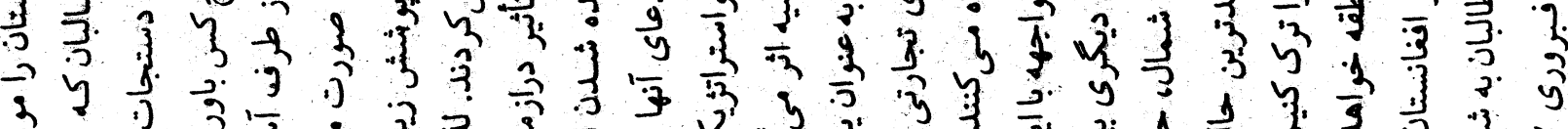

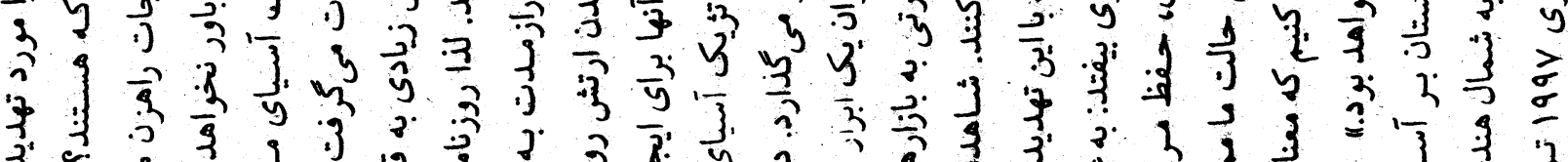

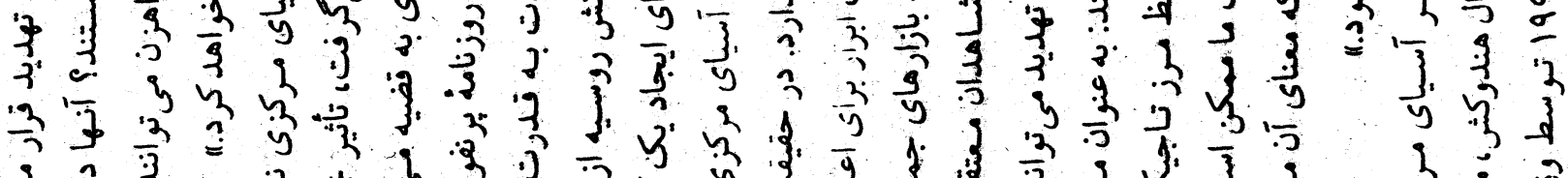

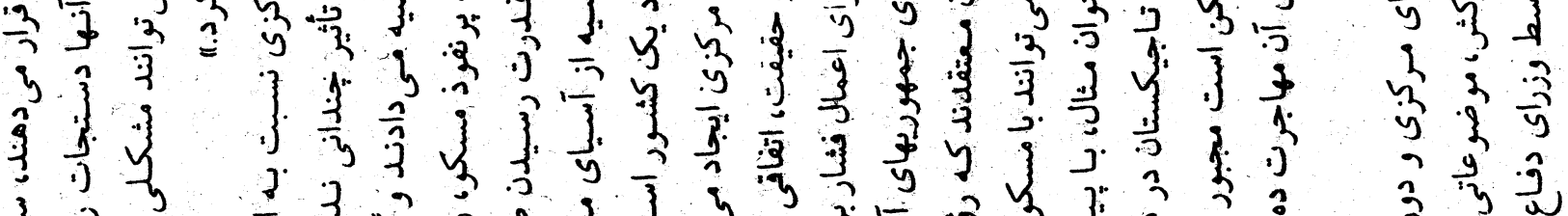

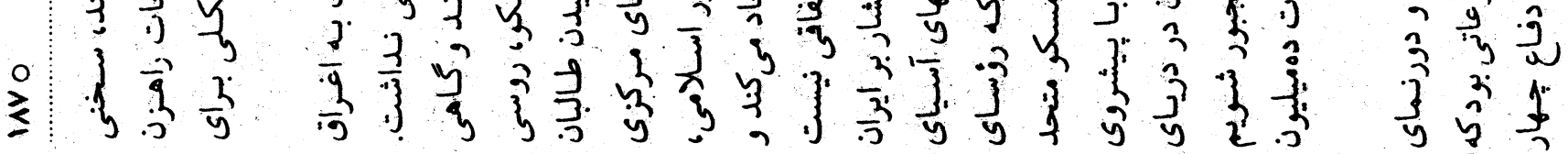




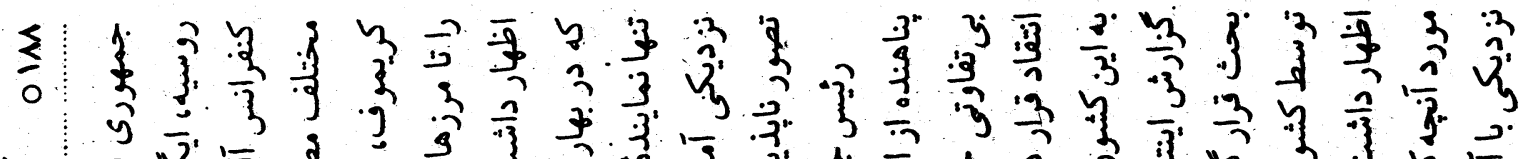

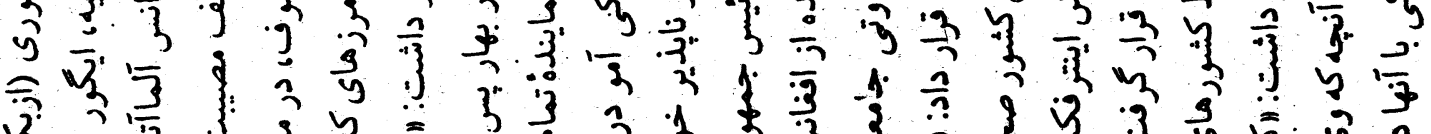

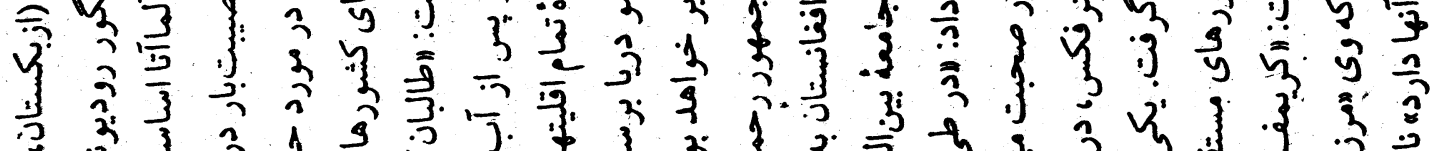

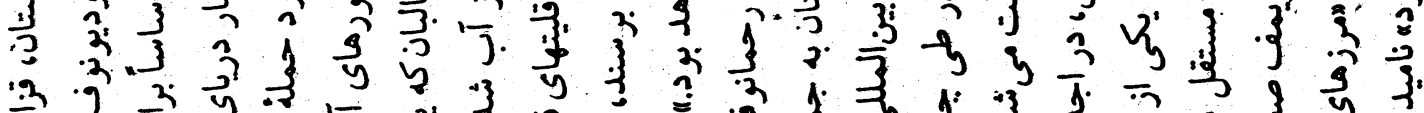

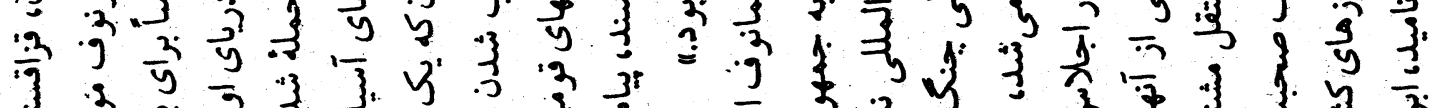

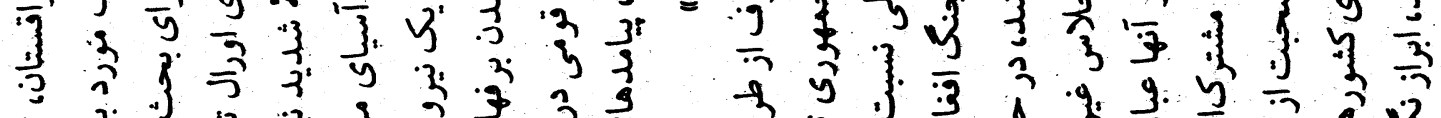

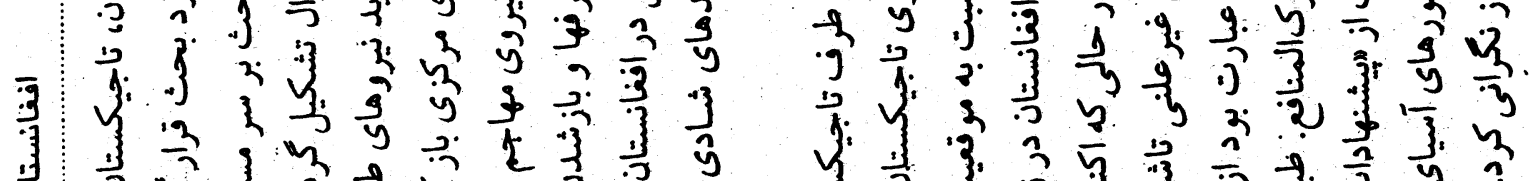

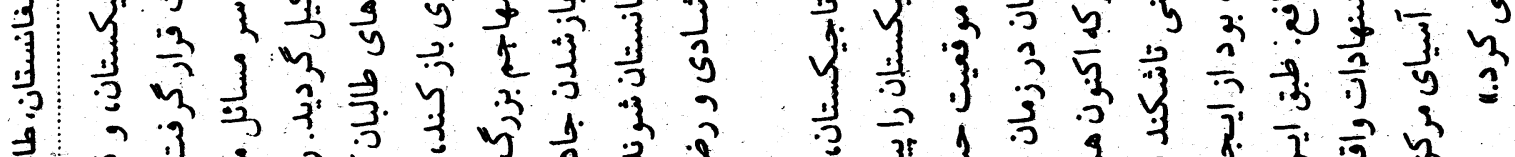

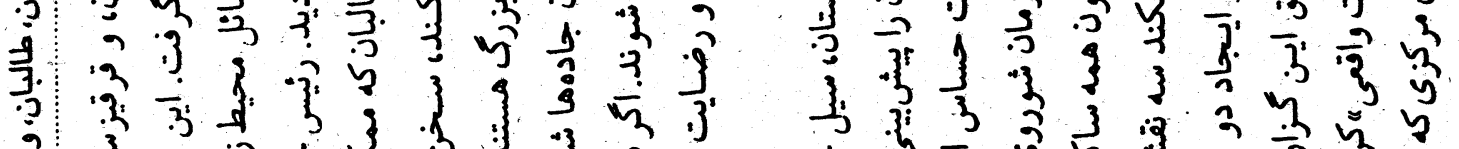

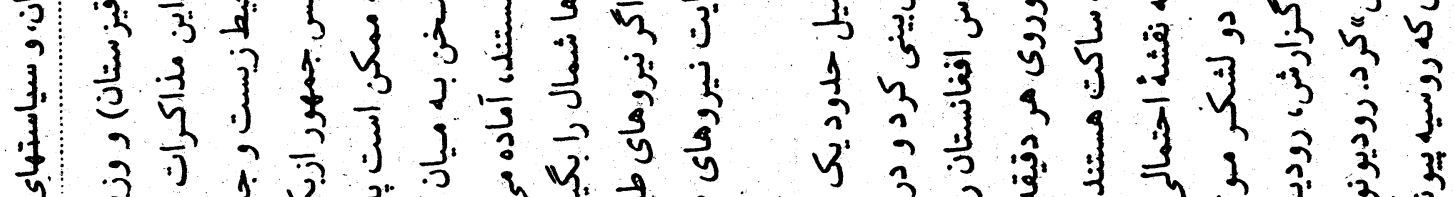

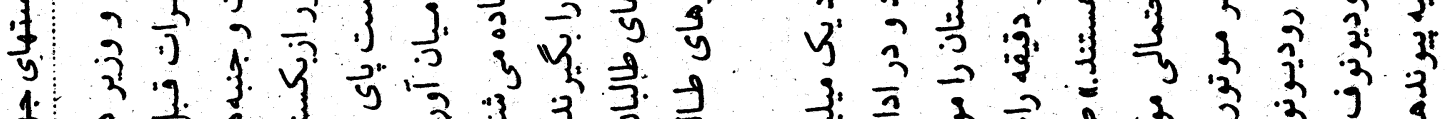

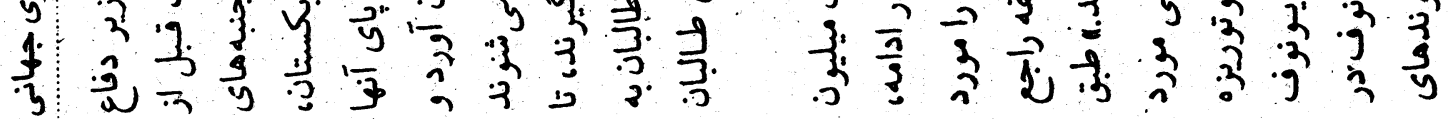

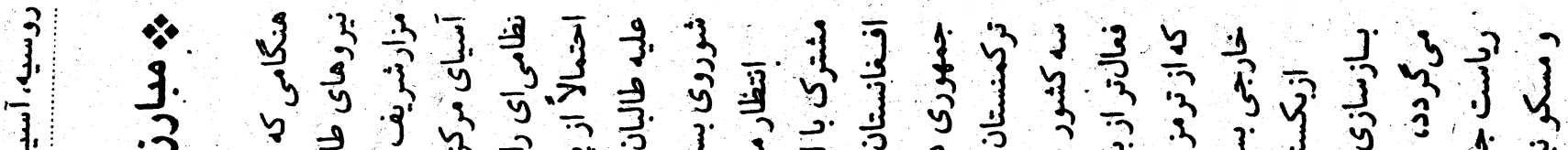

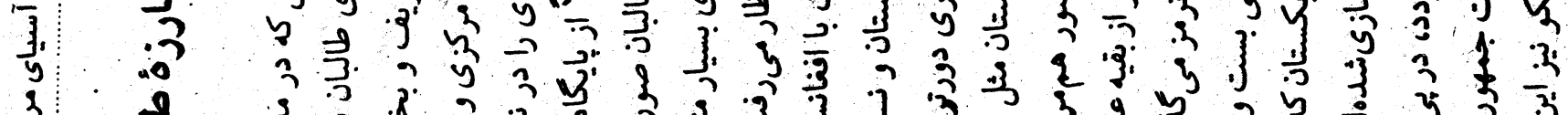

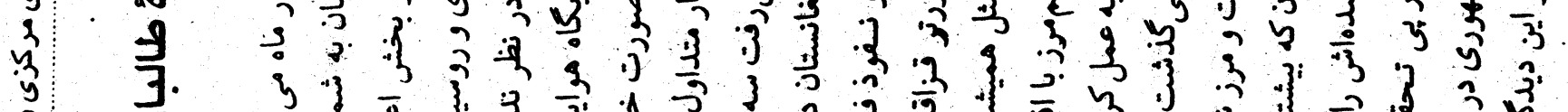

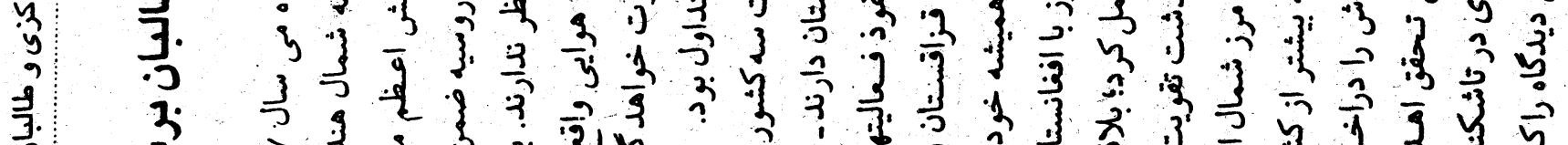

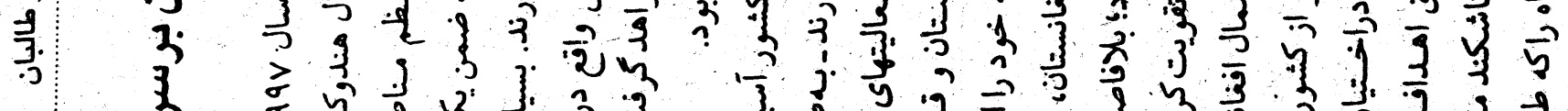

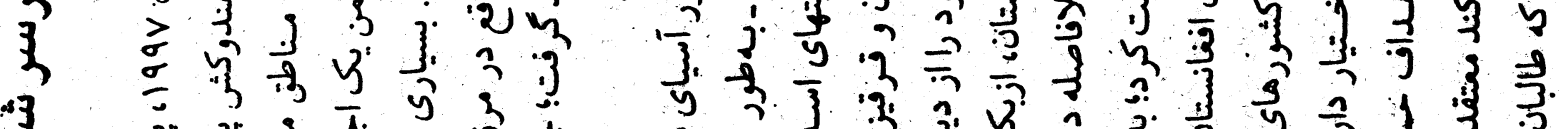

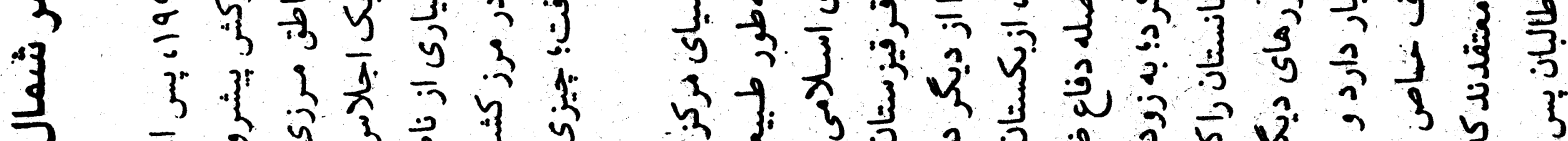

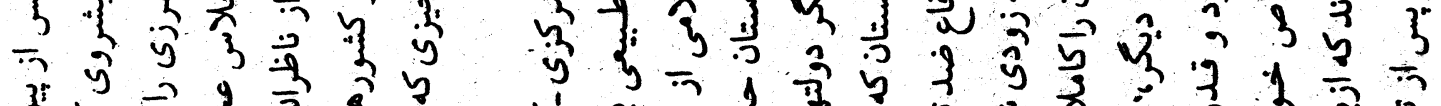
से

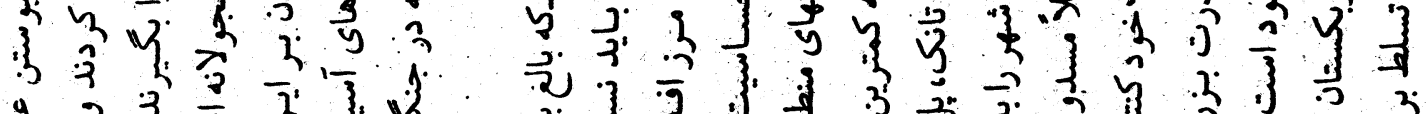

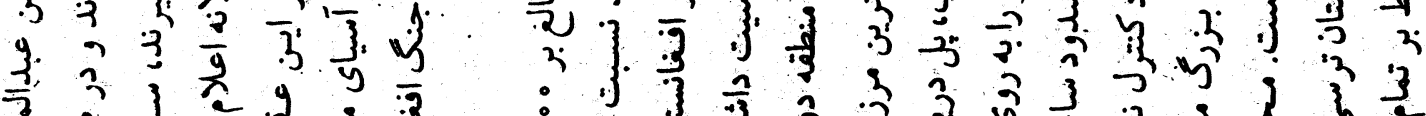

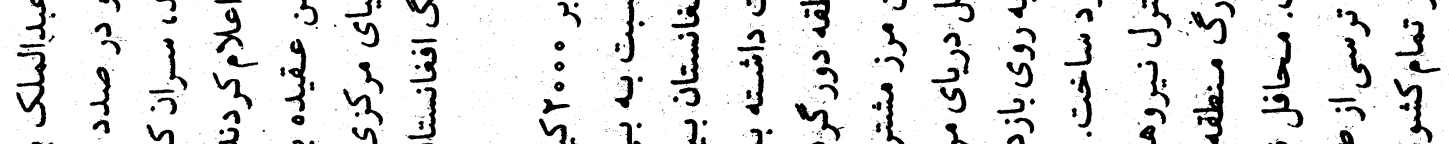

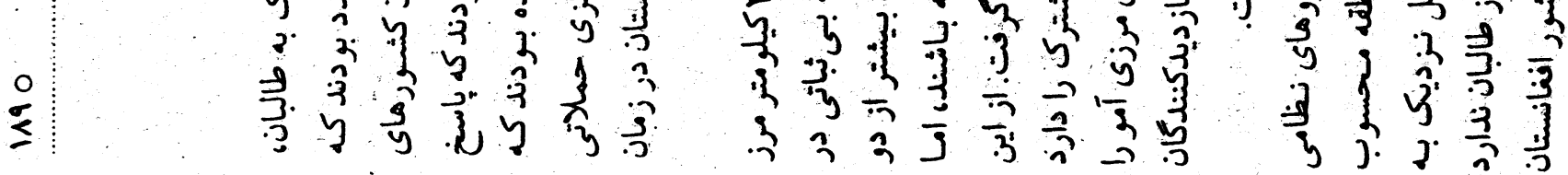




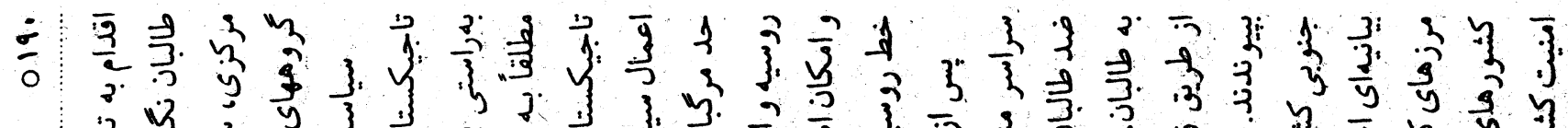
3. 3. 1) 9.

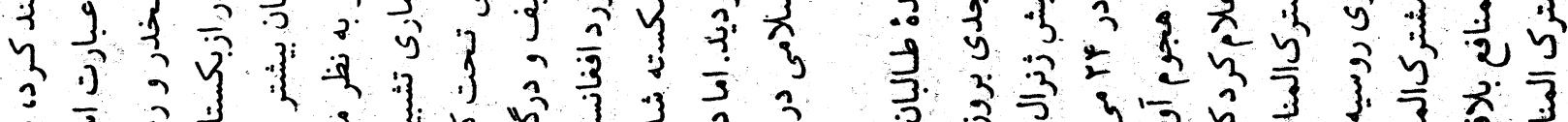

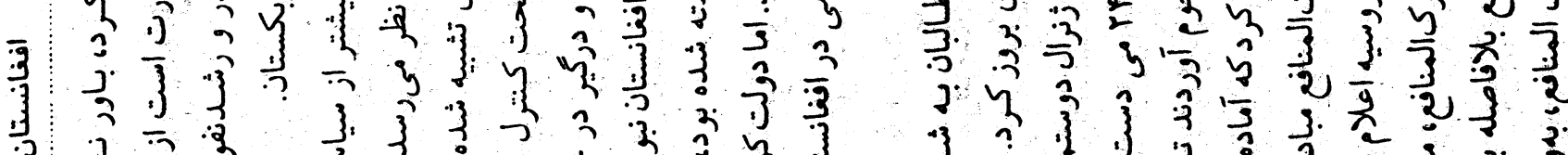

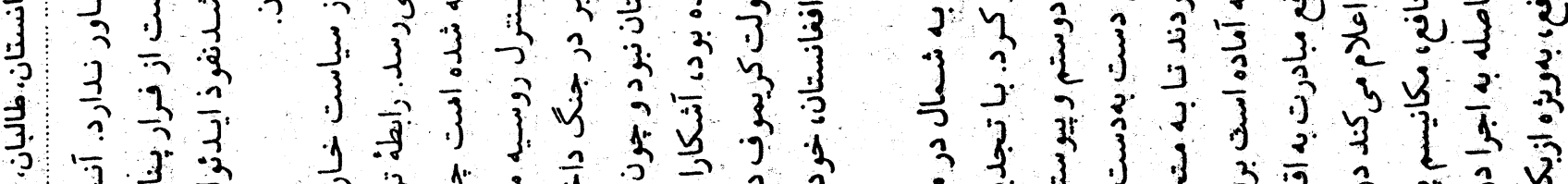

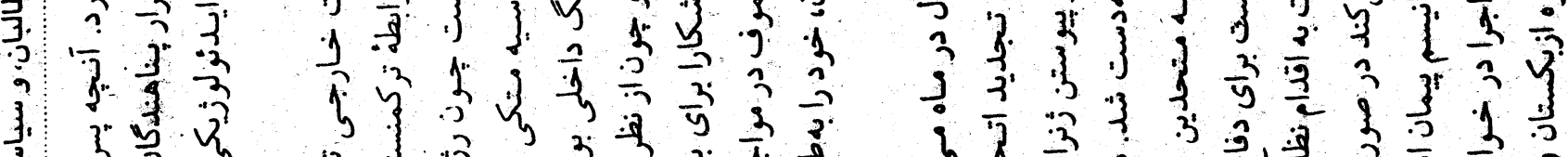

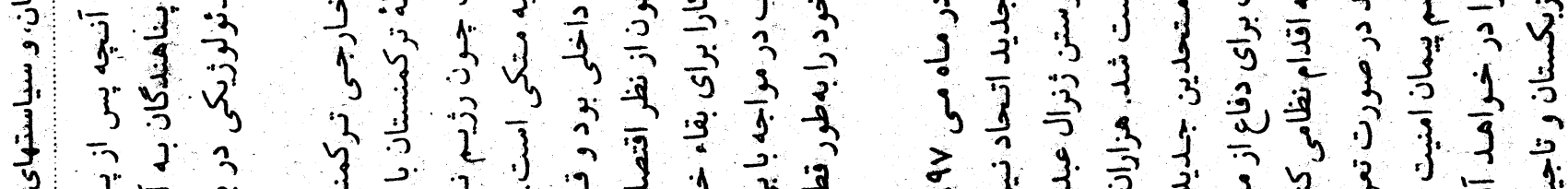

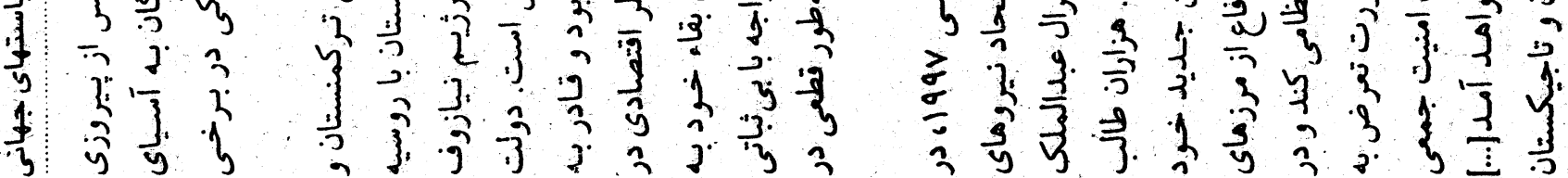

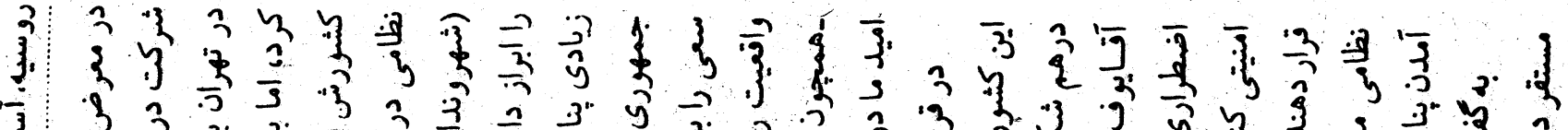

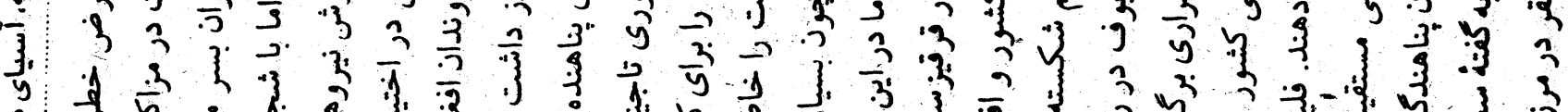

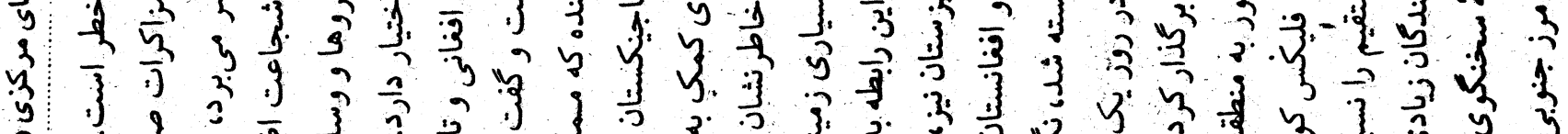

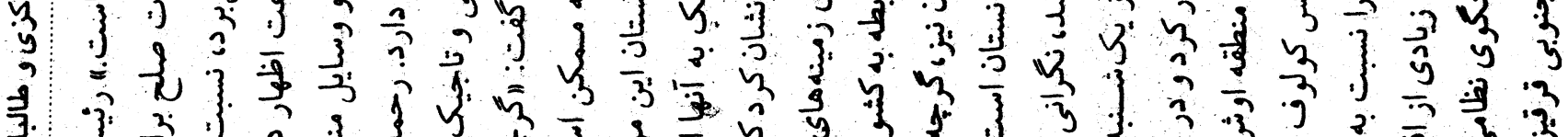

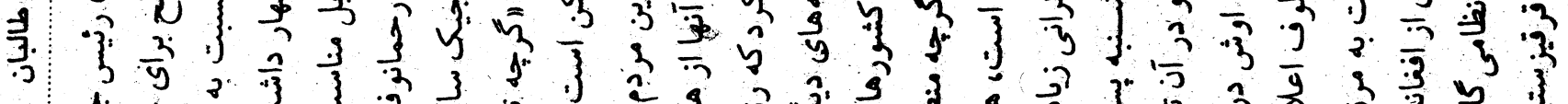

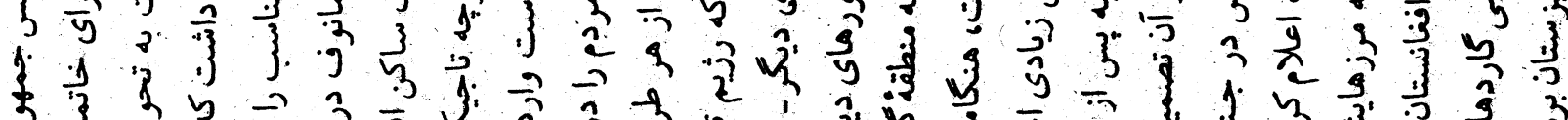

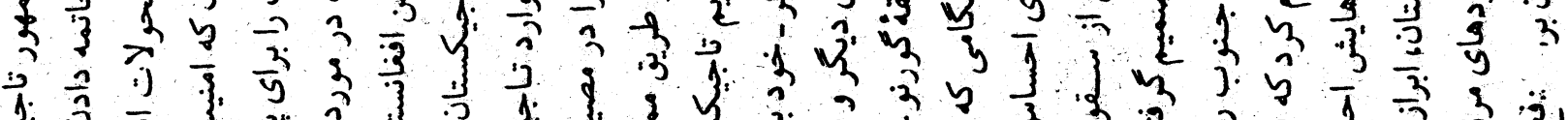
y.

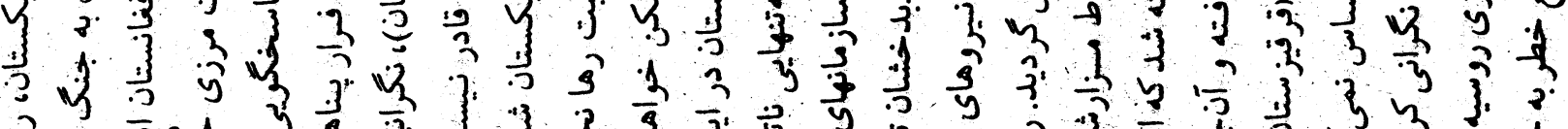

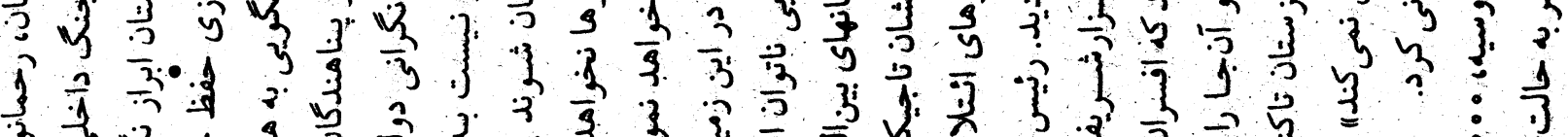

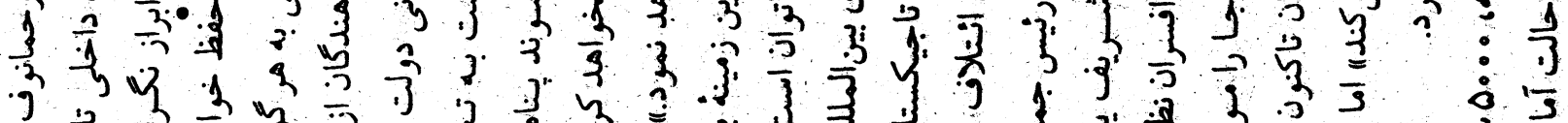

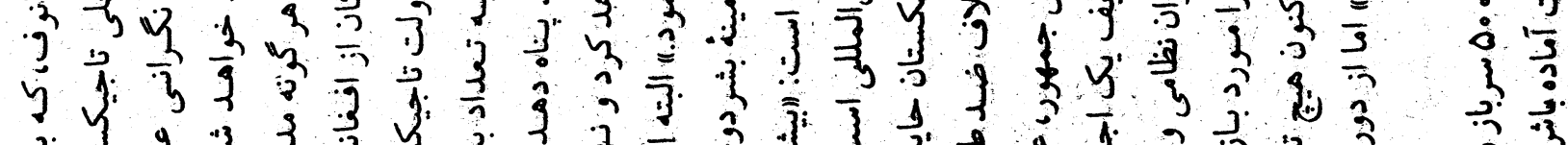

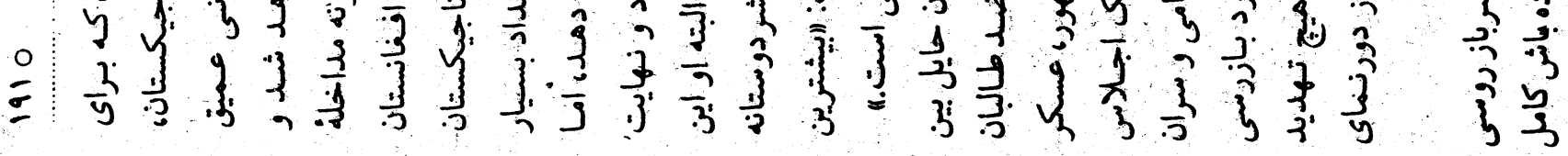



0
0
0

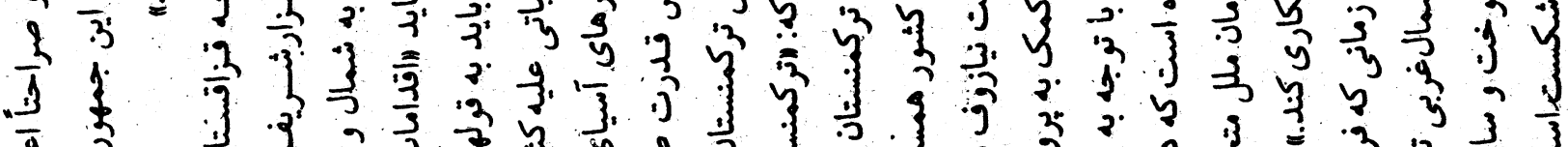

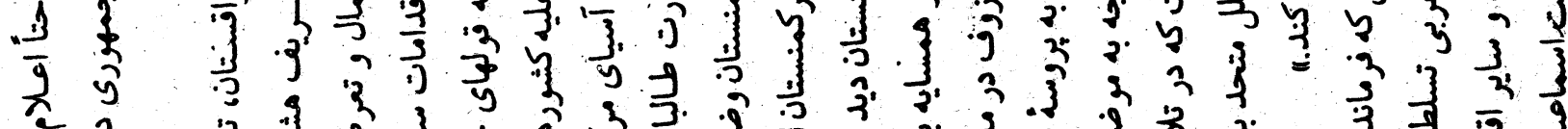

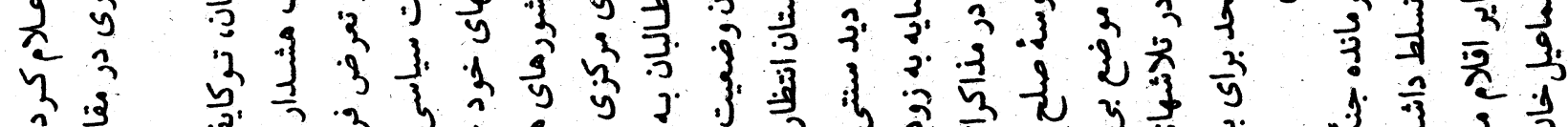

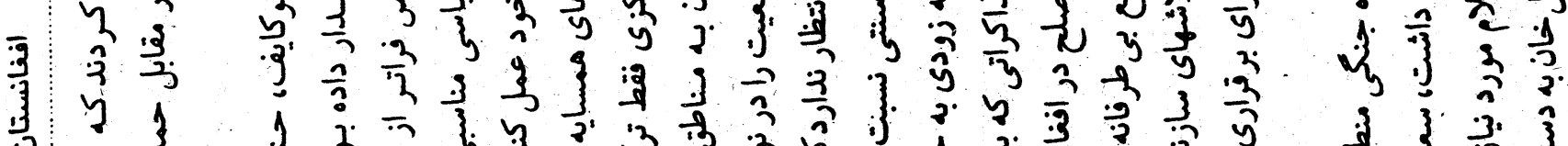

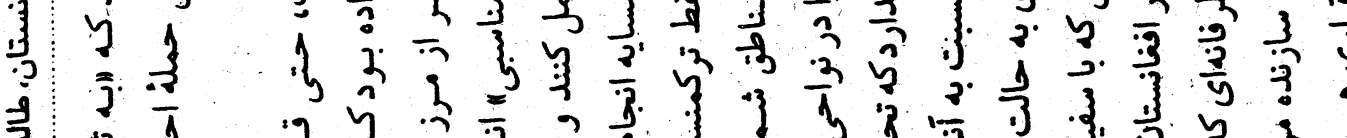

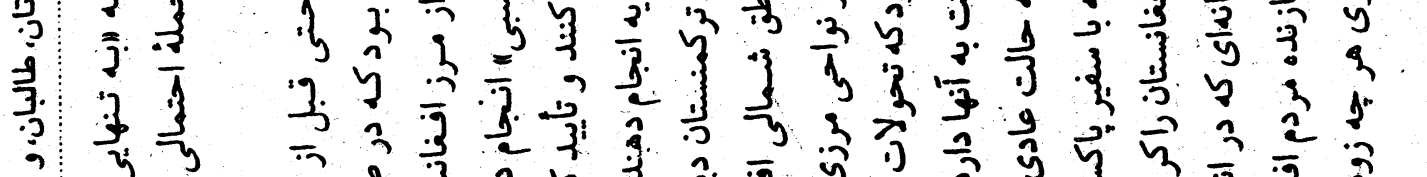

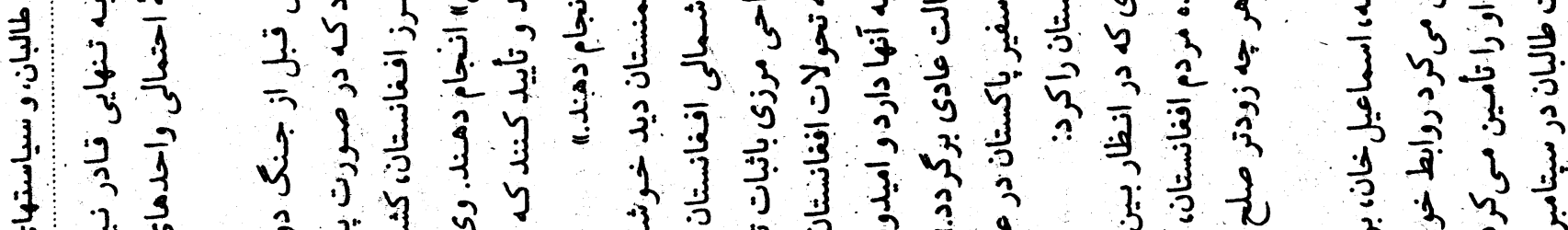

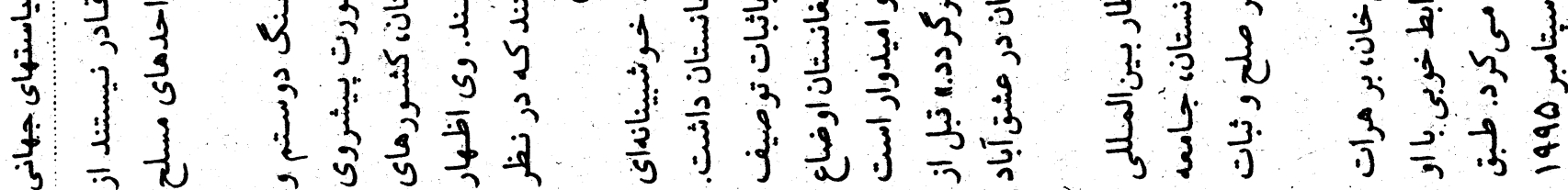

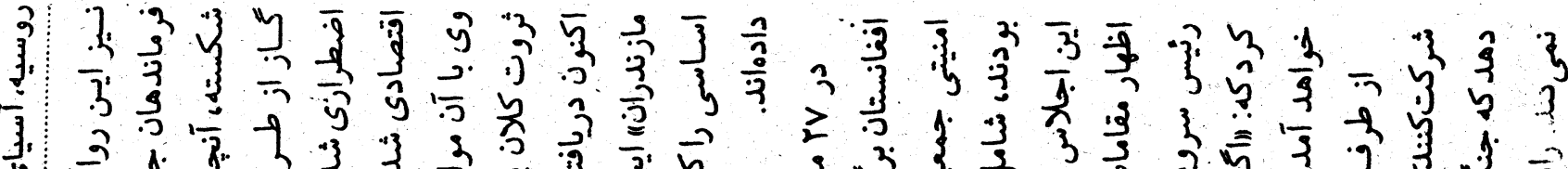

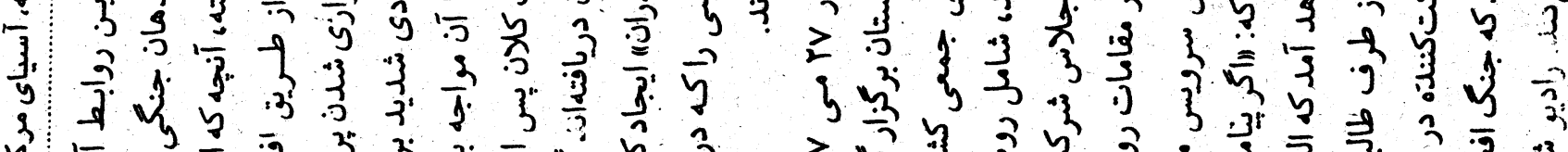

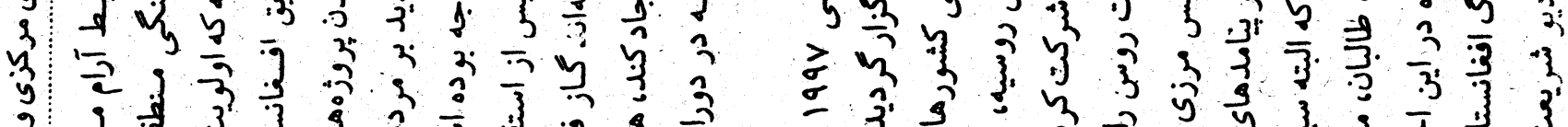

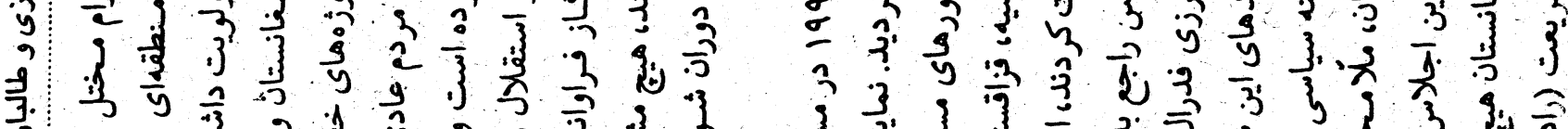

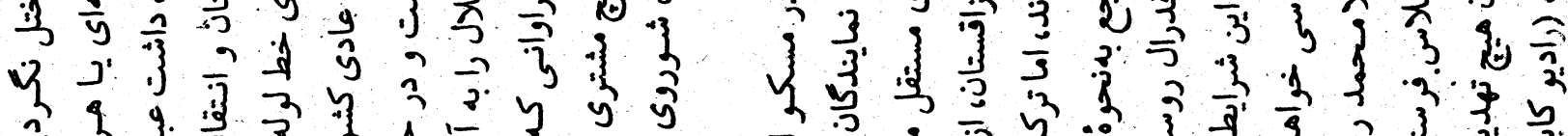

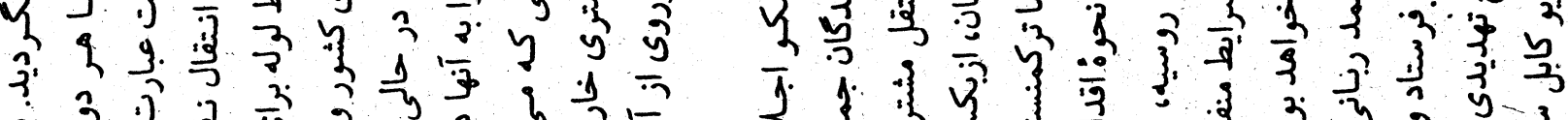

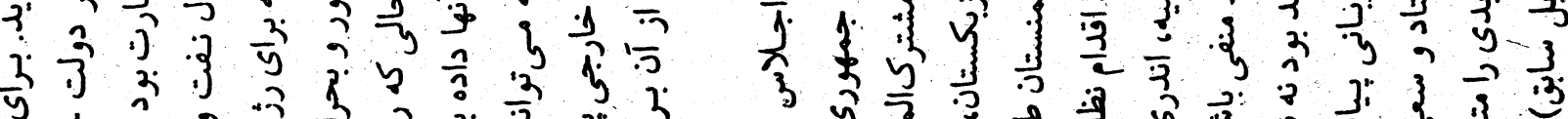

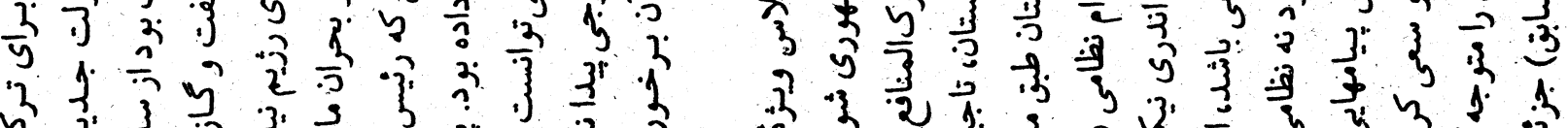

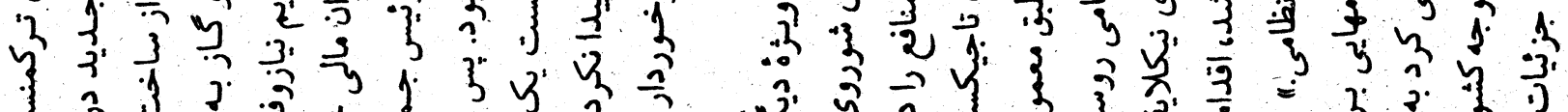

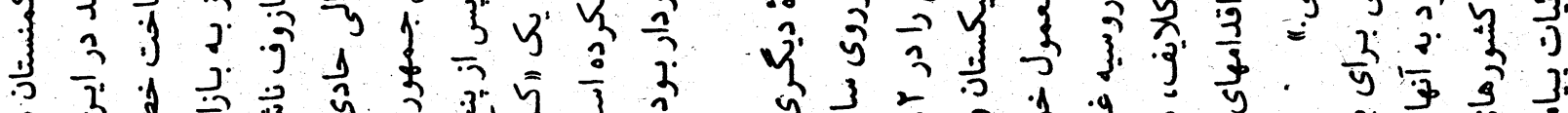

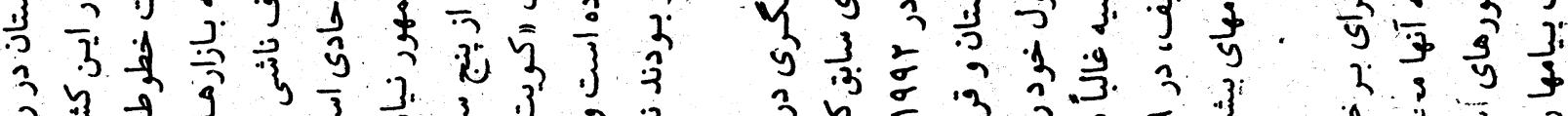

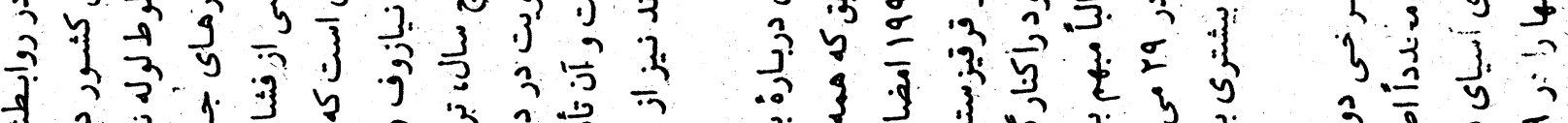

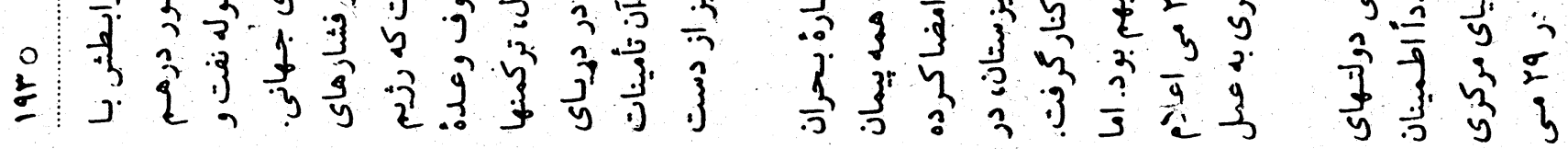


اتحاد شمال به بِايگاه هواييى كرلاب در جنوب تاجيكنتان برواز كردهاند. هاين فرودگاه به بايماهى براى نيروهاى شورشى مخالف كثور اسلامى افغانستان تبديل شده است. نيروماي شوردشى به به دستور مرانت خورد به به آن

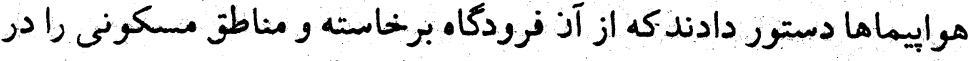

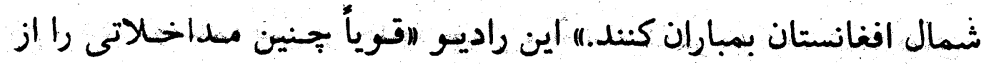

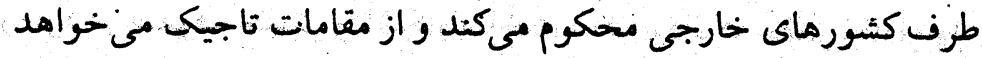

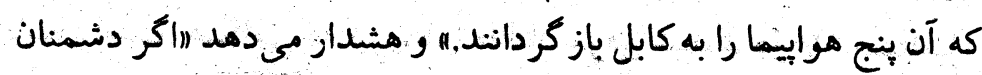

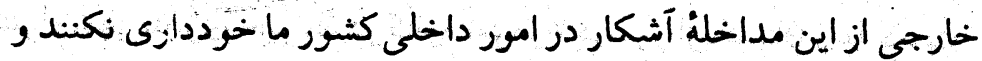

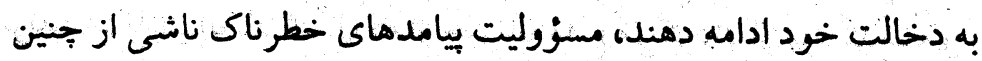

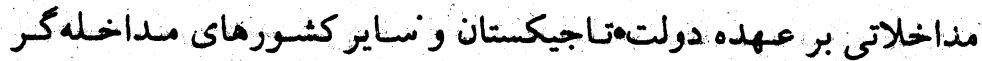

كرجه در اين اعتراض و ساير اعتراضات، دولت تاجيكسنان مستقيم

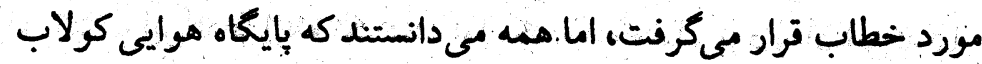

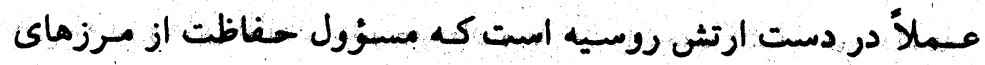

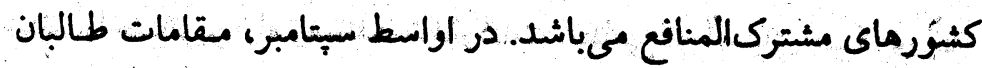
ادعا مىكردند كه اين قضيه و ماير مداخلات مخارجى به سطع "اغير قابل

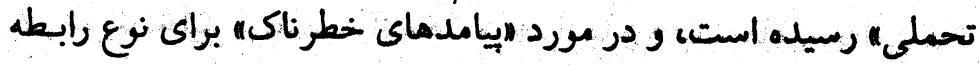

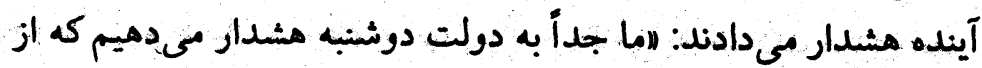
بازي با آتشى كه تومط ايرانيها و روسها در افنغانستان افروخته شـده

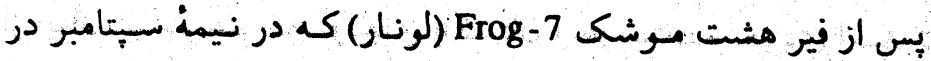
نزديكيى فرود

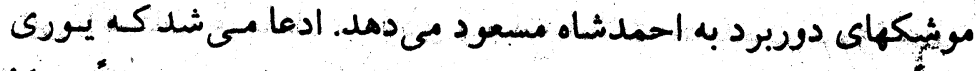

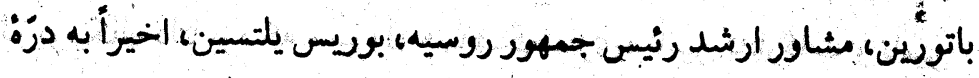

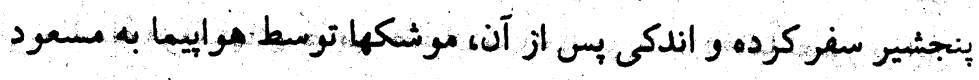

يخش كرد: الجمهورى اسلامى افغانستان خواهان برقرارى روابط دوستانه

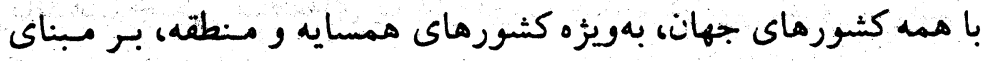

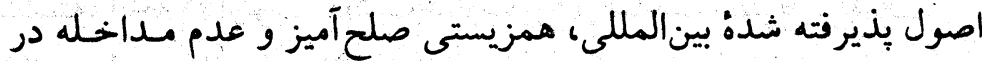

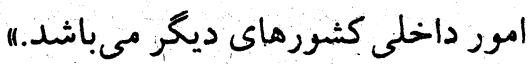

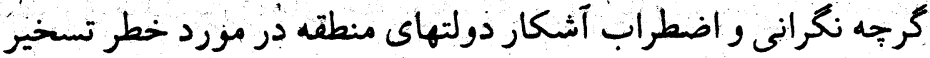

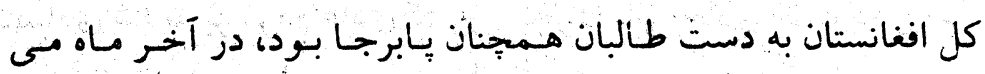
رسانه هاى جمعى رسمى ازبكستان تأكيذ مى مكردند كه شرايط عادى در

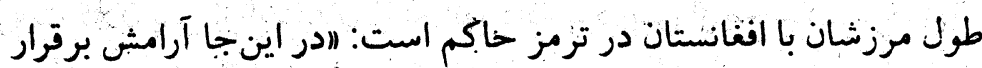

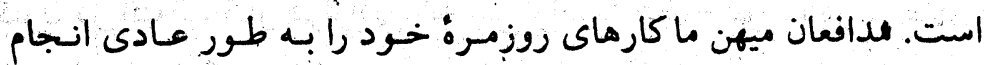

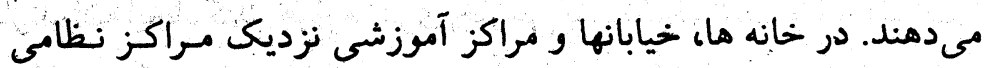

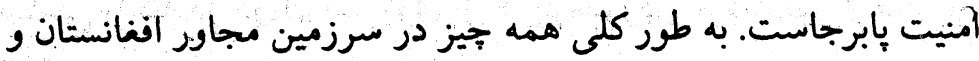

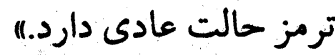

\section{هز تأمين اسلحه}

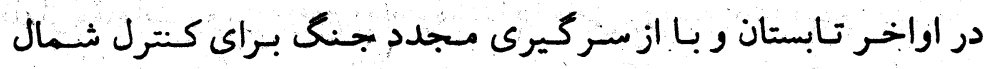

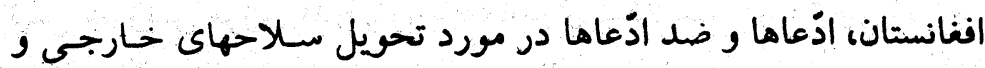

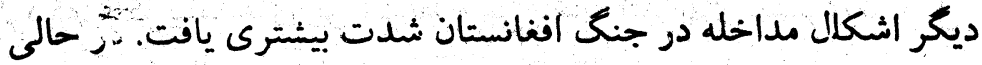
كه طالبان ادعا مى كردند كه روسيه، ازيكستان و و تاجيكستان، هـرواه بـان

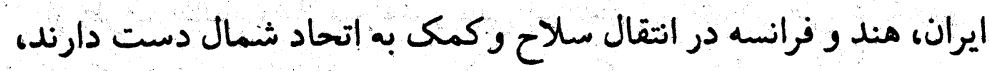

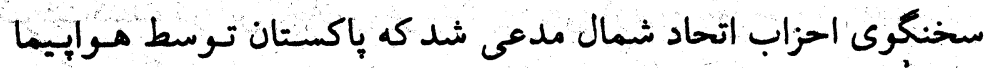
نيروماى تقويتى براى طالبان مىفرنثند و مهمات بيشترى در اختيار آنها

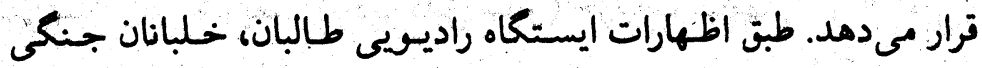


است كه يروزُة يونيكال ـدلتا مورد حمايت سيا (CIA) است. درست يـا

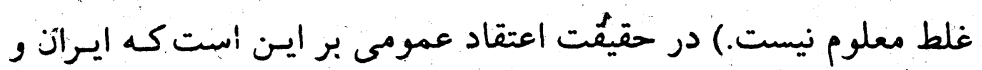

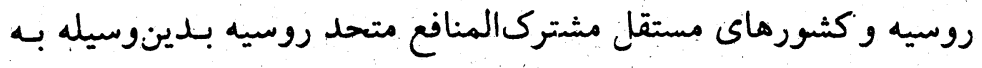

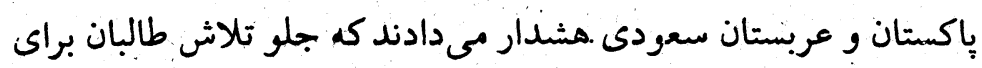

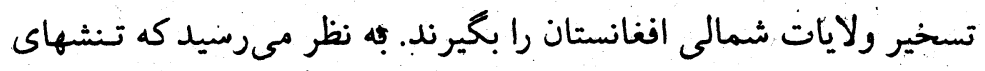

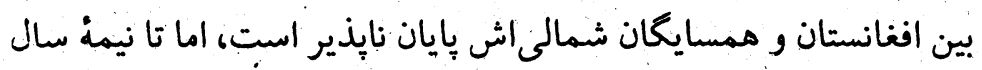

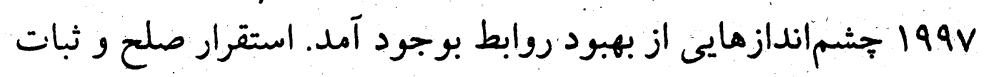

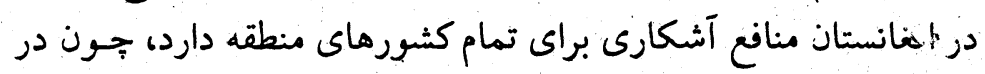

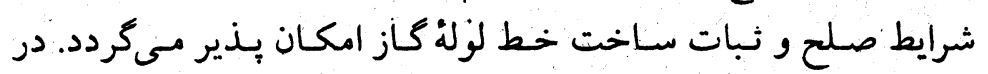
تاجيكستان امضاء توافق صلح بين جناحهاى رقيب در جنخ داخلى ــاته

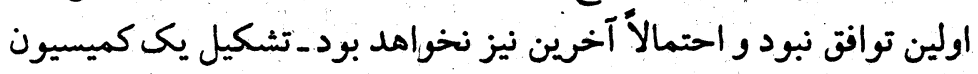

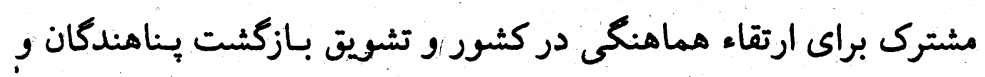

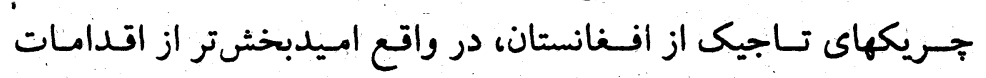

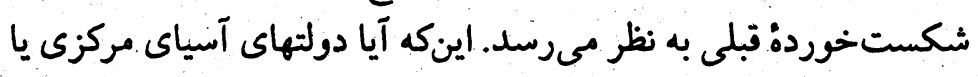

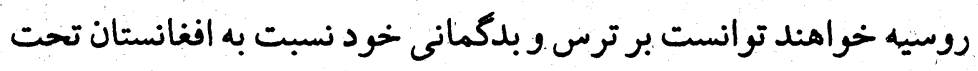

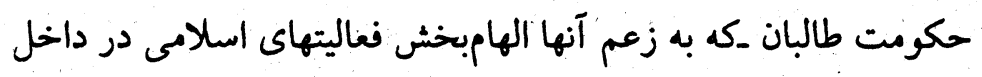

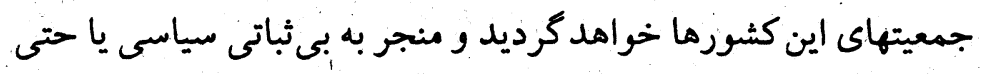
انقلاب اسلامى خواهد شد ـ فائ آيند، هنوز نامعلوم استـ.

然格
تحويل دادهشدهاند. مسعود اين ادعاها و ززإرشهاى متعاقب آن راكاملاً

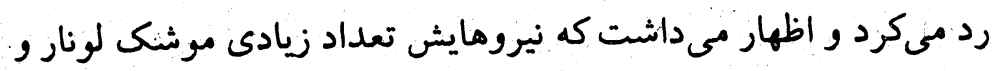

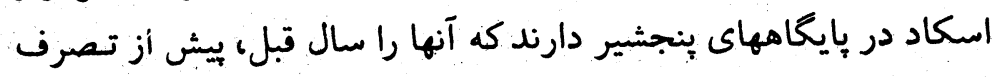

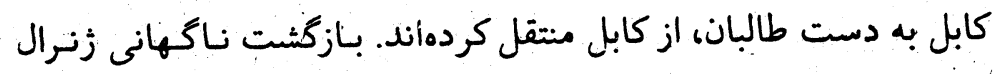

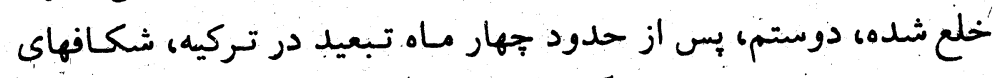

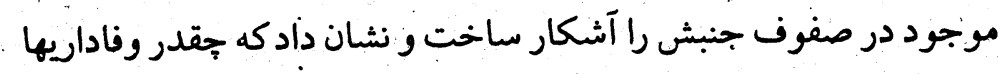

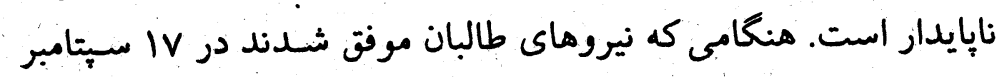

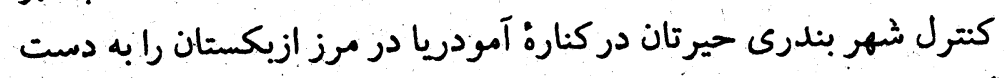

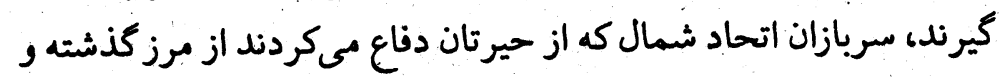

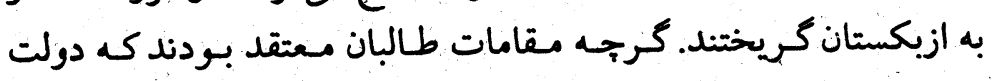

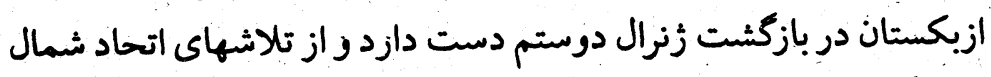

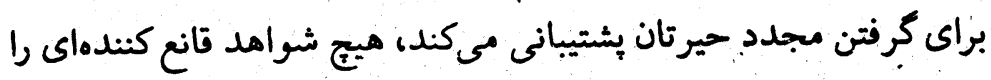

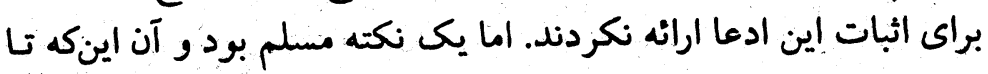

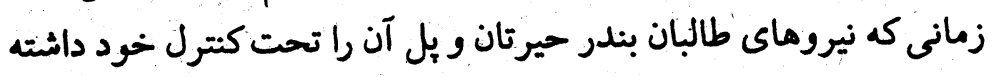

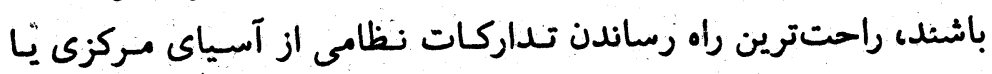
روسيه به اتحاد شمال، مسدود است. در مورد تحليل و تفسير بيانيه ما، مخنرانيها و هشدارماى مان مختلفى كه

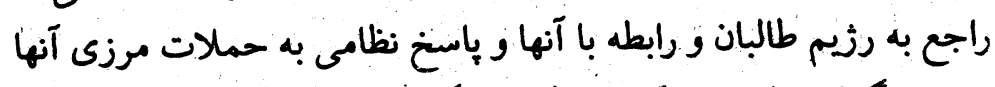

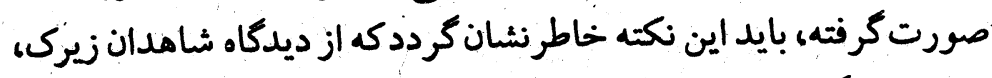

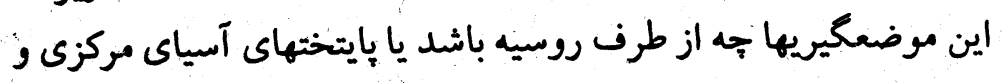
يا از ايران، بيشتر متوجه دولتهاى بإكسنان و عربستان سعودى است تـان خود رزيم طالبان.

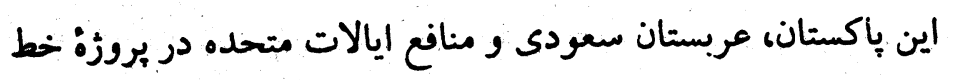
لول يونيكال دلتا بود كه مسؤول همامنك مازي، تأمين تداركات و وتأمين مالى ملسلة موفقيتهاى نظامى طالبان شناخته مى شد. (غالباً تصور بر اين 


\section{زنان افغان تحت حكومت طابلان}

هنانسى هاج دوير

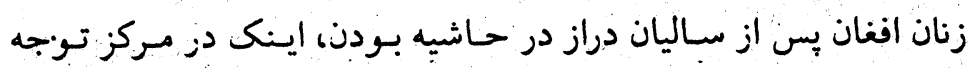

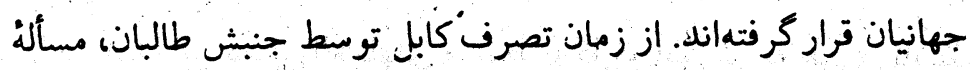

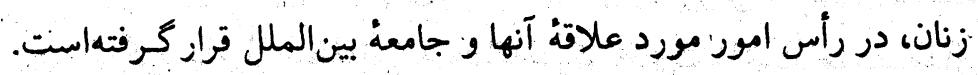

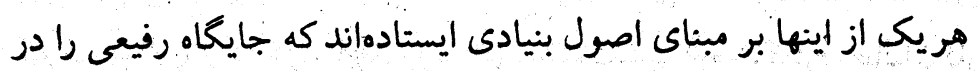

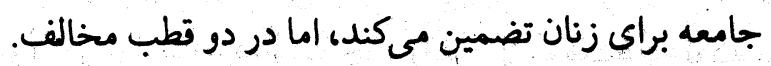

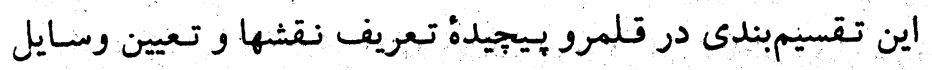

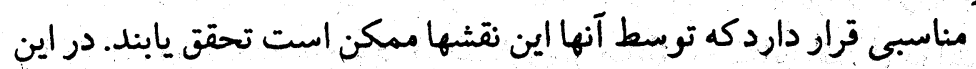

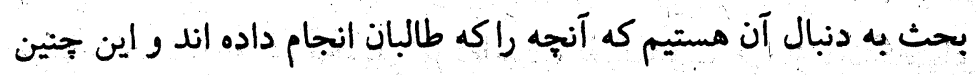

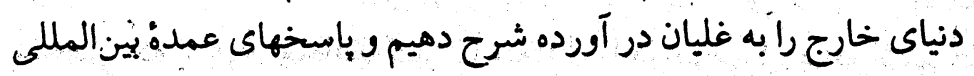

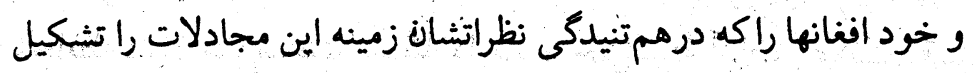
مي دهد بيان كنيم. هدف اعلام شده جنبش طالبانز عبارت إست از كامل نيمودن هـدف

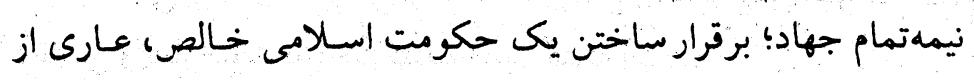

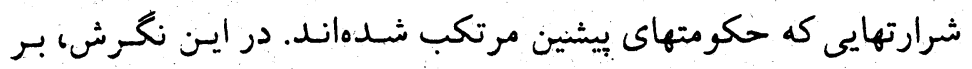

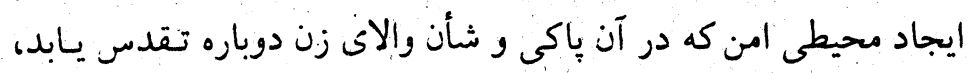

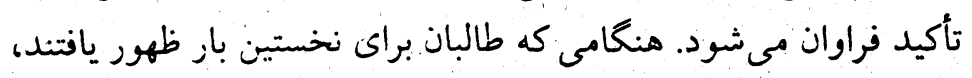

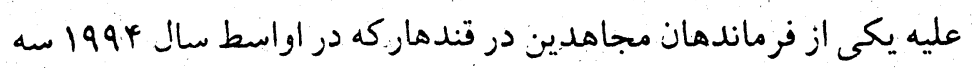


زن را ربوده، مورد تجاوز قرار داده و كشته بود، اقدام كردند.

\section{كنشها و و اكنشها}

كمكرزسانهاي جامعة بين المنل از سال 1994 به طور بيخيرانهاى بهويزه

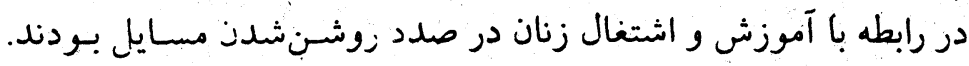

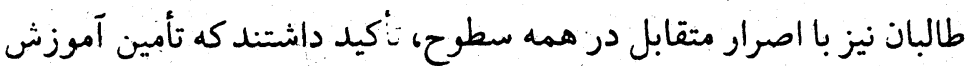

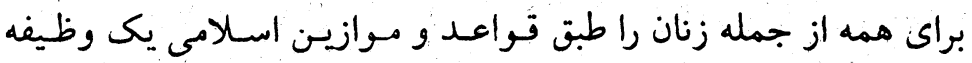

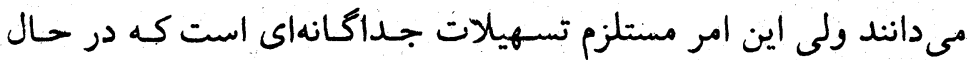

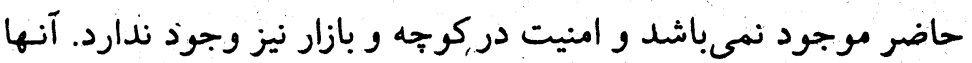

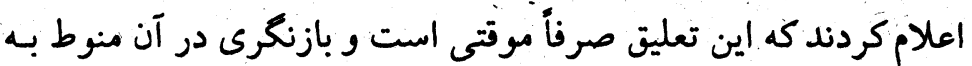

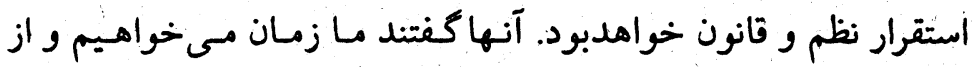

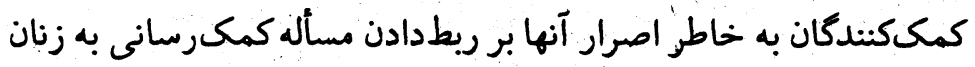

انتقاد كردند.

هنكامى كه بس از يك سال، هيج تغييرى در سياست طالبان رخ نداد،

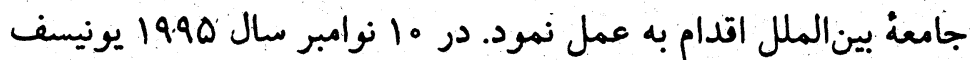

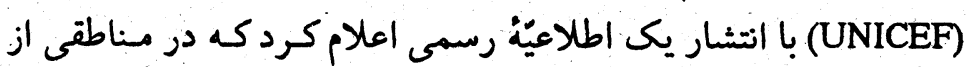

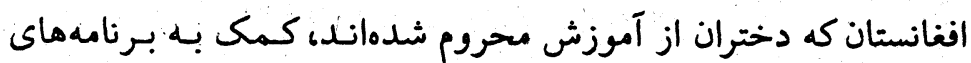
آموزشى رابه حال تعليق در مى آورد.

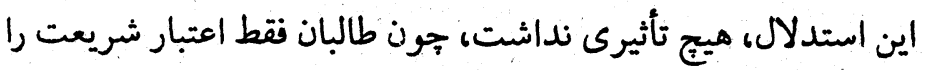

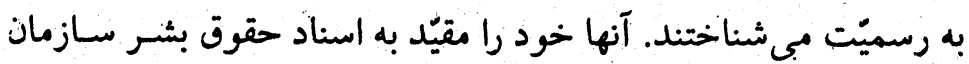

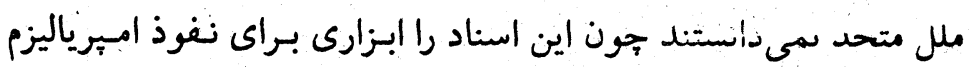

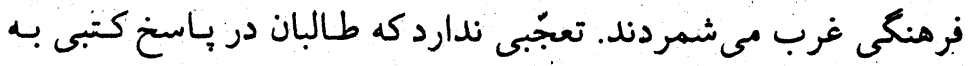

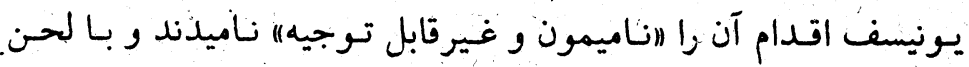

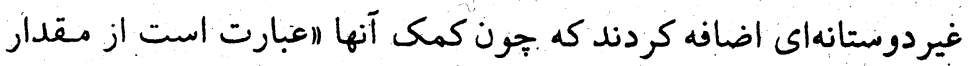

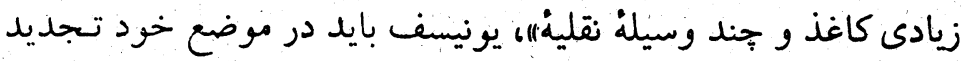

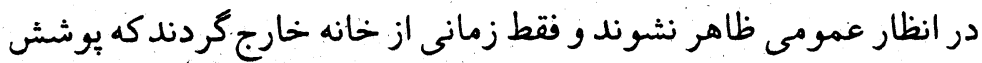

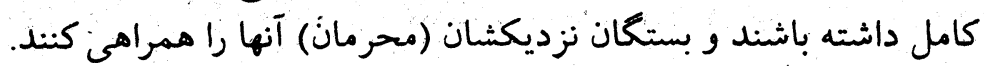

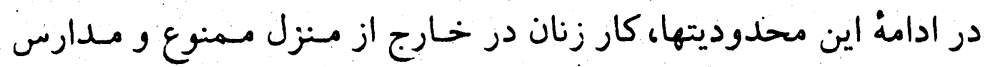

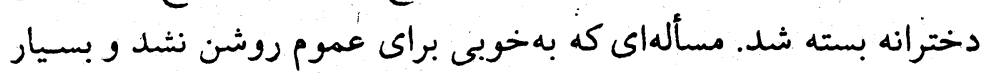

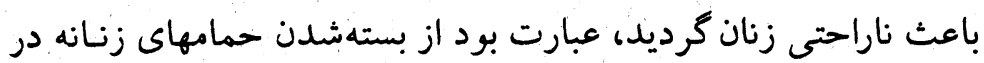

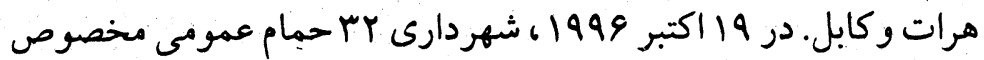
زنان را بست. در ابتدا اين دستورالعملهاى مربوط به كار و آموزش به طرزى نامنظم اجرا ميىگرديد و از منطقهاى به منطقهُ ديخر تفاوت 'داشت. مؤسسههاي كمكرسانى ایى كه در مناطق روستايى بشتوننشين تحت كنترل طالبان كار

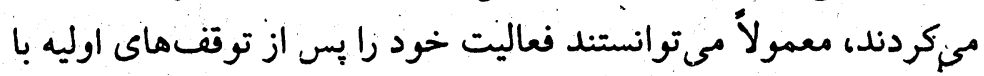

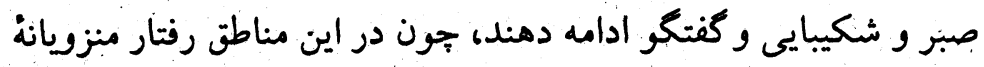
زنان يك روش جاافتاده بود. در بسيارى از مناطق روستايیى كنترل دولت مركزى هميشه امرى تحميلى بودهاست، طيف وسيعى از ديـدكاههاى شخصى كه از فوق مجافظهكار تـا مسعتدل را در بـرمىكيرد. در شهـهرها

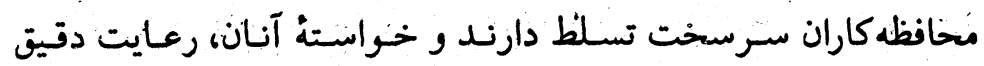
دستورات است، هر جند نـفوذ افراد مـعتدلتر نيز در سطوح بـايينتر

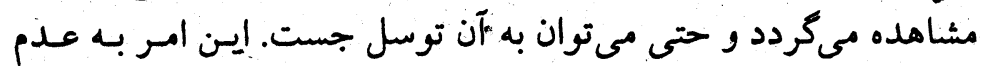
تجانس و,تعارضات ناراحتكننده منجر كُشته است. 


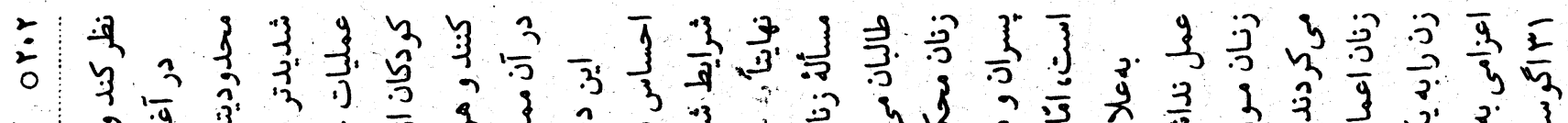

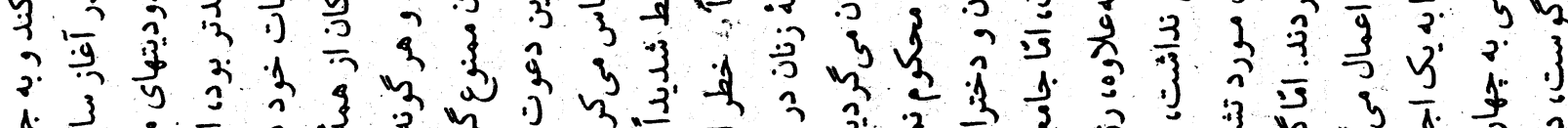

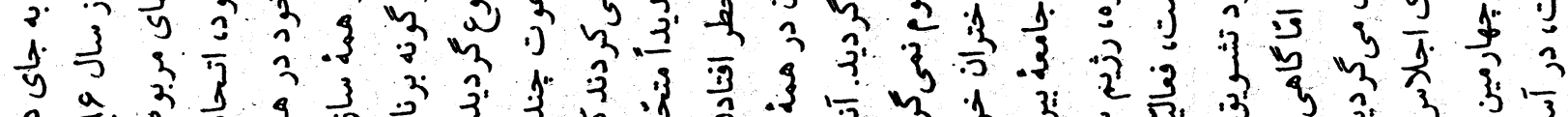

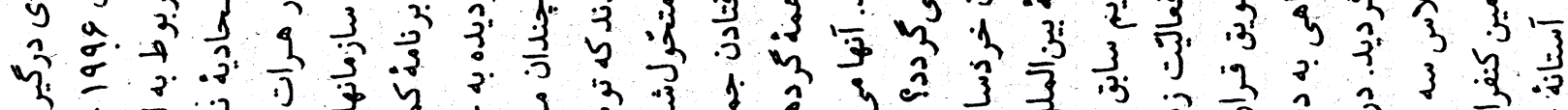

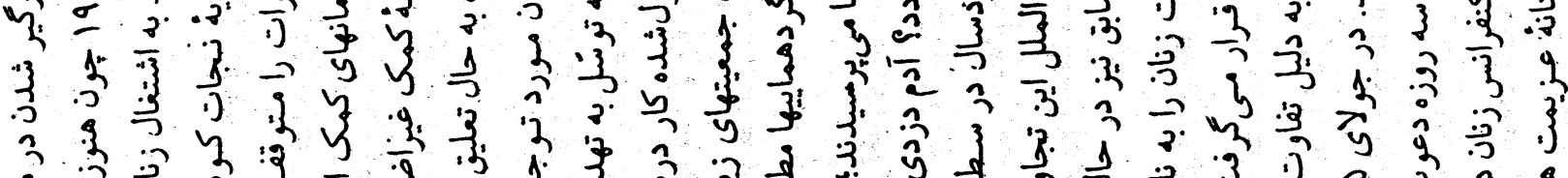

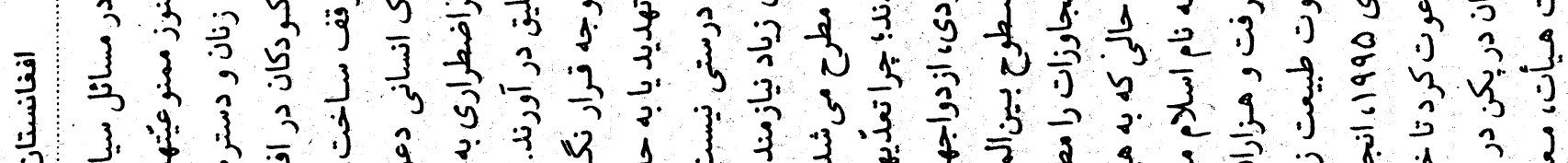

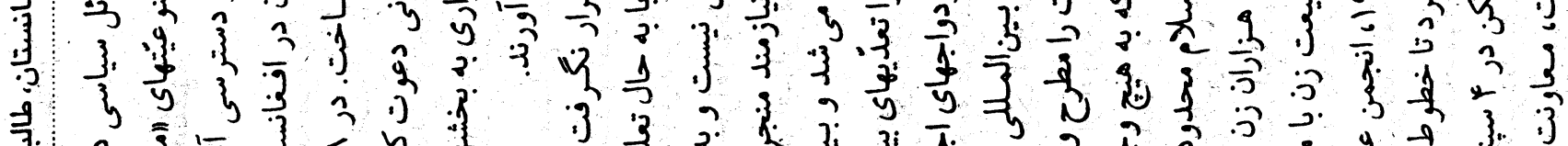

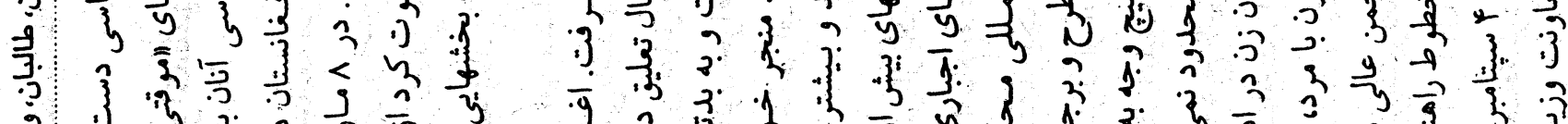
1.

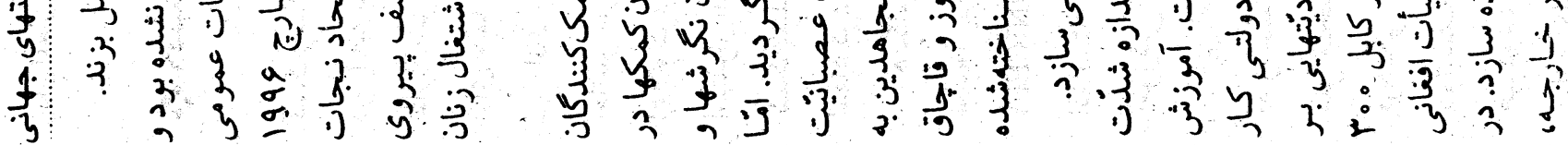

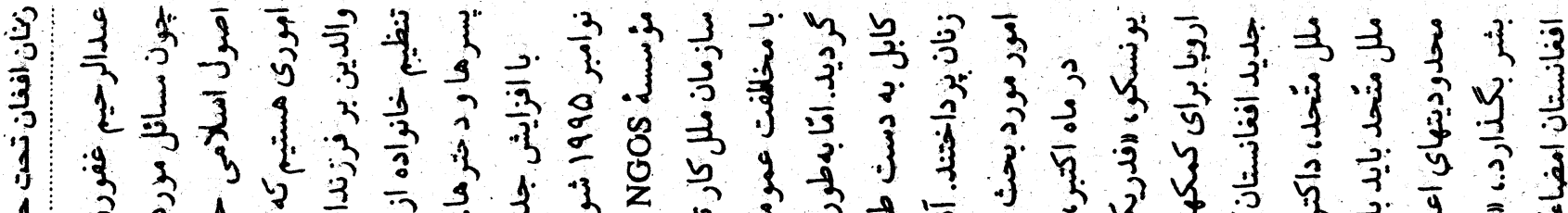

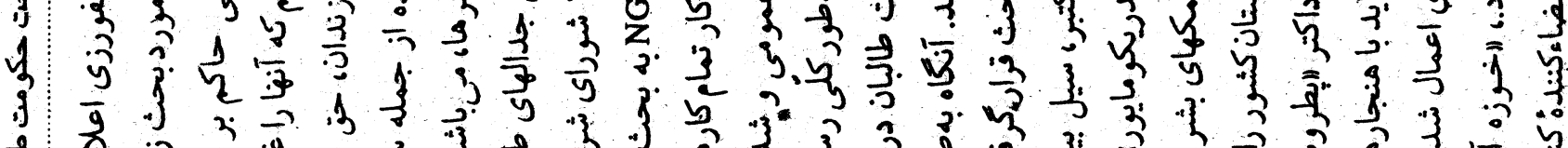

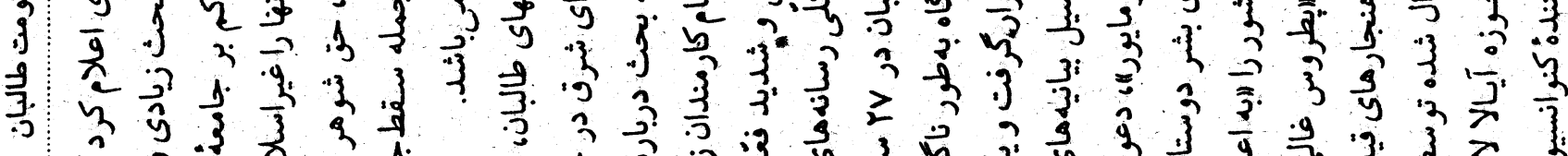

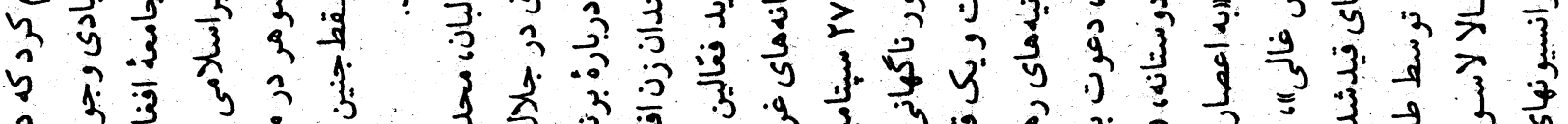

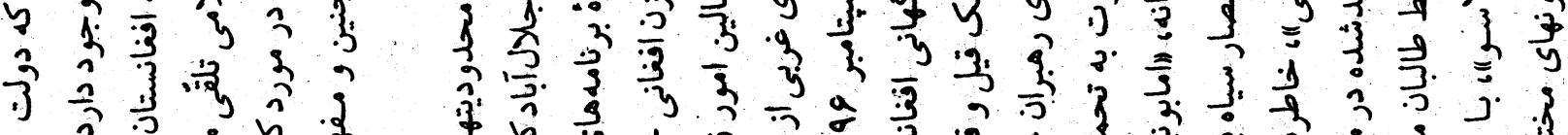

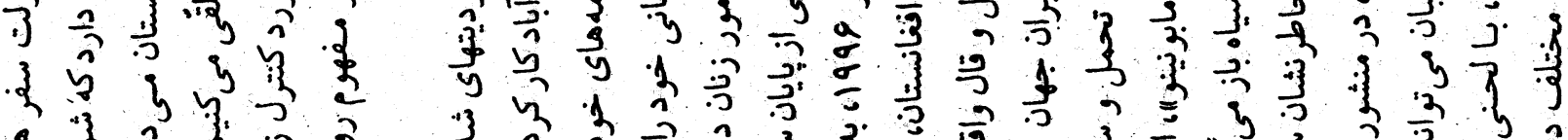
9.

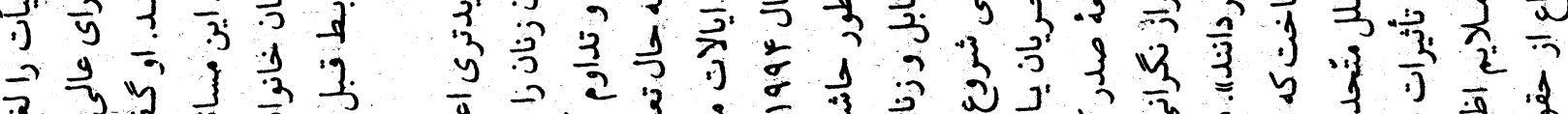

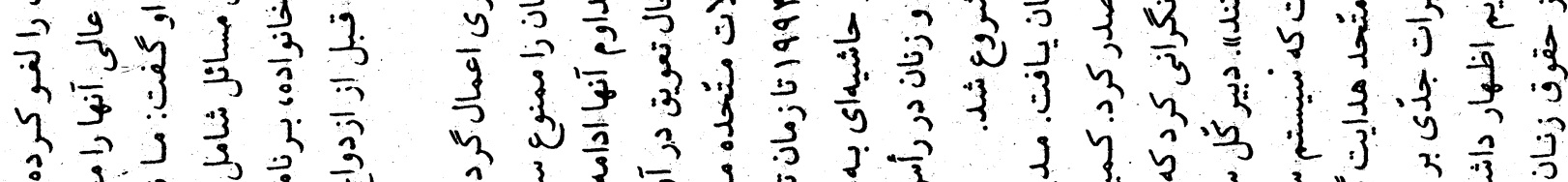

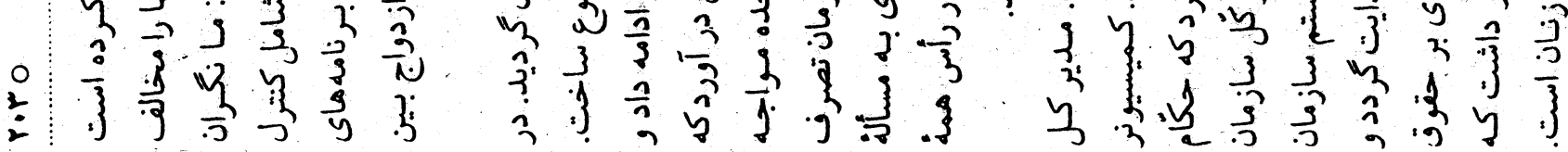


جنبش طالبان هنوز براى تأسيس دولت مي جنگحد.

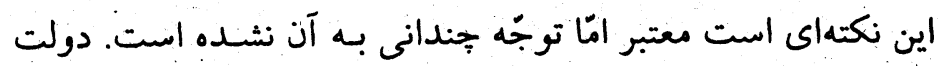

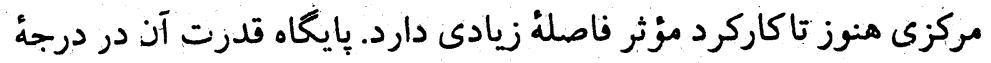

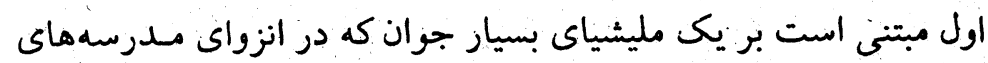

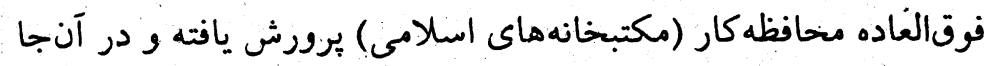

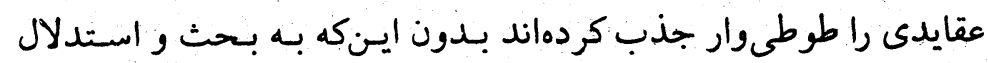

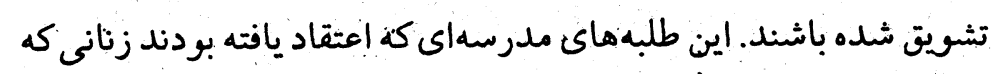

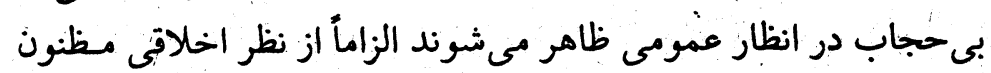

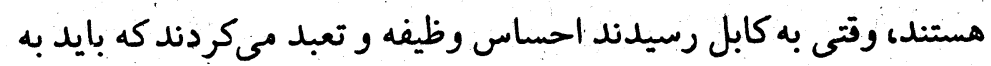

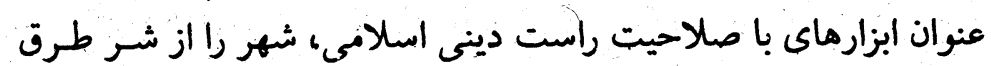

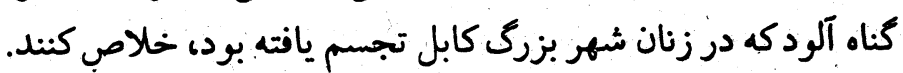

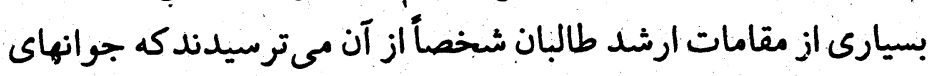

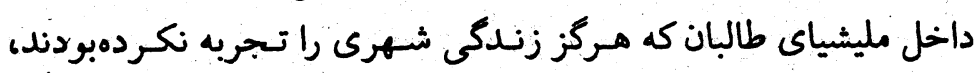

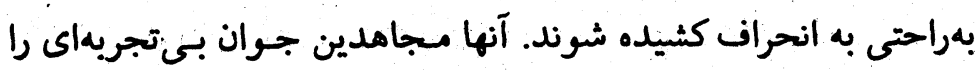

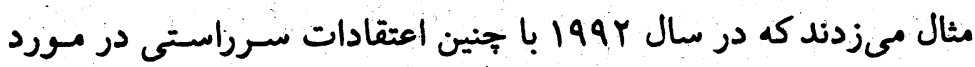

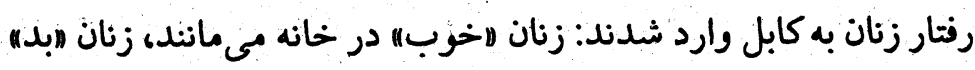

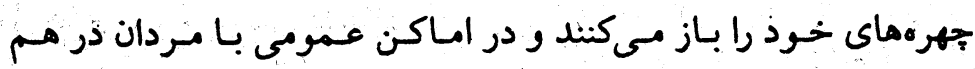

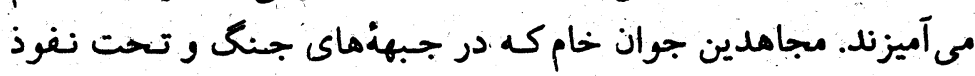

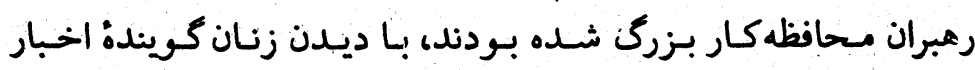

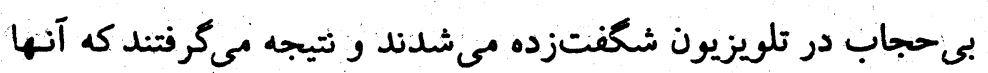

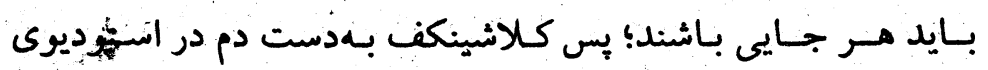

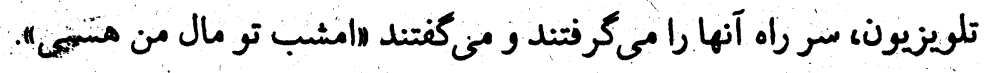

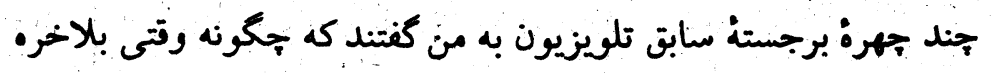

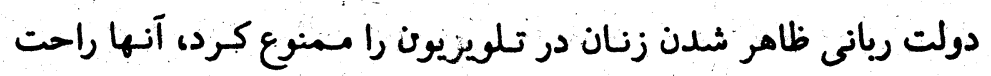

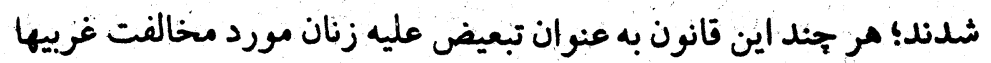

افغانستان، طالبان، و سياستهاى جهانى

or.p

داكتر لإنوربرت هالال، ميانجى صلح ويرٔة ملل متّحد، هشدار داد كه اعمال

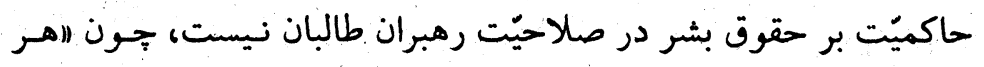

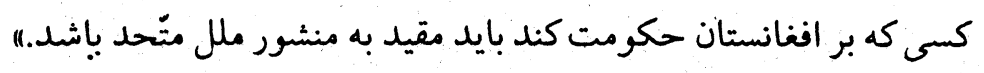

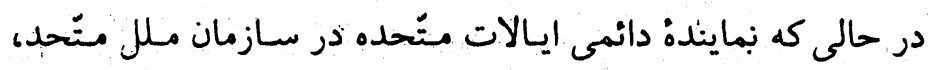

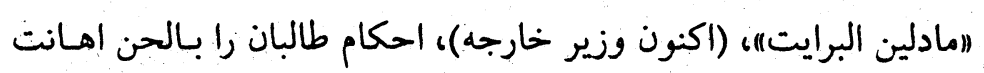

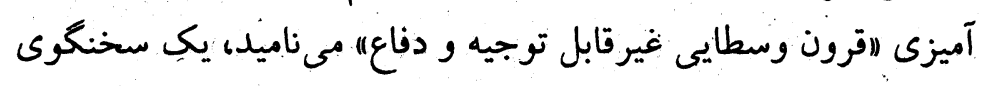

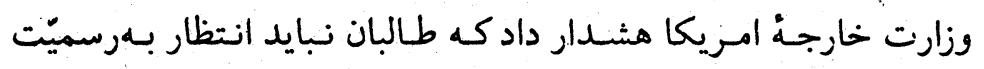

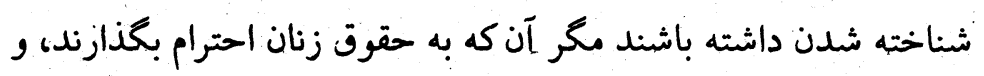

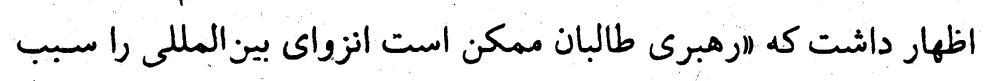

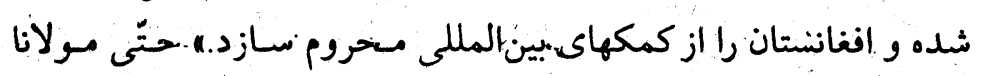

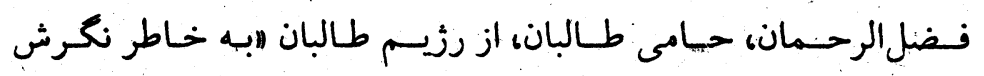

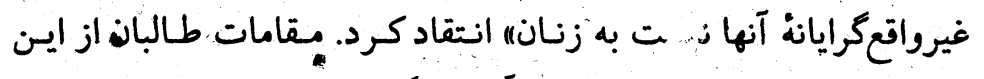

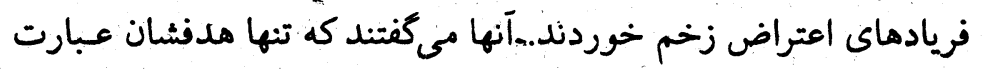

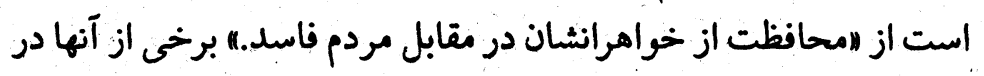

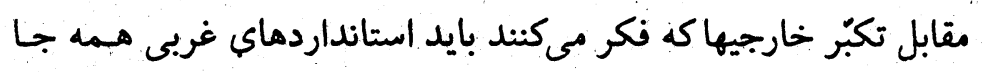

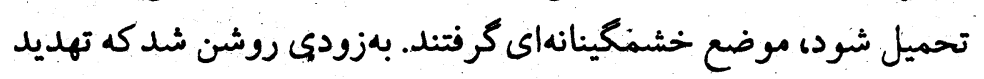

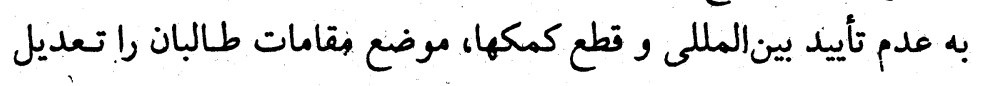

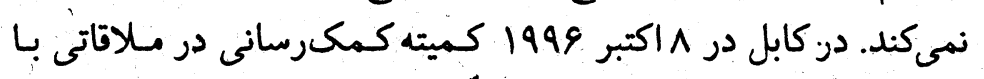

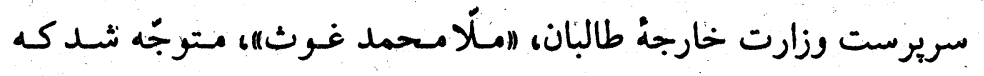

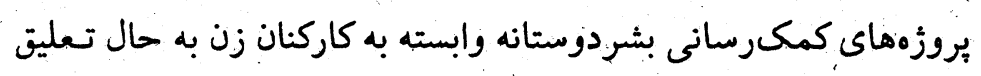

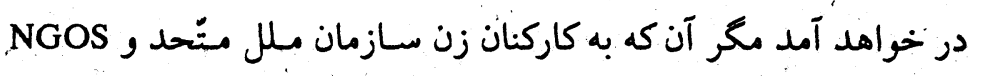

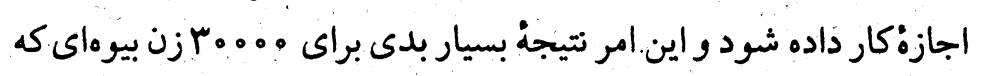

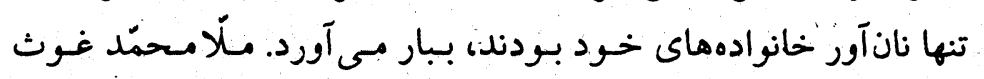

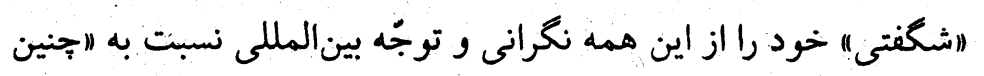

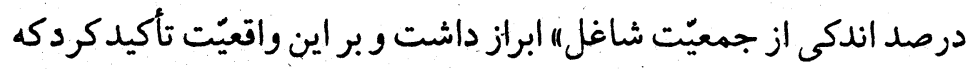




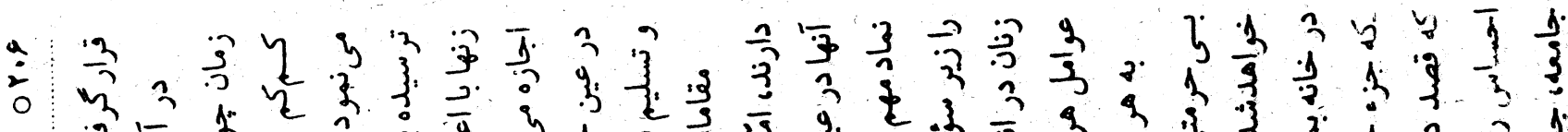

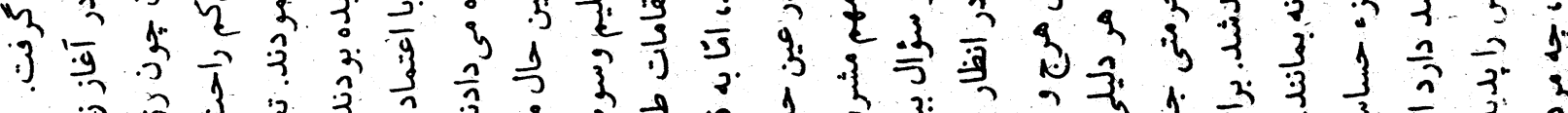

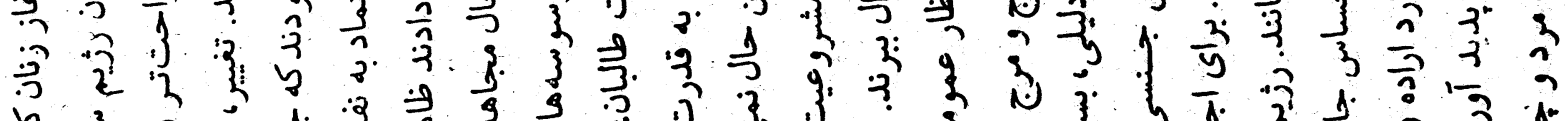

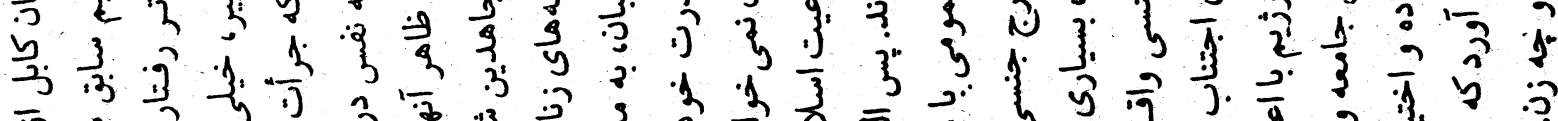

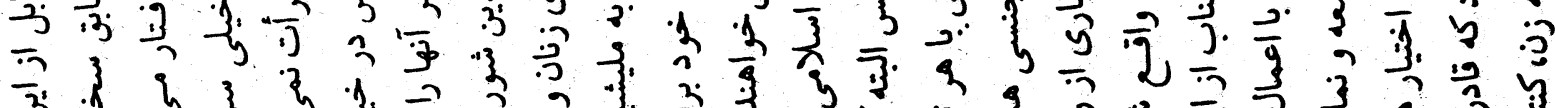

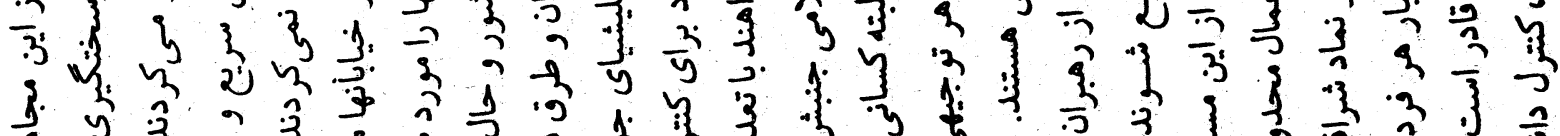

3
3
3
3
3
3

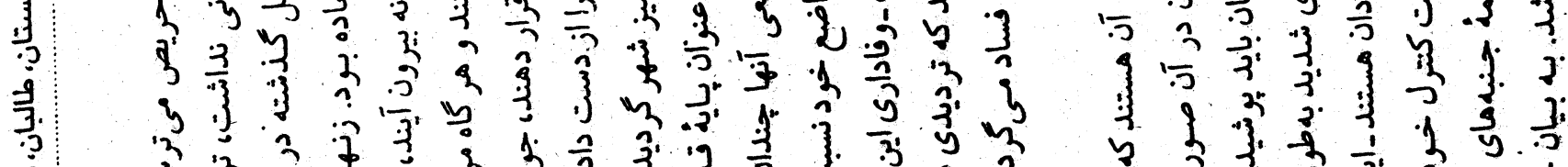

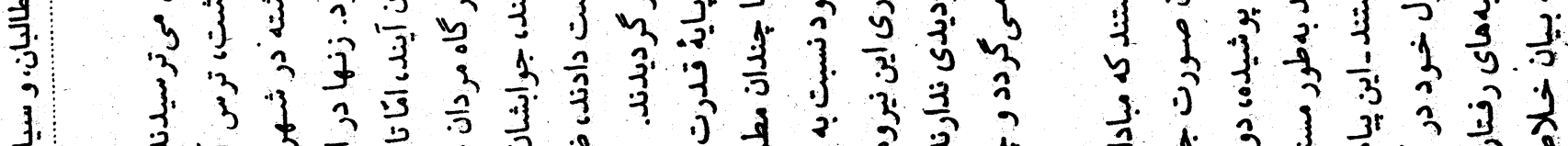

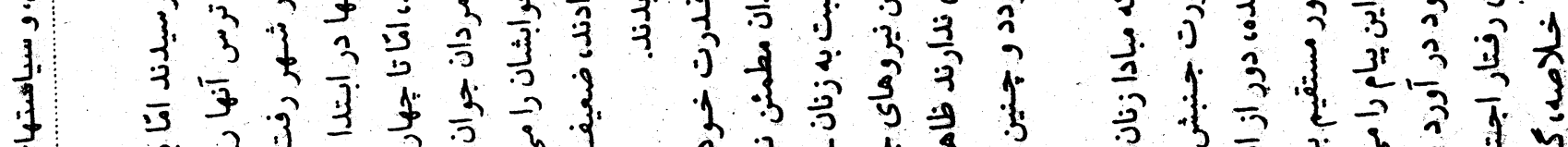

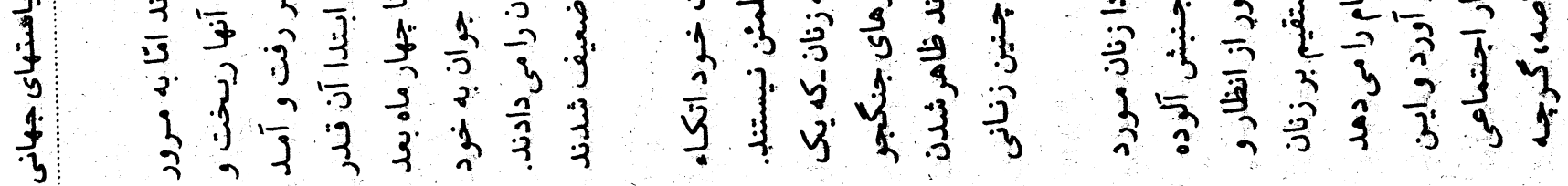

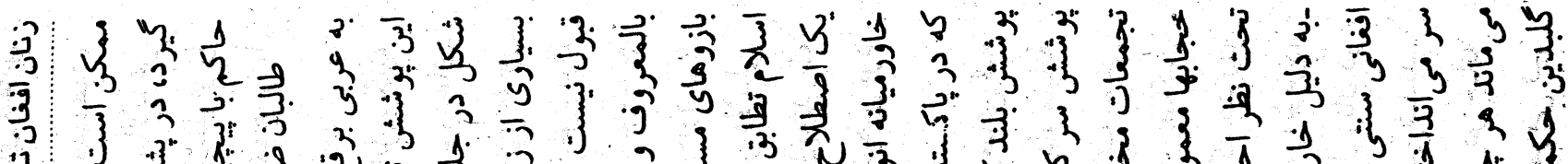
3 五

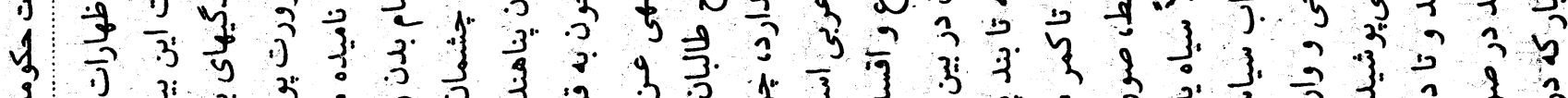

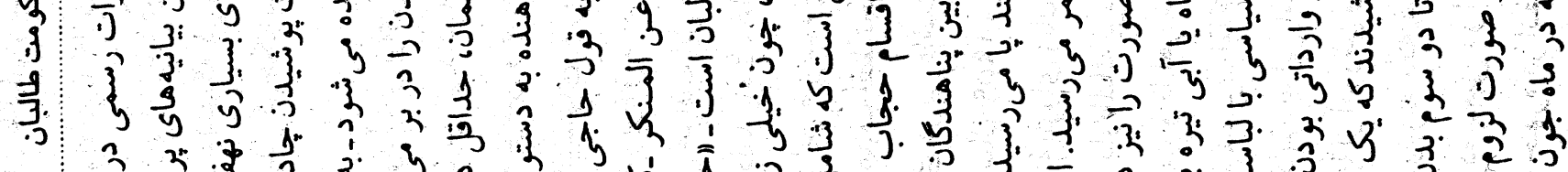

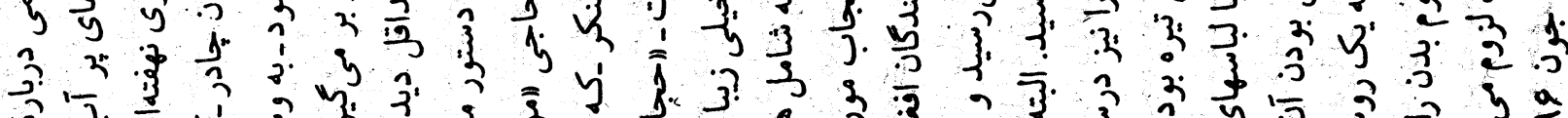

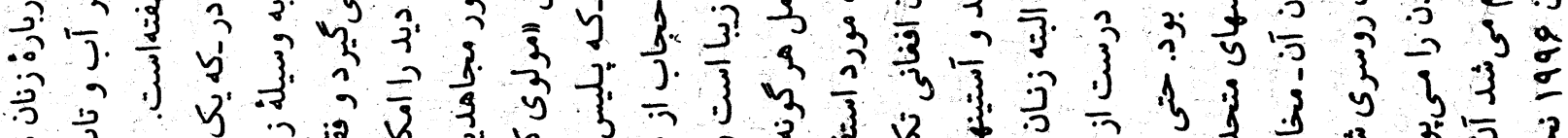
等 3. 至

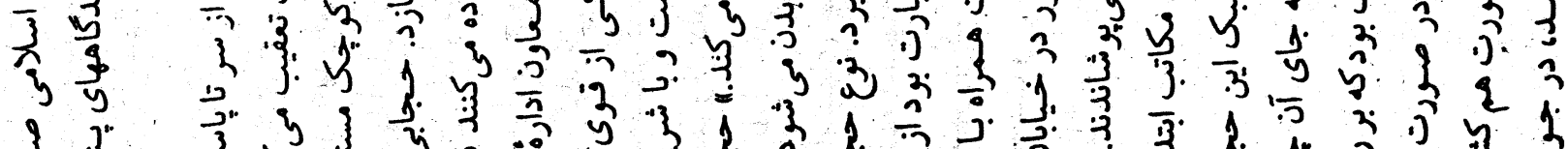

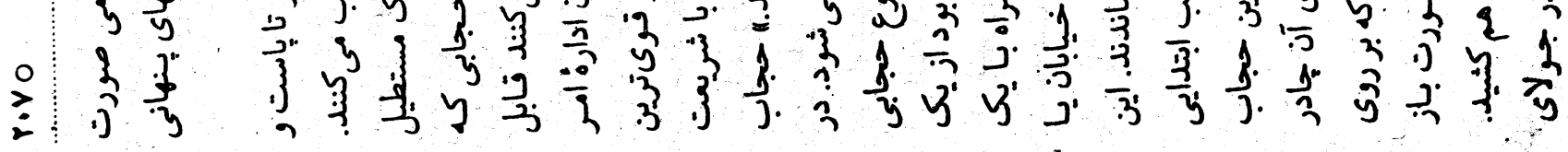




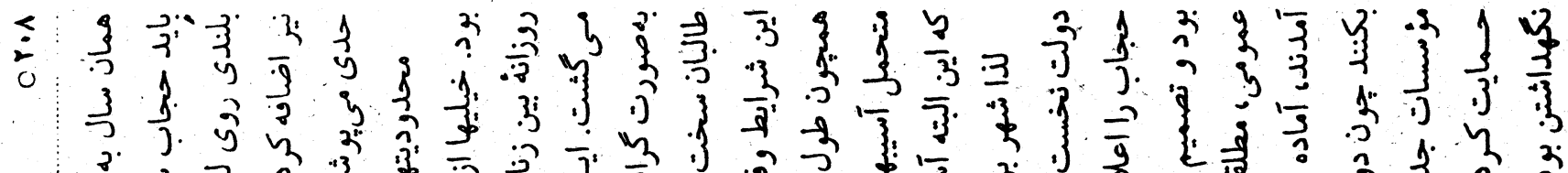
年3.

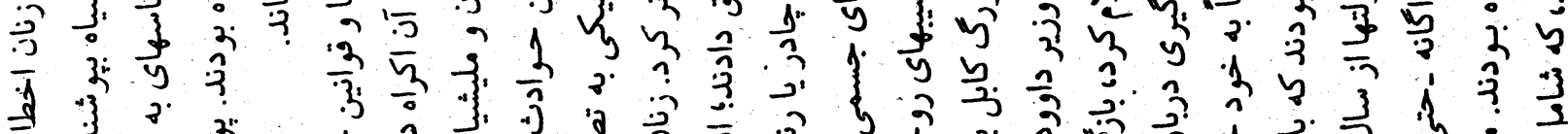

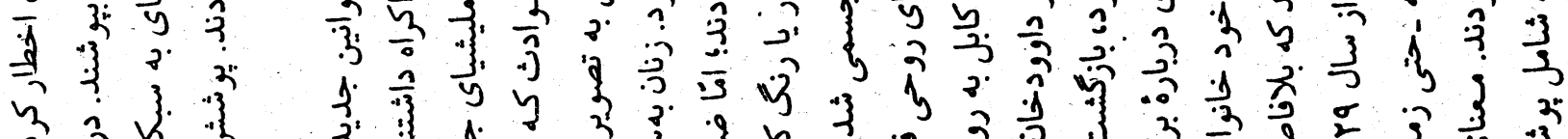

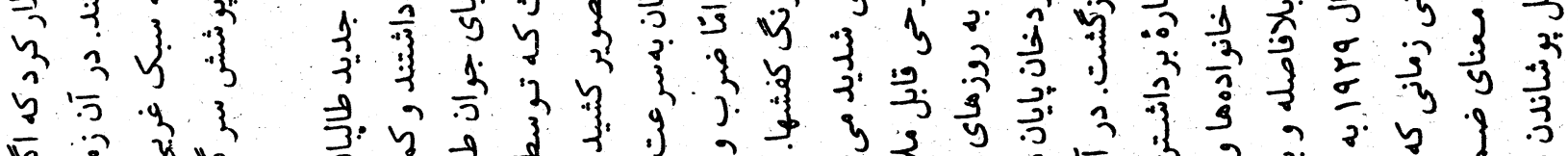

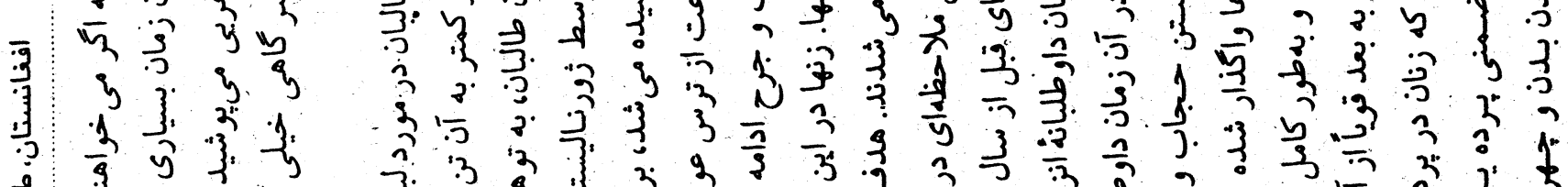

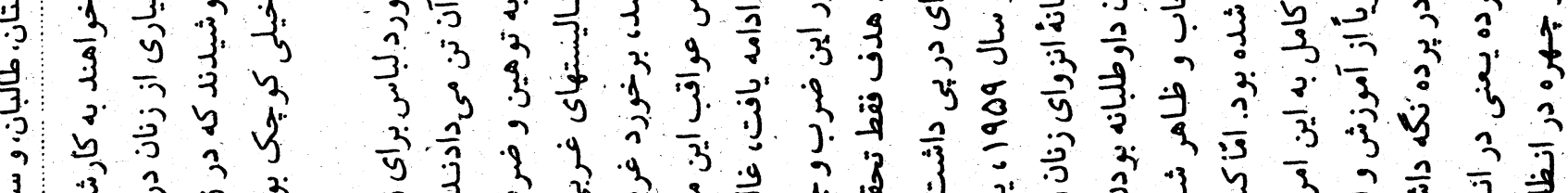

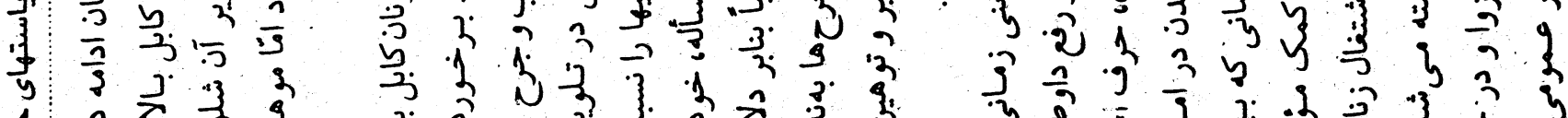

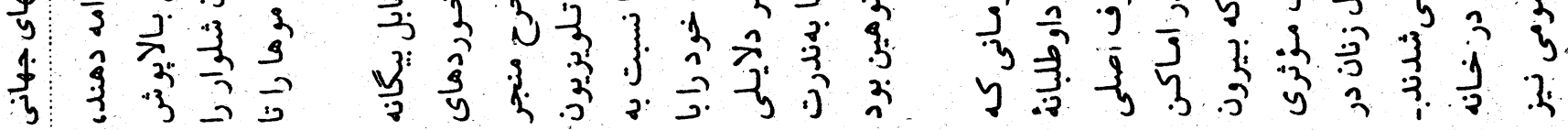

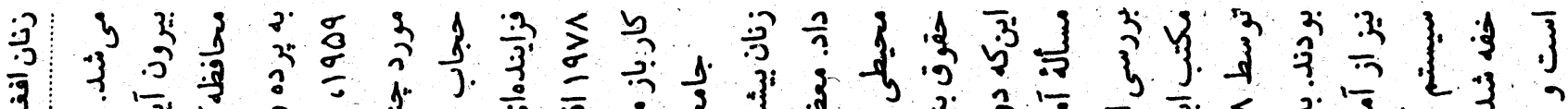

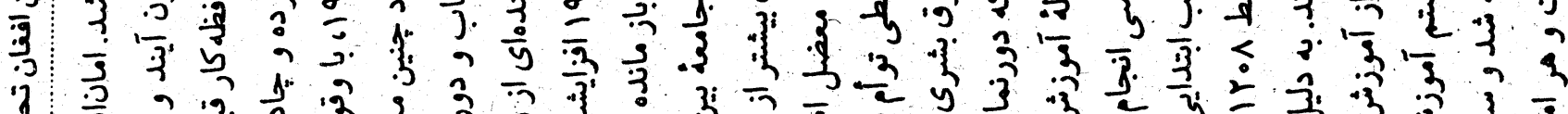

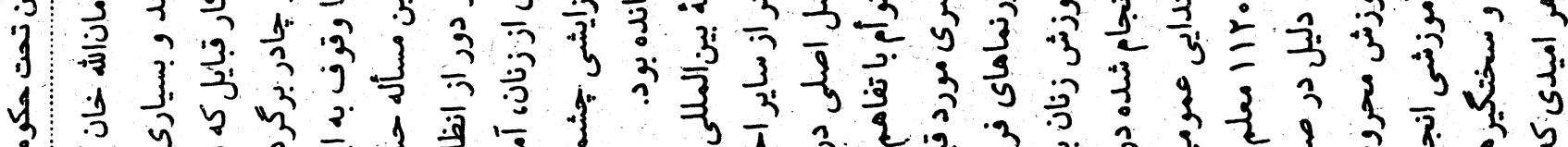

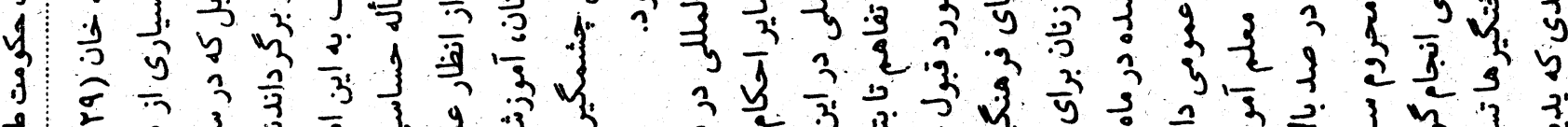

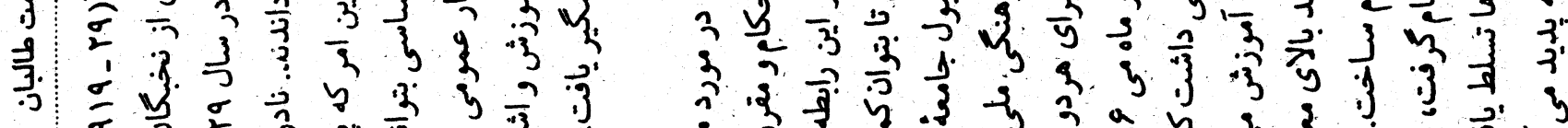

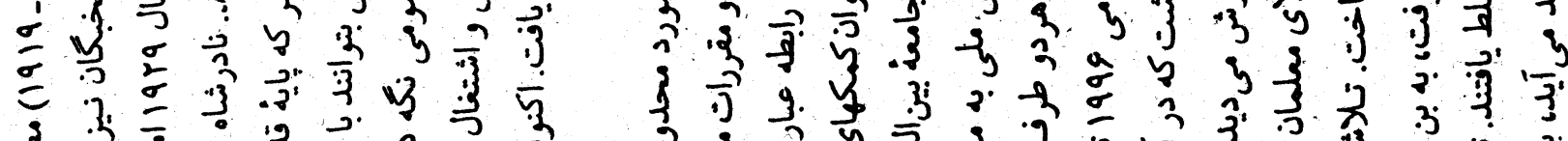
1

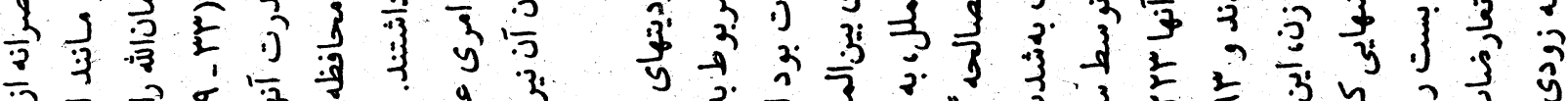

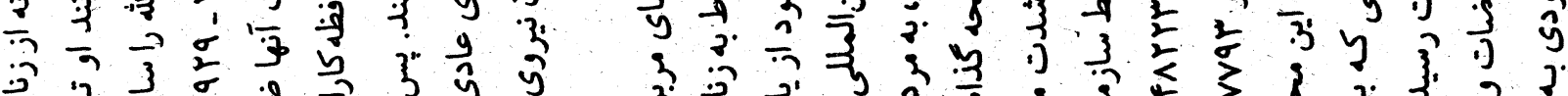

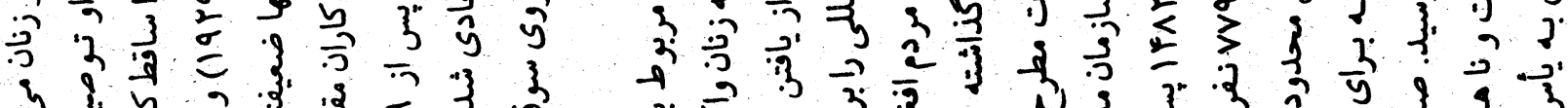

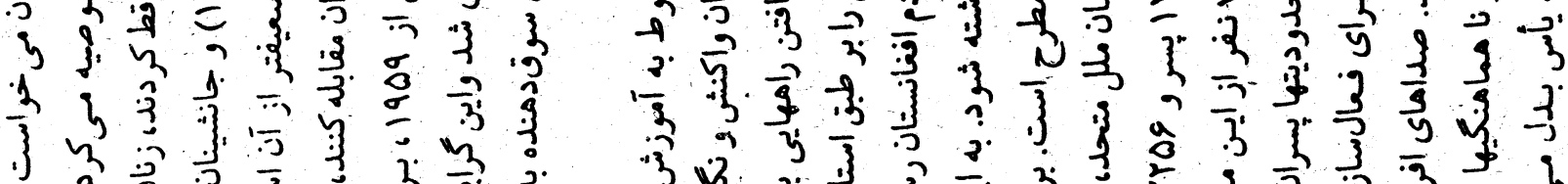

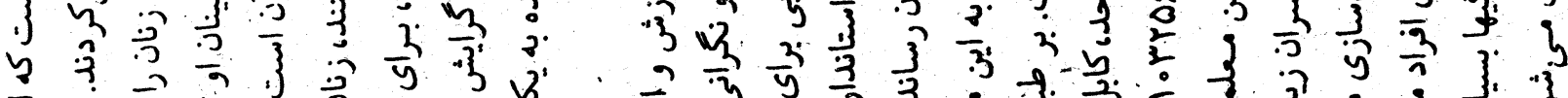

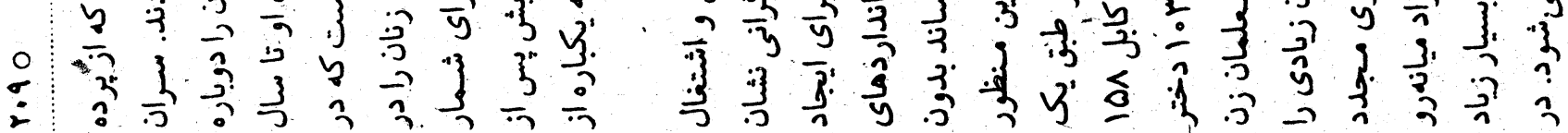




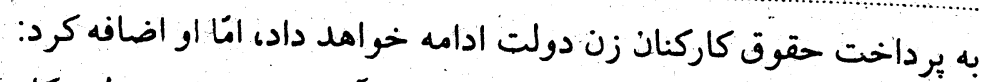

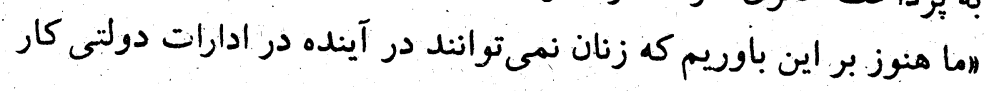

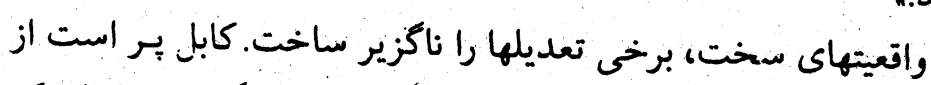

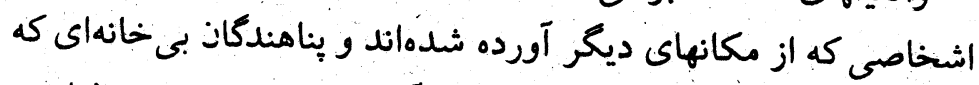

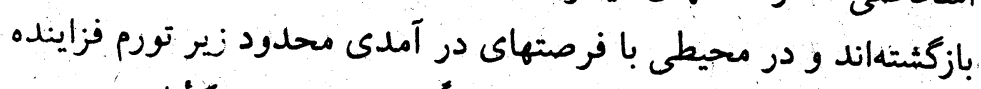

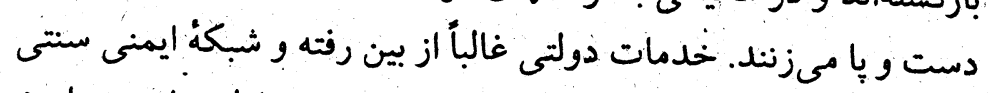

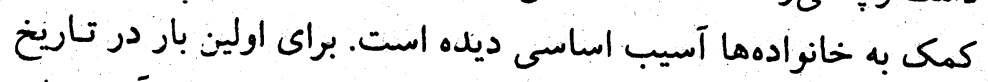

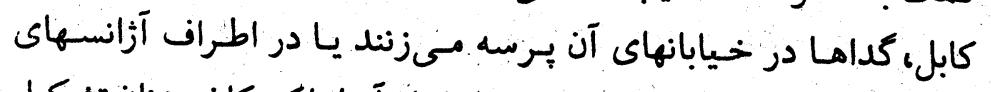

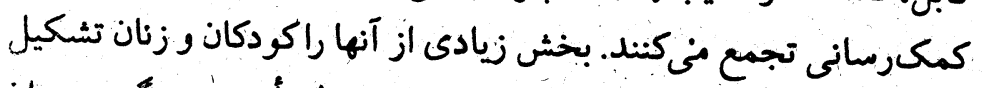

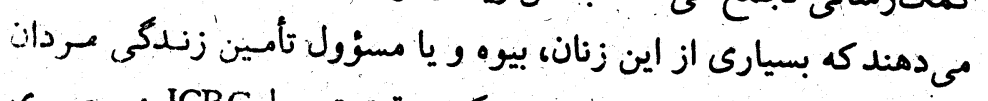

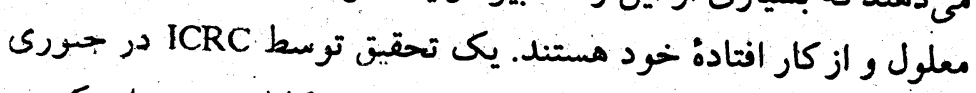

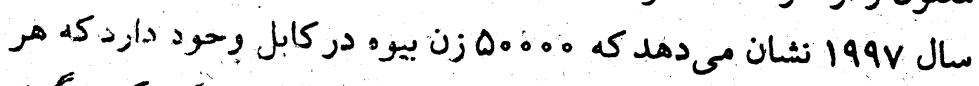

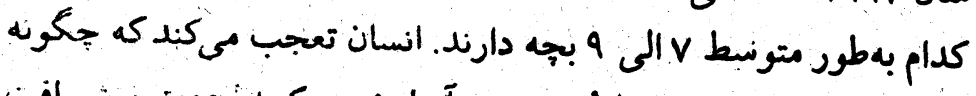

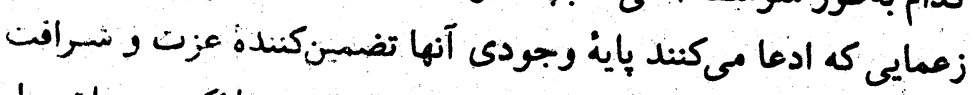

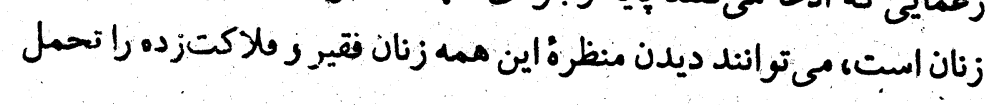
كبند.

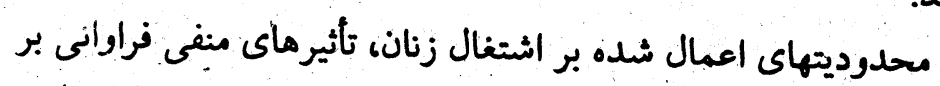

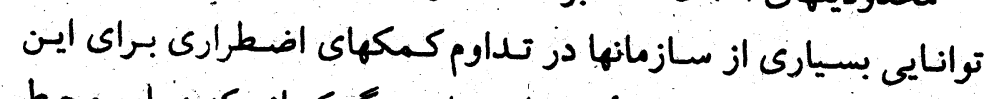

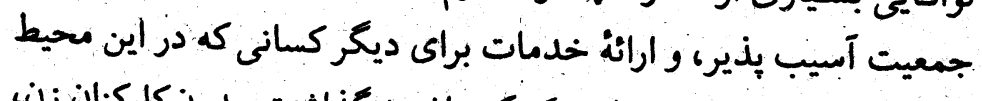

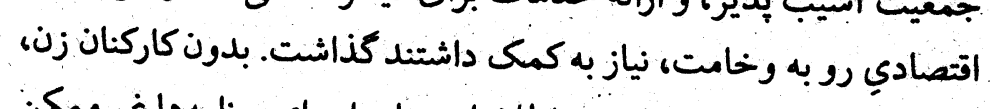

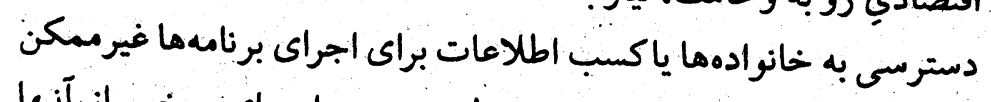

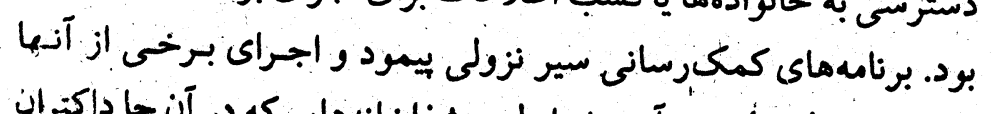

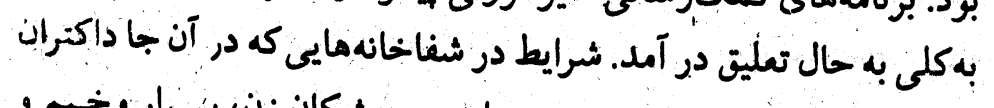

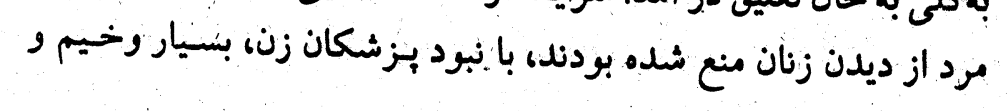

دسامبر 1999 ، خوشينى زيـأدى وجسود داشت كه يس از تعطيلات

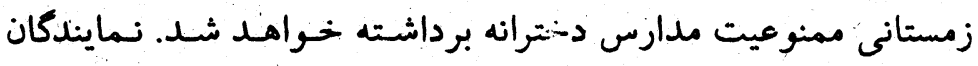

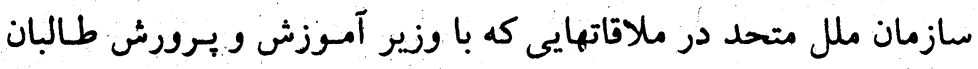

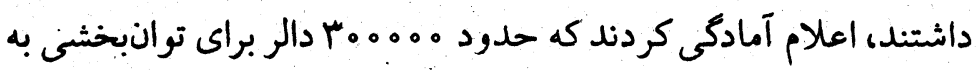

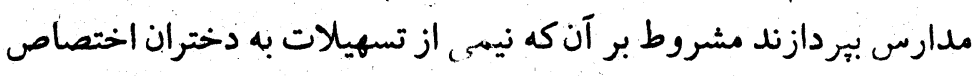

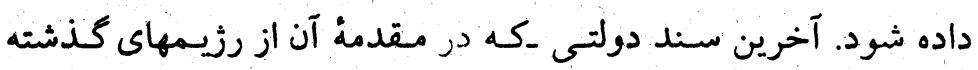

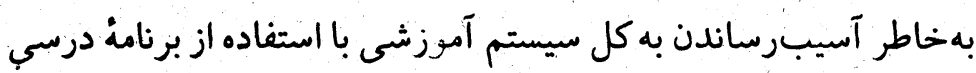

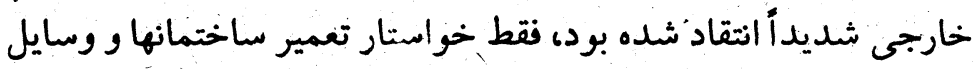

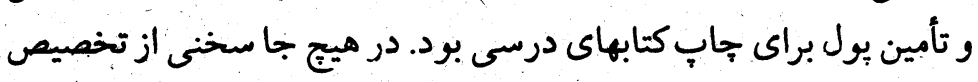

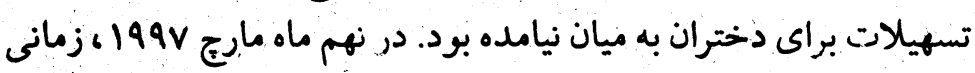

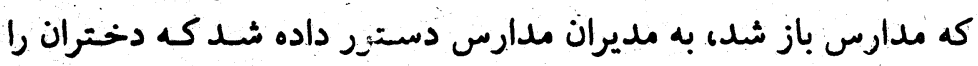

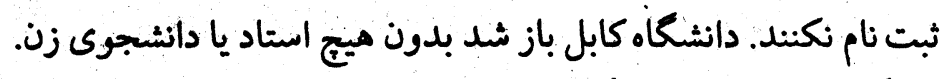

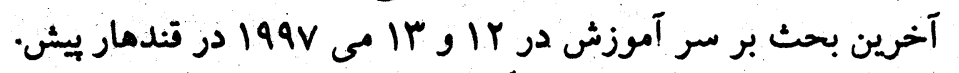

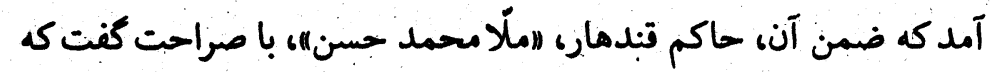

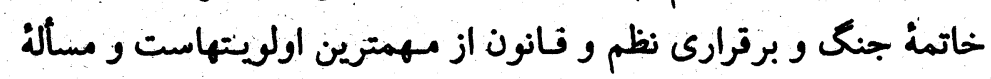

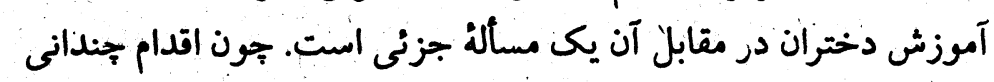

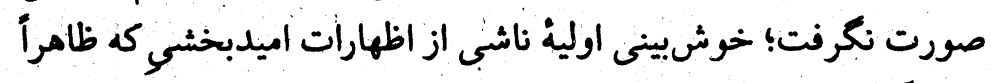

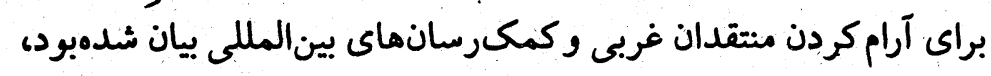

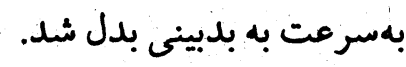

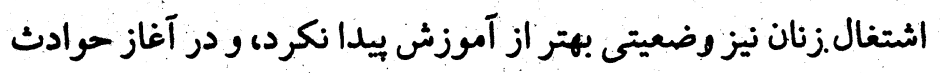

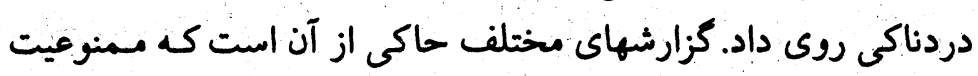

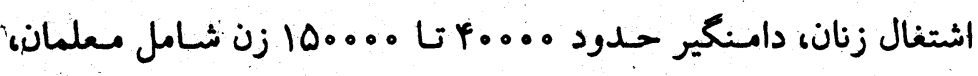

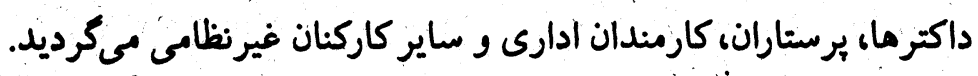

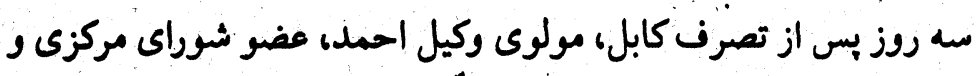

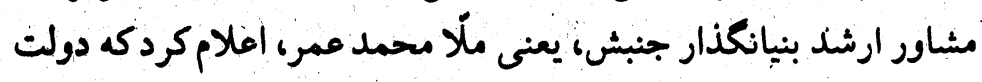




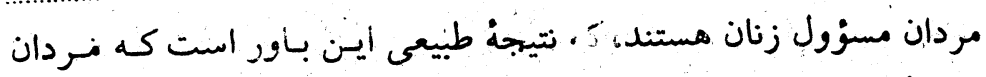

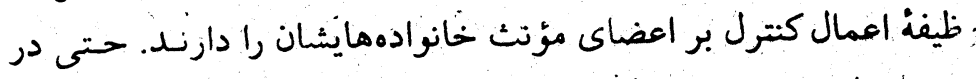

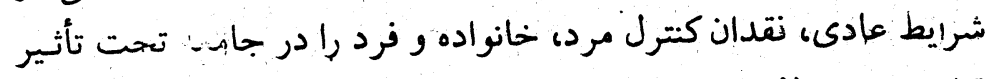
قرار مى دهد؛ لذا رفتار زنان عامل قطعى تعيينكننده وضعيت خـانواده

گرجه تعديل محدوديتزباىكار زنان در بخبش بهداشت، راه را براى كار

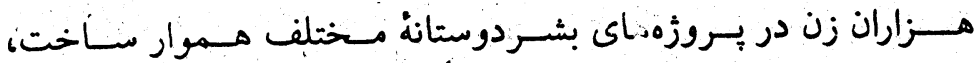

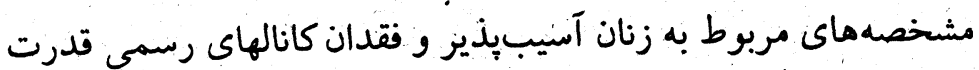
منجر به بروز حوادث جدى شد. در Yf مى 199V ينج كارمند زن سازمان

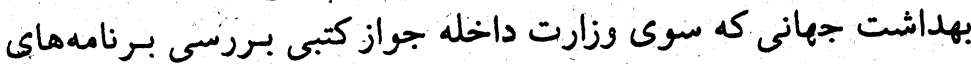

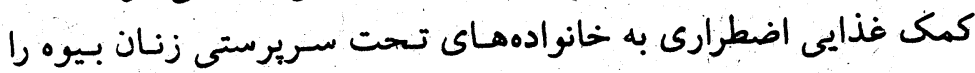
داشتند، توسط اعضاى امر بالمعروف و نهى عن المنكر از موز زشان بيرون

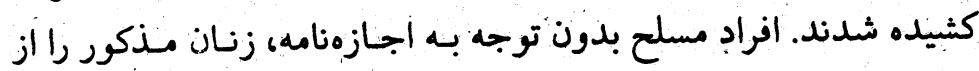

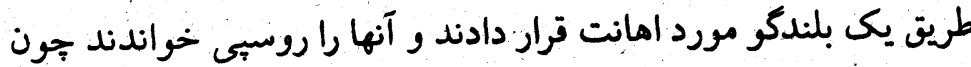

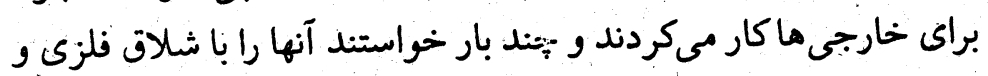

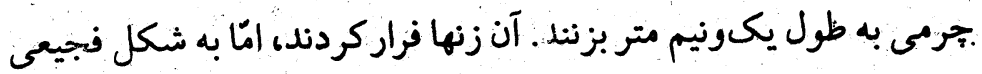
مورد تحقير و توهين واقع شهده بـودند. رإنـده دستيخير شـد و بـالاخره

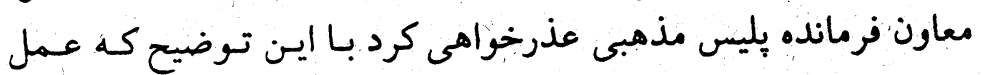

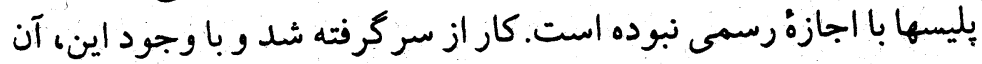

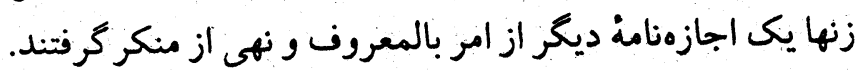

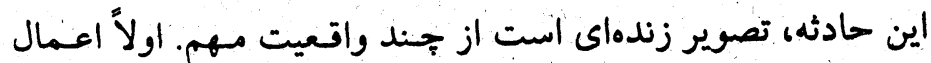
غيرقابل قبول بدون اجازه مقامات از طرف افراد انجام مى فيريرد، به ديل ديل

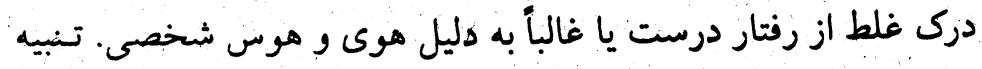

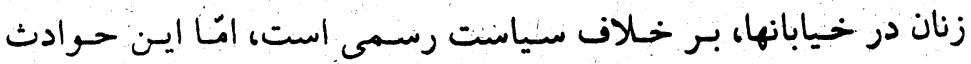

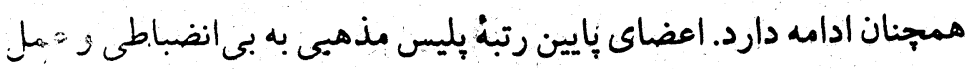

اسفانكيز شده بود.

با وجود فشارهاى مداوم در اين امور، مجموعهاى از يازده حكم براى

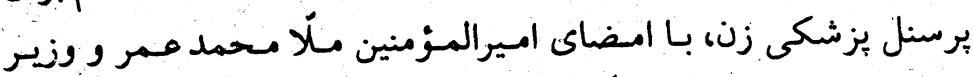

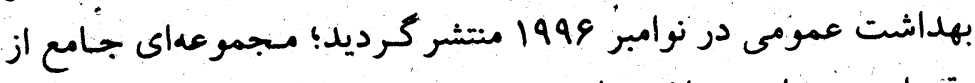

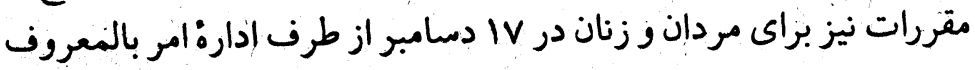

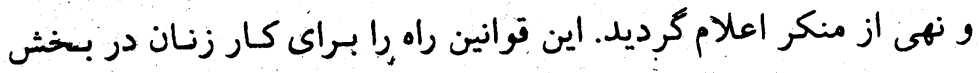

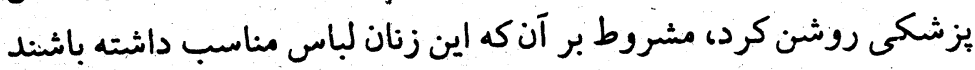

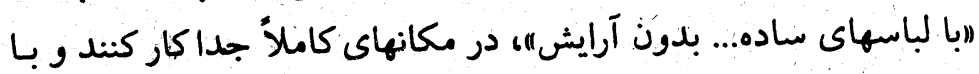

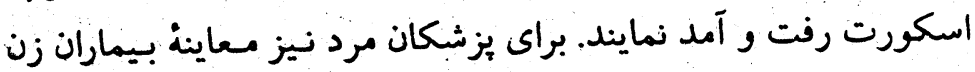

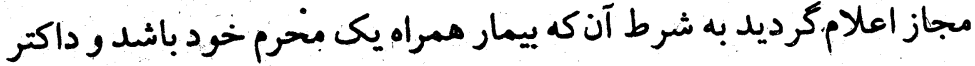
و بيمار هر دو لباس اسلامى داشته باشند و دكتر مرد "اجسز مسحل مـورد

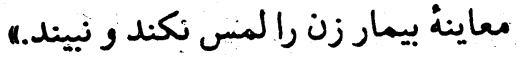
از مجموع اين مقررات عمومى، فقط مِه تا به زنان مسربوط مسى شهد.

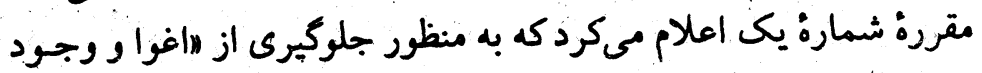
زنان بلدون حجابlا، هيج راندهاى مجاز نيست زنان ملبس به بهادرهائ كه صورت را نمىيوشاند يا زنانى كه لباسى تحريك كننده بر تن دارند ويا

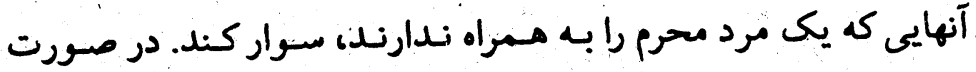

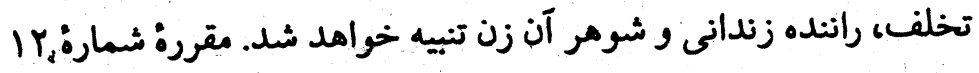
اعلام مىكرد كه بايد در تمام مساجد اعلام كردد كه زنـانى كه در دمر حسال.

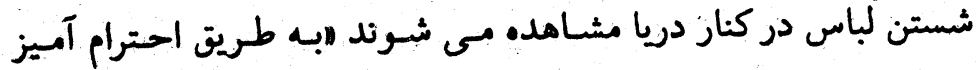

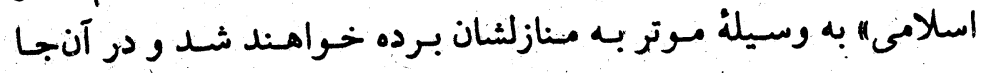

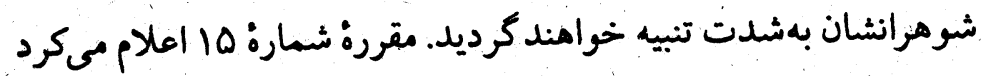
كِه خياطانى كه بلن زنان را اندازه كيرى كرده و مغازمهاى نمايش مد لباس

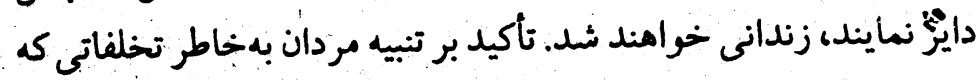

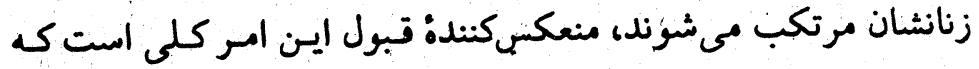


متوسط يك ماه حقوق است ـكه براى بسيارى از خانوادهها قابل تحمل

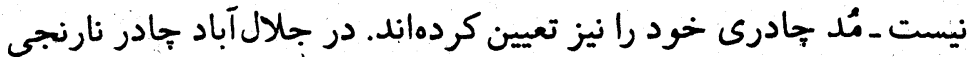

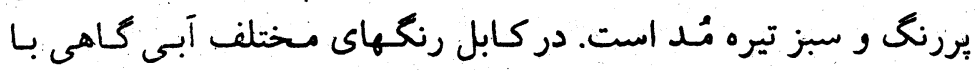

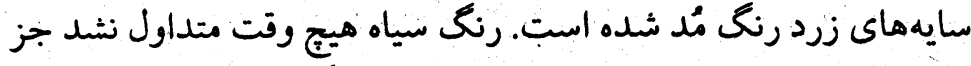

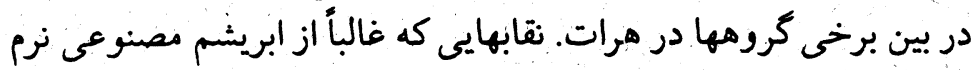

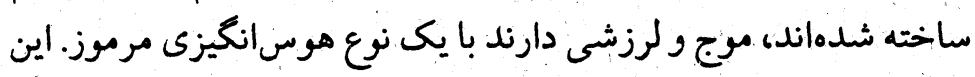
البته به هيج وجه منظور نظر مقامات نبوده است.

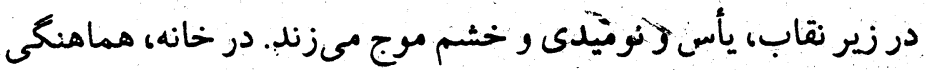
خانوادكى، به واسطة فشـار روحسى وارده بـر زنـان شـاغلى كـه بـهـ ايسن

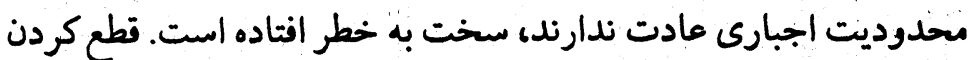

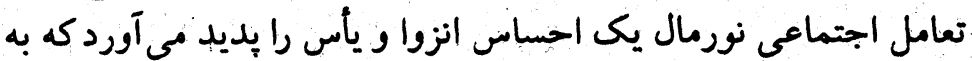
افسردكى منجر مىكردد. جريان حركت بناهندگان به خارج از إفغانستان

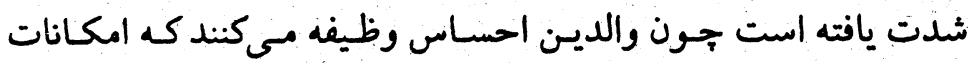

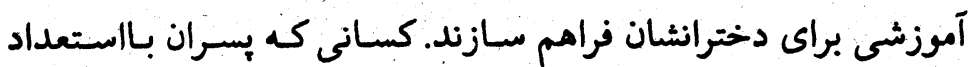

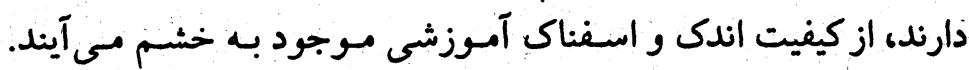
ازدحام كلهوار در صندليهاي عقب اتوبوسهاى فرسودة قديمى، به جاى فورئ

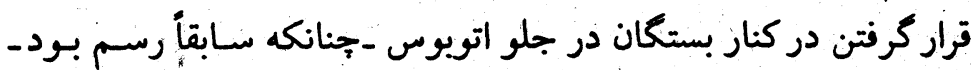

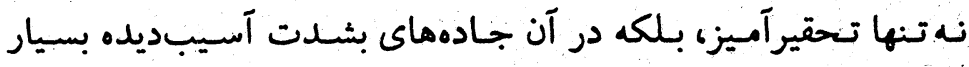

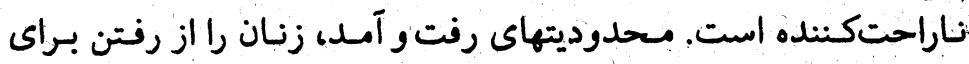
درمانهاى بزشكى ضرورى براى خود و فرزندانشان باز مى دارد. حضور

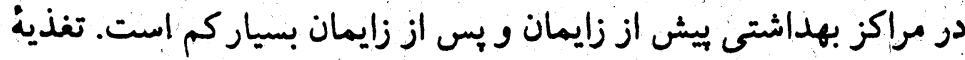

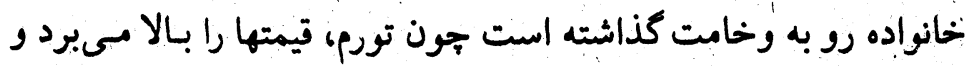

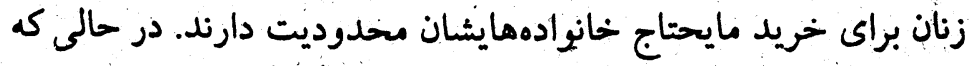
بهبود امنيت جسمى محسوس است، عدم امنيت اقتصادى اسفـانكيز

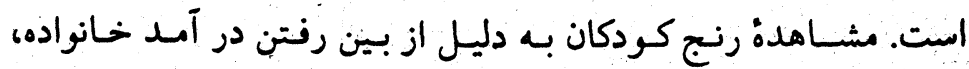

\section{هاسخ افغانها}

اكر حقيقتاً اجراى شديد مقررات براى آن است كه اطاعت زنان تضمين

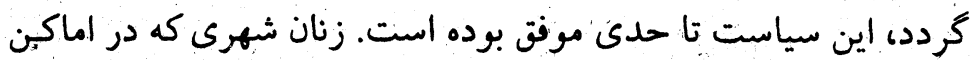

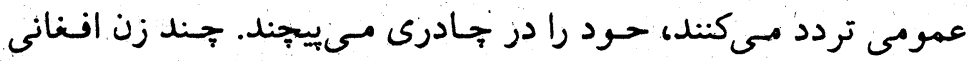

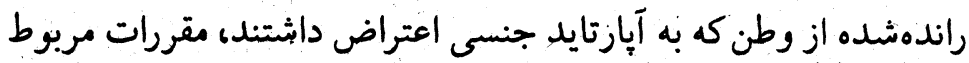

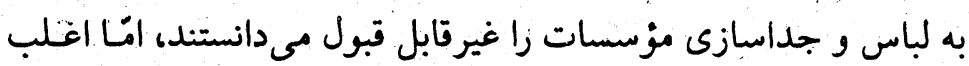

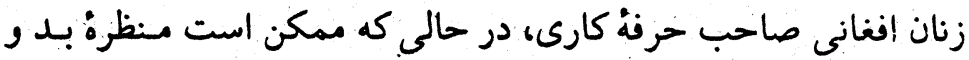

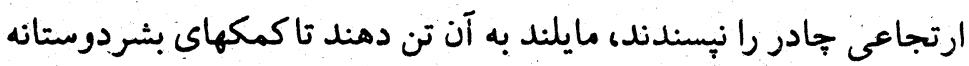

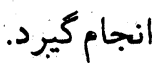

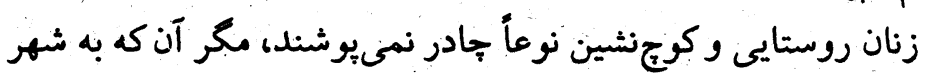

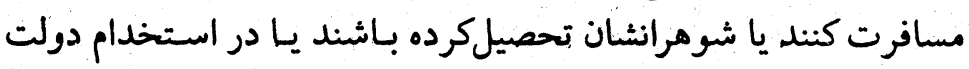

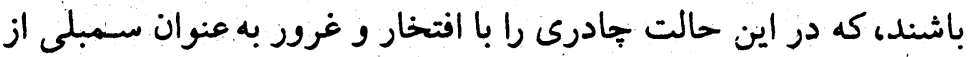

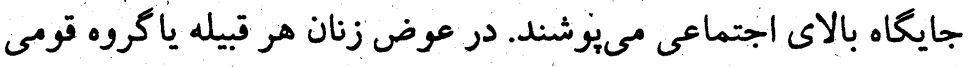

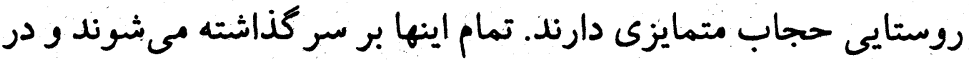

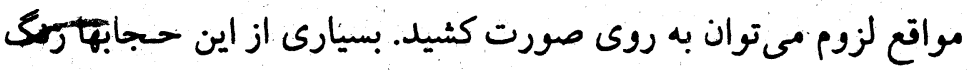

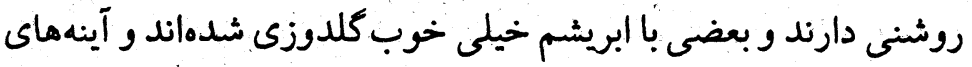

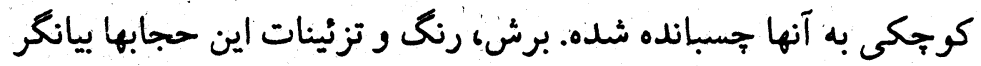

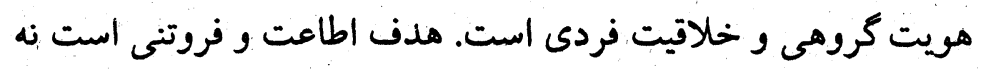

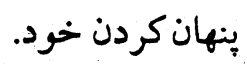

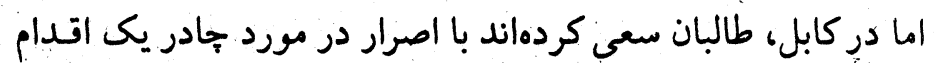

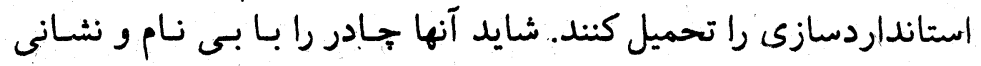

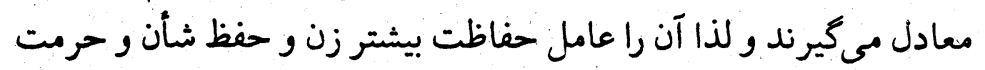

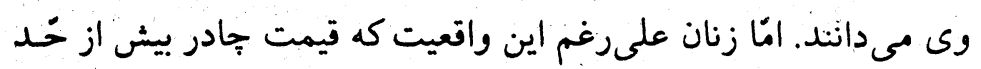


خلبدين حكمتيار، به سوى طالبان برگر دانده بودند. ساير گروههاى زنان

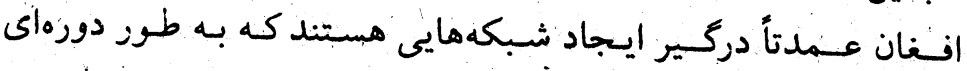
سمينارهايى بريا مى كنند و بيانيههايى منتشر مى سازند.

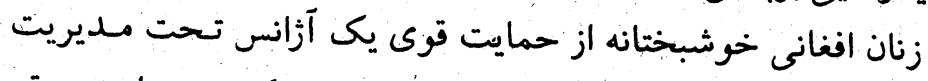

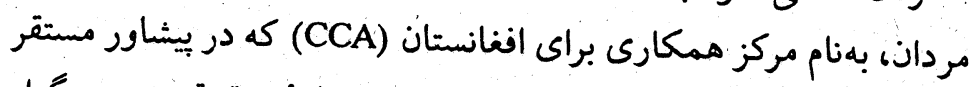

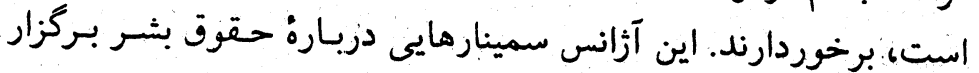

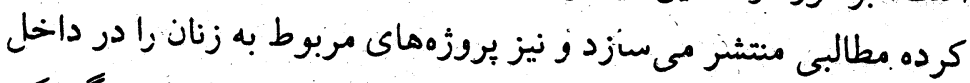

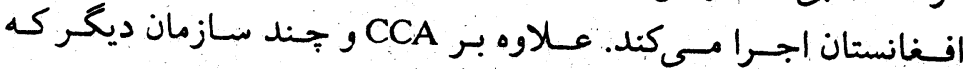

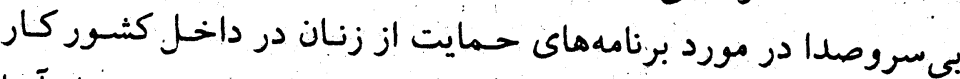

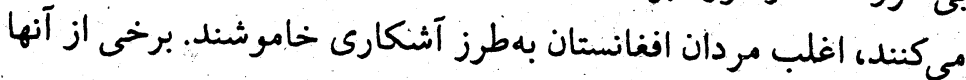

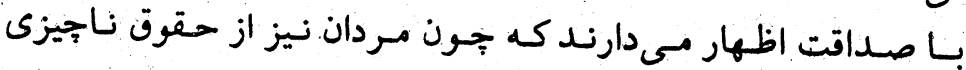

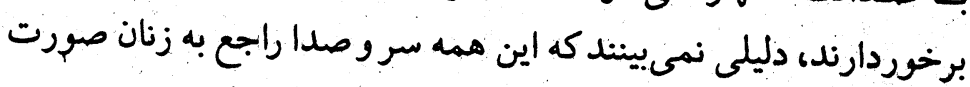

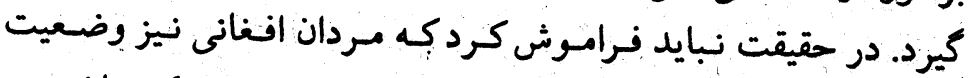

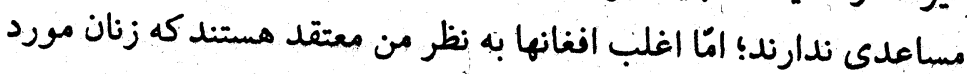

$$
\text { ظلم و تعدى بيشتر قراردارند. }
$$

به نظر مىرسد كه جامعه به دو بخش تقسيم شده است: كساني كه

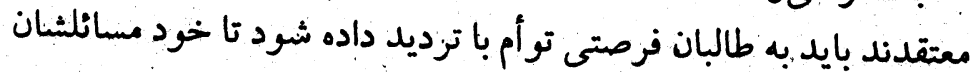
را حل كنند؛ و آنهايى كه تمام وعدههاى طالبان را با بدبينى تلقى مى مكنيد.

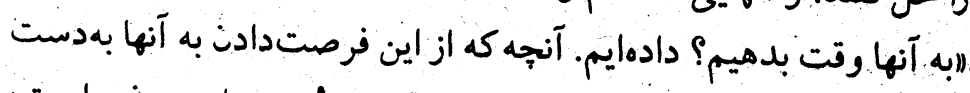

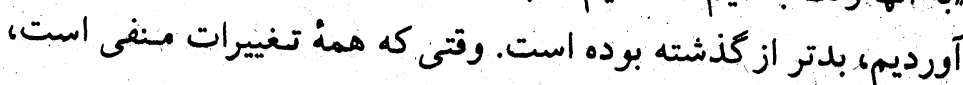

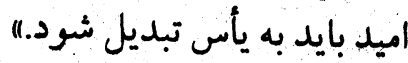

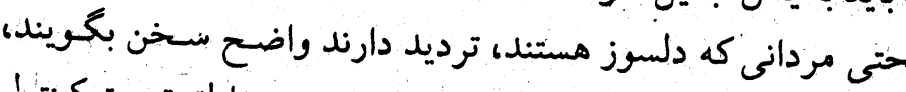

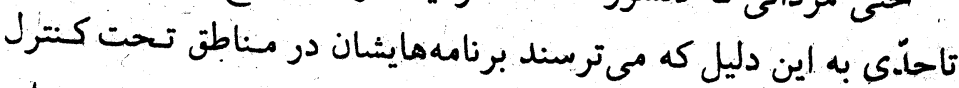

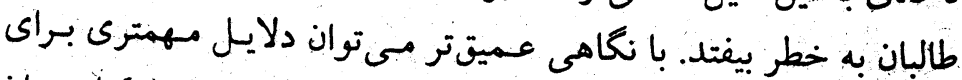

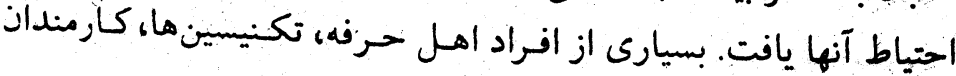

افغانستان، طالبان، و سياستهاى جهانى

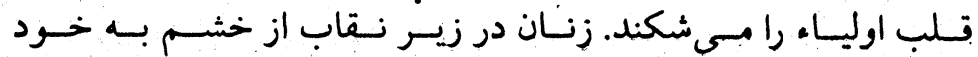

تنشها در زير فشُار زياد نظگه داشتهشده و هر لحظه ممكن است منفجر مى يبتجند

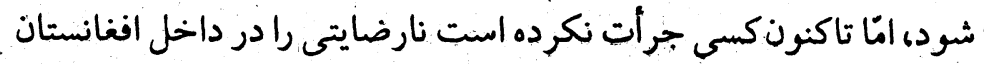

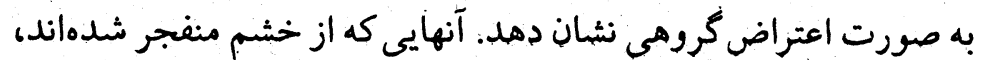
بهسرعت سركوب كرديدهاند جون هيج رهبرى مؤثرى براى ابقاى آنها

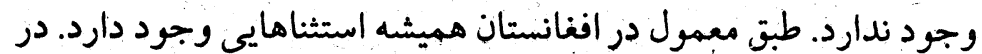
اوايل سال 1999، •109 زن در مقابل دفتر فرماندار قـندهار تظظاهرات

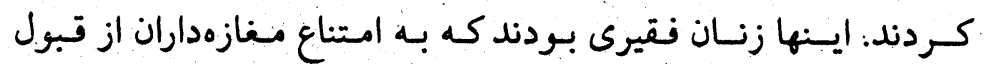
بانكنوتهاى (اسكناسهاى) خُرد اعتراض داشتند. همان شب فرماندار

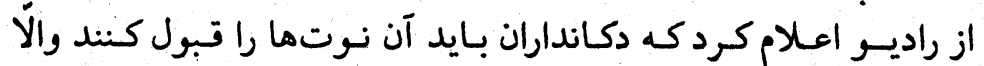

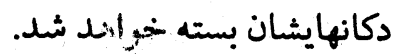

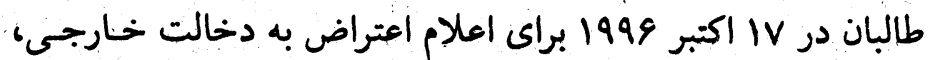

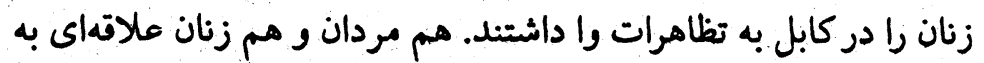

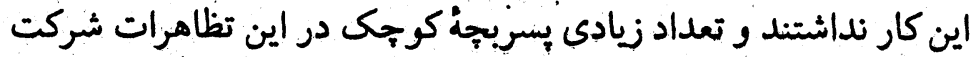

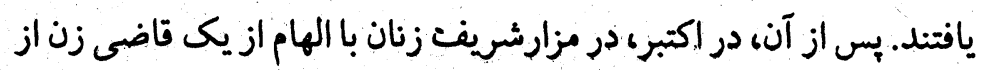
تشكيلات دوستم، ينج ساغت راهِيمايى كردند و شنعارهايى در دست

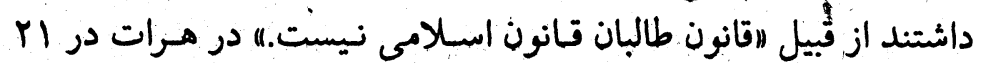
دسامبر 1999 تظاهرات •ه زن در اعتراض به بستهشدن حمامهاى زنانه به خشونت كشيده شد. •Y نفر دستخير شدند و خند نفر ديخر بهواسطة

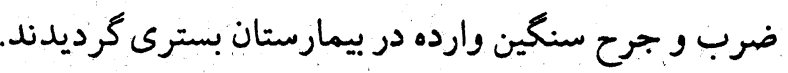
اينها حوادث داخل افنانستان بود. در بِاكستان انجمن انقلابى زنسان افغانستان (RAWA) كه بسيار سياسن است به تظاهرات در اسللام آباد،

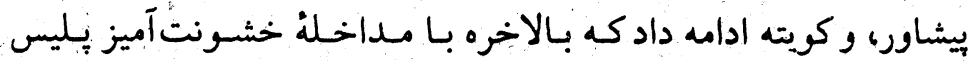

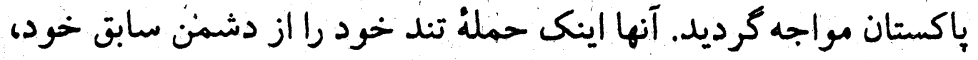


است از حفظ حرمت و اعتبار خانواده از طريق ثمكين به قوانين رفتارى

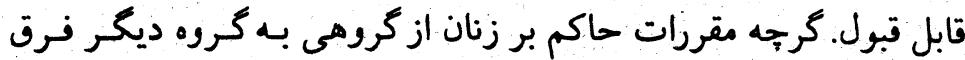

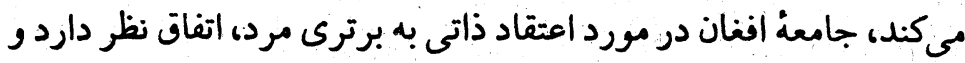

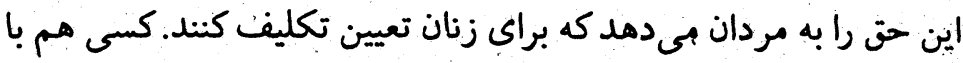
اين مسأله مخالفتى نذارد. لذا طالبان روشهاى يدرسالارانه را با بـوشاندن قباى اسلام بـر آنها

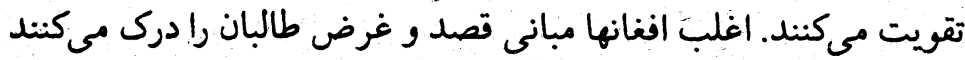

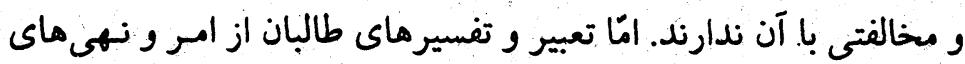

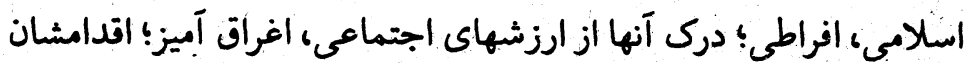

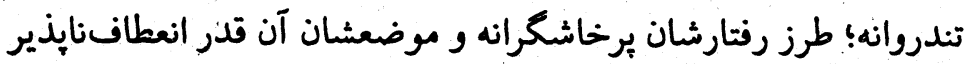

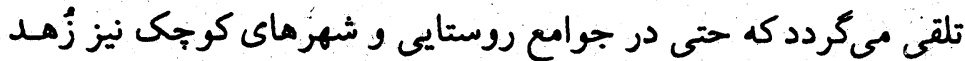

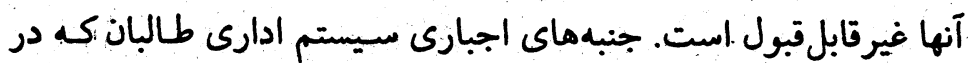

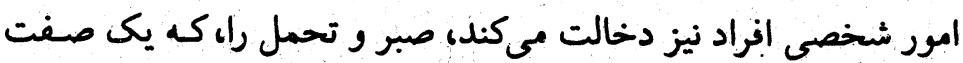

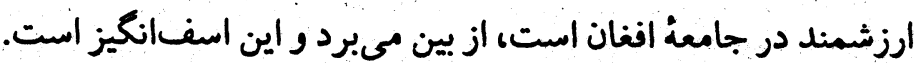

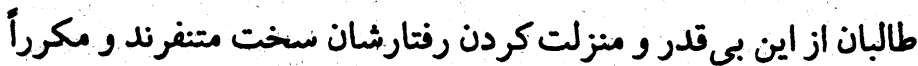

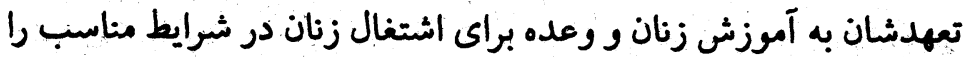

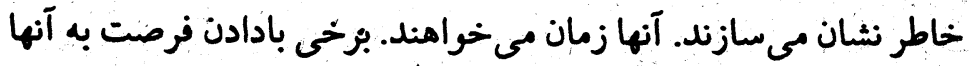

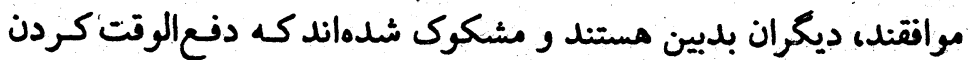

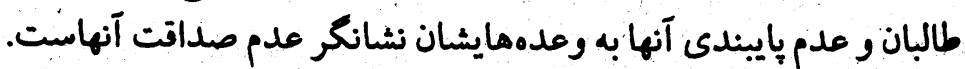

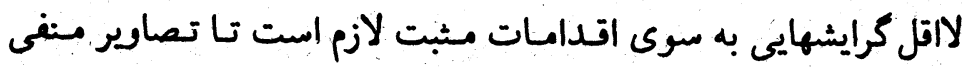

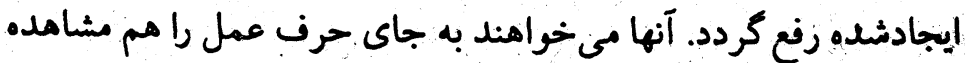

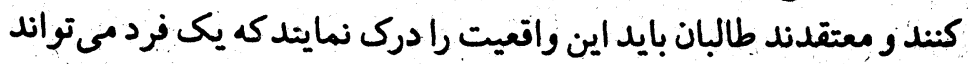
بدون ريش يا حادرى، مسلمان خويى باشيد.

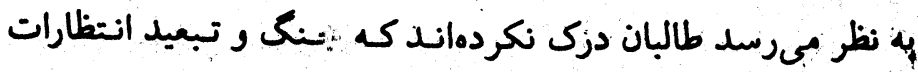

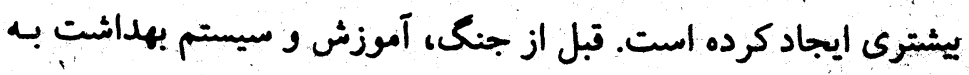

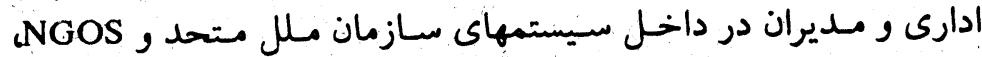

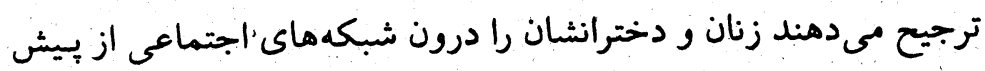

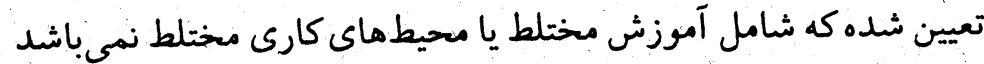

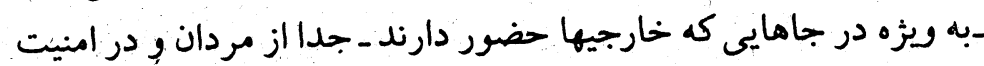

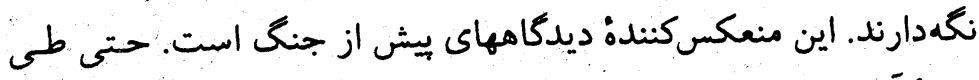

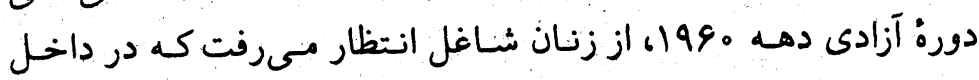

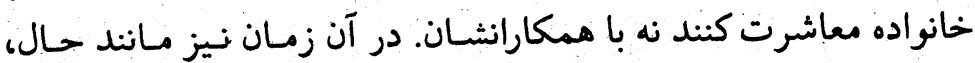

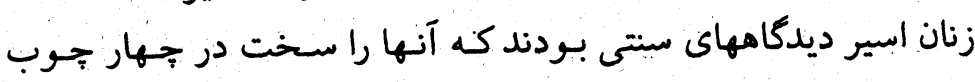

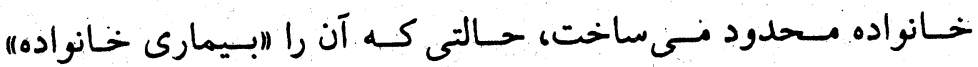
مي ناميدند.

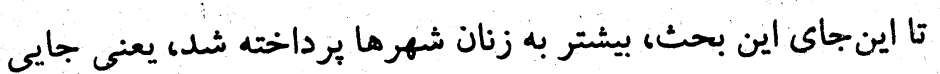

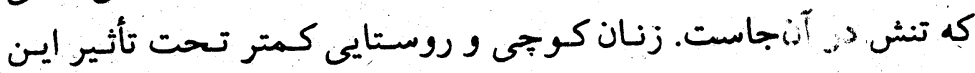

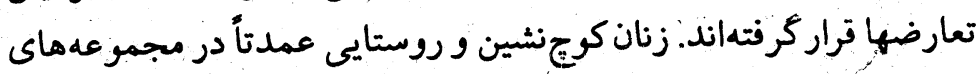

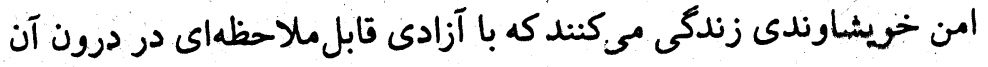

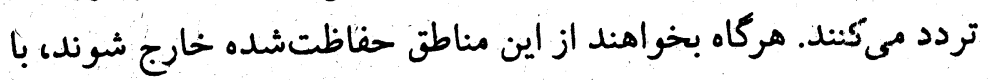

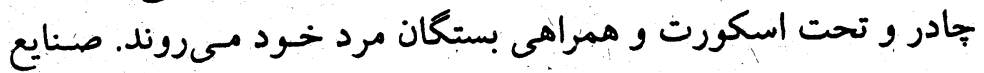

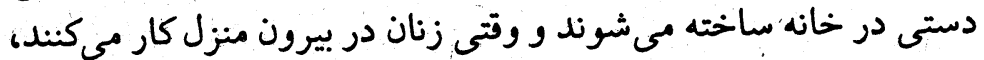

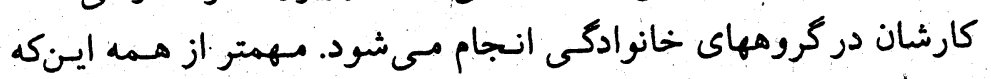

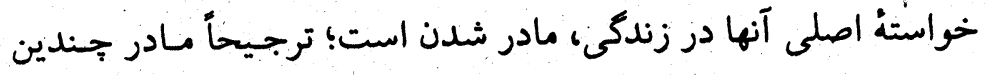

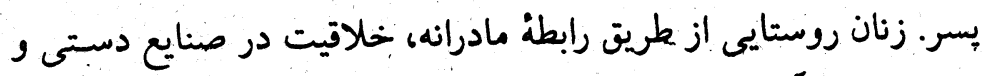

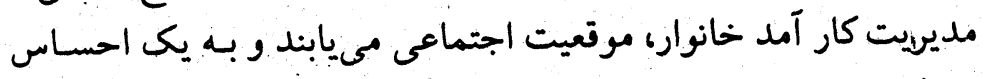
كمال شخصى دست مىيابند.

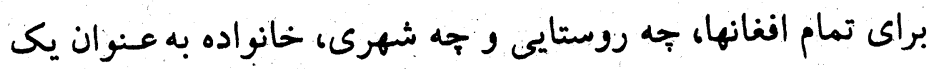

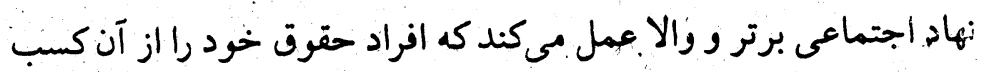

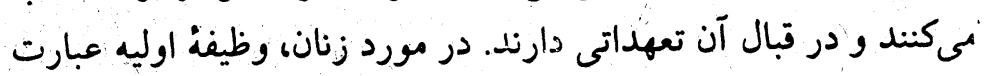




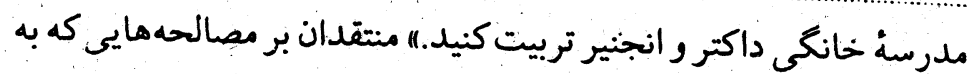

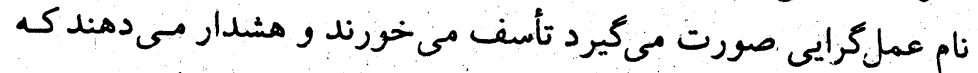

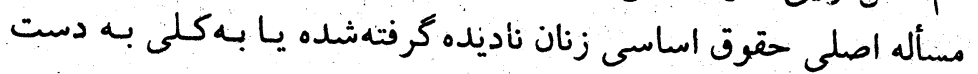

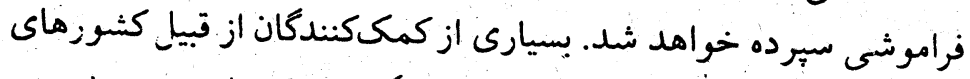

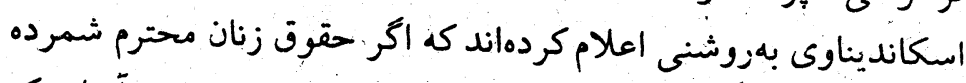

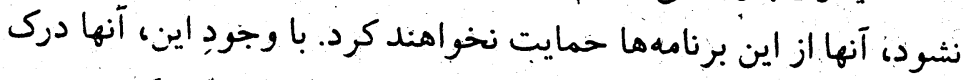

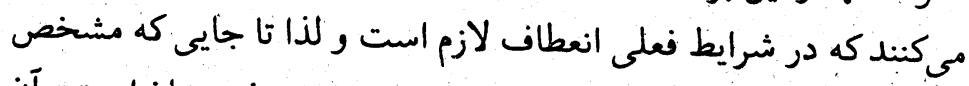

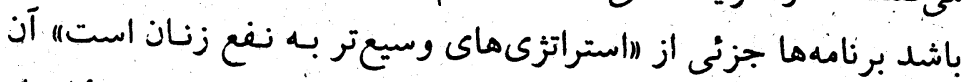

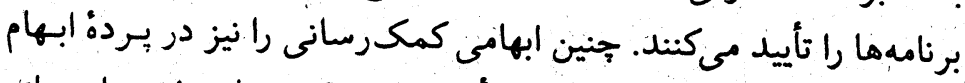

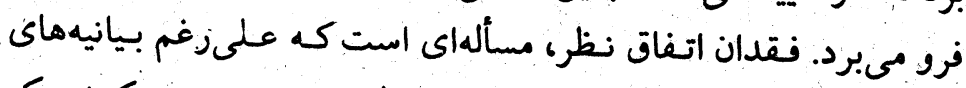

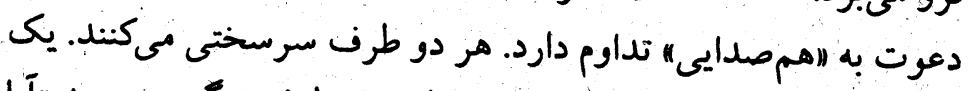

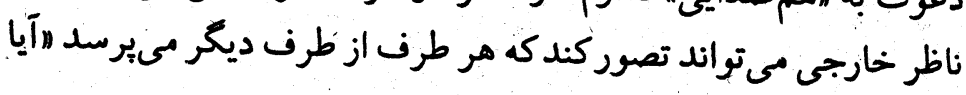

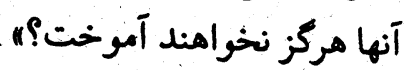

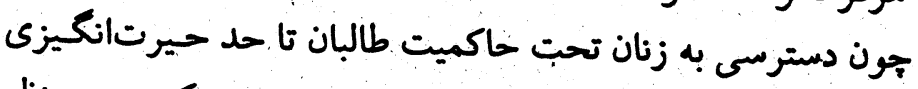

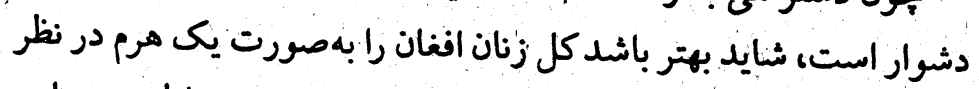

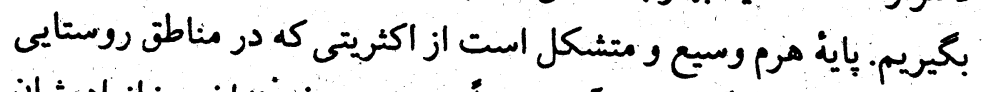

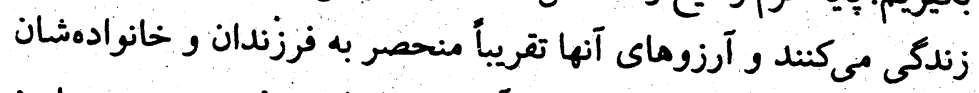

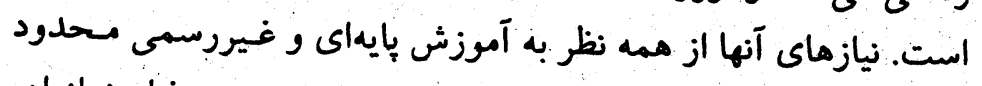

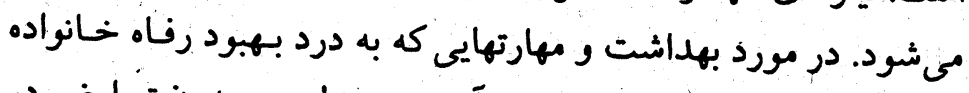

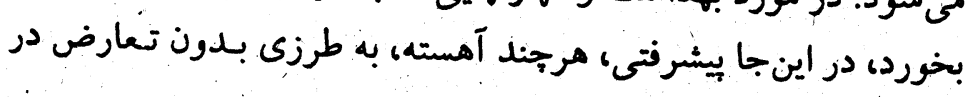

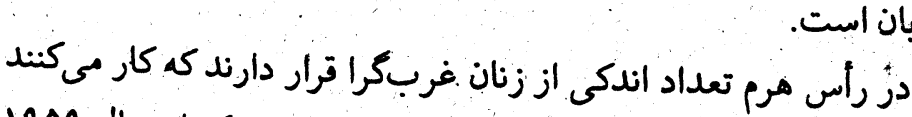

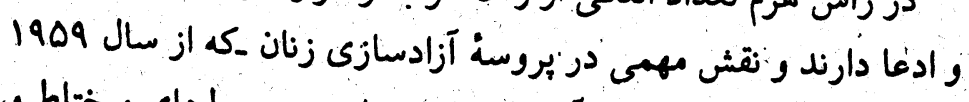

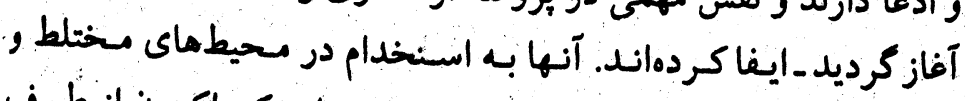

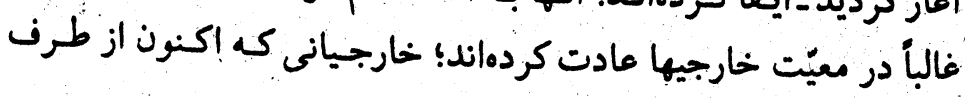

افنانستان، طالبان، و سياستهاى جهانى

orr

مناطق روستايى دوردست گسترش نيافته بود. نقط حسدود سـه درصــ

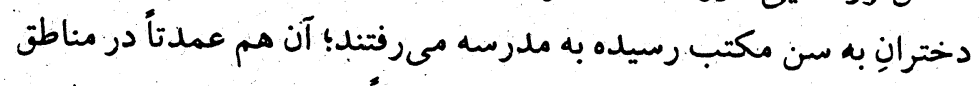

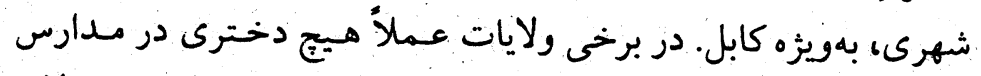

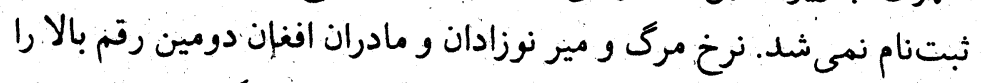

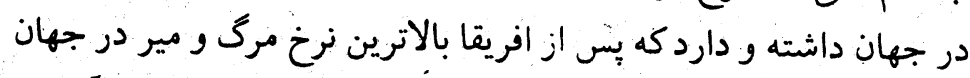

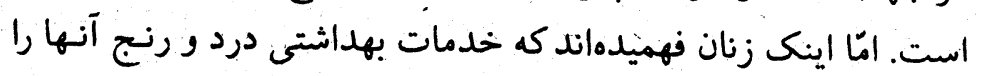

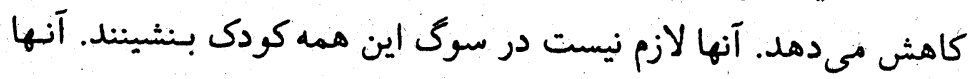

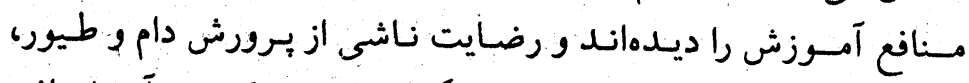

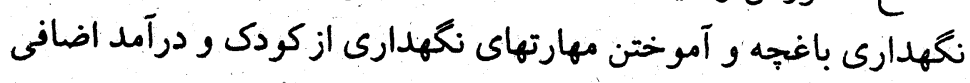
را تجربه كردماند.

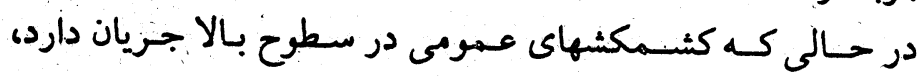

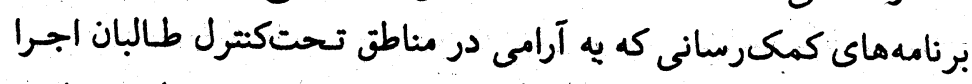

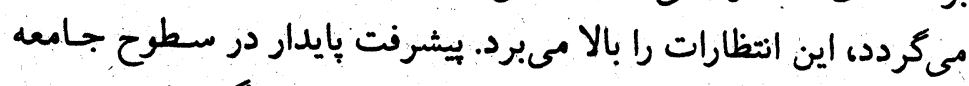

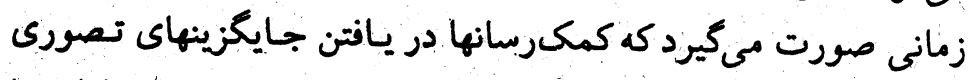

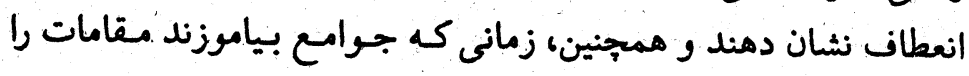

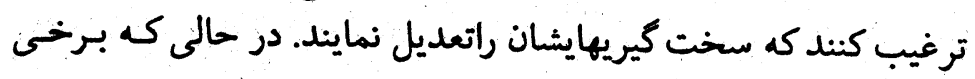

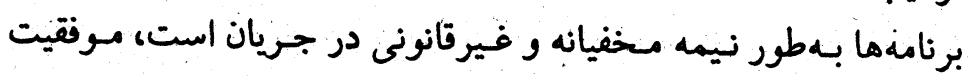

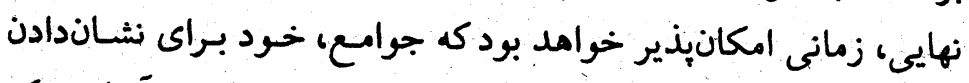

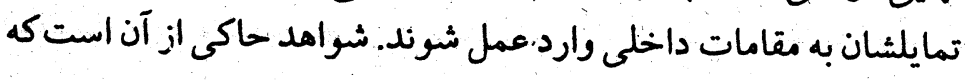

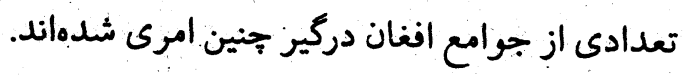

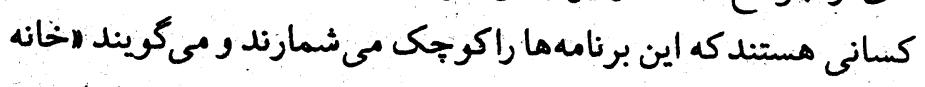

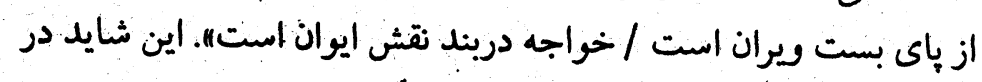

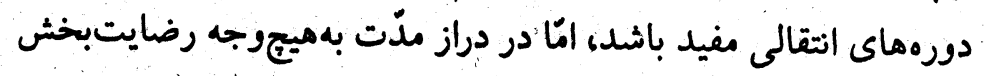

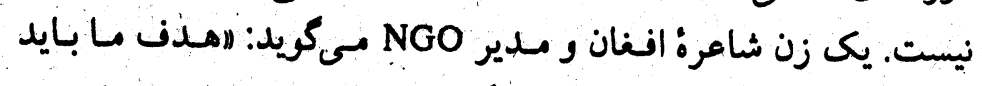

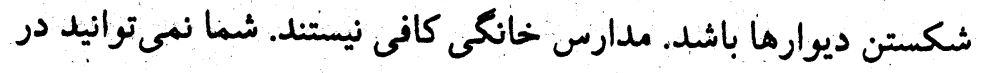




\section{آيا افغانستان در آستانه تجزية}

\section{قومى و تنيلهاى قرار دارد؟}

هبرنت كلاتزر
افغانستان، طالبان، و سياستهاى جهانى

orrp

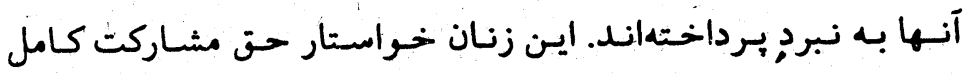

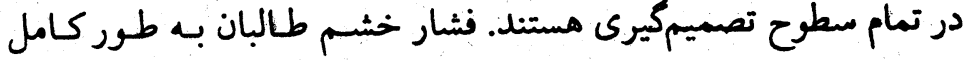

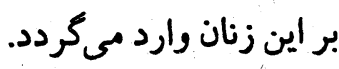

\section{خ مقدمه : نظام قومى}

معمولا براى جامعة افغانستان اصطلاح "اقبيلهاى" را به كار مى برندكة البته

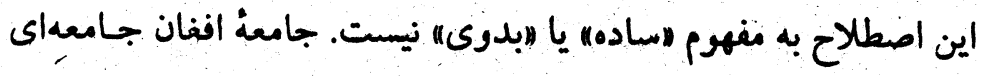

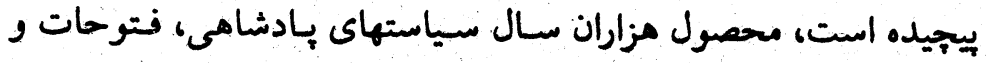

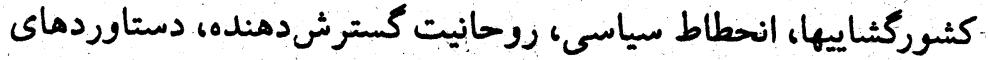

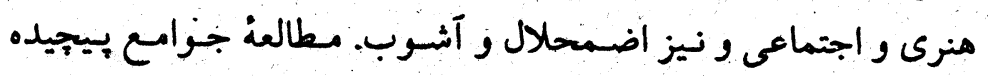

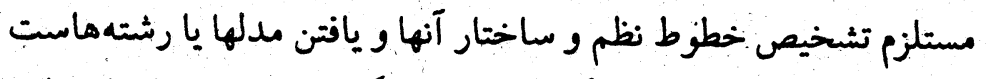

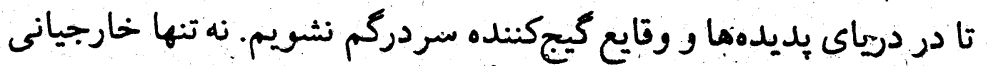

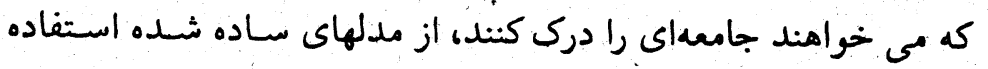

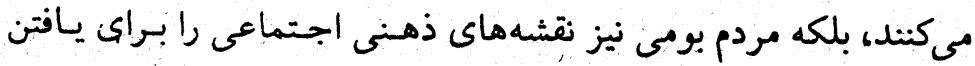

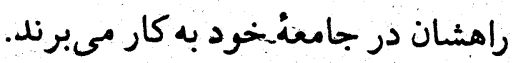

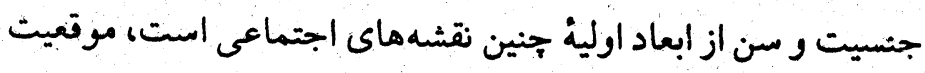

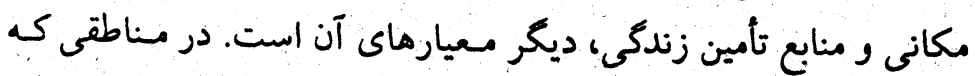

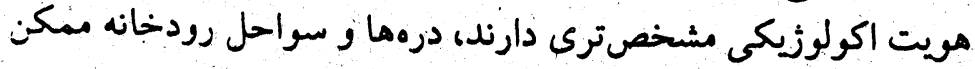

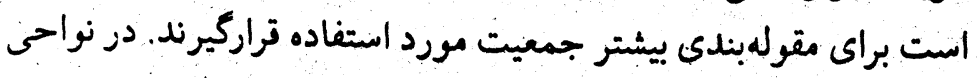

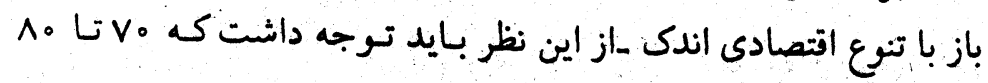




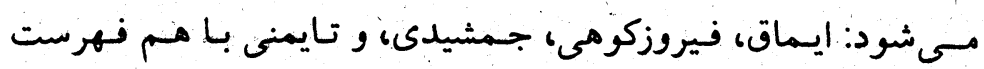

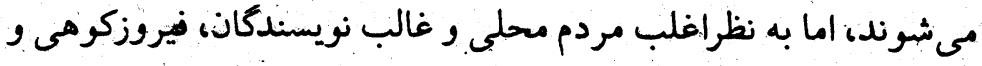
جمشيدى جزء ايماقها هستند. تايمنى ها معمولاً إيماق بودن خود هود را انكار مئىكند و بسيارى از آنها

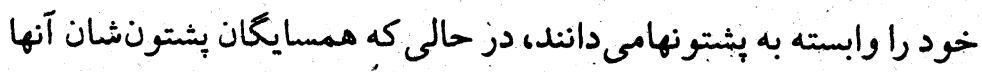

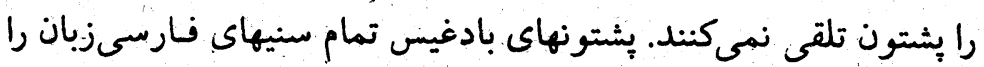
ايماق مى نامند، كه اين براى تاجيكهاى بحلى ـكه مسنيهاى فـارسىزيان

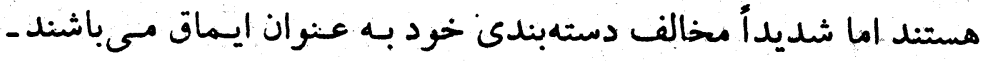

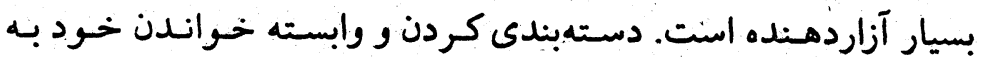

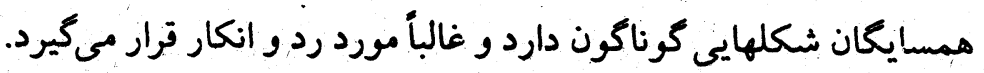

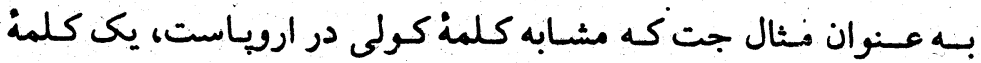

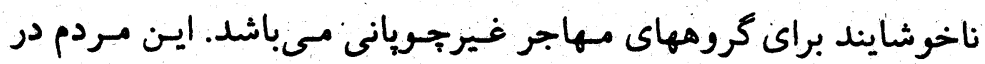

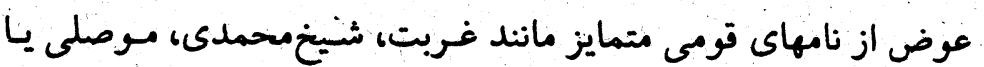
اصطلاحات شغلى خود استفاده مىكنند.

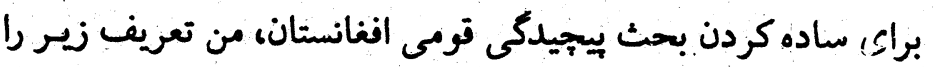

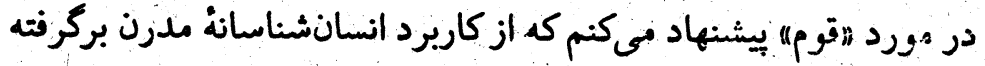
شدهاست: قوم يعنى يك اصل نظم اجتماعى و حد و مرز اجتمباعى مبتنى

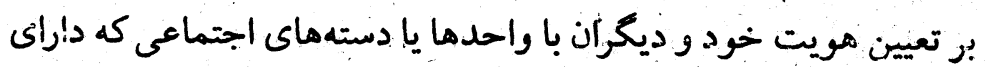

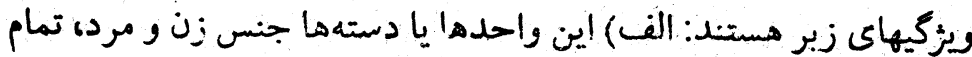

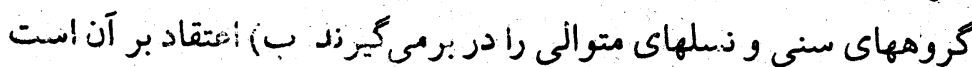

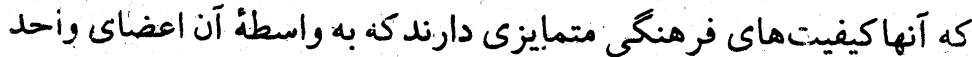

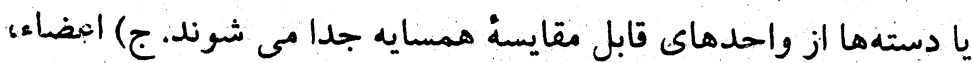

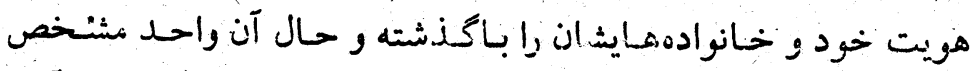

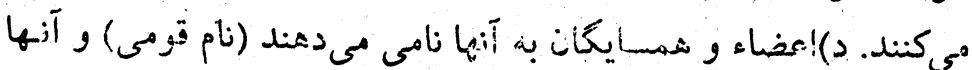

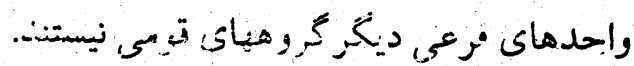

درصد افغانيهاى قبل از جنظ روستايى بودند ـديخر مقولهماى اجتماعى اهميت مى يابند، به عنوان مثال كرورههاى خويشاوند وكروهبندى قبيلهاى يا قومى. اين بدان معنا نيست كه ماختارهاى قومى و قبيلهاى حساصل

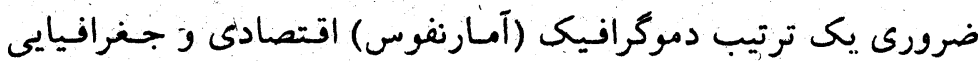

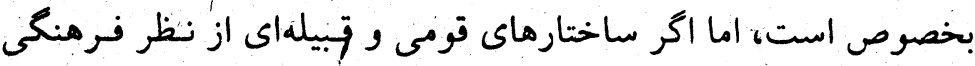
وجود داشته و مورد قبول باشند و بخشى از زرادخانه تاريخى نهادهاى

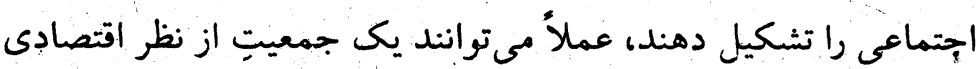

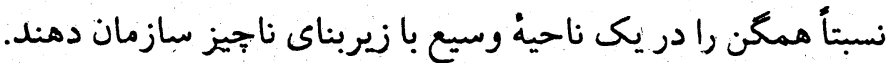

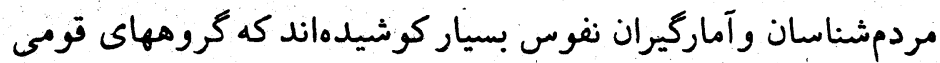
افغانستان را شمارش كنند، اما نتايج بسيار متفاوتى بهدست آورددهاند. تا فيا آنجاكه من مى دانم، جدى ترين تلاث بـراى فهربت كردن كرورههاى قومى در افغانستان توسط "اروين اريواله (Erwin Orywal) و همكارانش هرئ

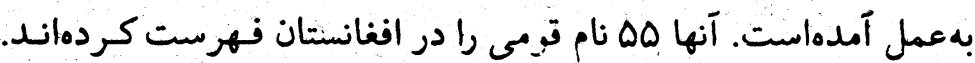
أبريوال همجنين خاطربشان مى نسازد كه كروههاى قومى و هويت قومى،

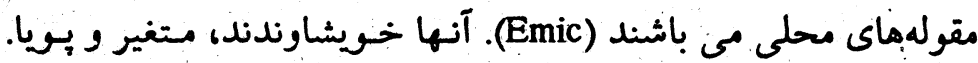

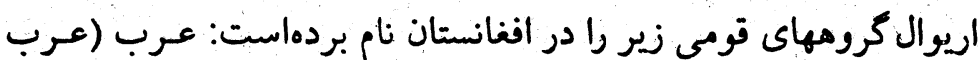

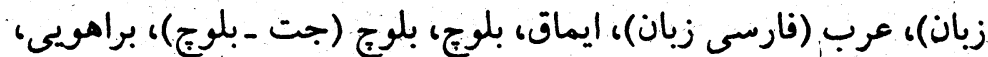

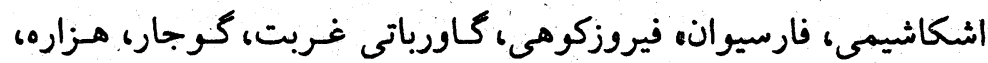

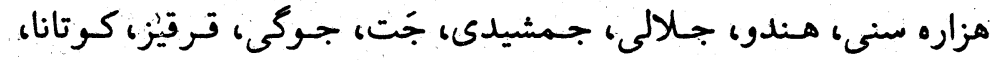

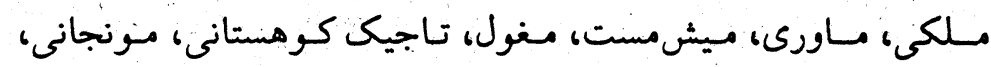

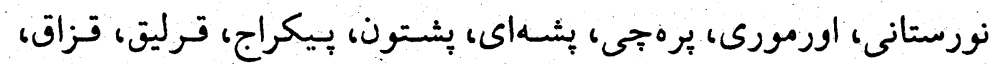

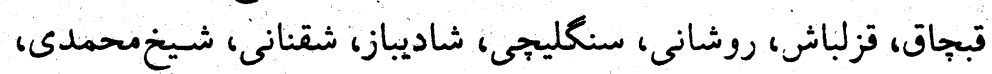

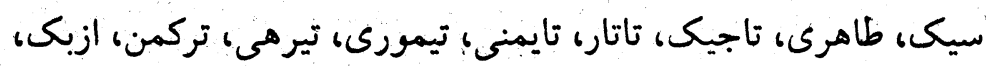
واخى، وانكورالى، يهودى و زورى.

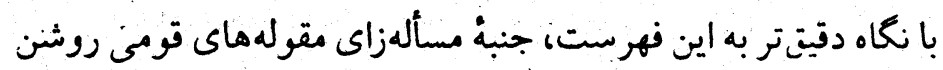




\section{* كروههاى اصلي دركير در جنى افغانستان}

يشتونها:

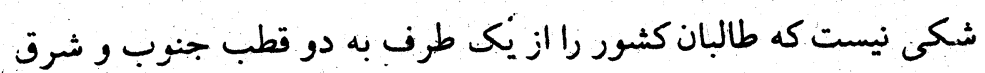

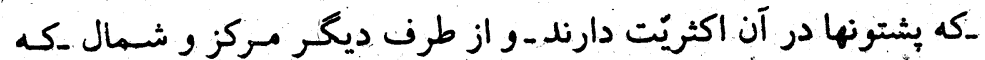

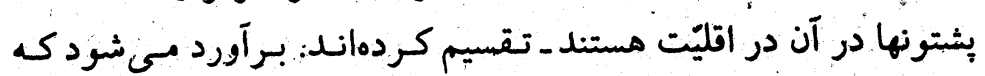

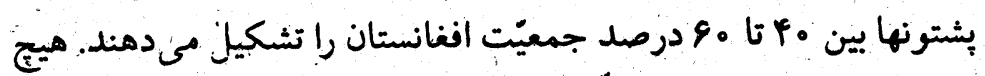

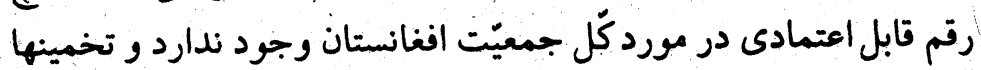

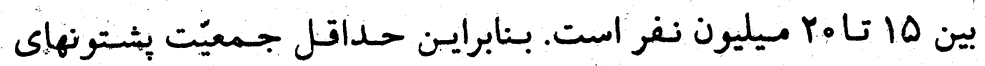

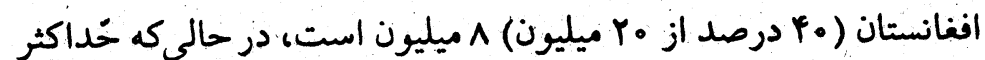

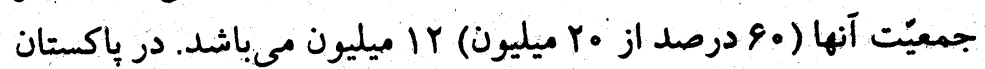

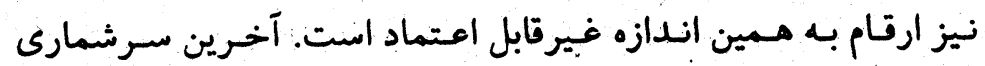

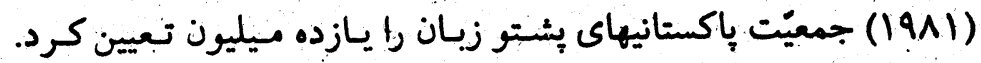

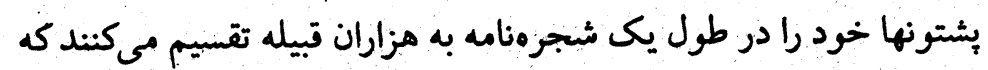

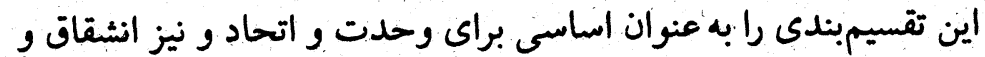

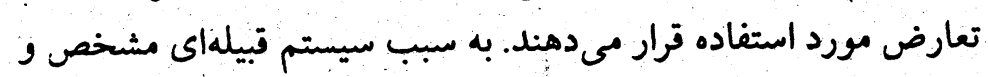

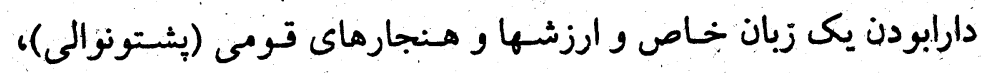

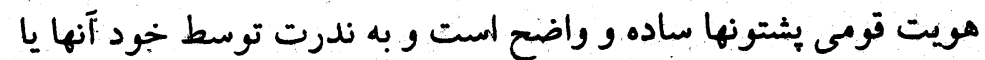

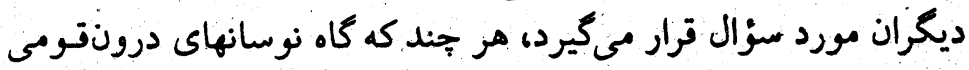

تاجيكها: بعد از بشتونها، تاجيكها بزركترين گروه قومى در افغانستان هستند. كروه
در اينجا مهم است خاطرنشان كردد كه دستهما و سيستمهاى قومى فئى

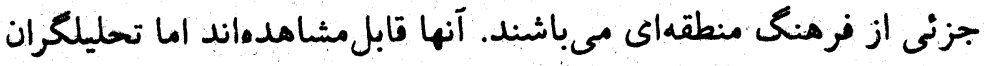

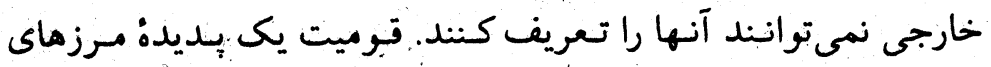

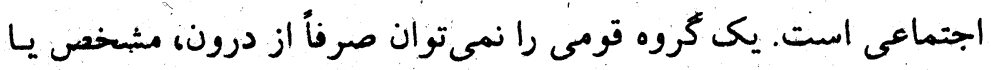

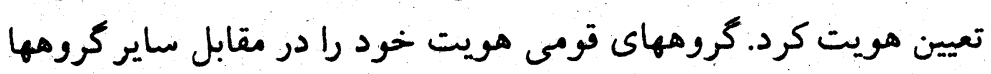

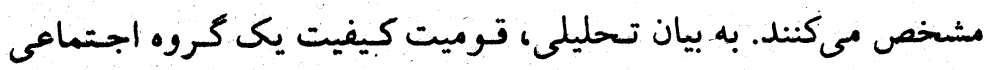

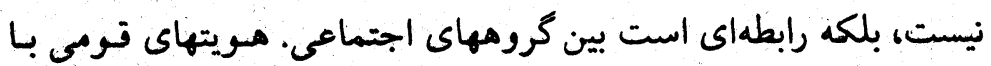

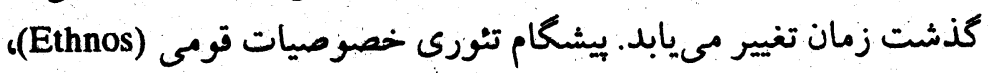

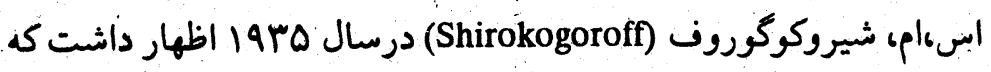

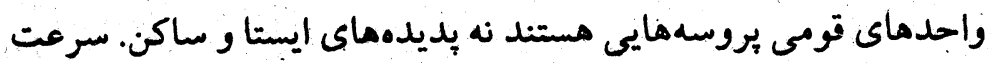

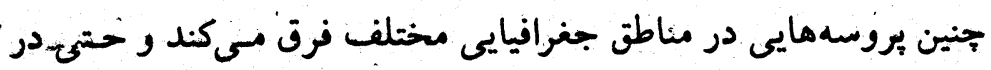

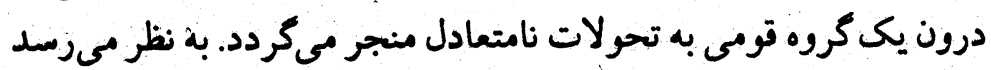

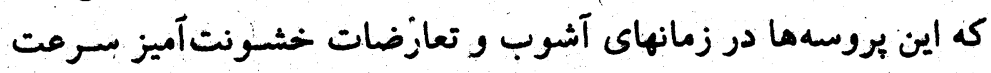

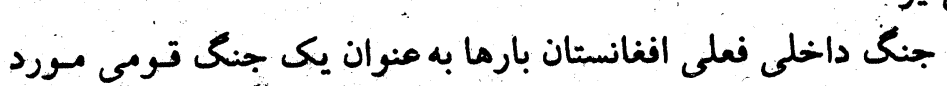

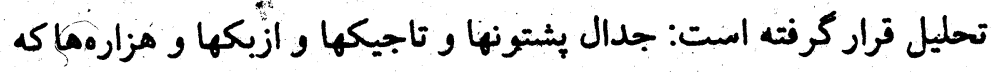

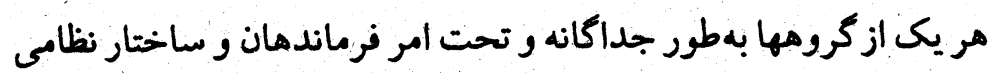

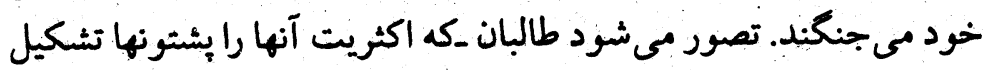

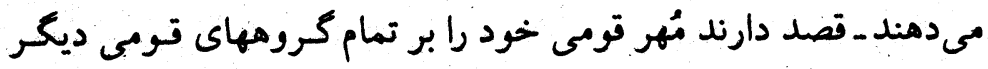

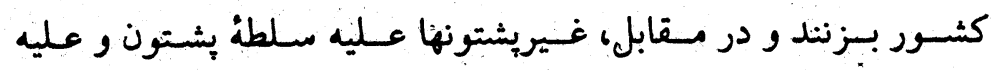

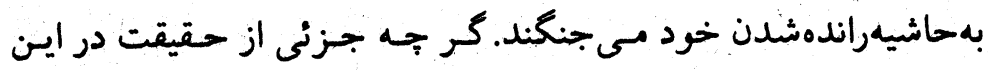

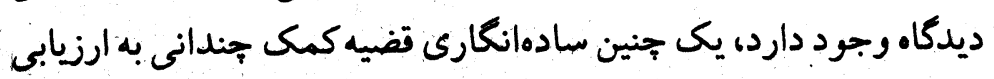

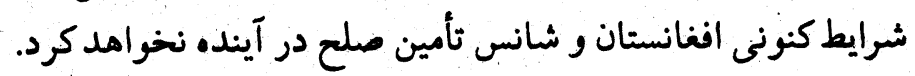




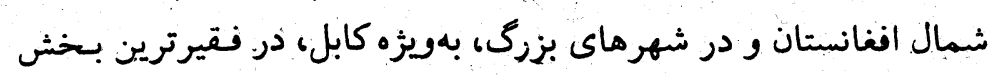

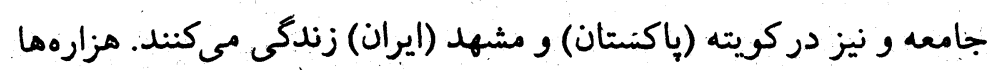

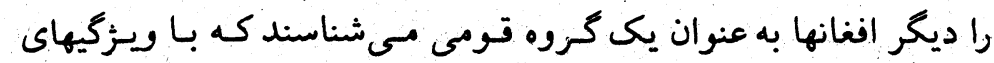

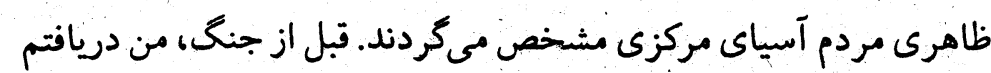

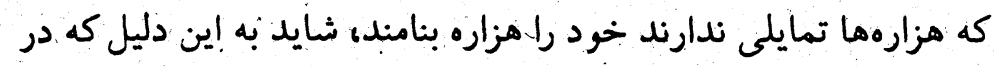

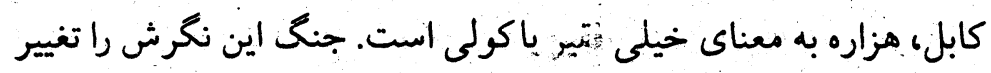

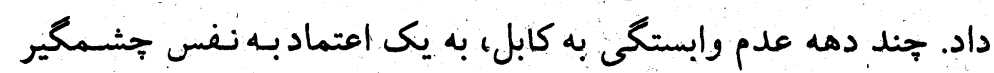

$$
\text { قومى منجر گرديده است. }
$$

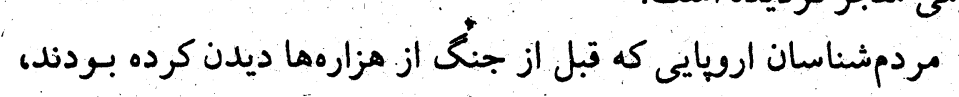

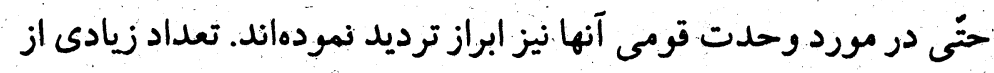

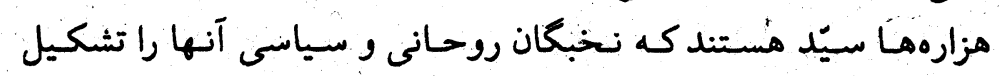

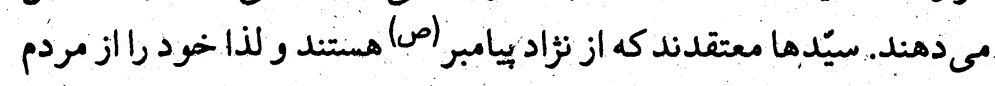

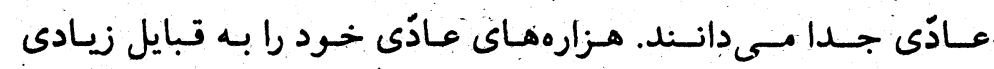

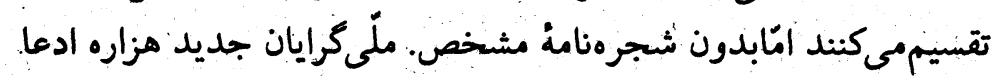

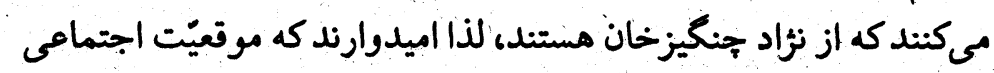

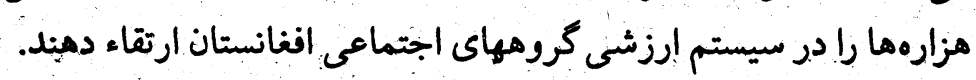

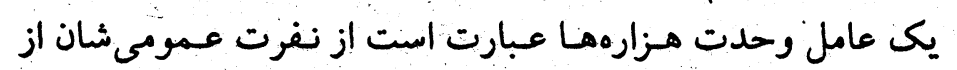

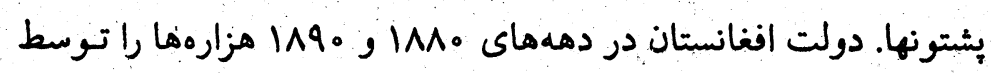

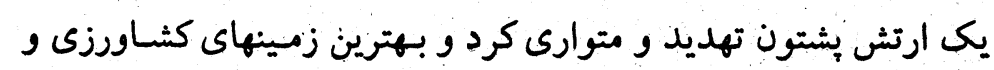

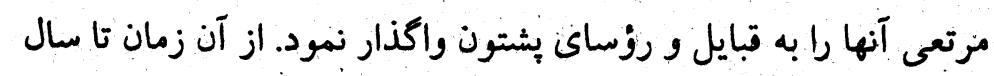

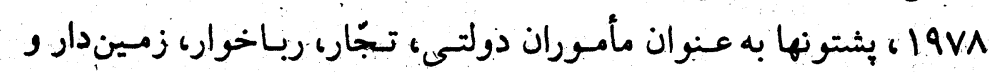

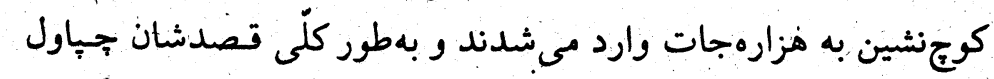

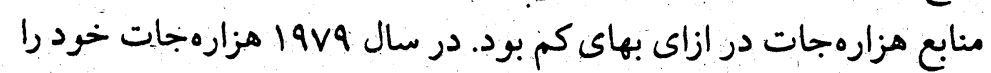

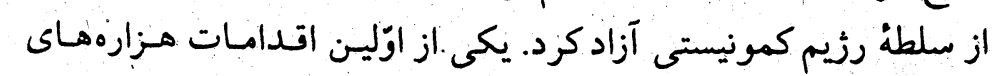

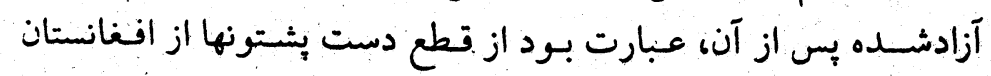

افغانستان، طالبان، و سياستهاى جهانى orr.

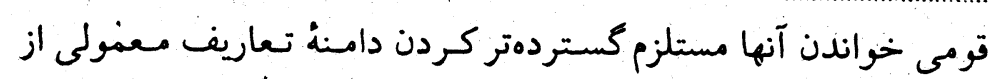

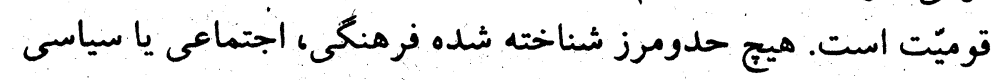

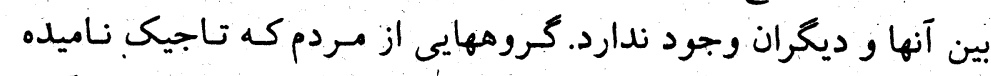

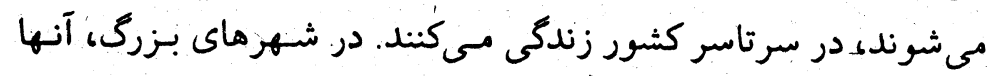

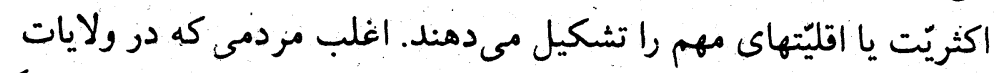

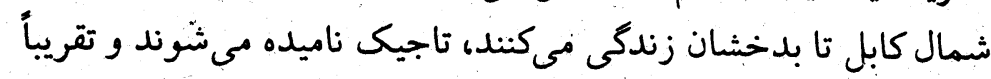

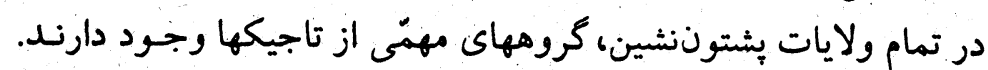

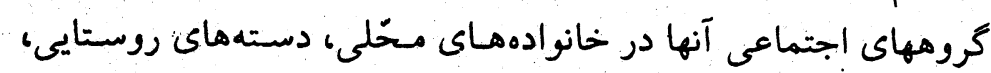

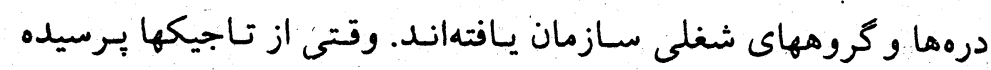

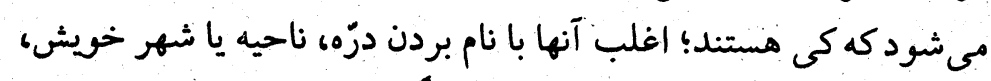

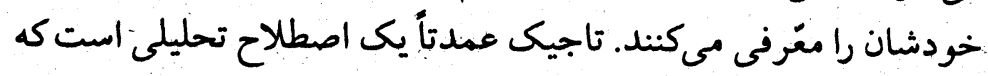

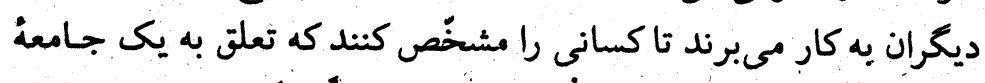

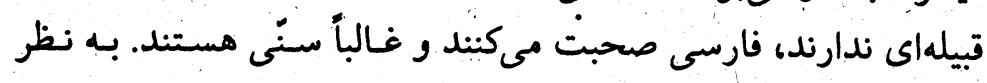

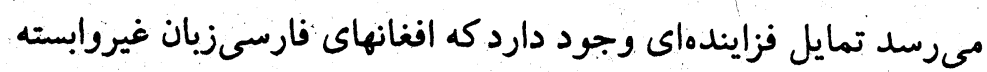

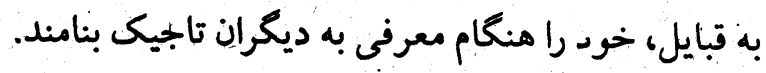

)

هزارهها:

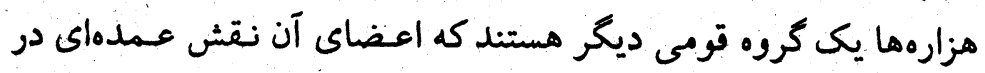

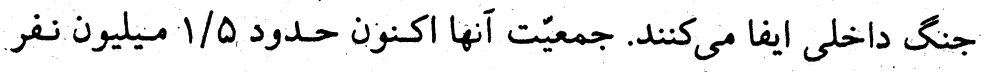

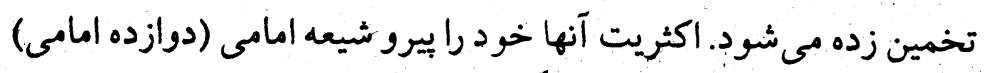

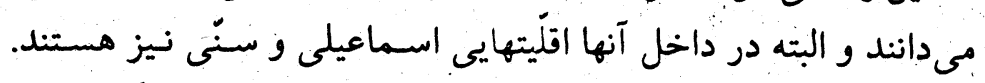

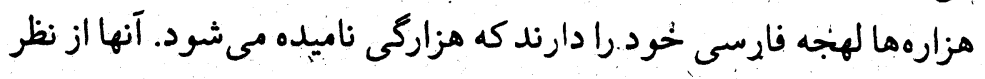

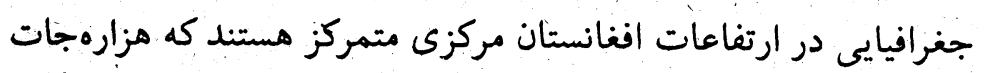

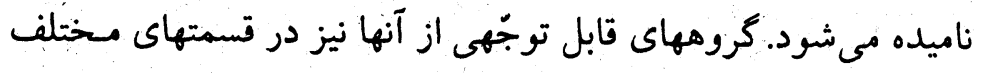


مهاجرين نوعى گروه قومى متمايز را تشكيل دادند. قبل از سالى 19V^

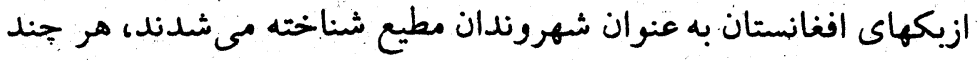

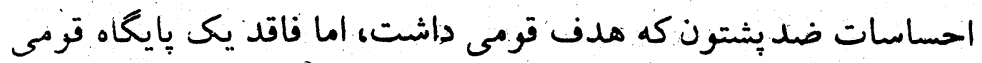

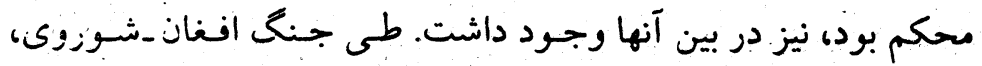

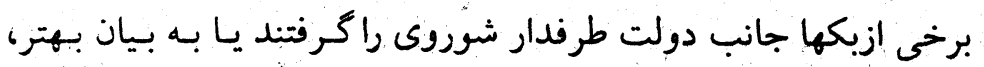
طرفدارى از سياستهاى اقليتهاى دولت جديد راكردهُ و تحت نام مليشياى جوزجانى رشيد دوستم سازماندهى نظامى شندند. ساير ازبكها جـانب

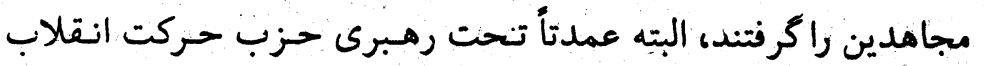

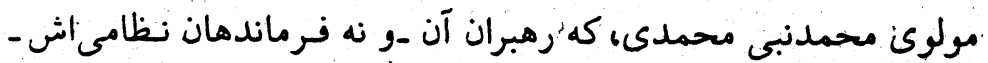
تقريباً همخى يشتون بودند.

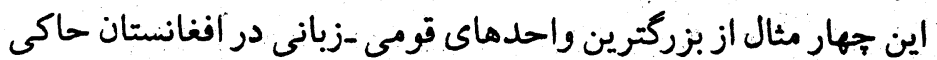

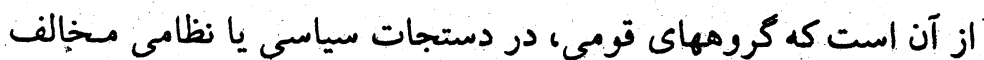

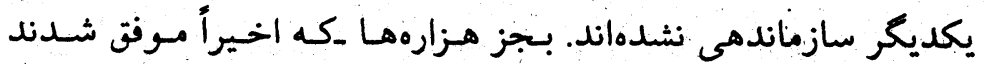

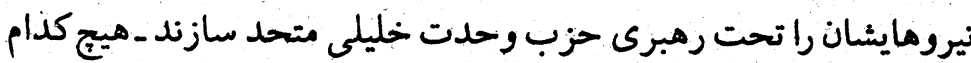

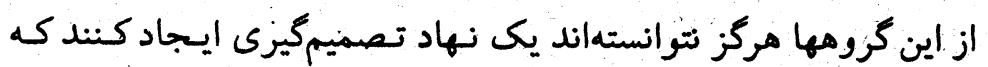

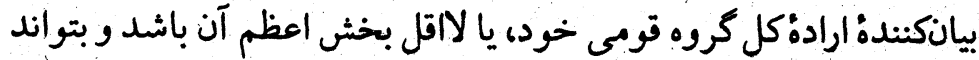

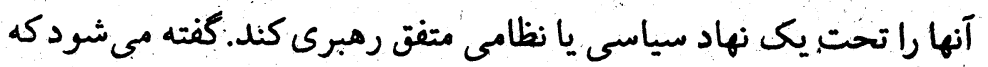

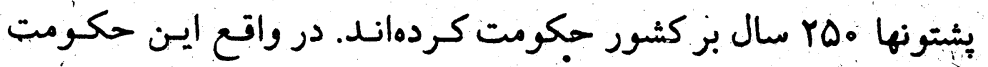

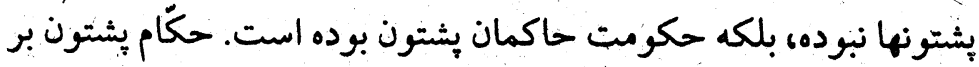

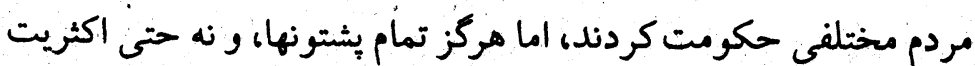

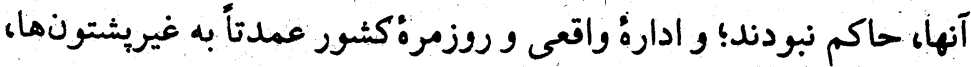

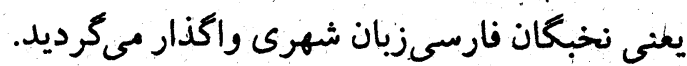

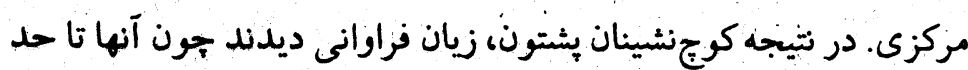

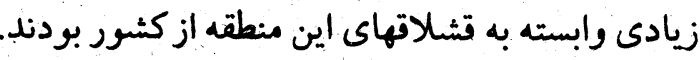

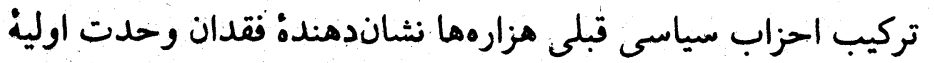

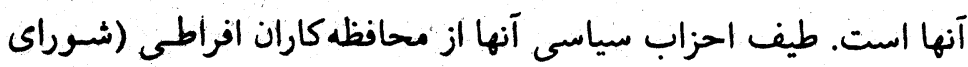

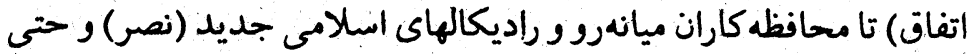

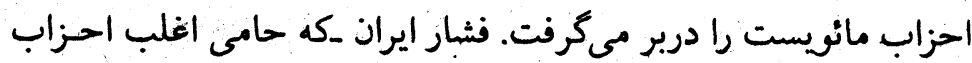

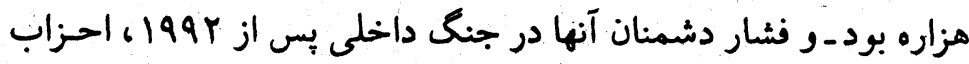

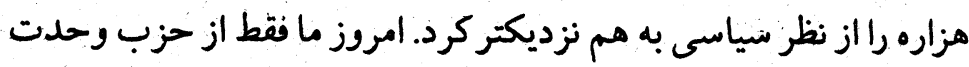

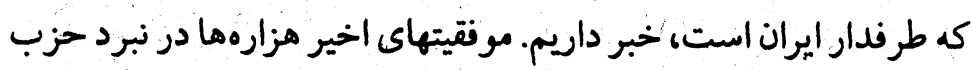
وحلدت عليه طالبان در غوربند، وردك و مزار، نشاندهندهُ وحلتى در بين

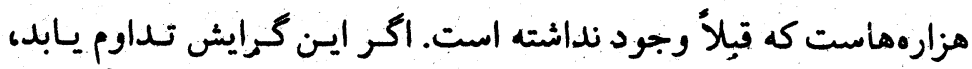

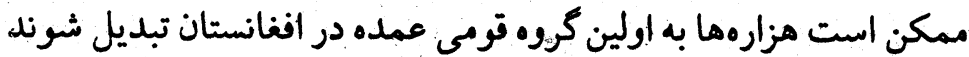
كه توانسته به وحدتى منسجم دستيابد.

ازبكها:

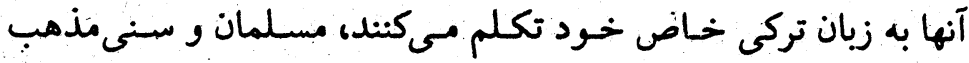

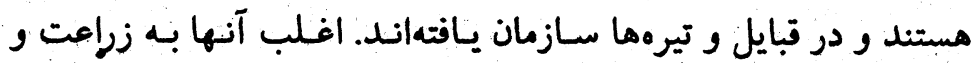
مالدارى فيركوجنشين اشتغال دارندّ. تعداد آنها تقريباً برابر هزارهماستان.

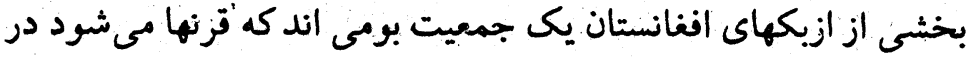

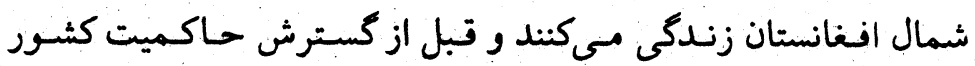

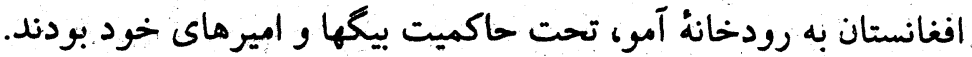

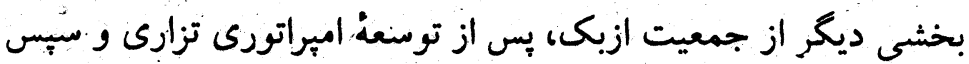

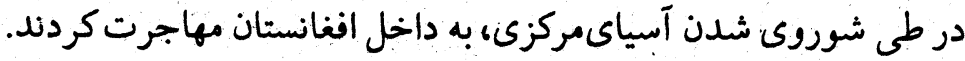

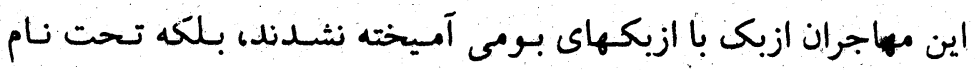




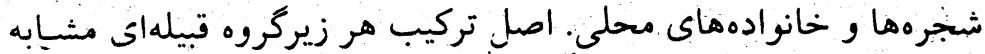

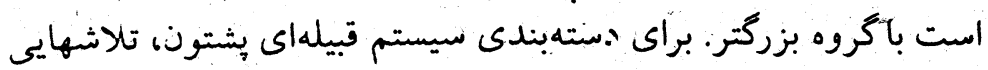

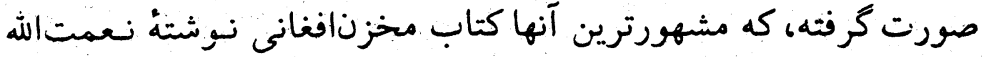

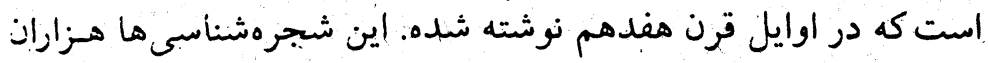

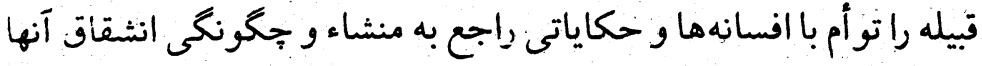

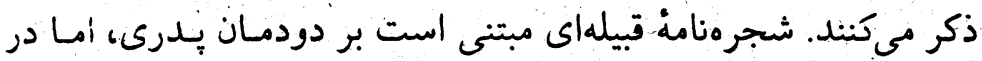

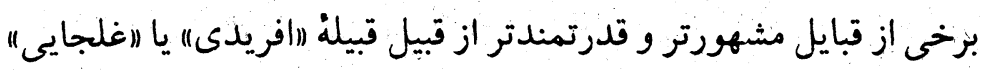

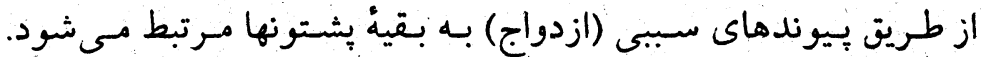

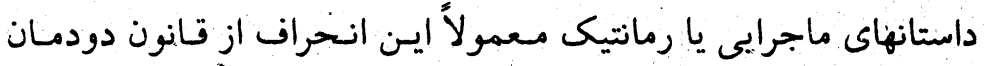

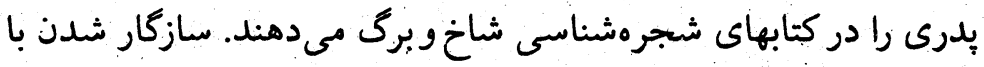

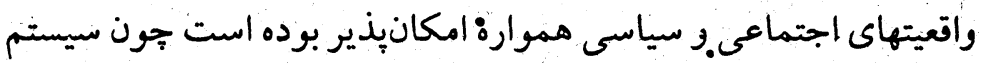

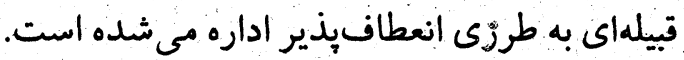

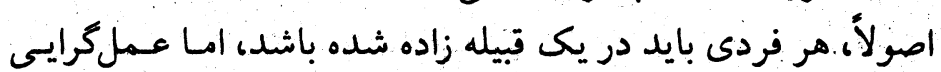

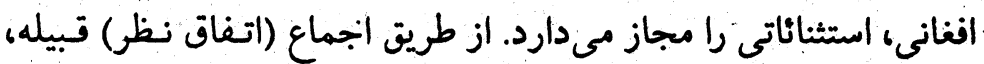

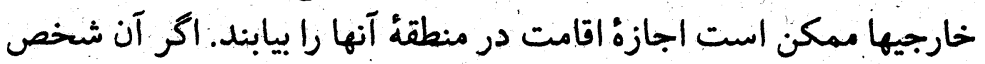

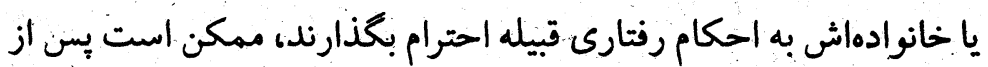

$$
\text { يك يا دو ننسل به عضويت قبيله بذيرفته شوندا }
$$

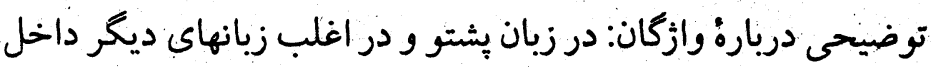

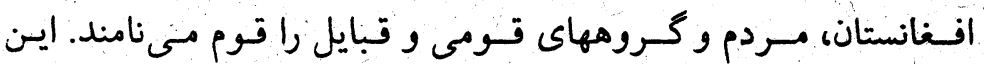

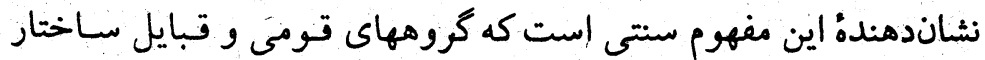

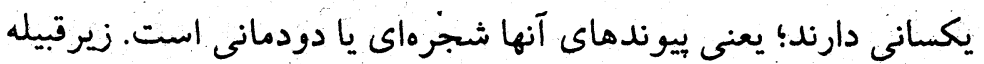

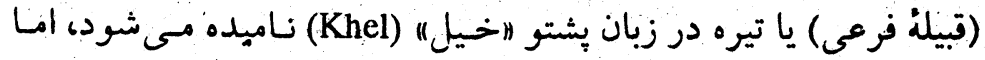

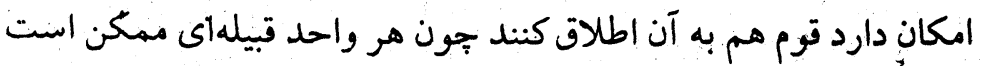

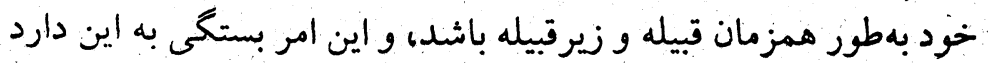

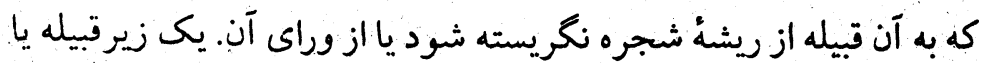

\section{خ ميستم قيلهاى:}

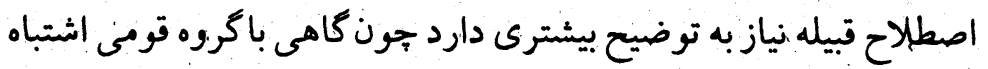

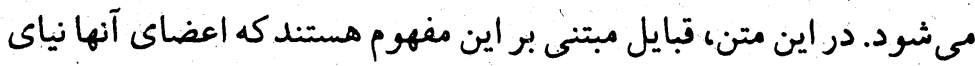

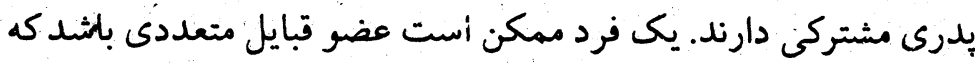

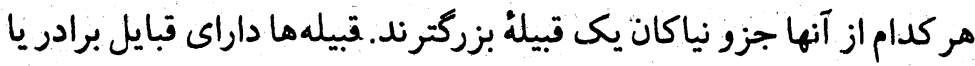

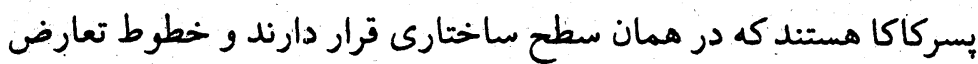

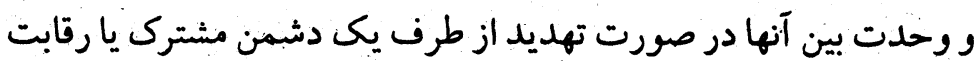

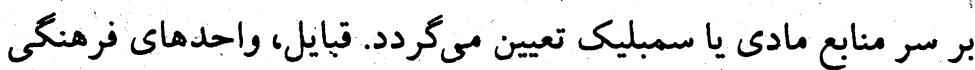

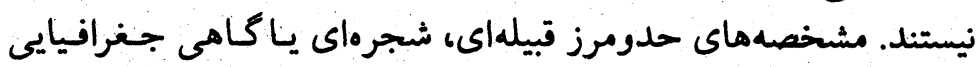

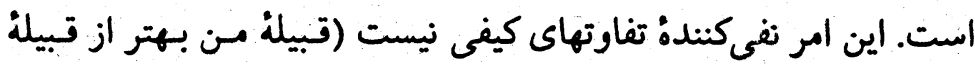

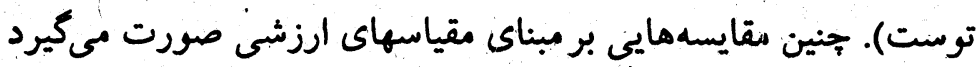

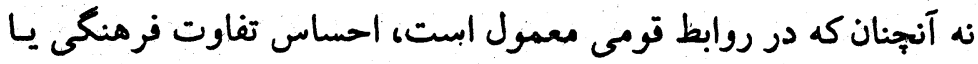

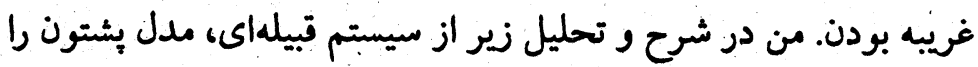

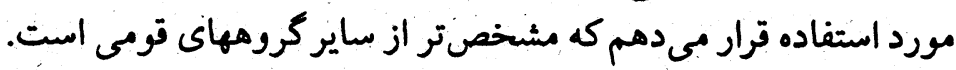

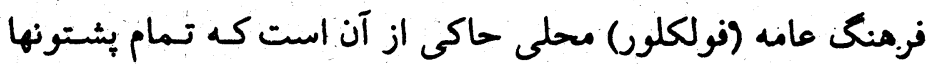

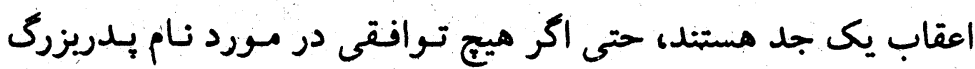

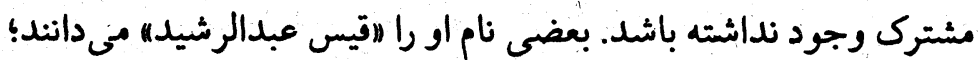

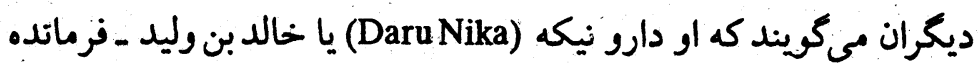

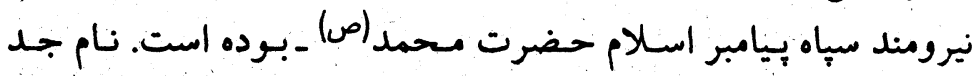

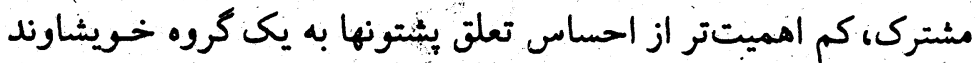

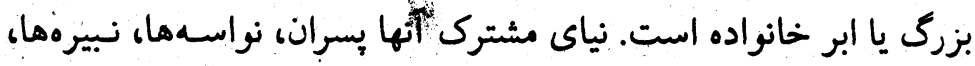

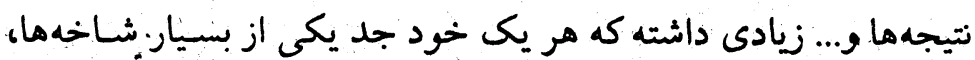

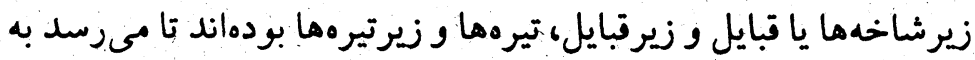


ابن حلدون در مورد ظهور و مقوط اميراطوريها.

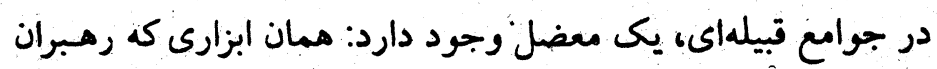

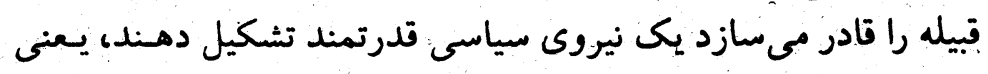

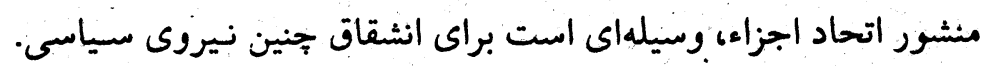

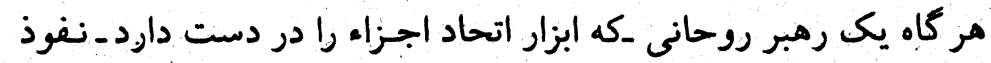

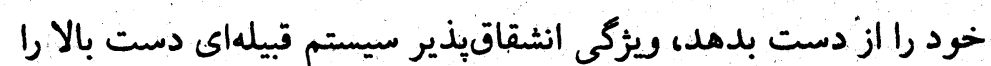

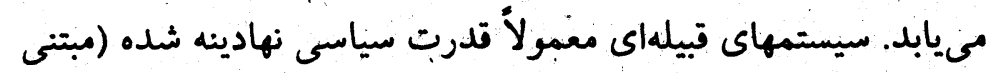

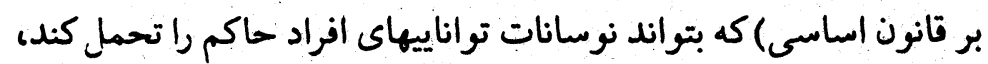

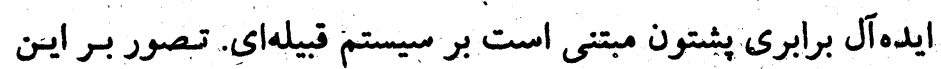

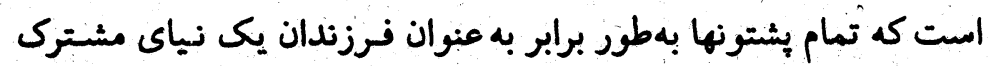

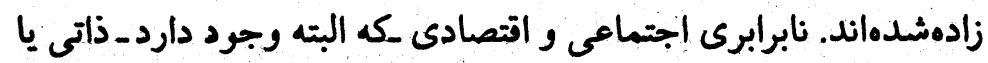

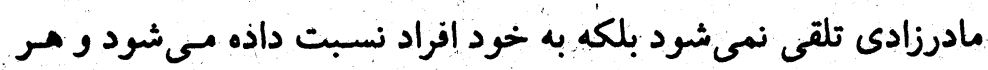

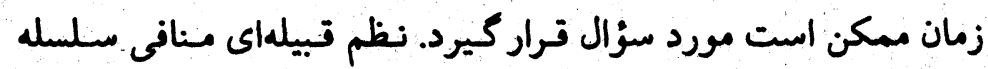

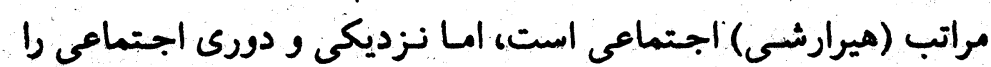

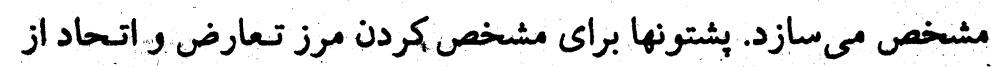

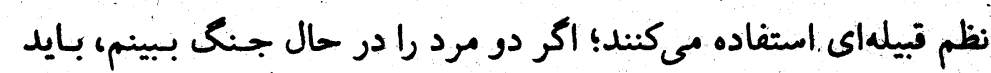

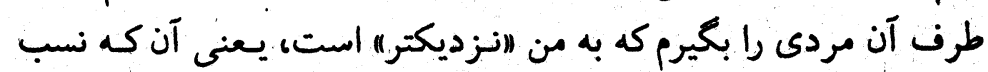

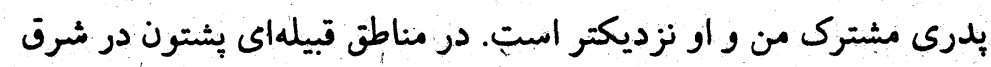

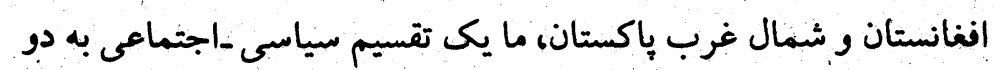

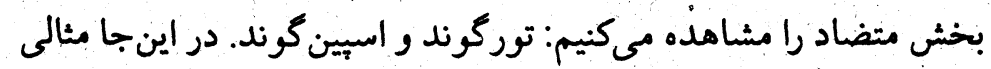

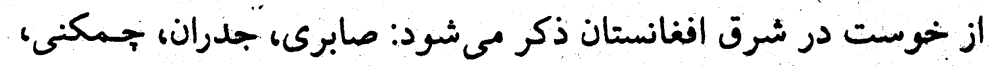

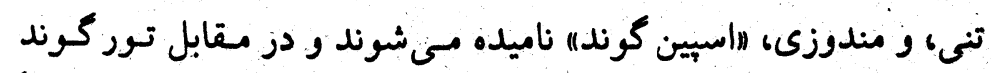

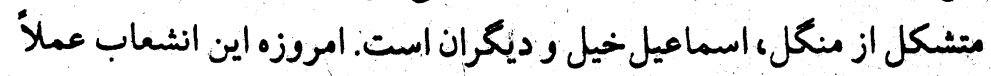

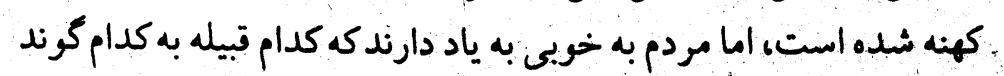

زيرتيرة يك خيل نيز خود يك خيل است، تا به سطح روستا. يك بِونوندِ

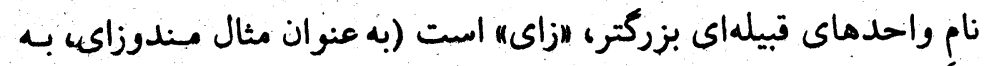

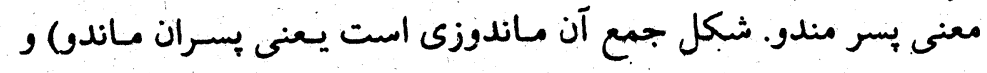

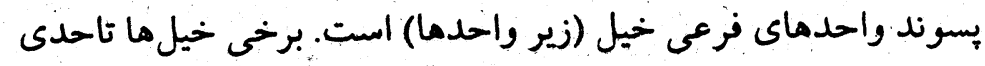

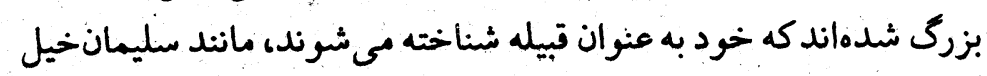

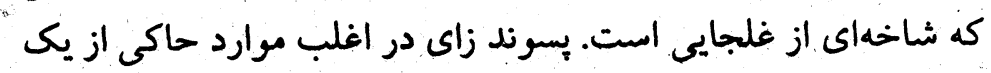

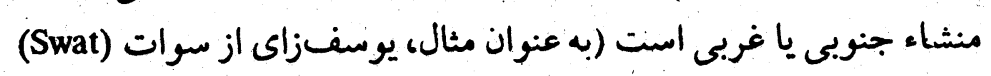

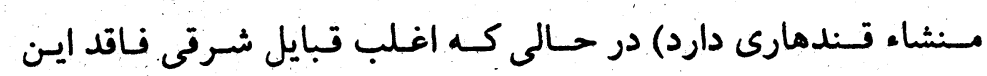

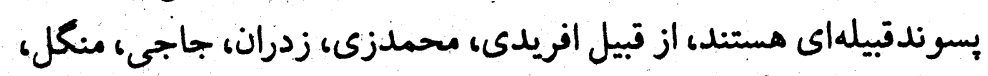

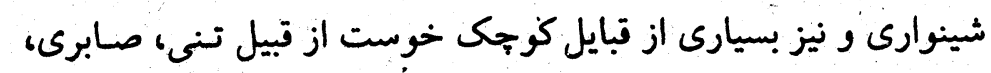
لاكان، و قوربوز. اغلب قبايل در الفغانستان نه به عنوان شخصيت حقوقيى مطرحند و ونه

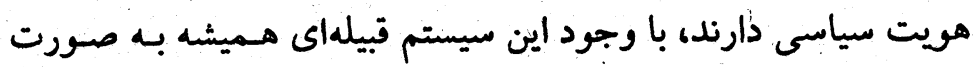

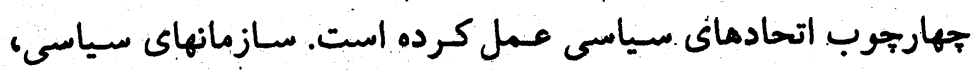

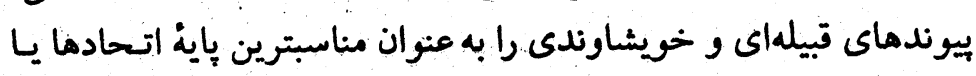

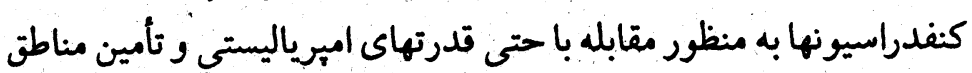

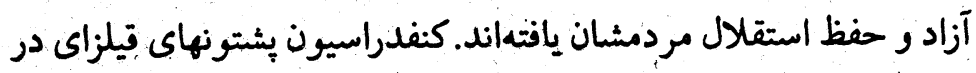

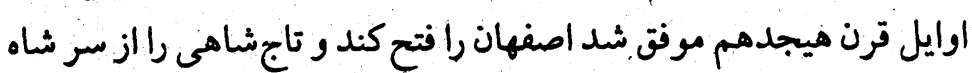

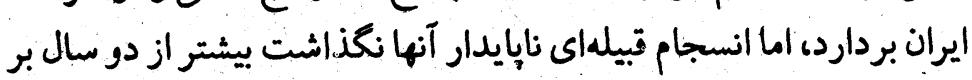

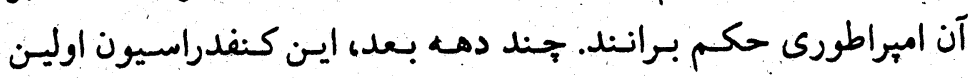

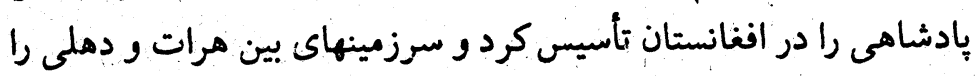

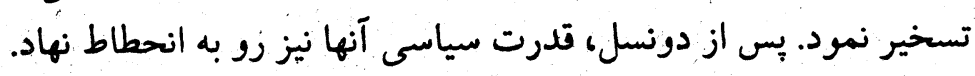

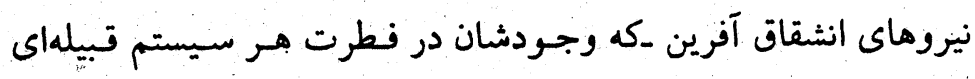

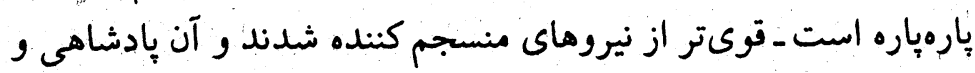

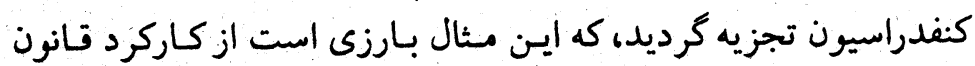


ميى شود. بر طبق برابرى قبيلهاى، هر شخص آزاد و با تجربة قبيله حق دارد

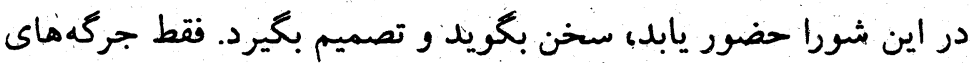

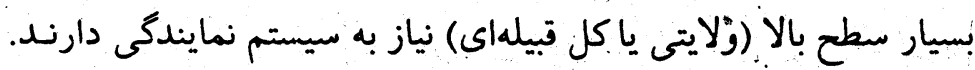

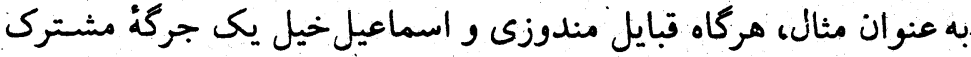

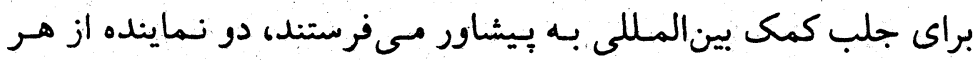

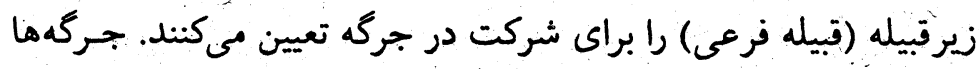

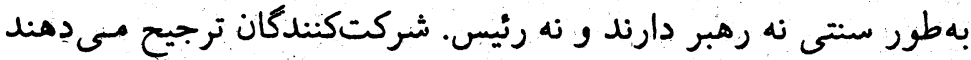

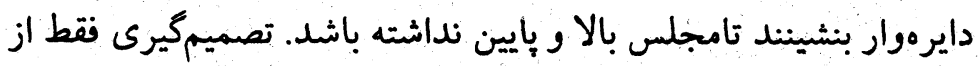

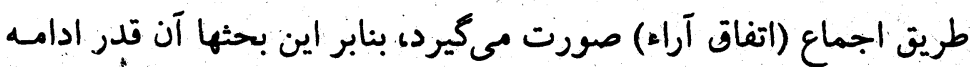

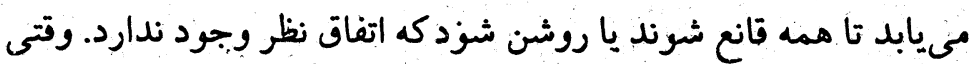

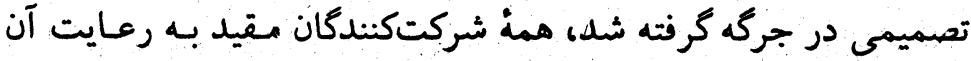

در زمان جنگ ضد شوند دوروى، يك اصطلاح سياسى جديد در افغانستان

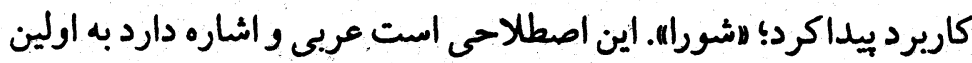

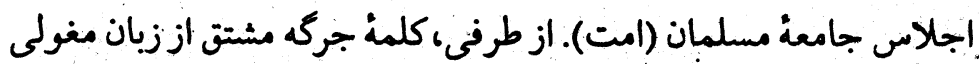

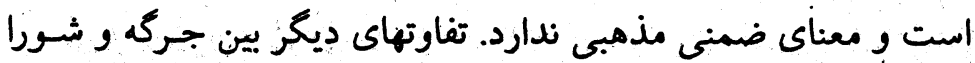

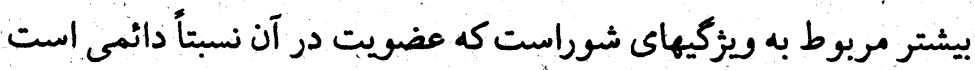

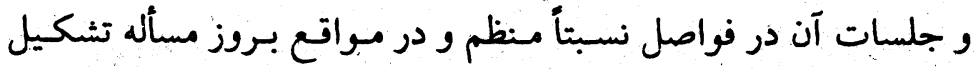

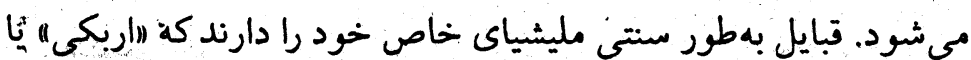

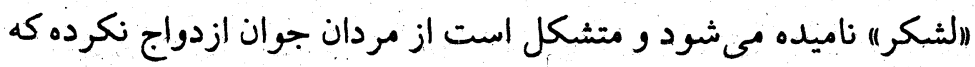

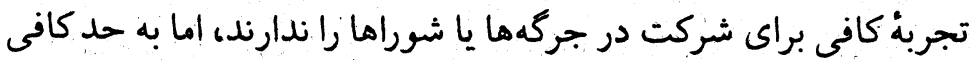

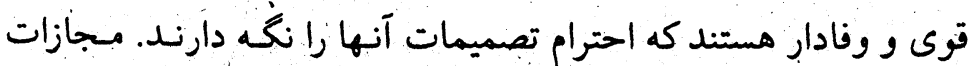

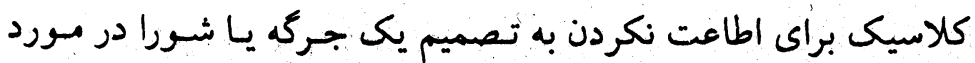

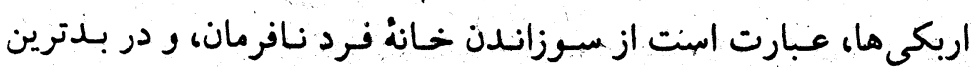
حالت، اخراج او از قبيله و مسرزمين قبيله.

افغانستان، طالبان، و سياستهاي جهانى .0 rra

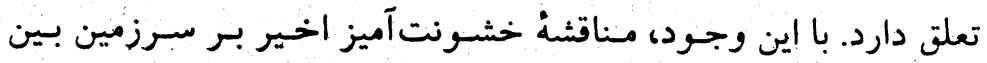

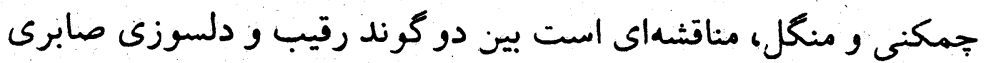

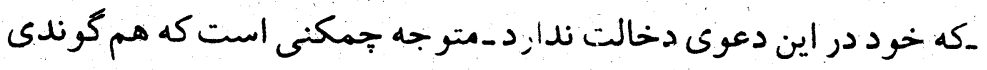
| ماوست.

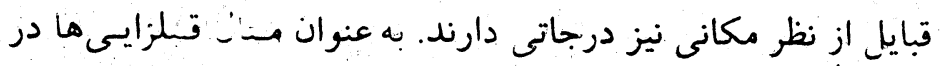

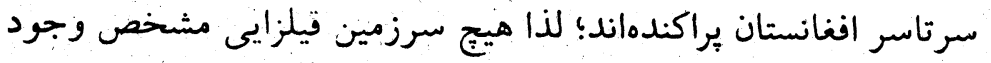

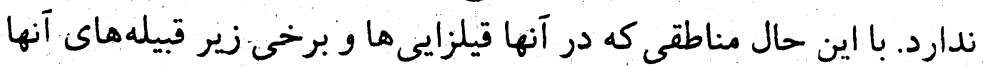

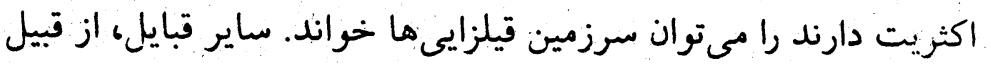

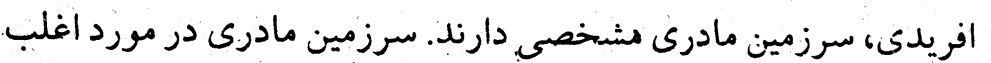

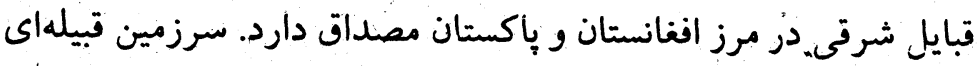

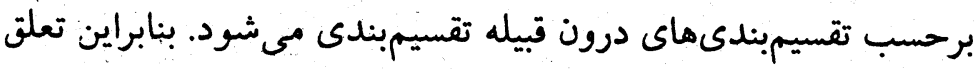

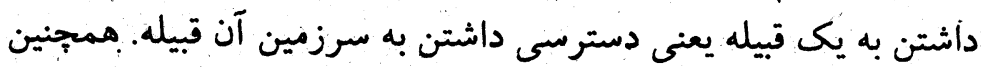

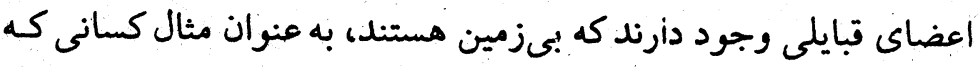

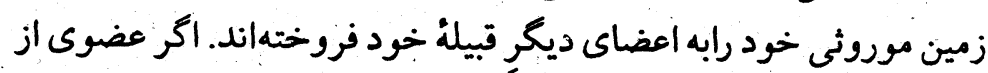

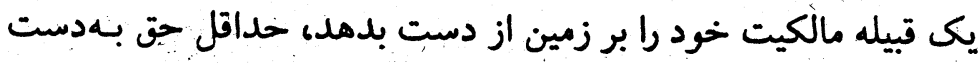

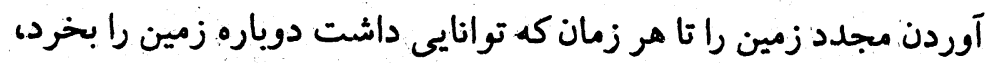

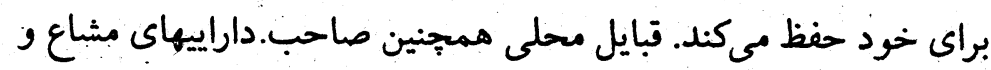

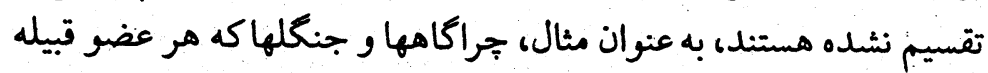

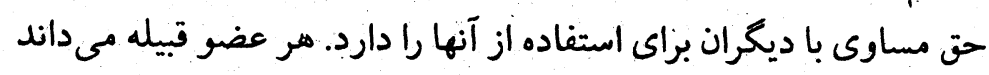

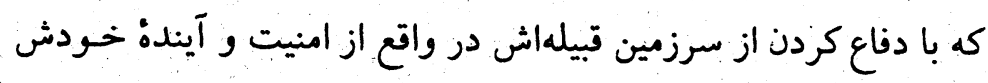
دفاع مىكند.

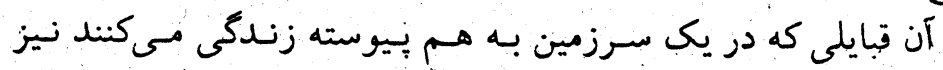

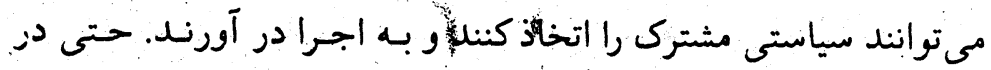

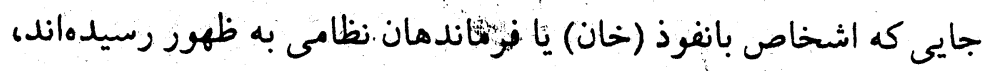
تصميمات مهم براى كل جامعة تبيلهاى در شوراى جامعه (جرگه) گرفته 
بازگُشت بناهندگان و توانبخشنى اقتصاد محلم به نهو بهتر و آرامترى ييش رفت.

كرجه ساختارهاى قبيلهاى در سرتاسر افغانستان وجود دارد، امكا همه آنها به خوبى برخى مناطق شرقى عمل نمى كنند، جون سيستم قبيلهاى و

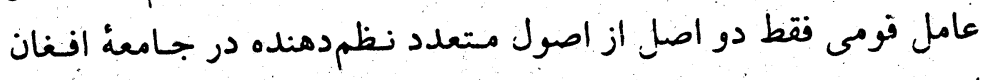

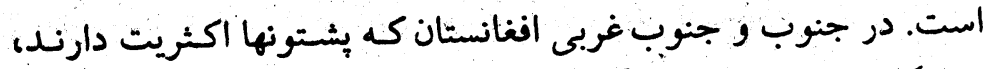

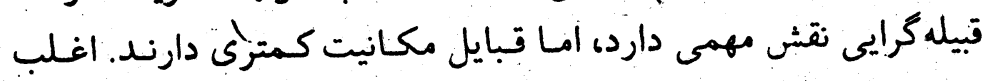

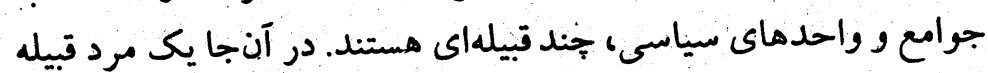
كه آمال سياسى داشنته باشد، بيروانى را از خحانواده، شنجره، تيره و قبيلة

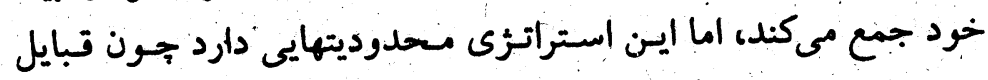
مشتون جنوبى در مناطق وميعى يراكنده هستند كه ومايز زيربنايى در اين

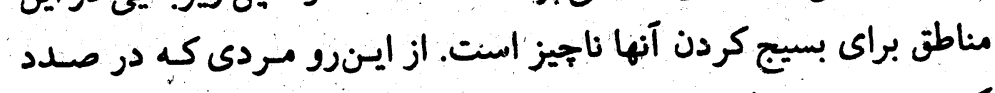

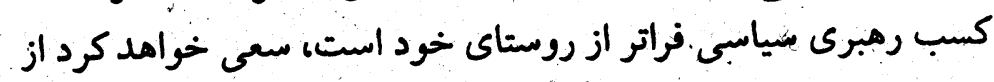

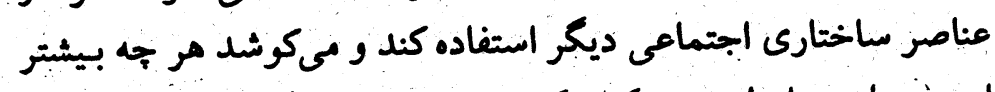

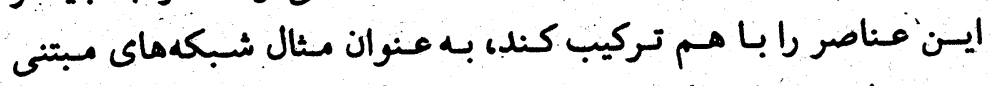

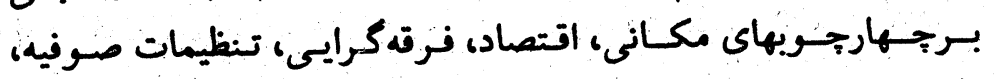
مكاتبمذهبى، احزاب منيابس و. مذهبى و غيره.

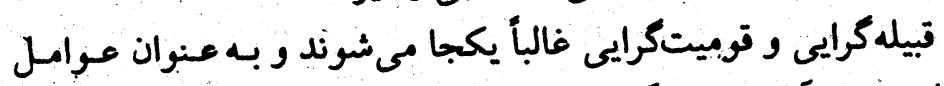

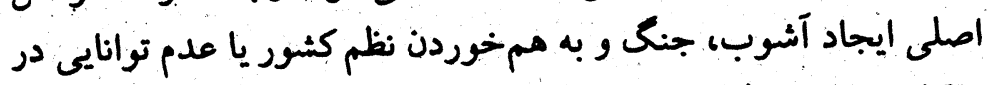
برقرارى مجدد نظم مورد ملامت قرار مىكيرند. من مسعى كردهام توضيح

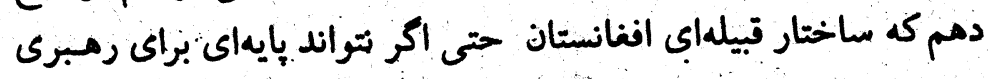

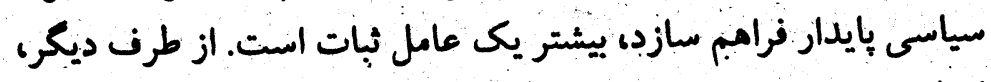
اصل قوميت نه عاملى انست براى ثبات ور نه ضرورتى براى عبدم ثبات.

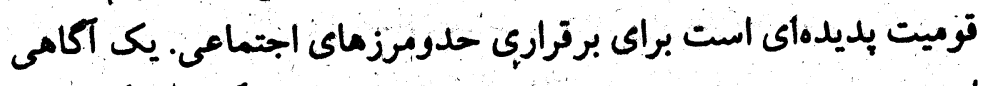

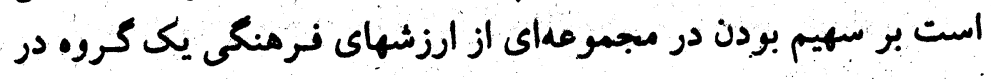

افغانستان، طالبان، و سياستهاى جهانى

orf.

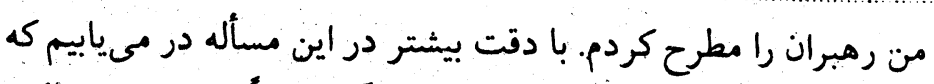

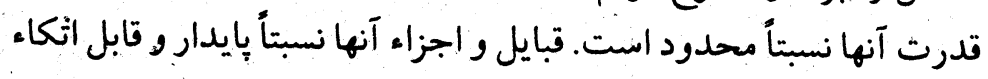

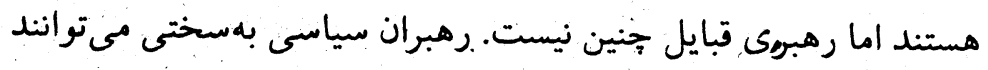

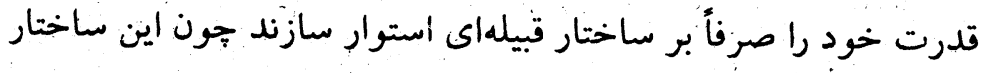

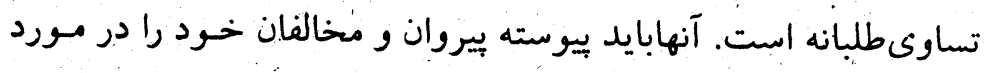
قابليتهاى شخصى برتر خود قـانع كـنـد و مسنابعى رأ از خـارج از تلمرور قيلهاى خود تهيه و در ميان آن توزيع نمايند؛ ييروان، از آنها انتظار منافع

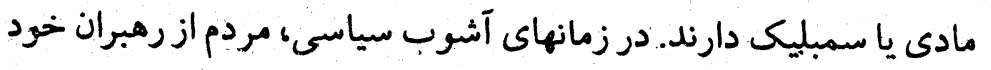

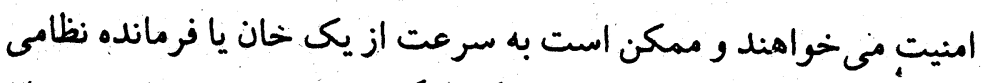

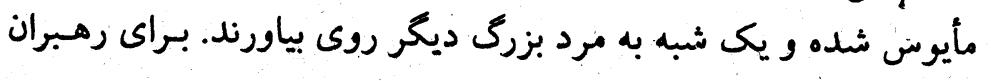
قبيله، هيج شبكة ايمنى نهادى وجود ندارد.

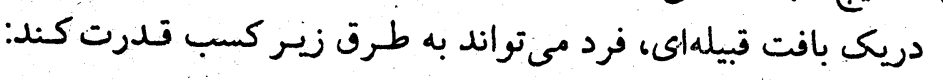

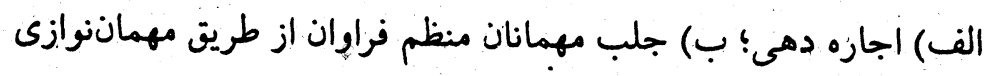

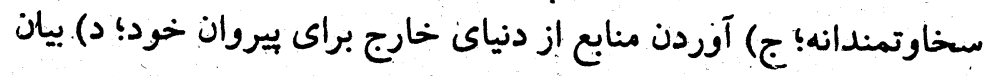

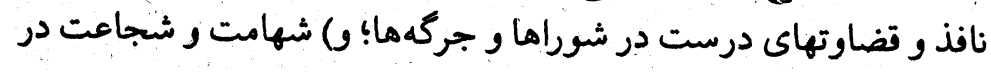

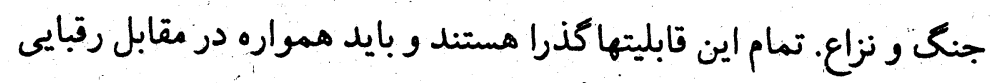
كه هميشه وجود دارند، تازه نظه داشته شوند. برخلاف ناستوارى ضربالمثل شده رهبرى قبيله، سيستم قبيلهاى متضمن ايمنى، امنيت قانونى و گرايش اجتماعى در دنيايى است كه بدون

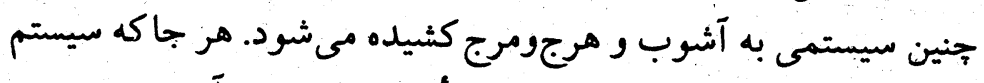

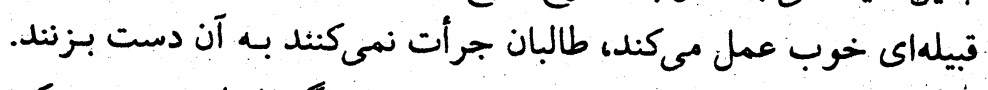
آنها در عوض همبجون دولتهاى افغان قبل از جنيك، اجازه مسى دهند كـه

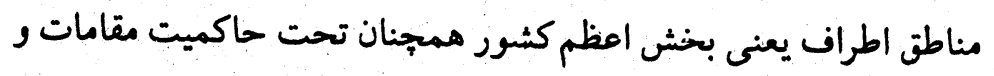

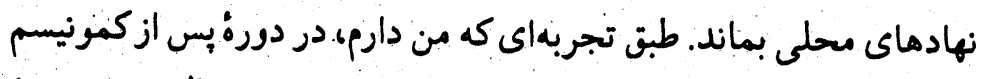

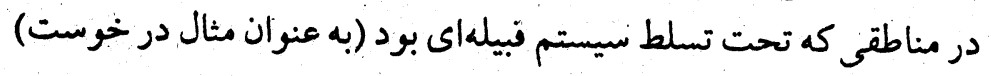


ميان كمونيستها، يك يا دو عضو را به ميان احزاب مختلف مبجاهدين و

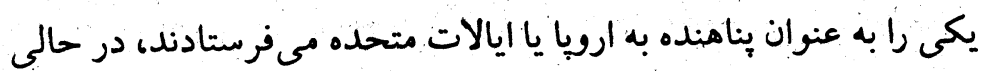

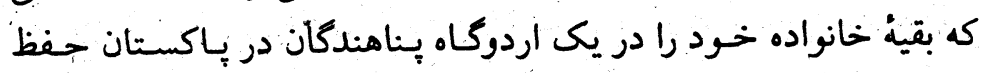

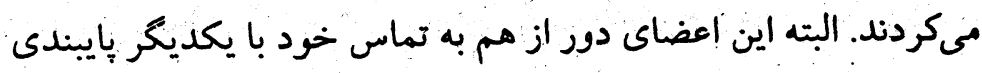
نشان مى دادند. طى سالهاى اوليه جنگ، ناظران خارجى و روشنفكران افغان در هر دو

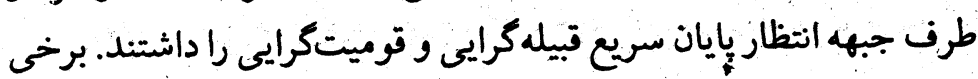

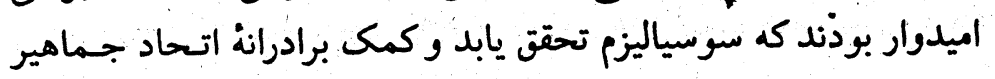

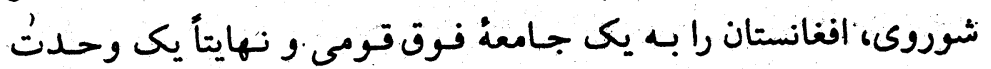

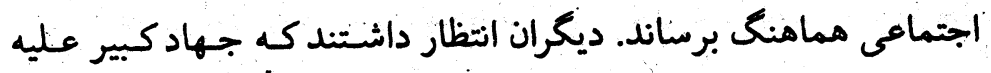

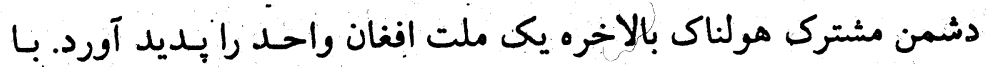

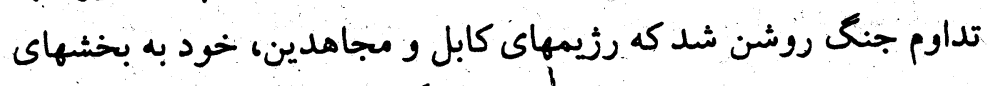

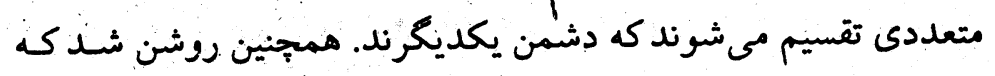

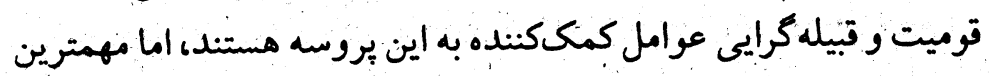

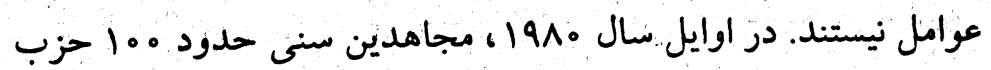
مختلف تشكيل داه بودند كه مودفتر در ييشاور داشتند. در طول يك سنال

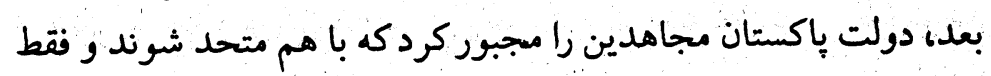
مفت حزب را به رسميت شناخت، كه وظايفى ادارى در رابطة با ميليونها يناهنده افغانى در ياكستان به آنها محول كرديد. بقية احزاب بـايد دفياتر خود را در ياكستان مىبستند. اين هفت حزب، كارتهاى هويت و كارتهاى

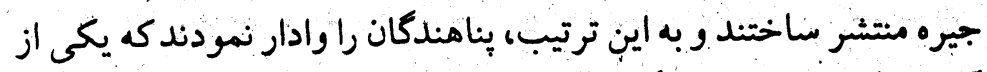

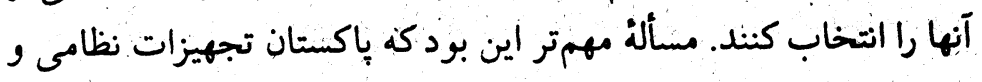

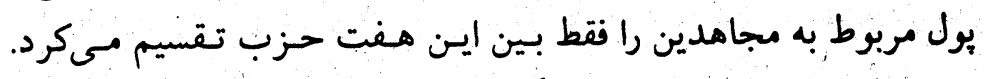

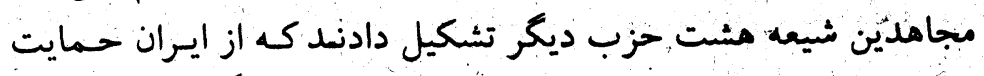

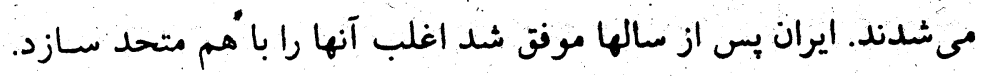

مقابل كروهى ديخر. اعضاى يك كروه قومى در يك اخسباس "ماسا در مقابل "آنهان سهيم هستند.

\section{هو قوميت و قبيلهكرايى: خطرات و فرصتها}

بس از اين مطالب خلاصه در مورد اصول قومى و قبيلهاى افغانبستان، من

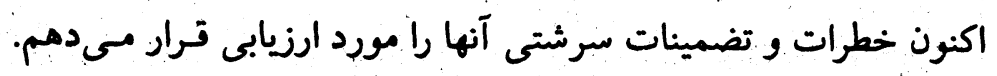

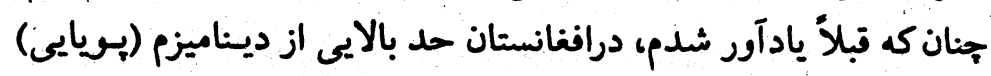

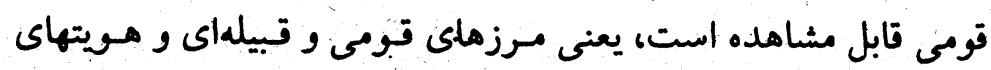

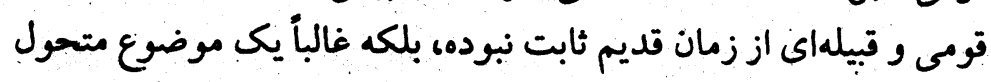

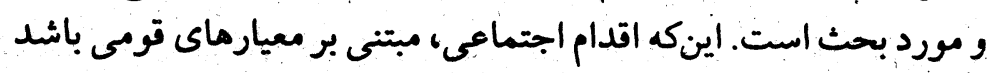

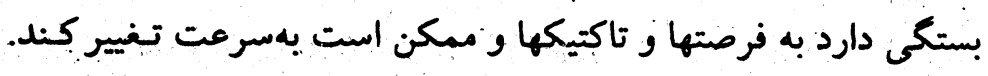

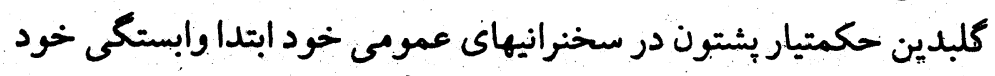

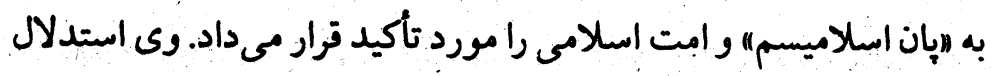

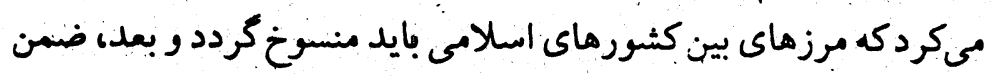
تلاشث براى كردآورى افراد در مناطق بشّتون، به اتحاد قومى بشّتون توبل

جنى ضد شوروى در افغنستان و منّس جنى جريكى عـليه رثزيم

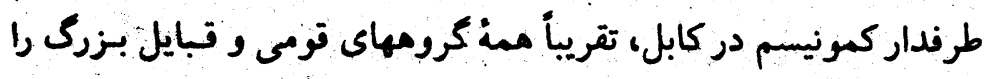

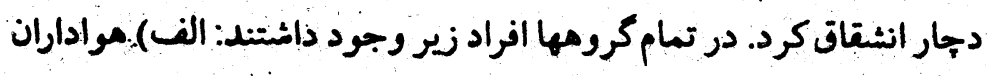

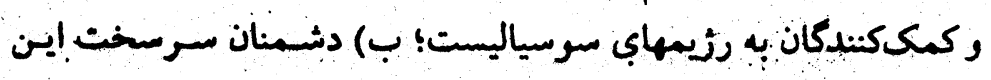

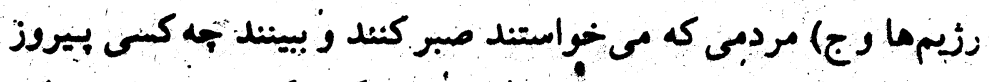

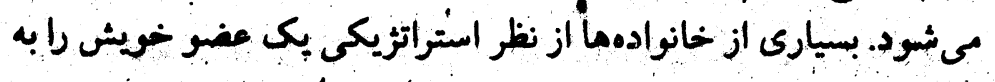




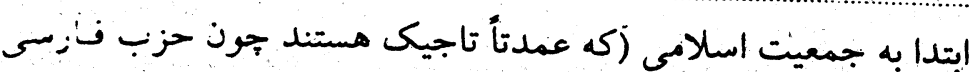

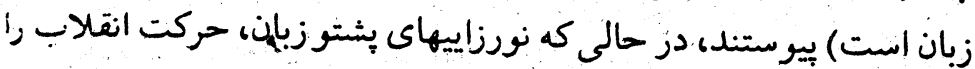

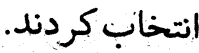

هويت قومى به دليل ،دارا بودن مضامين باستانى، بيشتر از كرايشهاكن

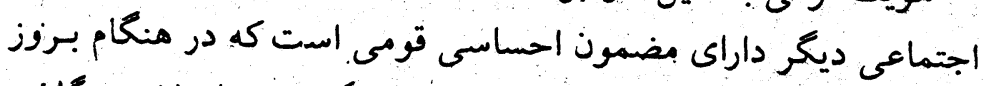

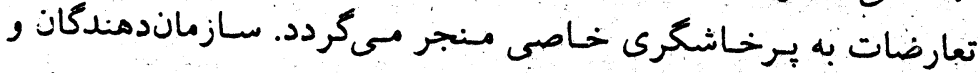

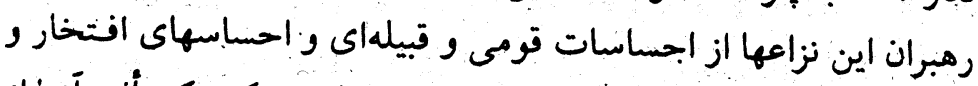

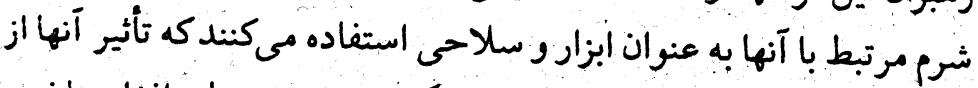

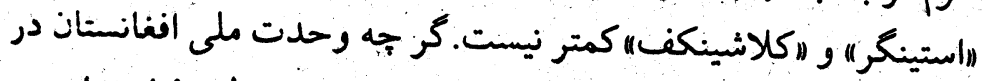

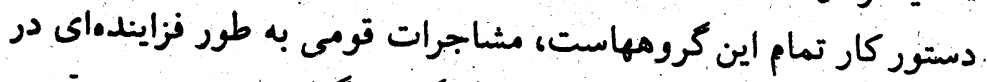

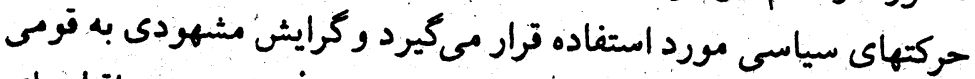

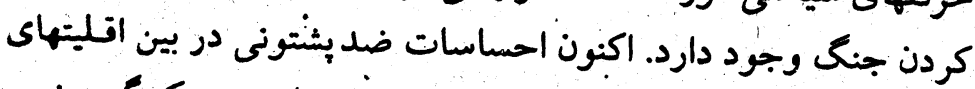

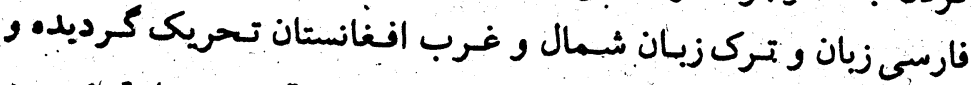

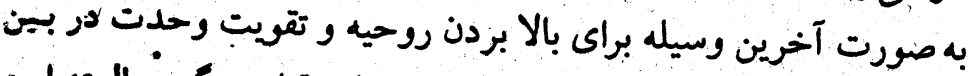

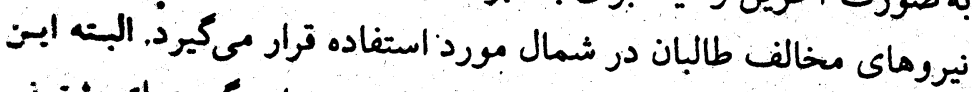

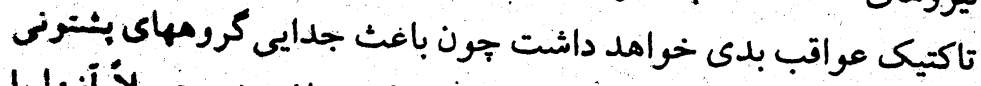

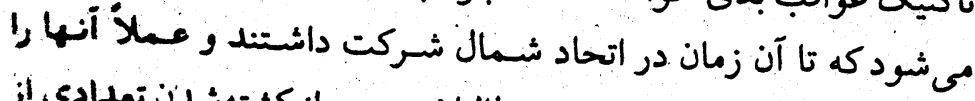

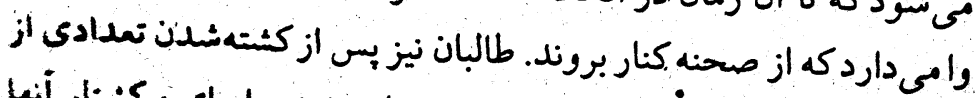

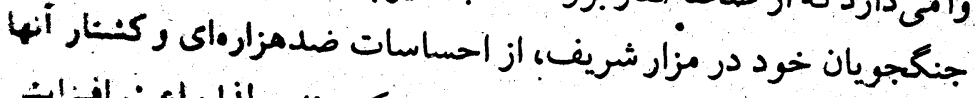

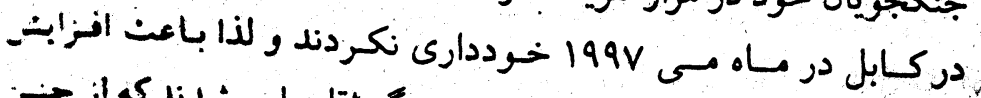

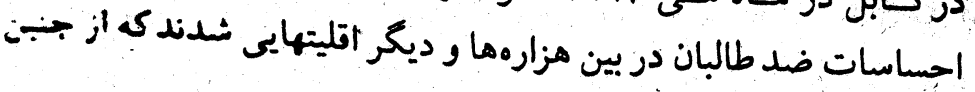

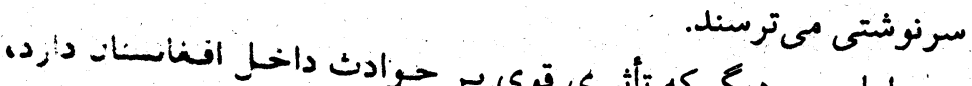

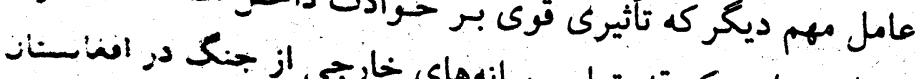

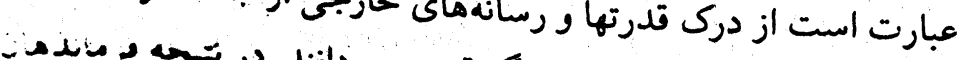

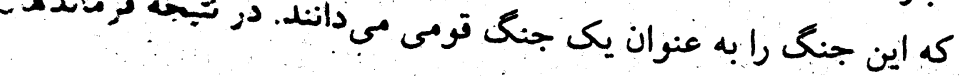

امروزه تنها دو حزب مهم شيعه عبارتند از حزب وحدت _كه اكثر هزارهها

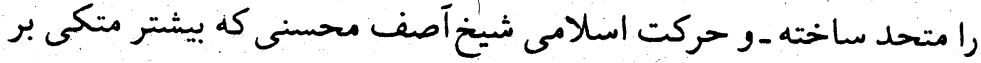

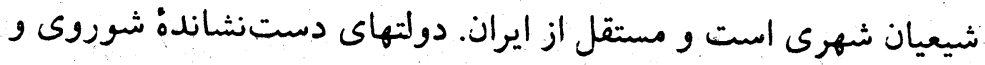

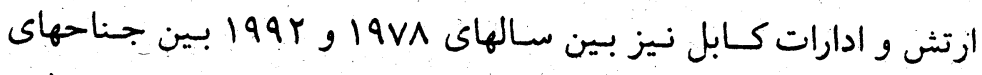

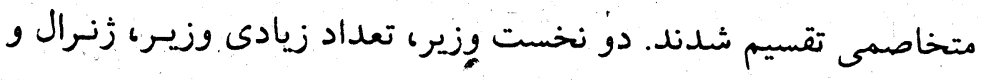

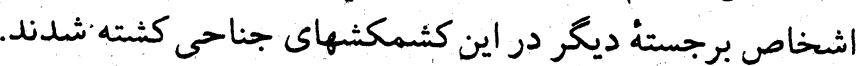

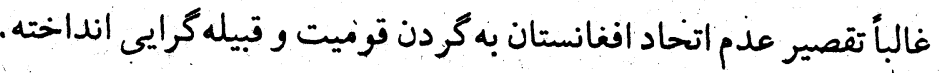

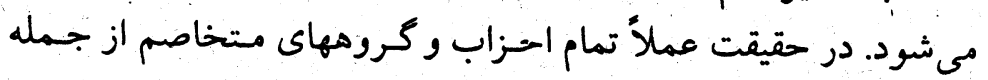

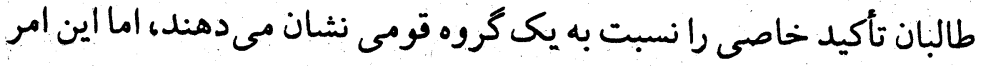

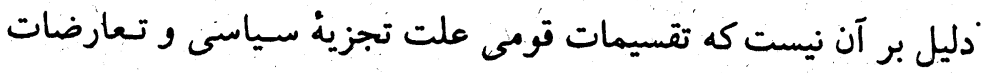

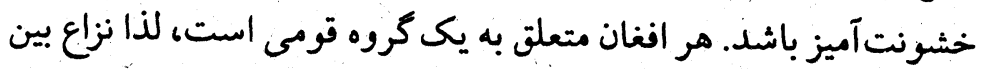

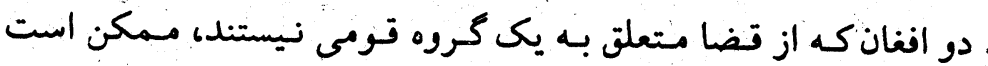

$$
\text { به سادكى نزاعى قومى تصور شود. }
$$

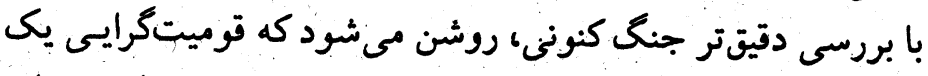

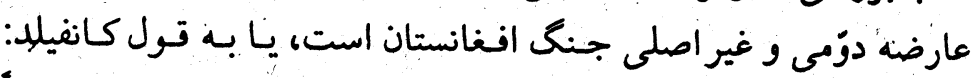

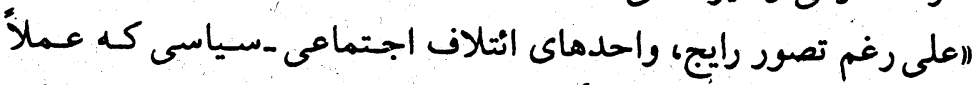

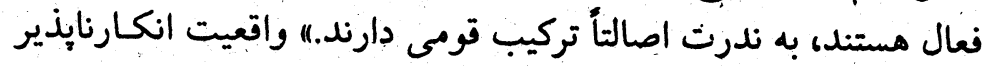

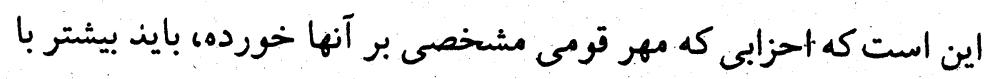

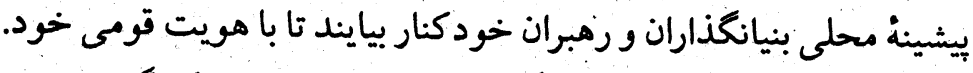

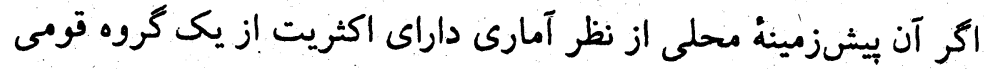

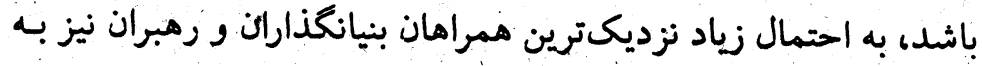

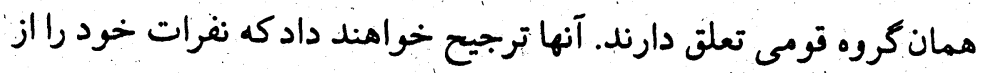

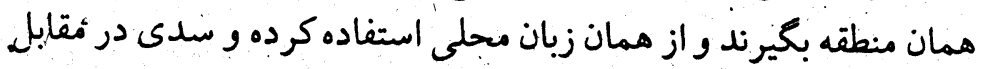

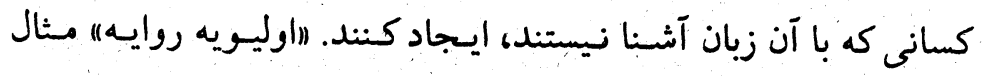

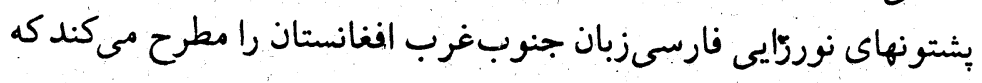


rPVo

آيا افغانستان در آستاناُ تجزية قومى و قبيلهاى قرار دارد؟

استفاده از قوميتكرإيى به عنوان يك سلاح دوانى ادامه خواهند داد يـا

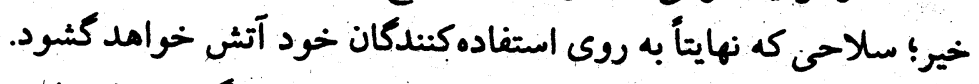

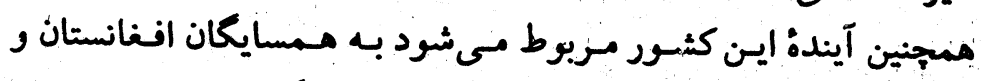

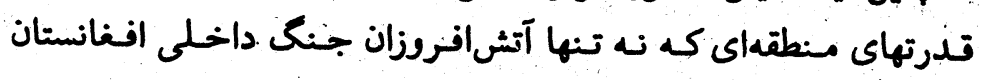

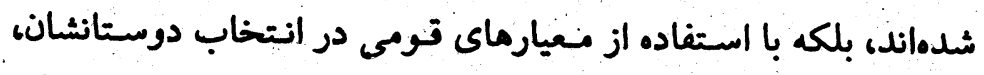
اوضاع رابدتو مىكند.

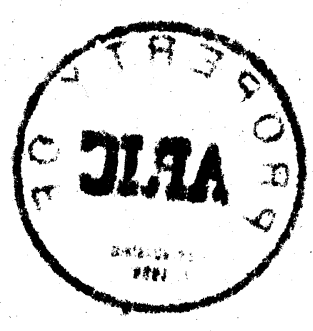

افغانستان، طالبان، و سياستهاى جهانى

orre

جنكى كه يُشينه. قومى خـاصى دارند ترجيـيح داده مسى شوند و رارتقاء

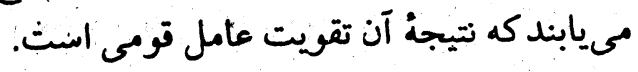

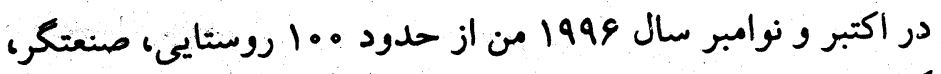

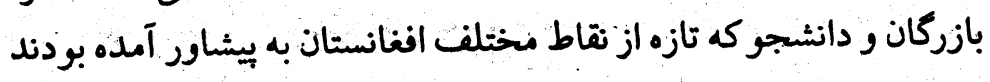
و قصد داشتند به زودى به وطنشان باز كردنل، يك نظر خواهى عمومى أنى

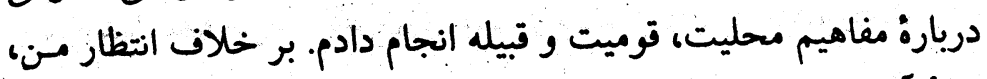

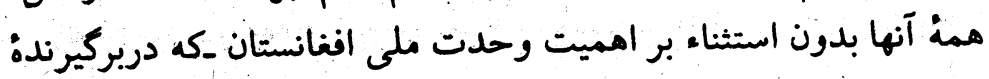

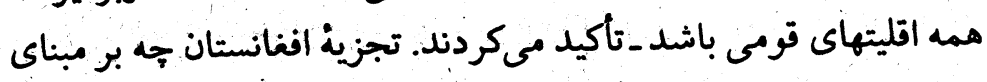

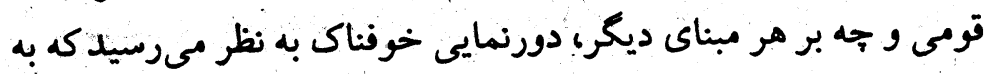

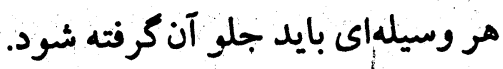

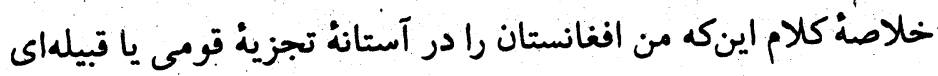
نمىينم، بلكه با نظر كسانى كه مصاحبه كردم مؤافق هستم كه اين كار، إنهان

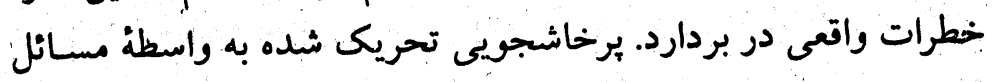

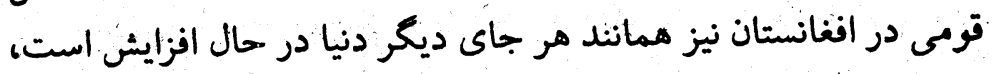

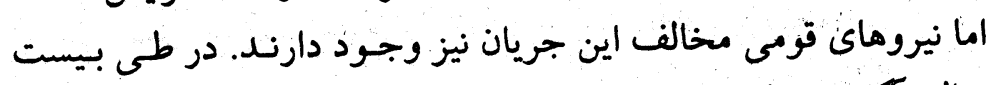
سال، اكاهى بر لزوم وحدت ملى به طور جشمئيرى افز افزايش يافته است.

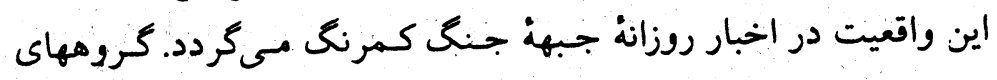

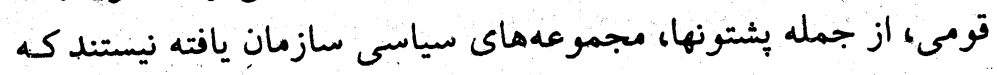

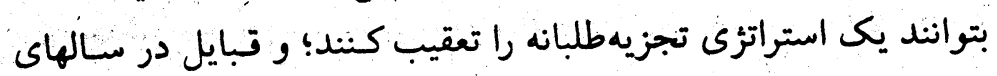

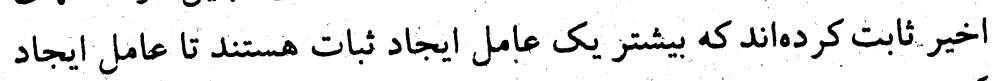

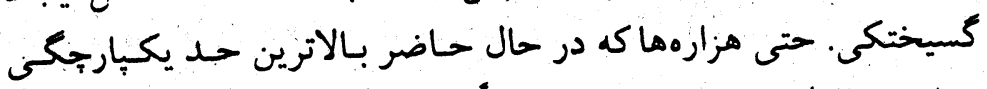

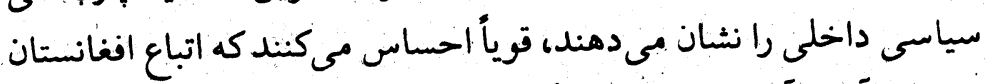

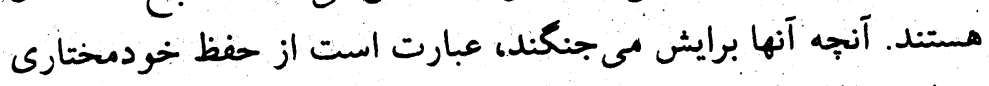

محلى و متذهبى، نه جدايى طلبى. آيندة افغانستان تا حدى به اين بستخى دارد كه آيا طرفهاى متخلى ماصم به 


\section{دولت رباني (1999) - 1994)}

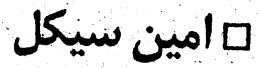

در اواخر إبريل 1997 با فروياشى دولت وابسته به شوروى نجيب الله در

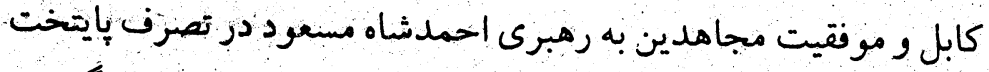

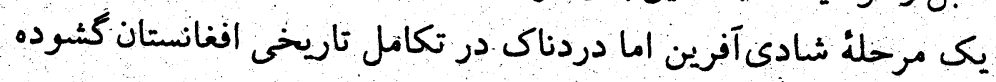

شله

بركنارى رزيم خوفناك نجيب الله نهايتاً حقانيت مقاومت مردمى افغانها

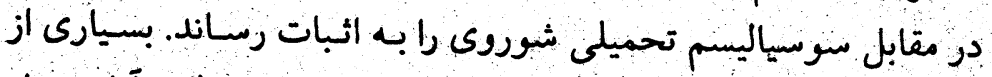

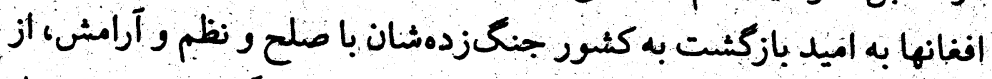

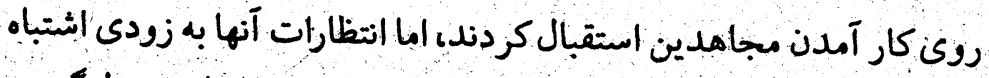

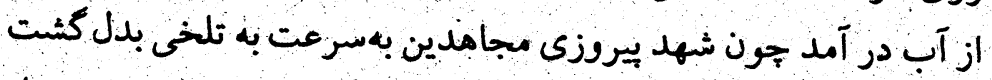

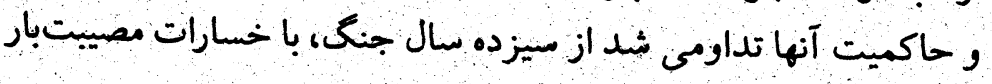
بيشتر براى افغانها.

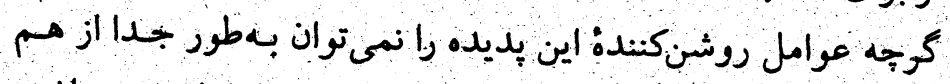

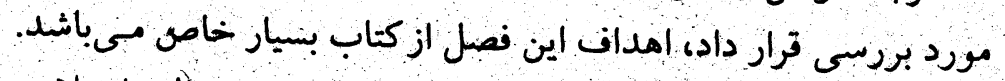

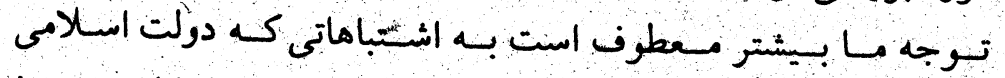

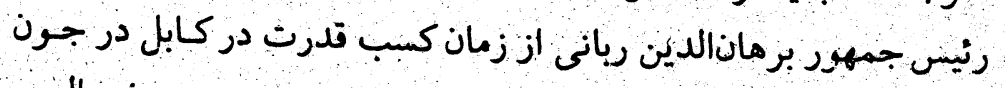

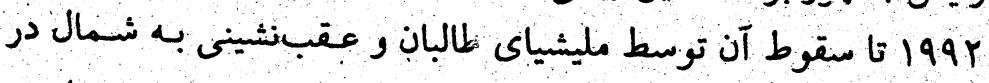

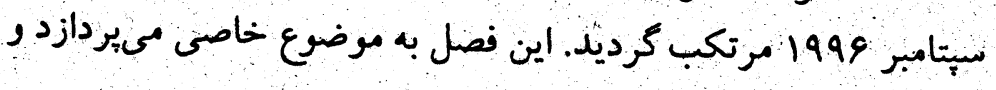

افغانستان، طالبان،و سياستهاى جهانى

درآورد يا تشريفات و آيين مذهبى بدون ايمان نيز به هرحال دربر دارنده

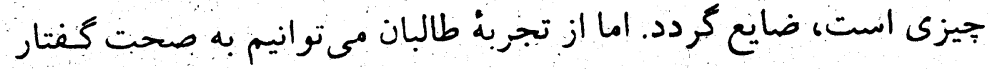

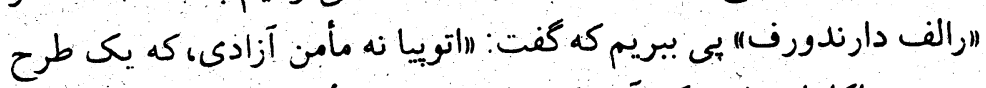

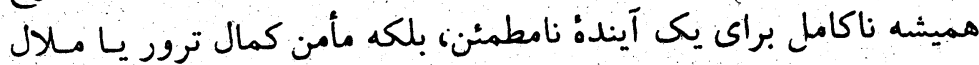

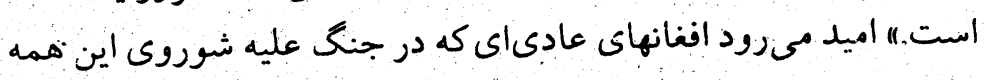

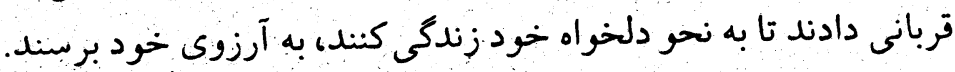

* * * * 